Milicz Ákos

\title{
BELSŐ KONTROLLRENDSZEREK \\ INTÉZMÉNYESÜLÉSE HAZAI ÜZLETI \\ SZERVEZETEKBEN
}


BUDAPESTI CORVINUS EGYETEM

VEZETÉSTUDOMÁNYI INTÉZET

Vezetés és Kontroll Tanszék

Témavezető: Lázár László PhD

Bírálóbizottság:

(C) Milicz Ákos 2016 
BUDAPESTI CORVINUS EGYETEM

Gazdálkodástudományi Doktori Iskola

\section{BELSŐ KONTROLLRENDSZEREK \\ INTÉZMÉNYESÜLÉSE HAZAI ÜZLETI \\ SZERVEZETEKBEN}

DOKTORI ÉRTEKEZÉS

Témavezető: Lázár László PhD

Milicz Ákos

Budapest, 2016 



\section{TARTALOMJEGYZÉK}

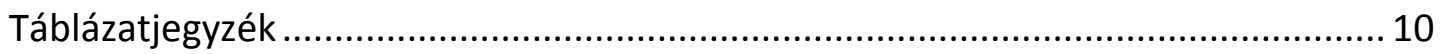

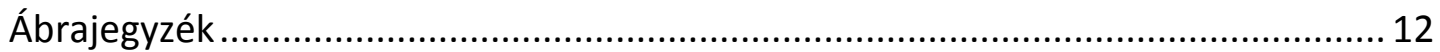

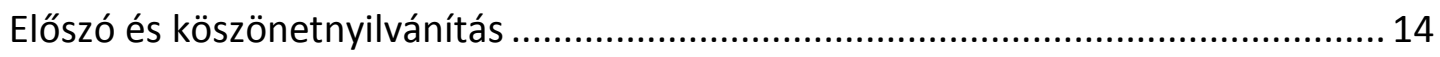

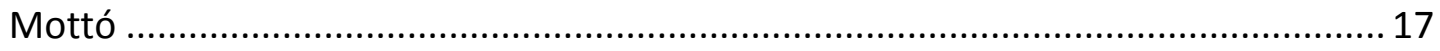

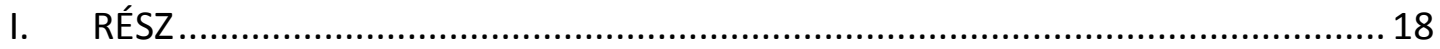

Bevezetés - a kutatási téma és a dolgozat bemutatása .......................................... 18

1.1 A téma célcsoportjai, relevanciája és időszerüsége ..................................... 18

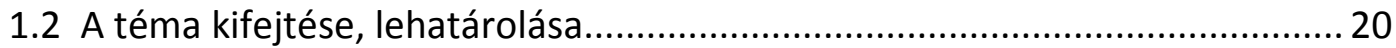

1.3 Alkalmazott módszerek és eredmények .................................................. 22

1.4 Az értekezés felépítése .............................................................................. 22

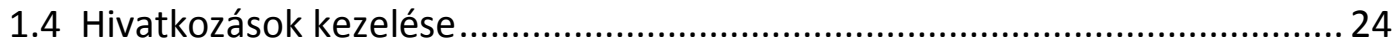

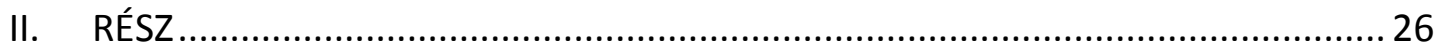

A kontroll értelmezése és a kontrollrendszer általános bemutatása ......................... 26

2.1 Fogalmi elhatárolás - a kontroll és az ellenőrzés szavak alapvető jelentéstartalma, értelmezése ...................................................................... 27

2.2 Belső kontroll a menedzsmenttanokban .................................................. 31

2.3 A kontroll és az ellenőrzés viszonya egymáshoz a magyar gazdasági

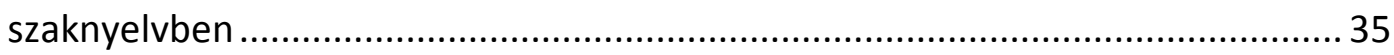

2.4 A rendszer fogalma, alapvető bemutatása ................................................. 40

2.5 A modern kori vállalati belső kontroll általános bemutatása ........................ 42

2.5.1 Nemzetközi meghatározások, standardalapú megközelítések.................... 42

2.5.2 Hazai meghatározások, szerzői jellemzések.......................................... 47

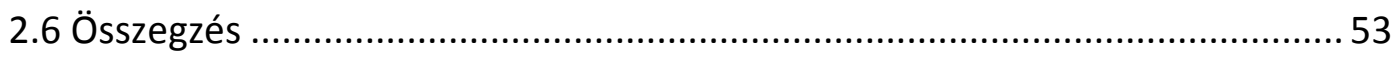

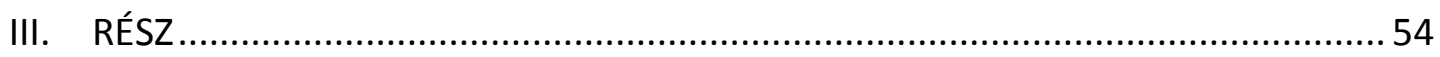

A vállalati belső kontrollrendszer részletes bemutatása, a COSO-modell kritikai

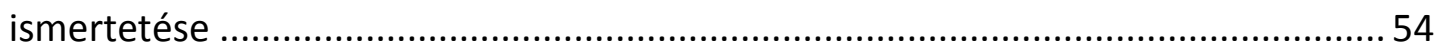

3.1 Belső kontrolltevékenység a COSO-modell szerint ...................................... 54

3.2 A COSO-keretrendszer komponensei és ezek összefüggései......................... 58

3.3 Kritikai észrevételek a COSO-modellel kapcsolatosan ................................66 
3.4 További modellek

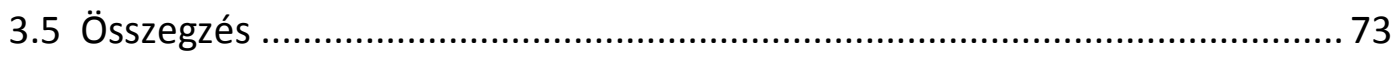

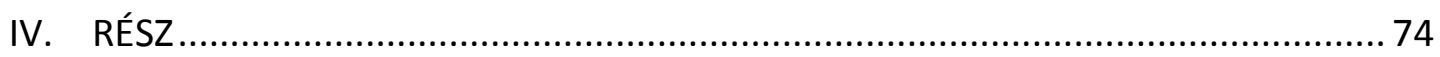

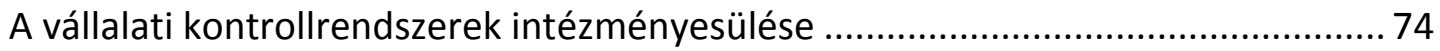

$4.1 \mathrm{Az}$ intézményesülés fogalma, folyamata................................................. 76

4.2 A kontroll mint vállalaton belüli intézmény .............................................. 83

4.3 Belső szabályozás mint az intézményesülés legitimizációja ........................... 88

4.4 Kontroll és konfliktuskezelés a szabályok fenntartása érdekében ................. 90

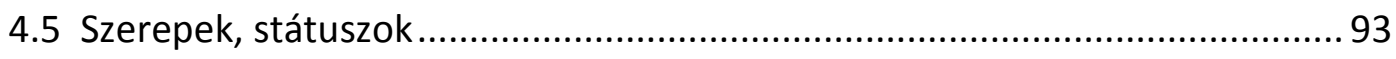

4.6 Kooptálás, szervezetközi szakmai hálózati szerveződés .............................. 94

4.7 Az intézményt múködtető struktúra, illetve szervezet ..................................96

4.8 Kritikák az intézményi szociológiai megközelítéssel szemben ....................... 97

4.9 Összegzés - az intézményesülés kulcsfogalmai .......................................... 99

$4.10 \mathrm{~A}$ belső kontrollrendszer intézményesülési szintjei - saját modell ............ 100

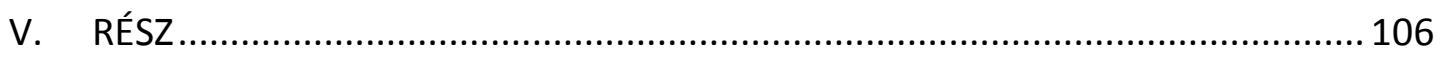

Kutatási kérdések és eredmények ..................................................................... 106

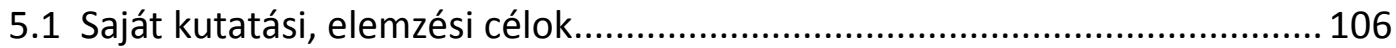

5.2 Korábbi hazai és nemzetközi kutatási eredmények bemutatása.................. 107

5.3 A kutatási téma konceptualizálása............................................................ 109

5.4 A választott kutatásmódszertan bemutatása ........................................... 111

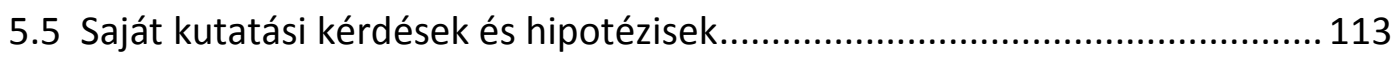

5.5.1 Disszertációm fő kutatási kérdései és a hipotézisek .............................. 113

5.5.1.1 Befolyásoló tényezők ................................................................. 113

5.5.1.2 Kulcsszereplők ............................................................... 114

5.5.1.3 Kontrolltevékenységek......................................................... 115

5.5.1.4 Az intézményesülés szintjei, érettsége .................................... 116

5.6 Adatgyüjtés, mintavétel .......................................................................... 119

5.6.1 A vizsgálati populáció lehatárolása, bemutatása .................................... 120

5.6.2 A mintavétel elvei, módszere, megbízhatósági kritériumai..................... 123

$5.7 \mathrm{Az}$ adatgyújtés folyamata és eredménye ............................................... 124

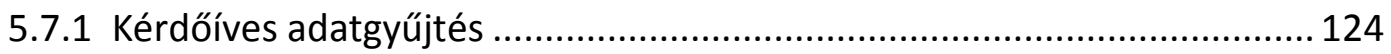


5.7.2 Válaszadási hajlandóság, reprezentativitás........................................ 125

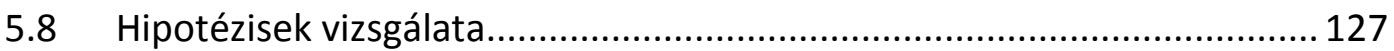

5.8.1 H1: A befolyásoló tényezők rangsorrendje............................................ 128

5.8.2 H2: Kulcsszereplők, aktorok ............................................................... 130

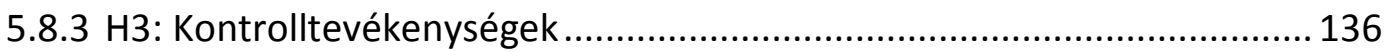

5.8.4 H4: A kontrollrendszer intézményesülése ........................................... 142

5.9 A fókuszcsoportok és a mélyinterjúk eredményei.................................. 148

5.9.1 Befolyásoló tényezők ........................................................................... 149

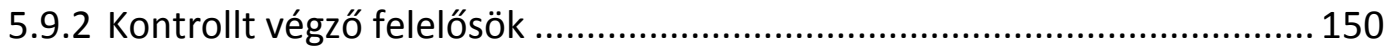

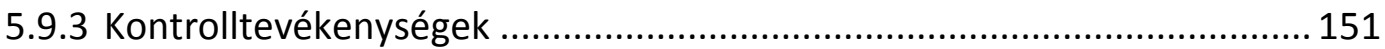

5.9.4 A kontrollrendszer intézményesültsége ................................................. 151

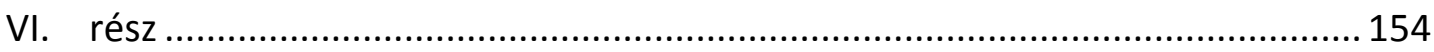

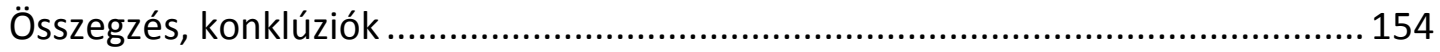

6.1 A disszertáció témájának bemutatása ....................................................... 154

6.2 A dolgozat íve, fókusza, alkalmazott módszerek .......................................... 156

6.3 A kutatási eredmények összegzése ........................................................ 158

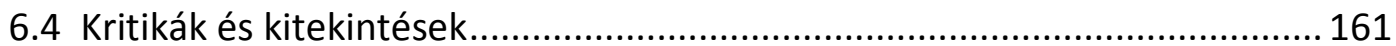

1. Függelék - A kontrollrendszerek szereplői, múködtetői a vállalatokban.........164

F11. A függetlenített belső ellenőrzés .......................................................... 165

F12. Belső kontroll a számviteli jogszabályi keretekben.................................. 174

Kontroll a hazai számviteli szabályozásban .................................................. 175

Ellenőrzés és kontroll a nemzetközi számviteli standardokban......................... 180

F13. Kontroll a vállalati könyvvizsgálati szabályozásban .................................. 182

F14. Kontrollt gyakorló bizottságok a gazdasági társaságokról szóló törvény

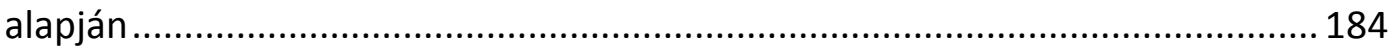

F15. Menedzsmentkontroll mint vezetési eszköz, illetve a vállalati

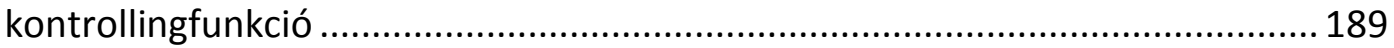

Menedzsmentkontroll mint vezetői tevékenység............................................ 190

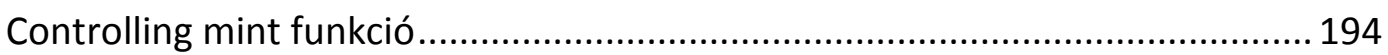

F16. Kontrollálás a vállalati szintű múködési és irányítási szabványokban ......... 196

Ellenőrzés és visszacsatolás az ISO 9001 szabvány szerint ................................ 198

Kontroll az ISO 31000 kockázatkezelési szabványban....................................... 204 
Kontrollok további szabványokban, normaalapú rendszerekben 205

F17. A vállalati kontrollrendszer további egyéni szereplői, múködtetői 206

2. Függelék - Kontrollmódszerek és -eszközök a gyakorlatban. 210

3. Függelék - Negatív jelenségek, jelentős kockázatok és veszélyek, melyek a vállalatok múködését befolyásolják

4. Függelék - A vállalati belső kontrollrendszer követelményeinek történelmi fejlődése 216

F41 Fejlődés a kapitalista országokban 216

F42 A szovjet-szocialista államberendezkedés kontrollfilozófiájának fejlődése 220

5. Függelék - Adatgyűjtő rendszer 222

F51 Alkalmazott adatgyújtő kérdőív 222

F52 Adatgyűjtő alkalmazás adatbázisstruktúrája 246

6. Függelék - Matematikai-stasztikai függelék 248

F61 A minta illeszkedése a populációhoz, $\chi^{2}$ próbák eredményei 248

F62 Hipotézistesztek eredményei 254

F 6.2.1 - H1 hipotézis 254

F 6.2.2 - H2 hipotézis . 264

F 6.2.3 - H3 hipotézis 266

Tevékenységek és felelőseik kereszttábla-elemzése 266

Kontrolltevékenységek klaszterelemzése 267

Kontrolltevékenységek faktorelemzése. 271

Kontrolltevékenységek működésére vonatkozó binomiális próba 276

F 6.2.4-H4 hipotézis 281

Egyetértés változóra vonatkozó vizsgálatok 281

F 6.3 - Másodlagos kutatási eszközökkel elért eredmények. 287

F 6.3.1 Vállalati esettanulmányok 287

Magyar Suzuki Zrt. 287

Magyar Telekom Nyrt. 298

Auchan Magyarország Kft. 306

F 6.3.2 Fókuszcsoportos megbeszélések emlékeztetői 316

BEMSZ workshop 316

MCE IGC workshop 318 


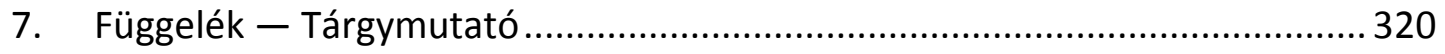

8. Függelék - Rövidítések jegyzéke .......................................................... 321

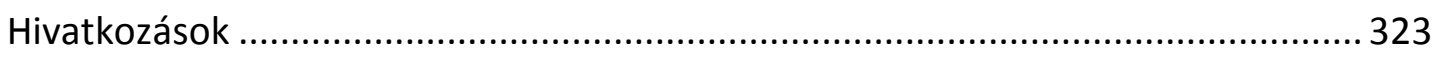

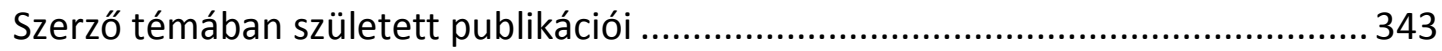




\section{TÁBLÁZATJEGYZÉK}

1. táblázat: Belső kontrollrendszer kiemelt szereplői területenként ....................... 94

2. táblázat: Az intézményesülés kulcsfogalmai............................................... 100

3. táblázat: A belső kontrollrendszerek intézményesülésének kulcstényezők szerinti

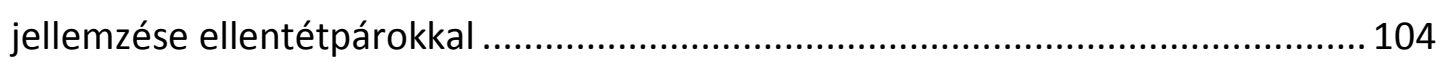

4. táblázat: Regisztrált gazdasági szervezetek száma Magyarországon 2015. dec. 31 -

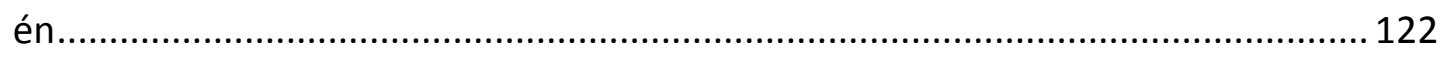

5. táblázat: Formakényszer szerint múködő gazdasági társaságok létszám szerinti

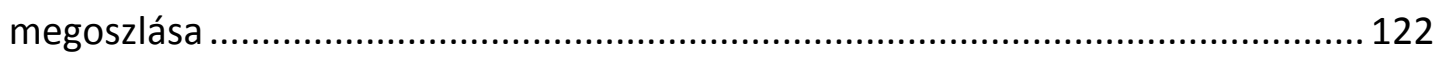

6. táblázat: Belső kontrollrendszert befolyásoló tényezők rangsorrendje.............. 128

7. táblázat: Belső kontrollrendszer kulcsszereplői, pozíciói ................................... 131

8. táblázat: TOP6 kulcsszereplő megoszlása napi teljes- és részmunkaidő alapján 133

9. táblázat: TOP6 kulcsszereplő megoszlása külső szolgáltatók igénybevételi szokásai

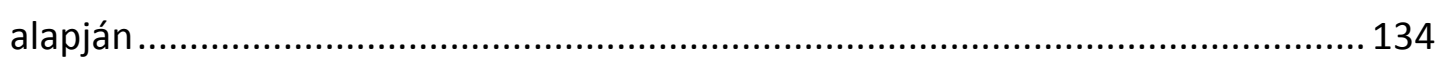

10. táblázat: TOP6 kulcsszereplő létszámadatai, leíró statisztikája.......................... 135

11. táblázat: TOP6 kulcsszereplő megoszlása szervezeti egységbe szerveződés

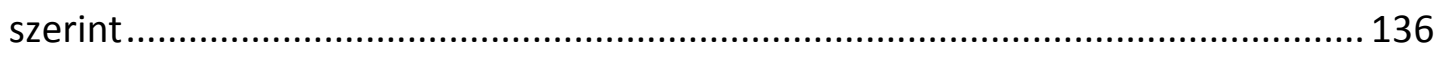

12. táblázat: Különféle kontrolltevékenységek elterjedtsége ............................. 137

13. táblázat: Egyetértésre vonatkozó átlag- és szórásmutató leíró statisztikája.... 143

14. táblázat: Egyetértések átlaga és szórása mutatók normalitásvizsgálati tesztjének

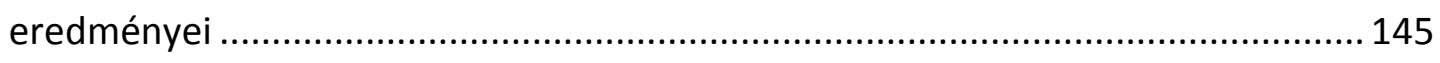

15. táblázat: Mélyinterjúba vont vállalkozások főbb jellemzői .............................. 149

16. táblázat: Az ellenőrzés időbeli fejlődése, tárgya és fókusza .............................220

17. táblázat: Populáció és minta társasági forma szerinti hasonlítása ................... 248

18. táblázat: Populáció és minta létszámkategória szerinti hasonlítása .................249

19. táblázat: Populáció és minta tevékenység szerinti hasonlítása ........................ 251

20. táblázat: Populáció és minta megye szerinti hasonlítása ................................ 253

21. táblázat: Befolyásoló tényezők gyakorisága a válaszadók körében ................. 255 
22. táblázat: Befolyásoló tényezők rangsorrendje, szórásjellemzői.....

23. táblázat: Befolyásoló tényezők Sperman-féle rangkorelációs mátrixa. 257

24. táblázat: Befolyásoló tényezők rangkorrelációja iparáganként. 261

25. táblázat: Befolyásoló tényezők rangsorrendje a hipotézisben és a mintában összehasonlítás 262

26. táblázat: H1 hipotézis és a minta szerinti rangsorrend elemzése 262

27. táblázat: Kulcsszereplők szerinti rangsor a hipotézisben és a mintában összehasonlítás 264

28. táblázat: H2 hipotézis és a minta szerinti rangsorrend elemzése 265

29. táblázat: A kontrolltevékenységekeket ellátó munkakörök - kereszttábla 266

30. táblázat: Klaszterelemzésbe bevont válaszolók száma 267

31. táblázat: Klaszterképzés összevonási táblázata 268

32. táblázat: Kontrolltevékenységek faktorelemzése.... 273

33. táblázat: Kontrolltevékenységek varianciatáblázata 275

34. táblázat: Kontrolltevékenységek múködésére vonatkozó binomiális teszt eredményei 280

35. táblázat: Egyetértési változó átlag és szórásmutatójának leíró adatai 282

36. táblázat: A változók normalitástesztjének eredményei. 282

37. táblázat: Az egyetértések átlagának és szórásának percentilisei 285

38. táblázat: Az egyetértés átlaga változó $3 \sigma$ szabály szerinti küszöbértékei 285 


\section{ÁBRAJEGYZÉK}

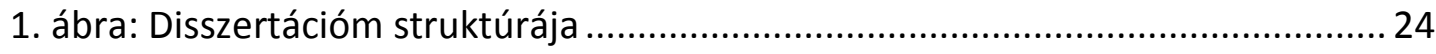

2. ábra: A kontroll fogalma és a COSO-keretrendszer közötti út 7 lépcsője - az

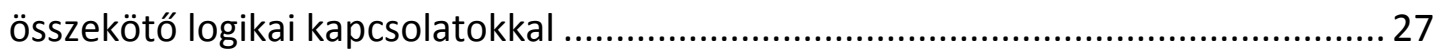

3. ábra: COSO I.- és COSO II. (COSO ERM)-modell összehasonlítása ..........................57

4. ábra: A COSO belső keretrendszer 5 komponense és hozzá tartozó 17 alapelve 59

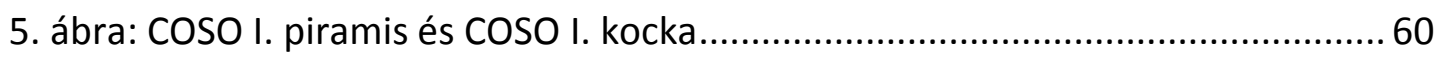

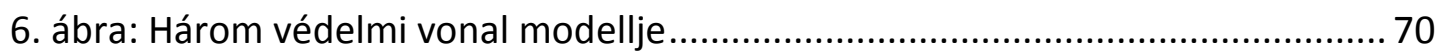

7. ábra: Irányítási Képességfelmérési Modell (Governance SPICE) .......................... 71

8. ábra: Intézményesülési folyamat komponensei ................................................ 78

9. ábra: Az intézményesülés rekurzív modellje..................................................... 79

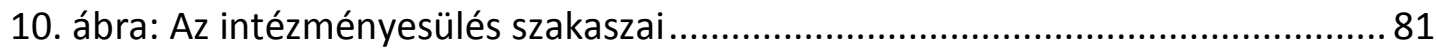

11. ábra: Az intézményesülés folyamata és keretrendszere ................................. 81

12. ábra: A belső kontrollrendszer intézményesülési szintjei.............................. 100

13. ábra: Kutatási térképem a hipotézisek feltüntetésével...................................119

14. ábra: Kontrollrendszer kulcsszereplőinek klaszterei (dendrogram) .................. 140

15. ábra: Kontrolltevékenységek megképzett klaszterei (dendrogram) ................. 141

16. ábra: Egyetértés szórásmutatójának hisztogramja.......................................... 144

17. ábra: Belső kontrollrendszer intézményesülési szintjeinek jellemzői a 3 szigma

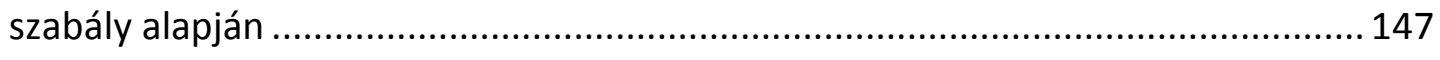

18. ábra: Kutatási eredmények szerint átdolgozott saját érettségi modell ............ 148

19. ábra: Függetlenített belső ellenőrzés tevékenységének átfogó folyamatábrája 5

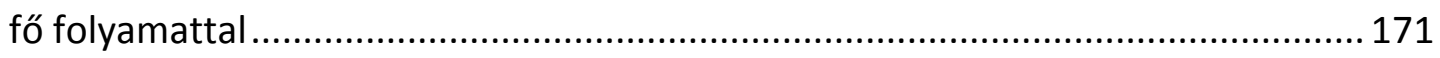

20. ábra: ISO folyamatszemléletű minőségirányítási modell és más szabványok

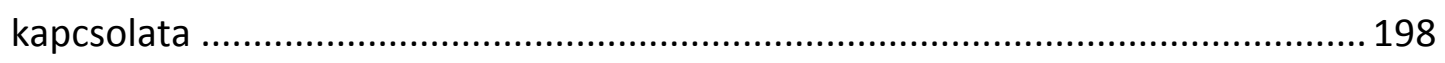

21. ábra: Minőségirányítási belső auditok folyamata és dokumentumai ............... 201

22. ábra: ISO 31000 kockázatkezelési elvek, keretrendszer és folyamatleírás........ 205 
23. ábra: Alkalmazás MSSQL adatbázis - alaptáblák

24. ábra: Alkalmazás MSSQL adatbázis - adatgyűjtő táblák.

25. ábra: Sperman-féle rangkorrelációs együttható egyenlete. 254

26. ábra: Befolyásoló tényezők (10 db.) fontosságának gyakorisági ábrái 260

27. ábra: A H1 hipotézisben és a minta szerinti rangsorrendek korrelációs scatterplot diagrammja. 263

28. ábra: A H2 hipotézisben és a minta szerinti rangsorrendek korrelációs

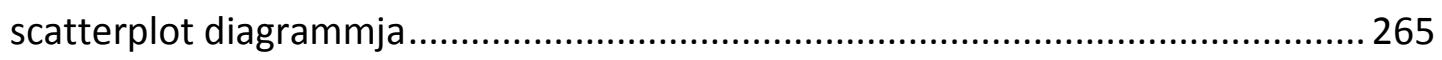

29. ábra: Kontrolltevékenységek klasztereire vonatkozó "jégcsapdiagram" ........... 269

30. ábra: Kontrolltevékenységek klasztereit ábrázoló dendogram ........................2270

31. ábra: Kontrolltevékenységekból képzett faktorkomponensek sceeplotja ........ 275

32. ábra: Az egyetértések átlagára vonatkozó változó normalitástesztjének Q-Q ábrája

33. ábra: Az egyetértések szórására vonatkozó változó normalitástesztjének Q-Q ábrája.

34. ábra: Az egyetértések átlaga változó hisztogramja 286

35. ábra: Az egyetértések szórása változó hisztogramja 286 


\section{ELŐSZÓ ÉS KÖSZÖNETNYILVÁNÍTÁS}

2010. szeptembere két okból kifolyólag is különleges volt életemben. Akkor született meg első lányom (Julcsi) és akkor kezdtem el a doktori képzésemet a Budapesti Corvinus Egyetem Gazdálkodástani Doktori Iskolájában. Julcsi lányomnak most ünnepeltük hatodik születésnapját, de a 2016. év azért is különleges, mert 6 év elteltével végre megszületett eme doktori disszertációm is.

Egykori kollégám sok éven át heccelt, hogy írjam meg többkötetes monográfiában a magyar gazdaság modernkori áttekintését a rendszerváltáskori vadkapitalista hajtásoktól egészen napjaink illiberális gazdaságpolitikai fordulatával bezárólag. Ilyen múvet végül nem írtam, de jelen doktori disszertációval végül mégis elkészültem, s most magyar és angol nyelven, előírt formában és terjedelemben, szükséges függelékekkel egybekötve nyújtom át olvasásra, mi több nyilvános bírálatra mindenki számára.

Nehéz irodalmi múfaj a doktori disszertáció írása. Nem adatik meg az embernek, hogy minden héten elkészítsen belőle egyet, kevés tehát a saját tapasztalata, mialatt végigjárja az alkotás rögös útját. Nehéz azért, mert rövidnek kell lennie. Nettó 160 darab oldalba kell belezsúfolnom minden tudást, mondanivalót, érvet, ábrát, amit éveken keresztül gyújtöttem és fogalmaztam a saját témámban. $A z$ ember úgy érzi, muszáj mindent beleírnia, mindent megmutatnia, amit olvasott, látott, és hallott a témáról, mert attól lesz egy doktori mú igazán egyedi. Aztán rá kellett döbbennem, hogy 160 oldalba nagyon kevés közlendő fér bele, és nagyon hamar betelnek a rendelkezésre álló oldalak, ezért nagyon oda kellett figyelnem, hogy mit tudok megtartani és mi mindent kell kihagynom a múből.

Nehéz azért is, mert objektívnek kell lenni és minden állítást hivatkozással, számítással, statisztikai összefüggéssel kell bizonyítani és nem lehet benne semmi érzelmi töltés. Belső ellenőri jelentést írótól ez az elvárás nem szokatlan. Ám mégis hogy maradjon érzelmektől mentes az ember, amikor látja a saját kutatása közben, hogy kérdőívére a vártnál kevesebben válaszolnak, vagy amikor szembesülnie kell hipotéziseinek szükségserű elutasításával? Mégis higgadnak és tényszerūnek kellett maradnom és talán ez az egyetlen olyan fejezet, ahol jelen sorokban mégis helyet hagytam némi emocionális faktornak.

Nehéz azért is, mert sok embernek írja a doktorjelölt múvét. Olvassa témavezető, tanszékvezető, intézetvezető, tanszéki kolléga, opponens és bíráló bizottsági tag, de vajon kinek mi a szájíze, tapasztalata, elvárása, heppje, kutatói beállítottsága, miközben ítéletet fog mondani a múről. És ez még csak az akadémiai szféra, ott van a vállalati szféra is, aki elmélet helyet inkább kézzel fogható gyakorlati tudást, tippeket, irányt kijelölő megállapításokat, saját cégében adaptálható módszereket szeretne megtudni e múből. Ők vajon végig fogják-e olvasni, vagy becsukják a 43. oldalon és mit fognak mondani, amikor személyesen találkozunk újra? 
Nehéz azért is, mert valami újat kell alkotni. Szervezett doktori képzésem 3 évén keresztül milliónyian figyelmeztettek rá, hogy a doktorjelöltnek valami olyat kell letenni az asztalra, ami új, egyedi, amivel bővíti a tudomány eddigi megállapításait, amit tehát eddig még senki nem állapított meg. Olyan ritka és egyedi eset ez, mint felfedezni a lakatlan szigetet, feltalálni a periódusos rendszer 119. elemét, vagy rábukkanni egy új égitestre az univerzumban. Nem mindennapi cselekmény felfedezni, bizonyítani és dokumentálni valami újat. Sőt, kifejezetten rémisztő volt szembesülnöm a ténnyel, hogy az általam kutatott témában nincs elérhető publikáció az EBSCO és egyéb adatbázisokban. Aztán megnyugodtam, mert rájöttem, én már jó úton járok, valami egyedit alkotok, amit még senki nem publikált.

Nehéz azért is, mert mélyre kell ásni és fókuszálni kell egy nagyon szűk témára, azt azonban nagyon alaposan kell körüljárni. Doktori tanulmányaim kezdetén úgy gondoltam, hogy általában fogok írni a kontrollt végző munkakörökről, erről fog szólni a disszertációm. Már a címe is megvolt: „Testőrök, avagy... „. Aztán be kellett látnom, hogy a doktori kutatási tézisek a nagyvilág széles spektrumának egy igen kicsi szeletéről szólnak, azt vizsgálják. Én kicsit sajnálom is, hogy diszertációm nem lehetett egy átfogó, rendszerező szemléletű mű, amivel bizonyítani tudom, hogy a téma komoly ismerője és elmélyült szakértője vagyok. Helyette a kontrollrendszerek egy szűk szeletét vizsgáltam részletekbe menően.

Nehéz azért, mert pénzigényes. Szerencsére nem kell hozzá mútő, gyógyszer, sterilizátor, labor, fárasztógép, vagy egyéb kísérleti eszköz. De kell hozzá nagyon sok szabadidő, aminek a feláldozott haszna a munkaidő, és a családi kasszából kiesett jövedelem. De nekem még kellettek hozzá szoftver, szakkönyvek, programozó, statisztikus, idegen nyelvi lektor, nyomda, vonatjegy, vállalati címlista, könyvtári belépő, tudományos konferencia, publikációs közzététel, szállás, étkezés, utazási eszköz, színes nyomtató és hozzávaló toner stb. és költségtérítéses doktoranduszként még be kellett fizetnem a féléves tandíjakat, a bírálati díjakat és az oklevél kiállítási díjat is. Az egyik autómat éppen a tanszéki értekezlet idején lopták el, a másiknak az ablakát éppen azalatt törték be, amíg én beszaladtam az intézeti titkárságra egy anyagot leadni! Erőforrás-igényes szakma tehát ez a doktori. Ha számszerűsítem, hogy összesen hány forintomba került a saját doktori disszertációm, magam is meglepődöm a végeredményen, ijesztő végösszeg adódik.

De a nehézségeket mégis leküzdöttem és derűsen várom a jövőt és bízom abba, hogy disszertációt bíráló és gyakorló menedzser is talál benne dicséretre érdemes részt, átolvasás után végül megalapozottnak és hasznosnak találja múvemet!

Megköszönöm támogatásukat mindazon személyeknek, aki nélkül e disszertáció nem jöhetett volna létre! Köszönetemet és hálámat mindenek előtt feleségemnek Zsófinak szeretném kifejezni e sorokkal is, aki helyettem dolgozott és pénzt 
keresett, lekötötte a gyermekek figyelmét és vigyázott rájuk akkor is, amikor én tudományos konferenciákra utaztam el, vagy éppen az Egyetemen oktattam, könyvtárban ültem. De ő volt az, aki kölcsönadta az autóját is, amikor az enyémet ellopták.

Köszönöm Szilágyi Attilának és Hurtony Péternek, hogy kutatói elképzeléseimet szoftveres kérdőív kitöltő és kiértékelő alkalmazássá alakították át és olykor a specifikációt meghaladóan gondoltak bele egy-egy kitöltési eset nehézségeibe! Köszönöm Lázár László témavezetőmnek a sok-sok iránymutatást, gondolatébresztőt és vitára lehetőséget adó konzultációt, amivel terelt a doktori képzés teljes folyamatában! Köszönöm Tirnitz Tamás adjunktus kollégámnak a megszámlálhatatlan nyelvhelyességi és didaktikai észrevételét, Drótos György tanszékvezetőmnek pedig intelmeit és segítségét a kutatási folyamat során, valamint Dobák Miklós intézetvezető professzor úrnak, hogy harcolt értem - mint hánykolódó TÁMOP támogatott doktoranduszért - az Egyetemen ott és akkor, amikor szükséges volt!

Köszönöm Kerti Lajos Úrnak, hogy a Wolters Kluwer Kft. Céginformációs Szolgálata részéről rendelkezésemre bocsátotta a kutatáshoz szükséges egyedi cégadatok listáját! Köszönöm a Belső Ellenőrök Magyarországi Közhasznú Szervezetének (BEMSZ) és a Magyar Controlling Egyesületnek (MCE), hogy a szervezet keretein belül egy-egy fókuszcsoportos workshopra kerülhetett sor! Köszönöm azon három vállalat kiemelkedő támogatását (Magyar Suzuki, Magyar Telekom, Auchan Magyarország), akiknél mélyinterjút készíthettem kutatásom során, név szerint Kovács Anikónak, Vas Tündének, és Balázs Ildikónak! Köszönöm Ferenczi Tamás adjunktusnak a statisztikai megállapítások felülellenőrzését és építő jellegű kritikáit, valamint Csekő István Benjaminnak az angol szaknyelvi lektorálásban nyújtott segítségét! A végleges angol nyelvű változat elkészültéért köszönettel tartozom az APT Hungária Kft. munkatársainak, fordítóinak!

Természetesen ez a lista nem teljeskörü, megannyi segítséget kaptam tanulmányaim során további oktatóimtól, kollégáimtól, tanácsadóktól, konzulensektől, szakmai egyesületi tagoktól, konferencia- és workshop résztvevőktől, szakmai publikációim összeállításához háttérszervezetek vezetőitől, cikkeimet olvasó érdeklődőktől, stb. Nekik is köszönöm a segítségüket, a támogatásukat a disszertációm elkészültéhez!

Julcsi lányomnak megígértem, hogy most már több időt tudok vele társasjátékozni, mert nem kell mindig a dolgozatomat írnom. Mire én habilitálok, ő már úgyis túl lesz az érettségin és nem velem akar majd játszani. Ez az élet rendje. Én pedig talán majd visszatérek a belső kontrollrendszerekhez és belekezdek egy új mú megírásába... 


\section{MOTTÓ}

„Doverjaj, no proverjaj!”

(Bízz, de ellenőrizz!)

Fenti mottó eredetileg orosz közmondásként terjedt el (Доверяй, но проверяй), tényleges szerzője nem ismeret. Németül "Fontos dolog a bizalom, de mégfontosabb az ellenőrzés - Vertrauen ist gut, Kontrolle ist besser!" változatban ismert. A XX. században sokan Lenin nevéhez kötötték e mondást, ám biztosan elhangzott Washingtonban 1987. december 8-án is, amikor Ronald Reagen és Michail Gorbacsov aláírta a történelmi jelentőségú INF szerződést.

E mottóval kívánom bevezetni azt a doktori tézist, melynek központjában a belső kontrollrendszer áll. Ennek kapcsán sokszor felmerül a vezetőkben is a dilemma, hogyan egyensúlyozzanak a belső bizalom és a kontroll, visszacsatolás között, azaz milyen hatékony és eredményes belső kontrollrendszert múködtessenek a szervezetekben. Ehhez a dilemmához kíván hozzájárulni az én disszertációm is. 


\section{RÉSZ}

\section{BEVEZETÉS - A KUTATÁSI TÉMA ÉS A DOLGOZAT BEMUTATÁSA}

Doktori disszertációm tárgya a vállalaton belüli kontrollrendszer intézményesülése. Arra keresem a választ, hogy a vállalatok belső kontrollrendszere hogyan intézményesül a hazai üzleti szervezetekben, és ennek a folyamatnak milyen jellemzői, stációi, elemei és kulcsszereplői vannak. Disszertációmban a belső kontrollrendszer fejlettségi szintjeivel, annak szabályaival, jellemzőivel, meghatározó szereplőivel, illetve a kontrollrendszerek internalizálódásával foglalkozom, és ennek kapcsán végzek kutatást a magyar vállalkozásokra vonatkozóan.

\subsection{A téma célcsoportjai, relevanciája és időszerüsége}

Disszertációm végső célja annak igazolása, hogy a belső kontrollrendszerek vállalaton belüli intézményesülése jellemezhető különféle kritériumokkal. További célom bemutatni: az intézményesültség szakaszai elméleti modellel leírhatók, és ezt ebben a témában önálló kutatási eredményekkel támasztom alá, ez által kívánom bővíteni új tudással a meglévő ismereteket a belső kontrollrendszerekről. Manapság elterjedt az interdiszciplináris társadalomtudományi kutatás, azaz több tudományterület integrálása egy-egy vizsgálati nézőpontba (Braun \& Schubert, 2008.). Értekezésemben a belső kontrollrendszer múködésének vizsgálata során közgazdasági, jogi, szociológiai tudományterületi szempontok egyszerre merülnek fel. A belső kontrollrendszerek intézményesülésének átfogó, több modellen keresztüli vizsgálata érdekes lehet más kutatók számára, mint ahogyan az intézményi szociológia alkalmazása is érdeklődésre tarthat számot a szervezetelméletek iránt érdeklődőknek.

Ugyanakkor a belső kontrollrendszer a vállalatok vezetői számára is vonzó témául szolgál. A vezetői feladatok, funkciók közé soroljuk a kontrolltevékenységet. Ezért vállalkozások vezetői, menedzserek, céget irányító igazgatók számára érdekes lehet, hogy vállalatukban, vállalkozásukban a múködést támogató belső kontroll hogyan szerveződik és intézményesül, kik a fő felelősei, szereplői, milyen elemekből tevődik össze egy hatékonyan és eredményesen működő rendszer, és annak milyen fejlődési szintjei vannak. Feltételezésem szerint a téma iránt fogékonyak lesznek az auditor munkatársak, a belső ellenőrzési szakma képviselői, de még a 
könyvvizsgálókat is érdeklődéssel töltheti el a belső kontrollrendszer alaposabb megismerhetőségének lehetősége.

A téma aktualitását inkább a kontrollrendszerek gyangesége adja. A vállalati belső kontrollok átfogó intézményesüléséről, működési mechanizmusairól a mindennapi üzleti életben keveset beszélünk, azonban hiányáról sokat értekezünk, a hiány káros következményei vissza-visszatérnek publikációkban, sajtóban, továbbképzéseken, szakmai előadásokon és konferenciákon. A csalás, a korrupció, a vállalaton belüli visszaélések, a pénzmosás jelenleg slágertémák a világban, és így hazánkban is. A nemzetközi és a hazai sajtó előszeretettel tudósít botrányokról ${ }^{1}$, melyek alapos kiértékelése a tudomány múvelői számára később évekig tart, sokszor leszűrve azt a tanulságot, hogy a belső kontrollrendszerek nem múködtek eredményesen. Az már kevésbé vezető hír a sajtóban, hogy az üzleti tevékenységet állandóan kontrollálni kell, a cég saját működését ellenőrizni és ennek eredményét visszacsatolni szükséges a kisvállalkozások vezetőinek is, miközben egy tetszőleges kkv is egy kockázatokkal teli piacon múködik, ahol az elért eredményt, az üzleti teljesítményt befolyásolja a stratégiai céltudatosság, az etikai normák, de a kockázatmenedzselési képesség is.

A téma ugyanakkor nem csak a kisvállalkozások számára releváns. A multinacionális cégek álláshirdetéseit böngészve állíthatjuk, hogy egyre több fraud managert, compliance advisort, forensic accountantot és internal control expertet keresnek hazánkban is. Felértékelődni látszik a hazai nagyvállalatokon belül is a kontroll szerepe, erre nyilvánvalóan hatással vannak az emelkedő hatósági bírságok, az egyre magasabb szintű anyavállalati igények és tulajdonosi elvárások, de a szigorodó nemzetközi standardok is. A jól múködő vállalati kontrollrendszernek számos előnye van a szervezetre és környezetére nézve is. A vezetők nyugodtan alszanak, a befektetők nem szabadulnak meg a cég részvényeitől, a pénzügyi beszámolók adataiban megbízik a sajtó és az adóhatóság is, a cég reputációja nem sérül stb. Mindezek összességükben a vállalat értékét is növelik, képessé teszik a gyorsabb reagálásra, váratlan események lekezelésére, a fenyegető kockázatok szakszerű kezelésére. A hatékony belső kontrollrendszer arra hivatott, hogy ezeket (is) igyekezzen biztosítani.

\footnotetext{
1 Lásd például az évtized top 30 magyar üzleti, gazdasági botrányát összefoglaló cikket itt: http://www.vg.hu/manager-magazin/az-evtized-top-30-magyar-botranya-348132 (2015. 02. 25.), valamint a cikk megjelenése óta eltelt időszakból az étolaj-áfabotrányt, az uniós agrártámogatások ügyében indult nyomozásokat, valamint a 2015 februárjában kirobbant brókercégek botrányát. Ugyancsak jelentős botrányokat mutat be könyvében nemzetközi és hazai elkülönítésben Lukács János is (Lukács, 2014, pp.14-42.).
} 


\subsection{A téma kifejtése, lehatárolása}

A vezetők által gyakorolt kontroll a szervezetek létrejötte óta létező tevékenység, tartalma azóta azonban sokszor átalakult, szerepe megváltozott. A tudomány és az üzleti gyakorlat egymásra hatásából kifolyólag a vállalatokban különféle ellenőrző-, visszacsatoló- és kontrollmechanizmusokat alakítottak ki. A világon legelterjedtebb, belső kontrollrendszert leíró, általános modell az 1992 óta létező COSOkeretrendszer. A belső kontrollt (internal control) szerzőtől és fordítástól függően belső kontrollrendszernek, belső kontrollfolyamatnak, integrált kontrollmechanizmusoknak is hívják, a publikációk egy részében a COSOkeretrendszer így jelenik meg. Kutatásom tárgya e kontrollmechanizmusok múködésének mélyebb vizsgálata, beleértve azok intézményesülését is a szervezetekben.

Az intézményi szociológia a szervezetközi terekben élőnormák, szokások, folyamatok állandóvá válásával, belső normává érésével foglalkozik. Dolgozatomban arra keresem a választ, hogy a belső kontrollrendszerek hogyan intézményesülnek, ki vagy kik az intézményesülés szereplői (aktorai), milyen formái vannak az intézményesülésnek, ezek mennyiben tekinthetők „puha” vagy „kemény” vállalati szabályoknak, és ezeken keresztül hogyan válik a belső kontrollrendszer egyre inkább szervezett, céltudatos, eredményorientált, vállalaton belüli folyamattá.

Doktori disszertációm fő kutatási kérdése: hogyan érhető tetten a belső kontrollrendszer múködési érettsége, ezáltal az intézményesülés folyamata, stációi. Erre vonatkozóan fogalmazok meg hipotéziseket és mutatom be kutatási eredményeimet.

Disszertációmban a kontrollt és a visszacsatolást szinonimaként használom, valamennyi mögött a szervezetekben múködő belső kontrollrendszert (internal control system) feltételezem, melynek csak egyik elemét képezik az ellenőrzési feladatok. Fogalmazásomban, példáimban a belső audit fogalmát is alkalmazom még könyvvizsgálati, illetve minőségirányítási aspektusban, melyek célja ugyancsak bizonyosság nyújtása valamilyen tényről, adatról, állapotról, azaz megközelítésemben a kontrollrendszer része.

A belső kontrollrendszerek múködését az üzleti szervezetekben, azaz a gazdasági társaságok életében vizsgálom. Dolgozatomban a vállalatokra koncentrálok, ezzel szinonimnak tekintem a szervezet, az üzleti szervezet, a cég kifejezéseket és a munkaszervezettel rendelkező vállalkozásokat. Ezért a kutatási fókuszomból kiesik a civil szféra és a költségvetési szerveken belüli kontroll, azaz az államháztartás belső kontrollrendszere. Noha a belső kontrollrendszerek mindhárom szektorban a COSO alapnormáira épülnek, s ebből kifolyólag mindháromnak hasonló a belső 
kontrollmechanizmusuk, mégis lehatárolom kutatásomat az üzleti szféra szervezeteire. Ennek legfőbb oka az eltérő gazdasági orientáció (nyereségszerzés vs. közszolgáltatás vs. társadalmi közjó), a különböző jogszabályok alkotta eltérő szabályozási környezet (vállalkozási számvitel és gazdasági társasági jog vs. államháztartási törvény vs. civil törvény) és az ott dolgozó munkavállalókkal szembeni eltérő követelmények (munka törvénykönyve vs. közalkalmazotti/köztisztviselői/kormánytisztviselői törvény vs. önkéntességről szóló törvény). Azt azonban el kell ismerni, hogy igen jelentős szakirodalom és módszertani leírás, jogszabály és előírás, norma és politikai kommüniké áll az államháztartási belső kontrollok témájában rendelkezésre már hazánkban is, ezért szakirodalmi merítés szintjéig e szektorban készült, a cOSO-keretrendszert alkalmazó művekből is idézek értekezésemben.

Disszertációmban elkerülöm a nem gazdasági jellegú kontroll tárgykörét, úgymint műszaki ellenőrzés, pedagógiai szakellenőrzés, élelmiszer-biztonsági ellenőrzés, fogyasztóvédelmi vagy egyéb szakmai, hatósági ellenőrzés stb. Noha ezeknek is van követelmény-visszacsatolás és szabálymegfelelősség aspektusa, mivel szakmai szabályokon alapulnak, szakmaspecifikus normák ellenőrzésére irányulnak, mégsem témái az disszertációmnak, hiszen én a pénzügyi-gazdasági természetú belső kontrollrendszer területét dolgozom fel.

Dolgozatomban nem írok a külső pénzügyi ellenőrzésről (tipikus ellenőrző szervei: NAV, OLAF, ÁSZ, KEHI, MNB, MÁK stb.), azaz külső szervezet/hatóság által végzett pénzügyi-gazdasági ellenőrzésekről, pályázatkezelők által végzett monitoring jellegú ellenőrzésekről, adó-, vám- és pénzügyőri ellenőrzésekről stb. Noha ezek módszertanukban nagy hasonlóságot mutatnak a belső kontrollrendszeren belüli ellenőrzési módszertannal és eszközrendszerrel, ezek sem témái a disszertációmnak, mert más a céljuk, normarendszerük, orientációjuk, mint a belső kontrollmechanizmusoké.

Dolgozatom középpontjában a COSO-normákból eredő belső kontrollrendszer áll, amely valamennyi belső kontrollmechanizmust, ellenőrzési aspektust lefed, egyfajta univerzális modellként tekinthetünk rá. Ezért dolgozatom nem szükül le pusztán a vállalati csalásfelderítésre, kockázatkezelésre vagy éppen a korrupciókutatásra, ezeket mind részelemeinek tekintem a belső kontrollrendszer múködésének. Dolgozatom elemeiben tartalmazza ezeket a kontrolltevékenységeket is, de nem hegyezem ki ezek egyikére sem értekezésemet, hiszen témájukban egy-egy önálló kifejtést (s ilyen módon akár egy-egy önálló disszertációt) igényelnek.

Értekezésemben nem foglalkozom az egyéni szintű, azaz személyen belüli önkontrollal sem, és nem tárgyalom az ellenőrzés pszichológiai aspektusát, az önellenőrzés és a vezetői önkontroll témáját. Ezek a pszichológia területére tartozó 
kutatási területek, noha van ráhatásuk a vállalaton belüli ellenőrzésekre is (lásd például az Ouchi-féle klán kontroll szerepét később kifejtve), azok személyes megélése és megértése ezen ismeretvilág alapján jobban megtehető.

A coso-keretrendszeren nyugvó belső kontrollrendszer intézményesülését az intézményi szociológiai megközelítésből kutatom, amely a szervezetelméletek egyikeként azt vizsgálja, hogy a szervezeten belüli cselekvések hogyan válnak állandóvá, beágyazottá, az írott szabályok és íratlan normák miképp alakulnak ki, azok hogyan válnak megkérdőjelezhetetlenné.

\subsection{Alkalmazott módszerek és eredmények}

Választott kutatási módszertanom kvantitatív elveken nyugvó, elsődlegesen kérdőíves megkeresést alkalmazó módszer. Másodlagos, ráerősítő céllal készítettem vállalati mélyinterjúkat is a belső kontrollrendszerekről konkért üzleti szervezetekben. Az adatfelvételt elektronikus úton, online-kérdőív kitöltés révén végeztem. Kutatási eredményeimet 132 vállalat által teljeskörően kitöltött kérdőívben található válaszok alapján fogalmaztam meg, megállapításaimnál figyelembe vettem továbbá három vállalkozásnál végzett személyes mélyinterjúm eredményeit. Két szakmai szervezet tagjai körében pedig egy-egy fókuszcsoportos megbeszélésen elemeztük a kutatás kérdéseit, illetve eredményeit.

Az alkalmazott kutatásmódszertani eszközöket a konkrét hipotézisekhez, valamint a kérdőíves adatbázis adataihoz igazítottam. Használtam leíró jellegű elemzéseket (átlag, szórás, csúcsosság, módusz, medián), Sperman-féle rangkorrelációt, faktorelemzést, Pearson féle korrelációt, klaszter- és faktorelemzést, normalitásvizsgálatot Kolmogorov-Szmirnov módszerrel, melyek eredményeit mellékeltem disszertációmhoz.

\subsection{Az értekezés felépítése}

Dolgozatom struktúráját, a részek egymásra épülését az alábbi logikai fonal határozza meg:

- 1. rész: Bevezetés, témafelvezetés, itt kapott helyet minden olyan alapvetés, amely a dolgozat témájára, a kutatási célokra és a disszertáció struktúrájára vonatkozik.

- 2. rész: Kontroll a vállalatokban, amely felvezető részként általánosságban mutatja be a gazdálkodástudományi, illetve menedzsmentszemléletű kontroll lényegét, legfontosabb szerzőinek definícióit.

- 3. rész: A COSO-keretrendszer bemutatása és kritikai szemléletű elemzése, ahol a szakirodalom ismertetésén túl utalok a belső kontrollrendszerek 
legfontosabb szereplőire, illetve más, e keretrendszerre épülő vagy ezt kiegészítő modellekre.

- 4. rész: A vállalati kontrollrendszerek intézményesülésének fejezete, ahol az intézményi szervezetelméletet, annak fogalmi kereteit, definícióit, folyamatát mutatom be, összekapcsolva a belső kontrollrendszerrel, annak intézményesülésével. $E$ fejezet végén kapott helyet az intézményesülés stációit bemutató saját modellem ismertetése.

- 5. rész: Saját kutatási terv és az eredmények bemutatása, ahol az elemzés, vizsgálódás pontosabb témáját, fogalmait mutatom be, itt fogalmaztam meg hipotéziseimet, továbbá ismertetem az alkalmazott kutatás-módszertant, a mintavétel és az adatfelvétel lépéseit, valamint ismertetem a hipotézisekre adandó kutatási eredményeket, válaszokat.

- 6. rész: Az összegzés és a további kitekintéseket tárgyaló fejezet, melyben összegzem disszertációm legfontosabb eredményeit, ráerősítek főbb téziseimre, bemutatom ezek határait és a kutatási eredmények korlátait, valamint a megállapításaimból táplálkozó új kutatási témákat javaslok.

- Az 1. számú függelék a szervezeten belüli kontrollt gyakorló tipikus munkakörök, munkavállalók, szereplök (aktorok) tevékenységi körét ismerteti vázlatosan. Ilyen formában szervesen kötődik a 3. és 4. számú részhez, az abban foglalt szereplők tevékenységének konkrét bemutatása volt célom a függelékben való elhelyezéssel.

- A 2. számú függelék a gyakran alkalmazott kontrollmódszerekkel, ellenőrzési eszközökkel foglalkozik, azt felsorolásszerúen mutatja be dolgozatom tárgykörével összhangban, így az a 3. és 4. számú részekkel van szoros kapcsolatban.

- A 3. számú függelék az előzőhöz hasonlóan vállalatra ható kockázati tényezőket, kedvezőtlen jelenségeket foglalja össze, melyekre kiterjedően, azok kivédése, illetve megoldása érdekében a vállalatok rendszerszerű kontrolltevékenységeket végeznek. Ezért e függelék szintén kapcsolódik a 3. és 4. számú részekhez.

- A 4. számú függelékben röviden áttekintem a gazdasági és pénzügyi kontrollok, valamint az ellenőrzés rendszerének fejlődését a kapitalista és szocialista berendezkedésű országokban.

- Az 5. számú függelék az V. részben ismertetett kutatási tervhez kapcsolódik, a hipotézisek igazolására vonatkozó kérdéseket, valamint a kutatás során használt adatgyűjtést megalapozó űrlapot (elektronikus kérdőívet) tartalmazza.

- A 6. számú függelék a matematikai-statisztikai függelék, itt kapott helyet valamennyi olyan bizonyítás, levezetés, SPSS output és táblázat, amely a 
hipotézisek tesztelésével és kiértékelésével kapcsolatossak és megállapításaim alátámasztását szolgálják.

- A 7. és 8. számú függelékbe került a tárgymutató, illetve a rövidítések jegyzéke.

Fentiek alapján dolgozatom részeit az alábbi 1 . ábra szemlélteti összefoglaló jelleggel:

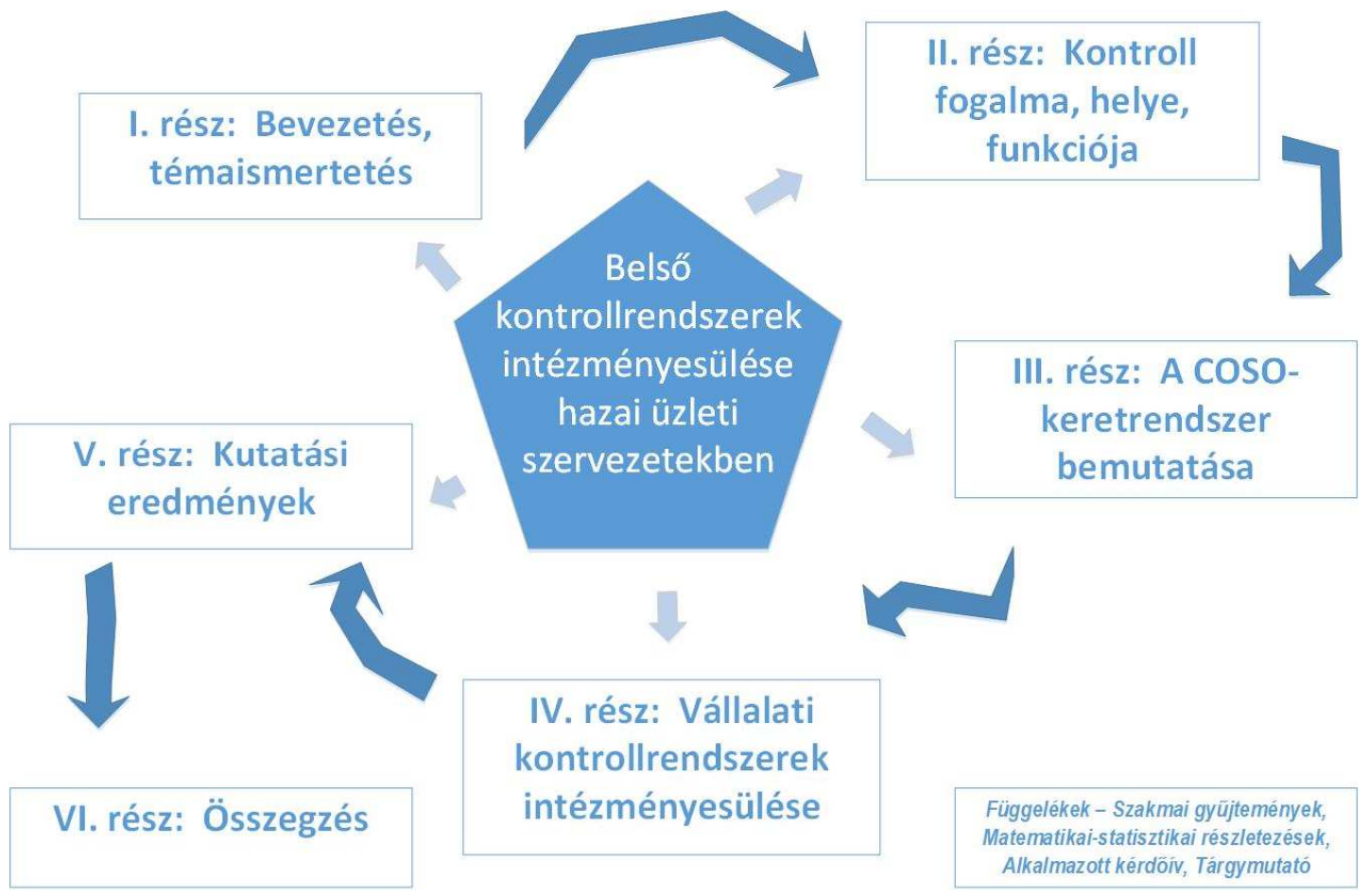

1. ábra: Disszertációm struktúrája

Forrás: Saját szerkesztés

\subsection{Hivatkozások kezelése}

Disszertációm főszövegében és a függelékekben egységesen harvardi hivatkozásrendszert használok, melyet technikailag háttérben a Word szövegszerkesztő program végez el automatizáltan².

Értekezésem végén sorrendbe szedve közlök valamennyi olyan felhasznált szakirodalmat, melyekre a főszövegben és a függelékekben hivatkozom legalább

\footnotetext{
${ }^{2} \mathrm{Az}$ általam használt harvardi hivatkozási stílust lásd részletesen a University of the West of England oldalán: http://www1.uwe.ac.uk/students/studysupport/studyskills/referencing/uweharvard.aspx (letöltve: 2016. 03. 11.), valamint a hozzá tartozó MS Word stílusformulát itt: http://james.greenhalgh.eu/blog/2013/uwe-harvard-referencing-in-word-2013/ (2016. 03. 11.)
} 
egyszer. Ezek között megtalálhatók a tudományos közlemények és szakkönyvek, valamint a sajtóban és honlapokon publikált egyéb források is.

Az egyes fejezetekben lévő szó szerinti hivatkozásokat eredeti angol nyelven mutatom be. Ennek oka, hogy láttatni akarom az eredeti originális meghatározást, majd azokból vezetem le a magyar meghatározásokat, definíciókat, időnként pedig szembe is állítom őket egymással.

Lábjegyzetben találhatók azok az egyéb kiegészítő információk és kitekintő források, amelyek a föszöveg tartalmától elvezetik az olvasót, de mégis fontosnak tartottam jelezni, hogy érdeklődés esetén hol lehet bővebben megismerni az általam közölt információkat. Ezért a láblécben található források csak kiegészítő szerepet töltenek be értekezésemben és a hivatkozások jegyzékében nem jelennek meg külön szakirodalomként.

Az áttekintést jobban elősegítő tartalomjegyzék, valamint ábra- és táblázatjegyzék az I. fejezetet megelőzően kapott helyett értekezésemben, míg az oldalszámozással bővített tárgymutató, és a gyakran használt rövidítések jegyzéke a függelékek között található meg. A disszertációban elhelyezett ábrák komplex szemléltető ábrák, ezért kis betűmérettel készültek, feltételezésem szerint az olvasók a dolgozat digitális példányát tudják szükség szerint nagyítani, az ábrák méretét növelni. 


\section{RÉSZ}

\section{A KONTROLL ÉRTELMEZÉSE ÉS A KONTROLLRENDSZER ÁLTALÁNOS BEMUTATÁSA}

A vállalati belső kontrollrendszerek mára a szervezetek működésének szerves elemévé váltak. A vezető kontrollálási feladatköre a szakirodalmakban az elmúlt évszázad során megkérdőjelezhetetlenné vált, és ma már senki nem vonja kétségbe azt sem, hogy a vezetőnek sokszínú munkája során kiterjedt, többszempontú és folyamatos visszacsatolásokat kell végeznie. Mindezeket annak érdekében, hogy a vállalati célok, stratégiák, tervek megvalósulását folyamatosan mérje és értékelje, szükség szerint a visszacsatolás alapján pedig a szervezet módosítani tudja saját működését, tevékenységét, folyamatait, vagy átértékelhesse céljait, módosíthassa üzleti folyamatait.

A szervezetben azonban nem csak a vezető végez kontrolltevékenységeket. A tulajdonos, a hatóságok, az alkalmazottak, a közvetlen irányítást végző munkavállalók is kontrollálnak munkájuk során. Ezért ahhoz, hogy megértsük a vállalatokon belüli, szervezett kontrollrendszerek múködését, le kell határolnunk azt definíciók segítségével, illetve számos elágazás révén jutunk el a belső kontrollrendszer COSO szerinti múködési keretrendszeréhez.

Ebben a részben tehát megalapozom a következő fejezetben részletezett COSO belső kontrollrendszert. Itt kap helyet a kontroll és az ellenőrzés fogalmi bevezetése a szakirodalmak alapján, illetve a történelmi fejlődés bemutatása, valamint a külső és a belső orientációjú ellenőrzés elkülönítése, a rendszer szó általános meghatározása, és több definíciót mutatok be arra vonatkozóan, hogy ki mit tekint kontrollnak, s miképpen viszonyul a kontroll és az ellenőrzés egymáshoz, hogyan lehet a kontrollt az ellenőrzéstől elhatárolni.

Saját logikám alapján összesen 6 lépcső végigjárásával jutok el a COSO-modellhez, mely lépéseknek a sematikus ábrája az alábbi, 2. számú ábra, ez egyben e fejezet tartalomjegyzékszerű bemutatására is alkalmas. Az ábrából kitűnik, hogy az egyes lépcsőfokok végén következtetést vonok le az egyes lépcsőket illetően, és megindokolom, hogy miért kell továbbhaladni, további elágazásokat tenni, illetve milyen irányban kell mélyebben vizsgálódni ahhoz, hogy a coso belső kontrollrendszerig eljussunk.

A szakirodalom bemutatása abban segít nekünk eligazodni, hogy a vezetői, illetve vállalatirányítási kontrollt mely fogalomrendszer, modell(ek) alapján szervezik meg, és ezeknek az eltérő modelleknek melyek a legfontosabb jellemzői. E definíciók bemutatásával az a célom, hogy láttassam a szervezeti kontroll sokszínúségét, és 
bemutassam a belső kontrollrendszer kifejezéshez elvezető utat az ide tartozó megközelítések segítségével.

Disszertációm II. fejezetének vázlatos útját a 2. számú ábra mutatja:
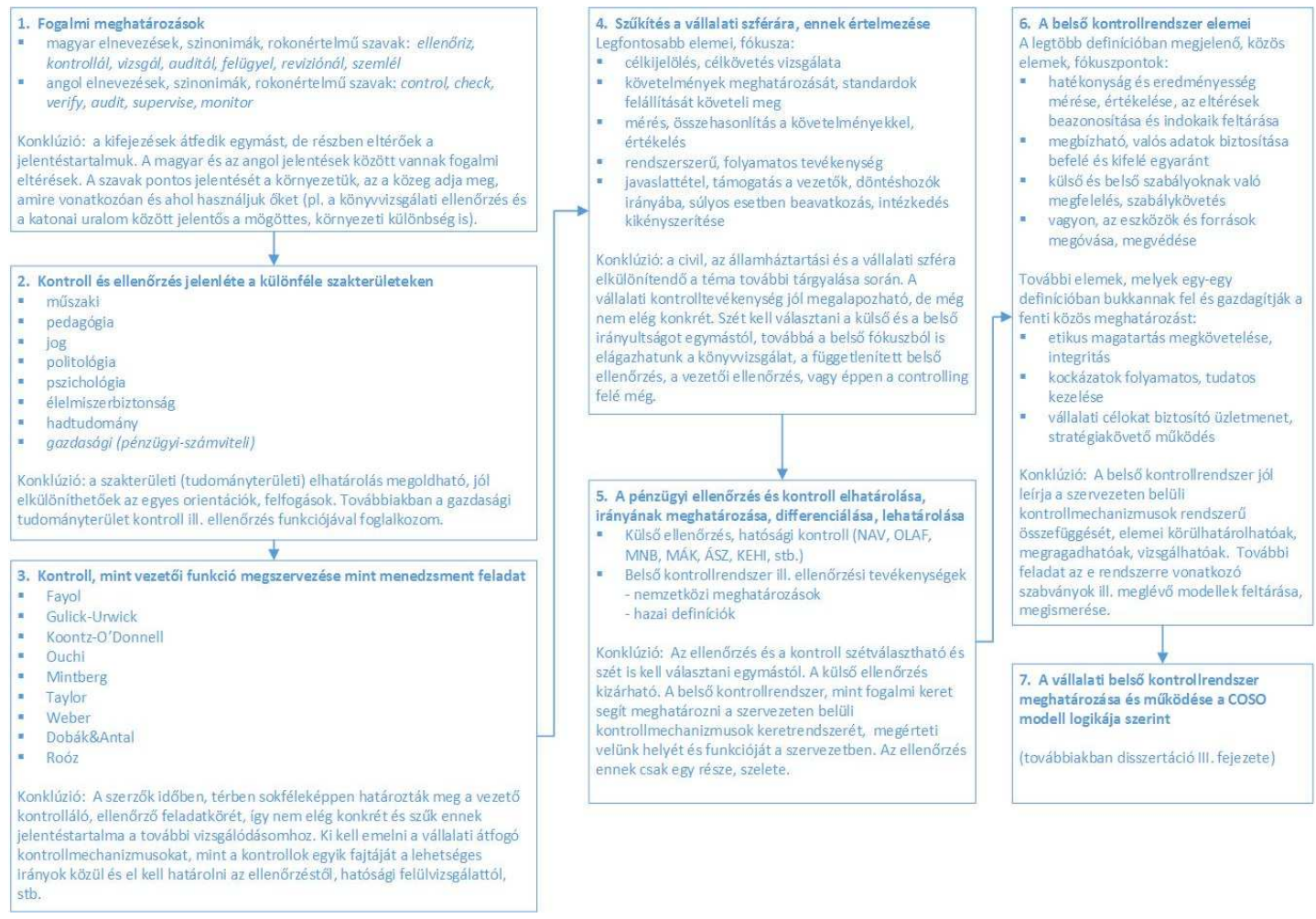

2. ábra: A kontroll fogalma és a COSO-keretrendszer közötti út 7 lépcsője - az összekötő logikai kapcsolatokkal Forrás: Saját szerkesztés

\subsection{Fogalmi elhatárolás - a kontroll és az ellenőrzés szavak alapvető jelentéstartalma, értelmezése}

A Magyar értelmező kéziszótárban (Magyar Tudományos Akadémia Nyelvtudományi Intézetének munkatársai, 2003.) az ellenőrzés és a kontroll fogalom szinonimájáról győződhetünk meg. Ha a szótárban a kontroll kifejezést keressük ${ }^{3}$, akkor a kiadvány az ellenőrzés szóhoz irányít minket. A kéziszótár szerint az ellenőriz ige ${ }^{4}$ nem más, mint:

„1. Vkit, illetve vmely tevékenységet, munkát vagy állapotot, helyzetet (elbírálás végett) megvizsgál, figyelemmel kísér.

\footnotetext{
${ }^{3}$ Magyar értelmező kéziszótár 731. oldal, kontrollál címszó, Akadémia Kiadó, 2003.

${ }^{4}$ Magyar értelmező kéziszótár 279. oldal, ellenőriz címszó, Akadémia Kiadó, 2003. A kéziszótár ismerteti még az ellenőrzés katonai értelmezését, mely szerint „valamely területet felügyelet és irányítás alatt tart”, továbbá az orvoslásból eredő: „kontrollra visszahív” kifejezést is ugyanitt.
} 


\section{Adatokat, méreteket helyességük szempontjából felülvizsgál."}

Ugyancsak itt találjuk azt az értelmezést is, miszerint az ellenőrzés mint főnév:

„1. Az a cselekvés, eljárás, hogy vkit, vmit ellenöriznek.

2. Az ezt végző szerv, részleg."

A vizsgál szónál pedig azt olvashatjuk ${ }^{5}$, hogy

„Alaposan, részletesen megnéz, figyel. Alaposan tanulmányoz vmit, hogy mivoltáról, állapotáról tudomást szerezzen. Ellenöriz."

Láthatjuk tehát, hogy a kontroll és az ellenőrzés, vizsgálódás kifejezések a magyar hétköznapi nyelvben egyazon dolgot jelentik, a napi szóhasználatban ugyanúgy értelmezik ezeket. További néhány rokonértelmű szót, közeli jelentéstartalmú, illetve olykor szinonimaként kezelt szót a kéziszótár a következőképpen határoz meg. A felügyel ${ }^{6}$ ige így szerepel benne:

„1. Vigyáz valakire, valamire, hogy baj ne érje.

2. Valakinek, valaminek a tevékenységét ellenörzi."

A revízió ${ }^{7}$ szóra a következő értelmezést találjuk:

„1. Felülvizsgálat alapján történő módosítás.

2. Ellenörző vizsgálat. Intézmény, vállalat gazdálkodásának hivatalos ellenörzése."

A szemlél ${ }^{8}$ ige meghatározása pedig a következő:

„Figyelmesen, hosszasan néz, vizsgál valakit, valamit.”

Néhány további kifejezés, szinonima megvizsgálása szükségszerű még ahhoz, hogy az ellenőrzés szó egyéb jelentéseivel tisztában legyünk. A Magyar értelmező kéziszótárban a mustra ${ }^{9}$ szót katonai ellenőrzésként definiálják, míg a monitoroz ${ }^{10}$ szót (természeti) jelenség tudományos módszerességgel, folyamatosan történő megfigyeléseként írják le.

A kontroll fogalma elvontabb szóhasználatban, illetve más tudományterületeken is ismert (Vértesy, 2012., pp.3-4.). A politikatudomány a kontrollt valami felett való uralomnak, illetve a kormányzás egyik eszközének tekinti, amely által a hatalom gyakorlója céljait megvalósítja. Az ellenőrzés szó a katonai szóhasználatban is

\footnotetext{
${ }^{5}$ Magyar értelmező kéziszótár 1481. oldal, vizsgál címszó, Akadémia Kiadó, 2003. A vizsgál szóhoz kapcsolódóan a könyvvizsgálat meghatározását is tartalmazza a szótár a 749. oldalon a következők szerint: „A könyvelés jogi és tartalmi helyességét ellenőrző vizsgálat, revízió."

${ }^{6}$ Magyar értelmező kéziszótár 380. oldal, felügyel címszó, Akadémia Kiadó, 2003.

${ }^{7}$ Magyar értelmező kéziszótár 1145. oldal, revízió címszó, Akadémia Kiadó, 2003., mely a fentieken túlmenően ismerteti a revízió szó nyomdai szedésre vonatkozó értelmezését is.

${ }^{8}$ Magyar értelmező kéziszótár 1242. oldal, szemlél címszó, Akadémia Kiadó, 2003.

${ }^{9}$ Magyar értelmező kéziszótár 952. oldal, mustra címszó 4. bejegyzés, Akadémia Kiadó, 2003.

10 Magyar értelmező kéziszótár 941. oldal, monitoroz címszó, Akadémia Kiadó, 2003.
} 
megjelenik, ott meghatározott földrajzi terület felügyeletét és irányítás alá vonását jelenti. Jogszociológiai értelemben a kontroll a társadalmi elvárások megtestesítője. A jogtudományban az ellenőrzés nem mást, mint jogalkalmazói határozatok, ítéletek, döntések jogszabályi megalapozottságának vizsgálatát jelenti.

A magyar ellenőrzés, illetve vizsgál és szemlél szavak áttekintése alapján tehát látható, hogy ezeknek a meghatározásoknak közvetlenül közgazdasági, vállalatgazdasági szintre szúkített értelmezése nincsen, a (pénzügyi) ellenőrzésre utaló szúkítése nem olvasható ki az értelmezésből. Ugyanakkor a revízió szó szótári értelmezésében a gazdálkodásra utaló jelző már megjelenik, csakúgy, mint a könyvvizsgálatra vonatkozó meghatározásban is. Ezért nem egyértelmű, hogy mely fogalmat miképpen helyettesítjük, illetve mely szót „szakmailag” mire használunk a témában.

Disszertációmban továbbiakban a kontrollt gazdálkodástudományi aspektusban mutatom be. Fontos tehát elhatárolni a kontroll (beleértve a (gazdasági/pénzügyi) ellenőrzés) fogalmát más tudományágban, szakterületen, munkakörökben alkalmazott ellenőrzésektől, mint például a műszaki ellenőrzés ${ }^{11}$, pedagógiaiszakmai ellenőrzés ${ }^{12}$, élelmiszer-biztonsági szakellenőrzés ${ }^{13}$, munkavédelmi és munkaügyi hatósági ellenőrzés ${ }^{14}$, helyi önkormányzatok törvényességi felügyeleti ellenőrzése ${ }^{15}$, ombudsmani vizsgálat ${ }^{16}$, vagy éppen az identitáskontroll, légtérellenőrzés, népességszabályozás (birth control), közlekedésfelügyelet (traffic control), illetve a kibernetikában használt vezérlés fogalmától.

A magyar kontrollál szót gyakran - és tévesen - az angol to control ige fordításaként vezetjük le a magyar nyelvbe, de a kontroll fönév is használatos a

\footnotetext{
11 Lásd bővebben http://www.ekt.bme.hu/BeruTerv/AMuszakiEllenor.pps. (letöltés ideje: 2015. 01. 12.)

12 Lásd bővebben az Oktatási Hivatal honlapját:

http://www.oktatas.hu/kozneveles/ellenorzesek/szakmai_ellenorzes (letöltés ideje: 2015. 01. 12.)

${ }^{13}$ Lásd bövebben: A hatósági élelmiszer-ellenörzés szervezete Magyarországon in: Dr. Jávor András, Dr. Szigeti Jenő (2011): Termékminősités és termékhigiénia Debreceni Egyetem, Nyugat-magyarországi Egyetem, Pannon Egyetem,

forrás: http://www.tankonyvtar.hu/hu/tartalom/tamop425/0010_1A_Book_17_Termekminosites_es_termekhigieni a/ch13.html\#id594374 (letöltés ideje: 2015. 01. 12.)

${ }^{14}$ Lásd bővebben: http://www.kormanyhivatal.hu/hu/szakigazgatasi-szervek/munkavedelmi-es-munkaugyiszakigazgatasi-szerv (letöltés ideje: 2015. 01. 12.)

15 Lásd bővebben: http://www.kormanyhivatal.hu/hu/ugytipusok/kormanyhivatalban-intezhetougyek/torvenyessegi-ellenorzes/helyi-onkormanyzat-torvenyessegi-ellenorzese (letöltés ideje: 2015. 01. 12.)

${ }^{16}$ Lásd bővebben: http://www.ajbh.hu/panasz-benyujtasa (letöltés ideje: 2015. 01. 18.)
} 
gazdálkodástudományokban és az ellenőrzési szakirodalomban is. A szótár szerint az angol control szónak a jelentései a következők lehetnek ${ }^{17}$ :

- valaminek az irányítása alatt van, kézben tart, uralma alatt tart vagy úrrá lesz valami felett, megfékez, megfegyelmez; valamint

- vezérlőegység, vezérlőmű, vezérlőberendezés;

- valaminek a korlátozása, felügyelet alá vonása, szabályozása.

Magay-Országh szótára azonban felhívja a figyelmet ${ }^{18}$, hogy az angol control szót hiba ellenőriz, kontrollál szavakkal fordítani. A to control ige helyett az angol check, illetve supervise igék használatosak, melyek jelentései:

- ellenőriz, felülvizsgál, meggyőződik valamiről, átvizsgál valamit valamiért;

- lektorál, ellenőriz nyelvtanilag;

- megjelöl, kipipál listán;

- megakaszt, féken tart, visszafojt, sakkban tart.

Nagy György Angol-magyar idiómaszótár c. művében a control szó ${ }^{19}$ erősíti MagayOrszágh fenti jelzését, e szótárban a control szó jelentései:

- „ura a helyzetnek;

- kezében tartja a dolgokat;

- nem csúszott ki a kezéből az irányítás."

A „to control” angol ige, illetve fönév a brit, illetve amerikai értelmező kéziszótárakban a fenti magyar értelmezéshez, illetve fordításhoz hasonló jelentéstartalmakat igazolnak vissza:

"con otrol $^{20}:$...

- to check by a duplicate register or account;

- to check, test or verify by counter or parallel evidence; verify by comparison;...

- to have over power; ..."

"con otroll.

- To exercise authority or dominating influence over; direct; regulate.;

- $\quad$ To hold in restraint; check. ...

- To verifiy. ...

\footnotetext{
17 Saját összesítés Magay Tamás (1004): Angol és amerikai kifejezések szótára 101. oldal, control címszó, Akadémia Kiadó, Budapest, valamint Magay Tamás-Országh László (2010): Angol-magyar kéziszótár 235. oldal, control címszó, Akadémia Kiadó, Budapest alapján 18 Magay-Országh (2010): Angol-magyar kéziszótár 236. oldal, Akadémia Kiadó, Budapest.

19 Nagy (2003): Angol-magyar idiómaszótár 130. oldal, control címszó, Akadémia Kiadó, Budapest.

20 Webster's Third New International Dictionary of the english language unabridged. 496. oldal, control címszó, Merriam-Webster Inc. Publishers, Massachusetts.

21 The American Heritage Dictionary, 319. oldal, control címszó, Houghton Mifflin Company, Boston.
} 
- A standard of comparison for checking or verifying the results of experiments."

"Control22:

- the power to influence people's behaviour or the course of events. ...

- a device by which a machine is regulated

- a person or thing used as a standard of comparison for checking the results of a survey or experiment

- a member of an intelligence organisation who personally directs the activities of a spy.

$A z$ angol nyelvben előforduló, alapvető szinonimái a control szónak a következők ${ }^{23}$ :

"- administer, boss (informal), call the shots, call the tune, command, conduct, direct, dominate, govern, handle, have charge of, have (someone) in one's pocket, hold the purse strings, keep a tight rein on, keep on a string, lead, manage, manipulate, oversee, pilot, reign over, rule, steer, superintend, supervise"

- bridle, check, constrain, contain, curb, hold back, limit, master, rein in, repress, restrain, subdue;

- (used of a machine, an experiment, etc.) counteract, determine, monitor, regulate, verify;

- authority, charge, command, direction, discipline, government, guidance, jurisdiction, management, mastery, oversight, rule, superintendence, supervision, supremacy;

- brake, check, curb, limitation, regulation, restraint"

Fentiekból következik, hogy az angol nyelvben használt "control” szó jelentéstartalma inkább felügyelet alatt tart, ural, irányít; míg a magyar nyelvben használt „kontroll” szó az ellenőrzési, vizsgálódási tartalmat jelenti. Disszertációmban én az angol jelentéstartalmat követem, és kontrollrendszerről (control system) írok.

\subsection{Belső kontroll a menedzsmenttanokban}

A szervezeten belüli kontrolltevékenységek megértése a menedzsmenttörténet fejlődésének fontosabb lépcsőin keresztül sokkal könnyebbé válik, ezért vázlatosan

\footnotetext{
22 Concise Oxford English Dictionary, 311. oldal, control címszó, nyolcadik kiadás, 1990., Oxford University Press, Oxford.

${ }^{23}$ Collins Cobuild English Dictionary for Advanced Learners, negyedik kiadás, 2003., HarperCollins Publishers, control címszó
} 
áttekintem a különböző menedzsmenttanokban beazonosítható kontrolltevékenységek létét és tartalmát.

A vezetési szakirodalom tanulmányozása során az önálló kontrollfunkcióval először Henri Fayol munkájában találkozunk 1916-ban, aki a következő vezetési funkciókat különböztette meg: tervezés, szervezés, direkt irányítás, koordinálás és végül ellenőrzés. A fayoli értelemben vett ellenőrzés a kiadott utasítások betartásának közvetlen ellenőrzését jelentette a vezető által, elsősorban a termelő, gyártó környezetre fókuszálva (Dobák \& Antal, 2013., pp.80-81.). Fayol felfogásában a rend és a fegyelem fenntartása a vezető dolga, az ellenőrzés pedig azért szükséges, hogy a vezető megbizonyosodjon arról, hogy a vállalaton belül minden a jóváhagyott tervek, kiadott utasítások, elfogadott elvek szerint történik (Fayol, 1984., p.169.). A fayoli értelemben használt ellenőrzés szó tehát szűken értelmezett közvetlen, vezetői ellenőrzés, és még nem utal a vállalati szintű kontrollrendszerre.

Gulick és Urwick 1937-ben publikált POSDCORB-modelljében az „R" betű a reporting, azaz beszámoltatás szót jelentette, míg a többi betû egy-egy további vezetői feladatot jelölt, mint például „P” - Planing (azaz tervezés), "S" - Staffing (azaz személyi ügyek), a „B” pedig a Budgeting (azaz költségtervezés). A reporting és a budgeting feladatkörben is megjelenik a vezetői kontroll- (visszamérési) tevékenysége (Gulick \& Urwick, 1937., pp.13-15.), (Dobák \& Antal, 2013., p.81.).

Winer 1950-ben a kontrollt a vezetői irányítás szinonimájaként használja, és rendszerelméleti alapokon nyugvó meghatározást ismertet múvében. Álláspontja szerint a kontroll (irányítás) nem más, mint olyan hírek küldése, amelyek hatásosan változtatják meg a hírek felfogóinak viselkedését (Kindler \& Kiss, 1969., pp.313314.).

Az önálló ellenőrzési funkció Koontz és O’Donnell 1967-es múvében is megjelenik, igaz, itt már átfogóan, standardokhoz való mérésként értelmezhető (Dobák \& Antal, 2013., p.81.). Múvükben standardként kezelik a célokat, a vállalati terveket, a készletek megengedett legmagasabb szintjét, a logisztikai ellátási lánc kiszolgálási reakcióidejét stb., és a mindezektől való eltérés mérését és szükség esetén a beavatkozás kötelezettségét írják elő a vezetők számára (Kontz \& O'Donnell, 1972., pp.579-655.).

Ouchi fő múvében a fentiektől eltérő aspektusban vizsgálta a szervezeten belüli kontrollmechanizmusokat ${ }^{24}$. Megközelítésében nem a vezetői feladat, hanem a kontroll típusa hangsúlyos. Múvében megkülönbözetett piaci típusú kontrollt, bürokratikus típusú kontrollt és az úgynevezett klánkontrollt (Ouchi, 1979., pp.833-

\footnotetext{
24 Ouchi művét továbbfejlesztette Malmi és Brown, akik a piaci kontrollt tervezésre, kibernetikai kontrollra (éves budget, teljesítménymérés) és javadalmazásra osztották fel, míg a bürokratikus kontrollt adminisztratív kontrollra cserélték. Lásd: Malmi \& Brown (2008): Management control systems as a package - opportunities, challenges and research directions, in: Management Accounting Research, 2008, 19 (4), pp. 287-300.
} 
843.). Ouchi piaci típusúnak (outputkontroll) tekintette a vállalatnak a piacon elért teljesítményét, eredményét, melynek lényege, hogy a szervezet a vevői, ügyfelei körében megmérettetik és elfogadottá válik, ha terméke, szolgáltatása jól árazott, megfelelő piaci keresletet elégít ki, jó minőségű stb., vagyis ez a vezetőnek a vevői elvárásokkal való tudatos vezetői foglalkozása. Ezzel szemben a bürokratikus kontroll (tevékenységkontroll) ${ }^{25}$ fő jellemzője a folyamatok szabályozottságának megléte és ezen szabályok betartásának kontrollálása a szervezeten belül. Ez a kontrolltípus azt vizsgálja, hogy a szervezet tagjai, munkavállalói a hierarchiakülönböző szintjein betartották-e az oda vonatkozó utasításokat, szabályzatokat, előírásokat, standardokat, melyek ahhoz kellenek, hogy a szervezet működése egységes és állandó legyen. Végül a klánkontroll (magatartáskontroll) lényege, hogy a szervezet tagjainak egyéni cselekedeteit és szervezethez való viszonyát minősíti. Itt kapott helyet a szervezeti kultúrával való azonosulás, a csoportmunka elveinek elfogadása vagy a szervezet iránti dolgozói lojalitás.

Dobák Miklós és Antal Zsuzsa múvükben a kontrollt a 4 vezetői funkció egyikének tekintik, és úgy fogalmaznak, hogy a kontroll a szervezeti célok elérését segítő, visszacsatoló folyamat, melynek alapját a standardoktól való eltérés adja, felelőse pedig bármely vezető, aki a stratégiaalkotás, a szervezetalakítás, illetve a személyes vezetés szereplője a szervezetben (Dobák \& Antal, 2013., p.442.), (Dobák, 1996., pp.157-158.).

Árnyaltabban ugyan, de más szerzők menedzsmentről szóló múveiben is megjelenik a kontrolláló vezetési feladatkör. Például Mintzberg 1979-ben publikálta a vezetői szerepeket bemutató művét. Ebben kontrolláló, ellenőrző funkciót nevesítetten nem találunk, ám az információgyűjtő szerepek között a monitoringfunkció, illetve az adatgyújtés és -értékelés, valamint a vállalkozói szerepkörben a környezeti feltételekhez való igazodás sikeressége megjelenik, melyek a gyakorlatban részben megfeleltethetőek a korábban bemutatott kontrolltevékenységnek.

Taylor Üzemvezetés című művében meghatározza az üzemi vezetés alapvető feladatait, sokat foglalkozik az üzemi szabványosítással, valamint a minőségellenőrzéssel (inspector), de ez utóbbit csak a legyártott termékek minőségellenőrzésére használja (Taylor, 1983., p.93.).

Max Weber a bürokráciáról szóló alapmúvében az ellenőrzés szót nem céltudatos feladatként említi, helyette az uralomról értekezik részletesen, illetve a bürokratikus szervezetek fenntartásának és múködtetésének rendszabályait ismerteti. Ebben komoly helyet kap a rend fenntartása, a szabályozás és a szigorú, egységes hivatali

\footnotetext{
25 Megjegyzés: Az Ouchi-féle bürokratikus vállalati kontroll nem azonos a Kornai János által publikált bürokratikus koordináció fogalmával, annak ellenére, hogy vannak hasonló vonásai mindkettőnek.
} 
fegyelem, ahol Weber is utal arra, hogy ezt - annak fenntartása végett - ellenőrizni is szükséges (Weber, 1987., p.228.). A weberi ellenőrzés szó - a fayolival ellentétben - tartalmában már sokkal közelebb áll a kontrollálási tevékenységhez, mely utóbbi a teljes vállalati múködésre (Webernél a bürokratikus szervezetre), a folyamatokra (Webernél az ügyintézés menetére) általánosságban és szabályozottan (Webernél univerzálisan és írásban rögzítetten) kiterjed.

Ugyanakkor számos szerző esetében hiányzik ezen aspektus a múveikből. Kotter például több múvet jelentetett meg $^{26}$ a vezető feladatairól, a leaderi szerepkörről, illetve a változásvezetés tudományáról, s bár érinti a tervezés, visszacsatolás és elemzés tárgykörét, műveiben mégsem jelenik meg hangsúlyosan önálló ellenőrző, kontrolláló vezetői szerepkör vagy menedzseri feladat.

A menedzsmenttudomány fejlődésével párhuzamosan a szervezeten belüli kontroll témája köré többféle megközelítés, illetve diszciplina is felsorakozott az elmúlt 5070 évben. Egyrészről a vállalati célkijelölés és tervezés, a magatartási befolyásolás és beszámolás, illetve a visszacsatolás hármasából mára kinőtte magát a vezetői számvitel, a menedzsmentkontroll, illetve controlling szakterülete. Ezzel szemben a jogi és pénzügyi számviteli szakterületen belül a nyilvántartások, a hatáskörök, ezek szabályozottsága, a beszámolók háttértartalma, a bizonylatok és a tranzakciók, valamint a szabálykövetés kaptak nagyobb figyelmet, ezekre koncentrálva kialakult a számviteli ellenőrzés, a könyvvizsgálat és a függetlenített belső ellenőrzés intézménye. A termelési, szolgáltatási területen pedig a minőségbiztosítási törekvések erősödtek meg, ami az ellenőrzésnek az auditáló, alapfolyamatokat elemző, hibákat feltáró és visszacsatoló eszközrendszerét erősítette meg, valamint a termékek és szolgáltatások minőségét, szabványok szerinti előállítását hangsúlyozza.

Napjainkban pedig egyre nagyobb hangsúlyt kap a felelős és etikus vállalati viselkedés, mely újabb követelményeket és kontrollálási, visszacsatolási pontokat iktat be a szervezetek múködésébe, miközben azok fenntartják, olykor megerősítik a már meglévő, fentebb bemutatott kontrolltevékenységeket is. Ugyancsak napjainkban terjed a szervezeten belüli szándékos visszaélések feltárásával és

\footnotetext{
${ }^{26}$ Lásd részletesen: http://www.kotterinternational.com/books/ (2015. 01. 22.), illetve Kotter megjelent publikációit, cikkeit (Kotter, 1991.).
} 
megakadályozásával foglalkozó fraud menedzsment ${ }^{27}$ irányzat, illetve a szabályos müködésre hangsúlyt helyező compliance ${ }^{28}$ terület.

A szervezeten belüli kontrollálás fontosságát több klasszikus mü, illetve napjainkban megjelenő általános menedzsmentkönyv, vállalkozói szakirodalom, illetve kisvállalati vezetőknek szóló könyv, periodika is hangsúlyozza ${ }^{29}$. Ezek mind alapot teremtettek, illetve teremtenek a vállalati belső kontrollrendszer kialakításához, működtetéséhez. Dolgozatomban alapul veszem Dobák és Antal vezetői funkciókat leíró modelljét, amelynek utolsó, negyedik eleme a kontroll. A menedzsmenttanok időben és földrajzi térben is eltérően közelítik meg a vezető feladatköreit, és nem adnak egy egyértelmú keretet, meghatározást arra, hogy a szervezeten belül milyen módon kell a vezetőnek megszerveznie, elvégeznie a kontrolltevékenységeket. Ezért további vizsgálódás, szűkítés szükséges annak megértéséhez, hogy hogyan és miért múködnek a belső kontrollrendszerek.

\subsection{A kontroll és az ellenőrzés viszonya egymáshoz a magyar gazdasági szaknyelvben}

A vállalati kontrollrendszer megértéséhez szükséges a kontroll, illetve az ellenőrzés, audit szavak megismerése, hogy ezeket miként használják pénzügyi, számviteli aspektusban, egyben el is határolva ezeket a műszaki, pedagógiai stb. megközelítésektől. A helyes ágazati szóhasználatot azonban árnyalja az a sokszínűség, melyet a különféle szakirodalmak használnak.

Rathe például összegyújtötte az angol control szó üzleti nyelvezetben használt konnotációit, és 57-féle variánst talált (Rathe, 1960., p.32.), Bragg 140 darab kontrollálandó pontot mutat be a vállalatirányítási és számviteli rendszerre vonatkozóan (Bragg, 2011., pp.20-47.), de Dobák Miklós is ismerteti a kontroll különféle jelentéstartalmait a magyar nyelvben (Dobák, 1996., p.157.).

\footnotetext{
${ }^{27}$ A kifejezésnek még nincs magyar megfelelője, fordítása, talán csalásfelderítő, illetve visszaélés-feltáró menedzsmentként lehetne fordítani. Lásd részletesebben az 1. számú függelékben.

${ }^{28}$ A szónak még nincs elfogadott magyar megfelelője, a gazdálkodástan területén leginkább a szabályszerűség, szabályoknak való megfelelés, szabályosságkövetés lehet a magyar fordítása. Lásd részletesebben az 1. számú függelékben.

29 Lásd néhány nagy becsben tartott vagy kevésbé ismert művet felsorolásszerüen: Kaplan \& Norton (2002): A stratégiaközpontú szervezet. p.357-390., Kaplan \& Cooper (2001): Költség \& Hatás. p.15-27., Rappaport (2002): Tulajdonosi érték. p.128-151., Neges \& Neges (1998): Vezetésmódszertan. p.105-107., Schönberger \& Cukier (2014): Big Data. p.189-204., Haarpst (2011): A kiválóság hat alapelve. p.175-178., Straat \& Sabin (1992): Amit a főnököd sem mond el. p.230-248., Rowntree (2006): Menedzserek ellenőrző listakönyve. p.55-295., Eiben (2010): Jelszó: Hatékonyság. p.196-203., Hegedűs (2009): Amit érdemes megtanulni a multiktól, és amit nem. p.105-118., Szilágyi (2008): Háború ez is. p.194-200., Vecsenyi (2009): Kisvállalkozások indítása és működtetése p.337-338., Roóz (2001): Vezetésmódszertan. p.130-131.
} 
Ahogy azt korábban bemutattam, a control angol szót gyakran és hibásan fordítjuk ellenőrzésnek, mivel ez utóbbinak az angol megfelelői a supervise és a check igék lennének. A control angol szót célszerúbb befolyásolásnak, célratartásnak, uralom alatt tartásként fordítani, ilyen módon az internal control system magyar megfelelője a szervezeti belső kontrollrendszer, nem pedig a belső ellenőrzési rendszer, sem pedig a függetlenített belső ellenőrzés.

Ugyanakkor a magyar szakirodalom a kontroll szó mellett igen gyakran használja az ellenőrzés szót is, szinonimaként. Ez eredhet helytelen fordításból, de eredhet tudatos döntésből is, amikor a szerző csak az ellenőrzésről (check, audit, supervise) és nem az átfogó kontrolltevékenységekről ír. Így a hazai független belső ellenőrzési, hatósági ellenőrzési szakirodalom az ellenőrzés szót helyesen, ellenőri tevékenységként használja. Azonban a belső kontrollrendszerrel, kontrolltevékenységekkel kapcsolatos hazai szakirodalomban az ellenőrzés és a kontroll olykor helytelenül szinonimként kezelt kifejezések. Mivel pedig disszertációm a vállalati kontrollrendszerek működéséről szól, a control-t helytelen lenne ellenőrzésként fordítani, vagy szinonimaként használni a kontroll és az ellenőrzés szavakat.

Értekezésemben a továbbiakban kontroll alatt a gazdasági szakterületen használt kontrollt értem, és azt alkalmazom. Jelen fejezetben a kontroll mellett az ellenőrzés még helyet kap, magyarázatokkal alátámasztva elhatárolom jelentésüket egymástól. Így a következő részben már tisztán a belső kontrollrendszerekről írok, míg jelen fejezetben a kontrollhoz és a kontrollrendszerhez képest elkülönítve, fogalmilag elhatárolva írok az ellenőrzésről is.

A kettő közötti különbségtételt igyekszem ebben az alfejezetben világossá tenni, a tartalmi-jelentésbeli különbséget érzékeltetni. Kovács Árpád jól illusztrálva mutatja be az ellenőrzés és a kontroll közötti tartalmi különbséget (Kovács, 2007., p.101.), s én elfogadom és követem ezt a logikai gondolatmenetet. Véleménye szerint az ellenőrzés vállalaton belüli független értékelés meghatározott kritériumok alapján (kulcsszavai: elért eredmény, tény), míg a kontroll feladatot és felelősséget jelent a tevékenységek szabályszerű, megfelelő minőségű, gazdaságos és hatékony teljesítésében (kulcsszavai: jövőbeni eredmény, felelősség a saját tevékenységért). Azt Kovács is jelzi, hogy a hazai gyakorlatban a kontrollt és az ellenőrzést gyakran és helytelenül szinonimaként kezelik. E gondolatmenetet követve a magyar gazdasági szaknyelvben a következő elhatárolást érdemes megtenni:

- Az ellenőrzés a szűken értelmezett, konkrét standardok megvalósulásának elemzését, az arról való megbizonyosodást jelenti. Az ellenőrzés tehát időszakos, konkrét követelményre irányul, s a belső munkavállalókon túlmenően külső személy és szervezet (pl. könyvvizsgáló, hatósági revizor) 
is gyakorolhatja. Ellenőrzési tevékenységnek tekinthetünk egy-egy konkrét vizsgálatot - lefolytatójától, külső vagy belső elrendelőjétől függetlenül.

- A kontroll bővebb megközelítésű, (cél)irányban, illetve uralom alatt tartást jelent. Állandó és szisztematikus rendszer kiépítését és fenntartását, fejlesztését feltételezi, amely révén képes lehet valaki a szervezet(i egység) feletti uralmat, vezetést a célokkal összhangban gyakorolni. Ebből következően a kontrollt belülről, munkatársak és vezetők révén gyakorolják ${ }^{30}$.

Az ellenőrzési szakirodalomban a gazdasági, üzleti szférában használt kontrollt - a fentiekből kifolyólag helytelenül - gyakran pénzügyi ellenőrzésnek vagy szakellenőrzésnek is nevezik. A pénzügyi szakellenőrzés angol megfelelője a financial audit (nem pedig a financial control), mely valójában megbízhatósági ellenőrzést jelent, és a szervezet számviteli éves beszámolójára koncentrál, az azt alátámasztó gazdálkodási rendszer megbízhatóságát vizsgálja (NAV KEKI, 2011., p.153.). A financial audit tehát valójában a választott könyvvizsgáló tevékenységét fedi le a nemzetközi könyvvizsgálói normák alapján (Lukács, 2005., p.11.). Ezért a pénzügyi ellenőrzés, pénzügyi audit szavak mellett hazánkban a gazdasági ellenőrzés szóösszetétel is használatos még, amely igyekszik magába integrálni és lefedni mindenféle belső ellenőrzési és kontrolltevékenységet is, és elhatárolni a pénzügyi, gazdasági ellenőrzés területét más szakterületektől, mint például a pedagógiai ellenőrzéstől vagy a műszaki ellenőrzéstől. A pénzügyi ellenőrzés kifejezés további funkcióit, jelentéstartalmait részletesen lásd Vigvári András múvében (Vigvári, 2005., pp.6-15.).

Disszertációm jelen részében a kontroll - illetve fentiek miatt szükségképpen az ellenőrzés - definícióit mutatom be annak érdekében, hogy fogalmilag megalapozzam a következő fejezetben bemutatásra kerülő belső kontrollrendszert. Mindazonáltal több hazai szerző rögzíti múvében, hogy a pénzügyi, gazdasági ellenőrzésnek nincs (nem lehet) szabatos, egyetlen közreadható és használható, közösen jónak vallott definíciója (Kovács, 2007., p.27.), (Nyikos, 2001., p.95.), (Lukács, 2005., p.13.). Alábbiakban a vállalati kontroll legfontosabb definícióit, meghatározásait mutatom be.

\footnotetext{
${ }^{30} \mathrm{Az}$ itt bemutatott logikából eredően a külső kontrollgyakorlás nehezen értelmezhető, de nem lehetetlen ebben az aspektusban sem. A szervezet felett a kontrollt - azaz az uralmat, hatalmat - gyakorolhatja pl. az anyavállalat operatív tulajdonosi irányítási eszközökkel, vagy egy hatóság is jogszabályi rendelkezésekkel és kinevezett intendánsok (pl. csődbiztos, felügyeleti biztos) kijelölésével, vagy akár maga az állam közvetlen költségvetési finanszírozás nyújtásával.
} 
Simons definíciója szerint a kontroll a célok elérése érdekében müködtetett vállalati információs folyamat, pontos meghatározása pedig a következő (Simons, 2000., p.765.):

"Control the process of using information to ensure that inputs, processes, and outputs are aligned to achieve organisational goals."

Sawyer idéz egy 1960-ból származó auditdokumentumot, mely a vállalati kontrollt a következőképpen határozza meg (Sawyer et al., 2003., p.63.):

"Control is the employment of all the means devised in an enterprise to promote, direct, restrain, govern, and check upon its various activities for purpose of seeing that enterprise objectives are met. These means of control include, but are not limited to, form of organisation, policies, systems, procedures, instructions, standards, commitees, charts of account, forecasts, budgets, schedules, reports, records, checklists, methods, devices, and internal auditing."

Ackoff meghatározásában a kontroll a teljesítményeket lekövető és értékelő rendszer. Meghatározása a következő (Ackoff, 1970., p.112.):

"Control is the evaluation of decisions, including decisions to do nothing, once they have been implemented. The process of control involves four steps:

1. Predicting the outcomes of decisions in the form of performance measures.

2. Collecting information on actual performance.

3. Comparing actual with predicted performance.

4. When a decision is shown to have been deficient, correcting the procedure that produced it and correcting its consequences where possible."

Naidu és társa több definíciót is idéz a kontroll különféle jelentésére, ezek közül Brech meghatározásában a teljesítmény és kontroll összekapcsolása figyelemreméltó (Naidu \& Rao, 2008., p.107.):

"Control is checking current performance against predetermined standards contained in the plans, with a view to ensure adequate progress and satisfactory performance."

A belső kontroll (illetve a pénzügyi ellenőrzés) hazai szakirodalma döntően a nemzetközi publikációkra támaszkodik, az ott közölt meghatározásokat adaptálja, honosítja. Szóhasználatában az ellenőrzés szó dominál, a kontroll szót kevésbé 
olvashatjuk a hazai publikációkban. Vörös László például a következő definíciót használja múvében a pénzügyi szakellenőrzésre vonatkozóan (Vörös, 2008., p.26.):

„... az ellenörzés valamilyen cél, vagy feladat leghatékonyabb

megvalósítása céljából végzett olyan tevékenység, amely a

követelményekhez viszonyított, intézkedésre alkalmas megállapítások,

állásfoglalások és javaslatok kialakitásával szolgálja a vezetést, az irányítást."

Vörös László definíciója szinte megegyezik Kamarás Jenő könyvében korábban megadottakkal (Kamarás, 1993., p.13.).

Kovács Árpád múvében a pénzügyi ellenőrzés jogi tartalmát a következők szerint határozza meg (Kovács, 2007., p.27.):

„Az ellenörzés (jogi) tartalma: információk szerzése, elemzése, értékelése és továbbitása intézkedések, korrekciós döntések céljából."

Kresalek és társa a pénzügyi ellenőrzésre a következő fogalommeghatározást adja (Kresalek \& Merétey-Vida, 2008., p.13.), s ezt idézi később Sebes is (Sebes, 2012., p.8.):

„Ellenörzés alatt általában valamely cél vagy feladat lehető

leghatékonyabb megvalósítása érdekében végzett ténymegállapító, követelményekhez viszonyító, értékelö és javaslattevő tevékenységet értünk."

Lukács János az ellenőrzést céltudatos tevékenységként határozza meg a következők szerint (Lukács, 2009., p.6.):

„Olyan céltudatos tényfeltáró, összehasonlító, elemzö és értékelo"

tevékenység, amely bizonyos érdekcsoportok védelmében, és az

ellenörzöttek jogainak csorbítása nélkül tárgyszerüen

- hozzájárul a hibák keletkezésének megelözéséhez (prevenció),

- megfigyel ...(ténymegállapítás),

- feltár... (összehasonlítás),

- kideríti az eltérések okait... (elemzés, oknyomozás),

- véleményt mond ...(értékelés),

- javaslatokat tesz ...(döntéselökészítés)."

A definíciók sokszínű bemutatásával az volt a célom, hogy érzékeltessem, a vállalati kontroll meghatározása a szakirodalomban nem egységes, az szerzők szerint eltérő. Bordáné múvében kifejezetten felhívja a figyelmet arra, hogy a hazai pénzügyi, könyvvizsgálati és ellenőrzési szakirodalom - olykor félreérthetően - keveri a megfelelő fogalmakat (Bordáné, 2011., pp.72-75.). Ezért önmagában a kontroll, 
illetve ellenőrzés szavakra a belső kontrollrendszert felépíteni még nem lehet, további magyarázatra, alapozó megközelítésre van szükség alapos megértéséhez. A pénzügyi szakellenőrzés a vállalati kontrolltevékenységnek ugyan jó alapot ad, de még nem kielégítő egyetlen eleme annak. Szét kell választani a külső (hatósági, közhatalmi) és a belső (szervezeten belüli) kontrollálást egymástól, továbbá a belső kontrollrendszert is tovább kell ágaztatni aszerint, hogy a könyvvizsgálat, a függetlenített belső ellenőrzés, a vezetői ellenőrzés, a tulajdonosi szerv ellenőrzése vagy éppen a menedzsmentkontroll felől közelítjük meg azt.

Egyrészről az egyes történelmi fejlődési pályákat kell jobban megismerni, mivel azok a mai modern belső kontrollt megalapozó ideológiák, eszmék, törekvések színterei voltak, másrészről a belső kontrollrendszereket, kontrollmechanizmusokat elméleti síkon, jellegük és orientációjuk szerint jobban kell még elemezni. Erre kerül sor a következő két alfejezetben.

Egyúttal visszautalok arra, a bevezetőben már rögzített meghatározásomra, hogy disszertációmban nem foglalkozom a szervezeteket kívülről, külső hatóságként vagy szervezetként vizsgáló eljárásokkal, így nem foglalkozom az adó-, vám-, fogyasztóvédelmi, pénzügyőri, élelmiszer-biztonsági hatósági ellenőrzésekkel. De ugyancsak nem foglalkozom az Állami Számvevőszék (ÁSZ), a Kormányzati Ellenőrzési Hivatal (KEHI), a Magyar Államkincstár (MÁK) vagy éppen az Európai Csalásellenes Hivatal (OLAF) vizsgálataival, amelyek a költségvetési szférán túlmenően, a vállalati szférában ugyancsak előfordulhatnak.

\subsection{A rendszer fogalma, alapvető bemutatása}

$\mathrm{Az}$ alapvető rendszerdefiníciók szerint a rendszer nem más, mint egymással kölcsönhatásban lévő elemek összessége, azok meghatározott totalitásként megjelenő sokasága, egésze (Ackoff, 1971., p.662.), (Bertalanffy, 1969., pp.27-28.), (Bodnár \& Paróczai, 1995., p.20.).

A rendszer elemeit valamely jellemzőjük szerint ragadhatjuk meg, mely jellemző segít nekünk abban, hogy eldöntsük, valami a rendszer részének tekinthető-e, vagy sem. Ilyen módon az elemek rájuk jellemző különféle tulajdonságokkal, ennek eredményeképpen entitásokkal bírnak. A rendszer elemei között pedig kapcsolat, valamiféle együttműködés van, ilyen módon az elemek kölcsönhatásban vannak egymással. A rendszerek belső múködésének általános célja a környezethez való alkalmazkodás, idomulás. Ennek érdekében a rendszeren belül részrendszerek, specifikálódó alrendszerek jönnek létre, melyeket a vizsgálódási fókusz szúkítésével kisebb önálló rendszernek is tekinthetünk a nagy rendszeren belül. A rendszerelmélet tárgyköréről, a fogalmakról, valamint a rendszert leíró jellemzőkről 
bővebben ír múvében (Boulding, 1956.), (Ackoff, 1971.), (Bodnár \& Paróczai, 1995.), (Kindler \& Kiss, 1969.), (Horváth, 1973.).

Az általános rendszerelméleti megközelítést a fizika, a biológia, a matematika, a szociológia és a közgazdaságtan tudománya is alkalmazza, saját tudományterületi korrekcióval kiegészítve. A szervezetek emberek által konstruált absztrakt csoportosulásként, azaz összetett és mesterséges rendszerként múködnek, és jellemezhetők a rendszerelmélet legfontosabb leíró tényezőivel (Kindler \& Kiss, 1969., pp.175-179.), (Bodnár \& Paróczai, 1995., p.29.). A szervezeteken belül a munkát végző munkavállalók tekinthetők egyes elemeknek; a köztük lévő kölcsönhatás révén a gazdálkodó szervezet outputként terméket állít elő, szolgáltatást nyújt, vagy éppen kereskedelmi tevékenységet lát el vevői megelégedettsége érdekében. Inputjai a felhasznált erőforrások. A szervezetek tehát maguk is rendszerként működnek, igazodnak környezetükhöz és különféle elvárásokhoz. A szervezetek közül disszertációmban az üzleti szervezetekkel foglalkozom részletesen, melyek legalapvetőbb célja jellemzően a hosszú távú növekedés, illetve fennmaradás, és kiszámítható nyereség, profit biztosítása a tulajdonosuknak (Chikán, 2008., pp.24-26.). Az üzleti szervezetek nyílt rendszerek, a környezetből érkező impulzusok, hatások közvetlenül éreztetik befolyásukat a szervezetben, és hatással vannak a rendszer elemeinek viselkedésére. Az elemek közötti kapcsolat dinamikus, azaz folyamatos ráhatásban vannak az elemek egymásra.

A belső kontrollrendszerekre vonatkozóan a következő rendszerdefiníciót használom a továbbiakban az értekezésemben:

„Rendszer bármely szervezet, munkafolyamat vagy ezek valamely része, ahol a forrásokat (inputok) olyan módon szervezik meg (dolgozzák fel), hogy elöre meghatározott szándékoknak (céloknak) megfelelő eredményeket (outcome) érjenek el." (NAV KEKI, 2011., p.298.).

A vállalati belső kontrollrendszer maga is nyílt, dinamikus rendszerként értelmezhető a vállalkozáson belül. Hatással van múködésére a számviteli rendszer, a jogi igazgatás rendszere, a minőségirányítási rendszer stb., és ezekkel állandó, folyamatos kapcsolatban van. E kapcsolatok jellegét vizsgálva beszélhetünk erősen befolyásoló, szabályozó, információátalakító, utasító (vezérlő) kölcsönhatásokról egyfelől és gyengének vagy semlegesnek tekinthető kölcsönhatásokról, úgymint tájékoztatást nyújtó, információt közlő, adatátvivő kapcsolatokról másfelől.

A belső kontrollrendszer az általános rendszerelmélet segítségével jól leírható, jellemezhető (Ackoff, 1971., pp.662-667.). A belső kontrollrendszer a vállalaton belül müködő alrendszerek egyikének tekinthető, de önmagában is rendszertulajdonságokkal bír, ha elemeinek az egyes kontrolltevékenységeket 
tekintjük, maga a belső kontrollrendszer pedig alkalmazkodik az őt körbevevő más elemekhez. Ezeket tekinthetjük a kontrolltevékenységek környezetének, ahonnan igények, elvárások, követelmények érkeznek a kontrollrendszer múködésére vonatkozóan. A kontrollrendszer igyekszik megfelelni a vállalat vezetői, a tulajdonosok, hatóságok, érdekeltek elvárásainak, célja pedig számukra eredményeket közvetítetni, megoldásokat nyújtani, információval ellátni őket a vállalat múködéséről. A kontrollrendszer maga is erőforrásokat használ fel, ilyenek az azt működtető munkavállalók, alkalmazott külső szakértők, különféle számítástechnikai eszközök és programok, inputként kapott, illetve felhasznált információk stb.

A vállalati belső kontrollrendszer maga is további részrendszerekre bomlik, például a kontrolltevékenységek egy részét manuális, más részét automatikus kontrolloknak azonosítjuk. A manuális kontrollokat vezetői szintek szerint tovább bonthatjuk felső vezetői, középvezetői és közvetlen irányítói, illetve munkatársi szinten alkalmazott kontrollokra. A kontrolltevékenységek (mint a rendszer elemei) tehát hierarchikusan egymásra épülnek, a szintek között sztochasztikus kapcsolat van, és részben emberek által irányítottak, részben pedig automatikus eszközök által vezéreltek.

\subsection{A modern kori vállalati belső kontroll általános bemutatása}

A nemzetközi és a hazai szakirodalom is igyekszik a vállalati belső kontrollrendszert alaposan, jól meghatározni, ezért e tárgykörben gazdag definíciós kínálattal találkozunk. A definíciók egyrészt történelmileg is fejlődtek, másrészt elemeikben is gazdagodtak, finomodtak. E publikációk vezetőknek, könyvvizsgálóknak, belső ellenőröknek vagy éppen szakterületi auditoroknak szólnak, és ilyen szemüvegen keresztül közelítik meg a belső kontrollrendszer témakörét, illetve a belső kontrollmechanizmusok múködését. Ebben az alfejezetben a cosOkeretrendszerhez hasonló, illetve attól eltérő definíciókat, és a belső kontrollrendszer jellemzőit mutatom be az egyes szakirodalmak alapján.

\subsubsection{Nemzetközi meghatározások, standardalapú megközelítések}

A belső kontrollt a nemzetközi szakirodalom egységesen a cOSO-modellben szereplő, disszertációm III. fejezetében részletesen bemutatásra kerülő keretrendszerben ragadja meg, definícióját onnan veszi át, mely a következő (COSO, 2013a., p.Ch 1.):

"Internal control is a process, effected by an entity's board of directors, management, and other personnel, designed to provide reasonable assurance regarding the achievement of objectives relating to operations, reporting, and compliance." 
A belső kontroll korábbi definícióit jellemzően a 2013-as módosításokat megelőzősen született hazai publikációkban találjuk meg. Ezek közül igen elterjedt és sokak által átvett meghatározás az alábbi (Kresalek \& Merétey-Vida, 2008., p.43.):

„A belső kontroll egy folyamat, amelyet a társaság igazgatósága, menedzsmentje és az alkalmazottai befolyásolnak ${ }^{31}$, és amelyet azért hoznak létre, hogy az alábbi célok elérését illetően ésszerü bizonyosságot ${ }^{32}$ nyújtson:

- a müködés hatékony és eredményes,

- a pénzügyi beszámolási rendszer megbízható,

- a vonatkozó szabályozásnak (jogszabályok és hatósági előírások, de ide értendők a belső szabályzatok is) a társaság eleget tesz."

A belső kontrollt az INTOSAI 9100. számú irányelvében a következőképpen határozza meg az alapfogalmak kapcsán (INTOSAI Professional Standards Committee, 2004., p.65.):

$$
\text { „Internal control - Belső kontroll }
$$

A belső kontroll egy összetett folyamat, amelyet egy szervezet vezetése és dolgozói valósítanak meg, és amelyet a kockázatok meghatározására és ésszerü biztositék biztosítására alakítanak ki ahhoz, hogy a szervezet a küldetésének teljesítése során megvalósítsa a következő fö célokat:

- a tevékenységeket (müveleteket) szabályszerüen, etikusan, gazdaságosan, hatékonyan és eredményesen hajtsa végre;

- teljesítse az elszámolási kötelezettségeket;

- megfeleljen a vonatkozó törvényeknek és szabályozásoknak;

- megvédje a szervezet forrásait a veszteségektöl, a nem rendeltetésszerű használattól és károktól."

Az IIA-normák nagyban építenek a fentebb bemutatott definíciókra, és a szervezeten belüli kontrollt a következőképpen határozzák meg a fogalomjegyzékben (IIA, 2013a, p.19.) ${ }^{33}$ :

\footnotetext{
${ }^{31}$ Az effect angol ige eredményez, eszközöl, végrehajt, befolyásol, hatást gyakorol szavakkal is fordítható, ilyen módon a befolyás szóval történt magyar fordítás jelentős ráhatásként, alapvető meghatározásként is értelmezhető, és nyomatékos, domináns szerepet feltételez a tevékenység végzése során.

${ }^{32} \mathrm{Az}$ assurance angol ige bizonyosságot, szavatolást jelent, de a szónak létezik garantálás és biztosítékadás jelentése is, ily módon a belső kontroll eredménye erősebb is lehet, mint a bizonyosság nyújtása a belső kontrollrendszerről.

33 Disszertációmban a BEMSZ által közzétett hivatalos magyar fordítást adom meg, a nemzetközi standard angol eredeti szövege itt érhető el: https://na.theiia.org/standardsguidance/Public\%20Documents/IPPF\%202013\%20English.pdf (2015. 01. 16.)
} 
„Kontroll: Minden olyan intézkedés a vezetés, a vezetö testület és egyéb felek részéröl, amely arra irányul, hogy kezelje a kockázatot és növelje a célok, célkitüzések megvalósulásának a valószínüségét. A vezetés megtervezi, megszervezi és irányítja azoknak a szükséges intézkedéseknek a végrehajtását, amelyek biztosithatják a célok és célkitüzések elérését."

Az ISACA által kidolgozott informatikai irányítási szabvány, a COBIT $4.1^{34}$ a vállalati belső kontrollrendszert az alábbiak szerint határozza meg (IT Governance Institute, 2007., p.219.):

"Belső irányítási és ellenőrzési rendszer/Internal control/ - Az üzleti célkitüzések elérésével és a nem kivánatos események megelözésével, illetve felismerésével és korrigálásával kapcsolatos bizonyosság nyújtására tervezett irányelvek, tervek, eljárások és szervezeti struktúrák összessége."

A kontroll kifejezést az üzleti kockázatkezelés szakirodalma is alkalmazza, mivel az üzleti folyamatok során feltárt kockázatok kezelése, menedzselése, illetve a kockázatok kézbentartása a vezetés feladata. Ezzel összefüggésben az ISO 31000 szabvány a kontrollt a következőképpen határozza meg (MSZT, 2015., p.14.):

„2.26. Kockázat-kézbentartás(control): A kockázat (2.1) módosítására irányuló intézkedés.

1. megjegyzés: Kockázat-kézbentartásnak tekinthető minden olyan folyamat, vezérlöelv, eszköz, gyakorlat vagy egyéb tevékenység, amely módosítja a kockázatot.

2. megjegyzés: A kockázat-kézbentartás azonban nem mindig éri el a kívánt vagy feltételezett mértékü módositó hatást."

A nemzetközi könyvvizsgálati standardok ${ }^{35}$ közül a belső kontrollrendszert a 315 . témaszámú ISA standard írja le részletesen (IFAC, 2009.). Ez a következő fogalmi meghatározást adja a belső kontrollra vonatkozóan (IFAC, 2009., pp.5-6.):

„Belső kontroll - az irányítással megbízottak, a vezetés és egyéb munkatársak által abból a célból kialakított, bevezetett és fenntartott folyamat, hogy megfelelö bizonyosságot nyújtson a gazdálkodó egység elé kitüzött célok eléréséről a pénzügyi beszámolás megbízhatósága, a

\footnotetext{
${ }^{34}$ A COBIT 5.0 szabvány szövege magyar nyelven még nem elérhető értekezésem készítésének időpontjában, ezért a korábbi 4.1-es magyar nyelvű változatot idézem.

http://www.isaca.org/Pages/Glossary.aspx?tid=1506\&char=I - Internal Control szó (2016. 03. 20.)

35 Lásd bővebben: http://www.ifac.org/auditing-assurance/clarity-center/clarified-standards (2015. 01. 20.).
} 
müködés hatékonysága és eredményessége, valamint a vonatkozó jogszabályoknak és szabályozásoknak való megfelelés tekintetében. A „kontrollok” kifejezés a belső kontroll egy vagy több komponensének bármely aspektusára vonatkozik."

A standard 4. (c)-(e) bekezdése és az 5. pontja alapján a kontrollrendszer akkor megbízható és elfogadható a könyvvizsgáló számára, ha az (megítélése szerint) a szándékos csalásból és a vétlen hibákból származó lényeges hibás állítások kiszűrésére alkalmas, és ilyen módon a könyvvizsgáló támaszkodhat rájuk (IFAC, 2009., pp.4-5.). E standard 12. pontjához kapcsolódóan - a gazdálkodó egység belső kontrolljára vonatkozóan - az A44-A59. pontjai és az 1., illetve 2. számú függelékek tartalmaznak magyarázó részeket. $E$ szerint a belső kontrollrendszer célja megegyezik a COSO-modell szerinti felfogással, tartalma találkozik a COSOkeretrendszer és az IIA normáival is. A standard a belső kontrollrendszer célját így fogalmazza meg:

„A belső kontrollt úgy alakítják ki, vezetik be és tartják fenn, hogy az

kezelje azokat az azonosított üzleti kockázatokat, amelyek veszélyeztetik a gazdálkodó egység alábbiakat érintő bármely céljának az elérését:

- a gazdálkodó egység pénzügyi beszámolásának megbízhatósága

- a müködés hatékonysága és eredményessége, valamint

- a vonatkozó jogszabályoknak és szabályozásoknak való megfelelés.

A belső kontroll kialakitásának, bevezetésének és fenntartásának módja a gazdálkodó egység mérete és összetettsége szerint változik."

A belső kontrollrendszer elemeire (komponenseire) a standard A51-es pontja a következők szerint hivatkozik (IFAC, 2009., p.31.):

a) a kontrollkörnyezet

b) a gazdálkodó egység kockázatbecslési folyamata

c) a pénzügyi beszámolás szempontjából releváns információs rendszer, beleértve a kapcsolódó üzleti folyamatokat, valamint a kommunikációt

d) a kontrolltevékenységek, továbbá

e) a kontrollok figyelemmel kísérése. ..."

Látható tehát, hogy a 315-ös standard átveszi és alkalmazza COSO-keretrendszer tartalmi elemeit.

A 315-ös standard a fentieken túlmenően megállapítja még, hogy a belső kontrollnak jelentős hatása van a pénzügyi beszámolók tartalmára, mivel az alapadatok betáplálása, azok konverziói, főkönyvbe történő továbbítása és a 
naplótételek különféle könyvelése mind azt eredményezheti, hogy a beszámoló torz, hibás végeredményeket közölhet. Ezért a standard rávilágít arra, hogy ezen adattranszformációs folyamatokat a könyvvizsgálónak részletesen kell ellenőriznie, tesztelnie, vizsgálnia. A belső kontrollrendszer ugyanis akkor működik jól, ha biztosítja, hogy a gazdasági események rögzítése során a hitelesség (valóban megtörtént-e?), a teljesség (mindent rögzítettek-e?), a pontosság (számszakilag így helyes-e?), az elhatárolás (jó időszakra rögzítették-e?), a besorolás (jó főkönyvi számlán rögzítették-e?) kritériumai teljesülnek. Ugyancsak kiemeli a standard, hogy a belső kontrollrendszernek az eszközökre és forrásokra, a mérlegen kívüli tételekre és a jogok, illetve kötelezettségek számszerüsítésére vonatkozó értékelését is vizsgálnia kell, hogy azok megbízható, hibamentes adatokat biztosítsanak a beszámolóban (A110-A112. pontok).

A standard felhívja a figyelmet továbbá arra, hogy a speciális tulajdonosi körökre (pl. állami szektorbeli gazdálkodók) jellemző egyedi szempontok a belső kontrollrendszer múködését befolyásolhatják (A113.), de ugyanilyen nyomást gyakorolhat a kontrollrendszerre maga a vezetés, amikor az adatok torzításában, szelektív bemutatásában érdekelt egy üzlet létrejötte, egy teljesítmény elismerése vagy valamilyen látszat fenntartása érdekében (A36.).

A kontrollrendszerek vizsgálatát is magában foglaló 315. számú ISA standard önmagában a kontrollrendszer követelményeit, objektív jellemzőit mutatja be. A standard hivatkozik más tárgyú, témájú standardokra is, melyek a belső kontrollrendszerrel érintőlegesen kapcsolatban vannak, további útmutatásokat adnak, ám szorosan nem tartalmaznak a belső kontrollrendszerre (de a kontrollkörnyezetre igen) előíró jellegú információt. Ezért ezeket a standardokat csak a felsorolás szintjén adom meg értekezésemben, nem mutatom be őket részletesen. E standardok a következők:

- ISA 240. norma: A könyvvizsgáló csalással összefüggő felelőssége a pénzügyi kimutatások könyvvizsgálatánál

- ISA 265. norma: A belső kontroll hiányosságainak kommunikálása az irányítással megbízott személyek és a vezetés felé

- ISA 330. norma: A könyvvizsgáló válaszai a becsült kockázatokra

- ISA 610. norma: A belső auditorok munkájának felhasználása

Meigs és társai múvükben a belső kontrollt a következők szerint definiálják (Meigs et al., 1985., p.172.):

„... internal control is to promote the efficient operation of an

organisation. The system of internal control consists of all measures

employed by an organisation to

(1) safeguard assets from waste, fraud, inefficient use;

(2) promote accuracy and reliability in the accounting records; 
(3) encourage and measure compliance with company policies;

(4) evaluate the efficiency of operations."

Meigs az AICPA 546-os számú standardjából levezetve megkülönbözteti az adminisztrációs belső kontrollokat és a könyvviteli belső kontrollokat. Utóbbiba tartozik minden számviteli elszámolással, adatrögzítéssel, bizonylatolással kapcsolatos kontrollálási feladat, míg az adminisztrációs kontrollok közé sorolják a szervezet múködésével kapcsolatos egyéb kontrollokat, mint például a menedzsment döntéshozatali rendjének, a munkatársak tevékenységének vagy a belső szabályzatok betartásának ellenőrzését (Meigs et al., 1985., pp.175-176.).

A belső kontrollrendszerek kontinentális, európai definícióinak fejlődését lásd bővebben kifejtve Löffler és társai művében (Löffler et al., 2011., pp.13-18.).

\subsubsection{Hazai meghatározások, szerzői jellemzések}

Hazánkban a korábban bemutatott fordítási nehézségek miatt (is), illetve az ellenőrzésre fókuszáló és arra leszűkülő szakirodalmak a kontrollrendszerek mellett előszeretettel használják az ellenőrzési szisztéma vagy ellenőrzési rendszer kifejezést.

Roóz József és Sztanó Imre könyvében belső ellenőrzési és szabályozási rendszerként határozza meg a belső kontroll rendszerét (Roóz \& Sztanó, 2000., p.165.):

„A vezetés által kidolgozott teljes ellenörzési rendszer (pénzügyi és más rendszerek is), amely azt a célt szolgálja, hogy a vállalkozás hatékonyan és szabályosan tudja üzleti tevékenységét folytatni, betartva a belső irányelveket, megvédve eszközeit és biztosítva-amennyire csak lehetséges - a nyilvántartások teljességét és pontosságát."

Vörös László múvében a kontrollrendszer helyett ellenőrzési rendszert használ. Szerinte az ellenőrzés rendszere szervezeti szinten magában foglalja a külső és belső szervek által végzett valamennyi ellenőrzést, és feltételezi azok egymásra hatását is. A szerző így fogalmaz az ellenőrzési rendszer tartalmát illetően (Vörös, 2008., p.47.):

„Az ellenőrzés rendszere a különböző célú és feladatkörü ellenőrzések olyan összessége, amelyben az egyes részelemek szervezetten és összehangoltan, egymást kölcsönösen kiegészítve teljes egészükben átfogják az ellenőrzés tárgyát képező társadalmi-gazdasági folyamatokat.

Az ellenörzési rendszer az irányítási rendszer részeként müködik, a vezetés egyik funkciója. Ennek megfelelöen az ellenörzési rendszer múködésének az eredményessége, vagy hiányosságai visszahatnak az irányítási tevékenység színvonalára, hatékonyságára." 
Vörös a vállalaton belüli ellenőrzést megvalósítókat az alábbiak szerint határozza meg (Vörös, 2008., pp.135- 167):

- tulajdonosi ellenőrzés, mely magában foglalja a legfőbb szerv (taggyúlés, közgyúlés stb.) beszámoltatási és felelősségre vonási feladatkörét, valamint a felügyelőbizottság és a választott könyvvizsgáló munkáját;

- vezetői ellenőrzés, melyet a vezető személyesen lát el az alárendelt területek kapcsán, elemei: információk elemzése, értékelése, beszámoltatás, aláírási jogkör alkalmazása, közvetlen helyszíni ellenőrzés (pl. gyári szemle);

- munkafolyamatokba épített ellenőrzés, amely az értékteremtő folyamat egyes pontjaiban elvégzett elő-, közbülső és végellenőrzéseket, automatizált és a vállalati egységek által végzett szakellenőrzéseket, illetve önellenőrzést fedi;

- függetlenített belső ellenőrzés, amely a vonatkozó irányelvek, szabványok, módszerek alapján végzi tárgyilagos bizonyosságot adó és tanácsadói tevékenységét, melynek célja a szervezet múködésének fejlesztése, eredményességének, hatékonyságának növelése.

Láthatjuk, hogy Vörös megközelítésében az ellenőrzési rendszer a vállalaton belüli kontrollrendszert fedi le. Ugyanakkor Vörös azt is állítja, hogy a vállalati ellenőrzési rendszer fő jellemzője, hogy annak megvalósításában a szervezet minden tagja részt vesz - legtöbbször a tevékenységük, feladataik elemeként -, de a folyamatban részt vevő tárgyi eszközök (pl. beléptetőeszközök, számítógépek, ipari vezérlők) is betöltenek mindinkább növekvő arányban ellenőrzési funkciókat, és ezt egészíti ki, illetve erre épül rá a vezetői, továbbá a függetlenített belső ellenőrzési funkció (Vörös, 2008., pp.146-147.).

Vörös a kontrollrendszert múködtető szereplőket illetően a következő személyeket nevezi meg, mint akik a belső kontroll felelősei:

- első számú vezető (feladata a stratégia, a célkitűzések meghatározása, tervek elfogadása/jóváhagyása, a függetlenített belső ellenőrzési rendszer múködtetése, a közvetlen vezetői ellenőrzés múködtetése, beszámoltatás stb.);

- felső vezetők (feladatuk a terv-tény eltérések értelmezése, intézkedések hozatala szakterületükön, az erőforrások feletti döntések hatékonyságának vizsgálata stb.);

- középvezetők (feladatuk információk gyűjtése és továbbítása a felső vezetőknek döntést, beavatkozást illetően stb.), illetve az operatív, helyi vezetők (feladatuk a közvetlen irányításból fakadó azonnali ellenőrzés, szemlézés, az önellenőrzések, munkaszakaszokba épített ellenőrzések és az automatizált ellenőrzések felügyelete stb.) a szervezet méretétől függően; 
- belső ellenőrzési vezető, akinek feladata a függetlenített belső ellenőrzési rendszer teljes múködtetése, irányítása, ide értve a belső ellenőrzési tervek összeállítását is.

Fentiekhez hasonlóan ismerteti Nyikos László is megállapításait múvében, aki az ellenőrzés általános, korábban már ismertetett definícióját alkalmazza (Nyikos, 1999., p.11.):

„Az ellenörzés valakinek (személynek) vagy valamely szervezetnek, tevékenységnek az elbírálás céljából történő megvizsgálása, figyelemmel kísérése."

Nyikos múvében a nem külső szervezetek által végzett ellenőrzés elemei között említi a tulajdonosi ellenőrzést, a vezetői, a munkafolyamatokba épített és a független belső ellenőrzést is (Nyikos, 1999., pp.137-152.), ugyanakkor kitér a vezetői ellenőrzés néhány egyedi, sajátos jellemzőjére is, melyek a következők (Nyikos, 1999., pp.148-150.):

- A vezetői ellenőrzés védelmi célzatú (vagyonvédelem, veszteségfeltárás stb.), de a vállalkozás támadó, expanziós magatartását (árpolitika, terjeszkedés) is szolgálja egyszerre.

- A vezetői ellenőrzésben megjelenik, visszatükröződik a vezető karizmája, habitusa, vezetési stílusa, azaz munkája, véleményalkotása, döntései, emberekkel való bánásmódja az ellenőrzési funkció gyakorlása során is olyan lesz, mint amilyen egyébként a vezető személyisége.

- A vezetőben egyszerre kell, hogy jelen legyen a kollégák irányában megtestesülő, megelőlegezett bizalom és a vállalat céljai érdekében felvállalt ellenőrzésből fakadó bizalmatlanság.

- A vezetői ellenőrzésen belül is szükségszerű az írásbeliség, azaz a vezetőnek beszámolókat kell írnia, ellenőrzési terveket kell készítenie/készíttetnie, megállapításai kiértékelését írásban kell lefektetnie.

Kovács Árpád múvében a belső kontrollrendszert az államháztartásban ismert FEUVE ${ }^{36}$-rendszeren keresztül, azt bemutatva ismerteti (Kovács, 2007., pp.100104.). Ugyanakkor meg kell állapítani, hogy a múben szereplő alapvető kijelentések nemcsak a költségvetési szférára, hanem a vállalati szféra belső kontrollrendszerére is helytállóak, ezért itt idézem fontosabb megállapításait.

„A FEUVE, azaz a belső kontrollrendszer a szervezeten belül a gazdálkodásért felelős szervezeti egység által müködtetett első szintű

\footnotetext{
${ }^{36}$ Folyamatba épített, előzetes és utólagos vezetői ellenőrzés (FEUVE), melyet a 370/2011.(XII.31.) kormányrendelet részletez a költségvetési szervek müködése kapcsán.
} 
pénzügyi irányítási és ellenörzési rendszer, amelynek létrehozásáért, működtetéséért és fejlesztéséért az adott költségvetési szerv

(disszertációmban: az üzleti szervezet) vezetője felelös."

Kovács a belső kontrollrendszer elemeire vonatkozóan a következő legfontosabb kritériumokat ismerteti:

- magában foglalják a pénzügyi irányítási és ellenőrzési feladatok szabályszerú lebonyolításának ellenőrizhetőségét (tervezés, kötelezettségvállalások, szerződések aláírása, jóváhagyások);

- ráirányítják a figyelmet az erőforrások pazarlására, a visszaélésekre, a rendeltetésellenes felhasználásra;

- biztosítják a naprakész, megbízható, ellenőrzött adatokat a vezetés számára;

- vizsgálják a szabályszerűség követelményének megtartását, és a szabálytalanságok kezelésére vonatkozóan eljárásrendet tartalmaz;

- ellenőrzési nyomvonalakat tartalmaznak a kontrollpontok azonosításával együtt, melyet folyamatábrák, táblázatos segédletek támogatnak;

- része a kockázatkezelési rendszer, a gazdálkodásban rejlő kockázatok beazonosítása, kezelése;

- a vezetői kontroll kiterjed a személyes irányításra, a szervezet teljesítményének felügyeletére és mérésére, a beszámoltatásra,a kapott információk feldolgozására;

- szervezeti kontrollt feltételez, ahol a felelősségi körök egyértelműek és lehatároltak, azaz a szervezeti hierarchia megfelelő szintjein az ott szükséges ellenőrzési jogosultságok ki vannak jelölve, azt a munkavállalók, középvezetők és közvetlen irányítók is alkalmazzák.

Kovács Árpád gondolataihoz igen hasonlóan mutatják be Fekete István és társai is a belső kontrollrendszer működését költségvetési szervi példákon keresztül (Fekete et al., 2006., pp.137-161.). Továbbá a fentiekkel egyező vagy igen hasonló leírást ad a belső kontrollrendszerről Kresalek Péter és szerzőtársa (Kresalek \& Merétey-Vida, 2008., pp.51-60.), valamint Sebes József (Sebes, 2012., pp.205-211.) és Saly Ferenc (Saly, 2006., pp.77-93.) is.

Kamarás Jenő múvében a szervezet irányítását és vezetésének vizsgálatát és értékelését a következő tartalmi elemek szerint határozza meg (Kamarás, 1993., pp.206-220.):

- A kontrollrendszernek a stratégiai koncepció meglétét, a fejlesztéspolitikai döntéseket, a céltudatos és tervszerű munkavégzést vizsgálnia kell, és azt is elemeznie kell, hogy ez a belső és a környezeti adottságokkal összhangban van-e, azaz reális-e, a belső adottságok lehetővé teszik-e elérését, a gyártmányskála iránti kereslet alátámasztja-e a hosszú távú döntéseket stb.? 
- Létezik-e és funkcióját betölti-e a szervezeti rendszer a vállalkozáson belül, azaz az irányítási lépcsők száma, nagysága összhangban van-e a vállalat méretével, a funkcionális tagoltság és más munkamegosztási elvek világosan érvényesülnek-e, vannak-e bürokratikus túlburjánzások, s a szervezeti felépítés szervezeti és múködési szabályzatban (SZMSZ) dokumentálva van-e?

- A tervezési rendszer milyen időtávon múködik a vállalatnál, vannak-e hosszú távú, közép-, illetve rövid távú tervezési rendszerek, a jövedelmezőség biztosítása tervezéssel alátámasztott-e, a tervek között vannak-e alternatívák stb.?

- A döntési és információs rendszer múködőképes-e, a döntéseket a megfelelő szinten hozzák-e meg, és ahhoz a megfelelő információk rendelkezésre állnak-e, a döntések végrehajtását, a határozatok megvalósulását ellenőrzike a vezetők?

- Érdekeltségi rendszerben működnek-e a szereplők (munkavállalók és szervezeti egységek), működik-e jól és igazságosan a premizálás rendszere, s ehhez egyértelmú követelményeket támasztottak-e?

- Komplex és átfogó belső irányítási rendszer múködik-e a vállalatnál, annak eredményre, a vezetés hatékonyságára gyakorolt hatása milyen, van-e független belső ellenőrzés, működik-e kontrolling, mit mutatnak a munkafolyamatokba épített ellenőrzések, vannak-e szisztematikus és elemzést lehetővé tevő adatgyűjtések, s hogyan reagál ezen adatokra a vezetés?

- A vezetés megítélése, minősítése megtörténik-e objektív alapokon; készségeik, céltudatosságuk, demokratikus attitűdjük gyakorlatiasságuk, következetességük, munkaidejük beosztása stb. hogyan hat a vállalat működésére?

- A szervezet eleget tesz-e a szabályszerűségi követelményeknek, a jogszabályi és a belső szabályozás szerinti előírásokat betartják-e?

Buxbaum Miklós könyvében a gazdasági társaság belső kontrollrendszerét igazgatóságra, felügyelő- és audit bizottságra és úgynevezett internal control systemre (ICS) ${ }^{37}$ osztja (Buxbaum, 2006., p.16.). Véleménye szerint:

„...a "control” nemcsak ellenőrzési rendszert jelent, hanem tartalmazza

mindazokat a belső eljárásokat, utasításokat, szabályokat, vállalati

biztonsági és irányítási rendszereket, valamint szervezeteket, amelyeket

${ }^{37}$ Magyar nyelven a belső kontrollrendszer adódik legjobb fordításnak. 
a társaság azért hozott létre, hogy a szabályszerü (törvényes) müködést

biztosítsa.

A vállalat belső szabályozási (control) rendszerének föbb részei:

függetlenitett belső ellenörzés (internal audit), a vállalatirányítási és

biztonsági rendszerek, valamint a minőségbiztositás és kockázatkezelés

rendszere, amely a társaság minden tevékenységére és szervezeti

egységére kiterjed."

Bodonyi Miklós a Közpénzek ellenőrzése II. című könyvében foglalkozik a belső kontrollrendszer elemeivel (Bodonyi et al., 2001., pp.38-48.). Eddig ismertetetteken túlmenően múvében

- kiemeli a számviteli rendszer fontosságát, s hangsúlyozza, hogy meg kell érteni, hogy a nem pénzügyi rendszerekből származó adatokat hogyan használja fel a pénzügy-számviteli rendszer, valamint

- megkülönböztet rutinügyleteket és nem rutinügyleteket, amely utóbbiaknál nagyságrendjük, illetve ritka előfordulásuk, súlyos következményeik miatti különös kockázatra hívja fel a figyelmet.

Ha áttekintjük a fenti definíciókat, akkor láthatjuk, hogy sok közös elemük van, míg néhány pontjuk csak itt-ott jelenik meg a szerzők múveiben. Összegzésül ezen közös elemeket foglalom össze, melyek a vállalati kontrollrendszerek vizsgálódásának további irányát jelölik ki. A legtöbb definícióban megjelenő közös elemek, fókuszpontok a következők:

1. hatékonyság és eredményesség mérése, a mérési eredmények kiértékelése, az eltérések beazonosítása és indokaik feltárása - melyek célja a szervezet üzletmenetének vizsgálata, jövedelemtermelő képességéről ítélet alkotása;

2. megbízható, valós adatok biztosítása befelé és kifelé egyaránt - ez a vállalati beszámolók, riportok, jelentések, bevallások megbízhatóságát, valós tartalmukat és a teljességükre való törekvést célozza meg;

3. a külső jogszabályoknak, standardoknak, szabványoknak és a belső utasításoknak, szabályzatoknak való megfelelés, szabálykövetés (compliance) biztosítása;

4. a vállalati vagyon, azaz az eszközök és források megóvása és megvédése az elherdálástól, fizikai behatástól - aminek célja a vagyontárgyak értékének megőrzése és fenntartása a szervezetekben.

További elemek is megtalálhatók egy-egy definícióban, melyek gazdagítják a fenti közös meghatározást, de nem állandó tagjai a szakirodalmi hivatkozásokban a kontrollrendszereknek: 
5. etikus magatartás megkövetelése, integritás biztosítása - amely a jogszabályok és a belső előírások betartásán túl azt követeli meg a dolgozóktól, hogy a cég nevében morálisan, az adott helyzetben etikus magatartással járjanak el akkor is, ha jogszabály nem ad iránymutatást a konkrét helyzetben egy-egy szituáció megnyugtató megoldására;

6. kockázatok folyamatos, tudatos kezelése, vagyis annak a követelménynek a megfogalmazása, hogy a szervezetnek vizsgálnia kell a múködésére ható külső és belső tényezőket, ezek közül ki kell emelnie a káros következményekkel, jelentős negatív hatásokkal járó kockázatokat, és azok kezelésére folyamatos intézkedéseket kell hoznia;

7. vállalati célokat biztosító üzletmenet, stratégiakövető múködés - amely lényegében a tudatos vállalati tervezési és végrehajtási magatartást fedi le, azaz a szervezet deklarálja a céljait, és ez utóbbiaknak megfelelően végzi a mindennapi tevékenységét is, $s$ amely célok mérhetők, a teljesítmény értékelhető és így mutatószámokkal kifejezhető.

\section{6 Összegzés}

A belső kontrollrendszerek múködésének leírásához az e fejezet elején bemutatott logikai láncolat alapján jutottam el. A fogalmi meghatározások és a kontroll gazdaságtudományi lehatárolása után a vezetés feladatkörére, funkcióira vonatkozó különféle elméleteket mutattam be, ám ezek egyike sem szolgált egyetlen biztos alapként a kontrollrendszer meghatározásához. A negyedik lépcsőben tehát a kontrollok közül a pénzügyi kontrollokat emeltem ki, és bemutattam annak jellemzőit, majd az ötödik lépcsőben elválasztottam a külső és a belső orientációjú ellenőrzést, és iránymutatást adtam az ellenőrzés és kontroll tartalmi szétválasztására vonatkozóan. A belső (szervezeten belüli) kontroll jellemzőinek feltárása volt a hatodik lépcsőfok, mely elvezetett oda, hogy feltehessem a kérdést: milyen standardok, szabványok írják le a belső kontrollrendszereket. Így jutottam el a COSO-keretrendszerhez, melyet disszertációm következő, harmadik részében mutatok be részletesen. 


\section{RÉSZ}

\section{A VÁLLALATI BELSŐ KONTROLLRENDSZER RÉSZLETES BEMUTATÁSA, A COSO-MODELL KRITIKAI ISMERTETÉSE}

\subsection{Belső kontrolltevékenység a COSO-modell szerint}

A Committee of Sponsoring Organizations of the Treadway Commission (COSO) elnevezésű szakmai szervezet ${ }^{38}$ 1985-ben alakult meg, eredetileg abból a célból, hogy segítséget nyújtson a vállalati belső visszaélések feltárásához, és így támogassa a közzétett éves beszámolók megbízhatóságát. A szervezetet - mint a belső kontrollokat és kockázatmenedzsment-tevékenységet összehangoló nemzeti csúcsszervezetet - öt, az USA-ban bejegyzett szakmai szövetség ${ }^{39}$ alapította meg közösen. A coSO nonprofit szakmai szövetség, jelenlegi célja a vállalatok függetlenített belső ellenőrzési, kockázatkezelési és visszaélés-feltárási tevékenységének segítése, a vezetői támogatás biztosítása a belső kontrolltevékenységek szakszerű, magas szintű megszervezéséhez. Ennek érdekében iránymutatásokat, ajánlásokat és útmutatókat ad ki, valamint tagjai bevonásával különféle felméréseket végez a belső kontrollok témakörében.

E szervezet 1992-ben adta ki először az Internal Control - Integrated Framework keretrendszert leíró múvét, melyet 2013-ban vizsgált felül ${ }^{40}$ és újított meg (COSO, 2013a.). A COSO-modell nemzetközi szinten terjedt el, népszerűvé vált a vállalati szférában, de követői átültették az államigazgatás ${ }^{41}$ és a nonprofit szervezetek múködésébe ${ }^{42}$ is. A coSO-keretrendszer ma a belső kontrollrendszert leíró és a belső kockázatkezelést megalapozó legelterjedtebb és legátfogóbb modell, amely a

\footnotetext{
${ }^{38}$ A szervezetről bővebben itt olvashat: http://www.coso.org/aboutus.htm (letöltés ideje: 2015. 01. 14.)

39 Alapítók: AAA (American Accounting Association - Amerikai Számviteli Szövetség), FEl (Financial Executive Internationals - Pénzügyi Tanácsadók Nemzetközi Szervezete), IMA (Institute of Management Accountants Vezetői Számviteli Könyvelök Szövetsége), AICPA (American Institute of CPA's - Bejegyzett Költségvetési Könyvelők Amerikai Szövetsége), IIA (Institute of Internal Auditors - Belső Ellenőrök Nemzetközi Szövetsége) 40 Lásd a felülvizsgálat eredményeit részletesen itt: http://www.coso.org/ermupdate.html (letöltés ideje: 2015. 01. 14.) és itt: http://www.protiviti.com/en-US/Documents/Resource-Guides/Updated-COSO-Internal-ControlFramework-FAQs-Second-Edition-Protiviti.pdf (2015. 01. 14.)

41 Lásd bővebben: http://www.intosai.org/issai-executive-summaries/view/article/intosai-gov-9100-guidelines-forinternal-control-standards-for-the-public-sector.html (letöltés ideje: 2015. 01. 14.) valamint a hazai implementációját itt: http://www.asz.hu/modszertan/iranyelvek-a-belso-kontroll-standardokhoz-a-kozszferabanintosai-gov-9100/issai-9100.pdf (letöltés ideje: 2015. 01. 14.)

42 Lásd például: http://friedmanllp.com/insights/the-new-internal-control-framework---for-nonprofits (letöltés ideje: 2015. 01. 14.)
} 
vezetés, illetve a szervezet szolgálatában áll. A COSO-rendszer történelmi fejlődését részletesen bemutatják cikkükben Wilson és szerzőtársai (Wilson et al., 2014.).

A coso-modell fő elve, hogy a vállalat belső kontrollrendszerét összekapcsolja a vállalat kockázatainak feltárási és kezelési feladataival. A modell a belső kontrollt a következőképpen definiálja (COSO, 2013a., p.Ch.1.):

"Internal control is a process, effected by an entity's board of directors, management, and other personnel, designed to provide reasonable assurance regarding the achievement of objectives relating to operations, reporting, and compliance."

Az eredeti meghatározást számos, a belső ellenőrzéssel, kontrollrendszerrel, audittal foglalkozó nemzetközi szakirodalom (Sawyer et al., 2003., pp.62-63.), (BPP, 2011., p.139.) is átvette, illetve több nemzetközi szervezet is adaptálta, mint az IFAC $^{43}$, az INTOSAI ${ }^{44}$, az ISACA ${ }^{45}$ és az IIA (IIA, 2013a).

A nemzetközi szakirodalomban a belső kontrollrendszernek a fenti definíciója többféle mutációban, részben módosulva jelenik meg. Horngren és társai a következő rövid definíciót használják múvükben (Horngren et al., 2008., p.7.):

"Internal controls: Policies to protect and make the most efficient use of an organisation's assets.".

Kimmel és társai a következő meghatározást használják múvükben (Kimmel et al., 2005., p.315.):

„Internal Control consists of all the related methods and measures adopted within a business to:

1. Safeguard its assets from employee theft, robbery, and unauthorized use; and

2. Enchance the accuracy and reliability of its accounting records by reducing the risk of errors (unintentional mistakes) and irregularities (intentional mistakes and misrepresentations) in the accounting process."

\footnotetext{
${ }^{43}$ Lásd bővebben: http://www.ifac. org/global-knowledge-gateway/risk-management-internal-control/revised-cosoframework-improved-additional (letöltés ideje: 2015. 01. 14.)

${ }^{44}$ Lásd: http://www.issai.org/media/13329/intosai_gov_9100_e.pdf (letöltés ideje: 2015. 01. 14.). International Organisation of Supreme Audit Institutions (INTOSAI), azaz a Legföbb Ellenőrzési Intézmények Nemzetközi Szervezete

${ }^{45}$ Lásd: http://www.isaca.org/Knowledge-Center/Research/Documents/Relating-the-COSO-Internal-ControlIntegrated-Framework-and-COBIT_whp_Eng_0314.pdf?regnum=303241 (letöltés ideje: 2016. 03. 11.)
} 
A fenti, a COSO-keretrendszerből eredő definíciót több korábbi magyar forrásban is viszont olvashatjuk, melyek a fenti meghatározást alkalmazzák hazánkban (Fekete et al., 2006., p.138.), (Ivanyos, 2011.). Ezek közül én a következő magyar fordítást tekintem irányadónak azzal a megjegyzéssel, hogy ez a magyar definíció még a COSO 2013-as módosítása előtt született meg (Kresalek \& Merétey-Vida, 2008., p.43.):

„A belső kontroll egy folyamat, amelyet a társaság igazgatósága, menedzsmentje és az alkalmazottai befolyásolnak, és amelyet azért hoznak létre, hogy az alábbi célok elérését illetően ésszerü bizonyosságot nyújtson:

- a müködés hatékony és eredményes,

- a pénzügyi beszámolási rendszer megbízható,

- a vonatkozó szabályozásnak (jogszabályok és hatósági elöírások, de ide értendők a belső szabályzatok is) a társaság eleget tesz."

2004 óta a modell továbbfejlesztett változatát COSO-ERM (COSO Enterprise Risk Management) néven ismerjük; legutóbbi felülvizsgálata 2014-ben történt meg ${ }^{46}$.

A COSO-keretrendszer úgynevezett „COSO-kocka” néven is ismert, mert háromféle aspektusból közelíti meg a szervezetet, ezért a modell mondanivalóját háromdimenziós kockaként szokták megjeleníteni. Az eredeti alapkocka COSO I. néven ismert, és annak 2004 óta használt kiegészítése (COSO-ERM) pedig a COSO II. elnevezést kapta (Löffler et al., 2011., pp.189-192.). A kibővített COSO-ERMrendszer esetében három további kockázatkezelési elem jelent meg az eredeti cosO I.-modellhez képest. A két kocka tartalmát a 3. számú ábrán mutatom be ${ }^{47}$, illetve tartalmát röviden ismertetem. Míg az 1992-ben kiadott COSO I. szerinti modell a vállalaton belüli kontrollmechanizmusok alapját adja meg, a coSO II.modell már kockázatmenedzsment-orientációjú. A kettő közötti átfedés nagy, de szemléletmódjukban, céljaikban eltérnek egymástól.

\footnotetext{
46 Lásd: http://www.coso.org/ermupdate.html (letöltés ideje: 2015. 01. 15.)

${ }^{47} \mathrm{~A}$ belső ellenőrzési rendszer működését, IIA-normák szerinti megvalósítását, és ezen keresztül a COSO I.modell szerinti kontrollrendszert a következő alfejezetben mutatom be.
} 
A cOSO I.- és COSO II.-modellek összehasonlítását lásd részletesen a 3. számú ábrán (COSO, 2013a., p.G.):

Belsố kontroll - integrált keretrendszer

Vállalati kockázatmenedzsment - integrált keretrendszer
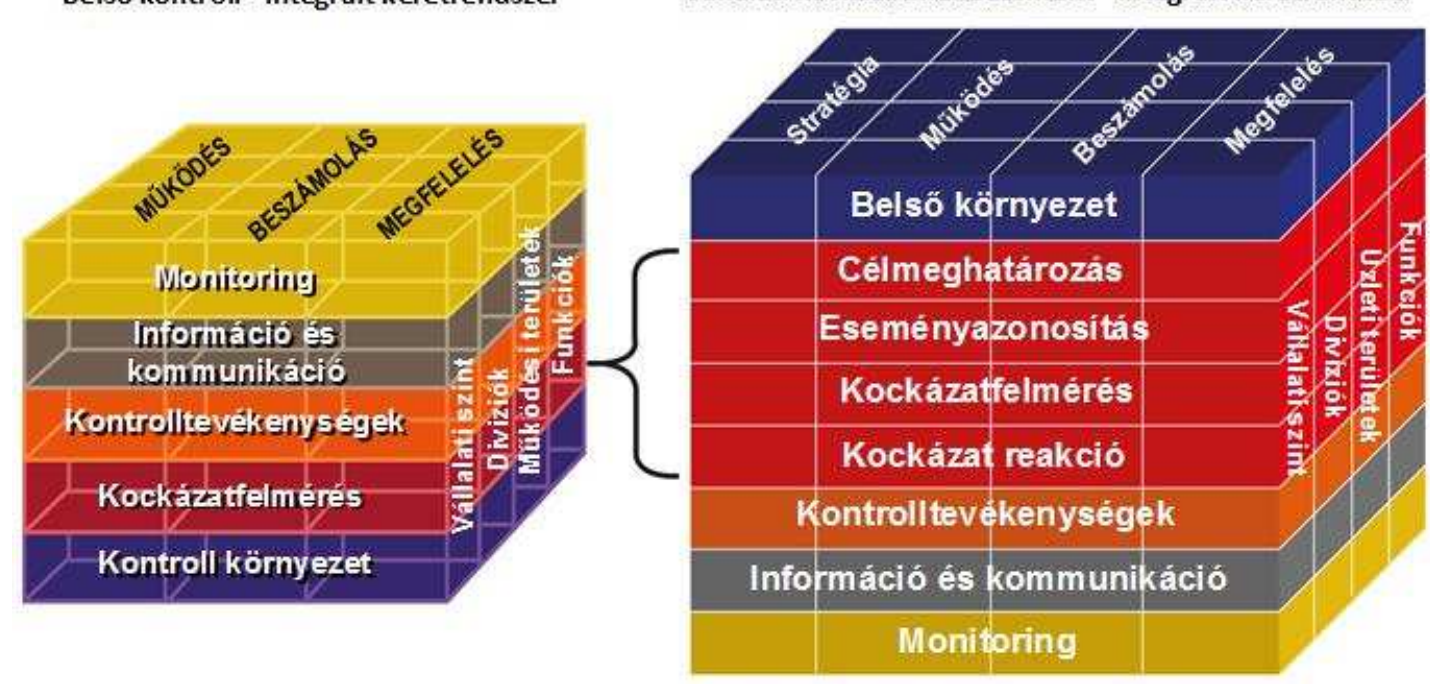

3. ábra: COSO I.- és COSO II. (COSO ERM)-modell összehasonlítása

Forrás: http://csqa.blogspot.no/2006/04/kc-922-coso-enterprise-risk-management.html (2015. 01. 14.) - saját fordítás

A COSO-modell egy kockaként értelmezhető, ahol a vállalati kontrollrendszert három dimenzióban egyszerre vizsgálhatjuk, így többféle kombináción keresztül tudja a modell leírni a belső kontrollrendszer tartalmát (ezek a dimenzionális elemek tehát egymást keresztezik).

A coso II.-kocka által definiált fókuszpontok a belső kontrollrendszert illetően a következők (COSO, 2004., pp.9-10.):

- A kocka négy kategóriát (célirányt) használ annak megfelelően, hogy a kockázatkezelés milyen célra irányul, azaz a vállalat milyen jellemzőjére kell vonatkoznia. Itt van helyük a

- a stratégiai (Strategic - azaz célkitűzések elérése, ennek támogatása),

- a működési (Operations - azaz erőforrások hatékony és gazdaságos felhasználása),

- a beszámolókészítési (Reporting - azaz megbízható riportok, jelentések) és

- a szabálykövetési (Compliance - azaz szabályzatok és előírások követése, azoknak való megfelelés)

tárgyú kontrolloknak, illetve kockázatkezelési tevékenységeknek.

- A kocka nyolc komponenst azonosít, amelyek hatással vannak a vállalati kockázatokra, ezen keresztül pedig a belső kontrollrendszerre. Ezekhez soroljuk 
- a belső kontrollkörnyezetet (Internal Environment - azaz a vállalaton belüli szervezeti felépítés, vezetési filozófia, etikai értékek, integritás stb. elemei);

- a célkitǔzések folyamata (Objective Setting - azaz a misszió és a vállalati hosszú távú célok kijelölése);

- az eseményazonosítás, vagyis avészhelyzetek értékelését (Event Identification - azaz képesség a káros hatások felismerésére);

- a kockázatfelmérés (Risk Assessment - vagyis a kockázatok azonosítása, feltárása és értékelése, melynek során a bekövetkezés valószínűségét, súlyosságát, gyorsaságát és erősségét kell mérlegelni);

- a kockázatreakció, vagyis a kockázatokra adott választ (Risk response - azaz a menedzsmentnek a kockázatok kezelése érdekében adott válaszlépése és kockázattűrése);

- a kontrolltevékenységeket (Control Activities - azaz a kontrollok gyakorlása érdekében bevezetett eljárások és szabályok);

- az információs és kommunikációs rendszert (Information and communication - azaz valós, ellenőrzött és releváns információk biztosításának képessége);

- a monitoringtevékenységet (Monitoring - azaz a kontrollok múködése érdekében és a kockázatok elhárítására tett intézkedések nyomon követése, utólagos elemzése).

- A kocka harmadik dimenziójában maga a szervezet és annak tetszőleges számú részterületre lebontása látható, mely arra szolgál, hogy a kockázatkezelés és kontrolltevékenység a vállalkozás megfelelő üzletágában, tetszőleges igazgatóságán, szervezeti egységében, részlegében, projektjében, főosztályán, tevékenységi körében stb. valósuljon meg.

\subsection{A cOSO-keretrendszer komponensei és ezek összefüggései}

Továbbiakban a coso-keretrendszert (COSO I.) ismertetem részletesen, a kockázatkezelési aspektusok nélkül (azok csak a COSO II.-modellben találhatók meg). A COSO I.-modell 5 komponensében összesen 17 alapelvet (principles) és azokhoz kapcsolódóan 79 fókuszpontot (points of focus) rögzít ${ }^{48}$, melyeket a

\footnotetext{
${ }^{48} \mathrm{~A}$ fókuszpontok felsorolásától, illetve részletes bemutatásától disszertációmban eltekintek. Azok részletesen megtekinthetők, olvashatók a COSO-keretrendszert leíró útmutatóban (COSO, 2013a.), (COSO, 2013b.).
} 
vállalatoknak szem előtt kell tartaniuk, amikor belső kontrollrendszereiket kiépítik, illetve múködtetik és fejlesztik (COSO, 2013a., p.Ch.2.).

Értelemszerúen a COSO egy kontrollrendszert leíró standardnak tekinthető, melyet a vállalatok önkéntes elhatározás alapján alkalmaznak és szabják magukra annak tartalmát, elemeit. Bár disszertációmban a létező és működő kontrollrendszerekről általában többes számban írok, egy vállalatban mindig egy konkrét kontrollrendszer múködik, tehát ott az egyes szám használata az indokolt. Az egyetlen vállalati belső kontrollrendszer azonban - ideális esetben - integrált, magában foglal több vállalati elemet, tevékenységet, kockázati tényezőt, kommunikációs formát stb.

A COSO-keretrendszer 17 alapelvét az eredeti felépítés szerint, a komponensekhez igazítva a 4. számú ábra ismerteti részletesen:

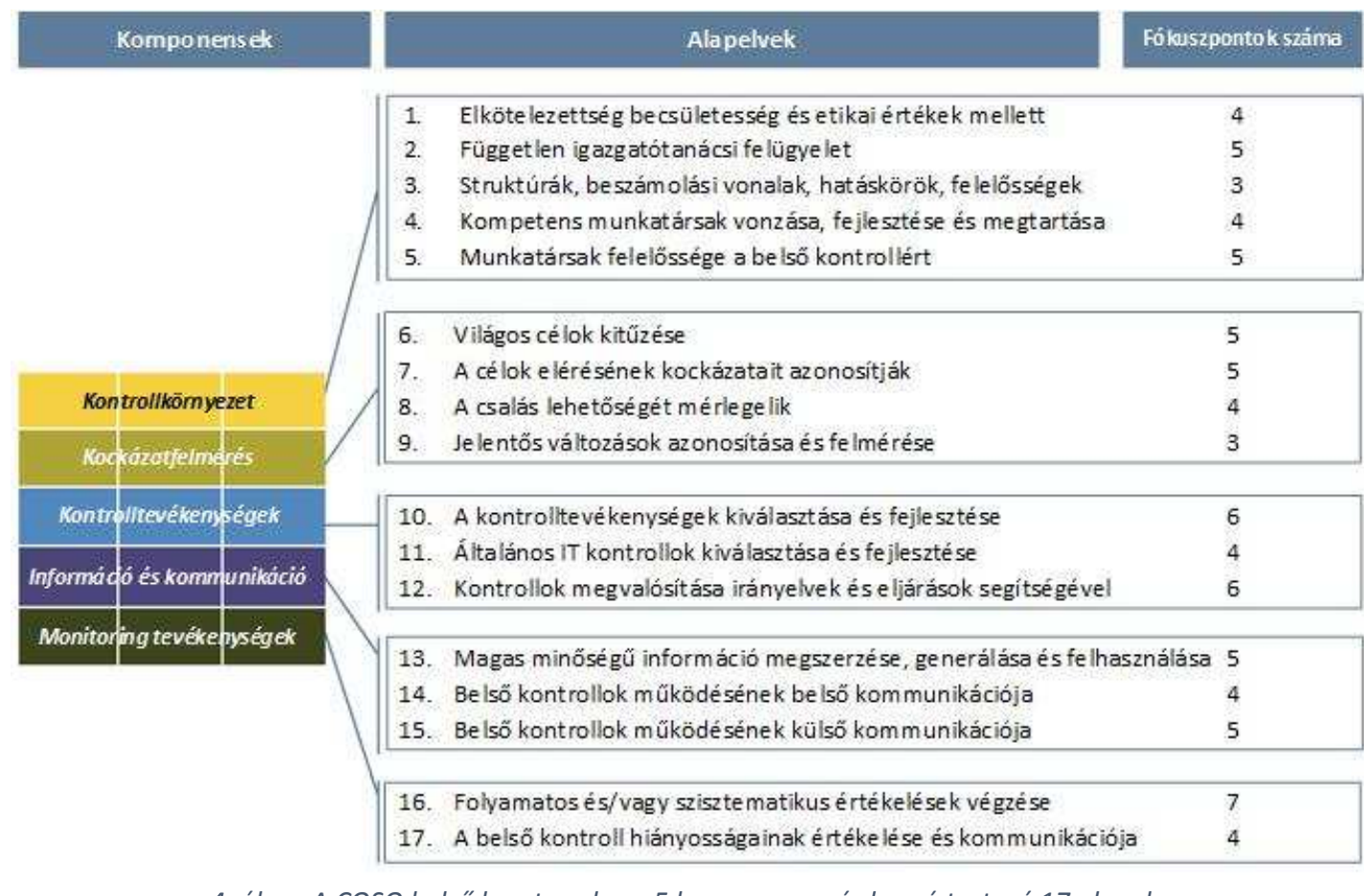

Forrás: http://www.bestgrc.com/leverage-compliance/insights-revised-coso-integrated-framework-revisedcoso-series/ (2015. 01.14.) - saját forditás

A vállalati belső kontrollrendszert a fenti háromdimenziós kocka mellett piramisalakzatban is ábrázolják. Az alábbi 5. ábra a cOSO I. modellt láttatja piramisnézetben, benne mind az öt komponenst. Ennek lényege, hogy a piramis alapköveit a kontrollkörnyezet testesíti meg (legalsó szint), erre épülnek rá a kockázatfeltárási folyamat és a kockázatokra adandó válaszok, azaz a kontrolltevékenységek (második és harmadik szint). A piramis csúcsán a monitoring komponens áll (negyedik szint), amely felülről tekint rá a teljes COSO rendszerre, és vizsgálja annak minden elemét. Ezt a kétirányú és minden szintet behálózó rendszermúködést a kommunikációs és információs csatornák teszik lehetővé, 
amely komponenst a piramis oldalain látjuk az ábrán. Ez kifejezi, hogy az információs és kommunikációs komponens a másik négy komponenssel állandó kapcsolatban van, összeköti azokat (Graham, 2015., pp.3-5.).
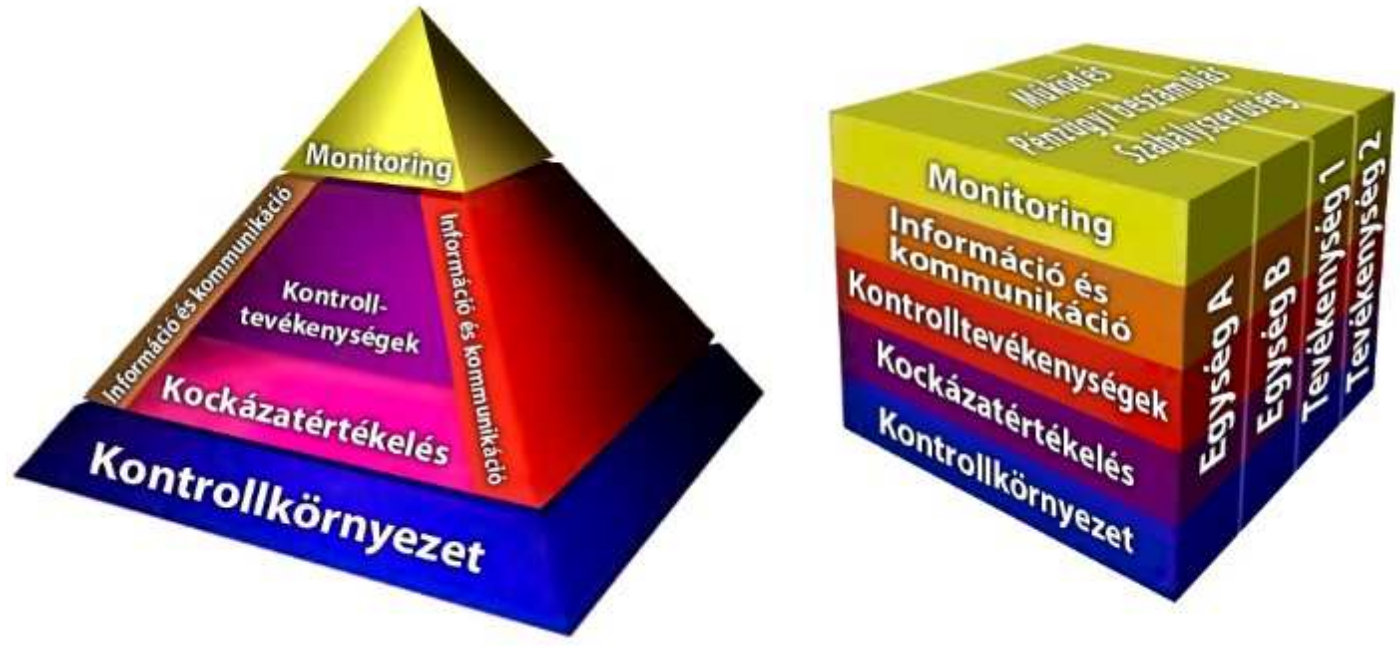

5. ábra: COSO I. piramis és COSO I. kocka

Forrás: https://s-media-cache-ak0.pinimg.com/736x/7a/33/4e/7a334ecd86a45c170dc8e631d429f6a9.jpg (letöltés: 2016. 03. 13.) - saját fordítás

A belső kontrollrendszer legfontosabb jellemzőit a szerzők az alábbiak szerint határozzák meg (Sawyer et al., 2003., pp.74-95.), (Löffler et al., 2011., pp.192-207.), (Kresalek \& Merétey-Vida, 2008., pp.44-45.) , (NAV KEKI, 2011., pp.302-303.), (Sebes, 2012., pp.205-211.):

- A kontrollrendszer mindent magában foglal, alkotóelemei az emberek, a vonatkozó szabályzatok, az erőforrások, a tervek és célkobjeitúzések, az informatikai alkalmazások, a követett normák és szokások stb. Ezekből áll össze a belső kontrollrendszer, ezek szükségesek a múködtetéséhez. Önmagukban azonban ezek az elemek nem tudnak múködni és kontrollálni egy szervezetet belülről, ehhez szükség van a vezetőre, aki az alkotóelemeket a rájuk vonatkozó logika szerint múködteti, kölcsönhatásba helyezi.

- A kontrollrendszert a vezetők alakítják ki, és ők múködtetik, ők irányítják, ők biztosítják hozzá az erőforrásokat, ők fejlesztik, és az ő felelősségük az is, ha e kontrollrendszer gyenge a szervezeten belül. A vezetők a kontrollrendszert erodálhatják, támadhatják is, ez esetben a kontroll kijátszása, eliminálása, megkerülése történik.

- A kontrollrendszer folyamatosan múködik és szolgálja a szervezetet, nem egyszeri aktus. Vannak ugyan ciklikusan visszatérő részrendszerei, de a jól 
múködő belső kontroll folyamatosan látja el feladatát, és azonnal felhívja a figyelmet a standardtól való eltérésre.

- A kontrollrendszer áthatja az egész szervezetet, a munkatársak is részt vesznek a napi munkájuk ellátása kapcsán a kontrollrendszer múködtetésében, ezért az állandó interakciók és kommunikáció révén alakul, idomul a szervezetben.

- A kontrollrendszernek nincs abszolút maximuma, teteje, soha nem lehet teljes értékü, mivel a szervezetet érő kockázatok sem csökkenthetők le nulla szintre, és nem zárhatók ki teljesen (reziduális kockázat). A belső kontrollrendszer tehát törekszik a teljességre, de azt soha nem tudja elérni, ám elfogadható szintű bizonyosságot nyújt.

A vállalat belső kontrollrendszerére a kontrolltevékenységek (Control Activities) vannak a legnagyobb befolyással. A modell alapján itt kapnak helyet azok a tevékenységek (vállalati aktivitások, cselekmények), melyek a kontrollrendszer napi működtetéséért, ilyen módon a kockázatkezelésért és -elhárításért is nagyrészt felelnek. E tevékenységekre jellemző továbbá, hogy a vállalkozás életében megelőző (preventív - azaz a káros esemény bekövetkezését elhárító) vagy utólagos feltáró/felderítő (detective - azaz utólagosan bizonyosságot nyerő) kontrolltevékenységnek tekinthetők, de például Sebes és mások múveikben még irányító (szabályozást előíró, megvalósíttató) és korrekciós (utólagos beavatkozás céljából megvalósuló) kontrollokat is bemutatnak (Sebes, 2012., pp.232-234.), (Nagy \& Németh, 2009., pp.110-111.).

A kontrolltevékenységet a COSO-keretrendszert leíró útmutató a következők szerint határozza meg (COSO, 2013a., p.Ch 7.), (INTOSAI Professional Standards Committee, 2004., p.34.):

„A kontrolltevékenységek azok az elvek (politikák) és eljárások, amelyeket a kockázatok meghatározása és a szervezet céljainak elérése érdekében alakítanak ki.

Ahhoz, hogy a kontrolltevékenységek hatékonyak legyenek, megfelelönek, az adott idöszakra vonatkozó tervnek megfelelöen funkciójukat tekintve következetesnek, valamint költséghatékonynak, átfogónak, ésszerünek, továbbá közvetlenül a kontrollcélokra vonatkozónak kell lenniük."

A szakirodalomban ezek a kontrolltevékenységek tipikusan a következők (Moeller, 2007., pp.83-86.), (COSO, 2013a., p.Ch 7.), (Fekete et al., 2006., p.160.), (Sebes, 2012., pp.230-235.), (Nagy \& Németh, 2009., pp.109-110.) alapján:

- Felső vezetői szintű áttekintés (Top-level reviews), amely szerint a legfelsőbb szintű menedzsment feladata - a pénzügyi vezetés és az 
auditorok támogatása révén - visszatérően, átfogóan megvizsgálni a szervezet működését, és szükség szerint beavatkozni, korrekciókat hozni. Ezek azok az általános kontrollok (General Controls), melyek az üzleti folyamatok, a technológiai előírások, az információs rendszer, a belső biztonsági előírások felett működnek, és kontrolljaik révén átfogják a vállalat teljes egészét.

- Közvetlen funkcionális vagy tevékenységmenedzsment (Direct functional or activity management), amely a topmenedzsment alatti és az onnan lefelé irányuló, azaz vállalaton belüli ágazati, funkcionális tevékenységek részletekbe menő kockázatkezelését és konkrét ellenőrzését foglalja magában. Valamint ide tartozik a múveletek, folyamatok és tevékenységek időnkénti felülvizsgálata is, valamint az általános felügyelet (Supervison) a különféle feladatkörök kialakításában, felülvizsgálatában és jóváhagyásában, az ezzel kapcsolatos vezetői útmutatásra és a beosztottak képzésére vonatkozóan.

- Információs tájékoztatási folyamat (Information processing), mely magában foglalja a vállalati adatok gyűjtését az IT-rendszer segítségével, valamint az egyéb forrásokból (papír, e-mail, szóbeli tájékoztatás) eredő adatok feldolgozását a hátrányos, kockázatos tényezők mielőbbi feltárása, beazonosítása érdekében.

- Fizikai kontroll (Physical controls), amely a vállalat vagyontárgyainak (készleteinek, tárgyi eszközeinek, létesítményeinek) szemlézését és a megóvásuk érdekében tett intézkedéseket foglalja magában annak érdekében, hogy azok védve legyenek az eltulajdonítással, a szándékos vagy vétlen károkozással szemben.

- Teljesítménymérés (Performance Indicator), amely pénzügyi és nem pénzügyi mutatók, átfogó kulcsteljesítmény-mérő eszközök révén teszi alkalmassá a szervezetet céljainak elérésére, a múködés mérését teszi lehetővé.

- Hatáskörök szétválasztása (Segregation of duties), amelynek értelmében a feladatokat megvalósító személytől függetleníteni kell azt a másik (legalább egy) személyt, aki a tevékenységet felügyeli, illetve ellenőrzi, annak eredményét jóváhagyólag nyugtázza, az azzal kapcsolatos pénzügyi teljesítéseket igazolja a szervezetben. Olyan engedélyezési és jóváhagyási folyamatok, eljárások meghonosítása és bevezetése tartozik ide tehát, ahol a „négy szem elve” (azaz legalább két külön személy részvétele szükséges a procedúrában) érvényesül annak érdekében, hogy a nyilvántartásokba csak szándékolt, jóváhagyott, ellenőrzött adatok kerülhessenek bele, illetve a vállalkozás védve legyen belső csalások, 
szabotázsok, szándékos vezetői szabálytalanságok (management-override) ellen.

Az INTOSAI útmutatójában (INTOSAI Professional Standards Committee, 2004., pp.26-34.) a fentieken túlmenően ismerteti még a következő, ide vonatkozó kontrolltevékenységeket is:

- Forrásokhoz és nyilvántartásokhoz való hozzáférés (Access to resources and records) kontrollja, amely a megfelelő jogosultsági rendszerek kialakítását és e rendszerek felülvizsgálatát jelenti, kiemelten az informatikai rendszerekre vonatkozóan ${ }^{49}$. Ez magában foglalja az érzékeny adatok hozzáférhetőségét, tárolását is.

- Egyeztetések, összevetések elvégzése (Reconciliations), azaz a folyamatokba ágyazott kontrollok elvégzése, amelyekkel az egyes múveletek mért eredményeinek, jellemzőinek nagyságrendje és összefüggései állapíthatók meg.

- Igazolások végzése (Verifications), mely lépés a gazdasági események megtörténtét, elvégzését, megvalósulását hivatott ellenőrizni mind mennyiségben, mind minőségét illetően.

A vállalati belső kontrollrendszer fenntartásának, működtetésének eredményeit, hasznait a következők szerint azonosíthatjuk (Salamon, 2013., p.38.):

- Célkitűzések elérését veszélyeztető kockázatok kezelhetővé válása a szervezetben, erre való felkészültség és módszertani tudás megléte.

- Tulajdonosi érdekek védelme, tulajdonosi érték növelése, valamint a vállalat jelenlegi és jövőbeni piaci értékének növelése.

- Általános rugalmasság előre nem látható esetekre, felkészültség és tudatosság az incidensek, eltérések, fenyegetések kezelése és elhárítása területén.

- Megbízható információk biztosítása vezetők döntéseihez, intézkedéseihez, beavatkozásokhoz.

- Magasabb hatékonyság, eredményesség, gazdaságosabb múködés elérése a szervezetben, ezáltal a jövedelmezőség és a profittermelő ${ }^{50}$ képesség javítása.

\footnotetext{
${ }^{49}$ E kontrolltevékenység jellegében a fizikai hozzáférési kontrolltevékenységekhez kapcsolódik, de ugyanakkor nem konkrét tárgyra, hanem adatbázisokra és annak rekordajira vonatkozik.

50 Amennyiben ez cél. Létezhet ugyanis nulla profitot maga elé kitűző, nonprofit szervezet, vagy veszteséget megcélzó, de azt minimalizáló szervezet is.
} 
- Érintettek (stakeholders) bizalmának növelése, kiemelve a külső érdekelteket, úgymint a hatóságokat, finanszírozó bankokat, stratégiai partnereket stb.

A fentiekben olvashattuk a coso-modell definíciójában azokat a nevesített szereplőket, akik a vállalati belső kontrollért felelősek. Ezt meghaladóan a COSOmodellben a belső kontrollrendszer és a kontrollfolyamatok működtetéséért és fejlesztéséért több szervezeti egység, illetve személy is felelős. Egy szervezetben mindenki visel valamilyen szerepkört, illetve felelősséget az üzleti kockázatok kezeléséért, a kontrollrendszer múködtetéséért - a vezetőktől kezdődően egészen a fizikai végrehajtó személyzetig. A középvezetők, a közvetlen irányítást végzők feladatkörükből adódóan ellátnak vezetői kontrollfunkciókat, de az automatikus kontrollok, illetve a folyamatba épített kontrollok révén a beosztott munkatársak is alkalmaznak kontrolltevékenységeket munkakörükben.

Moeller a kulcsszereplőket a következők szerint részletezi (Moeller, 2007., pp.112144.):

- Chief Executive Officer (CEO), azaz az első számú vezető, aki egyrészről irányítja, vezeti a szervezetet, másrészről képviseli a vállalatot az érdekeltek felé, harmadrészt kulcsszerepe van az erőforrások elosztásában, illetve az ezek feletti döntésekben. Ezért az első számú vezető többféleképpen is érintett a belső kontrollrendszer múködtetésében:

- Megszabja az alapvető elvárásokat az alább részletezett, kulcspozícióban lévő menedzsmenttagok számára, irányítja, vezeti őket, beszámoltatja őket, működteti a vállalaton belüli koordinációt, ebből fakadóan az információs rendszereket is.

- Szabályzatokkal, írásos eljárásrendekkel rögzíti a vállalaton belüli formalizált ellenőrzési és kontrollfolyamatokat, meghatározza azok elemeit, és (áttételesen) anyagi forrásokat biztosít az auditori, kontrolleri, kockázatkezelési, compliance-, IT-, fraud menedzsment stb. területeknek.

- A tulajdonosok felhatalmazásával, velük egyetértésben meghatározza a vállalat jövőképét, stratégiáját és azokat az elvárt kulcsteljesítményeket, melyeket a kontrollrendszernek mérnie és amelyekről visszacsatolást adnia kell.

- Személyes vezetése, habitusa, karizmája, cselekedetei meghatározó befolyással vannak a szervezeten belüli kultúrára, ezen keresztül ő a vállalati értékrend egyik fő alakítója, ilyen módon a nem formalizált kontrollok fő mozgatórugója, az etikai és morális követelmények megtestesítője, illetve számonkérője. 
- A jogszabályok és a vállalati belső előírások alapján neki van általános felelősségrevonási joga, de egyben neki van tájékoztatási és intézkedési kötelezettsége is (pl. a felügyelőbizottság irányába), ha a vállalat működése kapcsán negatívum (jogsértés, veszteség, lopás, visszaélés, káros kockázat stb.) jut tudomására.

- Chief Risk Officer (CRO), aki a vállalaton belüli kockázatkezelés rendszeréért és annak menedzsmentszintű működtetéséért felel. Felel valamennyi, a vállalat működését befolyásoló kockázati hatás feltárásáért, illetve menedzseléséért, beleértve ennek módszertani és irányítási feladatait is. Munkája során általában a pénzügyi vezetőnek $\left(\mathrm{CFO}^{51}\right)$ riportál, jelentéseit a felügyelőbizottság (FB), illetve az audit bizottság is megkapja.

- Chief Financial Officer (CFO), azaz a pénzügyi vezető, aki a vállalat tevékenysége során keletkező gazdasági események nyilvántartásáért, könyveléséért felel, összeállítja a társaság pénzügyi beszámolóit, és felel azért, hogy a pénzügyi-számviteli folyamatokban a beépített kontrollpontok eredményesen múködjenek. Felelős továbbá az utólagos egyeztetések, követő kontrollok működtetéséért, a feltáró kontrolltevékenységek ellátásáért.

- Chief Information Officer (CIO), vagyis az informatikai ügyek felelős vezetője, aki felel az IT-rendszer megbízható múködéséért, az ott tárolt adatokhoz való jogosultsági/hozzáférési rendszer naprakészségéért, az adatok állandó biztonságos meglétéért, azonban nem felel az adatok tartalmáért, mivel nem ő állítja azokat elő.

- Chief Organisation/Operational Officer (COO), aki az alaptevékenység elvégzéséért felelős termelési, szolgáltatási vezető, vagyis szervezőspecialista a vállalatnál. Munkaköréből kifolyólag ő szervezi a vállalat értékteremtő fő folyamatainak múködését, ő felel a végtermék előállításáért, és ezért rajta múlik a vállalat stratégiájának megvalósítása, a minőségi kiszolgálás, a vevők folyamatos ellátásának megszervezése. Ezért az alapfolyamatok szintjén a COO múködteti azokat a kontrolláló, elemző, feltáró és előrejelző eszközöket, amelyek hibákat, hiányokat jelezhetnek előre a napi működést illetően.

- Chief Audit Executive (CAE), aki a vállalaton belüli függetlenített belső ellenőrzési rendszer megszervezéséért és múködtetéséért felel, ilyen módon preventív és követő kontrollokat egyaránt gyakorol. Munkája révén a szervezet vezetője, menedzsmentje objektív bizonyosságot szerez,

51 Chief Financial Officer, lásd a következő pontban részletesen 
képet kap a tevékenységek célszerűségi, hatékonysági, eredményességi és gazdaságossági kérdéseiről csakúgy, mint a szabálykövetésről és a az adatok megbízhatóságáról.

A coso 2013-as felülvizsgálata során a felelős szereplők nevesített listájába bekerült még a Chief Legal Officer (CLO), aki a vállalat jogi feladatainak megszervezéséért és irányításáért felel (COSO, 2013a., p.Ch. B.).

Érdekesség ${ }^{52}$, hogy bár a definícióban a board of directors (igazgatótanács) kiemelten szerepel, a coso-modell szakirodalma részletesen nem foglalkozik az igazgatótanács, illetve az Audit Commitee (igazgatótanácsnak alárendelt audit bizottság) felelősségével, operatív múködésével és annak (legalább a) monitoringtevékenységben való részvételével. Pusztán rögzíti, hogy ezek a kontrollkörnyezet részét képezik (COSO, 2013a., p.Ch. B.). A monitoring kapcsán megfogalmazott minőségi elvárásokról és a tapasztalatok megosztásáról lásd részletesen Kinney cikkét (Kinney, 2000.).

\subsection{Kritikai észrevételek a COSO-modellel kapcsolatosan}

Egy tetszőleges modellre vonatkozóan több típusú kritikát is meg lehet fogalmazni. Az egyik módszertani jellegú, mely elfogadja a modell lényegét és értelmét, de kritizálja annak operatív tartalmát, míg a másik típusú kritika alapvetően a modell fő mondanivalóját, értelmét, létét igyekszik támadni. E megközelítések igyekeznek a coso keretrendszert kiegészíteni, illetve új szemléletben megközelíteni a vállalati kontrollok gyakorlásának módját, modelljét. Jelen kifejtésemben igyekszem mindkét típusú kritikát összegyújteni és bemutatni.

A kritikák egy része elfogadja a kontroll létét, de annak optimális mértékére és korlátaira hívja fel a figyelmet. A belső kontrollrendszer nem lehet csodafegyver, 100\%-os, abszolút kontroll soha nem garantálható a szervezetekben (COSO, 2013a., p.Ch.10.). Mivel a szervezetek ember alkotta és általa múködtetett rendszerek, ezért mindig lehetnek bennük hibák, vétlen tévedések és szándékos kijátszások. $A$ szervezeti belső kontrollok müködtetése önmagában tehát nem determinálja a szervezeti célok elérését, és nem következik a vállalati stratégia megvalósítása sem.

\footnotetext{
52 További érdekesség, hogy a modell csak általában említi a munkavállalók feladatait a kontrolltevékenységeket illetően, de nem részletezi szerepüket, helyüket a kontrolltevékenységekben (COSO, 2013a., p.Ch. B.). Az INTOSAI GOV 9100-as irányelvében a közszféra esetében a belső érintett munkavállalókat, a külső érintetteket és az ellenőrzést végzőket, valamint a törvényhozókat is megjelöli, mint akik a belső kontrollrendszer működésére valamilyen módon (értékeléssel, monitoringtevékenységgel, dokumentálással, szabályozással stb.) befolyással bírnak (INTOSAI Professional Standards Committee, 2004., pp.45-46.).
} 
Önmagában a belső kontrollrendszer reagál, figyelemfelhívást közöl, beavatkozásra figyelmeztet, igyekszik megóvni károktól, de kell a másik oldalon a vezetés, a menedzsment fogékonysága, akarata, szándéka is a problémák feltárása, megismerése és megoldása iránt. Mivel pedig az erőforrások szétosztását a menedzsment végzi, ezért ha nem jut a kontrolltevékenységekre erőforrás (pénz, ember, szakirodalom, szoftver stb.), akkor azok nem teljesítik be küldetésüket. A menedzsment válaszadási kötelezettségére, reagálási módjára azonban a COSOkeretrendszer nem ad érdemi iránymutatást, javaslatot.

Vita tárgya, hogy a vállalati belső kontrollrendszer mennyiben a nagyvállalatok sajátossága, és hogyan tudja azt egy kis- vagy középméretű vállalkozás alkalmazni. Egyrészt a KKV szektorban működő cégek sajátosságai eltérnek a nagyvállalatokétól, mert kisebb létszámban, laposabb szervezetben, kisebb földrajzi kiterjedtséggel, kevesebb erőforrással, kevésbé dokumentált belső folyamatokkal stb. dolgoznak. Másrészt viszont a KKV szektor vállalkozásai is csak akkor tudnak hosszú távon fennmaradni és túlélni, ha célirányosan követik stratégiájukat, mérik és értékelik hatékonyságukat, kezelik az üzleti folyamatokban felmerülő kockázatokat, és jogszabálykövető magatartást tanúsítanak. A dilemma az, hogy egy KKV hol találja meg az optimális kontrollmixet múködése során, amely mix nem viszi túlzásba a kontrollokat (felesleges bürokrácia), de nem is becsüli alul annak szükségességét (elégtelen kontrollok). E kettő áthidalására és az optimális szint megtalálásához a COSO 2006-ban kiadta a kis- és középvállalkozásoknak szóló ajánlását (COSO, 2006.) és az ehhez tartozó gyakori kérdésekre adott válaszait.

A kontrollrendszerek haszna és a múködtetésük erőforrásigényessége (cost-benefits analysis) kapcsán gyakran kritikaként fogalmazódik meg a túlzásba vitt kontroll (overcontrol) veszélye a kontrollmechanizmusokat illetően (Sawyer et al., 2003., pp.101-104.). Ez akkor következik be egy óriás méretű szervezetben, amikor a belső kontrollrendszer annyira szerteágazóvá, sokrétűvé és túlburjánzóvá válik, hogy az egyértelműen a folyamatok lelassulásához vezet, késői döntéshozatalt eredményez, kontraproduktívvá válik a szervezetben, passzivitásra sarkall, és végül éppen a kontrolleszközök alkalmazása nem hozza az elvártakat, sőt károssá és feleslegessé válik a szervezet számára. Ezért a vezetés nemcsak a kontrollrendszer múködtetéséért, hanem optimális mértékéért és mélységéért is felelős. Ennek megtalálása azonban nem magától értetődő a szervezetben.

A belső kontrollrendszer azért sem lehet mindenek felett álló, univerzális és tökéletes vezetői eszköz, mert korlátai vannak, melyek az alábbiak (COSO, 2013a., p.Ch. 10.), (INTOSAI Professional Standards Committee, 2004., p.12.), (BPP, 2011., pp.143-144.), (Salamon, 2013., p.36.): 
- Az emberi tévedést nem lehet kizárni, s egy vállalaton belül többen is tévedhetnek ugyanabban a kérdésben vétlenül, főleg ha esély van arra, hogy egymást meggyőzzék érvekkel, téves feltételezésekkel, helytelen forrásadatokkal.

- A kontrollok múködtetése is költségekkel jár, az erre fordított anyagi erőforrások felhasználásának pedig ésszerű korlátai vannak. Ezért a szervezet nem tud mindent, mindig, mindenáron ellenőrizni, mert a kontrollrendszer működtetési költségei ilyenkor meghaladják a várható hasznokat. Ezért a vezetés a kockázatokat csökkentheti ugyan, de maradéktalanul kizárni és megszüntetni nem tudja őket, s mindig van valamekkora maradékkockázat, amely a szervezetre negatív hatással lehet.

- A belső kontrollrendszer nem pótolja a vezetők elkötelezettségét, az alkalmazottak motiváltságát és a kontrollt működtetők szakmai felkészültségét, valamint a dolgozók etikai, morális stabilitását és értékrendjüket sem. Ezt más személyzeti programnak, emberierőforrásmenedzsment-rendszernek kell biztosítania (amennyire lehetséges).

- A szándékosság felülír minden védelmi mechanizmust. A belső kontrollrendszert ismerők az egyes kontrollpontokat kijátszhatják, az ellenőrzések eredményeit felülírhatják, a döntési és engedélyezési kontrollokkal az erre felhatalmazott vezetők visszaélhetnek, a szervezeti hatalommal rendelkezők a kontrollpontokat kiiktathatják vagy megszüntethetik. Ez végeredményben a belső kontrollrendszer szándékos veszélyeztetését, múködésképtelenné válását jelenti.

A kritikák egy másik, kisebbik része a cOSO II., azaz a COSO-ERM-rendszerrel kapcsolatos, és érdemben támadják annak kockázatkezelési irányultságát -. Ezen kritikák szerint a kontrollrendszer és a kockázatkezelési rendszer nem lehet ugyanazon rendszeren belül, mert a kettőnek más az iránya, célja a szervezeten belül (Williamson, 2007., p.1091.). Ezért e kritikák arra hívják fel a figyelmet, hogy a modern, önálló kockázatkezelési elvek (AIRMIC 200253, ISO 31000:200954, OCEG55, $\mathrm{BASEL}^{56}$ stb.) és módszerek jobb eredményekre vezethetnek, mint a COSO-ERMkeretrendszerbe ágyazott kockázatkezelés. Ugyancsak kritika illeti a COSO-ERM-

\footnotetext{
53 Lásd a szabványt bővebben itt: http://www.airmic.com/ (letöltve: 2015. 03. 09.)

54 Lásd bővebben: http://www.iso.org/iso/home/standards/iso31000.htm (letöltve: 2015. 03. 09.) angol nyelven, MSZ ISO 31000:2015 hivatkozásként magyar nyelven, valamint az 1. számú függelékben bemutatott szabványoknál.

55 Lásd bővebben: http://www.oceg.org/category/theme/risk-management/ (letöltve: 2015. 03. 09).

56 Lásd bővebben: http://www.bis.org/bcbs/ (letöltve: 2015. 03. 09.).
} 
keretrendszernek a zárt rendszerre vonatkozó feltételezését, a kritika szerint ugyanis a szervezet sem zárt rendszer, így annak kockázatkezelési eljárási keretrendszere sem lehet zárt és a környezettől független (Williamson, 2007., p.1101).

Másrészről a COSO I. és a ráépülő COSO-ERM-keretrendszerben használt kockázat definíciója eltér más, kifejezetten kockázatkezeléssel foglalkozó múvek definícióitól (Williamson, 2007., pp.1096-1097.), harmadrészt a COSO-ERM-rendszer megragadt a keretrendszer szintjén, és az optimális kockázatmérték, illetve kockázatvállalás szintjét nem adja meg nekünk (Kurniawanti, 2010., pp.317-322.), valamint nem elég konkrét és gyakorlatias, vagyis a felhasználók, menedzserek számára a gyakorlatba való átültetése és a mindennapok nyelvére való lefordítása nehézségeket okozhat (Quinn, 2006, pp.1-9.).

\subsection{További modellek}

A COSO-modellt alapul véve, arra építkezve, illetve annak hiányosságait kiküszöbölendő jöttek létre újabb, más aspektusú szervezetirányítási, -szabályozási és kontrollrendszer-modellek, hogy a coso-ból esetlegesen hiányzó vagy nem hangsúlyos elemeket pótolják más szempontokkal.

Az IIA 2013-ban publikálta a három védelmi vonalból álló modelljét (The Three lines defense model), mely a vállalkozások üzleti folyamataira vonatkozó kontrollokat három, egymásra épülő vonalban (lépcsőben) szemlélteti. A védelmi vonalak együttesen és egymással együttmúködve szolgálják az eszközök, a vagyon védelmét, a szabályszerű működést és az üzleti célok megvalósulását (IIA, 2013b), (Anderson \& Eubanks, 2015.). A védelmi vonalak rendszere és a rendszer kulcsszereplői a következők:

- 1. vonal: alaptevékenység szintje. Itt történik minden olyan operatív, mindennapi kontrolltevékenység, melyet az értékteremtő folyamatokban a szakterületek alkalmaznak a saját munkájuk ellenőrzése, kontrollja céljából. Ezek a kontrollok föként operatív vezetői, illetve a szabályszerűség betartását ellenőrző kontrollok. Az első vonalbeli kontrollokat tehát magukon a termelő, kereskedő, szolgáltató területeken belül alkalmazzák (pl. gyártó üzem, raktár, szállítmányozás, értékesítés) mégpedig azok, akik az üzleti folyamatok kulcsszereplői, az üzleti területek gazdái, folyamatgazdái. Az ő felelősségük a saját hatáskörükbe tartozó részfolyamat(ok) során felmerülő kockázatok kezelése, és ennek érdekében az elsődleges kontrollok alkalmazása.

- 2. vonal: szakosított támogató szervezetek szintje. A második védelmi vonalban helyezkednek el a támogató, szolgáltató szervezetek, amelyek az 
operatív múködésben közvetlenül nem vesznek részt, hanem azt szakértelmükkel, belső szolgáltatásaikkal, támogató funkciójukkal és részben belső irányító, direktív szabályalkotó feladatukkal ciklikusan, időről-időre visszatérően erősítik. Ilyen kontrollokat gyakorol többek között a controlling, a kockázatkezelés, a minőségirányítási szervezet, a jogi osztály, a belső elhárítás, a compliance terület stb. A második vonalban felülvizsgálják az első vonalbeli kontrollok eredményeit, ill. szakértelmükkel támogatják a kontrollok hatékonyabb gyakorlását.

- 3. vonal: függetlenített belső ellenőrzés szintje. A harmadik védelmi vonal egyetlen szereplője a függetlenített belső ellenőrzési szervezet. A belső ellenőrök mindentől és mindenkitől függetlenül, utolsó védelmi vonalként ellenőrzik az előző két szinten megvalósuló kontrollokat, és rendszerszintű megállapításokkal, javító szándékú észrevételekkel segítik a menedzsmentet és a társaságirányítási szintet.

A három védelmi vonal fölött helyezkedik el a top-menedzsment (operatív csúcsvezetés) és afelett a társaságirányítási szint (igazgatótanács, felügyelő bizottság, audit bizottság stb.). Az egyes védelmi vonalaktól érkező, összegzett beszámolókat, illetve komplex döntési javaslatokat e két vállalati csúcsszint értékeli, illetve hoz döntéseket.

A védelmi vonalak komplex modelljére külső szereplőként ráhatással vannak a külső hatóságok, amelyek ellenőrzéseket végeznek, illetve a jogalkotó szervek, amelyek jogszabályokkal, közleményekkel, határozatokkal befolyásolják a vállalatok múködését, így a kontrollrendszereiket is.

A három védelmi vonalból álló modell ábrája az alábbi (IIA, 2013b, p.2.):

Igazgatóság, FB, Audit Bizottság

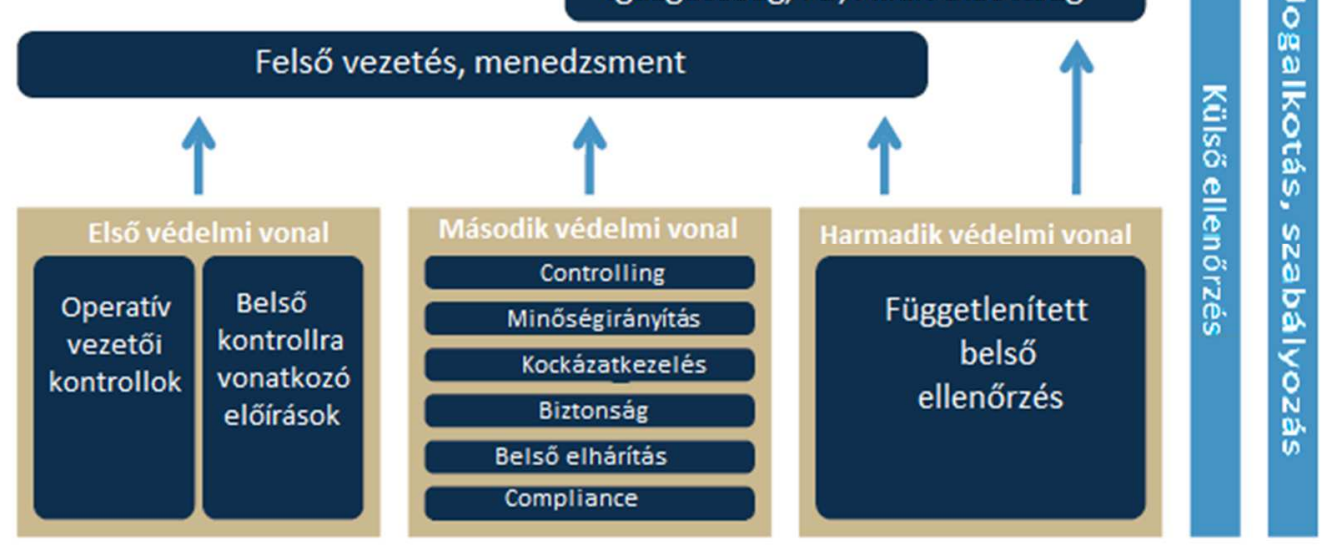

6. ábra: Három védelmi vonal modellje

Forrás: (IIA, 2013b, p.2.) - saját fordítás 
Meghatározó, a vállalati folyamatokat a COSO-modellel integráló eszköz az, mely a nemzetközi fórumokon Enterprise SPICE modellként ${ }^{57}$, hazánkban a felelős vállalatirányítás modellje néven vált ismertté. A modell a COSO, a COBIT és az ISO/IEC 15504-2 szabvány által meghatározott folyamat-attribútumok felhasználásával, ötlépcsős, egységes értékelési skála mentén méri a vállalat irányítási folyamatainak érettségét (Business Process Modelling for Governance SPICE \& Internal Financial Control (BPM-GOSPEL) konzorcium, 2012., pp.29-31.). A modell ábrája az alábbi:

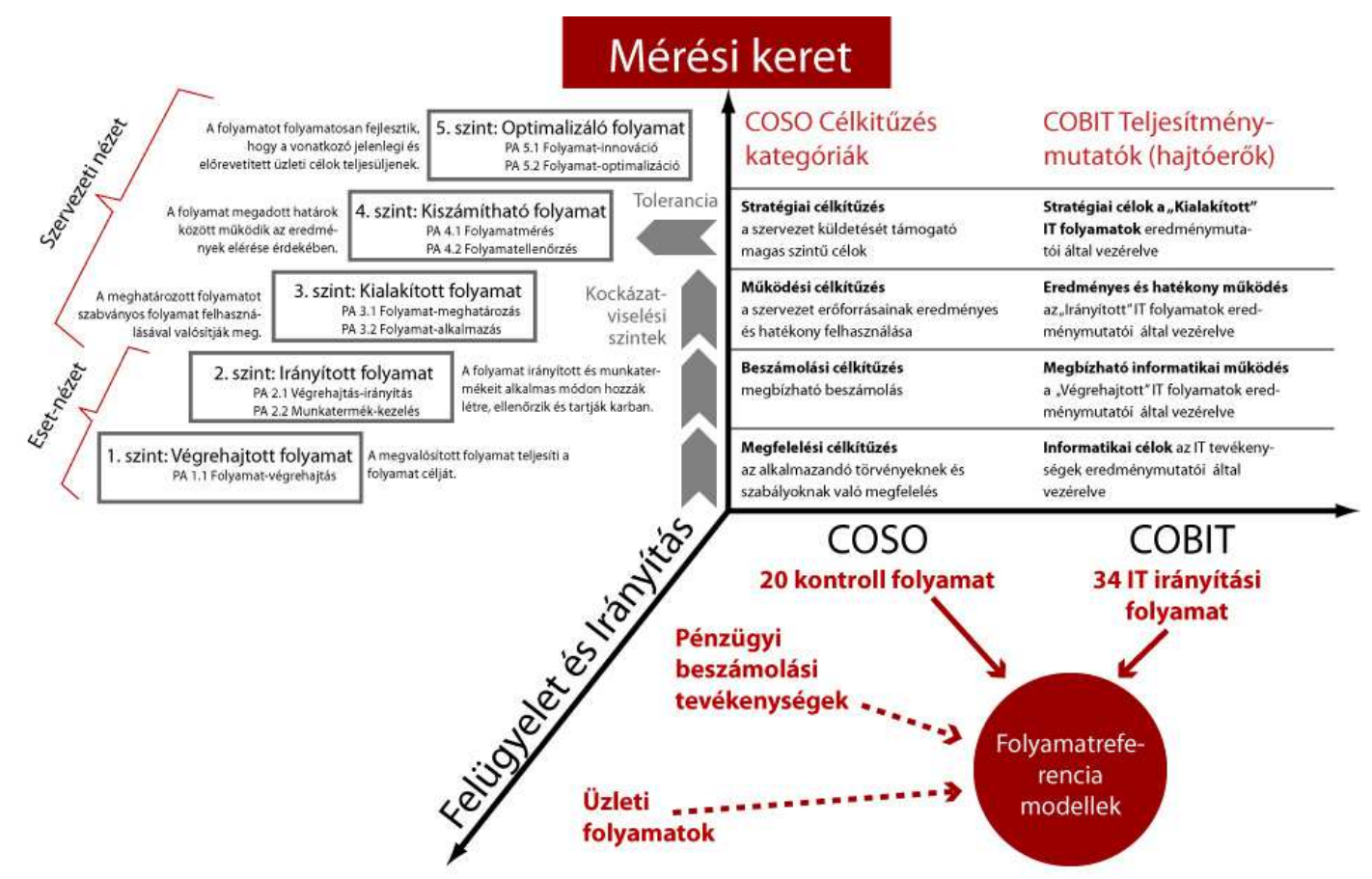

7. ábra: Irányítási Képességfelmérési Modell (Governance SPICE)

Forrás: (Business Process Modelling for Governance SPICE \& Internal Financial Control (BPM-GOSPEL) konzorcium, 2012., p.30.), magyar nyelvü változat

A Governance SPICE modell a következő területeket fedi le a vállalati múködés irányítása, célkitǔzésrendszere és kontrolltevékenységei közül (Ivanyos, 2011.):

- Szabályozott vállalati múködés elérése, biztosítása:
a) Kockázattudatosság
b) Elszámoltathatóság

\footnotetext{
${ }^{57}$ An Integrated Model for Enterprise-wide Assessment and Improvement Technical Report, lásd a szervezetet (csoportot) bővebben itt: http://enterprisespice.com/page/publication-1 (2015. 01. 16.) illetve itt: http://www.slideshare.net/ErnestWallmueller/strategies-process-improvementwithesspice2013v21ewa (2015. 01. 16.)
} 
c) Kompetencia

d) Hitelesség

e) Folyamatintegritás

f) Adatvédelem

g) Elkötelezettség

h) Kontrollhatékonyság

- Fenntartható vállalati múködés elérése, biztosítása:
a) Versenyképesség
b) Kiaknázhatóság
c) Elégedettség

A felelős társaságirányítás meghatározását és a vállalati kontrollban betöltött szerepét a fentiekhez hasonlóan említi Kovács Árpád, illetve Kresalek Péter és Merétey-Vida Zsolt múveikben (Kovács, 2007., pp.206-207.), (Kresalek \& MeréteyVida, 2008., p.28.). A Governance SPICE modell vállalati szférán túli, közszférában való alkalmazhatóságáról lásd bővebben Ivanyos János és Roóz József cikkét (Ivanyos \& Roóz, 2010.).

A mérlegképes könyvelők kanadai intézete ${ }^{58}$ a coSO-modelltől függetlenül, de annak elveit figyelembe véve kialakította a belső kontrollra vonatkozó saját útmutatóját (Guidance on Control), és ennek alapján négy területet határozott meg, melyekhez összesen húszpontos ajánlást tett közzé (Margaret E. \& Leon A.M., 2000., p.14.), (Sawyer et al., 2003., pp.68-69.). A négy terület a következő:

- Céltudatosság (Purpose), vagyis teljesítménycentrikusság, azaz a kockázatok feltárására és a célokat veszélyeztető helyzetekre való válaszképesség, illetve intézkedési hajlam megléte.

- Elköteleződés (Commitment), azaz a munkavállalók lojalitásának erősítése etikai normák beiktatásával, illetve a megbízhatóság hangsúlyozásával.

- Képesség (Capability), azaz a tudás, az információfeltárás és -elemzés, továbbá a szakmai képzés feltételrendszerének beépítése a vállalat múködésébe.

- Folyamatos tanulás (Monitoring \& Learning), azaz a környezet, az információk és a folyamatok vizsgálata, illetve rendszeres, objektív mérésen alapuló helyzetértékelés készítése a vállalat állapotát illetően.

A Londoni Tőzsdetanács Nigel Turnbull összegző jelentése alapján 1999-ben publikálta Guidance for Directors on the Combined Code című múvét a londoni

\footnotetext{
${ }^{58}$ A szervezet eredeti elnevezése: Canadian Institute of Chartered Accountants (CICA) volt, a szervezet mai neve Charted Professional Accountants of Canada. Tevékenységüket lásd bővebben:

https://www.cpacanada.cal (2015. 03. 09.)
} 
tőzsdére bejegyzett vállalatok számára, mely a későbbiekben Turnbullútmutatóként vált ismertté. A Turnbull-útmutató a COSO-modellhez hasonlóan a kontrollkörnyezethez igazítva határozza meg a vállalatok számára a kontrolltevékenységeket, az információs és kommunikációs folyamatokat és a monitoringfolyamatokat, azaz ezek köré építi fel a belső kontrollrendszert, azonban a COSO-ban megismert kockázatkezelési komponenst nem tekintették különálló elemnek (BPP, 2011., pp.36-38.), (Merétey-Vida, 2007., p.5.), (ICAEW, 1999., p.7.). Mára az útmutató számos felülvizsgálaton esett át, és $\mathrm{az} \mathrm{FRC}^{59}$ több különálló útmutatót adott ki helyette.

A szakirodalom a fentieken túlmenően egyéb szakmai standardokkal veti össze a cOSO-modellt, melyeknek vagy informatikai (pl. COBIT), vagy pénzpiaci (pl. BASEL) orientációjuk vagy egyéb kontrollaspektusaik vannak (Colbert \& Bowen, 1997., pp.111.).

\section{5 Összegzés}

Disszertációm jelen fejezetében a belső kontrollrendszer modelljét és jellemzőit mutattam be részletesen, azaz a COSO-keretrendszert ismertettem. E fejezetben hangsúlyt kaptak azok a szereplők, akik a kontrolltevékenységeket végzik, valamint a COSO-alapú belső kontrollrendszerek kritikáit mutattam be. A kulcsszereplők fontosak számomra azért, mert a következő, az intézményesülésről szóló fejezetben ezen szereplőkre visszahivatkozom majd. A kritikák ismertetése pedig azért fontos, mivel ezek adnak magyarázatot, ismertetnek okokat egy rosszul múködő, nem hatékony, pazarló és eredményeket felmutatni mégsem tudó belső kontrollrendszert illetően.

Értekezésem következő fejezetében - innen továbblépve - a belső kontrollrendszerek intézményesülését mutatom be, ahol a hangsúly a vállalati belső kontrollrendszer fejlődésén, organikus megszerveződésén, továbbá az ezzel kapcsolatos szervezetszociológiai modelleken van.

\footnotetext{
59 Financial Reporting Council (FRC), azaz a brit pénzügyi jelentések tanácsa. Lásd bővebben: https://www.frc.org.uk/Our-Work/Codes-Standards/Corporate-governance/UK-Corporate-GovernanceCode/Guidance-for-boards-and-board-committees.aspx (2015. 02. 23.)
} 


\section{RÉSZ}

\section{A VÁLLALATI KONTROLLRENDSZEREK INTÉZMÉNYESÜLÉSE}

$A z$ intézmény szó főnévi formában ${ }^{60}$ klasszikus jogi kifejezés: jogalanyisággal rendelkező szerv vagy szervezet ${ }^{61}$, valamely közösségi célra létesített, bizonyos személyi keretekkel rendelkező társadalmi vagy állami szervezet. Intézmény például a kórház, az egyetem vagy egy sportlétesítmény. Ugyanakkor a római jog bevezette a jogintézmény fogalmát ${ }^{62}$ is, amelyben maguk a jogi normák konstruálnak valamilyen cselekvési teret, eljárást. Ilyen jogintézmény például a tulajdonjog, a kártérítés, az adózás vagy az öröklés, melyeket a mai napig is használunk.

Az intézmény szót a politikatudomány is használja, igaz, politológiai megközelítésben, $s$ jellemzően politikai intézményeket azonosít vele. Ilyen intézmény például a többségi döntés elve, az állam, az önszerveződés vagy a pártrendszerek. Ezek mindegyikére jellemző, hogy tartósan elfogadott szabályrendszerek alapján, az emberek számára objektíven adottnak tekintve, de az ő befolyásolásukkal múködnek, és keretet adnak az emberi cselekvésnek (Goodin \& Klingemann, 2003., pp.137-221.), (Bayer, 1999., pp.89-92.).

$A z$ intézmény szónak azonban van szociológiai jelentéstartalma is, amely a társadalomban kialakult rendszereket, szokásokat, cselekvési formákat foglalja magában. Ezt támasztja alá az intézményesít ige alapvető jelentése is ${ }^{63}$ : intézményszerúvé tesz, így rendszeresít. Ha a szociológia az intézményesülést makroszinten vizsgálja, akkor társadalmi intézményekről beszélünk, ilyenek például az oktatás, az egészségügyi ellátás vagy a vallás. Ezeket szokás intézményrendszernek is nevezni, ahol magánszemélyek (orvosok), jogi személyek (pl. kórházak) és ezt szabályozó szervezetek (pl. egészségügyért felelős minisztérium) együttműködve hoznak létre és múködtetnek társadalmi szinten jelentős ellátórendszereket (pl. egészségügyi ellátórendszer) ${ }^{64}$. Ha pedig az

\footnotetext{
60 Magyar értelmező kéziszótár(2003), Akadémia Kiadó, Budapest, 572-573. oldal, intézmény szó

61 Hargitai József (2005): jogi fogalomtár, 702. oldal, intézmény szó

62 Értsd: „jogintézmény: jogi normák egy csoportjából felépített olyan normatív séma, mely egy állandósult társadalmi viszonytípust szabályoz". Szabó Miklós (szerk) (2012): Bevezetés a jog- és államtudományokba, p. 337., ötödik, átdolgozott kiadás, Prudentia luris, Miskolc, illetve lásd részletesebben: Földi \& Hamza (1996): A római jog története és institúciói, p.69-70., Nemzeti Tankönyvkiadó, Budapest.

63 Magyar értelmező kéziszótár(2003), Akadémia Kiadó, Budapest, 573. oldal, intézményesít ige

64 Disszertációmnak nem célja az ellenőrzés, illetve a kontroll hiányának makroszintű, azaz társadalmi problémaként való kezelése és bemutatása. Azt, hogy egy társadalomban mi számít problémának, és mik a
} 
intézményesülést mikroszinten ragadjuk meg, akkor a csoportok, közösségek, szervezetek múködését, belső mechanizmusait, a benne résztvevő egyének cselekvéseit elemzzük. Ilyen mikroszint például a család, a civil szervezet, a lakóközösség vagy éppen egy vállalkozás (McKiney \& Mone, 2003., p.363.), (Giddens, 1995., pp.375-377.) (Fulcher \& Scott, 1999., p.503.), (Kieser, 2003., pp.413-416.), (Farkas, 2001., pp.142-147.), (Andorka, 2003., p.351.).

Mikroszinten tehát az intézményi szociológia, a szervezetszociológia, valamint az új intézményi szervezetelmélete ${ }^{65}$ mikroinstitucionalista megközelítése segítenek számunkra tipizálni a bekövetkező eseményeket, megértetni és magyarázni a jelenségeket és az azok mögött húzódó kényszereket és motivációkat, valamint segítenek az egyéni és kisközösségi cselekvéseket leírni, jellemezni (Kieser, 2003., pp.386-390.). Az intézményesülés, mint folyamatra utaló fogalom, végigkíséri az intézmény létrejöttét, amelynek végeredményeképpen létrejön a stabilintézmény, amely beágyazódik, megszilárdul a szervezetekben.

Disszertációm ezen részében azt vizsgálom tovább, hogy a vállalatokon belüli kontrollok miképp állandósulnak és válnak a szervezet mindennapi működésének részévé, azaz hogyan intézményesülnek a vállalkozásokban. Mindezt az institucionalista (intézményi szervezetelméleti ${ }^{66}$ ) megközelítésből kívánom megtenni. A jobb megértés érdekében egy-egy fő gondolatot a belső kontrollrendszer témájához illeszkedő, tipikus példával támasztok alá az alábbi bekezdésekben ${ }^{67}$.

Egy szervezet keletkezésének okát, a szervezeten belüli folyamatokat, múködési eljárásokat, viszonyokat, élethelyzeteket a szervezetszociológia, ill. a különféle szervezetelméletek széleskörúen vizsgálják. Számos megközelítés létezik, amelyek leírják egy vállalat múködésének sajátosságait, mozgatórugóit. Ilyen például a megbízó-ügynök elmélet, az evolúcióelmélet, a tranzakciós költségek elmélete vagy az institucionalista szervezetelmélet. Ezen elméletek megalkotói különféle kutatói irányultsággal, lényegfeltáró aspektussal, nézettel közelítenek egy-egy szervezethez és elemzik annak múködését (Kieser, 2003., p.2.), (Arwinge, 2013., pp.29-36.).

megközelítés elméleti alapjai, a kezelés módjai, lehetséges megoldásai, lásd részletesen Fuller, Myers, Blumer, Merton, Durtkheim, Spector, Kitsuse műveiben és értekezéseiben.

${ }^{65} \mathrm{Az}$ intézményi szervezetelméletek régi és új megközelítéseit és a kettő közötti hasonlóságok és különbségek bemutatását lásd részletesen Powell és DiMaggio művének bevezető fejezetében (DiMaggio \& Powell, 1991., pp.11-15.), valamint Kieser művében (Kieser, 2003., pp.393-398.).

${ }^{66} \mathrm{Az}$, hogy a szervezetek működése a vezetéstudomány, a menedzsmenttanok érdeklődési területévé vált, szükségszerüen magával hozta azt, hogy az intézményi szociológia mellett intézményi közgazdaságtan is kialakult. Utóbbi a cselekvéseket gazdasági szempontból vizsgálja, és nem azonos az intézményi szociológiai megközelítéssel.

67 „Példa:” figyelemfelkeltéssel: a bekezdés behúzásával, valamint eltérő betűtípussal jelölve 
Ezek közül én azért választottam az intézményi megközelítést, mert úgy ítélem meg, hogy a kontrolltevékenységek szervezetbe integrálásának elméleti magyarázatához éppen ebben a megközelítésben találhatjuk a legtöbb kapaszkodót, segítséget. Kifejezetten az intézményi megközelítésben találtam meg számos olyan elemet, melyek magyarázatul szolgálhatnak a vállalatokon belüli kontrollmechanizmusok értelmezéséhez és megértéséhez, úgymint a szabályok követése, az aktorok szerepe és hatalomgyakorlása, ellenőrzés és szankcionálás, szerepek és viselkedésminták a szervezetekben stb.

\subsection{Az intézményesülés fogalma, folyamata}

Az intézményesülést a szervezetszociológiai szakirodalom kétféleképpen is megközelíti: egyrészt állapotnak, másrészt folyamatnak tekinti. A folyamatszerü felfogásban kialakul a formalizált magatartás, a cselekvési sémák rendszere, míg állapotra vonatkozó felfogásban akkor említünk intézményesültnek valamit, ha létrejöttek és megszilárdultak a beágyazódás kritériumai. Ezért a különféle szakirodalmakban hol intézményről (állapotról, végeredményről), hol pedig az intézményesülés folyamatáról olvashatunk. Disszertációm jelen részében mindkét megközelítést bemutatom, először az elméleti modelleket külön-külön, majd kiemelem hasonlóságaikat és különbségeiket is.

Selznick 1955-ös, korai definíciója szerint az intézményesülés a következőt jelenti (Selznick, 1996., p.271.):

„....institutonalization is a neutral idea, which can be defined as the emergence of orderly, stable, socially integrating patterns out of unstable, loosely organized, or narrowly technical activities."

Veblen megközelítésében az intézményesülés a következőket jelenti (Veblen, 1969., p.611.):

"An institution is of the nature of a usage which has become axiomatic and indispensable by habitation and general acceptance. Its psychological counterpart would presumably be one of those habitual addictions that are now attracting the attention of the experts in sobriety."

Meyer és Rowan struktúraalapú megközelítése az intézményesülést a következőképpen határozza meg (Meyer \& Rowan, 1977., p.341.):

„.... Institutionalization involves the processes by which social processes, obligations, or actualities come to take on a rulelike status in social thought and actions."

DiMaggio és Powell megfogalmazásában az intézményesülés a cselekvések keretrendszerét (frameworks of rules or programs) határozza meg, és az egyén 
számára múködési mintákat (activity scipts) állít fel. Ilyenkor az intézmények a belső kultúrában, formális szervezeti struktúrában és a hatalommal bíró vezetők (regimes) által irányított múködési rendszerekben testesülnek meg (DiMaggio \& Powell, 1991., pp.146-151.).

Az intézmény szociológiai fogalma szerzőnként eltérő, de nagyrészt Berger és Luckmann meghatározásával mutatnak hasonlóságot (Berger \& Luckmann, 1998., p.82.), mely magyar fordításban a következő (Farkas, 2001., p.121.):

„Az intézmények a megszokott cselekvések kölcsönös és rendszeresen ismétlődő tipizálásának bizonyos fajtái, melyek a magatartás elöre meghatározott mintái révén irányítják az emberi magatartást."

Scott definíciója szerint az intézmény szervezetszociológiai értelemben az alábbi (idézi (Lawrence \& Suddaby, 2006., p.216.)):

„... consisting of cultured-cognitive, normative and regulative elements that ... provide stability and meaning to social life... Institutions are transmitted by various types of carriers, including symbolic systems, relational systems, routines and artifacts."

Más megfogalmazásban az intézményesülés a szervezet vagy közösség alulról szerveződő68, belső kezdeményezései révén kialakuló normarendszer (Biró et al., 1991., p.6.):

„....az intézményesülés az a mechanizmus, amelynek során kikristályosodik valamely közösség alulról szerveződő belső világa (kialakulnak fenntartó intézményei), megszokottá válnak bizonyos cselekvési stratégiák, kiszámitható és elöre látható lesz, hogy a közösség milyen típusos cselekvői milyen típusos cselekvéseket végeznek, felállítódnak a magatartási minták, melyek elöírják, hogy milyen magatartások lehetségesek a közösségen belül, kialakul a különbözó helyzetek közös értelmezési sémája, kiépül az együttlét beidegzett háttere, s mindez a tagok számára magától értetődő kezd lenni, majd a megszokásokon és tipizáláson túl megerösödik a közösségnek az őt pillanatnyilag alkotó egyénektöl független realitása, a közösség belső rendje objektív társadalmi valósággá válik, olyanná, ami másoknak átadható, és az új tagokra kényszerítő erőként hathat."

Tolbert és Zucker múvükben az intézményesülés folyamatát alapvetően három egymás utáni lépésben határozzák meg (Tolbert \& Zucker, 1996., pp.180-185.):

\footnotetext{
${ }^{68}$ A szerzők később maguk is felhívják a figyelmet, hogy az intézmények tudatosan és kívülröl érkező
} kezdeményezésként is létrejöhetnek (Biró et al., 1991., p.7.). 
I. Berögződés (habitualization): intézményesülés előtti szakasz, amikor a szervezet tagjainak újszerű viselkedése, egyedi reakciója van egy újszerű, külső hatásra vagy probléma megoldására vonatkozóan. Ilyen kiváltó ok lehet pl. új technológiai innováció megjelenése, versenytárs feltűnése, jogi szabályozás változása, szervezési probléma a szervezeten belül stb.

II. Tárgyiasítás (objectification): az intézményesülés kezdetleges szakasza, amikor a döntéshozók, aktorok, hatalommal bíró szereplők megállapodnak arról, hogy a továbbiakban a szervezet a habitualizációs szakaszban adott választ fogja adni minden további esetben, amikor az ott azonosított probléma, kihívás, impulzus újra bekövetkezik.

III. Leülepedés (sedimentation): az intézményesülés lezáró szakasza, amikor az objektifikációs szakaszban megerősített viselkedés későbbi pozitív hasznokat eredményez, és az érdekeltek hosszabb távon is elismerik az intézményesült reakciót mint hasznos problémamegoldási folyamatot, így az a normák részévé válik.

Modelljük az intézményesülés folyamatát a következő, 8. számú ábrával szemlélteti:

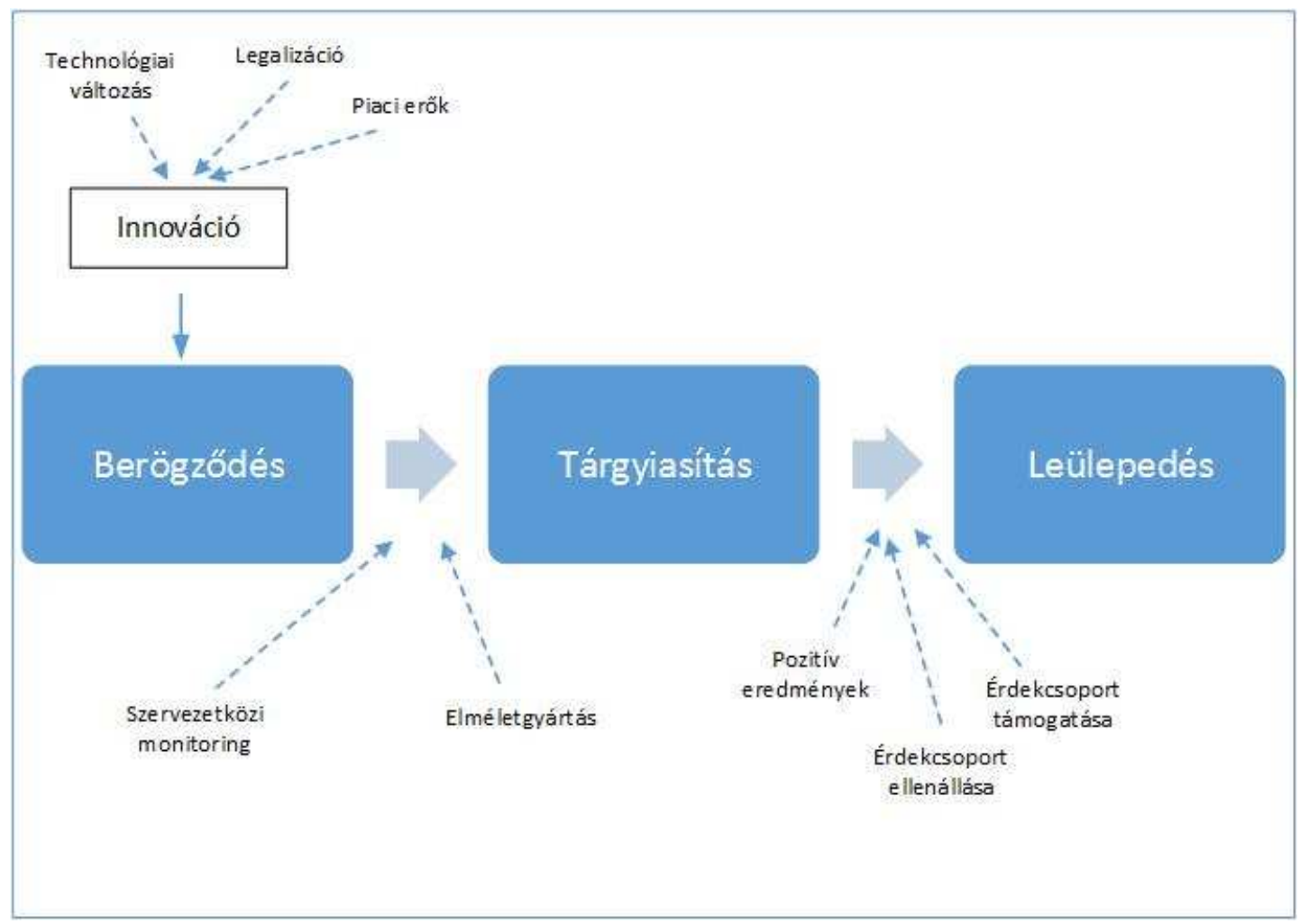

8. ábra: Intézményesülési folyamat komponensei

Forrás: (Tolbert \& Zucker, 1996., p.182.), saját technikai átdolgozással, saját fordítás

Barley és Tolbert az intézményesülés folyamatának sematikus összefoglalását az alábbi ábra szerint mutatják be (Barley \& Tolbert, 1997., p.9.): 


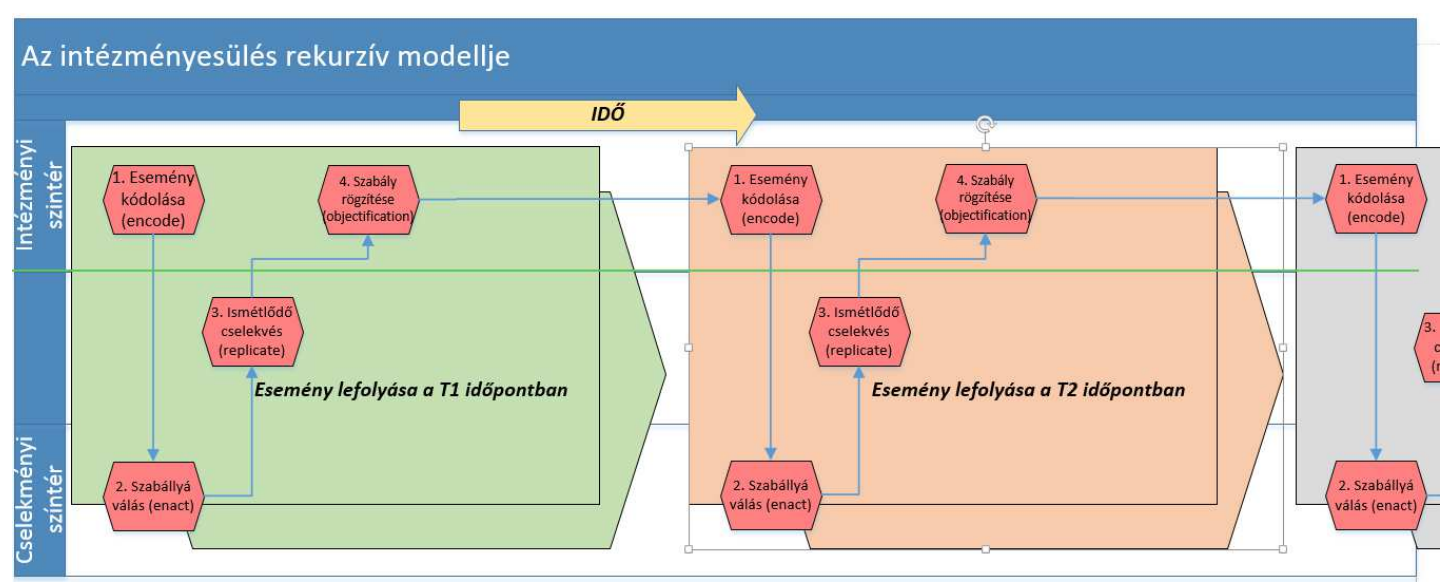

9. ábra: Az intézményesülés rekurzív modellje

Forrás: (Barley \& Tolbert, 1997., p.9.), saját technikai átdolgozással, saját fordítás

Barley és Tolbert az intézményesülési folyamatot négy lépcsőre bontja, az intézményesült cselekvés kialakulását az időben előrehaladva egy önmagába visszatérő modell szerint ismerteti, amelynek négy momentuma sorrendben a következő:

1. Esemény kódolása (encode), amikor a szereplők felismernek és azonosítanak valamilyen eseményt, és megállapítják, hogy erre az eseményre még nincs cselekvési mintájuk.

2. Szabállyá válás (enact), amikor az eseményt és az arra adott választ, cselekvést a szereplők közmegegyezéssel nyugtázzák, vagyis kialakul az elfogadott norma, a követendő cselekmény.

3. Ismétlődő cselekvés (replicate), amikor az eseményre újra és újra az előző pont szerinti szabály alapján reagálnak a szereplők.

4. Szabály rögzítése (objectification), amikor beteljesedik az intézmény, azaz amikor a szereplők a szabályt objektivá teszik, azaz már a résztvevő felektől és az egyéb szereplőktől függetlennek és kívülről adottnak veszik.

A modell alapján így T1 időpontban már létrejön az intézmény, amely azonban a T2 időpontban egy új szituáció megválaszolására nem alkalmas, ezért egy új intézményesülési ciklus kezdődik, melyben sorra újra a fenti négy momentum zajlik le, amelynek eredményeképp T2 időpontra egy újabb intézmény alakul ki. Idővel azonban egy újabb szituáció áll elő, melyre újfent nincs megoldási készlete a benne lévő egyéneknek, ezért újraindul a fenti négy momentum stb., aminek eredményeképp T3 időpontra (a fenti, 9. számú ábrán már szándékosan nem látszik) egy újabb intézmény jön létre (Barley \& Tolbert, 1997., pp.10-13.). 
Példa gyanánt megkísérlem a kontrolling kialakulását bemutatni a fenti modell alkalmazása révén egy fiktív ${ }^{69}$ történet segítségével. $A z$ 1. számú függelékben ismertetett kontrollszereplők közül a kontrollerőse Franciaországban már az 1600-as években tetten érhető volt komptroller néven. A föúr felismerte, hogy pénzügyeinek kezelésével meg kell bíznia valakit az udvarában, így a komptrollerre esett a választása, aki addig istállójának lóállományát tartotta nyilván a birtokon (esemény kódolása). Valamivel később a főúr megbízta a komptrollert a vagyonának nyilvántartásával is, mert az igen közel állt az előző megbízatás tartalmához. A föúr elhatározta hát, hogy ezentúl a komptrollerre támaszkodik majd saját birtoka pénzügyi kérdéseiben (szabályalkotás). Ezt követően valahányszor pénzügyi, vagyonnal kapcsolatos, üzleti feladat vagy igény merült fel a birtokon, a komptroller volt az, aki azt feladatul kapta és elvégezte (ismétlődés). A begyakorlás olyan jól sikerült, hogy a föúr is, és a komptroller is magától értetődőnek tekintette, hogy pénzügyi kérdésekben a továbbiakban a komptroller segítette a föúr döntéseit, illetve vezette a birtok nyilvántartásait, és beszámolt a mindenkori vagyoni helyzetről (szabály rögzítése). Így a T1 időpontra már intézményesült a komptroller munkaköre és vele együtt a birtokon belüli kezdetleges menedzsmentkontroll-rendszer müködése is. A föúr azonban gyanút fogott, hogy az udvari konyhában a szakácsok vagy a felszolgálók lopják a húst, a tojást, a lisztet. Erre a szituációra a komptroller munkaköre nem adott megoldást, ezért megbízta nádorát a konyha és a szakácsok titkos megfigyelésével. A nádor feltárta a visszaéléseket, és a későbbiekben újra ő kapott megbízást a főúrtól az esetleges csalások felderitésére és kivizsgálására az udvaron belül. Így T2 időpontra létrejött a belső ellenőrzés és csalásfelderités intézménye az udvarban, melyet a nádor - mint intézményesült belső revizor - látott el a továbbiakban.

Dambrin és társai múvükben az intézményesülés folyamatát szintén négy lépésre osztják (Dambrin et al., 2007.). Felfogásukban az intézményesülés egy új javaslat, ötlet, gondolat szervezeti megfogalmazásával indul, melynek forrása a szervezeten kívülről, a szervezetközi kapcsolatrendszerből ered. Modelljük középpontjában a vállalaton belüli diskurzus áll, ahol a szereplők egyeztetik nézeteiket az új, kívülről érkezett javaslatról, és megállapodnak az újdonságszerü ötlet, javaslat, megoldás alkalmazásáról, majd azokra technikai, technológiai stabilizációs célú eljárásokat indítanak (pl. szabályzat kiadása, budgetbe foglalás, projekt indítása). Így válik végül az újdonság a szervezeten belüli alkalmazott, intézményesült formává. Modelljük ábrája alább látható (Dambrin et al., 2007., p.178.):

\footnotetext{
${ }^{69}$ A példa fiktív abban a tekintetben, hogy történelmi tények nem igazolják az itt bemutatásra kerülő komptroller (lásd Franciaországban „Contrôleur général des finances” néven az eredeti pozíciót), illetve nádor munkakörök kialakulását az intézményesülés rekurzív modellje alapján, de e két munkakör, illetve e két ellenőrzési intézmény kialakulása Barley és Tolbert modelljével jól illusztrálható.
} 


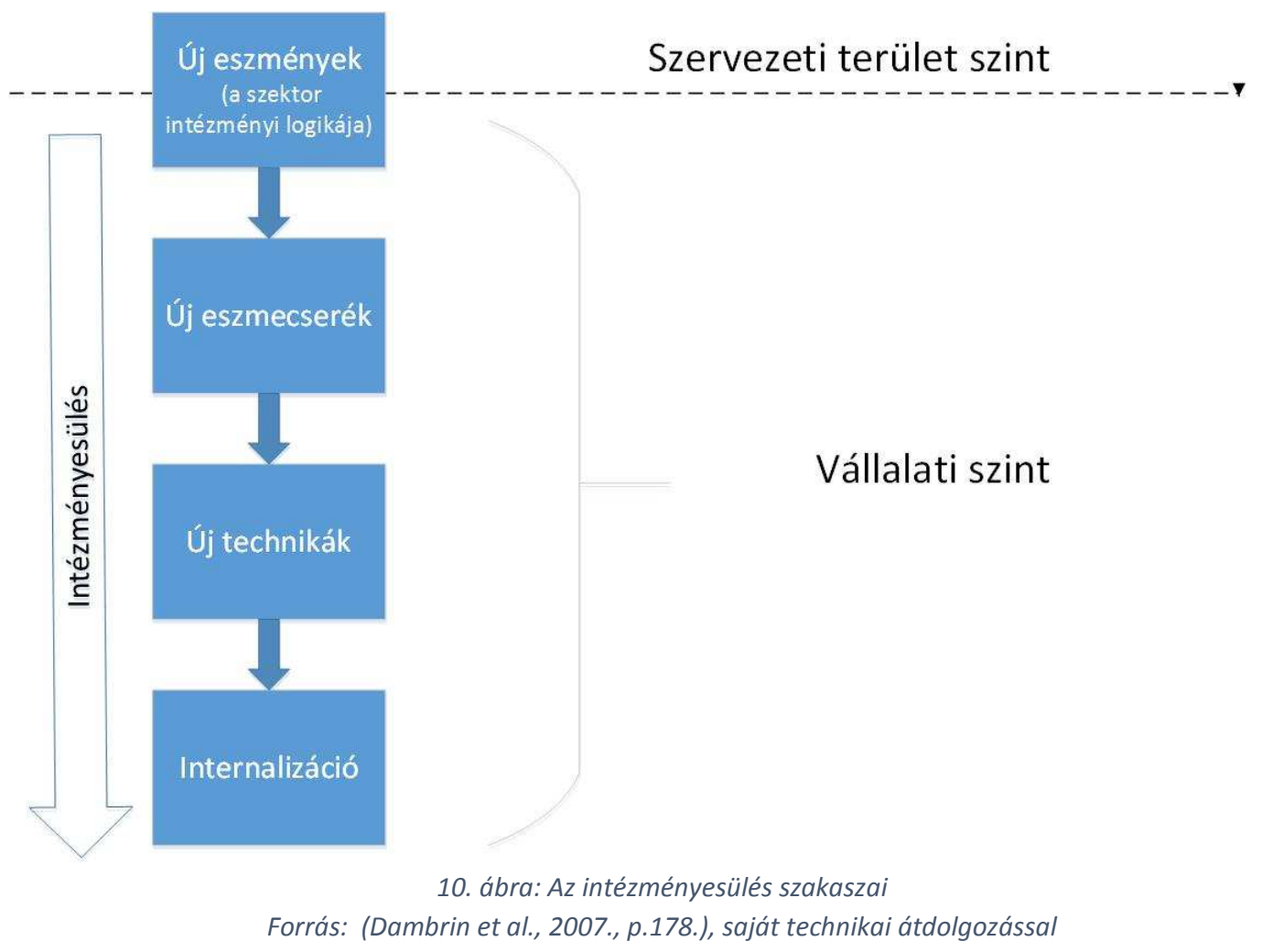

$\mathrm{Az}$ intézményesülés folyamatát - Bourdieu múve alapján - Sieweke a kognitív tudás (cognitive perspective) és a viselkedés perspektíváiból (behavioral perspective) nézve, a mimézis jelenségén keresztül az alábbiak szerint írta le (Sieweke, 2014., p.31.):

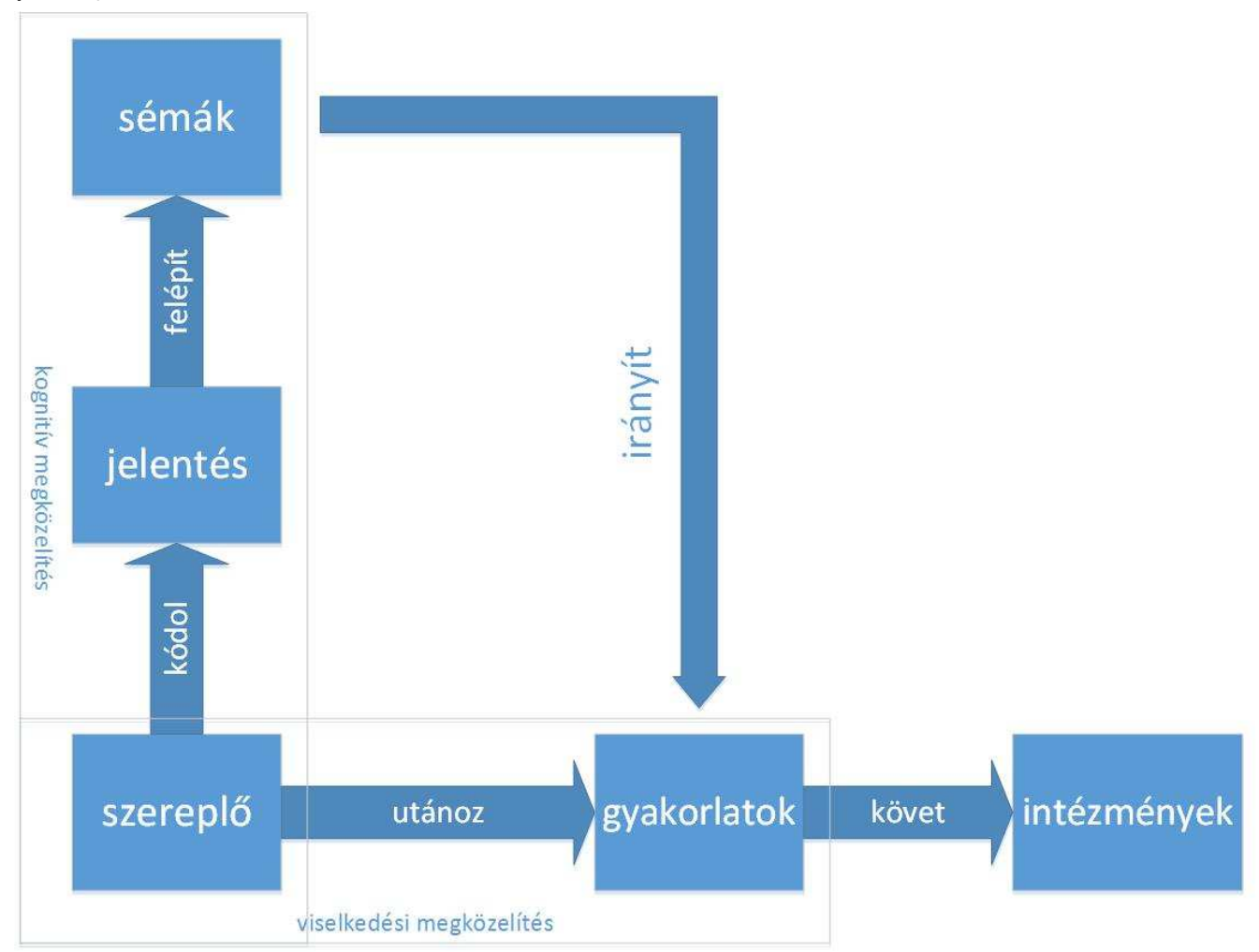

11. ábra: Az intézményesülés folyamata és keretrendszere Forrás: (Sieweke, 2014., p.31.), saját technikai átdolgozással 
Sieweke modelljében a viselkedési perspektíva jelöli a szereplők egymástól való tanulásának folyamatát, ahol az utánzás (mimics), a kifejezések, a jelképek révén válik a cselekvés bevett gyakorlattá a szervezet tagjai között. A kognitív perspektíva jelenti a cselekmények tudatos megértését (meaning) és feltárását, illetve elsajátítását, melyek révén viselkedési sémák (schemata), normák, szabályok alakulnak ki a szervezetekben. E szabályok, normák aztán direkt módon megerősítik a kialakult gyakorlatot (practices), és e két hatás együttes eredőjeként a szervezet tagjai a bevált gyakorlatokat követik (follow), alkalmazzák továbbiakban is, így létrejön az intézmény.

Lawrence \& Suddaby 2006-ban publikált könyvfejezetükben az intézményesülés folyamatának három lépcsőfokát azonosítják, egyúttal megadják az egyes lépcsőfokok legfontosabb jellemzőit, a rájuk jellemző formákat, amely cselekvések útján az intézmény létrejön, azt karbantartják, illetve felbomlik (átalakul) (Lawrence \& Suddaby, 2006., pp.220-238.):

- létrejövetel (creating), mely az intézmény kialakulását, létrejövetelét segíti. Elemei: tanácskozás, definiálás, tagok jogokkal való felruházása, identitás konstruálása, meglévő normatívák újragondolása, , utánzás, érvelés és indokokgyártása, képzés.

- karbantartás-fenntartás (maintaining), mely a létrejött intézmények kiteljesedését és múködését támogatja. A következő cselekmények tartoznak ebbe a kategóriába: múködtetési feladatok, normatívák visszaellenőrzése, korlátok megalkotása, értékek közvetítése, mitológiai történetek kreálása, intézmény beágyazása és rutinná tétele.

- felbomlás (disrupting), amely egy intézmény megszűnését, illetve átalakulását eredményezi, ehhez vezet. Cselekvési elemei: szankciók leválasztása a jó gyakorlatokról, meglévő morális és szabályozási elemek kiiktatása, begyakorlott hiedelmek gátlása, megtagadása.

Az intézményesülés folyamatát a fentiekhez hasonlóan bemutatja még (Meyer \& Rowan, 1977., pp.345-346.), illetve idézi alapelveit (DiMaggio \& Powell, 2011., pp.65-67.), mely utóbbi szerint az intézmények akkor válnak tartóssá, ha fenntartásuk költsége és a múködtetésükkel járó tranzakciós költségek alacsonyabbak, mint a velük realizált szervezeti haszon.

Fentiek alapján látható, hogy a különféle modelleknek vannak közös vonásaik. Egy intézmény létrejötte általában feltételezi, hogy létezik az emberek adott közösségére jellemző közös kultúra, amely alapján az egyének döntenek saját cselekedeteikről. Azonban ezek a cselekedetek különféle normák, elvárások, 
szabályok alapján mennek végbe az egyén akarata révén, így egyfajta mintázatul szolgálnak minden más egyén számára is. Az intézményesülés akkor megy végbe, amikor az egyének ezeket az elvárásokat, normákat, szabályokat a szocializációs folyamat során magukévá teszik, és megkérdőjelezésük nélkül alkalmazzák ${ }^{70}$ a későbbiekben.

A bemutatott modellek azonban sokban különböznek is egymástól. Egyfelöl megkülönböztetünk intézményesülési (folyamat) és intézményt (állapot) vizsgáló modelleket. Másrészt a modellek különböznek abban is, hogy a változást beindító újdonság szervezeten kívülről vagy szervezeten belülről érkezik-e. Különfélék a modellek a kialakulási lépcsők számát illetően is és eltérnek a változás lekezelésének módját illetően is.

Disszertációm további vezérfonalát a modellek hasonlóságaira épülő logikai gondolatmenet adja a kontrollrendszerek intézményesülése tárgyában, mivel egy konkrét modellt nem tudtam kizárólagosan kiválasztani a belső kontrollrendszerek intézményesülésének bemutatására. Ezért konkrétan egy modellt nem választok ki további elemzésem elapjául, hanem általános érvénnyel alkalmazom a különféle modelleket, és a továbbiakban azt keresem, hogy a kontrollrendszerek általános sémái, magatartásmintái hogyan válnak a vállalatok belső szabályaivá, miképpen hatnak az események a belső kontrollra, és az milyen választ ad, milyen cselekvést hoz létre erre reagálva.

\subsection{A kontroll mint vállalaton belüli intézmény}

A kontrollrendszerek témája szempontjából azt kívánom mélyebben megvizsgálni, illetve feltárni, hogy hogyan épül be a kontroll a vállalatok mindennapi életébe, azaz hogyan intézményesül, melyek ennek célszerű okai és főbb elemei, melyek a cselekvéseket meghatározó szervezeti motívumok. Ezen alfejezetben néhány szerzőnek a kontrollok intézményesüléséről szóló nézeteit és kutatásait mutatom be.

Hayne és Fee cikkükben - Lawrence \& Suddaby fent idézett modelljére alapozva mutatják be a COSO-ERM-rendszer létrejöttének, kialakulásának okait, formáit az

\footnotetext{
70 Vajon ezt az egyének az értékek egyezősége miatt, önérdekkövetésből, a tranzakciós költségeik minimalizálása érdekében, legális kényszerítés hatására vagy egyéb kulturális okból teszik? Erről többféle feltételezés ismert, és nincs egyetlen elfogadott nézet, lásd részletesebben itt: (Goodin \& Klingemann, 2003. pp.170-175.).
} 
intézmény kialakulásához vezető úton. Cikkükben a COSO-ERM keretrendszer létrejöttének 15 olyan kulcsszereplőjét interjúztatták, akik vezetőként, tisztségviselőként vagy támogatóként a COSO-ERM-rendszer megalkotási folyamatának, intézményesülésének szereplői voltak (e szereplők különféle vállalatoknál dolgoztak). A szerzők érzékeltetik a COSO-rendszer bomlasztó hatását, vagyis láttatják azt, hogy a rendszer bevezetése hogyan kényszerítette a vállalatokat a 90-es évek elején a meglévő belső normáik, rendelkezéseik átírására, felülvizsgálatára; de példákkal támasztják alá a coso alkotói hatását is, azt tehát, hogy hogyan válik az új dolgok elindítójává, meghonosítójává a vállalatokban. Végül a cikk rávilágít a COSO-keretrendszer fenntartó, karbantartó szándékára is, amely révén korteskedő publikációk és elrettentő történetek egyaránt megjelennek. Sikeres, jó gyakorlatok bemutatásával próbálja a coSO szervezete a modell intézményesülését tovább mélyíteni a világon az összes lehetséges szervezet bevonásával (Hayne \& Free, 2014., pp.318-327.).

John Groenewegen Who Should Control the Firm? cimú cikkében az intézményi megközelítést vizsgálja a vállalaton belüli kontroll szemszögéből, kifejezetten a SOXtörvény, illetve más nemzeti jogszabályok életbe lépésének következményeként. Azt a kérdést teszi fel, hogy az államnak szabályozási eszközökkel, vagy a vállalatnak belső intézményi megoldásokkal kell-e kialakítania a belső kontrollmechanizmusok múködését. Megállapításaiban végül elfogadja a coSO útmutatásait valós belső motornak, eszerint az igazgatótanács és a menedzsment a felelősek a kontrollmechanizmusok létrehozásáért és működtetéséért (Groenewegen, 2004., pp.353-361.), mivel nekik érdekük a múködtetése. A SOX-törvényből fakadó menedzsment-, illetve társaságirányítási kötelezettségek vállalaton belüli hasonló beágyazódását, továbbá a kontrollrendszerek hiányosságaira, valamint a belső kontrollrendszer riportjára vonatkozó kötelezettségek teljesítésének attitűdjét lásd még Hermanson és szerzőtársa cikkében (Hermanson \& Zhongxia, 2009.).

Burns és Scapens cikkükben a vezetői számvitel (management accounting) változásainak intézményesülési folyamatát mutatják be Barley és Tolbert fent idézett modelljével, két cégen belül végzett felmérésük alapján. Megállapítják, hogy a vezetői számvitel keretében előállított jelentési és elszámolási standardokban bekövetkező változások intézményesülésének legfontosabb színterei a formális belső szabályok változtatása és ezzel egy időben az informális normákban bekövetkező változások (amelyek Barley és Tolbert modelljében az „enact” névvel megjelölt elembe tartoznak). A szerzők ezenkívül a változások külső hatásait és a fokozatos belső módosításokat, valamint a regresszív és a progresszív változtatásokat azonosították az intézményesülési modell elemeiként (Burns \& Scapens, 2000., pp.17-21.). 
Goretzki és társai cikkükben a német kontrolleri munkakör, illetve foglalkozás intézményesülési szakaszait mutatják be egy német családi vállalkozásból kinőtt, technológiaintenzív multinacionális cég példáján keresztül. Megállapításaik szerint az adott cégnél a kontrolleri munkakör fejlődésében a vezetőknek, kifejezetten az újonnan csatlakozott pénzügyi vezetőnek (CFO) volt nagy szerepe, valamint a kontrollingstátusz intézményesüléséhez nagyban hozzájárultak azok a képzőintézmények (egyetemek, Kontrolling Akadémia stb.), amelyek a kontrolleri hivatást, illetve a kontrollingszemléletet megismertették az e munkakörben foglalkoztatott dolgozókkal a szervezetben. Ennek hatására a vállalat kontrollingrészlege professzionális szakmaközi egyeztető fórumok részesévé vált, ahonnan újabb kontrollingeszközöket és innovációkat tudtak átörökíteni a vállalatba (Goretzki et al., 2013., pp.50-58.).

Simons múvében a menedzsmentkontroll-rendszerek evolúciós szakaszait mutatja be. Meglátása szerint a nagy, érett szervezetekben a stratégia játssza a kulcs-, irányító szerepet a kontrollfolyamatokban, s ez a stratégia követendő szimbólumként, mintaként szolgál a szervezet tagjainak, aki azt igyekeznek magukévá tenni. Álláspontja szerint a szervezetek a kontrollfolyamataikban az értékekre, a kockázatok elkerülésére, a teljesítménykényszerre és a stratégiai hiányosságokra fókuszálnak, e négy tényező együttesen segíti hozzá a szervezetet a sikerhez. A jól szervezett, kiegyensúlyozott kontrollrendszer tehát keresi a vállalati expanziós lehetőségeket, és egyidejűleg a hibás működést is igyekszik feltárni. Ezen elemek állandó, dinamikus egymásra hatása révén fejlődik a szervezet kontrollrendszere (Simons, 1995., pp.153-161.).

Az MTA Szociológiai Intézete 1970-72 között kutatást végzett a magyar vállalatoknál a belső szervezettség, a kontrollmechanizmusok és a vállalati teljesítmény összefüggése és egymásra hatása témájában. A kutatási eredményeket összegző múben a szerzők definiálják a vállalaton belüli kontrollmechanizmust mint intézményt (Héthy \& Makó, 1972., p.6.):

„... a szervezet létrehozott egy külön intézményt is, amelynek egyetlen

specifikus feladata van: az emberek cselekvése fölötti ellenörzés

biztosítása; az emberek, gazdasági és nem gazdasági értelemben vett

jutalmazása, illetve szankcionálása. Ezt az intézményt nevezzük

kontrollmechanizmusnak."

A szerzők megállapítják, hogy a kontrollmechanizmus(ok) hiánya a vállalaton belüli szervezetlenség eluralkodását eredményezi, amely hatékonytalan múködést, rosszabb termelési eredményeket, kommunikációs zavarokat, csökkenő vállalati presztizst stb. okoz. A szerzők szerint a kontrollmechanizmusok intézményesülése 
általánosságban posztokban, kötelességek lefektetésében, felelősségi rendszerekben, döntési mechanizmusokban, információs csatornák múködése révén testesül meg.

Sharma és társai hat éven keresztül, longitudinális vizsgálat keretében kísérték figyelemmel a privatizációt követően az izlandi Fiji Telecom cégnél bevezetett TQMrendszer intézményesülését annak kezdetétől az elért eredményekig. Elemzésükben bemutatják, hogy a minőségmenedzsment-intézkedések az évek folyamán miként váltak rutinná, illetve később hogyan jelentek meg a mutatószám-alapú teljesítményértékelések. A TQM-filozófia meghonosodásában nagy szerepe volt az innovatív, vállalkozó szemléletű menedzsmentnek is, akik múködésbe hozták és fejlesztették a cég TQM-rendszerét. Mindezek sorozataként a vizsgált hat év alatt a TQM-rendszer lépésről-lépésre beágyazódott és a mindennapi munka részévé vált a cégnél, intézményesült a szabályrendszerekben és a dolgozók kulturális hozzáállásában is (Sharma et al., 2010., pp.255-262.).

Sacomano és társai cikkükben egy brazíliai autóipari beszállító cég példáján keresztül mutatják be a vállalati kontrollrendszerek intézményesülését, különös tekintettel annak izomorfizmusra ${ }^{71}$ visszavezethető következményeitey. Cikkükben kifejtik, hogy az autóipar erősen standardizált, hálózatszerűen felépülő, vertikálisan tagolt iparág, ahol az elvárások, követelmények gyakran változnak, és a vállalatot érő impulzusok száma nagy, ami alkalmazkodásra kényszeríti őket. Ebben a környezetben felértékelődik a „másolás” képessége, azaz valamely eljárás vagy norma kialakulásában a külső kényszernek jelentős hatása van, az intézményesülés izomorfizmus révén következik be. Cikkükben a szerzők - Scottal azonosan bemutatják a „másolás” különféle kategóriáit, úgymint:

- kényszeralapú izomorfizmus: jogszabályok és belső szabályok betartása, valamint az ezekhez kapcsolódó szankciók alkalmazása miatt;

- normatív alapú izomorfizmus, amely aktív belső kommunikációra és megegyezésre épül, amely kommunikációban beszállítók, fejlesztők, minőségellenőrök vesznek részt, és hoznak közösen döntéseket;

- utánzásra épülő izomorfizmus, amikor a legjobb gyakorlatot önként alkalmazzák más szervezetek, és elismerik a felek annak felsőbbrendűségét, s kívánják az annak való megfelelést (pl. autóipari szabványok alkalmazása).

\footnotetext{
${ }^{71}$ Az izomorfizmus a másolást, kooptálást jelenti az intézményi szociológiában. Szó szerinti értelemben azonosalakúságot jelent, alapvetően matematikai fogalom: Két halmaznak az a tulajdonsága, hogy az elemeik közötti azonos viszonyok rendszere alapján egymásra kölcsönösen leképezhetők.

Lásd bővebben: http://www.kislexikon.hu/izomorfizmus.htm|\#ixzz3QyGnAfca (2015. 02. 06.).
} 
A szerzők azt is megállapították megfigyeléseik alapján, hogy az iparágban a sikeres intézményesülésnek három kulcstényezője van, ezek: (1) a társas érintkezés képessége, azaz az együttmúködés, egyeztetés, az irányított vitában való részvétel képessége; (2) az erős formális és informális kontrollok alkalmazása a célok elérése érdekében (pl. kulcsteljesítmény-mutatók, határidők figyelése), valamint (3) kiválóságra törekvés a saját területükön, ezzel legitimálni státuszukat a piacon és presztízsüket más autóipari vevők, illetve beszállítók irányába is (Sacomano et al., 2013., pp.536-539.).

Az etika döntéshozatalbeli intézményesülését vizsgálta 173 török cégben Torlak (Torlak et al., 2014.); Marta és a többiek ugyanezt a folyamatot kutatták korábban amerikai és thaiföldi marketingmenedzserek körében (Marta et al., 2013.). E témában publikált még Vitel és társa is (Vitell \& Singhapakdi, 2008.). Hazánkban Radácsi László doktori értekezése és publikációi foglalkoznak az etika vállalati intézményesülésével (Radácsi, 2000., pp.118-160.). Radácsi múvében a vállalati etikai intézmények a szociális kontroll eszközeiként jelennek meg. Az etikai normák kódexek, krédók, valamint bizottságok, etikai igazgató, etikai iroda, belső forródrót és képzési programok révén intézményesülnek, illetve az etikai audit és az etikai jelentés játsszák a kulcsszerepet az intézményesülés folyamatában.

Számos további cikk és publikáció szól arról, hogy az egyes kontrollelemek, illetve maga a kontrollrendszer hogyan intézményesül a szervezetekben. Yi és társai 585 kínai cégen belül vizsgálták a menedzsmentkontroll-rendszerek intézményesülését és a radikális innovációk összefüggését (Yi et al., 2012.). Williamson a COSO-ERMrendszer kritikája kapcsán leírja cikkében a vállalati kockázatkezelés intézményesülését (Williamson, 2007., pp.1105-1107.). Amudo és szerzótársa egy ugandai esetpéldán keresztül mutatják be a vállalati kontrollrendszerek kezdeti hiányosságait és fejlődésüket a projekteket finanszírozó Afrikai Fejlesztési Bank szemszögéből (Amudo \& Inanga, 2009.). Junxun és társa kínai textiliparágban múködő vállalkozások belső kontrollrendszerének kialakulását és fejlődését elemzik tanulmányukban, mégpedig intézményi megközelítésben (Junxun \& Xiaoyan, 2008.). Covaleski cikkében foglalkozik a számvitelen belüli folyamatok intézményesülésével, valamint külön vizsgálta a kerettervezés (budgeting) intézményesülését wisconsini közszolgálati szervezetekben (Covaleski et al., 2013.). Brignall és Modell pedig a teljesítménymérés és -menedzsment intézményesülését mutatják be a közszolgálati szervezetek vonatkozásában (Brignall \& Modell, 2000.).

Látható tehát, hogy a szervezeten belüli kontrollnak, a kontrollrendszer elemeinek, illetve az egyes kontrolltevékenységeknek, kontrollmechanizmusoknak az intézményesülése a fogalmi keretek között megragadható, azt többen és többféle 
nézőpontban, szervezetben, földrajzi területen kutatták. A továbbiakban azt kívánom feltárni disszertációmban, hogy a kontrollrendszerek intézményesülése hogyan ragadható meg konkrét motívumokban.

\subsection{Belső szabályozás mint az intézményesülés legitimizációja}

Az intézményesülés feltételezi, hogy a szabályok (normák, kultúrák, szokások, minták) végeredményben kívülről adottá válnak a munkavállalónak, az egyének számára nem megkérdőjelezhetővé érnek. Kieser említi Meyer és Rowan példáját, miszerint a vállalatok az elektronikus adatfeldolgozást azért alkalmazzák, mert azt eleve elfogadottnak és szükségesnek tekintik, még akkor is, ha nem jár kimutatható termelékenységi, hatékonysági előnyökkel ${ }^{72}$ (Kieser, 2003., pp.384-386.).

Példa: E szempontból az 1. számú függelékben bemutatott szabványok, standardok és jogszabályok mind a külső környezet adta írásos befolyásoló dokumentumok, a kontrollkörnyezet elemei. Más alkotta meg őket, de a vállalatnak alkalmaznia kell működésében ezeket, és nem kérdőjelezik meg a vállalat vezetői, munkatársai, tulajdonosai e szabályok, szabályzatok hasznát, illetve nem firtatják alkalmazásuk szükségességét, hanem azt adottságként kezelik vállalatuk tevékenysége és a saját munkájuksorán.

Az intézményesülés tehát megköveteli az explicit, az egyén számára kívülről jövő adottságok elfogadását szabályként, ha az alkalmas a kialakult szituáció kezelésére.

Farkas Zoltán részletesen foglalkozik az intézményesüléssel létrejövő belső szabályokkal. Véleménye szerint az egyén cselekvését befolyásoló elvárások, referenciák különfélék lehetnek aszerint, hogy miből származnak, és megsértésük milyen következménnyel jár. Idézi Gibbs meghatározását, aki ezeket legáltalánosabb értelemben magatartási szabályoknak nevezte el, melyek lehetnek szóban vagy írásban közöltek, vagy csupán gondolatban létrejöttek és viselkedésben megtestesülők, melyek kifejezik, hogy miképpen kell viselkedni, és milyen szankció jár megsértésük esetén (Farkas, 2001., p.120.). Ez alapján a szervezeteken belül többféle elvárás, illetve szabály ${ }^{73}$ van egyszerre jelen:

- Morális szabály, mely esetén a cselekvő belső indíttatása és motívumai megegyeznek a külső elvárásokkal, s így válnak a közösség normáivá, függetlenül attól, hogy ezek milyen súlyúak, jelentőségűek a vállalat

\footnotetext{
${ }^{72}$ Az állítás 1977-ben kelt, nyilvánvalóan az azóta eltelt mintegy 40 évben az adatfeldolgozás szükségszerüsége még inkább beigazolódott, megkerülhetetlenné vált, és mára annak költséghatékonysági vetülete is ismert. ${ }^{73}$ A szabály itt értendő definícióját Parsons adta meg, e szerint: „a szabály a cselekvés olyan konkrét lefolyásának a leírása, amelyet kívánatosnak tekintenek, és melynek betartására utasítás vonatkozik". A szabályok bővebb szociológiai megközelítését lásd itt: (Farkas, 2005.)
} 
életében. Vállalaton belül ilyen morális szabály lehet például a beérkező emailekre történő érdemi válaszadás, visszajelzés a küldő számára. Ilyen szabály lehet például az, hogy karácsonykor a szervezeti egységben dolgozók kis értékű ajándékokkal lepik meg egymást.

- Intelem, amely olyan elvárás, melynek ellenőrzése szabályozatlan, és megsértése nem jár jelentős normatív következményekkel. Intelem például az, hogy a vállalati buszon a férfiaknak át kell adniuk a helyüket a női munkavállalóknak. Tisztázatlan, hogy ki ellenőrzi e szabály betartását, kinek kell érvényt szereznie ezen elvárásnak, ugyanakkor a vállalat alaptevékenységére minimálisan hathat negatívan az az eset, ha a női dolgozónak állnia kell a vállalati buszon munkába menet.

- Kötelem, amelynek kontrollja szabályozott, megsértése jelentős következményekkel jár. A kötelem általában jogilag megerősített, pl. belső utasítás, szabályzat is rendelkezik róla, és alkalmazására azért volt szükség, mert valaki korábban felmérte és eldöntötte, hogy ezt a cselekvést erős szankciók ${ }^{74}$ kilátásba helyezésével kell irányítani a vállalaton belül. Ilyen kötelem például a heti munkarend, az árukiadás szabályai vagy a számviteli politika. Mindhárom tipikusan írásban rögzített, előre kiadott, utólagosan ellenőrzött dokumentum, melynek végrehajtását kontrollálják a szervezetben, $s$ melyek egyben az egyén viselkedését, magatartását is befolyásolják a szervezetben, megsértésük pedig komoly hibához (pl. a számvitelben a jelentős hiba értékhatárának túllépéséhez), következményekhez (pl. áru sérüléséhez, termelés leállásához, kár keletkezéséhez, azonnali felmondáshoz) vezet.

Farkas Zoltán a szervezetek múködése szempontjából azokat a kötelmeket, melyek a legalapvetőbbek, intézményes szabályoknak nevezi. Az intézményesülés tehát feltételezi, hogy vannak megkonstruált szabályok, azokat ellenőrzik a szervezetben, lefolyásuk normatívan meghatározott, és érvényesek valamennyi egyén számára (Farkas, 2001., pp.131-133.). Az írásos szabályok szervezetben betöltött szerepét hangsúlyozza (Goodin \& Klingemann, 2003., pp.149-150.) is.

Példa: $A$ belső kontrollrendszerek maguk is feltételezik az írásos formát és a formalizált szabályok meglétét. A kiadott belső utasitások, szabályzatok, a minőségpolitika írásban rögzítettek, a falra kifüggesztettek, átvételüket a dolgozóknak olykor saját kezű aláírásukkal is igazolniuk kell (a vállalatnál). Az éves tervek, budgetek táblázatokban, számítógépes rendszerekben elmentve találhatók meg, gombnyomásra előhívhatók, nyomtathatók, lefüzhetők. Az egyes beruházások

\footnotetext{
74 Értsd: Az ellenőrzés meghatározott szabályok érvényesítését szolgálja, és magában foglalja az adott szabályok érvényességi körébe eső cselekvések megfigyelését, a megfigyelt cselekvések összevetését az azokra vonatkozó szabályokkal és a szankciók érvényesítését (Farkas, 2005.).
} 
projekttervei, a minőség-ellenőrzési utasítások, az etikai kódexek ugyanúgy írásos kötelmek, írott szabályozások összességei a vállalatokban.

A szabályozással egy tekintet alá esik a belső dokumentációk készítése és kiadása is, ide tartoznak a szabályzatok, folyamatábrák, útmutatók, kézikönyvek, eljárásrendek, de a faliújságra kitett hirdetmények vagy az e-mailen kiküldött tájékoztatók is. Ezek könyvvizsgálati áttekintésének kérdéseiről részletesen értekeznek Bierstaker és szerzőtársai (Bierstaker et al., 2009.). A dokumentációs kontrollok fontosságáról és más kontrollokkal való kapcsolatukról, valamint a dokumentumok elektronikus kezelésével kapcsolatos elvárásokról bővebben ír Blumné Bán Erika összefoglaló elemzésében (Blumné, 2011., pp.386-391.).

$A z$ institucionalista szemléletben tehát a kontrollelemek intézményesülnek, az intézményesülés belső szabályozás, írásos normák megalkotásában érhető tetten. Igaz rá a fejezet elején hivatkozott Farkas Zoltán-féle fogalmi definíció (Farkas, 2001., p.121.). Nincs objektíven adott, a cselekvőktől függetlenül létező kontroll, mert a szereplők maguk is alakítják ezeket a magatartásmintákat. Ilyenek a szabályzatok, a belső utasítások, a körlevelek, a vezérigazatói tájékoztatók, a procedúrák, a munkautasítások és minden egyéb írásos norma, amely kötelező érvényű a szervezetben, de az érintettek javasolhatják módosításukat, felülvizsgálatukat.

Amikor az egyes a cselekvések, szokások már berögzülnek, és széles körben ismerté válnak, sokszor menedzsment-divatként tekintünk rájuk. Ezek azok az újdonságok, melyeket egyre többen kezdenek el alkalmazni, s amelyek kívülröl érkeznek a szervezetbe.

\subsection{Kontroll és konfliktuskezelés a szabályok fenntartása érdekében}

Az intézményi megközelítés a szabályok fenntartására, és betartásuk ellenőrzésére jelentős hangsúlyt helyez (Berger \& Luckmann, 1998., pp.83-84.). Ha nincs kontroll, a szabályok felhígulnak, és ha nem tartják be a lefektetett normákat, kötelmeket, akkor ezek már nem képesek többé keretet szabni az egyéni cselekvésnek. Ezért az intézményi megközelítés magától értetődőnek tartja, hogy az egyéni cselekvést ellenőrzik, ilyenformán a szervezet múködése magában foglalja a megfigyelés és beavatkozás, a szükséges szankcionálás alkalmazását is.

Goodin és Klingemann könyvükben részletesen írnak az intézményekröl, ezen belül a szabályok születésével és módosításával foglalkozó négy szerepkörrel is, melyek a következők (Goodin \& Klingemann, 2003., pp.137-138.): 
- szabályalkotók, amelyekre azért van szükség, hogy a közös érdekeket egyezményesen kimondják, lefektessék (pl. vezetők),

- szabályalkalmazók, akik végrehajtják a megalkotott szabályokat, rendelkezéseket, alkalmazzák és betartják azokat (pl. végrehajtó munkavállalók),

- szabálymódosítók, akik a szabályok értelmezésével foglalkoznak egyedi esetekben, és az ebből eredő viták, konfliktusok eldöntése révén erősítik az általános szabályt (pl. precedenst teremtők, ügydöntők, mediátorok),

- szabálykikényszerítők, akik ellenőrzik a szabályok betartását, és eljárnak a szabályszegőkkel szemben, büntetést rónak ki azokra (pl. belső ellenőrök).

Az ellenőrzés az intézményi szociológia hangsúlyos eleme, a szabályok kikényszerítését, fenntartását hivatott ellátni. Az ellenőrzés itt is összehasonlítással, értékeléssel zárul, amely megállapításokban manifesztálódik. A szabályok betartása jutalmat (pozitív megerősítést, kedvezmények nyújtását stb.), az előírások megsértése pedig büntetést, negatív visszacsatolást, retorziót stb. eredményez arra nézve, aki a szabályokat betartja, illetve az utóbbi esetben nem tartja be. Az intézményesült szabálykövetés esetén a szervezetben magától értetődik, hogy vannak szereplők, akiknek hatalmából és küldetéséből (feladatköréből) következik a szabályok betartásán őrködni, illetve jutalmat és büntetést osztani. Az ellenőrzés akkor hatékony, ha megállapítása nem megkérdőjelezhető, azaz egzakt, továbbá vitathatatlan a következménye is. Ezért a „jól”, illetve „magasan” intézményesült szabálykövetést kialakító szervezetek a belső kontrollmechanizmusaikat is írásban rögzített szabályokba vésve alkotják, és ezen szabályok szerint végzik feladataikat (Farkas, 2005., pp.30-33.).

Példa: $A$ belső kontrollrendszer alapvetően a szabálykikényszerítés eszköze, és a fenti felsorolásból a negyedik alintézmény része. A szervezet célkövetését, a szabályok betartását, a teljesitmény elérését vizsgálja, elemez és értékel, visszajelez és rávilágít a problémás müködési területekre (szabálytalanság, kockázat megléte, indokolatlan költségek stb. - lásd a 3. számú függelékben felsorolt devianciákat), adott esetben felelösöket is megnevezve.

A belső kontrollrendszer előírásaival szembeni ellenállásról az intézményi megközelítés keretei között bővebben ír Shapiro és Matson cikkében (Shapiro \& Matson, 2008.).

A szabályok betartása konfliktusokkal jár, illetve a konfliktusok kialakulása magában az intézményesülés folyamatában kódolva van. Ennek oka egyrészt az intézményesülés erőforrás-elvonó szerepében testesül meg (értsd: a szabályok kialakítása, másolása, meghonosítása pénzt, munkaerőt, időt kíván meg a szervezettől), és ez nem érdeke a vezetőknek; másrészt az intézményesülés útján elmélyített általános szabályok nem adnak mindig egyértelmű útmutatást egy-egy 
konkrét helyzetre vonatkozóan, ezért az intézményeket úgy kell alkalmazni, hogy valójában azok nem érik el szabályozási céljaikat a konkrétan megoldandó probléma esetén (Kieser, 2003., pp.409-410.).

Ezért a konfliktusok kezelése az intézményesült szabálykövetéssel jellemezhető szervezetek részévé válik, és megjelenik a szétválasztás (decoupling) módszere. Ennek lényege, hogy a formális szervezeti struktúrát és a konkrét tevékenységeket (termelőfolyamatok, nyújtott szolgáltatások stb.) szétválasztják egymástól, a struktúrát tartósnak és állandónak, míg a konkrét folyamatokat a mindenkori helyzethez illeszkedőnek, rugalmasnak, adaptívnak tekintik (Kieser, 2003., p.411.), (DiMaggio \& Powell, 1991., pp.55-58.). Ugyanezt a megoldást Farkas a múvében az intézmények normatív és tényleges funkciója közötti különbségként mutatja be, és összesen hat okra vezeti vissza a belső konfliktusok kialakulásának okát. Végeredményben ő is azt állapítja meg, hogy a szervezet tagjai a tényleges funkciók adta keretek között cselekszenek, amely akár ellentétes is lehet az intézményes szabályok normatív funkciójával (Farkas, 2001., pp.134-137.).

A decoupling eljárásról Ouchi is értekezik a szervezeten belüli kontrollrendszerek múködése és a szervezeti struktúra szétválasztása kapcsán. Megítélése szerint a szervezetekben a bürokratikus, a klán- és a piaci kontroll egyszerre jelen van, de eltérő mértékben, és ezek a kontrollmechanizmusok alig függnek a vállalat szervezeti felépítésétől, struktúrájától. Ouchi álláspontja szerint a vállalatok törekednek a szabályok, jogi előírások betartására (bürokratikus kontroll), a piaci folyamatoknak megfelelő árazási és teljesítménymérési rendszereket alakítanak ki és múködtetnek (piaci kontroll), és a vezetők személyes karizmája, a vállalati kultúra, a megrögzött szokások, az állandó viselkedési sémák képezik a harmadik, úgynevezett klánkontrollt a szervezetekben (Ouchi, 1979., pp.843-845.). Ouchi tipológiáját bővebben kifejtve lásd (Dobák \& Antal, 2013., pp.427-437.) és (Bodnár et al., 1996., pp.23-25.) műveiben.

DiMaggio és Powell a szervezeten belüli konfliktusokat a "maradás” és a "haladás" ellentétére vezetik vissza, és ebből vezetik le a szervezeten belüli állandó konfliktusokat. Nézetük lényege, hogy az intézmények a saját stabilitásuk megőrzésére törekednek (maradás), miközben a külső impulzusok és az aktorok új ötleteket hoznak be a szervezetekbe, és azok intézményesítésére törekednek (haladás). Így a régi intézményi szabályok az újat ellenségesnek, a régi intézményt veszélyeztetőnek tekintik, míg a haladók a régit, a maradás mellettit támadják. Az intézményesülési paradoxon abban áll, hogy az intézményesülés mindig egyensúlyra törekszik a maradás és a változás között, amelyek közül rövidtávon egyik sem következik be (DiMaggio \& Powell, 1991., pp.63-67.). 
A konfliktusok tehát lényegükben az intézményesülés velejárói, a normaalkotási folyamat részének tekinthetők, és emberek közötti viszonyok és érdekütközések okán következnek be. Az intézményesült szabálykövetést alkalmazó szervezetben e konfliktusok szervezett feloldása is részét képezi az intézményesülési folyamatnak, végeredményben külön módszereket vezetnek be rájuk.

\subsection{Szerepek, státuszok}

A szabályok és elvárások manifesztálódása a szervezetben szerepek köré összpontosul, a cselekvés aktorok révén történik. Az intézményi szociológia modelljében a szabályok és a normák kirajzolnak különféle státuszokat, ahol az elvárásokat végrehajtják, teljesítik és közvetítik a többi szereplő számára. E szereplők képviselik a megszilárdított normákat, szabályokat, kötelmeket. E státuszok a belső rendet reprezentálják az egyének felé (Berger \& Luckmann, 1998., pp.106-108.). E státuszok a szervezetben gyakran konkrét munkakörökhöz is köthetők. Ebben az esetben az individuum helyett már egy személytelen szereplővel állunk szemben, akitől elvárjuk, hogy úgy cselekedjen, ahogy azt az intézményülés eredménye megköveteli. Berger és Luckmann múvében például a bírói igazságosztói szerepet - mint a jogi intézmény képviselőjét - mutatja be a bírói foglalkozás mint munkakör révén, és rávilágít arra, hogy a bíró egyénisége, viselkedése és személyes hite, vallása elválasztódik a bírói munkakörtől, az igazságszolgáltatás intézményétől (Berger \& Luckmann, 1998., p.107.).

A szerzők szerint a szerepek segítenek eligazodni a szabályok alkalmazásában, ilyen módon a szervezetek működését könnyebben megérthetővé teszik a bennük lévő egyének számára. A munkaköröktől ugyanis szakmaiságot és teljesítményt lehet megkövetelni. A szerepek akkor válnak éretté, ha tudáskészletük (értsd: szaktudásuk és társas készségeik) illeszkedik a szerephez (munkakörhöz), így tehát megjelennek a specialisták, akik a munkamegosztási elvek alapján egy-egy szakterület fő tudósai, elméleti szakemberei lesznek, és e nézeteiket közvetítik is a közösség, a szervezet többi tagja felé. Ebből következik, hogy az intézményesülés feltételezi a szerepek, azaz specializált státuszok, érett munkakörök létrejöttét, meglétét a szervezetben (Berger \& Luckmann, 1998., pp.106-113.).

A kontrollfunkciók érett szerepei a 1. táblázatban összefoglaló jelleggel megtalálhatóak, az 1. számú függelékben pedig részletesen bemutatásra kerültek:

\begin{tabular}{|l|l|}
\hline \multicolumn{1}{|c|}{ Szabálykikényszerítő intézmény neve } & \multicolumn{1}{|c|}{ Az intézmény aktora, szereplője } \\
\hline függetlenített belső ellenőrzés & $\begin{array}{l}\text { belső ellenőrzési vezető, belső ellenőr, } \\
\text { revizor, vizsgálatvezető }\end{array}$ \\
\hline $\begin{array}{l}\text { vezetői ellenőrzés és folyamatokba épített } \\
\text { ellenőrzések }\end{array}$ & $\begin{array}{l}\text { felső- és középvezetők, szervezeti } \\
\text { egységek vezetői, folyamatgazdák }\end{array}$ \\
\hline könyvvizsgálat elvégzése & könyvvizsgáló, auditor \\
\hline felügyelöbizottság, auditbizottság, egyéb & bizottsági elnökök és tagok, az általuk \\
\hline
\end{tabular}




\begin{tabular}{|l|l|}
\hline tulajdonosi ellenőrző testület & megbízott szakértők, felkért elemzők \\
\hline $\begin{array}{l}\text { menedzsmentkontroll-rendszerek, } \\
\text { kontrollingeszközök }\end{array}$ & $\begin{array}{l}\text { kontrollerek, Bl-szakemberek, kalkulációt, } \\
\text { költségallokációt, riportokat készitő } \\
\text { munkavállalók }\end{array}$ \\
\hline minőségirányítási rendszer, minőség- & minőségirányítási megbízott, vezető belső \\
ellenőrzés és minőségbiztosítási auditok & auditor, minőségellenőrök \\
\hline további felderítő, megelőző intézmények & $\begin{array}{l}\text { fraud manager, compliance coordinator, } \\
\text { etikai megbízott, risk manager, forensic } \\
\text { accountant }\end{array}$ \\
\hline
\end{tabular}

1. táblázat: Belső kontrollrendszer kiemelt szereplői területenként

Forrás: saját összeállítás

\subsection{Kooptálás, szervezetközi szakmai hálózati szerveződés}

Az intézményi megközelítésben az izomorfizmus a homogenizációt, a hasonlóvá válás igényét jelenti. Ennek révén a specializált szerepkörökben lévő munkavállalók elkezdenek kapcsolatba lépni más hasonló szerepkörben lévő, azaz más szervezetben, más intézményekben hasonló munkakört betöltő szereplőkkel, s így kialakul egy - az eredeti szervezettől már független - szakmai csoport, amely a specializálódott téma képviselőiből összeálló szakmai hálózattá, szektorrá érik meg, sőt akár maga is formális szervezetté (szövetséggé, klaszterré, szakmai egyesületté stb.) válik (Kieser, 2003., pp.402-409.). A szakmai grémium ezt követően már maga is megfogalmaz elvárásokat, iránymutatásokat a vele kapcsolatban álló szervezetek felé $^{75}$, melyeknek azok igyekeznek érdekeik és lehetőségeik szerint eleget tenni. Ilyen kapcsolati hálóra hoz példát McKinley és Mone, akik az amerikai tőzsdefelügyelet (SEC) befolyását vizsgálták a tőzsdén jegyzett vállalatok belső múködésére vonatkozóan (McKiney \& Mone, 2003., p.362.). Ilyen módon a szervezetek elkezdenek egymásra hasonlítani, mivel mindannyian ugyanazokat az elvárásokat igyekeznek hasonló vagy azonos módszerekkel, eljárásokkal, procedúrákkal kielégíteni. A vállalatok az uralkodó koncepciókat veszik át, ilyen követelményeknek akarnak megfelelni, az intézményesülés tehát végső soron a más szervezetekben követett eljárások másolását, kooptálását is magával hozza, s abba az irányba tereli a szervezeteket, hogy a már máshol működő, célszerű és bevált mechanizmusokat honosítsák meg maguknál is belső múködésük jobbá tétele érdekében. A szervezetek pedig azért másolják a máshol már „bevált”, „bevett

\footnotetext{
75 Megjegyzés: Jogszabály, definíció, illetve a szakmai közösség érettségi szintje határozza meg, hogy a szakmai munkaközösség tevékenysége pusztán csak kollektív módszertani fáradozásban merül ki, vagy azon túllépve bizonyos munkateljesítmények irányítása felé is lép, belső standardokat alkot a tagság részére, és/vagy az együttgondolkodásból kiindulva szakmai autonómiai és érdekképviseleti feladatok felvállalásához is elvezet (Kieser, 2003., p.406.).
} 
gyakorlatokat”, „mintaértékű dolgokat”, hogy saját magukat erősítsék, fenntartsák, végső soron a szervezet túlélését biztosítsák, mert azt feltételezik, hogy ha mindenki más is hasonlóan cselekszik, akkor az a helyes, a jó, az eredményre vezető cselekedet. Példaként idézi Kieser a közgazdasági elemző eljárások és az elemző közgazdász munkakör elterjedt alkalmazását a vállalatokban, amelyekre ugyan kevéssé volt szükség, mégis „divatos trendként” alkalmazták a cégek. Hasonló példaként hozza a szerző a lean menedzsment elterjedését is (Kieser, 2003., p.399.). Davila és munkatársai 200, főleg termékfejlesztésben is érdekelt vállalat megkérdezésével mérték fel a menedzsmentkontroll-rendszerek elterjedésének, adaptálásának okait a cégeken belül. Felmérésükben hat jól elkülöníthető okot tudtak feltárni és bizonyítani, ezek közül a legitimációs szándék és a szerződések által előírt kötelezettségek mint külső tényezők voltak a meghatározók, ezek miatt adaptálták a cégek a menedzsmentkontroll-rendszereket maguknál is (Davila et al., 2009., pp.335-341.).

Példa: $A$ belső kontrollrendszerek müködésével, alakításával foglalkozó szakmai szervezetek jól tetten érhetőek. Nemzetközi szinten a cOSO Org.,az IIA, az INTOSAI, az IGC, az AICPA, az ISACA, az AAA stb. szövetségek müködnek, míg Magyarországon ilyen szakmai és érdekképviseleti szervezetté vált a BEMSZ, az MPGE, az MKVK, az MCE stb. E szervezetek szakanyagai, ajánlásai, nemzetközi publikációk fordításának honlapon való közzétételei mind az egységesítés és az azonosulás irányába terelik a szervezeteket, az általuk szervezett képzések, workshopok, szakmai délutánok pedig teret biztosítanak, hozzájárulnak a másoláshoz, a jó gyakorlatok megismeréséhez és egymás közötti átvételéhez.

DiMaggio és Powell az izomorfizmus három mechanizmusát azonosítják: a kényszert, a színlelést és a normatív nyomást, melyeket Fligstein publikál kutatásában, idézi (Kieser, 2003., p.408.). Az izomorfizmus e három mechanizmusa közül leginkább a normatív nyomás jelenti a szabályok belső úton történő rögzítését, vagy más külső személyek által alkotott, kötelező szabályok alkalmazását.

A legnagyobb normaalkotó és -érvényesítő szereplő az állam maga. Az állam az intézményesülés egyik szervezete, tehát ugyancsak elvárásokat fogalmaz meg a vállalatok mint piaci szereplők számára, ezt azonban kötelező jogi normák keretében, jogszabályokkal teszi, illetve az államigazgatás egyéb irányítási eszközeivel, mint például (hatósági) engedélyezési feltételek megszabásával, ajánlások megfogalmazásával, útmutatók, kézikönyvek közreadásával. A vállalatok ezen ajánlásokat, útmutatókat stb. pedig - részben kényszerből, részben 
önérdekkövetésből - alkalmazzák, még akkor is, ha tartalmukkal nem tudnak mindig egyetérteni.

Példa: Magyarországon jó példák erre a költségvetési szervekre vonatkozó, államháztartási belső kontroll és belső ellenőrzés rendszerét leíró jogszabályok ${ }^{76}$ és az NGM által közreadott ajánlások ${ }^{77}$ a költségvetési szervek belső ellenőrzéséhez, valamint a követendő tartalmat megadó belső ellenőrzési kézikönyv-minta (lásd NGM honlapján a 77. számú lábjegyzetben). Ezek egységesen, azaz méret, létszám, földrajzi tagozódás, felettes irányító költségvetési szerv szerinti megkülönböztetés nélkül támasztanak követelményeket az államháztartás szervezetei számára, amelyek ezeket többé-kevésbé igyekeznek teljesíteni. Az intézményesülés ellenőrzési momentumát pedig az Állami Számvevőszék képviseli, amely vizsgálataiban a különféle költségvetési szervek belső kontrollrendszereit értékeli, és ezek eredményeit jelentéseiben hozza nyilvánosságra ${ }^{78}$, bennük pedig a szereplőknek fogalmaz meg ajánlásokat.

\subsection{Az intézményt működtető struktúra, illetve szervezet}

Meyer és Rowan cikkükben elemzik az intézményesülés és a szervezeti struktúrák kialakulásának kapcsolatát, összefüggéseit. A szerzők szerint az intézményesülés a szabályok, rendszerek túlélését hivatott elérni, ezért a vállalatok logikusan olyan formációkat, formális szervezeti struktúrákat alakítanak ki, amelyek biztosítják ezeket hosszú távon, figyelembe véve a szervezet környezeti jellemzőit is (Meyer \& Rowan, 1977., pp.343-347.).

Az intézményesülés magával hozza a szabályok legitimálását és megalkotásának kényszerét, legitimálását, a szabálykövetés ellenőrzését és a különféle szerepeket. Ezek együttesen szervezeti formát is öltenek, azaz létrejön, kirajzolódik egyfajta szervezeti struktúra az intézmény, illetve intézmények ${ }^{79}$ mögött. A legitimációs folyamat megteremti a formális vezetői szerepkört, valamint a munkamegosztást, majd az írott szabályok révén kialakulnak a hatáskörök, a szervezeti kultúra pedig stabilizálja az egyének belső viszonyát és kommunikációját a szervezet többi

\footnotetext{
76 Lásd 370/2011. (XII. 31.) Korm. rendelet a költségvetési szervek belső kontrollrendszeréről és belső ellenőrzéséről (2016. 03. 10-én hatályos szöveg alapján, letöltés napja: 2016. 03. 10.)

77 Lásd: http://ngmszakmaiteruletek.kormany.hu/belso-kontrollrendszer (letöltés: 2016. 03. 10.)

78 Lásd részletesen az ÁSZ 14236. számú jelentését az állami vagyon feletti tulajdonosi joggyakorlással kapcsolatos tevékenységek ellenőrzéséről, valamint az 1298. számú jelentését a belső kontrollrendszer és a belső ellenőrzés szabályszerűségének a zárszámadási ellenőrzésbe bevont központi költségvetési intézményeknél lefolytatott ellenőrzéséről, továbbá a 13087. számú jelentését az önkormányzatok belső kontrollrendszerének kialakítása, valamint egyes kontrolltevékenységek és a belső ellenőrzés müködése ellenőrzéséről.

${ }^{79}$ Értsd: egy formális szervezeten belül számos intézmény müködik, ezek pedig egymásra hatnak, egymással állandó kapcsolatban vannak.
} 
tagjával. Miközben az intézményi megközelítés igyekszik választ adni arra, hogy miképpen jönnek létre a különféle szervezeti normák, egyben legitimálja azt, hogy az intézmény, illetve az intézményesülés gyakran együtt jár, a kettő együtt okozza a formális szervezet létrejöttét és működését is. Az így létrejövő intézménynek tehát van története, eredete, van hová visszanyúlni, és meg lehet magyarázni a szervezet tagjainak, hogy az miért jött létre, és miért érdemes fenntartani a szervezetet, amely az intézményesült magatartást támogatja (DiMaggio \& Powell, 1991., pp.174230.), (Kieser, 2003., p.391.).

Példa: $A$ belső kontrollrendszer intézményesülése a kontrolláló szervezetek (szervezeti egységek, csoportok, részlegek) létrejöttét is eredményezi a vállalatokban. E belső szervezeti egységek hatásköröket kapnak, illetve harcolnak ki (pl. betekintés joga a nyilvántartásokba, vétójog, megfigyelési és elemzési jogosultság), a továbbiakban formális belső keretek között szabályozzák tevékenységüket (pl. éves munkaterv, SZMSZ, munkaköri leírások), meghatározzák munkaköri feladataikat (jelentések készítése, információ nyújtása, tanácsadás a vállalat vezetésének, a vagyon védelme stb.).

\subsection{Kritikák az intézményi szociológiai megközelítéssel szemben}

$A z$ institucionalista szervezetelméletet kritikusan nézve megállapíthatunk több olyan hiányosságot, illetve gyenge pontot, amelyek az elmélet sajátosságait kikezdik, illetve vitatják. Ezek közül a legfontosabbak a fentiekhez kapcsolódóan (Kieser, 2003., pp.421-428.):

- Az intézményesülés egyik útja a jelek, jelrendszerek használata a szervezetekben. Ugyanakkor az elmélet nem foglalkozik érdemben a jelekkel, a jelképekről nem mond semmit, noha az a közös kultúra egyik fontos eleme. A szimbólumok személytől független jelentéstartalommal bírnak és a kultúra meghatározó elemei, az intézményi megközelítés mégsem vizsgálja őket. Így a kontrollrendszer témakörében például nem kapunk választ arra, hogy a különféle jelentésekben, riportokban, dashboardokon miért éppen a zöld szín a megfelelőség, a sárga a figyelmeztetés és a piros a problémás területek színe, túl azon, hogy a közlekedési lámpák is e színeket használják.

- Nem ad választ arra a kérdésre, hogy az egyének a normákat, a szabályokat miért fogadják el, és miért teljesítik a hatalommal rendelkező legitim szereplők iránymutatásait, intelmeit. Bár kísérletek voltak arra vonatkozóan, hogy a racionális döntés elvét, a közösséghez tartozás, az önérdekkövetés stb. elvét itt is alkalmazzák, tudományosan bebizonyítani ezek egyikét kizárólagos magatartásbefolyásoló elemként sem sikerült. Témánk szempontjából például nincs egzakt válasz arra a kérdésre, hogy egyáltalán miért fogadják el és engedik meg a munkatársak a belső ellenőr vizsgálati 
munkáját, és miért ismerik el tárgyilagos megállapításait, javaslatait többnyire hasznosnak.

- Nem ad egyértelmű iránymutatást az elmélet a változások kezelésére vonatkozóan. Az intézményekre ható nyomás következményeit, az intézmények átalakulását vagy esetleges megszúnését kevéssé magyarázza az intézményi szociológia, illetve a változások végbemenetelét többféleképpen értelmezi. Kevés magyarázatot kapunk arra, hogy ezen intézmények hogyan viszonyulnak egymáshoz, miképpen integrálhatók. Disszertációm tárgyát alapul véve kérdéses például az egyes szereplők közötti áthatások, áthallások és az integrációs lehetőségek magyarázata az institucionalista elmélet alapján, ezért például az elmélet alapján nehezen tudjuk megmondani, hogy miért olvad vagy éppen nem olvad össze eggyé a kontroller és a belső ellenőr munkaköre, és ez milyen külső hatásra, divathullámra, illetve rendelkezésre következhetne be.

- Nem egyértelmú a szereplők hatalmi helyzete, legitimációs forrása sem. Kérdéses, hogy azt valakitől elnyerik, vagy valamely más intézményből, illetve szabályból adódóan automatikusan jár nekik, esetleg saját maguk kivívják, azaz hogy honnan származik pontosan a legitimitásuk, szerepük és munkakörükhöz kapcsolódó joguk. Például nem tudjuk egyértelmúen megmagyarázni, hogy a belső ellenőr esetében a függetlenség biztosítéka miért az első számú vezetőhöz való tartozás, ha egyébként a gazdasági igazgató alá tartozó kontrollereket is, vagy a jogi irodában dolgozó compliance managert is ugyanúgy függetlennek, elfogulatlannak és tisztességesen dolgozónak tekintjük.

- Nem ad választ a megközelítés arra, hogy milyen életciklusban zajlik le az intézményesülés folyamata, hogyan kezdődik, mi mit követ, és mikor éri el a maximális érettségi szintjét. Így például az elmélet alapján nem világos, hogy az intézményesülés egyes szakaszaira mi a jellemző szervezeti magatartás. A kontrollrendszerek tárgykörében például nem tudjuk, hogy a stációk közül az ellenőrzési szabályzatok és programtervek összeállítása történik-e hamarabb, vagy a kontrollrendszerrel foglalkozó pozíciók kialakulása következik-e be előbb. Utóbbi oda vezet, hogy a hasonló pozíciók szervezeti egységet képeznek, és a későbbiekben az auditütemterveket ők készítik elő és terjesztik elő a vezetés számára.

A fenti kritikák jól rámutatnak arra, hogy az intézményesülés elmélete is támadható egy-egy elemében, illetve az általa hangoztatott lefolyás többféleképpen is megközelíthető. Ez megvilágítja az intézményi szervezetelméletnek a gyakorlati oldalát, vagyis hogy nemcsak elméletileg létező kitalációról van szó, hanem a gyakorlatban is alkalmazható modellről. Úgy ítélem meg, hogy az intézményi 
megközelítés szemüvegén keresztül a kontrollrendszerek jól vizsgálhatóak, elemezhetőek. S bár más felfogások is szóba jöhetnének (kontingenciaelmélet, bürokráciaelmélet, evolucionista felfogás), az intézményi szociológia elemei (pl. szabályozás, izomorfizmus, diskurzusok) jól illeszthetők a belső kontrollrendszer témaköréhez.

\section{9 Összegzés - az intézményesülés kulcsfogalmai}

A fenti szakirodalom saját összegzése révén kívánom bemutatni az intézményi megközelítések legfontosabb szakszavait, koncepcióját, posztulátumának meghatározó jelzőit és fogalmait. Ezeknek az elemeknek a későbbiekben szerepük lesz a saját kutatási kérdéseimben, valamint alapvetően befolyásolják az intézményesülés folyamatát a szervezetekben. A legfontosabb kulcstényezők és jellemzőik a következők:

\begin{tabular}{|c|c|}
\hline $\begin{array}{l}\text { Az intézményesülés } \\
\text { kulcstényezői }\end{array}$ & A kulcstényező kapcsolódó szavai, kulcsmotívumai \\
\hline Alapmotívuma, fő üzenete & $\begin{array}{l}\text { beépülés, integráció, stabilizálódás, berögzülés, } \\
\text { meghonosodik, betagozódik, beleolvad a már } \\
\text { meglévőbe }\end{array}$ \\
\hline $\begin{array}{l}\text { Standarizálás és hasonulási } \\
\text { törekvések }\end{array}$ & $\begin{array}{l}\text { adoptáció, rutinszerú reprodukció, társadalmi minta, } \\
\text { másolás, kooptálás, hasonlóvá válás, örökítés, átadás, } \\
\text { felülés divathullámokra, uralkodó koncepciók } \\
\text { internalizálása, izomorfizmus, homogenizáció }\end{array}$ \\
\hline Normaalkotási célok & $\begin{array}{l}\text { kényszerűség, normatívák, kötelezettségek, szabályok, } \\
\text { kötelmek, írott normák, formalizált eljárásrendek; } \\
\text { valamint nem formalizált előírások, úgymint kultúra, } \\
\text { kulturális keret, közös értékrend, viselkedésminta, } \\
\text { közös felfogásrendszer, bevett szokás, cselekvési } \\
\text { keret, müködési elv, rutin, praktika, gyakorlat, kvázi- } \\
\text { automatikus magatartási sémák }\end{array}$ \\
\hline $\begin{array}{l}\text { A valóság } \\
\text { megkérdőjelezhetetlensége }\end{array}$ & $\begin{array}{l}\text { objektív valóság, külső adottság, már létező rend és } \\
\text { helyzet elfogadása, meg nem kérdőjelezett realitás }\end{array}$ \\
\hline $\begin{array}{l}\text { Alakító személyek szerepköre, } \\
\text { szervezeti és strukturális } \\
\text { alkalmazkodás }\end{array}$ & $\begin{array}{l}\text { aktorok, érdekeltek, hatalombirtokosok, } \\
\text { individuumok, domináns pozícióban lévők, } \\
\text { specialisták, technikai kivitelezők, működési terep, } \\
\text { keretrendszer, szervezeti megoldás, formális } \\
\text { struktúra, pozíció, munkakör }\end{array}$ \\
\hline $\begin{array}{l}\text { Megvalósítást biztosító } \\
\text { személyi közeg, társadalmi tér }\end{array}$ & $\begin{array}{l}\text { kulturális közösség, kognitív közeg, közös } \\
\text { felismerések, tárgyalás, diskurzus, konstruktív vita }\end{array}$ \\
\hline $\begin{array}{l}\text { Személyek egymáshoz való } \\
\text { viszonya }\end{array}$ & $\begin{array}{l}\text { (szabályoknak és) személyeknek való behódolás, } \\
\text { egyetértés, azonosulás, alávetés; valamint } \\
\text { szabályokkal szembeni szembenállás, konfrontáció, }\end{array}$ \\
\hline
\end{tabular}




\begin{tabular}{|l|l|}
\hline Klánhatás érvényesülése & konfliktusok, szankciók akaratlagos alkalmazása \\
\hline Elvont eszközök alkalmazása & hörténetek, elmesélések \\
\hline $\begin{array}{l}\text { Cselekvés motorja, dinamizmus } \\
\text { alapjai }\end{array}$ & jelentésrendszerek, szimbólumok \\
\hline
\end{tabular}

2. táblázat: Az intézményesülés kulcsfogalmai

Forrás: Saját összeállitás a szakirodalom szintézise révén

\subsection{A belső kontrollrendszer intézményesülési szintjei - saját modell}

A fent bemutatott intézményi megközelítéseknek, illetve az intézményesülés folyamatának a belső kontrollrendszer kapcsán való alkalmazhatóságára vonatkozóan a következő alapelemekből álló saját megközelítést, kiinduló modellt határoztam meg. További kutatásaim alapjául, vázául is ez szolgál a disszertációmban. A modellt a 12. számú ábra tartalmazza.

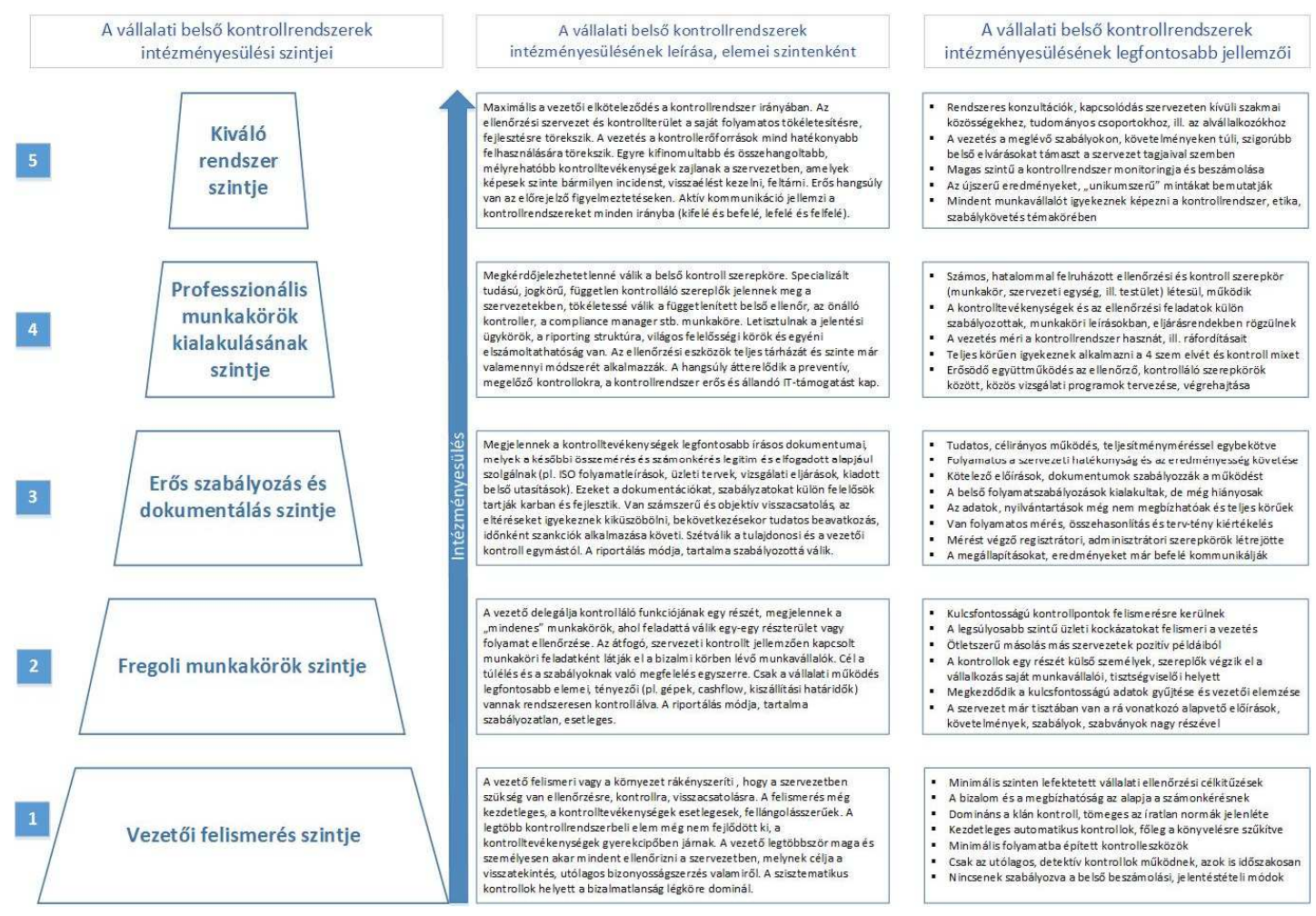

12. ábra: A belső kontrollrendszer intézményesülési szintjei

Forrás: saját összeállitás 
A saját modell összeállításának alapelvei megközelítésemben a következők:

- Tartalmazza és kezelje a belső kontrollrendszer elemeit a korábban bemutatott definíciókra és a COSO-modellre alapozva. Tükrözze vissza a kontroll környezeti és tevékenységi elemeit, fontosabb eszközeit.

- Használja az intézményi szociológia megközelítését, az intézményesülési elveket és ezek hangsúlyos elemeit a korábban bemutatott alfejezetek alapján. Mutassa a szervezetekben megtörténő emberi cselekvések okait, motívumait, láttassa az intézményesülés fejlődését, folyamatát, dinamizmusát.

- Tegye láthatóvá a kontrollrendszerek intézményesülésének stációsorát, mutassa be fokozatait, érettségi szintjeit és az egyes szintek legfontosabb, meghatározó jellemzőit. Így tegye lehetővé azt, hogy modell egyes szintjeibe kísérleti úton besoroljuk a gazdasági társaságokat a modell által meghatározott fejlettségi szintjeik vizsgálata alapján.

- Tegye lehetővé saját kutatási kérdések megfogalmazását a kiinduló modellre, illetve annak tartalmi elemeire vonatkozóan, segítse a feltevések és hipotézisek megfogalmazását, valamint alapul szolgáljon azok igazolására vagy elvetésére.

Ezen elvek mentén a hivatkozott, 12. számú ábrában összegeztem saját modellemet, mely öt lépcsőfokban, stációban láttatja a szakirodalom alapján a belső kontrollrendszerek intézményesülését. Az egyes lépcsőfokok közötti elhatárolásra a főbb jellemzők és a legfontosabb elemek megadásával teszek kísérletet. A modell hierarchikusan értelmezhető ${ }^{80}$, egy magasabb szint azt jelenti, hogy az intézményesülés szakaszának érettebb, előrehaladottabb állapotában van a szervezet, legalábbis a belső kontrollrendszer múködését illetően. A szervezet az intézményi modellek által bemutatott előrehaladással tud magasabb szintre lépni, ami feltételezi a belső tapasztalást, a kiérlelt, kifinomult eszközrendszerek alkalmazását.

A modell exogén változókat nem jelenít meg, azokat nem kezelem, de az intézményesülésben feltételezhetően ${ }^{81}$ nagy befolyásoló szerepe van a szervezetek külső és belső adottságainak (Dobák \& Antal, 2013., pp.41-65.), úgymint:

- A szervezet kora, az alakulás óta eltelt, múködéssel érintett időszak, mely feltételezi, hogy egy kezdő vállalkozás kezdetleges kontrolleszközökkel rendelkezik, míg egy érett stádiumban lévő, 50-70 éve működő cégben

\footnotetext{
80 Értelemszerűen a 0. szint azt jelenti, hogy egyáltalán nincs belső kontrollrendszer a szervezetben, ez esetben annak intézményesüléséről sem beszélhetünk. Ezt a szintet a 12. számú ábra nem tartalmazza.

${ }^{81} \mathrm{~A}$ feltételezést a következő fejezetben hipotézisként is megfogalmazom, s ennek bizonyítása kutatásom része.
} 
már kialakulhattak a belső kontrollrendszer elemei, és megtapasztalták annak működését.

- A szervezet mérete, mely a pénzügyi mutatók (árbevétel, mérlegfőösszeg, saját tőke) mellett a telepítettség, a fióktelepek és létesítmények, a gyártó és szolgáltató részlegek száma, a foglalkoztatottak száma, a használt eszközök, gépsorok, gépjármúvek és egyéb naturális mutatók révén írható le. Minél nagyobb a szervezet, annál kevésbé átlátható, minél nagyobb a fizikai távolság az egységek között, annál több irányítási, szervezési kockázat merül fel, ebből következően feltételezni lehet, hogy a kontrollrendszernek is fejlettebbnek, specifikáltabbnak, komplexebbnek kell lennie.

- A szervezet küldetése, alaptevékenysége, fő iparági-üzleti tevékenysége, termékeinek száma, a versenypiac változékonyságának, komplexitásának jellemzői, melyek alapján a szervezet kevés vagy éppen sok piaci, múködési és technológiai kockázattal bír, ebből következően (az utóbbi esetben) komplexebb, átfogóbb belső kontrollrendszerre van szükség a szervezetben.

- A külső, illetve tulajdonosi elvárások, külső jogi előírások (jogszabályok, utasítások, beszámolási kötelezettségek, hatósági kívánalmak stb.) a szabályoknak való megfelelés magas szintjét követelik meg (pl. élelmiszeripar), míg egy jogilag minimálisan szabályozott iparágban múködő szervezetben (pl. kereskedőház) feltételezhetően a támasztott compliance követelmények is alacsonyabbak.

Ezek a tényezők összességében a COSO-kontrollkörnyezet fejezetében leírtakkal, a szervezetre vonatkozó külső jellemzőkkel mutatnak párhuzamot, a szervezet alapvető leírására, jellemzésére vonatkoznak.

$A z$ egyes hierarchiaszintek építenek a korábbi szintekre, így azokat magukba foglalják. A magasabb szinten lévő stációra igaz, hogy az alacsonyabb szinten lévő elemekből megtartja azokat, amelyekkel ellentétes gyakorlat magasabb szinten nem alakul ki. Így például a választott könyvvizsgáló megjelenése a harmadik szinten azt jelenti, hogy könyvvizsgálat van a negyedik és az ötödik szinten múködő vállalatokban is, azonban elképzelhető, hogy az ötödik szinten a kifinomult és alternatív eszközök alkalmazása révén projekt-könyvvizsgálatra vagy belső, előzetes felkészülő-könyvvizsgálatra (internal pre-audit) is sor kerül a választott könyvvizsgáló tevékenységétől függetlenül.

A belső kontrollrendszerek saját modellem szerinti alacsony, illetve magas szintű intézményesülését összevetettem az intézményesülés elméleti kulcstényezőivel, melyeket lentebb a 3 . táblázatban foglaltam össze. A kapott eredményeket 
ellentétpárokként külön táblázatban foglaltam össze, melyet alább közlök. A táblázat utolsó oszlopában a COSO-keretrendszer 17 alapelvének saját besorolása látható aszerint, hogy azok melyik kulcstényezőre jellemzők leginkább.

\begin{tabular}{|c|c|c|c|}
\hline $\begin{array}{l}\text { Az } \\
\text { intézménye- } \\
\text { sülés } \\
\text { kulcstényezői }\end{array}$ & $\begin{array}{l}\text { Kulcstényező jellemzője a } \\
\text { legalsó (1) szinten }\end{array}$ & $\begin{array}{l}\text { Kulcstényező jellemzője a } \\
\text { legfejlettebb (5) szinten }\end{array}$ & $\begin{array}{l}\text { A } 17 \text { cosO-alapelv } \\
\text { melyike } \\
\text { kapcsolható ehhez } \\
\text { a } \\
\text { kulcstényezőhöz? }\end{array}$ \\
\hline $\begin{array}{l}\text { Alapmotívuma, } \\
\text { fő üzenete: } \\
\text { átható } \\
\text { beépülés, } \\
\text { teljeskörűség }\end{array}$ & $\begin{array}{l}\text { A kontroll nem épült be a } \\
\text { múködésbe, esetleges, ad hoc } \\
\text { módon merül fel az igénye. }\end{array}$ & $\begin{array}{l}\text { A kontrolltevékenységek teljes } \\
\text { mértékben beépültek a } \\
\text { szervezet működésébe, } \\
\text { áthatják a tevékenységeket, az } \\
\text { ellenőrzés a mindennapok } \\
\text { részévé vált, és ezt } \\
\text { folyamatosan igyekeznek } \\
\text { fejleszteni. }\end{array}$ & 9., 10., 11. \\
\hline $\begin{array}{l}\text { Standardizálás } \\
\text { és hasonulási } \\
\text { törekvések }\end{array}$ & $\begin{array}{l}\text { Befelé fordul a szervezet, nem } \\
\text { nyitott más vállalkozások } \\
\text { gyakorlatának megismerésére, } \\
\text { nem vesz át mintákat, nem } \\
\text { adaptál semmit sem. }\end{array}$ & $\begin{array}{l}\text { Átvesz más vállalatoktól jó } \\
\text { gyakorlatokat, keresi a szakmai } \\
\text { szervezeteket, igyekszik } \\
\text { azújdonságokat megismerni és } \\
\text { beépíteni a saját működésébe. }\end{array}$ & - \\
\hline $\begin{array}{l}\text { Normaalkotási } \\
\text { célok }\end{array}$ & $\begin{array}{l}\text { Nincs formalizáltság, az íratlan } \\
\text { hagyományok és szokások sem } \\
\text { jelölik ki a kontroll kereteit, } \\
\text { legfeljebb az első számú vezető } \\
\text { karizmája és szóban } \\
\text { ismertetett elvárásai } \\
\text { teremtenek } \\
\text { (kontroll)szokásokat. }\end{array}$ & $\begin{array}{l}\text { Keményen formalizált, szigorú } \\
\text { és írásos szabályok mentén } \\
\text { zajló kontrollfolyamatok } \\
\text { vannak, ezt kiegészítik az erős } \\
\text { íratlan, belső kulturális } \\
\text { cselekvési elvárások és a } \\
\text { magas szintű morális } \\
\text { értékrend. }\end{array}$ & 1., 5., 12. \\
\hline $\begin{array}{l}\text { A kontroll } \\
\text { szükségessége, } \\
\text { megkérdőjelez- } \\
\text { hetetlensége }\end{array}$ & $\begin{array}{l}\text { A kontrollrendszer nyűg és } \\
\text { felesleges teher, időrabló } \\
\text { tevékenység a szervezet } \\
\text { múködése szempontjából. }\end{array}$ & $\begin{array}{l}\text { A kontroll fontossága } \\
\text { megkérdőjelezhetetlen, } \\
\text { magától értetődő, } \\
\text { szükségességét és fontosságát } \\
\text { érzik a szervezetben, és ezt } \\
\text { deklarálják, kommunikálják is a } \\
\text { szereplők. }\end{array}$ & 13., 14., 15. \\
\hline $\begin{array}{l}\text { Alakító } \\
\text { személyek } \\
\text { szerepköre, } \\
\text { szervezeti és } \\
\text { strukturális } \\
\text { alkalmazkodás }\end{array}$ & $\begin{array}{l}\text { Nincs gazdája, formálója, } \\
\text { érdekeltje a belső } \\
\text { kontrollrendszernek. A } \\
\text { kontrollálás sem munkaköri } \\
\text { kötelességként, sem szervezeti } \\
\text { egység feladatkörében nem } \\
\text { jelenik meg. A kontrollok } \\
\text { gyakorlása esetleges, } \\
\text { következetlen, vagy nincs is. }\end{array}$ & $\begin{array}{l}\text { Számos szereplő és testület } \\
\text { alakítja, formálja a belső } \\
\text { kontrollrendszereket. A } \\
\text { kontrollokat számos e célból } \\
\text { foglalkozatott munkatárs } \\
\text { gyakorolja, illetve létrejöttek } \\
\text { külön ellenőrzést végző } \\
\text { szervezeti egységek is e célból, } \\
\text { alkalmaznak külön } \\
\text { bizottságokat, szakértőket, } \\
\text { megbízottakat. Minden } \\
\text { szereplőnek világos a } \\
\text { feladatköre és felelőssége a } \\
\text { kontrollrendszerben. }\end{array}$ & 2., 3 . \\
\hline $\begin{array}{l}\text { Megvalósítást } \\
\text { biztosító } \\
\text { személyi közeg, } \\
\text { közösségi tér }\end{array}$ & $\begin{array}{l}\text { Nincs szervezeten belüli } \\
\text { egyeztetés, vita a } \\
\text { kontrollrendszer fejlesztésének } \\
\text { tartalmáról, illetve irányáról. }\end{array}$ & $\begin{array}{l}\text { A kontrollmechanizmusok } \\
\text { belső egyeztetések, szakmai } \\
\text { fejlesztési ötletek révén, } \\
\text { diskurzus útján fejlődnek. }\end{array}$ & 4., 16., 17. \\
\hline
\end{tabular}




\begin{tabular}{|l|l|l|l|}
$\begin{array}{l}\text { Személyek } \\
\text { egymáshoz } \\
\text { való viszonya a } \\
\text { szabályok } \\
\text { betartása során }\end{array}$ & $\begin{array}{l}\text { A kontrollrendszereknek nincs } \\
\text { visszatartó erejük, súlytalanok, } \\
\text { elemeik nem meghatározóak. }\end{array}$ & $\begin{array}{l}\text { A kontrollrendszerek komoly } \\
\text { fegyelmező erőt képviselnek a } \\
\text { szervezetben, megsértésük } \\
\text { jelentős szankciókkal jár. }\end{array}$ & 8. \\
\hline $\begin{array}{l}\text { Klánhatás } \\
\text { érvényesülése }\end{array}$ & $\begin{array}{l}\text { Nincs előélete a } \\
\text { kontrollrendszereknek, nem } \\
\text { kapcsolódnak hozzájuk } \\
\text { szervezeten belüli történetek, } \\
\text { mítoszok. }\end{array}$ & $\begin{array}{l}\text { Számos történet, legenda } \\
\text { ismert a múltból, amikor a } \\
\text { belső kontrollrendszer feltárt, } \\
\text { megakadályozott valamilyen } \\
\text { kedvezőtlen, káros dolgot a } \\
\text { szervezetben. }\end{array}$ & - \\
\hline $\begin{array}{l}\text { Elvont } \\
\text { eszközök } \\
\text { alkalmazása }\end{array}$ & $\begin{array}{l}\text { A belső kontrollrendszernek } \\
\text { nem érhető tetten semmilyen } \\
\text { szimbolikus, elvont } \\
\text { jellegzetessége, nincsenek } \\
\text { formulák, modellek, elvont } \\
\text { eszközök a munkavégzés } \\
\text { szolgálatában. }\end{array}$ & $\begin{array}{l}\text { A belső kontrollrendszer } \\
\text { létezését számos szimbólum, } \\
\text { jel fejezi ki, elvont eszközöket } \\
\text { és modelleket is alkalmaz } \\
\text { tevékenysége során. }\end{array}$ & 7. \\
\hline $\begin{array}{l}\text { Cselekvés } \\
\text { motorja, } \\
\text { dinamizmus } \\
\text { alapjai }\end{array}$ & $\begin{array}{l}\text { Nincsenek vezetői vagy } \\
\text { tulajdonosi, hatósági } \\
\text { elvárások, a } \\
\text { kontrollmechanizmusokat } \\
\text { senki sem presszionálja. }\end{array}$ & $\begin{array}{l}\text { A kontrollok múködésére és } \\
\text { eredményességére, } \\
\text { hatékonyságára erős nyomás } \\
\text { nehezedik a különféle } \\
\text { szereplők (tulajdonosok, } \\
\text { hatóságok, menedzsment stb.) } \\
\text { részéről. }\end{array}$ & 6. \\
\hline
\end{tabular}

3. táblázat: A belső kontrollrendszerek intézményesülésének kulcstényezők szerinti jellemzése ellentétpárokkal Forrás: saját összeállitás

A belső kontrollrendszerek fejlődési szintjei egymásra épülő, hierarchikus modelljének megalkotásakor intuíciót merítettem más témakörben született, de hasonló logikával felépülő modellekből, elméleti keretekből. Boulding a rendszerelméleteket leíró múvében a rendszereket 9 evolúciós lépcsőből álló modell szerint jellemezte a statikus strukturális rendszerektől egészen a transzcendentális rendszerszintig (Boulding, 1956., pp.202-205.). Horváth Péter ismerteti a vállalati kontrollingfunkció egyre növekvő és minőségileg új feladatokat jelentő szerepköreit („babszámláló”, regisztrátor, navigátor, innovátor) a vállalat növekedésével és a pozíció jelentőségével összefüggésben (Horváth \& Partners, 2009., pp.195-196.). A költségvetési intézményeket az ÁSZ kifinomult, 367 kérdésből álló vizsgálati kérdőív segítségével, pontozásos módszerrel sorolja be a belső kontrollrendszer különféle (nem felelt meg, részben megfelelt, megfelelt) megfelelőségi kategóriáiba (Dormán et al., 2013., p.208. 4. ábra). Simons múvében a 6.1 ábrán bemutatja a szervezeten belül múködő menedzsmentkontroll-rendszer evolúciós fejlődési modelljét a cég egyes életszakaszaiban (Simons, 1995., p.128.). A minőségügyi tevékenységek szintjeit és vállalaton belüli életszakaszait a minőségellenőrzéstől a minőségirányítási szintig minőségirányítással foglalkozó könyvek is ismertetik (Koczor, 2006., p.35.).

Van példa lépcsőzetes, fejlődést feltételező saját modellek bemutatására is disszertációm témájához hasonló tárgykörökben. A KPMG-BPC szoftvere 5 
lépcsőfokban határozza meg a belső kontrollrendszerek szabályozottsági fokait (nem szabályozott, informális, standardizált, minőségbiztosított, optimális) (Löffler et al., 2011., pp.34-35.). Hwang kifejlesztette az ISO 15504 szabványban alkalmazott, ötlépcsős folyamatszabályozási szinteket (ezt alkalmazza a fentebb hivatkozott Governance SPICE modell is) a szoftverfejlesztésben alkalmazott alkalmazásfejlesztés-menedzsment érettségi szintekkel ötvöző modelljét, így jött létre a háromlépcsős saját K-modellje (Hwang, 2009). Kurniawanti publikációjában a függetlenített belső ellenőr munkakörének öt fejlődési stációját mutatja be a nemlétezéstől egészen a partneri szintig (Kurniawanti, 2010., p.325.). 


\section{RÉSZ}

\section{KUTATÁSI KÉRDÉSEK ÉS EREDMÉNYEK}

\subsection{Saját kutatási, elemzési célok}

Doktori disszertációm tárgya a vállalati belső kontrollrendszer intézményesülése, érettségének vizsgálata. $E$ kettő témám szempontjából összefügg, azonosként tekintek rájuk. A téma vezetői és kutatói szemmel is megközelíthető, s e két személynek eltérő nézetei, igényei, reakciói és szokásai lehetnek (Sajtos \& Mitev, 2007., pp.15-17.). Vezetői szinten (menedzseri megközelítésben) a problémát úgy definiálnám, hogy miképpen kell kialakítania, felépítenie és múködtetnie egy vezetőnek a saját szervezetén belül a hatékony, irányítást támogató belső kontrollrendszert. Kutatói szemmel a kérdést úgy lehet feltenni, hogy mik ennek a hatékony és eredményes kontrollrendszernek a különféle ismérvei, összetevői, jellemzői. A kutatói kérdés tehát a vezető szintjénél mélyebb, a kutatási probléma összetettebb, bonyolultabb, és alaposabb körbejárást igényel. Disszertációm ezen részében saját kutatásom eredményeit mutatom be akadémiai megközelítésben (Babbie, 2001., pp.103-246.), (Sajtos \& Mitev, 2007., pp.19-37.).

Értekezésemben arra keresem a választ, hogy

1. mely tényezők befolyásolják a belső kontrollrendszer működését,

2. kik és hogyan múködtetik azt, kik a szereplői,

3. milyen elemei vannak e rendszernek, és azok hogyan hatnak egymásra,

4. a kontrollrendszer hogyan épül bele a szervezet mindennapi működésébe, tevékenységébe, azaz hogyan intézményesül?

Dolgozatom eddigi részeiben fogalmi meghatározásokat és az elméleti, szakirodalmi háttér bemutatását végeztem el. Értekezésem jelen fejezetében e téma kapcsán fogalmazok meg saját kutatási kérdéseket, illetve állítok fel és vizsgálok meg hipotéziseket a magyar vállalkozásokra vonatkozóan, melyek alapján levonom következtetéseimet.

Kutatási célom annak szakszerű feltárása és empirikus alapokon nyugvó elemzése, hogy egy vállalatban milyen jellemzőkkel írható le a belső kontrollrendszer, milyen fejlettségi, érettségi szintjei vannak, és maga a belső kontrollrendszer miképpen professzionalizálódik a vállalkozásokban. A kutatás célja válaszolni a fenti kutatási kérdésekre, empirikus úton megerősíteni a saját kiinduló modellemet, igazolni a hipotéziseimet. 


\subsection{Korábbi hazai és nemzetközi kutatási eredmények bemutatása}

A nemzetközi és hazai szakirodalom feltárása során nem találtam olyan tudományos közleményt, szakcikket, könyvet vagy publikációt, amely átfogóan és tudományos szempontból tárgyalná az üzleti szervezetek belső kontrollrendszerének intézményesülési folyamatait, jellemzőit. Ezért egy ilyen kutatási célkitűzés eleve inspiráló téma volt a számomra. A témámhoz legközelebb az a - cOSO-modell kidolgozásáról és annak elterjedéséről szóló - cikk áll, mely a „COSO-mozgalom” intézményesülését mutatja be makroszinten a kezdetektől napjainkig (Hayne \& Free, 2014.), de nem mutatja be az intézményesülés vállalaton belüli folyamatát és szintjeit. Az intézményesülés témáját érinti még saját kutatásában Olof Arwinge is, aki az ügynökelmélettel párhuzamosan idézi az institucionalista szervezetelméletet is a belső kontrollrendszerek múködésének megértéséhez (Arwinge, 2013., pp.2836., p.134.).

Természetesen egyes szakirodalmak a téma egyes részleteivel ( $\mathrm{pl}$. COSO-rendszer leírása, függetlenített belső ellenőrzés, menedzsmentkontroll, minőségbiztosítási audit, információrendszerek védelme stb.) mélyebben foglalkoznak, kiragadnak egyegy ügyet, melyet mélyrehatóan vizsgálnak, kutatnak. Az általam készítendő disszertáció átfogóan, a szinergialehetőségeket keresve és az intézményi megközelítési szempontból mutatja be és vizsgálja meg a belső kontrollrendszerek múködését, formáit, szereplőit. Az általam elvégzett kutatás pedig ennek hazai elterjedtségét és érettségét, elemeinek gyakoriságát, hasznosulását és ezek eredményességét tárja fel.

Janvrin és kutatótársai publikációja kifejezetten a COSO-rendszer múködésével kapcsolatos dilemmákat fedi fel, ezek napjaink legizgalmasabb kutatási kérdései a coso-rendszer általános működése kapcsán. A cikk azonban csak a dilemmák megfogalmazásáig jut el (Janvrin et al., 2012., pp.195-209.).

A coso-rendszer integráns és institucionalista alapokon nyugvó fejlődését bemutató tudományos értekezés kapcsolódik kutatási kérdéseimhez, igaz, a cikk makroszinten, a COSO világszintű globalizációjával foglalkozik, nem annyira a COSO mikroszintű intézményesülésével a vállalatokban. Összegző fejezete felvet olyan érdekes témákat, mint például a COSO további földrajzi terjeszkedése (pl. fejlődő és diktatórikus országok felé), a hibridizáció és a homogenizáció belső ellentéte, illetve, hogy a vállalatok 30-35\%-a miért állítja azt, hogy nem népszerü a COSO-ERMrendszer a körükben (Hayne \& Free, 2014., p.327.).

A COSO-rendszert, illetve kapcsolódó témaköreit más aspektusban jelenleg is vizsgálják. $A$ belső kontrollrendszer aktuális nemzetközi kutatásai szűk, célirányos 
résztémákat dolgoznak fel. Egyrészről aktuális kutatási téma a COSO-keretrendszer 2012-ben megkezdett és a 2014. évben lezárt felülvizsgálata, valamint a vállalatoknak a módosított keretrendszerhez való viszonyulása, reakcióik és adaptációjuk megvalósulása (PCAOB, 2012.), (Janvrin et al., 2012.), (D'Aquila \& Houmes, 2014.), (Wilkins \& Haun, 2014.), (Zhang \& Pany, 2008.). Erre a folyamatra rásegítenek a nagy tanácsadó és könyvvizsgáló cégek is saját tudásuk és felméréseik piaci felkínálásával (KPMG, 2013.), (EY, 2014), (PwC, 2016).

A COSO-rendszerrel kapcsolatos időszerű kihívások és aktuális elemzési, kutatási kérdések jelenleg a következők (a már megjelent és elérhető művek, publikációk alapján):

- hogyan múködtethető a belső kontrollrendszer külső szolgáltatók, outsource vállalkozások segítségével (Tysiac, 2015., pp.1-3.), (Brown Jr. et al., 2004.);

- hogyan hangolhatók össze a belső kontrollrendszer és a vállalat által használt vállalatirányítási (ERP) rendszerek (Huang et al., 2008.), (Turner \& Owhoso, 2009.), (Morris, 2011.), (Chang et al., 2014.);

- hogyan mérhető a hasznossága, illetve mikor tekinthető eredményesnek a belső kontrollrendszer múködése (Kerr \& Murthy, 2013.), (Hermanson et al., 2012.);

- újszerű kockázatmenedzsment-eszközök és -módszerek alkalmazása a vállalatok múködésében (Arwinge, 2013., pp.150-151.), illetve ezek terjedése a közszektor szervezetei felé (Schwartz, 2014.), (Vijayakumar \& Nagaraja, 2012), (Gatzert \& Kolb, 2014.)

- átláthatóság, transzparencia és antikorrupciós törekvések, főleg a keletközép-európai országokban múködő állami, önkormányzati tulajdonú vállalatoknál, illetve közösségi támogatások, EU-s finanszírozási alapok felhasználása kapcsán (Pallai \& Kis, 2014.), (Világgazdaság Online, 2013.), (Transparency International Magyarország, 2011.),

- Hogyan integrálható jobban a védelmi vonalak 3 tényezős modellje és a coso-keretrendszer, illetve a most 30. születésnapját köszöntő COSO-nak milyen további fejlődési irányai lehetnek (Chambers \& Odar, 2015.), (Tabuena, 2015), (Hirth \& Chambers, 2015.).

Másrészről a kutatások még mindig jelentős számban foglalkoznak a 2002-ben megjelent SOX-törvény előírásaival, a törvény 404-es cikkelyének vállalati gyakorlatba ültetésével, valamint a társaságirányítási jelentések és a belső kontrollrendszer riportjának tartalmával, összeállításával (Owusu-Ansah \& Ganguli, 2010.), (Deumes \& Knechel, 2008.), (Dana \& Zhongxia (Shelly), 2009.). 
Harmadrészt a kutatások a COSO egy-egy komponensén belüli elemének célirányos, mélységi vizsgálatával foglalkoznak, mint például az informatikai rendszerek ellenőrzési kérdései, a dokumentációs hiányosságok problémái, könyvvizsgálók részéről a belső kontrollrendszerek auditjára vonatkozó módszertanok vizsgálata stb. A coso-keretrendszerrel mint átfogó modellel általánosságban kevés publikáció foglakozik, így az intézményesülésével, beágyazódásával kapcsolatos felmérések, kutatások sem jelentek meg.

A belső kontroll tárgykörében, illetve a menedzsmentkontroll-rendszerek múködése kapcsán rendelkezésre állnak korábbi hazai versenyképesség-kutatási adatok és ezeket ismertető publikációk: (Bordáné, 2012.), (Milicz, 2011.), (Bodnár et al., 1997.). Ezenkívül felhasználtam a Big4 könyvvizsgáló cégek ( (KPMG, 2014.), (PwC, 2014.), (Ernst \& Young, 2012.), (Deloitte \& Touche, 2012.)) és a Belső Ellenőrök Magyarországi Közhasznú Szervezete (BEMSZ) által készített korábbi hazai compliance, illetve belső ellenőrzési témájú felmérések ${ }^{82}$ vizsgálati eredményeit is. Témám szempontjából és a kutatási kérdések felvetése miatt is értékesek a belső kontrollrendszernek a költségvetési szektorból kiinduló elemzései (noha azok nem üzleti szervezetek), ezért hivatkozom továbbá az ÁSZ vizsgálati jelentéseire, melyekben a központi költségvetési szervek, illetve az önkormányzati tulajdonban lévő gazdasági társaságok belső kontrollrendszereit vizsgálta a Számvevőszék (lásd: ÁSZ 1298 sz., 13087 sz. és 14236 sz. vizsgálati jelentései és az ebből született publikációk: (Benedek et al., 2014.), (Dormán et al., 2013.), (Gyüre, 2012.)).

\subsection{A kutatási téma konceptualizálása}

Kutatásom témája a belső kontrollrendszerek intézményesülése, a vállalati kontrollmechanizmusok múködési jellemzői az üzleti szervezetekben. A kutatási téma legfontosabb alapfogalmait az alábbiakban adom meg, visszautalva a korábbi fejezetekben tárgyaltakra; egyúttal a kutatási szakirodalom által megkövetelt fő indikátorokat és legfontosabb attribútumokat is összefoglalom (Babbie, 2001., pp.140-151.):

- Kontroll: számomra nem szinonim az ellenőrzési tevékenységgel. Az ellenőrzés vállalati célkitűzések, tervek és előre rögzített standardok,

\footnotetext{
82 Lásd a témához kapcsolódóan a következő hazai felmérések eredményeiről kiadott tájékoztatókat: http://www.pwc.com/hu/hu/kiadvanyok/globalis_gazdasagi_bunozes_felmeres/assets/Globalis gazdasagi_bunoz es_2014_magyar_riport.pdf (2015. 03. 09.), http://beszerzes.hu/2010/11/30/felforgatta-a-valsag-a-belsoellenorzesi-gyakorlatot (2015. 03. 09.), http://www.bankszovetseg.hu/wp-content/uploads/2012/10/86-97iglamanda.pdf (2015. 03. 09.), http://etk-rt.hu/images/dokumentumok/deloitte_eloadas.pdf. (2015. 03. 09.), http://hvg.hu/kkv/20071213_belso_ellenorzes (2015. 03. 09.).
} 
elvárások és szabályok teljesülésének vizsgálatát jelenti, míg a kontroll a szervezet múködésének átfogó irányítási képességét, célirányban, illetve uralom alatt tartását jelenti. A kontroll és az ellenőrzés elhatárolása, fogalmaik részletezve értekezésem II. részében találhatók meg. Kontrolláltnak tekinthető egy szervezet, ha az erre feljogosított szereplők (vezetők, munkatársak, tisztségviselők) folyamatosan, rendszerszerűen, dokumentáltan végzik vizsgálódásukat, és ezt a tevékenységet igyekeznek folyamatosan fejleszteni, hatékonyabbá és eredményesebbé tenni a szervezet céljainak elérése érdekében. A kontroll minőségi fogalom, főleg jelzőkkel írható le, mint például jól, erősen, nagyrészt, átfogóan, teljes körüen kontrollált valamely szervezet, program, projekt stb.

- Belső kontrollrendszer: a coso-keretrendszer által definiált, 5 komponensével megragadható leírása, annak jellemzőivel, használatának keretfeltételeivel együtt (részletezve disszertációm III. részében). Egy vállalatban akkor létezik COSO-alapú keretrendszer, ha a szabvány értelmezése szerinti kontrollkörnyezet vizsgálata tetten érhető, van kockázatmenedzsment, elvégzik a kontrolltevékenységeket, e tevékenység eredményeinek információs és kommunikációs alrendszere működik, és a rendszer belső monitoringja és értékelése rendszeresen megtörténik, valamint ezen 5 komponens egymással integráns egységet alkot, összehangolt múködés jellemzi őket. A coso-rendszer múködése, jelenléte minőségileg megragadható, úgymint alig-nagyrészt, vagy néhányösszes komponensében alkalmazott.

- Intézmény és intézményesülés: a szervezetekben végbemenő normalizálódás, szokások és cselekvések megegyezéses alapokon nyugvó állandósulása a benne részt vevő szereplők között (részletezve disszertációm IV. részében). Valaminek az intézményesüléséről beszélhetünk egy szervezetben, ha a szereplők között egy tanulási és kommunikációs folyamat eredményeképpen tartós megállapodás jön létre arról, hogy egy tevékenységet miképpen végeznek el, vagy egy helyzetre miképpen reagálnak, és ennek írásos alapja vagy nem formális, de egyéb módon tetten érhető normarendszere biztosított a szervezetben. Az intézmény létezését bizonyítják a közösen vallott normák, állandósult szokások, írásos vagy verbális szabályok, konszenzuson alapuló megállapodások és a szereplők közötti diskurzus révén létrejövő cselekvési sémák.

- Szereplők: azok a kulcsfontosságú munkavállalók, vezető tisztségviselők, megbízottak, alkalmazottak, akik egy üzleti szervezeten belül a belső kontrollrendszer kialakítását, felépítését, működtetését, fejlesztését végzik, és ilyen módon hatást gyakorolnak annak intézményesülésére, 
meghonosítására és elmélyítésére az üzleti szervezeteken belül (tömören, de nem teljes körüen bemutatva disszertációm I. számú függelékében). A kulcsszereplők cselekvőképes magánszemélyek, tipikusan ilyenek a vállalkozás (közép- és felső) vezetői, a belső ellenőr, a kontroller, a felügyelőbizottság és az audit bizottság tagjai, a minőségbiztosítási belső auditor, valamint egyéb munkavállalók, mint például a compliance koordinátor, a fraud manager vagy az etikai megbízott.

- Üzleti szervezet: üzleti értelemben a vállalatok és a vállalkozások, jogi értelemben a gazdasági társaságok és a szövetkezetek, tehát mindazon szervezetek, amelyek tevékenységüket üzleti haszonszerzés végett végzik (részletezve disszertációm IV. részében). Üzleti szervezetek hazánkban a PTK III. rész XI-XV. címében definiált társas vállalkozások, úgymint a betéti társaság, a közkereseti társaság, a korlátolt felelősségű társaság és a részvénytársaság, valamint a XVI. címben definiált szövetkezet.

\subsection{A választott kutatásmódszertan bemutatása}

A kutatásmódszertant befolyásolják a kutatási kérdések, valamint az, hogy a kutató a valóságot milyen módon akarja megismerni, leírni, jellemezni. A módszer determinálja az alkalmazandó módszereket, megköveteli a szakma szabályai szerinti kutatási folyamatot, és behatárolja a kapott eredmények hasznosítását, illetve a következtetések lehetséges körét (Babbie, 2001., pp.125-128.), (Sajtos \& Mitev, 2007., pp.20-23.).

Saját kutatásom primer adatgyűjtésen alapuló, összegző jellegű, keresztmetszeti kutatás. A lehetséges mértékben ok-okozati összefüggéseket is igazolni kívánok, ide értve a saját magam által kidolgozott modell érvényességét is. Ebből kifolyólag kutatásom kvantitatív módszereket alkalmazó, elméletorientált kutatás, mely a modellemmel és az intézményesülési folyamat bemutatásával gyarapítja a már meglévő ismereteket.

Az elsődleges kérdőíves kutatást, annak eredményeit három vállalati mélyinterjúval, valamint két fókuszcsoportos ${ }^{83}, 84$ feltáró megbeszéléssel erősítettem meg kutatásom során. Ezek célja az volt, hogy különféle gyakorló szakemberektől, a belső kontrollrendszert múködtető vállalati szereplőktől kapjak személyes

\footnotetext{
83 Lásd bővebben: http://iia.hu/images/stories/dokumentumok/2016jandelutan.pdf (letöltés: 2016. 03. 13.) ${ }^{84}$ Lásd bővebben:

http://mce.hu/index.php?option=com_content\&view=category\&layout=blog\&id=116\&ltemid=200077 (letöltés: 2016. 03. 13.)
} 
impulzusokat, benyomásokat, magyarázó háttér-információkat vizsgálati témámban. A személyes interjúk, ill. a kiscsoportos szakmai egyeztetések lehetőséget adnak a szereplőknek reagálni az elméleti állításokra, bemutatni a saját élő gyakorlatukat, ill. bővíteni a téma ismerethalmazát új nézetekkel, új állításokkal.

Az előző fejezetekben bemutatott szakirodalom alapján látható, hogy a belső kontrollrendszernek önmagában széles körű nemzetközi és hazai szakirodalma van. $A z$ intézményesülés folyamatát, szervezeten belüli megvalósulását, létrejöttét szintén több tudományterület vizsgálta, és számos publikáció áll rendelkezésre. A kettő összekapcsolása azonban még vezetéstudományi oldalról nem kutatott, legalábbis erre utal az ez irányú tudományos publikációk hiánya. Ezért helye lenne interpretatív megközelítésü85, a részleteket feltáró, szubjektív elemeket is alkalmazó, megismerő kutatásmódszertannak, amely kvalitatív alapokon nyugvó módszertant, elsősorban narratív interjúkat és dokumentumelemzéseket, személyes megfigyeléseket, esettanulmányok összeállítását jelentené. Ez esetben a hogyan (intézményesül...), milyen módon (érhető tetten a kontroll...), hogyan éli meg (ön a munkakörében a belső kontrollrendszert...) stb. kezdetű kutatási kérdésekre kaphatnánk válaszokat végső disszertációmban. Ezekből pedig egyedi következtetéseket vonhatnék le, ideografikus érvényességet feltételezve (Feischmidt, 2013.), (Babbie, 2001., pp.411-437.). Az én kutatói alapállásom szerint a kvalitatív kutatási módszereket csak másodlagos forrásként, megerősítés céljából alkalmazom jelen kutatásban.

Helye lenne longitudinális vizsgálatoknak is, ahol egy-egy szervezet kontrollrendszerének fejlődési szakaszait - kutatóként - éveken keresztül végigkísérném, megfigyelném a fejlődés szakaszait, s ezen tapasztalatokból vonhatnék le általánosítható következtetéseket. Úgy vélem azonban, hogy az így kapható eredmények nehezen lennének általánosíthatók valamennyi hazai vállalkozásra. Nem utolsósorban pedig végső doktori disszertációm elkészítésének idejét is kitolná kb. 4-6 évvel (a jelen időponthoz képest), ezért ezt a kutatási módszert is elvetettem.

Mindezeket mérlegelve funkcionalista alapokon nyugvó, kvantitatív, klasszikus nagymintás felmérésen alapuló kutatásmódszertant választottam. A kapott válaszokat számszakilag mérhetőnek és értékelhetőnek, kutatási eredményeimet pedig a mérési adatok révén összehasonlíthatónak tekintem.

\footnotetext{
${ }^{85} \mathrm{Az}$ interpretatív paradigma szerinti társadalomtudományi elméletalkotásról lásd bővebben Burrel és Morgan 4 dimenziós modelljét leíró művükben (Burrel\&Morgan (1979): Sociological Paradigms and Organisational Analysis - Elements of the Sociology of Corporate Life, Ashgate Publishing, Burlington.).
} 


\subsection{Saját kutatási kérdések és hipotézisek}

\subsubsection{Disszertációm fő kutatási kérdései és a hipotézisek}

Fő kutatási kérdéseim jelen dolgozatban a következők: Milyen főbb jellemzőkkel írhatjuk le az intézményesült vállalati belső kontrollrendszert? Hogyan jellemezhető a belső kontrollrendszer egy rendszerezett modell egymásra épülő fejlettségi szintjei segítségével? Kutatási kérdéseimet tovább bontom alkérdésekre, és ezekre vonatkozóan fogalmazok meg szakmai hipotéziseket, alhipotéziseket.

Szakmai hipotézisnek tekintem a hagyományos kutatásmódszertani megközelítésben alkalmazott előfeltételezést, vagyis azt a kijelentést, amely az elméleti megközelítésből eredően a dolgokra jellemző állítás vagy felvetés (Babbie, 2001., p.Sz5. Hi*), (Falus \& Ollé, 2008., pp.24-25.), (Hunyadi \& Vita, 2006., pp.402406.). Kutatásomban ezen elméleti feltételezéseket megpróbálom igazolni empirikus úton, statisztikai módszerekkel támogatva, hipotézisvizsgálat segítségével. Hipotéziseimbe tehát beépítettem a kontrollrendszerek szakmai elméletére és az intézményesülés folyamatára vonatkozó, a korábbi fejezetekben már részletesen bemutatott elméleteket, valamint építek saját kiinduló modellemre (lásd: 12. ábra), annak szintjeire is. Állításaimat a kutatási kérdéseimből levezetve, a szakirodalom feldolgozására építve, logikai következtetés alapján fogalmaztam meg. Hipotéziseimet a kutatási kérdésekkel összefüggően mutatom be.

A fő kutatási kérdést kibontó részletes vizsgálati kérdéseim és hipotéziseim a következők:

\subsubsection{Befolyásoló tényezők}

K1 kutatási kérdés: Melyek a belső kontrollrendszert befolyásoló főbb tényezők a vizsgált magyar vállalkozások esetében, és ezek az adottságok mennyiben meghatározóak a belső kontrollrendszer intézményesülésének folyamatában?

H1 szakmai hipotézis: A hazai vállalkozások belső kontrollrendszerét sorrendben leginkább (1) a vállalat tulajdonosi körének elvárásai, (2) a foglalkoztatottak száma és (3) a jogi környezet befolyásolja.

A hipotézis összetettségére tekintettel annak részekre bontása szükségszerü, melyet a következők szerint teszek meg:

- (1): A hazai vállalkozások belső kontrollrendszerét leginkább a tulajdonosi kör elvárása mint a szervezetre jellemző külső adottság befolyásolja.

- (2): A hazai vállalkozások belső kontrollrendszerét második helyen a vállalati foglalkoztatottak létszáma mint a szervezet belső adottsága befolyásolja.

- (3): A hazai vállalkozások belső kontrollrendszerét harmadik helyen a vállalatra vonatkozó jogi előírások, illetve szabályozási környezet befolyásolja, mint a szervezetre ható külső befolyásoló tényező. 
Magyarázat a hipotézis elfogadhatóságára vonatkozóan: A hipotézis mögött a vállalatok külső és belső adottságait vizsgáló, leíró elméletek állnak (Dobák \& Antal, 2013., pp.41-61.), valamint alapul vettem a cosO-keretrendszer kontrollkörnyezetre vonatkozó állításait, az ott szereplő felsorolásokat és példákat (COSO, 2013a., p.Ch.5.), valamint Arwinge művének e témájú részét (Arwinge, 2013., pp.94-106.). Az intézményesülés egyik kulcskérdése, hogy melyek annak kiváltó okai, befolyásoló tényezői, hatást kifejtő motorjai. Másrészt a belső kontrollrendszerrel szemben különféle vállalaton belüli (belső) és a környezetből érkező (külső) elvárások, követelmények fogalmazódnak meg, melyekre a vállalatok különféleképpen reagálnak. Ezért a befolyásoló tényezők feltárását és az azok közötti fontossági sorrendet mindenképpen fontos vizsgálati pontnak tekintem.

A H1 hipotézis elfogadható, ha a (1), (2), (3) részhipotézisek közül mindegyik különkülön is elfogadható. Az (1), (2), (3) részhipotézisek önmagukban elfogadható vagy elvethető állítások.

\subsubsection{Kulcsszereplök}

K2 Kutatási kérdés: Kik a kulcsszereplői a belső kontrollrendszer múködésének? Melyek a legelterjedtebb munkakörök? Mely aktorok válnak az intézményesült kontrollrendszer múködtetőivé a mindennapokban?

H2 szakmai hipotézis: A hazai vállalkozások belső kontrolltevékenységeit tipikusan a következő munkakörben foglalkoztatott dolgozók végzik, mégpedig a következő gyakorisági sorrend szerint:

- $\quad$ H21: leggyakrabban bármilyen vezető szerepet betöltő személyek;

- H22: másodsorban a minőségirányítási rendszer auditorai;

- H23: harmadsorban a vállalati kontrollerek;

- H24: negyedsorban a függetlenített belső ellenőrök;

- H25: ötödsorban a felügyelőbizottság bármely tagja;

- H26: hatodsorban egyéb, nem a fenti munkakörökben foglalkoztatott személyek.

Magyarázat a hipotézis elfogadhatóságára vonatkozóan: A hipotézis megfogalmazásánál nagyban építettem a COSO keretrendszerben leírt felelősségi körökre (COSO, 2013a., p.Ch.B.), alapul vettem a védelmi vonalak 3 tényezős modelljében (IIA, 2013b), (COSO, 2015) szereplő konkrét munkaköröket, valamint a belső kontrollrendszer intézményesülésének kulcsszereplőiről szóló saját gyújtésemet a 1. táblázat szerint, valamint a Függelék - A kontrollrendszerek szereplői, múködtetői a vállalatokban című függelékben felsorolt konkrét szereplőket. A hipotézis megfogalmazásánál - mögöttes elvárásként - feltételezem, hogy az egyes munkakörök tipizált, szokásos pozíciók az egyes szervezeteken belül, 
azok tartalma, operatív tevékenységeik jórészt azonosak a vállalatokon belül. Másrészt feltételezem a pozíciókról, hogy azok ténylegesen részt is vesznek a különféle kontrollok gyakorlásában a vállalatokon belül, azaz ha léteznek, akkor végeznek is érdemi kontrolltevékenységeket.

A H21-H26 hipotézisekben megadott sorrend gyakoriságot jelez, rangsorrendként is értelmezhető, azaz az egyes szereplők ilyen sorrendben, ilyen gyakorisággal veszik ki részüket a kontrolltevékenységek múködtetéséből. A sorrend felállításához saját korábbi, a hazai versenyképesség-kutatás kapcsán mért gyakorisági jellemzőket vettem alapul (Milicz, 2011., pp.28-34.). A H2 hipotézis elfogadható, ha a H21-H26 hipotézisek közül mindegyik külön-külön is elfogadható. A H21-H26 hipotézisek önmagukban elfogadhatók vagy elvethetők.

\subsubsection{Kontrolltevékenységek}

K3 Kutatási kérdés: Mely kontrolltevékenységek gyakoriak, melyek az elterjedt kontrollmechanizmusok, illetve -módszerek a hazai vállalkozásoknál? Mennyire személyfüggőek és mennyiben automatizáltak ezek?

H3 szakmai hipotézis: A hazai vállalkozások által alkalmazott kontrolltevékenységek típusai közül az alábbiak a leginkább elterjedtek:

- H31: a vezetők által végzett kontrolloknak legalább háromnegyedét alkalmazzák;

- H32: a folyamatba épített kontrolloknak több mint felét alkalmazzák;

- H33: a fizikai kontrolloknak kevesebb mint felét működtetik;

- H34: automatikus kontrollokat legfeljebb az esetek egynegyedénél múködtetnek;

Magyarázat a hipotézis elfogadhatóságára vonatkozóan: A kontrolltevékenységek összeállításánál a jelen disszertációm Függelék - A kontrollrendszerek szereplői, múködtetői a vállalatokban címú függelékére építettem, valamint felhasználtam a disszertációm II. és III. részében hivatkozott, ott részletesen bemutatott kontrolltevékenységeket. Mindezeket összevetettem még a COSO-keretrendszer kontrolltevékenységekre vonatkozó fejezetével (COSO, 2013a., p.Ch.7.) és a COSOnak a kis- és középvállalkozások számára készült ajánlásával is (COSO, 2006., pp.5574.). Ennek megfelelően a felsorolásokban egyformán szerepelnek detektív (utólagos-feltáró) és preventív (előzetes-megelőző) kontrollok, illetve manuális (emberi közremúködéssel létrejövő) és automatikus (magától megvalósuló) kontrolltevékenységek is helyet kaptak. A fenti szakirodalmi ajánlásokból levezetve soroltam be az egyes kontrolltevékenységeket a fenti 4 kategóriába.

A gyakoriságok megállapításában saját korábbi, a hazai versenyképesség-kutatás kapcsán mért gyakorisági jellemzőket vettem alapul (Milicz, 2011., pp.28-43.), 
valamint felhasználtam a Deloitte Zrt. 2013. évi, belső ellenőrzés és compliance tárgyú felmérésének adatait (Deloitte, 2013.).

A H3 hipotézis önmagában technikai jellegű gyűjtő hipotézis, ezért nem vizsgálható az állítás statisztikai úton, csak az alhipotézisek megfogalmazását segíti. A H31-H35 hipotézisek közül mindegyik külön-külön is vizsgálható és elfogadható vagy elvethető. A hipotézisek egymást nem kizáró kontrollokat feltételeznek, azaz egy vállalkozásban többféle kontrolltevékenységet is végezhetnek.

A hipotézis kapcsán azzal a feltételezéssel élek, hogy amit létezőnek jelölnek a válaszadók, azt alkalmazzák, tehát az valóban múködik is a vállalkozásban, de nem teszek különbséget a működés minőségében, azaz hogy kicsit, közepesen vagy nagyon múködik-e. Illetve feltételezem, hogy minél elterjedtebb egy kontrolltevékenység, annál többen jelölik meg létezőnek, elvégzett tevékenységnek azt. Ezért az elterjedtséget minden esetben az alkalmazásra, múködésre adott pozitív válasz alapján minősítem majd.

\subsubsection{Az intézményesülés szintjei, érettsége}

K4 Kutatási kérdés: Hogyan írhatók le objektív tényezőkkel a belső kontrollrendszerek intézményesülésének érettsége és fejlettségi szintjei a hazai vállalkozások esetében?

H4 szakmai hipotézis: 7 fokozatú Likert-skálát alkalmazva a vizsgált hazai vállalkozások legalább $80 \%$-ára igaz, hogy a saját belső kontrollrendszerükre vonatkozó egyedi érettséggel való egyetértés szórásmutatója a 0,8289-os értéket nem haladja meg, és ennek alapján kontrollrendszerük érettsége homogénnek tekinthető.

Magyarázat a hipotézis számítására és a benne szereplő számadatok eredetére vonatkozóan: A kérdőív kitöltésekor a válaszadók a vállalatuk kontrollrendszerére vonatkozóan találnak 49 darab állítást, melyek összességében a kontrollrendszerük fejlettségét, érettségét fejezik ki. Az egyedi érettségi szint fejlettségét a válaszadók 7 fokozatú Likert-skálán értékelik a kérdőívben szereplő kérdésekre adott válaszaik révén. Összesen legfeljebb 49 darab ilyen kérdésre adnak tehát 1-7 közötti választ saját vállalatukra vonatkozóan. A skála ordinális, az intézményesülés fejlettségére vonatkozó állítással való egyetértést fejez ki, ahol a 7-es érték fejezi ki a maximális egyetértést, míg az 1-es jelenti az állítás teljes elutasítását. 
49 darab állításra adott válasz átlaga ${ }^{86}$ fejezi $\mathrm{ki}$ a kitöltő vállalat kontrollrendszerének átlagos intézményesültségi szintjét, míg a szórása kifejezi azt, hogy ettől az átlagtól a 49 kérdésre adott válaszérték átlagosan mennyivel tér el. $A z$ átlag és a szórásmutató jellemzői a következők lehetnek:

- Az átlagérték 1-7 között lehet. Az alsó értéket $(1,00)$ akkor veszi fel a mutató, ha a kitöltő minden fejlettségre, intézményesültségre vonatkozó állítást teljesen elutasít. Ezzel szemben a felső értéket $(7,00)$ akkor éri el a mutató, ha mind a 49 esetben a válaszadó maximálisan egyetért az állítással.

- A szórás értéke 0,00-3,03 között lehet. A szórás értéke akkor 0,00, ha a kitöltő mind a 49 kérdésre azonos választ ad, amely a 7 fokozat bármelyike lehet, hiszen a szórás nem az értéket, hanem az attól való eltérések átlagát fejezi ki. A maximális 3,03 értéket pedig akkor veszi fel a mutató, ha a 49 kérdésre szélsőségesen kétféle választ ad a kitöltő és ezek a lehető legtávolabb vannak egymástól, azaz 24-24 darab 1-es és 7-es választ, valamint a 49. kérdésre vagy 1-et, vagy 7 -et ${ }^{87}$. Ebben az esetben a válaszok a két pólusnál, az 1-es (teljes elutasítás) és a 7-es (teljes egyetértés) értéknél csúcsosodnak ki, az bipolárisak.

Amennyiben a 49 állításra a kitöltő nagyjából homogén válaszokat ad, akkor azt lehet mondani, hogy a kontrollrendszerének intézményesültségi szintje az átlagmutatóval jól jellemezhető, és a szórás mutatójával meg tudjuk erősíteni, hogy ez az érték stabil, a 49 esetből egyetlen esetben sem történt kiugró, a többi saját választól eltérő válasz. Nagyjából homogén válasznak tekintem az $\mathrm{n} \pm 1$-es sávban adott válaszokat, ahol $n$ értéke 1 és 7 közötti diszkrét értéket vehet fel, azaz ha csupa 1-3, 2-4,... vagy 5-7 közötti válaszokat ad a kitöltő. Ebben az esetben a 49 állításra adott válaszok szórásának maximuma 0,8289 lehet, függetlenül azok átlagértékétől. Amennyiben a szórás értéke magasabb 0,8289-nál, az arra utal, hogy a 49 állítással való egyetértés során a válaszok nem tekinthetők homogének, van köztük kiugró, kirívó válasz is. Másképpen leírva: a „nagyjából homogén” esetben a 49 állítással való egyetértésre adott válaszok ténylegesen mért szórásértéke legfeljebb a maximális szórásérték 27,36\%-a ${ }^{88}$ lehet.

\footnotetext{
86 Likert skálán átlagot számítani elviekben csak akkor szabad, ha a fokozatok között távolság azonossságát garantálni lehet. Adatfelvételi kérdőivemben ezt a fokozatosságot a 7 lépcsővel kívántam biztosítani.

87 Megjegyzem, hogy a 3,00-ás szórás elméleti érték, és akkor érhető el, ha a 49. kérdésre a válaszadó 3,5-ös középértéket adna meg. Matematikai képlet alkalmazásával ez az eredmény adódik. Mivel azonban a kérdőívben szereplő fokozatok diszkrétek, és az utolsó kérdésre adott szélsőséges válasz akár 1 vagy pedig 7 is lehet, ebből kifolyólag a maximális szórás értéke a gyakorlatban 3,03 lehet, az ehhez tartozó átlag várható értéke pedig az elméleti 4,00 helyett 3,94 vagy pedig 4,06.

88 Számítás módja: az ebben a kategóriában maximálisnak definiált 0,8289-as szórásérték (ami a homogenitás határát jelöli) / 3,03 maximálisan lehetséges szórásérték hányadosából adódik a 0,27356-os mérték.
} 
A hipotézisben szereplő $80 \%$-os arány szubjektíven választott arányszám. Azt feltételezem ugyanis, hogy a mintában szereplő válaszadók nagy részének, azaz legalább 4/5-ének az intézményesülési fejlettségi mutatója - a fent részletezett módszert figyelembe véve - homogénnek tekinthető. Ha a $80 \%$-os kritérium teljesül, a hipotézis elfogadható, ha nem, akkor a $\mathrm{H} 4$ hipotézist el kell vetni. Ha a hipotézis elfogadható, az azt is jelenti egyben, hogy az intézményesülés mértéke a fent leírt algoritmussal és kritériumokkal leírható, matematikailag is kifejezhető, objektíven számítható és a kitöltők esetében jellemzésre, ill. összevetésre ad lehetőséget. Ha a hipotézis teljesül, az alapján a válaszadó vállalat egyértelmúen besorolható a 12. ábran bemutatott érettségi modell öt, hierarchikusan egymásra épülő intézményesülési szintjének valamelyikébe.

Magyarázat a hipotézis elfogadhatóságára vonatkozóan: A hipotézis megállapításánál felhasználtam a 4.10 A belső kontrollrendszer intézményesülési szintjei - saját modell címú alfejezetemet, hangsúlyosan az ott szereplő 12. ábra szerinti kiinduló modellt.

A homogenitásra vonatkozó $80 \%$-os bizonyosság azt jelenti, hogy a válaszadók kb. 20\%-a fog az elfogadási tartományon kívülre esni saját válaszai alapján, azaz a szórás mértéke esetükben a 0,8289-es értéket meghaladja. Feltételezhetően van ugyanis olyan vállalat, amelynél kaotikus a kontrollrendszere különféle elemeinek érettsége, a rendszer maga nem tekinthető integráltnak, van, amiben kiugróan jó, és van, amiben kifejezetten gyenge. Az ilyen kontrollrendszer jellemzői a rájuk vonatkozó kérdések alapján nagy szórást mutatnak, azaz a rendszer egésze nagy bizonyossággal nem sorolható be egyértelműen az 5 érettségi szint egyikébe sem.

A fenti kutatási kérdéseket sematizálja, összefüggéseit szemlélteti a 13. ábra, mely a fent bemutatott hipotéziseket $H$ betűvel, sorrend szerint jelöli. A H1, H2, H3, H4 tématerületek hipotézisei egy-egy különálló vizsgálati területet fednek le, ugyanakkor nem tekinthetők függetlennek egymástól, köztük sztochasztikus összefüggések, áthatások vannak. 


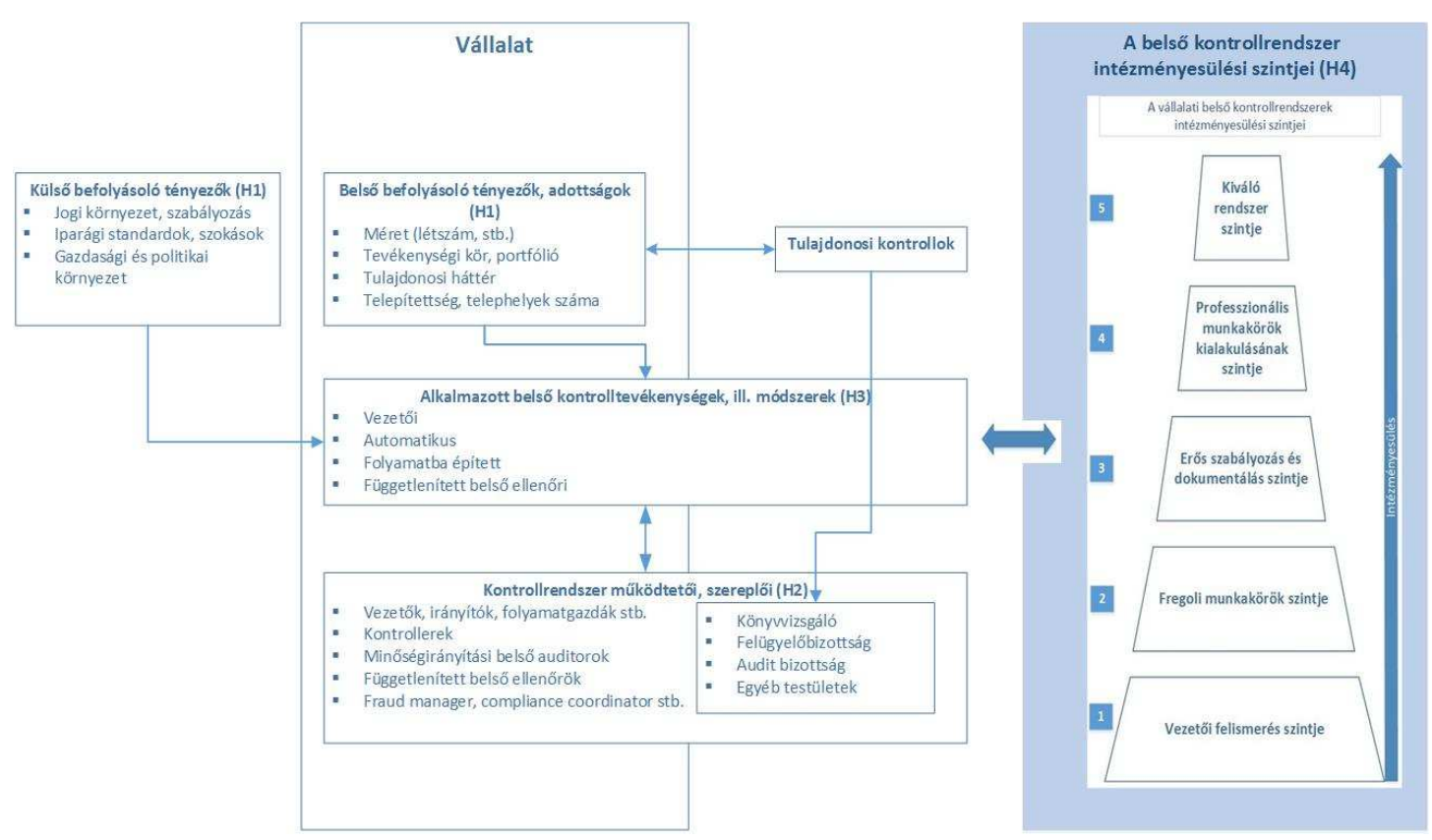

13. ábra: Kutatási térképem a hipotézisek feltüntetésével

Forrás: saját összeállitás

\subsection{Adatgyűjtés, mintavétel}

Az adatfelvétel célja a mintába került vállalkozásoktól információk, adatok begyújtése a belső kontrollrendszerük múködését illetően. A kapott adatok alapján vontam le következtetéseket a hipotézisekben rögzített állítások helyességére vonatkozóan.

Kutatásomban az adatok felvételét zárt kérdéseket tartalmazó, önkitöltő kérdőívvel valósítottam meg. A mérés a kérdőívben szereplő kérdésekre adott válaszok alapján történt, ordinális (7 fokú Likert-skálával), illetve intervallum- és arányskála segítségével (sorba rendezés, numerikus érték megadása alapján).

Ebben az alfejezetben az adatgyújtés részletes módszerét, általam alkalmazott módját mutatom be a szakirodalmi elvárásoknak megfelelően (Ghauri \& Gronhaug, 2011., pp.81-119.), (Babbie, 2001., pp.129-133.), (Majoros, 2004., pp.29-34.). Kutatásom mintavételi módszertanát és korlátait is jelen alfejezetben ismertetem. Egyúttal itt rögzítem a mintaépítés elveit is, melynek során a következő szempontokat vettem figyelembe:

- elméleti sokaság, a populáció, azaz a regisztrált társas vállalkozások meghatározása;

- maximálisan elérhető sokaság definiálása a választott elektronikus kérdőív módszerének figyelembevételével;

- mintavételi elvek rögzítése, mintavételi módszertan bemutatása;

- a címlista összeállítása, tisztítások szükségessége, részleges szűrések alkalmazása; 
- $\quad$ reprezentativitás és a megbízhatósági kritériumok figyelembe vétele.

\subsubsection{A vizsgálati populáció lehatárolása, bemutatása}

Saját kutatásomban a vizsgált populáció főbb jellemzői és lehatárolása a következők voltak:

- földrajzi terület alapján: csak Magyarországon székhellyel rendelkező, Magyarországon bejegyzett, magyar adóhatóság által kiállított adószámmal rendelkező társas vállalkozásokat vizsgáltam. Tehát más országokban bejegyzett szervezeteket (beleértve a külföldi vállalkozások belföldi fióktelepeit és az offshore bejegyzésű társaságokat) nem vontam be a vizsgálódásba, és nem vizsgáltam a külföldön bejegyzett, de Magyarországon is szolgáltatását végző, ám hazánkban székhellyel nem rendelkező szervezeteket.

- szervezeti forma alapján: csak Magyarországon bejegyzett, a GFO'14 $4^{89}$ nomenklatúra alapján jogi személyiségű társas vállalkozásokat vizsgáltam, tehát nem kerültek megszólításra a civil szervezetek (alapítványok, egyesületek, szövetségek stb.), sem az államháztartási törvény alá tartozó költségvetési szervek (államigazgatási szervek, központi költségvetési szervek, önkormányzatok, minisztériumok, alapok stb.). Vizsgáltam azonban az állami vagy önkormányzati tulajdonban lévő gazdasági társaságokat (mivel azok gazdasági társasági formában múködnek) és a nonprofit gazdasági társaságokat is. A szervezeti formából következően nem elemeztem az egyéni vállalkozókat, az őstermelőket és az egyéni cégeket, annak ellenére, hogy akár kiterjedt szervezeti struktúrával is rendelkezhetnek. Ennek oka, hogy csak a PTK alá tartozó társas vállalkozásoknál értelmezhető szervezeti struktúrát, illetve az ehhez kapcsolódó hatásköri rendszerben kialakuló belső kontrollrendszert kívánom elemezni, másrészről az egyéni vállalkozók címjegyzékszerű megszólítása sokkal nehézkesebb, mint a cégbíróságon vezetett társas vállalkozásoké. Az olyan egyszerű és egyszavas kifejezések, mint a cég, az üzleti szervezet, a vállalat ill. a vállalkozás elnevezések nem a GFO által használt konkrét kategóriák, hanem a gazdasági szaknyelvben használt egyéb gyűjtőkifejezések, ezért disszertációmban ezeket a jogi személyiségű társas vállalkozás szinonimájaként használom.

\footnotetext{
${ }^{89}$ A GFO'14 a Gazdasági Szervezetek Regiszteréhez használt KSH osztályozás hazánkban. A gazdasági szervezetek gazdálkodási forma szerinti osztályozása tartalmazza a vállalkozás, költségvetési és nonprofit formában müködő egységeket a rájuk vonatkozó jogszabályokkal együtt. Lásd bővebben:

http://www.ksh.hu/docs/osztalyozasok/gfo/gfo_rovid_leiras.pdf (letöltve: 2016. 03. 12.)
} 
- méret alapján: vizsgálatom a társas vállalkozások közül azokra koncentrált, amelyeknél - legalább minimális mértékben - lehetséges a belső kontrollrendszereket vizsgálni, elemzés tárgyává tenni. Ezért a kontrollrendszerek tanulmányozásába a kisebb méretű, egyszerúbb üzleti szervezeteket is érdemesnek láttam bevonni a nagyok mellett. Alsó peremként a mikrovállalkozásokra vonatkozó Európai Uniós ajánlás (2003/361/EC - Commission Recommendation of 6 May 2003 concerning the definition of micro, small and medium-sized enterprises (Text with EEA relevance) (notified under document number C(2003) 1422) Article 2.) és az ezzel összhangban lévő magyar szabályozás szerinti határértékeket fogadtam el. A kis- és középvállalkozásokról, fejlődésük támogatásáról szóló 2004. évi XXXIV. törvény $3 . \S(3)$ bekezdése alapján a maximum 9 fő foglalkoztatotti létszámú és a 2 millió eurónak megfelelő forintösszeget el nem érő éves nettó árbevételű vagy mérlegfőösszegű vállalkozások tekinthetők mikrovállalkozásnak. Tehát a mikrovállalkozásokat nem vontam be a felmérésembe, de ez ennél magasabb kategóriába eső vállalkozásokat (azaz a kis- és középvállalkozásokat, valamint a nagyvállalatokat) már igen.

- tevékenységi kör alapján: vizsgálatomat valamennyi tevékenységet végző szervezetre elvégeztem, az elemzésnél a vállalkozások cégjegyzékben feltüntetett, TEÁOR'08 ${ }^{90}$ besorolás szerinti főtevékenységét vettem alapul. Ezek közül senkit, illetve semmilyen tevékenységi kört nem zártam ki, illetve nem emeltem ki a vizsgálódásom során.

- múködési státusz alapján: csak a regisztrált és múködő gazdasági szervezetek kerültek vizsgálatom fókuszába, azaz nem vizsgáltam a felszámolás és a végelszámolás alatt lévő társaságokat és a már megszűnt társaságokat sem.

Az adatfelvétel előkészítését a 2016. január-május közötti időszakban végeztem. A KSH honlapján publikált STATINFO V39 adatbázis szerint ${ }^{91}$ a Magyarországon regisztrált gazdasági szervezetek száma 2015. december 31-én mindösszesen 1837704 db volt, ebből társas vállalkozásként 560853 db működött. Ezen belül a formakényszerből eredő négyféle társas vállalkozás (kkt., bt., kft., rt.), valamint a

\footnotetext{
90 A TEÁOR'08 a gazdasági tevékenységek egységes ágazati osztályozási rendszere, amely az EU tevékenységi osztályozásának, a NACE Rev.2-nek magyar nyelvű változata. Az 1893/2006/EK rendelet alapján hazánkban 2008. január 1-jétől a TEÁOR'08-at alkalmazzuk a gazdasági egységek főtevékenységének meghatározására, a gazdasági és társadalmi mutatók számításánál, valamint a statisztikai adatok publikálásánál. Lásd bővebben: http://www.ksh.hu/docs/osztalyozasok/teaor/teaor_rovid_leiras.pdf (letöltve: 2016. 03. 12.)

91 Forrás: A regisztrált gazdasági szervezetek száma, honlap: http://statinfo.ksh.hu/Statinfo/haViewer.jsp. Az adatok 2015. december 31-re vonatkoznak. Letöltés dátuma: 2016. 08. 30.
} 
szövetkezetek száma mindösszesen 552932 volt, amely az összes regisztrált és múködő társas vállalkozás 98,59 \%-át' ${ }^{92}$ teszi ki. Ezen belül potenciálisan KKV-, ill. nagyvállalati besorolásba tartozik - mérete alapján - 33434 darab szervezet, mivel ezeknél a foglalkoztatotti létszám elérte a 10 főt.

\begin{tabular}{|c|c|}
\hline & Időszak \\
\hline Gazdálkodási formák 2015-töl & 2015. év \\
\hline Mindösszesen Gazdálkodási formák 2015-töl & 1837704 \\
\hline - ebböl önálló vállalkozó & 1130025 \\
\hline - ebböl társas vállalkozás & 560853 \\
\hline - ebböl költségvetési szervek és költségvetési rend szerint gazdálkodó szervek & 12757 \\
\hline - ebböl nonprofit és egyéb nem nyereségérdekelt szervezet & 128271 \\
\hline - ebből egyéb gazdasági szervezet & 5798 \\
\hline
\end{tabular}

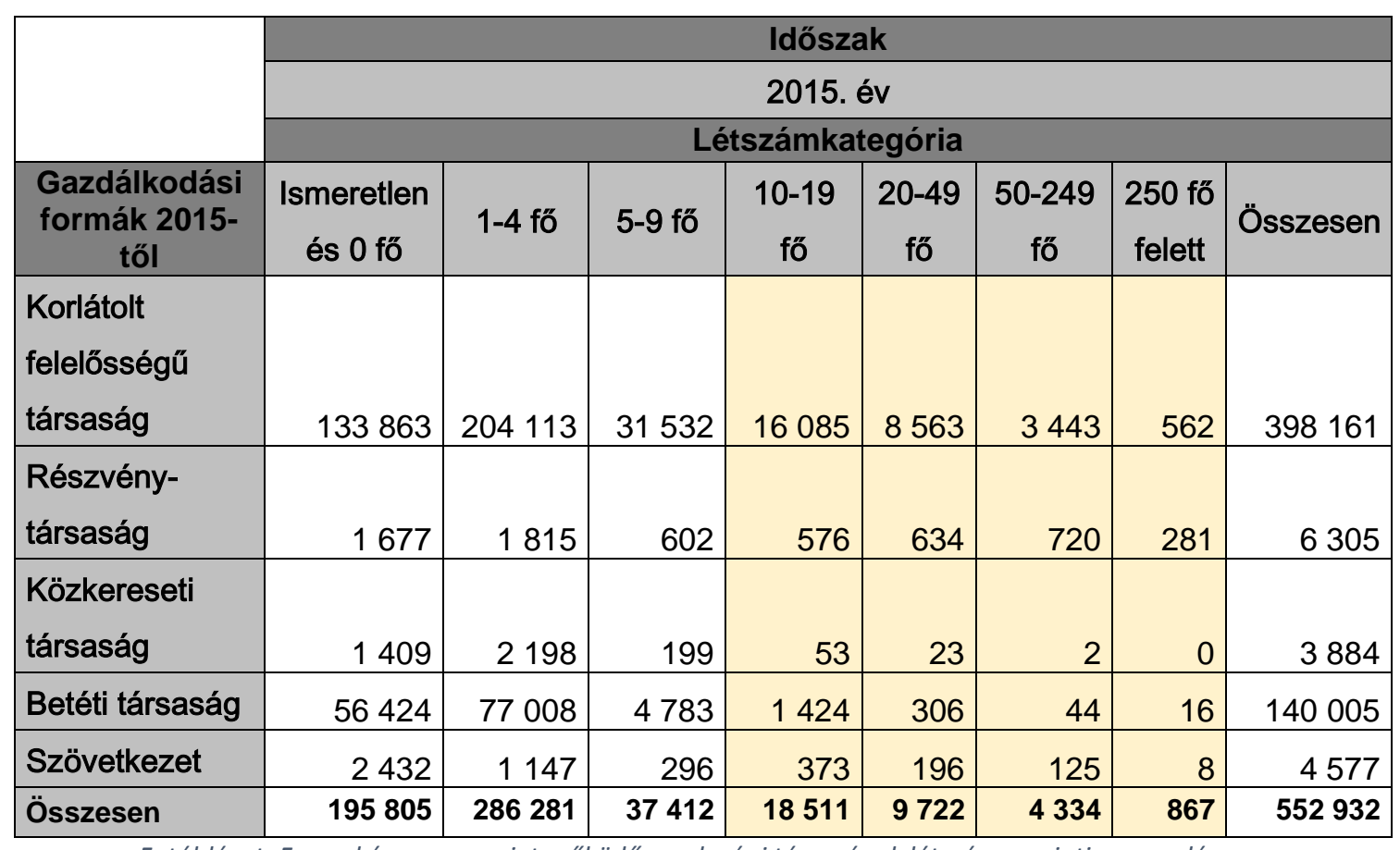

5. táblázat: Formakényszer szerint múködó gazdasági társaságok létszám szerinti megoszlása Forrás: KSH STATINFO - http://statinfo.ksh.hu/Statinfo/haViewer.jsp (2016. 08. 30), saját szerkesztés

A fent ismertetett szűkítések figyelembevételével (székhely, szervezeti forma, méret stb.), az 5. táblázat alapján vizsgálatom alapsokaságának elvi elemszáma $33434 \mathrm{db}$ szervezet, amelyek tételes listáját, közhiteles jegyzékét a területileg illetékes cégbíróságok vezették, és amely jegyzék nyilvános, hozzáférhető és megvásárolható

92552932 cég / összesen 560853 darab társas vállalkozás hányadosából adódik a 98,59 \%-0s arányszám. 
volt bárki számára. A vizsgálati populáció teljes listája a kutatás megkezdésekor tehát létezett és elérhető volt.

\subsubsection{A mintavétel elvei, módszere, megbízhatósági kritériumai}

A mintavételbe azok a regisztrált társas vállalkozások kerültek bele, amelyek megfeleltek a fenti szűkítési kritériumoknak. További szűrési szempont volt, hogy a cégnyilvántartásban rendelkeznek-e hivatalos e-mail címme ${ }^{93}$ elérhetőség gyanánt vagy ez egyéb módon beszerezhető legyen (például honlapjukról, szóróanyagaikból). Az e-mail cím léte azért volt fontos, mert a megkérdezett szervezetek online módon töltötték ki a kérdőívet, ezért aki nem adott meg e-mail címet, annak megszólítása lehetetlen volt elektronikus úton.

A címlista összeállítását a fenti szúkítési kritériumok alapján a Wolters Kluwer Kft. Céginformációs Üzletága végezte el számomra 2016. január 06-án. A cégadatok lekérdezése során az akkor érvényes, 2014 évre vonatkozóan közzétett (legfrissebb) adatok alapján történt a mintavételi adatbázis összeállítása. Ennek eredményeképpen a Kft-től egy nyers, 36024 cég bevallási adataiból álló adatbázist kaptam kézhez. A nyers adatbázisból a fenti szűrési feltételek érvényesítését követően egy 32271 gazdálkodó szervezetből álló, szűrt címlistát állítottam össze, mely a későbbi online megkeresések kiinduló listája volt. Ez a gyakorlati mintaelemszám a fent említett elemi populációnak a 96,52 \%-át ${ }^{94}$ fedi le.

Sajnos a címlistából már első áttekintésre kitúnt, hogy 7272 darab cégnek nincs egyetlen bejegyzett e-mail címe sem az adatbázisban, így ők a további kutatási adatfelvételből eleve kimaradtak, és számosságuk olyan magas, hogy ezt kézzel, emberi erővel pótolni lehetetlen. Az első kiküldött e-mailes megkereséskor pedig kiderült az is, hogy a fennmaradó mintegy 25 ezer e-mail címből további 772 darab e-mail cím bizonyult hibásnak, nem létezőnek, amelyen keresztül a címzett cégek megszólítása nem volt lehetséges. Mindösszesen tehát 24227 darab potenciális, elérhető szervezet került megszólításra elektronikus úton.

A kielégítő minimális kérdőív-darabszám meghatározásához az alább kifejtett matematikai elveket vettem figyelembe. A reprezentativitásra törekvés érdekében alapul vettem a minta nagyságára vonatkozó elméleti iránymutatásokat és szakirodalmakat (Babbie, 2001., pp.212-226.), (Hunyadi \& Vita, 2006., pp.254-310.), (Sajtos \& Mitev, 2007., pp.33-37.), (Falus \& Ollé, 2008., pp.31-34.), valamint

\footnotetext{
${ }^{93}$ Ezen adat feltüntetése a cégjegyzékben 2014. március 15. óta kötelező a Ctv. 24 . § (1) bekezdés $m$ ) pontja alapján.

9432271 cég / 33434 cég hányadosából adódik a 96,52 \%-os lefedettség.
} 
kifejezetten építettem a Kehl és társa cikkében közölt, a Likert-skálák alkalmazása során szükséges minimális elemszámok meghatározására vonatkozó iránymutatásokra (Kehl \& Rappai, 2006.). E szakcikk 10. számú táblázatában közölt egyenletesen növekvő, illetve egyenletesen csökkenő valószínűségeket fogadtam el, mivel azok jobban fedik a téma szempontjából a várható eloszlást. Ennek alapján 5\%-os hibahatárt és 95,5\%-os megbízhatóságot feltételezve, 7 fokozatú skálát alkalmazva legalább 4800 darabból ${ }^{95}$ álló mintára lett volna szükség (Kehl \& Rappai, 2006., p.867.) kutatásom során.

\subsection{Az adatgyűjtés folyamata és eredménye}

\subsubsection{Kérdőíves adatgyüjtés}

Az adatgyűjtés online, elektronikus önkitöltő kérdőív segítségével zajlott, mely a saját fejlesztésű https://coso.hu/ portálon keresztül történt. A portál adminisztrációs felületén magam végeztem a kérdőív specifikálását, azaz a kérdések és a lehetséges válaszok előzetes meghatározását, valamint az adminisztrációs felületen történt a címlista feltöltése, a kísérőlevél megszövegezése és innen történt a válaszok exportálása is nyers, pontosvesszővel tagolt CSV file-ba.

Az alkalmazott kérdőív csak zárt kérdéseket tartalmazott (lásd: F51 Alkalmazott adatgyújtő kérdőív címú függelék), a változók numerikus számadatok értékeit vagy 7 fokú Likert-skálás, illetve sorba állításból eredő értékeket tartalmazhatnak (Babbie, 2001., pp.273-314.), (Majoros, 2004., pp.85-100.).

A kitöltést személyre szóló felkérő levél alapozta meg, melyet a cég első számú vezetője e-mailen kapott meg, a levélben szerepelt az a titkos kód (token), melyre kattintva a kérdőív kitöltését a címzett meg tudta kezdeni, és amely kód számomra a kitöltés nyomon követését biztosította. A kitöltést technikai útmutató segítette, ill. az egyes kérdésekhez magyarázó szövegbuborékok (tooltip) társultak, ezzel is segítve a válaszadók munkáját.

A kérdőív címzettje az első számú vezető volt, illetve azon munkatársa, akitől a belső kontrollrendszerre vonatkozó szakszerű válaszok leginkább elvárhatóak voltak. Tipikusan ilyen kompetens személy lehetett az ellenőrzési igazgató, a függetlenített belső ellenőr, a pénzügyi vezető, a compliance manager, a kontroller, végső esetben a cég választott könyvvizsgálója. Feltételezésem szerint ők a munkakörükből adódóan már ismeretekkel és saját tapasztalatokkal kellett, hogy rendelkezzenek a vállalatuk belső kontrollrendszeréről.

\footnotetext{
${ }^{95} n=400 \times\left[\frac{2}{9} x(7-1) x(7+2)\right]$ képletből adódik a min. 4800 darabos mintaelemszámra vonatkozó
} követelmény (Kehl \& Rappai, 2006., p.867.). 
A kérdőív kitöltése önkéntes, de nem anonim volt, mivel a kitöltő vállalkozást a cégük adószáma egyértelmúen azonosította. Ez azt jelentette, hogy a kapott válaszokat a kitöltők cégnévvel felvállalva adták meg részemre, és erre a kitöltést végzőket előre figyelmeztette a program.

A kitöltésre felkérő levelek 2016. 06. 06-án kerültek kiküldésre, a kitöltéshez rendelkezésre álló idő mindösszesen 55 nap volt, mivel a kitöltésre 2016. 07. 31-i befejezési határidőt tűztem ki célul. A lejárati határidő előtt a survey alkalmazás emlékeztető e-mailt küldött a címzetteknek, melyben újra felhívta a figyelmet a korábbi megkeresés tényére, kérve a címzett segítségét a kérdőív kitöltésében. $A$ kitöltésre ráerősítettek júniusi hírlevelükben a BEMSZ, az MCE, az MMT szakmai egyesületek is, valamint fizetett felhívás formájában a portálra mutatott egy google adwords hirdetés ${ }^{96}$ is. $A z$ utolsó válaszadó a kérdőívét 2016. 07. 27-én véglegesítette.

A válaszokat az online survey rendszer folyamatosan gyújtötte be és tárolta el MS SQL adatbázisban (az adatbázis szerkezetet, táblák sematikus ábráját lásd: F52 Adatgyűjtő alkalmazás adatbázisstruktúrája című függelékben). Az adatbázisból exportálással kinyert, majd tisztított adatokat az IBM SPSS Statistics 22.0 verziójában ${ }^{97}$ további részletes elemzésnek vetettem alá. Ennek segítségével készültek el az alábbi többváltozós matematikai-statisztikai elemzések és tesztek (klaszterelemzés, faktorelemzés, komponenselemzés, korrelációs táblák stb.), valamint az ebből kinyerhető hisztogramok, screen plotok stb. (Babbie, 2001., pp.497-510.), (Sajtos \& Mitev, 2007., pp.245-328.), (Falus \& Ollé, 2008., pp.231261.), (Ghauri \& Gronhaug, 2011., pp.220-226.), (Hajdu, 2003., pp.290-445.).

\subsubsection{Válaszadási hajlandóság, reprezentativitás}

Az online módon, e-mailben kiküldött kérdőívet összesen 832 címzett nyitotta meg és kezdte el kitölteni, ami 3,43\%-os ${ }^{98}$ megnyitási aránynak felel meg. Azonban a kérdőívet mindösszesen csak 139 darab kitöltő (szervezet) véglegesítette, azaz ennyien adtak választ valamennyi feltett kérdésre. Ezek közül 5 cég tesztelés céljából, igazoltan nem valós adószámmal (dummy adatokkal) töltötte ki a

\footnotetext{
96 lásd: https://www.google.hu/aclk?sa=L\&ai=DChcSEwi5otyAnrOAhVieXIKHa4dBjYYABAA\&sig=AOD64 OUGGatz9mCTIG08C4dewi4FGoMAQ\&q=\&ved=0ahUKEwibrtmAnrOAhXGkCwKHQOmCSwQ0QwlHw\&adurl= (letöltés: 2016. 08. 31.)

97 Lásd a program magyarországi forgalmazójának leírását a programról részletesen itt: http://clementine.hu/termekek/statisztika (letöltés: 2016. 08. 31.)

98832 darab kitöltést megkezdő / 24227 darab elért, potenciális kitöltő cég hányadosából adódóan.
} 
kérdőívet, további 2 cég pedig az aktualizált alapadatai alapján mikrovállalkozásnak minősült vissza, szemben a korábbi, magasabb KKV besorolással. Ezért ezen 7 cég válaszait a teljes körúen válaszolók adataiból töröltem, így végeredményként adódott 132 olyan, teljes értékű válaszokat adó, kitöltő vállalkozás, amelyekre vonatkozóan a hipotéziseim tesztelését el lehetett végezni. Ez 0,395 \%-os ${ }^{99}$ válaszadói hajlandóságnak felel meg a teljes elméleti populációt nézve. További elemzéseimben a minta elemszáma tehát 132 darab regisztrált gazdasági társaság lesz.

Az alacsony válaszadási hajlandóság miatt sajnos az ideálisként megkívánt, fentebb megindokolt és alátámasztott, 4800 darabos mintaelemszámot nem sikerült elérni, ezért a kapott eredmények nem tekinthetők megbízhatónak 95,0\%-on, 5\%-os hibahatár mellett. Ezért azt, hogy a kitöltések alapján egy-egy álításom mennyire tekinthető megbízhatónak, illetve érvényesnek, mindig a kapott eredményeknél tüntettem fel.

Az alacsony kitöltési arány értékelésénél a következő szubjektív szempontokat, okokat azonosítottam be. Egyrészt a kitöltésre rendelkezésre álló idő egybeesett a nyári szabadságolások időszakával. Másrészről a mintavétel időszaka egybeesett az éves beszámoló készítését követő időszakkal, ill. a konszolidált éves beszámoló összeállításának tipikus időszakával. Harmadrészt 2016. június 10. és július 10. között zajlott a labdarugó Európa bajnokság. Vélelmezem, hogy mindhárom esemény elvonta a figyelmet és az erőforrásokat az én kutatási kérdőívem kitöltésétől.

Az alacsony kitöltési aránynak azonban további, tartalmi indokait is megfigyeltem kutatásom során. Több megszólított cég jelezte nekem, hogy nem kívánnak ilyen jellegű belső, bizalmas információkat megosztani egy külső, ismeretlen személlyel. További ok volt, hogy a kérdőív nem volt anonim, a válaszadók névvel, adószámmal beazonosítható módon töltötték ki a kérdőívet az online felületen, ezért vélhetően többen elutasították a válaszadást. És okként azonosítottam azt a visszajelzést is, hogy a kérdőív hosszú, ezért alapos és megfontolt kitöltéséhez legalább 30 percre volt szükség, mely a gazdasági szereplők egy jelentős részénél nem állt rendelkezésre.

Az általam elért 132 darabos mintaelemszám ennek ellenére meghaladja a Deloitte Zrt. korábban, hasonló témában végzett 2013. évi - belső ellenőrzés és compliance témájú - felmérését, ők ugyanis 70 teljesen kitöltött kérdőívet elemeztek ki (Deloitte, 2013., p.6.). Ugyancsak meghaladja a PwC 2014. évi, a globális gazdasági búnözés témájában végzett felmérésének elemszámát, mely 91 darab hazai

\footnotetext{
99132 darab teljes értékű kitöltés (minta) / 33434 darab gazdálkodó szervezet a KSH STATINFO adatbázisból.
} 
vállalkozás volt (PwC, 2014., p.17.). Az általam választott módszer ugyanakkor kevésbé volt hatékony, ugyanis a PwC és a Deloitte is saját hazai csatornán keresztül, saját ügyfélkörében, illetve a BEMSZ tagjai között végezte az adatfelvételt nagyságrendileg kisebb populáción. Ezzel szemben én országos kiterjedéssel, cégbírósági címlista alapján szólítottam meg a populációban lévő mintegy 24 ezer darab üzleti szervezetet.

Reprezentativitás szempontjából a populáció és a minta megoszlását a különféle szúkítési szempontok szerint elemeztem illeszkedésvizsgálat segítségével. Ennek során a megfelelő szabadságfokú, $\alpha=0,05$ szignifikanciaszintű $\chi^{2}$ próbát elvégezve a következő eredmények adódnak. A 132 darabból álló minta

- a gazdálkodási formák szerinti megoszlás alapján nem illeszkedik a populációhoz, azaz a minta és a populáció \%-os megoszlása nem tekinthető közel azonosnak, a részvénytársaságok túlsúlyban vannak a mintában;

- a méretre (létszámra) vonatkozó megoszlási ismérv alapján nem illeszkednek a populáció megoszlásához, mivel a nagyméretű cégek felülreprezentáltak a mintában;

- a tevékenységi kör szempontjából ugyan közelítően illeszkedik a minta a populáció belső megoszlásához, de a minta statisztikai értelemben mégsem tekinthető reprezentatívnak, mivel a tevékenységi körök nagyon sok kategóriájából a mintában egyetlen válaszadó sincsen,

- területi (megyei) megoszlása hasonlóságot mutat a populációéval, de az alacsony mintaelemszám és a túl sok megyekategória miatt statisztikai értelemben nem tekinthetjük reprezentatívnak a mintát.

A populáció és a minta elemszámait tartalmazó táblázatokat deskriptív jelleggel közlöm, a $\chi^{2}$ próbák részletes számításait és eredményeit, valamint a populáció és a minta összehasonlítását a különböző szürési kritériumoknak megfelelően ugyancsak lásd a F61 A minta illeszkedése a populációhoz, $\chi^{2}$ próbák eredményei című függelékben bemutatva.

\subsection{Hipotézisek vizsgálata}

Elöljáróban rögzítem, hogy vizsgálódásomat a 132 kitöltő által adott válaszokra vonatkozóan végeztem el, ám a válaszadók nem mindig és minden kérdésre adtak kiértékelhető választ, ezért minden esetben $\mathrm{N}$ jelöli az adott ismérvre vonatkozó, kiértékelhető válaszok darabszámát az egyes kérdéseknél.

Az alacsony mintaelemszám miatt az érvényességre vonatkozóan rögzítenem kell, hogy megállapításaim nem tekinthetők reprezentatívnak és következtetéseim nem 
általánosíthatók a 33434 vállalkozás mindegyikére. Állításaim pusztán a 132 darab kitöltő vállalkozásra korlátozódnak azzal a megjegyzéssel, hogy a szelekciós torzítás mértékét a populáció és a minta között - a szükséges adatok hiányában - nem számszerűsíthettem.

Az alább közölt táblázatokban zöld háttérszínekkel jelöltem a hipotézis szerinti várakozásnak megfelelő, azzal logikailag összeillő eredményeket és a piros különféle árnyalatai mutatják a hipotézistől eltérő értékeket, eredményeket.

\subsubsection{H1: A befolyásoló tényezők rangsorrendje}

Az első szakmai hipotézis a belső kontrollrendszerre hatást gyakorló, befolyásoló tényezőkre vonatkozott. Az alábbi 6. táblázat azt szemlélteti, hogy a válaszadók szerint a 10 különféle befolyásoló tényező milyen mértékben befolyásolja a kontrollrendszer működését a vállalkozásoknál. Egyértelműség végett a lehetséges tényezőket sorrendbe állítottam aszerint, hogy a válaszadók milyen erős (1-es) vagy gyenge (10-es) befolyásolást adtak a kitöltéskor, és ennek alapján milyen rangsorrendje alakult ki a tényezőknek.

\begin{tabular}{|c|c|c|c|c|}
\hline Befolyásoló tényezők & $\begin{array}{l}\text { Befolyás } \\
\text { mértéke }\end{array}$ & Nr. & $\mathrm{N}$ & Szórás \\
\hline Tulajdonosi kör jellege, tulajdonos(ok) elvárásai, előírásai & 4,16 & 1 & 125 & 3,166 \\
\hline $\begin{array}{l}\text { Vállalkozásra vonatkozó jogi előírások, jogszabályok, } \\
\text { külső szabályozó tényezők }\end{array}$ & 4,19 & 2 & 121 & 2,757 \\
\hline $\begin{array}{l}\text { Fötevékenység jellege, technológiája, elvégzésének } \\
\text { sajátosságai }\end{array}$ & 4,54 & 3 & 130 & 2,263 \\
\hline Első számú vezető karizmája, vezetési stílusa & 4,66 & 4 & 101 & 2,524 \\
\hline $\begin{array}{l}\text { Alaptevékenységre vonatkozó üzleti-piaci normák, } \\
\text { szabványok, szokások }\end{array}$ & 4,75 & 5 & 125 & 2,016 \\
\hline Menedzsment vezetési stílusa, döntései, határozottsága & 5,30 & 6 & 128 & 2,665 \\
\hline $\begin{array}{l}\text { Vállalaton belüli kultúra, szokások, munkatársak } \\
\text { viselkedése }\end{array}$ & 5,76 & 7 & 126 & 2,022 \\
\hline Foglalkoztatottak száma, dolgozói létszám & 6,17 & 8 & 124 & 2,396 \\
\hline Telephelyek, fióktelepek (darab)száma & 7,07 & 9 & 125 & 2,794 \\
\hline Egyéb, itt fel nem sorolt tényező(k) & 7,77 & 10 & 83 & 3,144 \\
\hline
\end{tabular}

6. táblázat: Belső kontrollrendszert befolyásoló tényezők rangsorrendje

Forrás: saját összeállitás

H1 szakmai hipotézis: A hazai vállalkozások belső kontrollrendszerét sorrendben leginkább (1) a vállalat tulajdonosi körének elvárásai, (2) a foglalkoztatottak száma és (3) a jogi környezet befolyásolja.

H1 szakmai fóhipotézis értékelése: Fentiek alapján megállapítom, hogy a hipotézist el kell vetnem, mert az általam előzetesen feltételezett sorrend csak részben azonos 
a válaszokból kirajzolódó tényleges sorrenddel. Azaz a (1) részhipotézis teljesül (vállalat tulajdonosi körének elvárásai), de a (2) és a (3) részhipotézisek nem.

A hipotézis elvetésének részletes indoklása, illetve a kapott eredmények további értékelése, elemzése a következő:

- Az előzetes várakozásaimhoz képest eltérés mutatkozik a 2. helyen (lásd (2) részhipotézist az 5.5.1.1 Befolyásoló tényezők című fejezetben), mivel nem a foglalkoztatottak száma, hanem a külső jogi környezet befolyásolja második legjobban a belső kontrollrendszert. Ebből kifolyólag a további sorrend is felborult. A 3. helyen várt befolyásoló tényező is másnak bizonyult a valóságban, mégpedig a főtevékenységre jellemző technológiai előírások, sajátosságok lett az, szemben a vállalkozásra vonatkozó külső jogi környezeti előírásokkal. Ezért a (3) alhipotézis sem teljesült.

- A ragsorrend felállítása a kapott átlagok alapján történt, de mind a 10 tényező esetében magas a szórás mértéke is, ami arra utal, hogy a válaszadók heterogén módon közelítették meg a kérdést, és a befolyásoló tényezőket nagyon különböző hatásúaknak ítélték meg saját vállalkozásukban. A szórást és az egyéb leíró statisztikákat tartalmazó részletes táblázatot a $\mathrm{F}$ 6.2.1 - H1 hipotézis című függelékben közlöm.

- A rangsor elején egyértelműen minőségi ismérvekkel jellemezhető, előíró jellegű tényezők szerepelnek (szabályozás, elvárások, követelmények), míg a mennyiségi úton jellemezhető ismérvek (létszám, telephelyek száma) a rangsor végére kerültek. A rangsor közepén a „soft”-nak tekintett ismérvek találhatók, úgymint karizma, stílus, kultúra. E felismerés alapján megállapítható az is, hogy a belső kontrollrendszerre ható tényezők közül a külső forrásból származó jogi, tulajdonosi, illetve iparági elvárások, követelmények, szabványok fejtik ki a legnagyobb befolyást, és csak ezt követik a belső befolyásoló faktorok.

- A rangsorolt elemek további vizsgálatát, összehasonlítását a Sperman-féle rangkorrelációs együtthatóval javasolja a szakirodalom megvalósítani (Hunyadi \& Vita, 2006., pp.165-166.), (Falus \& Ollé, 2008., pp.215-217.), ezért a részletes értékelések elvégzéséhez én is ezt a módszertant alkalmaztam. A Sperman-féle rangkorrelációs együttható szokásos képletét lásd a F 6.2.1 - H1 hipotézis című függelékben, a kritikus értékekre vonatkozó táblázatát pedig Falus és társa közli művük függelékében (Falus \& Ollé, 2008., p.334). A rangsorrendek vizsgálatát érdemes volt elvégezni iparági megoszlásban. Feltehető tehát a kérdés, hogy vajon minden iparágban azonos-e a tényezők rangsorrendje a fenti átlagos sorrenddel? Megállapítható, hogy többnyire igen, azaz hasonló a sorrend, ám 4 iparág (pénzügy, Információ-kommunikáció, turizmus, egyéb szolgáltatások) sorrendje eltér az átlagostól, míg a többi ágazatban tevékenykedőké 
legalább 95\%-os valószínúséggel hasonló sorrendet mutat a teljes minta szerinti sorrendhez. Az iparágak szerinti rangsorrendek táblázatát és a Sperman-féle rangkorrelációs elemzéseket a 24. táblázat: Befolyásoló tényezők rangkorrelációja iparáganként című táblázatban mutatom be részletesen.

- A befolyásoló tényezők közötti összefüggés kizárása miatt a változók egymásra hatását részletesen is meg kellett vizsgálnom. Ennek érdekében a 10 tényező közötti Sperman-féle korrelációs együtthatókat vizsgáltam meg, s megállapítottam, hogy 0,5-ös, azaz közepes összefüggést egyetlen befolyásoló tényező sem ért el - egy mutató kivételével (Egyéb tényezők és Tulajdonosi kör). A tényezők közötti korrelációs mátrixot a 23. táblázatban közlöm. Mivel a tulajdonosi kör és a vállalkozásra vonatkozó külső jogi előírások - mint befolyásoló tényezők - között pozitív igen gyenge ( $r=+0,151, p=$ nem szignifikáns) kapcsolatot találtam, e két változó között csak alacsony mértékű sztochasztikus kapcsolat van. Ennek ellenére a hipotézisem vizsgálatát kiterjesztettem a rangsorban negyedik legerősebb befolyással bíró tényezővel, amely tényezőnek az első számú vezető karizmája bizonyult. Ez a tényező a sorrendben őt megelőző tényezőkkel gyenge $(-0,207$ és $+0,102$ közötti) korrelációt mutat, ezért gyakorlatilag függetlennek tekinthető az előző háromtól ( $p=0,05$ érték mellett). Egyúttal azt is megállapítottam, hogy a H1 szakmai hipotézisemben felállított rangsorrendben ez a tényező sem szerepelt, ezért ha a vállalkozásra vonatkozó, külső jogi előírások nevű tényezőt a harmadik helyről elhagynánk, akkor rangban a negyedik helyről a következő befutó a vezető karizmája lenne, ám a (3)-as részhipotézis még ekkor sem teljesülne.

\subsubsection{H2: Kulcsszereplők, aktorok}

A második szakmai hipotézis a belső kontrollrendszert múködtető kulcsszereplőkre, azaz konkrét, operatív munkakörökre vonatkozott. Az alábbi 7. táblázat ismerteti a válaszadóknál kontrollt gyakorló pozíciókat, azok gyakorisági (előfordulási, létezési) sorrendje szerint. A csökkenő sorrend azt fejezi ki, hogy egy-egy kontrollt gyakorló pozíció a 132 válaszadó közül hány cégnél fordult elő. Az egyes pozíciókra vonatkozóan részletes elemzéseket alább, a hipotézis kiértékelésénél adok. 


\begin{tabular}{|c|c|c|c|c|c|}
\hline Nr. & Munkakör, funkció, ill. pozíció megnevezése & $\begin{array}{l}\text { Igen } \\
\text { létezik } \\
\text { (db.) }\end{array}$ & $\operatorname{Igen}(\%)$ & $\begin{array}{l}\text { Nem } \\
\text { létezik } \\
\text { (db.) }\end{array}$ & $\begin{array}{c}\text { Összesen } \\
\text { (db.) }\end{array}$ \\
\hline 1 & $\begin{array}{l}\text { Vezető (felső-, közép-, közvetlen irányítói szint } \\
\text { együtt) }\end{array}$ & 128 & $96,97 \%$ & 4 & 132 \\
\hline 2 & Könyvelő, számviteli-pénzügyi munkatárs & 108 & $81,82 \%$ & 24 & 132 \\
\hline 3 & $\begin{array}{l}\text { Informatikus, vállalatirányítási rendszergazda, } \\
\text { alkalmazás-rendszergazda, adattárház- } \\
\text { specialista }\end{array}$ & 70 & $53,03 \%$ & 62 & 132 \\
\hline 4 & ISO minőségirányítási belső auditor & 62 & $46,97 \%$ & 70 & 132 \\
\hline 5 & Controller & 49 & $37,12 \%$ & 83 & 132 \\
\hline 6 & $\begin{array}{l}\text { Egyéb kontrollokért felelős személy } \\
\text { (portaszolgálat, belső elhárítás, jogász stb.) }\end{array}$ & 49 & $37,12 \%$ & 83 & 132 \\
\hline 7 & Könyvvizsgáló & 46 & $34,85 \%$ & 86 & 132 \\
\hline 8 & Minőségellenőr, MEO & 44 & $33,33 \%$ & 88 & 132 \\
\hline 9 & Felügyelőbizottsági tag & 29 & $21,97 \%$ & 103 & 132 \\
\hline 10 & Biztonságügyi felelős & 22 & $16,67 \%$ & 110 & 132 \\
\hline 11 & Függetlenített belső ellenőr & 14 & $10,61 \%$ & 118 & 132 \\
\hline 12 & Compliance manager & 11 & $8,33 \%$ & 121 & 132 \\
\hline 13 & Kockázatkezelő & 9 & $6,82 \%$ & 123 & 132 \\
\hline 14 & Etikai koordinátor & 6 & $4,55 \%$ & 126 & 132 \\
\hline 15 & Csalásfelderítő (Fraud manager) & 5 & $3,79 \%$ & 127 & 132 \\
\hline
\end{tabular}

7. táblázat: Belső kontrollrendszer kulcsszereplói, pozíciói Forrás: saját összeállitás

H2 szakmai hipotézis: A hazai vállalkozások belső kontrolltevékenységeit tipikusan a következő munkakörben foglalkoztatott dolgozók végzik, és a következő gyakorisági sorrend szerint:

- $\quad$ H21: leggyakrabban bármilyen vezetői szerepet betöltő személyek;

- H22: másodsorban a minőségirányítási rendszer auditorai;

- H23: harmadsorban a vállalati kontrollerek;

- H24: negyedsorban a függetlenített belső ellenőrök;

- H25: ötödsorban a felügyelöbizottság bármely tagja;

- H26: hatodsorban egyéb, nem a fenti munkakörökben foglalkoztatott személyek.

H2 szakmai fóhipotézis vizsgálata: Fentiek alapján megállapítom, hogy a hipotézist el kell vetnem, mert a pozíciók általam előzetesen megjelölt sorrendje eltér a válaszokból kirajzolódó, tényleges sorrendtől a másodiktól az ötödik helyig, ezért a H22-H25 alhipotéziseket el kell vetnem.

A hipotézis elvetésének részletes indoklása, illetve a kapott eredmények további értékelése, elemzése a következő: 
- Az előzetes várakozásnak megfelelően a rangsor első helyén a vezetői pozíció áll, ezért a H21-es alhipotézis megerősítést nyert. Azonban a második helyen a könyvelő-számviteli munkatárs jelent meg, mint második leggyakoribb kontrollt végző munkatárs, szemben az ISO minőségirányítási auditorral, ezért a H22-es alhipotézis elvetendő. Hasonlóképpen elvetésre kerül a H23-as alhipotézis is, mivel a harmadik helyre az informatikai pozíció került, szemben a várt kontrolleri munkakörrel. A sorrendet tovább vizsgálva látható, hogy eltérés látszik a negyedik helyen is, mivel a függetlenített belső ellenőri funkció csak a 11. lett a rangsorban, míg az ötödik helyen várt FB tagi státusz a valóságban a 9. helyre került. Ezért a H24 és H25 alhipotéziseket elvetettem. Végül az egyéb szereplőkre vonatkozó H26-os alhipotézist el lehet fogadni, mert az erre a gyújtő munkakörre vonatkozó sorrend a várakozásokkal megegyezően a hatodik leggyakoribb munkakör.

- A könyvelö-számviteli munkatárs, ill. az informatikai specialista (adattárházspecialista, ERP rendszergazda, stb.) pozíciók előkelő helyezése felborította az előzetes várakozásokat, ezért további elemzés tárgyává tettem őket. Főleg a vállalati interjúk kapcsán (lásd: A fókuszcsoportok és a mélyinterjúk eredményei című fejezetben részletesen) rajzolódott ki az a tartalmi hozzáadott értékük, ae pozíciókban ellátnak a COSO rendszer múködtetése során a munkavállalók. Konkrétan ide tartozik a számviteli területen a partnerek ellenőrzése (létezik-e a cég, adószáma nincs-e felfüggesztve, bizonylata az adójogszabályoknak megfelel-e, nincs-e feketelistán a lejárt kinnlevőségei miatt, számlájához a megrendelés/keretszerződés/lehívás, ill. teljesítésigazolás csatolva van-e stb.), amivel a számviteli terület konkrét anyagi kártól óvja meg a vállalkozást, másrészről betartatja a belső szabályzatokat a vállalkozás más szakterületeivel. Hasonlóképpen értékes, tényleges kontrolltevékenységet végeznek azok az informatikai területhez sorolt specialisták is, akik a nagyméretű belső adatbázisok, adattárházak segítségével állítanak elő riportokat, illetve olyan kimutatásokat, amelyek a vállalat folyamatairól, a tevékenységek eredményességéről és hatékonyságáról tükröznek vissza képet. Ezen információk (pl. egyedi SQL lekérdezések eredményei, a szokásostól eltérő (kirívó) tranzakciók detektálása, jogosultsági anomáliák jelzése, riasztás adatszivárgás, ill. adatlopás esetén, IT outsourcing kockázatjelentés) a COSO 11. alapelvével függnek össze, és további felhasználói a vezetők, a kontrollerek, a kockázatkezelők, akik ezek alapján meghozzák a szükséges korrekciós döntéseket. Megállapítom tehát, hogy ezen aspektusban a számviteli munkatársak és az informatikus specialista munkakörök beleillenek a védelmi vonalak háromtényezős modelljébe, és annak második vonalában látnak el szakosított kontrolltevékenységeket. 
- Továbblépve mélyebben megvizsgáltam az első hat szerepkört az intézményesülés különféle aspektusaiból is. Érdemesnek találtam kétváltozós összefüggésekkel elemeznem azt is, hogy a válaszadók körében mi jellemzi ezen, kontrollt gyakorló munkaköröket, pozíciókat a gyakorlatban - összevetve az institucionalista szervezetelmélettel, vagyis hogy az elmélet és a valóság hogyan viszonyul egymáshoz. Ezen ismérvek elemzése a következő eredményeket hozta:

- E szerepeket inkább főállásban, főfeladatként végzik a munkavállalók és nem részmunkaidőben, kapcsolt feladatként. Kivételt képez az ISO minőségirányítási belső auditori szerepkör, melyre inkább a részmunkaidő a jellemző. Az alábbi 8. táblázat a válaszok belső arányát mutatja aszerint, hogy e szerepet milyen minőségben látják el a munkavállalók. A válaszadók többségében teljesül tehát az intézményesülés azon elvárása, hogy a szereplők főfeladatként, azaz erre specializáltan lássák el kontrolltevékenységüket. Nem egyértelmű még az egyéb kontrollokért felelős személyek helyzete sem a kapott válaszok alapján.

\begin{tabular}{|l|r|r|r|r|}
\hline & & \multicolumn{1}{|c|}{$\begin{array}{r}\text { Inkább } \\
\text { részmunka- } \\
\text { időben, } \\
\text { részfeladat- } \\
\text { ként (\%) }\end{array}$} & $\begin{array}{c}\text { Nem } \\
\text { tudom } \\
\text { Inkább } \\
\text { fóállásban, } \\
\text { föfeladatként } \\
\text { (\%) }\end{array}$ & $\begin{array}{c}\text { nemi, } \\
\text { nem } \\
\text { kívánok } \\
\text { válaszolni } \\
\text { (\%) }\end{array}$ \\
\hline $\begin{array}{l}\text { Vezető (felső-, közép-, közvetlen irányítói } \\
\text { szint együtt) }\end{array}$ & $100,0 \%$ & $18,0 \%$ & $78,9 \%$ & $3,1 \%$ \\
\hline Könyvelö, számviteli-pénzügyi munkatárs & $100,0 \%$ & $13,0 \%$ & $81,5 \%$ & $5,6 \%$ \\
\hline $\begin{array}{l}\text { Informatikus, vállalatirányítási } \\
\text { rendszergazda, alkalmazás-rendszergazda, } \\
\text { adattárház-specialista }\end{array}$ & $100,0 \%$ & $40,0 \%$ & $51,4 \%$ & $8,6 \%$ \\
\hline ISO minőségirányítási belső auditor & $100,0 \%$ & $69,4 \%$ & $27,4 \%$ & $3,2 \%$ \\
\hline Controller & $100,0 \%$ & $36,7 \%$ & $61,2 \%$ & $2,0 \%$ \\
\hline $\begin{array}{l}\text { Egyéb kontrollokért felelős személy } \\
\text { (Portaszolgálat, belső elhárítás, jogász stb.) }\end{array}$ & $100,0 \%$ & $42,9 \%$ & $46,9 \%$ & $10,2 \%$ \\
\hline
\end{tabular}

8. táblázat: TOP6 kulcsszereplő megoszlása napi teljes- és részmunkaidő alapján

Forrás: saját összeállítás

- A belső szereplők ugyanakkor kapnak segítséget kívülről, külső személytől vagy szervezettől is. Ez a segítség lehet eseti vagy állandó jellegú is. Tartalmát tekintve ez lehet tanácsadói megbízás egyedi feladatra, esetileg igénybe vett specialista, szerződéses bedolgozói jogviszony vagy akár állandó feladat ellátása kiszervezett cégben. Az 
alábbi 9. táblázat mutatja, hogy a válaszadók a különféle szerepkörökhöz milyen mértékben vesznek igénybe külső tanácsadót, specialistát. Látható, hogy a controlleri szerep kivételével az eseti és az állandó külső támogatás minden más szerepkörben többségben van. Ezáltal az institucionalista szervezetelmélet azon elve is többségében érvényesülni látszik, hogy a szervezetek külső szereplők bevonása révén jutnak hozzá új tudáshoz, implementálnak újszerű gyakorlatokat, szokásokat, honosítanak meg máshol már bevált, bevett eljárásrendeket a kontrolltevékenységek során.

\begin{tabular}{|c|c|c|c|c|c|}
\hline & $\Sigma \%$ & $\begin{array}{c}\text { Igen, } \\
\text { állandó } \\
\text { jelleggel }\end{array}$ & $\begin{array}{c}\text { Igen, } \\
\text { eseti } \\
\text { jelleggel }\end{array}$ & Nem & $\begin{array}{c}\text { Nem } \\
\text { tudom, } \\
\text { nem } \\
\text { kívánok } \\
\text { válaszolni }\end{array}$ \\
\hline $\begin{array}{l}\text { Vezető (felső-, közép-, közvetlen irányítói } \\
\text { szint együtt) }\end{array}$ & $100,0 \%$ & $6,3 \%$ & $44,5 \%$ & $46,1 \%$ & $3,1 \%$ \\
\hline Könyvelő, számviteli-pénzügyi munkatárs & $100,0 \%$ & $34,3 \%$ & $30,6 \%$ & $33,3 \%$ & $1,9 \%$ \\
\hline $\begin{array}{l}\text { Informatikus, vállalatirányítási } \\
\text { rendszergazda, alkalmazás-rendszergazda, } \\
\text { adattárház-specialista }\end{array}$ & $100,0 \%$ & $31,4 \%$ & $47,1 \%$ & $21,4 \%$ & $0,0 \%$ \\
\hline ISO minőségirányítási belső auditor & $100,0 \%$ & $12,9 \%$ & $64,5 \%$ & $21,0 \%$ & $1,6 \%$ \\
\hline Controller & $100,0 \%$ & $12,2 \%$ & $22,4 \%$ & $59,2 \%$ & $6,1 \%$ \\
\hline $\begin{array}{l}\text { Egyéb kontrollokért felelős személy } \\
\text { (Portaszolgálat, belső elhárítás, jogász } \\
\text { stb.) }\end{array}$ & $100,0 \%$ & $36,7 \%$ & $38,8 \%$ & $14,3 \%$ & $10,2 \%$ \\
\hline
\end{tabular}

9. táblázat: TOP6 kulcsszereplő megoszlása külső szolgáltatók igénybevételi szokásai alapján

Forrás: saját összeállítás

- A kontrollt gyakorló vezetői pozíciók darabszáma magasabb, míg ISO auditorból és kontrollerből kevesebbet alkalmaznak a válaszadók. Az alábbi 10. táblázat a hat kiemelt szerepkörre vonatkozó létszámadatokat mutatja be különféle mutatók szerint. Látható, hogy a kontrollt ellátó szerepkörökben dolgozó munkatársak létszáma abszolút számadatként vizsgálva alacsonynak tekinthető, pozíciónként jellemzően 2-5 fö100 között tendál (a vezetői munkakört figyelmen kívül hagyva), miközben a válaszadók többségénél a

\footnotetext{
100 Lásd a 10. táblázat adataiban a 75\%-os felső percentilis értékét, mely 2 és 5 között mozog. Azaz 4 válaszadóból 3 esetében igaz az az állítás, hogy a kontrollt gyakorlók száma (a vezetői pozíciót figyelmen kívül hagyva) legalább 2 fö, és nem több 5 fönél.
} 
foglalkoztatottak száma a 27 főt nem haladta meg, az átlagos éves statisztikai létszám pedig 433 fő volt a minta egészét.

A mediánértékeket egymáshoz viszonyítva azt látjuk, hogy a kontrollt gyakorló munkakörök aránya a mintabeli vállalatok felénél nem több 22,2 \%-nál ${ }^{101}$, azaz a válaszadók felének adatai alapján kb. minden ötödik munkavállaló lát el kontrolltevékenységet a vállalatokon belül. Ha a vizsgálatot kibővítjük a nagyobb létszámú vállalatokra is, akkor a 75\%-os felső percentilis figyelembevételével ugyanezen hányados 8,25\%-ra ${ }^{102}$ esik le. Azaz a vállalati méret (létszám) növekedésével nem arányosan növekszik a kontrollt gyakorlók létszáma, ami egybevág az általános méretgazdaságossági elvvel.

\begin{tabular}{|l|r|r|r|r|r|r|}
\hline & \multicolumn{1}{|c|}{ N } & Átlag & Medián & Módusz & $\begin{array}{c}\text { Percentilis } \\
\mathbf{2 5 \%}\end{array}$ & $\begin{array}{c}\text { Percentilis } \\
\mathbf{7 5 \%}\end{array}$ \\
\hline $\begin{array}{l}\text { Vezető (felső-, közép-, közvetlen } \\
\text { irányítói szint együtt) }\end{array}$ & 128 & 15,99 & 4,00 & 2 & 2,00 & 7,75 \\
\hline $\begin{array}{l}\text { Könyvelő, számviteli-pénzügyi } \\
\text { munkatárs }\end{array}$ & 108 & 4,46 & 2,00 & 1 & 1,00 & 3,00 \\
\hline $\begin{array}{l}\text { Informatikus, vállalatiráný́tási } \\
\text { rendszergazda, alkalmazás- } \\
\text { rendszergazda, adattárház- } \\
\text { specialista }\end{array}$ & 70 & 5,54 & 1,00 & 1 & 1,00 & 3,00 \\
\hline ISO minőségirányítási belső auditor & 62 & 4,58 & 1,00 & 1 & 1,00 & 3,00 \\
\hline Controller & 49 & 3,73 & 1,00 & 1 & 1,00 & 2,00 \\
\hline $\begin{array}{l}\text { Egyéb kontrollokért felelős személy } \\
\text { (Portaszolgálat, belső elhárítás } \\
\text { jogász, stb.) }\end{array}$ & 49 & 12,02 & 1,00 & 1 & 1,00 & 5,00 \\
\hline
\end{tabular}

10. táblázat: TOP6 kulcsszereplő létszámadatai, leíró statisztikája

Forrás: saját összeállítás

- A kontrollt gyakorlók inkább önállóan dolgoznak, nem szerveződnek funkcionális egységbe. Noha a számviteli, az informatikai és a kontrollingterületen a szervezeti egységek képzése minden harmadik válaszadónál előfordult, a másik három szerepkörben dolgozóknál ez az arány 26,5\%-nál alacsonyabb, azaz csak kb. minden 4-5. cégnél fordul elő.

\footnotetext{
101 Számítás: kontrollt gyakorlók mediánjainak összege vezetök nélkül 6 fö $(2+1+1+1+1=$ mindösszesen 6 fö) / 27 fő átlagos statisztikai létszám (medián) hányadosából adódik a 22,22\%-0s arányszám.

102 Számítás: kontrollt gyakorlók mediánjainak összege vezetők nélkül 6 fő $(2+1+1+1+1=$ mindösszesen 6 fő) /

72,75 fő felső kvartilis (75\%) átlagos statisztikai létszám hányadosából adódik a 8,25\%-os arányszám.
} 
A 11. táblázat azt mutatja meg, hogy a hat kiemelt szerepkörben dolgozók milyen arányban alkotnak önálló szervezeti egységet a vállalatukon belül. Az alacsony szerveződés arra utal, hogy nem teljesül az institucionalista szervezetelméletek azon elvárása, hogy a specializált szerepkörökben dolgozók maguk is létrehozzák saját funkcionális egységüket, amely egységek aztán az SZMSZ-ben vagy más, a szervezetet leíró, formális szabályzatban is megjelennek, ezáltal a szerepkör megerősítetté, megkérdőjelezhetetlenné, technokratikus eszközökkel bebetonozottá válik.

\begin{tabular}{|l|r|r|r|r|}
\hline & \multicolumn{1}{|c|}{$\begin{array}{c}\text { Szervezeti } \\
\text { egységet } \\
\text { képeznek } \\
\text { (\%) }\end{array}$} & $\begin{array}{c}\text { Önállóan } \\
\text { végzi(k) } \\
\text { feladatai(ka)t } \\
\text { (\%) }\end{array}$ & $\begin{array}{c}\text { Nem tudom } \\
\text { megítélni, } \\
\text { nem kívánok } \\
\text { válaszolni (\%) }\end{array}$ \\
\hline $\begin{array}{l}\text { Vezető (felső-, közép-, közvetlen irányítói szint } \\
\text { együtt) }\end{array}$ & $100,0 \%$ & $22,7 \%$ & $68,0 \%$ & $9,4 \%$ \\
\hline Könyvelö, számviteli-pénzügyi munkatárs & $100,0 \%$ & $42,6 \%$ & $50,0 \%$ & $7,4 \%$ \\
\hline $\begin{array}{l}\text { Informatikus, vállalatirányítási rendszergazda, } \\
\text { alkalmazás-rendszergazda, adattárház- } \\
\text { specialista }\end{array}$ & $100,0 \%$ & $34,3 \%$ & $57,1 \%$ & $8,6 \%$ \\
\hline ISO minőségirányítási belső auditor & $100,0 \%$ & $12,9 \%$ & $82,3 \%$ & $4,8 \%$ \\
\hline Controller & $100,0 \%$ & $36,7 \%$ & $57,1 \%$ & $6,1 \%$ \\
\hline $\begin{array}{l}\text { Egyéb kontrollokért felelős személy } \\
\text { (Portaszolgálat, belső elhárítás, jogász stb.) }\end{array}$ & $100,0 \%$ & $26,5 \%$ & $61,2 \%$ & $12,2 \%$ \\
\hline
\end{tabular}

11. táblázat: TOP6 kulcsszereplő megoszlása szervezeti egységbe szerveződés szerint

Forrás: saját összeállitás

\subsubsection{H3: Kontrolltevékenységek}

A harmadik szakmai hipotézis az alkalmazott kontrolltevékenységek elterjedtségére, alkalmazottságára vonatkozott. Az alábbi 12. táblázatban közlöm a válaszokból összesített gyakoriságokat az egyes kontrolltevékenységeknek a hipotézissel azonos, típus szerinti megbontásában. 


\begin{tabular}{|c|c|c|c|c|c|c|}
\hline $\begin{array}{c}\text { Kontroll } \\
\text { típusa }\end{array}$ & $\begin{array}{c}\text { Kérdések } \\
\text { száma a } \\
\text { kérdőíivben } \\
\text { (db.) }\end{array}$ & \begin{tabular}{|c|} 
Alkalmazott \\
kontrollok \\
lehetséges \\
maximális \\
száma (db.)
\end{tabular} & \begin{tabular}{|c|} 
Alkalmazott \\
kontrollok \\
száma a \\
kitöltők \\
körében \\
(db.) \\
\end{tabular} & $\begin{array}{l}\text { A kontrollt } \\
\text { hány } \\
\text { esetben } \\
\text { végzi konkrét } \\
\text { személy (db.) }\end{array}$ & $\begin{array}{c}\text { Kontroll- } \\
\text { tevékenység } \\
\text { elterjedtsége } \\
(\%)\end{array}$ & $\begin{array}{l}\text { Kontroll- } \\
\text { tevékenység } \\
\text { személy- } \\
\text { függősége } \\
\text { (\%) }\end{array}$ \\
\hline vezetői & 10 & 1320 & 961 & 875 & $72,8 \%$ & $91,05 \%$ \\
\hline $\begin{array}{l}\text { folyamatba } \\
\text { épített }\end{array}$ & 7 & 924 & 668 & 595 & $72,3 \%$ & $89,07 \%$ \\
\hline fizikai & 6 & 792 & 411 & 344 & $51,9 \%$ & $83,70 \%$ \\
\hline automatizált & 3 & 396 & 183 & 111 & $46,2 \%$ & $60,66 \%$ \\
\hline Végösszeg & 26 & 3432 & 2223 & 1925 & $64,77 \%$ & $86,59 \%$ \\
\hline
\end{tabular}

12. táblázat: Különféle kontrolltevékenységek elterjedtsége

Forrás: saját összeállitás

H3 szakmai hipotézis: A hazai vállalkozások által alkalmazott kontrolltevékenységek típusai közül az alábbiak a leginkább elterjedtek:

- H31: a vezetők által végzett kontrolloknak legalább a háromnegyedét alkalmazzák;

- H32: a folyamatba épített kontrolloknak több mint felét alkalmazzák;

- H33: a fizikai kontrolloknak kevesebb mint felét múködtetik;

- H34: automatikus kontrollokat legfeljebb az esetek egynegyedénél múködtetnek;

H3 szakmai főhipotézis vizsgálata: Fentiek alapján megállapítom, hogy a hipotézist el kell utasítani, mert az általam előzetesen feltételezett elterjedtségi kritériumok csak kettő esetben teljesülnek, további kettő esetben pedig nem.

A táblázatban szereplő adatok részletes magyarázata, ill. a H3 hipotézis elvetésének részletes indoklása és a kapott eredmények további értékelése, elemzése a következő:

- Elterjedtség alatt azt értem, hogy egy kontrolltevékenységre hány válaszadó és összesen hány alkalommal mondja azt, hogy az múködik nála, vagyis alkalmazza azt. A vezetői kontrolltevékenységek száma a kérdőívben szereplő 26 kérdésből összesen 10 darab (12. táblázat második oszlopa), így a lehetséges maximális alkalmazhatósága ennek a típusnak 10 kérdés x 132 vállalat $=1320 \mathrm{db}$ kontrolltevékenység (harmadik oszlop). A kitöltők által ténylegesen visszaigazolt vezetői kontrollok darabszáma ezzel szemben csak 961 db. (negyedik oszlop) volt, s e két szám arányaként adódik a 72,80\%-os alkalmazottsági arány a válaszadó vállalkozások körében (hatodik oszlop). Ugyanilyen számítási logikával adódik a folyamatokba épített, a fizikai és az 
automatikus kontrolok elterjedtsége is, mely számítások eredményei ugyancsak a 12. táblázat hatodik oszlopában szerepelnek.

- A H3 szakmai hipotézis négy alhipotézise közül a H31-est azért kell elvetni, mert a 72,80\%-os elterjedtség nem éri el a hipotézisben előzetesen közölt 75,00\%-os értéket. Hasonló ok miatt kell elvetni a H33-as hipotézist is, mert a fizikai kontrollok esetében a tényleges elterjedtség $51,90 \%$, ami meghaladja a hipotézisben szereplő max. 49,99\%-os határértéket. Megjegyzés az értelmezéshez: az, hogy egy kontroll jobban elterjedt a vártnál, szakmai értelemben üdvözlendő és örömteli, ám a hipotézist matematikai voltából kifolyólag - ez esetben is el kell utasítani. Viszont a H32 alhipotézist el lehet fogadni, mert H32 esetében a 72,30\%-os érték meghaladja az 50,01\%-os megkívánt határértéket, a H34 alhipotézis esetében a 46,20\% több, mint a hipotézisben szereplő 25,00\%.

- Bár hipotézis közvetlenül nem vonatkozik a kontrolltevékenységek manuális vagy automatizált voltára, mégis e pontban érdemesnek találtam elemzés alá vonni a kapott válaszokat. A kontrolltevékenységekről ugyanis feltételezhetjük, hogy akkor tekinthetők intézményesültnek és a mindennapokban beépültnek, ha azokat inkább automatizáltan, az üzleti folyamat részeként végzik el. A válaszadók a kérdőív kitöltése során megjelölhették azt, hogy a megadott 26 darab kontrolltevékenységet ki végzi el a szervezeten belül. Amennyiben ezt konkrét munkavállaló látja el, akkor ezt személyhez kötött (manuális) kontrollnak tekinthetjük (darabszámukat lásd az ötödik oszlopban), ha pedig automatizált eszköz (gép, szoftver, alkalmazás), akkor az személyfüggetlen (automatikus) kontroll. A 12. táblázat utolsó (hetedik) oszlopában szereplő \%-os érték azt jelöli, hogy az adott kontrolltevékenységet milyen arányban látják el manuálisan a szervezeteken belül. Megállapítom, hogy a vezetői kontrollok erősen személyorintáltak (91,05\%-ban dolgozók, azon belül is jellemzően a vezetők látják el), ami egyébként összecseng a vezetői ellenőrzés eszményével. Az automatizált kontrollok esetében ez az arány 60,66\%, ami igen magas manualitást jelez, miközben a kontroll típusából következően ennek alacsony értékúnek kellene lennie. Az adatok mélyebb elemzésénél megállapítottam, hogy a magas értéket az okozza, hogy az automatikusnak vélt azonnali figyelmeztető rendszereket és monitoringalkalmazásokat a valóságban mégis manuálisan alkalmazzák a válaszadó cégek, főleg a kontrollerek és a könyvviteli-számviteli munkatársak látják el nagyszámban (azaz nem automatizáltan) ezt a kontrollt.

- A H3 hipotézis kapcsán érdemesnek találtam azt is megvizsgálni, hogy az egyes kontrolltevékenységeket ki (mely szerepkör) látja el a szervezeten belül. Erre vonatkozóan a válaszok kiértékelését a 29. táblázat mutatja, mely 
egyfajta feladat-felelősség mátrixként is értelmezhető. A benne szereplő számadatok a kontrolltevékenység (sorokban) gyakoriságát mutatják munkakörönként (oszlopokban), azaz két szempont egyidejü elemzésének eredményét láttatják. A mátrixból kiolvashatók a következő szerepcsoportok:

○ A vezető önmagában képez egy jelentős szereplőt, ő maga végzi az összes alkalmazott kontrolltevékenység 40,8\%-át, s ezek jellemzően maguk a vezetői kontrollok (bejárás, beszámoltatás, problémamegoldó egyeztetések, jóváhagyási pontok rögzítése stb.).

- Pénzügyi adatokból kinyert számításokkal, kimutatásokkal, mutatószámokkal, analitikákkal foglalkozik a kontroller és a könyvelöszámviteli munkatárs, ők végzik a kontrollok további 20,9\%-át.

○ Bejövő, termelésközi és végellenőrzéssel, valamint a folyamatok szabályozásával és az ezzel kapcsolatos önértékeléssel lát el kontrollokat az ISO minőségirányítási belső auditor és a minőségellenőr, ők képezik a harmadik csoportot, s a kontrollok 9,0\%-át látják el.

- Adatbányászati, adattárház-elemzési kontrollokat végez a specializált informatikus munkakörben dolgozó munkavállaló, ő végzi a kontrollok további 4,3\%-át.

○ A kontrolltevékenységek fennmaradó 11,6\%-át egyéb szereplők látják el, akik közül a kérdőívben nem szereplő pozícióban dolgozik a kontrolltevékenységeket végzők 6,0\%-a (pl. portás, jogász stb.), a fennmaradó 5,6\%-át látják el a kevésbé elterjedt munkakörök, mint pl. compliance manager, kockázatkezelő, etikai koordinátor stb.

○ A válaszadók a kontrolltevékenységek 9,9\%-áról nem tudták eldönteni, hogy kik látták el azokat, és további 3,5\% esetében a kontrolltevékenységek automatizált kontrollok, amelyeket nem munkavállalók láttak el.

$A z$ itt felsorolt csoportokat a 29. táblázatból (mátrixból) olvastam ki szemrevételezéssel. A tudományos alátámasztás végett azonban elvégeztem ugyanezen 15 (szerepkörként definiált) változó hierarchikus klaszterelemzését Ward-módszerrel, nem standardizált változókkal. A kapott eredmény dendogram formájában az alábbi 14. ábran látható, a részletes számításokat és SPSS outputokat a F 6.2.3 - H3 hipotézis című függelékben közlöm.

Az alábbi dendogramból beazonosítható öt szerepkör, amelyeket az ábrán alulról-felfelé haladva 1-2-4-3-5 sorszámokkal láttam el, és piros oválisokkal jelöltem az egyes csoportok összetartozó elemeit. Megállapítom tehát, hogy a többváltozós elemzéssel előállított, tudományos alapon nyugvó eredmény 
nagyban megegyezik a fentebb leírt, ránézésen alapuló előzetes elemzéssel, azaz alátámasztja az ott leírtakat.

A szereplőkre vonatkozó megállapítások, itt kapott eredmények egyébiránt nagyban átfedést mutatnak a $\mathrm{H} 2$ hipotézisnél ismertetett eredményekkel, s az ott felsorolt kulcsszereplőkkel. Egyetlen jelentősebb eltérés a MEO, minőségellenőr szerepkörben van, amely a H3-as hipotézis jelen elemzésében megjelent, de a H2-es hipotézis tárgyalásánál nem.

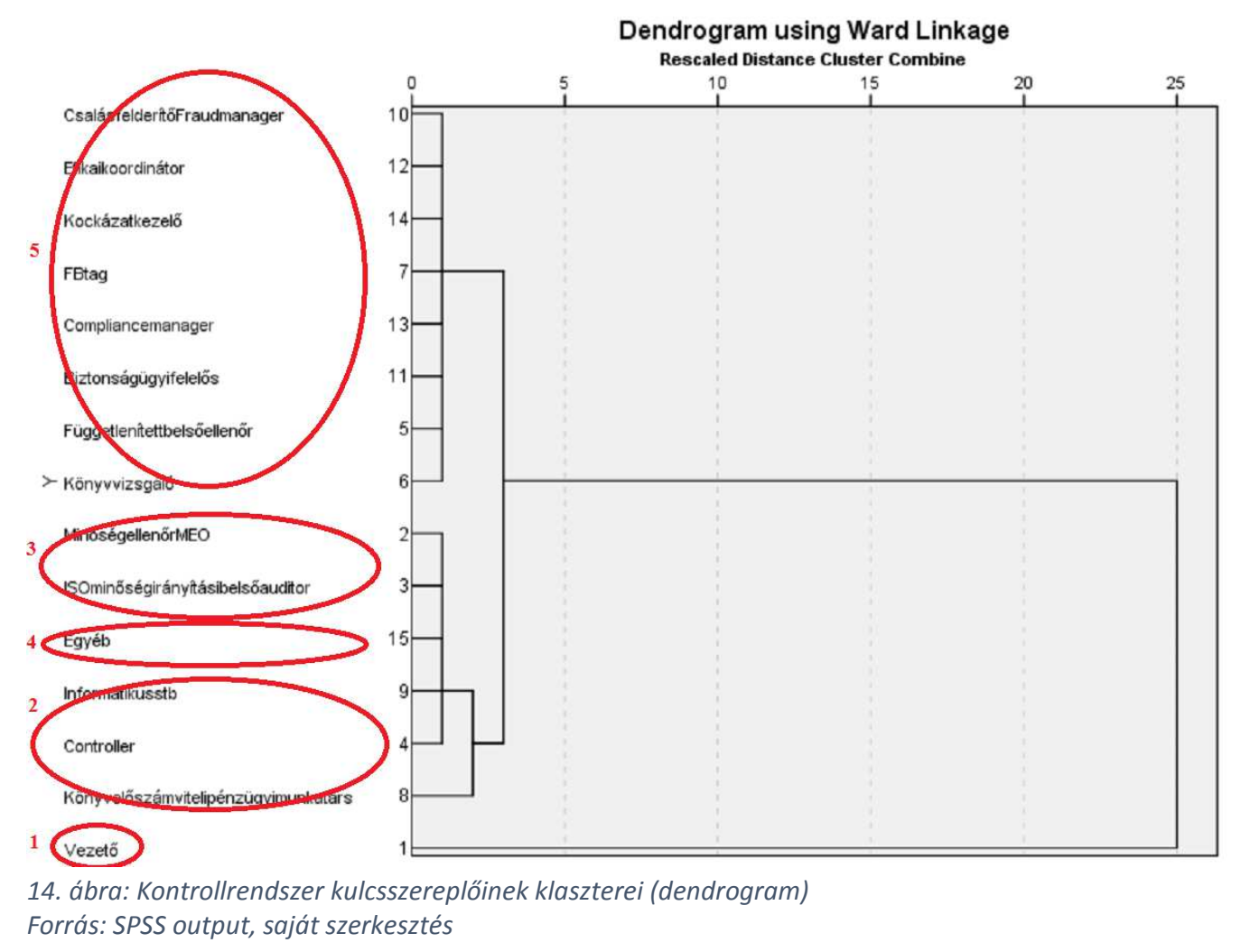

- A H3 hipotézis kapcsán a kérdőívben összesen 26 darab konkrét kontrolltevékenységet szerepeltettem. Felmerül azonban a kérdés (az igény), hogy lehetséges-e kategorizálni ezeket, illetve összevonni, redukálni lehet-e őket? Ennek megválaszolására előállítottam a 26 kontrolltevékenység korrelációs mátrixát (terjedelmi okok miatt nem csatoltam be a függelélek közé), ebben sok pozitív magas, +0,6 és +0,9 közötti korrelációs együtthatót találtam, ami arra utal, hogy a kontrolltevékenységek egy része „együttesen mozog", azaz nagy eséllyel csoportosíthatók közös változókba.

Ezt követően e 26 darab kontrolltevékenységet megtestesítő változóra elvégeztem a faktorelemzést és a klaszterelemzést, melynek végeredményei a F 6.2.3 - H3 hipotézis címü függelékben találhatók részletes számításokkal és eredményekkel együtt. A két módszer részben eltérő eredményeket adott, ami az eltérő módszereknek tudható el. A két módszer közül a 
klaszterelemzés eredményét mutatom be itt részletesen, mivel az a diszkrét változókra jobban alkalmazható, szemben a faktorelemzéssel, amely inkább folytonos változók értékeinél ad pontosabb eredményt.

A klaszterelemzést hierarchikus klaszterelemzéssel, Ward módszerrel végeztem el, ahol a változók diszkrét értékek és a módszer Khi-négyzet alapú (Count + Chi-squared measure). A 15. ábran látható dendogram szemlélteti az azonos klaszterbe tartozó, azaz a logikailag összetartozó, egy típusba sorolható kontrolltevékenységeket. Ezek típusait az ábrán F, V1, V2 stb. betűkkel jelöltem.

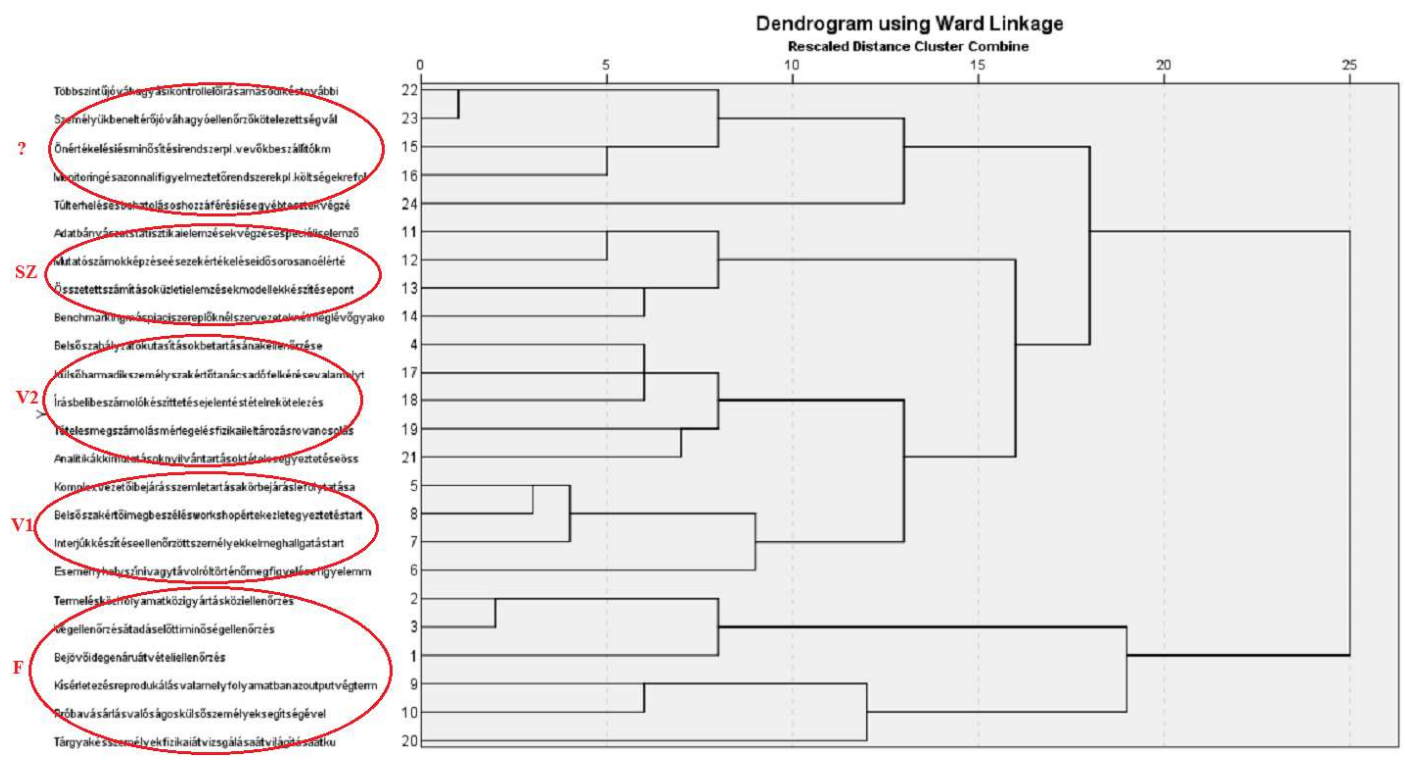

15. ábra: Kontrolltevékenységek megképzett klaszterei (dendrogram) Forrás: SPSS output, saját szerkesztés

A klaszterek értelmezése, tartalommal való feltöltése mindig a kutató feladata és felelőssége. A konkrét esetben az egyes kontrolltevékenységeket megtestesítő klaszterek interpretációját kutatóként én az alábbiak szerint adom meg:

- F: Fizikai kontrollok, azok a tevékenységek, melyeket az üzletmenet során fizikai ellenőrzés, közvetlen kontaktus révén végeznek el.

- V1: A vezetők által végzett, verbális tájékoztatáson, szóbeliséget feltételező, beszámoltatásból eredő benyomásokra épülő kontrollok.

- V2: A vezetők által végzett, objektív tényeken, számszerúsített adatokon nyugvó, szabályok révén megvalósuló kontrollok.

- SZ: Számértékek kiértékelése révén létrejövő, mutatószámokkal, adatok értelmezése révén megvalósuló kontrolltevékenységek, melyeket nem a vezetők végeznek. 
- ?: A kontrolltevékenységek ötödik csoportja, melynek elemeit nem sikerült egyértelmúen, egyetlen ésszerú jelzővel illetni, s e klasztert jól jellemezni. Itt kaptak helyet a folyamatokat elemző és értékelő, ill. a négy szem elvére épülő jóváhagyási kontrollok. Megkockáztatom, hogy ez az üzleti folyamatok során gyakorolt, folyamatba épített, ill. automatizált kontrollok gyűjtőkategóriája.

A klaszterelemzés tehát visszaigazolja a vezetői és fizikai kontrollok jelenlétét, érzékelteti a számadatokkal operáló kontrolltevékenységeket, de nem igazolja vissza egyértelmúen az automatikus, ill. a folyamatba épített kontrolltevékenységeket.

\subsubsection{H4: A kontrollrendszer intézményesülése}

A negyedik szakmai hipotézis a hazai vállalatok belső kontrollrendszereinek intézményesültségi fokára, annak általam javasolt és objektíven számítható módszerére vonatkozik. Az alábbi 13. táblázat a válaszadók által a 49 állításra adott, 7 fokozatú Likert-skála szerinti egyetértésük átlagát, ill. szórását mutatja. Ezekből képzett egy-egy mutatószám „Az egyetértések átlaga mutató” illetve „Az egyetértések szórása mutató”. 10 esetben a válaszadók a nem tudom, nem kívánom megadni választ jelölték a kérdőíven mind a 49 kérdésre, ezért őket a további vizsgálatból kizártam, és az alább közölt adatok 132 vállalat helyett csak 122 vállalat válaszait összesítik.

\begin{tabular}{|l|l|r|r|}
\hline \multicolumn{2}{|c|}{ Statistics } \\
\hline \multicolumn{2}{|l|}{} & $\begin{array}{c}\text { Az egyetértések átlaga } \\
\text { mutató }\end{array}$ & $\begin{array}{r}\text { Az egyetértések szórása } \\
\text { mutató }\end{array}$ \\
\hline \multirow{2}{*}{ N } & 122 & 122 \\
\cline { 2 - 4 } & Missing & 10 & 10 \\
\hline Mean & 4,1005 & 1,3138 \\
\hline Median & 4,2766 & 1,2964 \\
\hline Mode & $3,00^{\mathrm{a}}$ &, 79 \\
\hline Std. Deviation & 1,30413 &, 43956 \\
\hline Variance & 1,701 &, 193 \\
\hline Skewness &,- 195 &, 234 \\
\hline Std. Error of Skewness &, 219 &, 219 \\
\hline Kurtosis &,- 632 &, 422 \\
\hline Std. Error of Kurtosis &, 435 &, 435 \\
\hline Sum & 500,26 & 160,29 \\
\hline Percentiles & 20 & 2,9446 &, 9533 \\
\hline
\end{tabular}




\begin{tabular}{|l|l|r|r|}
\hline & 25 & 3,0965 &, 9993 \\
\cline { 2 - 4 } & 40 & 3,8128 & 1,1871 \\
\cline { 2 - 4 } & 50 & 4,2766 & 1,2964 \\
\cline { 2 - 4 } & 60 & 4,5000 & 1,3790 \\
\cline { 2 - 4 } & 75 & 5,1064 & 1,5880 \\
\cline { 2 - 4 } & 80 & 5,2896 & 1,6863 \\
\hline
\end{tabular}

13. táblázat: Egyetértésre vonatkozó átlag- és szórásmutató leíró statisztikája

Forrás: SPSS output, saját szerkesztés

H4 szakmai hipotézis: 7 fokozatú Likert-skálát alkalmazva a vizsgált hazai vállalkozások legalább 80\%-ára igaz, hogy a saját belső kontrollrendszerükre vonatkozó egyedi érettséggel való egyetértés szórásmutatója a 0,8289-os értéket nem haladja meg, és ennek alapján kontrollrendszerük érettsége homogénnek tekinthető.

H4 szakmai főhipotézis vizsgálata: A 13. táblázat adatai alapján megállapítom, hogy a H4 hipotézist el kell utasítani, mert az egyetértésre vonatkozó szórási mutató minimális értéke 1,6863 kell legyen ahhoz, hogy teljesüljön a válaszadók $80 \%$-ára vonatkozóan a kritérium, szemben az általam kijelölt 0,8289-es értékkel.

A táblázatban szereplő adatok részletes magyarázata, ill. a H4 hipotézis elvetésének részletes indoklása és a kapott eredmények további értékelése, elemzése a következő:

- A H4 hipotézis megfogalmazásánál abból a szigorú feltételezésből indultam ki, hogy az állításokkal való egyetértések viszonylag kis terjedelmen belül, tipikusan az $\mathrm{n} \pm 1$-es sávba esnek, és az egyetértési mutató szórása a 0,8289-et nem fogja meghaladni az esetek 80\%-ában. Ezzel szemben a valóság az, hogy ez a szórásmutató nagyobb terjedelmet fog be, a válaszadók $80 \%$-a esetében - a 80\%-hoz tartozó percentilis értékét figyelembe véve - ez az érték legalább 1,6863 kell legyen (lásd az alábbi 16. ábran zöld függőleges vonallal jelölve). A percentilisek vizsgálatából az is látszik, hogy az általam kijelölt, legfeljebb 0,8289-es érték a válaszadók mindössze 12,30\%-ára érvényes (lásd az alábbi 16. ábran piros függőleges vonallal jelölve). 


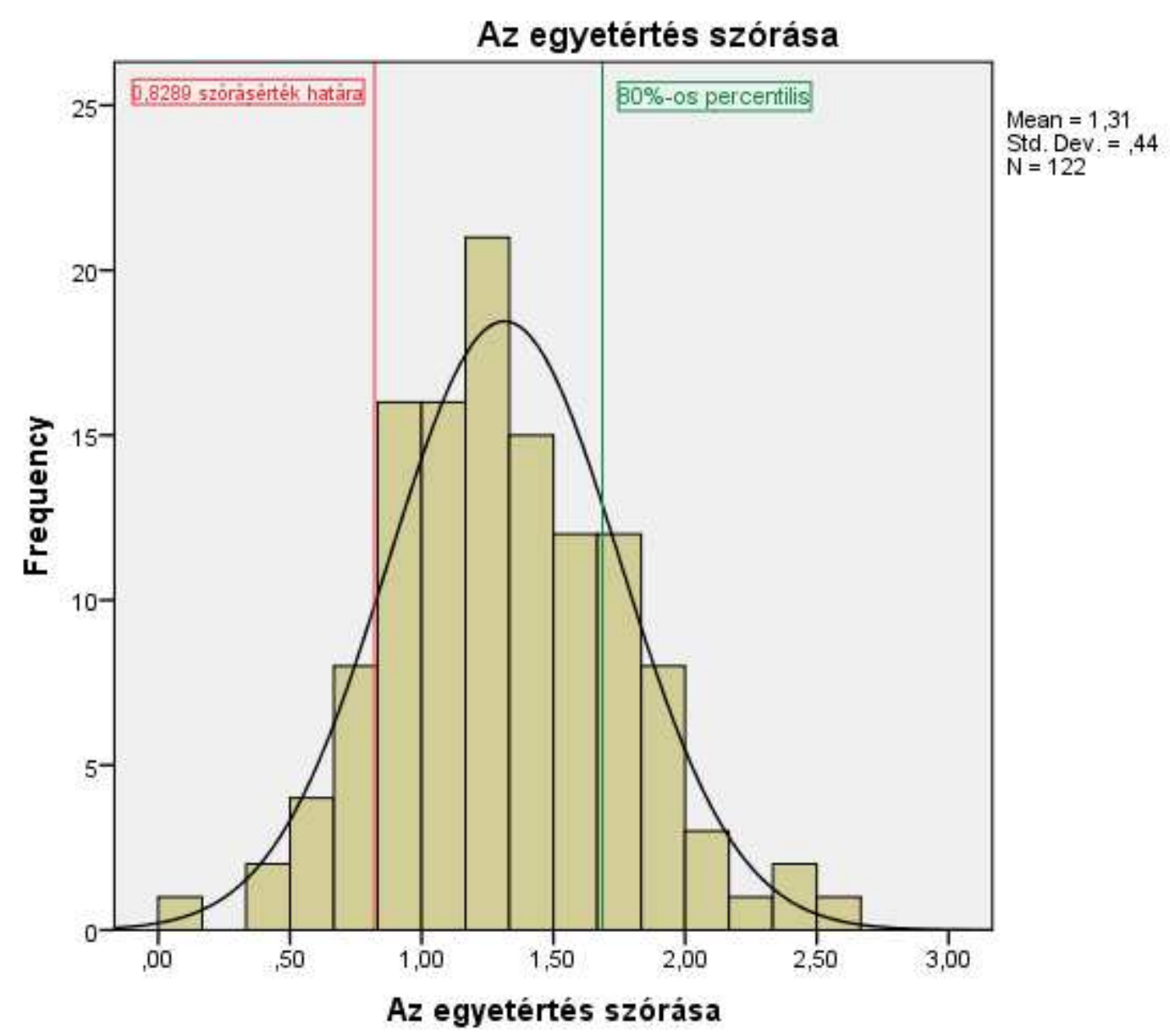

16. ábra: Egyetértés szórásmutatójának hisztogramja

Forrás: SPSS output, saját szerkesztés

Ebből le kellett vonnom azt a kettős következtetést, hogy

- a válaszok homogenitására vonatkozó és a szórásmutatót alkalmazó matematikai modellem használható algoritmus, de

- a szórási mutató megengedett értékét lazább keretek (tágabb terjedelem) között kell meghatározni ahhoz, hogy a válaszadók jelentős többsége az elfogadási tartományba kerüljön.

- Az egyetértésre vonatkozó szórási mutatót alaposabban megvizsgálva (elsősorban a hisztogramra tekintve) felmerül a vélelem, hogy a szórásmutató normál eloszlású-e. Ha ugyanis az, az jogossá teszi a mélyebb átlag- és a szóráselemzést, valamint részletesebb következtetések levonását. Ezért elvégeztem a változó nem paraméteres Kolmogorov-Smirnov tesztjét az illeszkedés igazolása vagy elvetése céljából. Ennek a normalitástesztnek az eredményei az alábbi 14. táblázatban láthatóak. Ennek alapján megállapítottam, hogy a változó nem tér el szignifikánsan a normális eloszlástól. Ugyanakkor a 16. 
ábran látszik, hogy a normál eloszlás görbéjére a hisztogram oszlopai nem tökéletesen illeszkednek, azaz részleges torzulásról beszélhetünk.

\begin{tabular}{|c|c|c|c|c|c|c|}
\hline \multicolumn{7}{|c|}{ Tests of Normality } \\
\hline & \multicolumn{3}{|c|}{ Kolmogorov-Smirnov ${ }^{a}$} & \multicolumn{3}{|c|}{ Shapiro-Wilk } \\
\hline & Statistic & df & Sig. & Statistic & df & Sig. \\
\hline $\begin{array}{l}\text { Az egyetértések átlaga } \\
\text { mutató }\end{array}$ & 063 & 122 & ,200* & ,984 & 122 & , 159 \\
\hline $\begin{array}{l}\text { Az egyetértések } \\
\text { szórása mutató }\end{array}$ & ,054 & 122 & ,200* & ,991 & 122 & ,597 \\
\hline \multicolumn{7}{|c|}{ *. This is a lower bound of the true significance. } \\
\hline a. Lilliefors Significance & Sorrectior & & & & & \\
\hline
\end{tabular}

Mivel pedig a változó normál eloszlású, az egyetértésre vonatkozó szórásérték átlagától (ami a konkrét esetben 1,3138) egy szórásértéknyire (ami a konkrét esetben 0,4396) eső minimum és maximum küszöbérték kijelöli azt a tartományt, amibe a válaszadók egyetértésre vonatkozó szórásértékeinek 66,66\%-a (kétharmada) esik. Amennyiben tehát a fentebb említett $80 \%$-os kritérium helyett inkább a normál eloszlásból eredő három szigma szabályt (Lawrence B. et al., 2003, pp.452-453.) alkalmazom, úgy lehetővé válik a küszöbértékek könnyű és „,igazságos” meghatározása.

- A 14. táblázatból az is kitűnik, hogy nemcsak az egyetértésre vonatkozó mutató szórása normális eloszlású, hanem az egyetértés mértékének átlagai is a 122 esetet vizsgálva. A fenti 13. táblázatból kiolvasható az átlagos egyetértés mértéke, ami 4,10. Ezt azt is jelenti, hogy a válaszadók összességében közepes szintre értékelték a saját kontrollrendszerük intézményesültségét, mivel az átlag (és egyébként a medián is) a 7 fokozatú skála elméleti középértékéhez, azaz a 4,00-ás értékhez közel helyezkedik el. Mivel az átlagok normál eloszlásúak, a sokaságra is könnyen lehet további feltételezéseket tenni, ill. szegmenseket kialakítani. Ez pedig hozzásegít az intézményesültségi szintek határmezsgyéinek, szeparációs értékeinek meghatározásához, a minimális és maximális belépési szintek megállapításához.

A normál eloszlásra jellemző három szigma szabályt (Lawrence B. et al., 2003, pp.452-453.) alkalmazva tehát az alábbi belső arányok rajzolódnak ki az egyes tartományok gyakoriságait illetően:

○ A válaszadók kb. kétharmada (68,26\%-a) esik a középső tartományba, amelyet az átlagtól vett \pm 1 szórásérték jelöl ki. Esetünkben az egyetértések átlagos értéke 4,101, az alsó, ill. felső határ pedig ebből 
adódóan 2,797 (=4,101-1,304), ill. 5,405 (=4,101+1,304). A tartományt középen szimmetrikusan kettévágja az átlagmutató, a válaszadók fele az átlag alatti, fele pedig az átlag feletti tartományba esik. Az ő esetükben a szórás átlagosnak, szokványosnak tekinthető, e vállalkozásokat lehet tehát tipikus vállalatoknak is tekinteni az egyetértés homogenitását illetően.

○ A szélsőségek felé haladva a válaszadók 13,59-13,59 \%-a esik az átlag \pm 2 szórás és az előbb bemutatott átlag \pm 1 szórás értékével kijelölt tartományok közé, esetünkben ez a két érték 1,493 (=4,101-1,304 × 2), illetve 6,709 $(=4,101+1,304 \times 2)$. Őket tekinthetjük átlagaik alapján a gyenge, ill. az erős tartományba eső válaszadóknak.

○ A normál görbe két végén fennmarad a válaszadók $2,28 \%-2,28 \%$-a, ők tartoznak az extrém alacsony (szinte alig mérhető), ill. extrém magas (kiváló, majdnem maximumhoz közelító) tartományba.

Ezeket a gyakoriságokat alapul véve az intézményesülési mutatóra vonatkozóan adódik a következő hat tartomány, azok belépő (minimális) egyetértésre vonatkozó átlagértékei, egyúttal az ábrán feltüntettem azt a minősítő elnevezésemet is, ahogyan az adott tartományt szakmailag, a téma alapján ki lehet fejezni. Az eredményeket az alábbi 17. ábra mutatja, melynek értelmezése a következő:

- A 6 tartományt az egyes oszlopok jelölik, a szinteket piros számokkal jelöltem a fejlécben. Ugyanezeket a tartományokat a táblázat alatt lévő Gauss-görbén is megjelöltem. A görbe mutatja az egyszeres, kétszeres, háromszoros szórási terjedelmet $(1 \sigma, 2 \sigma$ és $3 \sigma)$ az átlaghoz képest.

- A terjedelem alsó határát (belépő szintjét) az egyetértés átlaga és szórása alapján jelöltem meg a táblázatban. A modell szempontjából ennek értelmezése a következő: amely válaszadó egyetértéseinek átlaga eléri az itt feltüntetett belépési korlátot, az a tartományok közül azon legmagasabba illik bele, amelynek még teljesíti a belépési szintjét; és ezáltal lehet minősíteni az ő belső kontrollrendszerének intézményesültségi szintjét.

○ Feltüntettem a 122 válaszadó tényleges (gyakorlati) megoszlását e hat tartományban, valamint alatta közlöm az elméleti eloszlás szerint számított (elvárt) megoszlási értéket. $A$ kettő közötti eltérést a mintának a tökéletes normál eloszlástól való eltérése (torzítottsága) okozza.

- Ugyanezen arányszámok figyelembevételével - kísérletképpen, mivel a minta nem reprezentatív - megbecsültem, hogy a vizsgálati populációba tartozó 33432 jogi személyiségú társas vállalkozás hogyan oszlik meg ezen 6 tartományba. Ezáltal indukcióval következtettem vissza a sokaságra vonatkozóan. 
○ Végül kiszámoltam, hogy 95\%-os valószínúséggel az egyes tartományokon belül a belépési szinteknek milyen minimum- és maximumértékét lehet elfogadni. A konkrét esetben az alsó szint egy megengedő (már ebbe a tartományba tartozhat...), a felső szint egy szigorú belépési küszöböt (még az eggyel alatta lévő tartományba eshet...) fejez ki, és lényegében a Gauss-görbe balra (megengedő) vagy jobbra (szigorú) eltolását jelenti döntéstől függően.

\begin{tabular}{|c|c|c|c|c|c|c|c|}
\hline Szint & 1 & 2 & 3 & 4 & 5 & 6 & \\
\hline Szint neve & $\begin{array}{c}\text { Nem } \\
\text { intézmé- } \\
\text { nyesült }\end{array}$ & Gyenge & Átlag alatti & $\begin{array}{l}\text { Átlag } \\
\text { feletti }\end{array}$ & Eredményes & Kiváló & \\
\hline Belépés alsó határa & 0 & $4-2 \sigma$ & $4-1 \sigma$ & 4 & $4+1 \sigma$ & $4+2 \sigma$ & \\
\hline $\begin{array}{l}\text { Egyetértés átlagának } \\
\text { belépő szintje }\end{array}$ & 0 & 1,492 & 2,796 & 4,101 & 5,405 & 6,709 & \\
\hline Elemszám eloszlása & $2,28 \%$ & $13,59 \%$ & $34,13 \%$ & $34,13 \%$ & $13,59 \%$ & $2,28 \%$ & \\
\hline \multirow[t]{2}{*}{ Kum. eloszlás } & $2,28 \%$ & $15,87 \%$ & $50,00 \%$ & $84,13 \%$ & $97,72 \%$ & $100,00 \%$ & \\
\hline & & & & & & & $\Sigma$ \\
\hline $\begin{array}{l}\text { Gyakoriság a mintában } \\
\text { (db) }\end{array}$ & 2 & 17 & 41 & 42 & 16 & 4 & 122 \\
\hline Elméleti eloszlás (db) & 2,7816 & 16,5798 & 41,6386 & 41,6386 & 16,5798 & 2,7816 & 122 \\
\hline $\begin{array}{l}\text { Sokasági becslés } \\
\text { elemszámra (db) }\end{array}$ & 762 & 4544 & 11411 & 11411 & 4544 & 762 & 33434 \\
\hline $\begin{array}{l}\text { Szintek alsó határai } \\
\text { (megengedő) }\end{array}$ & 0 & 1,261 & 2,565 & 3,869 & 5,173 & 6,477 & megengedő \\
\hline $\begin{array}{l}\text { Szintek alsó határai } \\
\text { (szigorú) }\end{array}$ & 0 & 1,724 & 3,028 & 4,332 & 5,636 & 6,940 & szigorú \\
\hline
\end{tabular}

17. ábra: Belső kontrollrendszer intézményesülési szintjeinek jellemzői a 3 szigma szabály alapján Forrás: saját összeállitás

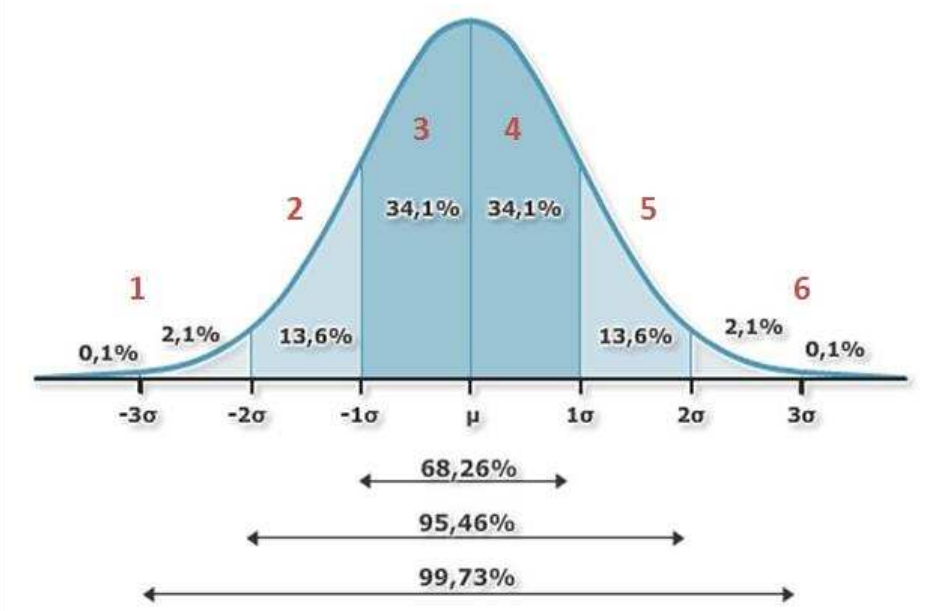

A fenti 17. ábrat összevetve a saját modellem eredeti 12. ábrajával, adódik annak szintézise, mely a kutatási eredményeimből levezetett értéktartományoknak megfelelően mutatja az egyes szintek belépési határait, a 
szintek nevét, valamint főbb matematikai jellemzőit. A végeredményt az alábbi 18. ábra tartalmazza

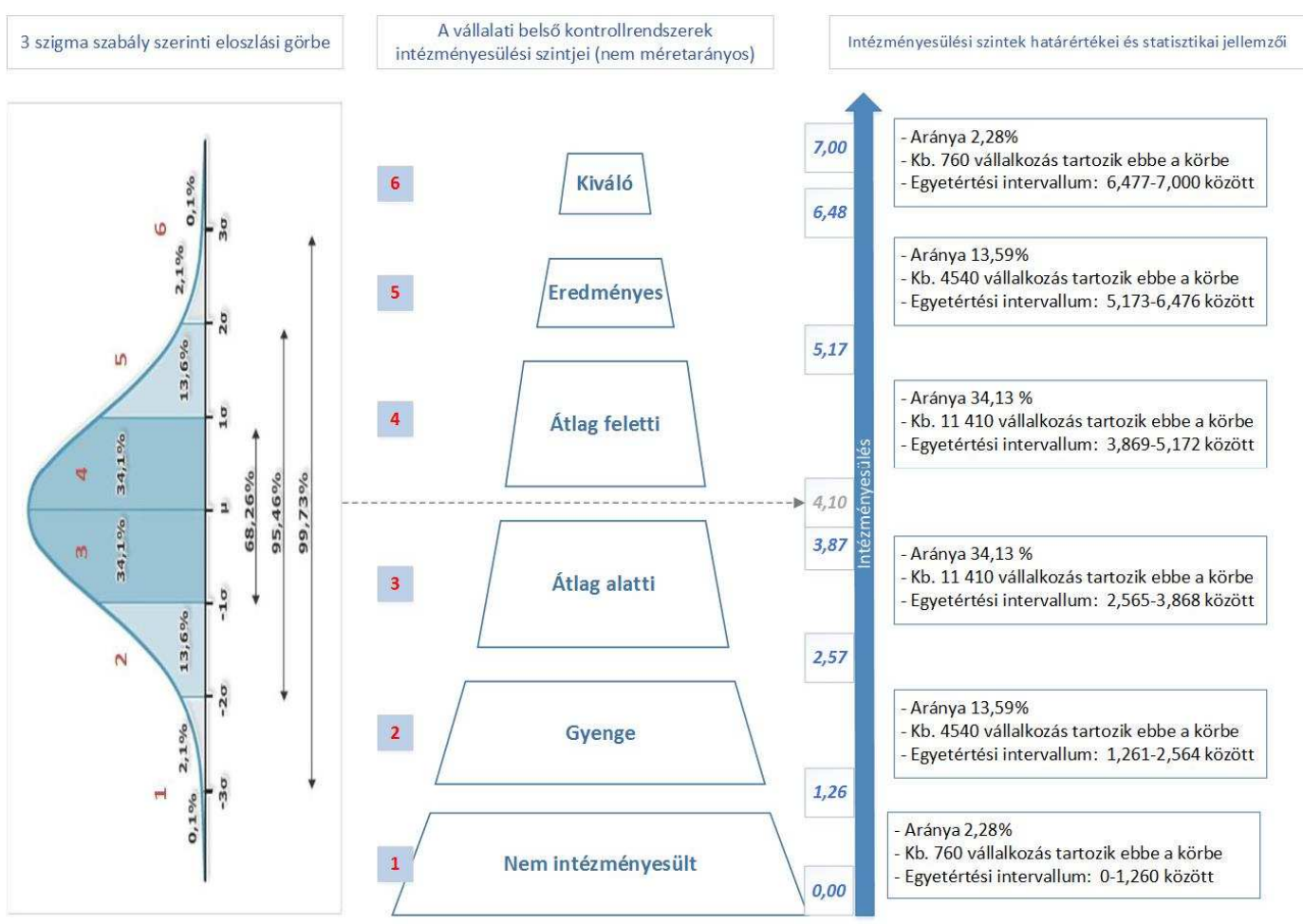

18. ábra: Kutatási eredmények szerint átdolgozott saját érettségi modell

Forrás: saját összeállitás

Megjegyzés: a szintek mérete nem arányos a szintbe tartozó vállalkozások darabszámával

\subsection{A fókuszcsoportok és a mélyinterjúk eredményei}

Kutatásom során 3 vállalatnál készítettem mélyinterjúkat a belső kontrollrendszert ismerő munkatársakkal, illetve a BEMSZ és az MCE tagsága körében egy-egy fókuszcsoportos megbeszélésre került sor a belső kontrollrendszerek múködése kapcsán. Ezen személyes megkeresésekkel az volt a célom, hogy a belső kontrollrendszerek múködését ne csak pusztán kérdőíves adatok feldolgozása révén, hanem - másodlagos módszerként - egyéni kérdések-feleletek formájában mélyebben is megismerhessem, és a vállalatok képviselői részéről szubjektív észrevételeket, visszajelzéseket fogadjak be. Ennek segítségével rejtett, a kérdőíves adatokból ki nem rajzolódó egyéb összefüggéseket kívántam feltárni, megismerni.

A megkeresett vállalatok a kutatási kérdőívet előzetesen nem töltötték ki. Válaszadó partnereim mind a három cégnél olyan munkatársak voltak, akik a kontrollrendszerre közvetlen rálátással bírnak, jellemzően belső ellenőrök a cégeknél. 
Mélyinterjúba vont partnereim szándékosan különféle vállalatokat képviselnek, a heterogén összetétel már a kiválasztáskor szempont volt számomra. Igyekeztem az interjúk körébe bevonni termelő, szolgáltató és kereskedő vállalkozást egyaránt, de kiválasztásukkor a tulajdonosi körre, főtevékenységre és méretre is tekintettel voltam. Ennek megfelelően interjúpartnereim cégei a következő adottságokkal jellemezhetők:

\begin{tabular}{|l|l|l|l|l|}
\hline \multicolumn{1}{|c|}{ Vállalat neve } & \multicolumn{1}{|c|}{ Iparág } & \multicolumn{1}{|c|}{ Főtevékenység } & \multicolumn{1}{|c|}{ Tulajdonosi kör } & \multicolumn{1}{c|}{ Méret } \\
\hline $\begin{array}{l}\text { Magyar Suzuki } \\
\text { Zrt. }\end{array}$ & Termelés & Gépjármúgyártás & $\begin{array}{l}\text { Japán székhelyü, } \\
\text { tokiói tőzsdén } \\
\text { jegyzett } \\
\text { anyavállalat }\end{array}$ & $\begin{array}{l}1 \text { gyártóegység, } \\
2800 \text { fő } \\
\text { munkavállaló }\end{array}$ \\
\hline $\begin{array}{l}\text { Magyar } \\
\text { Telekom Nyrt. }\end{array}$ & Szolgáltatás & $\begin{array}{l}\text { Távközlési } \\
\text { szolgáltatás }\end{array}$ & $\begin{array}{l}\text { Deutsche } \\
\text { Telekom német } \\
\text { anyavállalat, sok } \\
\text { kisebbségi } \\
\text { tulajdonos }\end{array}$ & $\begin{array}{l}\text { Sok telephely, } \\
6900 \text { fó } \\
\text { munkavállaló, } \\
14 \text { leányvállalat }\end{array}$ \\
\hline $\begin{array}{l}\text { Auchan } \\
\text { Magyarország } \\
\text { Kft. }\end{array}$ & Kereskedelem & $\begin{array}{l}\text { Lakossági } \\
\text { kiskereskedelem }\end{array}$ & $\begin{array}{l}\text { Francia } \\
\text { holdingközpont, } \\
\text { zárt tulajdonosi } \\
\text { kör }\end{array}$ & $\begin{array}{l}19 \text { áruház és 2 } \\
\text { logisztikai bázis, } \\
7000 \text { fó } \\
\text { munkavállaló }\end{array}$ \\
\hline
\end{tabular}

15. táblázat: Mélyinterjúba vont vállalkozások föbb jellemzői

Forrás: saját összeállitás

\subsubsection{Befolyásoló tényezők}

A mélyinterjúk során egyértelmúen igazolódott, hogy a tulajdonosi elvárások és a külső jogi előírások a meghatározó faktorok minden vállalat esetében, melyeket számukra kötelező figyelembe venni. A különbség igazából csak a mértékben van, azaz hogy mennyire domináns az egyik tényező a többihez képest, illetve hogy a magyar menedzsmentnek mekkora mozgástere van egyéni döntéseivel befolyásolnia a belső kontrollrendszer működését.

Egy-egy mondatban a sajátosságokat kiemelve (saját interpretációmban):

- Magyar Suzuki Zrt.: A japán anyavállalat (SMC) határozza meg a belső kontrollrendszer múködését, annak elemeit, és ehhez igazítja az auditkövetelményeket is, ezt a magyar vezetés nem alakíthatja át/tovább. $A$ magyar menedzsment felel az autóipari szabványok átültetéséért, meghonosításáért a mindennapi múködés során.

- Magyar Telekom Nyrt.: A német többségi tulajdonos (DT) adja ki a keretrendszert, és az ehhez szükséges szoftver tartalmaz minden követelményt, ezen kívül az éves ellenőrzési roadmap is DT előírásként 
érkezik a vállalathoz. A magyar menedzsmentnek csak a helyi kockázatok mértékének megállapításába van beleszólási lehetősége.

- Auchan Magyarország Kft.: A tulajdonosi körnek csak általános iránymutatásai vannak a belső kontrollrendszer múködését illetően, de konkrét módszerekkel, tartalommal a helyi vezetés tölti meg ezeket. A magyar menedzsmentnek nagyobb önállósága van ennek során. Sokkal nagyobb hangsúly van a magyar jogszabályoknak és az élelmiszerbiztonsági szabványoknak való megfelelésen, melyek be nem tartása figyelmeztetéssel és szankcionálással jár.

\subsubsection{Kontrollt végző felelősök}

A mélyinterjúk során egyértelmúvé vált, hogy a három vállalat mindegyikénél diverzifikált a kontrollrendszert működtetők köre, azaz többen és többféle aspektusban múködtetik a belső kontrollrendszereket. A védelmi vonalak 3 tényezős modellje többé-kevésbé tetten érhető, és a szereplők beazonosíthatók minden vállalatnál. A szereplők legitimitását a tulajdonosi elvárások, ill. a menedzsment által támasztott követelmények adják. A kiemelt legfontosabb észrevételeim, megállapításaim ehhez a következők:

- Magyar Suzuki Zrt.: Az első és a harmadik védelmi vonal egyértelműen elkülönül, világosak a felelősségi körök. A vezetők, ill. a folyamatgazdák felelősek első körben a belső kontrollok elvégzéséért. A második védelmi vonal összemosódik az első védelmi vonallal, bizonyos szakosított ellenőrzéseket az üzleti szervezetek maguk végeznek el. Ennek oka a járműgyártási szabványokban keresendő (ISO, $6 \sigma$ stb.), ill. a japán kultúrából fakad (lean, kaizen stb.).

- Magyar Telekom Nyrt.: A belső kontrollokért elsősorban 165 fő, erre kijelölt munkavállaló felel, akik kontrollfelelősi titulust is kapnak. Ezen felül a második és a harmadik védelmi vonal is müködik, ill. a belső kontrollrendszernek saját operatív menedzsere is van a vállalaton belül. $A$ tőzsdei jelenlét miatt itt markánsabb az Igazgatótanács, a FB, illetve az Audit Bizottság szerepe, ám ők inkább a belső kontrollrendszer alapvető múködését ellenőrzik, nem az egyes kontrollokat önmagukban.

- Auchan Magyarország Kft.: A belső hierarchiából eredően a kontrollokat elsősorban az áruházi vezetők végzik, valamint a központban lévő szervezeti egységek (igazgatóságok) nyújtanak ehhez szakmai támogatást. A védelmi vonalak 3 tényezős modelljét nem ismerik a cégnél, ugyanakkor a modell elemeit a gyakorlatban használják, például az elkülönített és független belső ellenőrzés végzi a kontrollrendszer átfogó ellenőrzését és értékelését, amely tipikusan a harmadik védelmi vonal egyik feladata. 


\subsubsection{Kontrolltevékenységek}

A mélyinterjúk során nem vállalkoztam arra, hogy valamennyi kontrolltevékenységet összepárosítsunk az azt ellátó munkakörrel, de felmértem a legfontosabb kontrolltevékenységek jellegét. Megállapítottam, hogy mind a három társaságnál diverzifikált, a teljes tevékenységet átható kontrollrendszert szándékoznak múködtetni a társaságok, és alkalmazzák a különféle kontrolltípusokat, ill. kontrollformákat is, azaz a kontrollmix követelménye teljesül. A legfontosabb egyediségek az következők:

- Magyar Suzuki Zrt: A rendszer erősen kockázatorientált, ezért azok a kontrolltevékenységek a hangsúlyosak, melyekről az üzleti területek úgy gondolják, hogy a múködést veszélyeztető jelenséget tudnak vele kezelni, megelőzni, minimalizálni. A feltárt kockázatokra a kontrollfelelősöknek (akik az 1. védelmi vonalban vannak) kell intézkedési terveket kidolgozniuk és végrehajtaniuk, ezt ellenőrzi vissza a függetlenített belső ellenőrzés.

- Magyar Telekom Nyrt: Mindenre kiterjedő, szinte valamennyi üzleti területet és folyamatot lefednek a kontrolltevékenységeik. Kifejezetten odafigyelnek arra, hogy a kontrollmixet alkalmazzák. A kontrollok nagy része manuális, ill. vezetői kontroll.

- Auchan Magyarország Kft.: Az áruházvezetés munkaköri listájában szerepel részletesen, hogy melyek azok a kontrollpontok, amelyeket az üzletmenet során rendszeresen (akár óránként is) el kell végezniük. Ezek nagy része kereskedelemorientált kontrollpont, melyek az alaptevékenységből erednek (pl. polcfeltöltöttség, készpénz-logisztika, számlalikvidáció). Igyekeznek minél több kontrolltevékenységet automatizálni és működési folyamataikba beépíteni.

\subsubsection{A kontrollrendszer intézményesültsége}

Valamennyi interjúpartnerem számára némi nehézséget okozott beleélniük magukat a szervezetszociológiai megközelítésbe, ezzel a tudományterülettel a gyakorlati munkájukban nem találkoztak eddig. A kontrollrendszerük érettségét, annak erős és gyenge pontjait, korábbi sikereit és fejlesztésre váró területeit azonban jól be tudták azonosítani. Ugyancsak könnyedén tudtak válaszolni az institucionalista megközelítés különféle hívószavaira is, mint pl. hatalomgyakorlás, jelek és szokások stb., és nem okozott gondot azok saját vállalatukra való adaptálása sem; így gyakorlatilag az intézményesültség kulcskérdéseit minden cégnél meg tudtuk tárgyalni a mélyinterjú során. 
Az alábbiakban a közös vonásokat, a hasonlóságokat emeltem ki az intézményesülési aspektusból:

- Erős az írásbeliség, a dokumentáltság, nem hangsúlyosak a szokások, a hagyományok, a (követett) íratlan normák. Erős formalizáltság (szoftver, úrlap, dokumentáció, belső jelentések) jellemzi a szervezeteket, és kifejezetten törekszenek is erre a belső kontrollrendszer működtetése során is. Ami nincs leírva, az nem számon kérhető, ezért igyekeznek a döntést, gyakorlatot, bevált módszert azonnal szabályzatba, utasításba, auditprogramba illeszteni.

- A hatalom és a hatalomgyakorlás ezen módja nem értelmezhető a belső kontrollrendszer kapcsán. A szereplők nem élnek vele, és nem élnek vele (vissza). A belső kontrollrendszer nem azért múködik, hogy deklarálja és megvalósíttassa a tulajdonosi, vezérigazgatói akaratot. A szereplőknek vannak jogkörei, döntési kompetenciái, ezekhez tartoznak különféle felelősségi körök, munkaköri kötelességek, és a munkatársak azért múködtetik a kontrollokat, mert ez a munkájuk része, nem pedig azért, mert hatalmuk révén ez nekik megadatik.

- A belső kontrollrendszer aktorai mindig beazonosíthatók a szervezeteken belül. Ezek közül kiemelkedik tevékenységével az első számú vezető, az auditálásért felelős igazgatók, a függetlenített belső ellenőrzés. Ezek a szereplők általában egy-egy tipikus munkakörben dolgoznak, kifejezetten feladatuk ilyen kontrolltevékenységek elvégzése, ellátása.

- Több szereplő együttmúködésére épül a rendszer közös múködtetése. Az együttműködés munkakörök között értendő, a bizottságok inkább csak formális szerepet játszanak a kooperációban, inkább csak beszámoltató szerepük van. Ezért az interakciók, az intézményesülés inkább munkavállalók, ill. anyavállalat-leányvállalat felelős munkatársai között zajlanak.

- A kontrollrendszer múködése több évre (akár az alapításig) visszanyúlik, az eltelt időszakban volt lehetőség alakítani, testre szabni, befolyásolni a rendszert, ezáltal a benne lévők is jobban elfogadják, és nem diktátumként (tulajdonosi utasításként) tekintenek rá.

- A belső kontrollrendszer legitimitását a tulajdonos és a menedzsment adja, ők fejezik ki azt a szándékot a vezetők és a beosztottak irányába, hogy ezt a rendszert múködtetni szükséges. Ugyanakkor a müködtetés során gyakran hivatkozik a menedzsment arra is, hogy ezt megéri múködtetni, mert több haszna van, mint amennyibe kerül. Azért nem megkérdőjelezhető, mert a vezetés is és a tulajdonos is számon kéri a múködését.

- A működtetés egyik kulcsa a rendszeresség, az állandó napirenden tartás, vagyis nem fellángolás-szerúen történik a megvalósítás. A kontrollok 
gyakorlása a vizsgált társaságok mindegyikénél mindennapi kötelesség, a könyvvizsgáló, a belső ellenőrzés, a vezetés pedig rendszeresen (visszatérően) ellenőrzi a kontrolltevékenységek megvalósulását, a kontrollgyakorlás módját. Tehát a kontroll gyakorlói állandó „nyomás alatt” vannak.

- A rendszer múködését kifelé nem igazán, de házon belül ismétlődő jelleggel terjesztik, oktatják (képzések, intranet, vezetői programok, hírlevél, vezetői kommüniké), ill. a cégcsoporton belüli (más leányvállalatokkal történő) egyeztetés, eszmecsere inkább a jellemző. 


\section{RÉSZ}

\section{ÖSSZEGZÉS, KONKLÚZIÓK}

Disszertációmban a belső kontrollrendszerek múködésével, intézményesülésével foglalkoztam részletesen, saját kutatásomat pedig 132 vállalatra kiterjedő mintán végeztem el e tárgykörben. Jelen lezáró fejezetben összefoglalom a téma legfontosabb tudnivalóit, és összegzem a kutatási megállapításaimat is. Egyúttal kritikai szemmel rámutatok a kapott eredmények korlátaira, és továbblépési lehetőségeket és gyakorlati javaslatokat is felvázolok magam és mások számára.

\subsection{A disszertáció témájának bemutatása}

A gazdasági tevékenység, az üzlet, a vállalkozások élete nem tudja nélkülözni a folyamatos visszacsatolást, a különféle kontrollok gyakorlását a szervezetekben. A vezetőknek szükségszerű visszatekinteniük és értékelniük az elért eredményeket, számot adniuk a célok, illetve a stratégia teljesüléséről, garanciákat adniuk a számadatok megbízhatóságáról, a szabályos múködésről, kezelniük a kockázatokat és kivédeniük az üzletre ható káros jelenségeket. E felelősség a menedzsmentet terheli, kiemelt szerepe van ebben az első számú vezetőnek. Ám a tulajdonos, a választott könyvvizsgáló, az adóhatóság, az érdekelt helyi civil szervezetek, a hitelezők, a finanszírozó bank stb. is elvárják a szabályszerü, eredményes, hatékony, megbízható múködést a vállalattól. Ezzel egyidőben a gazdasági bűnözés, a pénzmosás, a munkavállalói csalás, a korrupció, az adathalászat stb. még inkább felértékelték a belső kontrollrendszerek fontosságát. Ezért a revízió, a célra tartás, az ellenőrzés, a visszacsatolás, a folyamatok kontrollja a vállalatok sajátjává vált, ennek múködtetése pedig az egyik vezetői funkció lett. A vállalatok mára ezt a munkát szervezett keretek között végzik, melyet belső kontrollrendszernek (internal control system) nevezünk.

A belső kontrollrendszer célja, hogy a vállalat múködésével kapcsolatosan biztosítsa a szabályszerű működést, az eredmények (kitűzött célok) hatékony elérését, és mindezekről megbízható beszámolók (jelentések) szülessenek. A belső kontrollrendszer működtetéséért a vezetés, azaz a menedzsment a felelős, ám a kontrolltevékenységeket a vállalat minden területén, szintjén, telephelyén és részlegén alkalmazzák a beosztottak, a középvezetők és a közvetlen irányítást végző munkatársak is. A belső kontrollrendszer áthatja a szervezet mindennapjait, szokás úgynevezett védelmi vonalakkal együtt bemutatni. A védelmi vonalak 3 tényezős modellje deklarálja, hogy a vállalaton belüli folyamatokban a kockázatok kezelését, 
a veszélyek elhárítását, a vagyon védelmét, a stratégiai célok figyelemmel kísérését, a visszaélések felderítését stb. az üzletmenetet ellátók, a szakosított szervezetek és a független belső ellenőrzés párhozamosan, egymással együttműködve végzik el. Ezt a kooperatív együttműködést a vállalatvezetés, a felügyelő bizottság és egyéb tulajdonosi bizottságok, a tulajdonosi grémium, valamint a külső ellenőrzést végző szervezetek is figyelemmel kísérik, akik nem a 3 védelmi vonalban, hanem afelett múködnek, ill. attól függetlenek.

A belső kontrollrendszer követelményeit első ízben 1992-ben publikálták keretrendszerként, azóta 2004-ben a kockázatkezeléssel bővült a modell, és 2013ban megjelent a keretrendszer módosított, aktualizált második verziója.

A belső kontrollrendszert öt komponensre szokás bontani, ezek a következők:

- kontrollkörnyezet, ahol helyet kapnak a kontrollrendszert befolyásoló tényezők, elemek, melyeket a vezetésnek fel kell ismernie és figyelembe kell vennie a szervezet múködtetése során;

- kockázatfeltárás, amelyen belül a szervezet beazonosítja az üzleti tevékenységet veszélyeztető jelenségeket és azok lehetséges hatásait;

- kontrolltevékenységek, amelyeknek keretében alkalmazzák a különféle kontrollokat, ezek mixét, egyúttal kijelölik felelőseiket, meghatározzák az időzítést, a gyakoriságot, továbbá a szükséges beavatkozási szinteket, eljárási szabályokat;

- információ és kommunikáció, amelynek segítségével tájékoztatják az érintett külső és belső szereplőket a kontrollok gyakorlásával kapcsolatos információkról;

- monitoringfeladatok, melyek keretében elemzik és értékelik a teljes belső kontrollrendszer múködését, annak erős és gyenge pontjait, és fejlesztési javaslatokat dolgoznak ki.

A vállalati belső kontrollrendszer meghonosodása és mindennapokba való beépülése, megkérdőjelezhetetlenné válásának folyamata jól jellemezhető az institucionalista szervezetelmélet segítségével. Az intézményesülés elvont, szervezetszociológiai foglalom, azonban a szervezetelméletek közül ez az egyik, igen jól alkalmazható teória a belső kontrollrendszerek vizsgálata esetében. Az intézményesülési megközelítés azt vizsgálja, hogy egy tevékenység miképpen válik a szervezeten belüli mindennapok részévé, mikortól nem elhagyható, kik a kulcsszereplői (aktorai), milyen szankciókat von maga után annak megsértése, valamint hogy hogyan változik (és változtat meg másokat) egy már intézményesült múködési rendszer. Az institucionalisták olyan kérdéseket is elemeznek, mint például a viselkedés másolása (kooptálás), a hatalomgyakorlás, a jelek és 
szimbólumok szerepe a vállalatok múködésében, a tudásmegosztás jellemzői a szervezetközi terekben.

Intézményesülési aspektusból vizsgálva tanulmányozni lehet a vállalatok belső kontrollrendszerének múködését, és fel lehet tenni kutatási kérdéseket, fel lehet állítani hipotéziseket. Mindezek közül disszertációmban a következő összefüggésekkel foglalkoztam részletesen:

1. Milyen külső és belső tényezők, elemek befolyásolják a belső kontrollrendszerek múködését a hazai vállalatok esetében?

2. Kik és hogyan múködtetik a belső kontrollrendszert, kik a kulcsszereplői egy ilyen rendszernek, főleg mely munkakörökben testesülnek meg ezek a feladatok?

3. Milyen kontrolltevékenységek, kontrollmechanizmusok az elterjedtek e rendszerben, és azok milyen kapcsolatban vannak egymással?

4. A belső kontrollrendszer mennyire érett, hogyan épül bele a szervezet mindennapi múködésébe, tevékenységébe, azaz hogyan érhetők tetten az intézményesülésre utaló konkrét jelek?

\subsection{A dolgozat íve, fókusza, alkalmazott módszerek}

Dolgozatom szerkezete lineáris, logikai kifejtések mentén ismerteti a jelenlegi szakirodalmat és a szerzők megközelítéseit, téziseit. A téma alapvető bemutatását, aktualitását és jelenlegi trendjeit, valamint saját érdeklődési területem ismertetését dolgozatom bevezetése tartalmazza.

A tartalomjegyzékre tekintve láthatjuk, hogy a téma felvezetését az alapoktól, azaz a belső kontrollrendszer kulcsszavainak definiálásával kezdtem. Bemutattam az egyes szakszavak hétköznapi és szakmai jelentéseit, és rávilágítottam arra, hogy a magyar és az eredeti angol elnevezések között fennálló fordítási különbségek tévútra terelhetik annak használóit, ezért körültekintően kell alkalmazni őket.

Az alapvető fogalmak definiálását követően leszűkítettem a belső kontrollrendszer témakörét az üzleti szervezetekre. Bemutattam az egyes elágazásokat, azaz a különbségeket a külső ellenőrzés és a belső kontroll között; érvekkel alátámasztva kizártam az államháztartási szervezetekre vonatkozó követelményeket, és megindokoltam, hogy miért nem foglalkozom egyéb funkcionális revizori feladatokkal, úgy mint múszaki, pedagógiai, munkavédelmi stb. ellenőrzésekkel. Egyúttal rávilágítottam arra is, hogy disszertációmban a belső kontrollt rendszerszinten elemzem, ezért a tematikus altémákra sem fókuszálok részletesen, nem ragadok ki egyetlen kockázatot sem (mint például korrupció, könyvelési csalás, adatbiztonság stb.). 
Értekezésemben a szúkebb téma megalapozása céljából kitértem a kontroll szó konnotációira, a menedzsmenttanokban használt különféle (nemzetközi és hazai) értelmezéseire is, és történelmi fejlődését is bemutattam annak érdekében, hogy a belső kontrollrendszerek múködését célirányosan tanulmányozni tudjam. A vállalatokon belüli kontrolltevékenységek rendszerszerű megközelítését az általános rendszerelmélet és -szemlélet segítségével végeztem el. Ennek során feltártam és beazonosítottam a rendszer elemeit, az elemek közötti kölcsönhatásokat és a rendszerre ható környezeti tényezőket.

Ezt követően részletesen bemutattam a belső kontrollrendszerre vonatkozó konkrét előírásokat, a keretrendszer szabványát, annak alapelveit, múködésének filozófiáját. E modell adta meg a belső kontrollrendszereket leíró szakmai alapot dolgozatomban, mely keretrendszer 3 dimenzióban, 5 komponensben, háromféle célirányban és 17 alapelvben rögzíti a kontrollrendszerek elvi múködését. Ugyancsak a szakirodalmak alapján ismertettem a szereplőit, végül kritikákkal illettem a modellt. Kitekintettem a védelmi vonalak 3 tényezős modelljére és további, a COSO keretrendszerre épülő vagy amellett létező modelleket is bemutattam.

Disszertációmban helyet kapott az intézményesülési megközelítés is, ezért az intézményi szervezetelméletre vonatkozó ismereteket mutattam be disszertációm negyedik fejezetében, ahol először ezen elmélet fő téziseit vázoltam, majd összekötöttem ezeket a belső kontrollrendszerre vonatkozó elméleti keretrendszerrel, végül saját intézményesülési-érettségi modellt mutattam be. $\mathrm{E}$ fejezetben példák segítségével összekapcsoltam az intézményi szervezetelméleteket a belső kontrollrendszerek jellemzőivel, kiemelve a legfontosabb illeszkedési pontokat, illetve tényezőket, melyek későbbi kutatási kérdéseimhez járultak hozzá.

$A z$ intézményesüléssel foglalkozó fejezetben már felvázolt összefüggések alapján megfogalmaztam a saját kutatási kérdéseimet, felállítottam $\mathrm{H} 1-\mathrm{H} 4$ hipotéziseimet, és bemutattam az ezek tesztelésére vonatkozó eredményeket. Ezzel együtt ismertettem az adatgyűjtés és kiértékelés módszertanát, az online kérdőíves adatfelvétel főbb lépéseit, az érvényesség és megbízhatóság kritériumait. Téziseimhez vezető utam végén kiértékeltem az egyes szakmai hipotéziseimet, és azokat alábontó, részletes feltáró elemzéseket végeztem, melyeknek eredményeként további megállapításokat tettem.

Kutatási módszertanom kvantitatív elveken nyugvó, elsődlegesen kérdőíves megkeresést alkalmazó módszer volt. Kutatásom kezdetén mintegy 33 ezer hazai kis-, közép- és nagyvállalatból álló címjegyzéket állítottam össze, ezek közül mintegy 24 ezer vállalkozást tudtam megszólítani e-mailen keresztül. A kiküldött kérdőívet 839 vállalat nyitotta meg, és végül 139 vállalat töltötte ki teljes körűen azt. Ezek 
közül 7 vállalat válaszait kellett kiszűrnöm, figyelmen kívül hagynom. Kutatási eredményeimet így 132 vállalat által teljes körüen kitöltött kérdőíves válaszok alapján fogalmaztam meg, megállapításaimnál figyelembe vettem további 3 vállalkozásnál végzett személyes mélyinterjúm eredményeit.

Az alkalmazott kutatásmódszertani eszközöket a konkrét hipotézisekhez, valamint a kérdőíves adatbázis adataihoz igazítottam. Használtam leíró jellegú elemzéseket (átlag, szórás, csúcsosság, módusz, medián), Sperman-féle rangkorrelációt, faktorelemzést, Pearson-féle korrelációt, klaszter- és faktorelemzést, normalitásvizsgálatot Kolmogorov-Smirnov módszerrel, melyek eredményeit mellékeltem disszertációmhoz. Kutatásom során három vállalatnál mélyinterjút is végeztem, ill. két szakmai szervezet tagjai körében egy-egy fókuszcsoportos megbeszélésen elemeztük a kutatás kérdéseit, illetve eredményeit.

Munkámra vonatkozó szakmai gyújteményeimet, a kutatási kérdőívet, a kérdőív mögött lévő adatbázis struktúráját, valamint a hipotézisek kiértékelését alátámasztó részletes számadatokat, táblázatokat mellékeltem disszertációmhoz. Függelékbe kerültek a szakirodalom szintetizálásából előállított saját gyűjtéseim, listáim is, melyeket a kutatási kérdőívem összeállításánál figyelembe vettem.

\subsection{A kutatási eredmények összegzése}

Disszertációmban négy különálló szakmai hipotézist - azokon belül összesen 13 alhipotézist - állítottam fel és teszteltem, és valamennyi hipotézis kiértékelését követően mélyebb elemzést végeztem a vizsgálati kérdések kapcsán.

A H1 szakmai hipotézis kapcsán a belső kontrollrendszert befolyásoló tényezőket vizsgáltam rangkorrelációs eszközökkel. Megállapítottam, hogy az előzetesen felállított hipotézisemet azért kell elvetni, mert a befolyásolási rangsor elején nincsen a vállalati méretet (létszám, telephelyek száma) megtestesítő tényező. Helyette a követelményeket előíró, szabályozó, diktáló tényezők kerültek a rangsor elejére, úgy mint a tulajdonosi kör elvárásai, a jogszabályi rendelkezések, valamint az iparági standardok, a tevékenységre vonatkozó előírások. A kontrollkörnyezet főbb tényezőiként tehát ezek a faktorok befolyásolják leginkább a belső kontrollrendszereket. Ezt a megállapítást 4 ágazat kivételével valamennyi szegmensre igaznak találtam, azaz megállapítottam, hogy az intézményesülésük során nincs érdemi különbség az egyes iparágakban.

A H2 szakmai hipotézisben a kontrolltevékenységeket ellátó szereplőket vizsgáltam részletesen munkaköri aspektusban, vizsgálódásom kitért az intézményesült belső kontrollrendszer kulcsszereplőire, aktoraira. A H2 hipotézist végül el kellett vetnem, ennek fő oka az volt, hogy a számviteli-pénzügyi terület, ill. a belső adatokkal 
dolgozó kontrollerek és vállalatirányítási specialisták szerepe sokkal markánsabb volt, mint ahogyan azt korábban feltételeztem. Ezzel szemben a minőségbiztosítási belső auditor és a függetlenített belső ellenőr szerepe a valóságban sokkal gyengébb volt, mint azt előzetesen vártam. A kapott válaszok alapján azt is megállapítottam, hogy olyan „egzotikus” munkakörök, mint például a compliance officer, a forensic accountant, a fraud manager vagy az etikai koordinátor, csak elvétve léteznek a választ adó gazdasági szervezeteknél.

A kulcsszereplők kapcsán megállapítottam azt is, hogy a kontrolltevékenységeket végzők jellemzően főállásban, ám nem szervezeti egységbe tömörülve, hanem inkább önállóan látják el a kontrollrendszer múködtetését. Vagyis az intézményesülés folyamatában inkább individuumként és nem szakosított szervezeti egységként vesznek részt. Létszámuk alacsony, kontrolltípusonként tipikusan 1-2 fő között mozog (a vezetői munkakört nem számítva), egy vállalaton belül összesen 4-5 fö lát el ilyen szakosított feladatkört. Bár e létszámok abszolút értékben elég alacsonynak tekinthetők, az összvállalati létszámadatokhoz hasonlítva azt is megállapítottam, hogy kb. minden ötödik foglalkoztatott végez kontrolltevékenységet a vállalkozásokban, azaz múködtetője a vállalati belső kontrollrendszereknek.

A H3 szakmai hipotézis a különféle kontrolltevékenységek elterjedtségét és ezek egymással való összefüggését vizsgálta. A négyféle kontrolltípus mindegyike ismert és alkalmazott a szervezetekben, de nem az előzetesen feltételezett arányban alkalmazzák ezeket a válaszadók, ezért a H3 hipotézist el kellett vetnem. Az elvetés azonban sokkal inkább technikai jellegú, mert az elutasítást okozó két alhipotézis mindegyike esetében arról van szó, hogy az érintett kontrolltípusok jobban elterjedtek, mint én azt korábban feltételeztem.

A kontrolltevékenységek kapcsán azt is megállapítottam, hogy a vállalkozások alkalmazzák a kontrollmixet, mivel mind a négyféle kontrolltevékenység elterjedt volt esetükben. Azonban azt is láttam, hogy a manuális (ember által végzett) kontrollok túlsúlyban vannak az automatizált (folyamatba épített) kontrollokhoz képest, és sok esetben emberi közreműködésre van szükség olyan esetben is, amikor az elhagyható lenne. A vizsgált kontrolltevékenységeket ezt követően faktorelemzésbe, ill. klaszterelemzésbe vontam be, melynek eredményeként megerősítést nyert a $\mathrm{H} 2$ hipotézisnél már kirajzolódó modell: önálló csoportot képeznek a vezetői kontrollok, a számadatokkal végzett visszatekintő kontrollok, a fizikai vizsgálódáson alapuló kontrollok, és végül maradnak egyéb kontrollok, melyek leginkább a folyamatokba épített kontrollok körébe tartoznak.

A H4 hipotézis kiértékelése kapcsán kísérletet tettem a belső kontrollrendszerek érettségének saját modelljét is kiértékelni és matematikai képlettel, 
szóráselemzéssel lehetővé tenni az érettségi modell jellemzését. A kísérlet pozitív eredménnyel zárult, és ennek eredményeképpen a $\mathrm{H} 4$ hipotézist el kellett utasítani, mert az abban szereplő homogenitási kritérium túl szigorú volt a kitöltők válaszai esetében. Megállapítottam, hogy az intézményesülésre vonatkozó állításokkal való egyetértés során a kitöltők 80\%-a esetében az érettség szintjére adott válaszok 7 fokozatú skálán legfeljebb 1,69-es szórást mutattak, tehát ezen kitöltők esetében az ő kontrollrendszerük érettsége 49 homogén válaszból kikövetkeztethető.

A homogenitásra vonatkozó követelmény mellett Kolmogorov-Smirnov próbával igazoltam, hogy az egyetértés szintjére vonatkozó 122 átlag- és szórásmutató normál eloszlást mutat, amiből következtettem az intézményesültségi szintekre, azok belépő számértékeire. A $3 \sigma$ szabályt alkalmazva megállapítottam, hogy a 7 fokozatú skálát figyelembe véve a 2,80-5,41 tartományokba esik a válaszadók azon kb. 2/3-a, ahol a belső kontrollrendszer intézményesültsége átlag közelinek (adott mértékkel az átlag alattinak, ill. adott mértékkel az átlag felettinek) tekinthető, és amit modellemben (3.) és (4.) szintnek jelöltem meg. Az ezen tartományon kívül eső válaszadókat pedig további 2-2, összesen 4 darab tartományba soroltam, nekik az (1.) nem intézményesült, (2.) gyenge, (5.) eredményes, (6.) kiváló fokozatokat adtam. Ezzel megteremtettem a saját modellem hat fokozatának felülvizsgált elnevezését, és kijelöltem a fokozatok tartományi határait is.

Összességében az értekezésemben megfogalmazott téma vizsgálatával és saját kutatásom révén a következő eredményeket értem el:

- feltártam a vonatkozó szakirodalmakat, részletesen bemutattam a kontroll aspektusait, és végigvezettem azt egészen a belső kontrollrendszer leírásáig, majd összekapcsoltam ezt az institucionalista szervezetelmélettel, és ennek metszeteként előállítottam kutatási kérdéseimet;

- a feltárt szakirodalmak és a saját kutatásom eredményeképpen információkat nyertem ki, illetve összefüggéseket ismertem meg a hazai vállalkozások belső kontrollrendszereinek aktuális múködésére és a ráható tényezőkre vonatkozóan;

- függelékbe kerültek az egyes hipotézisekhez kapcsolódó saját gyújtések, kategorizálások a szereplőkre, kontrolltevékenységekre, kockázatokra vonatkozóan;

- a kiindulásul szolgáló saját érettségi modellem igazolását követően jellemeztem a belső kontrollrendszerek intézményesülésének szintjeit;

- többváltozós statisztikai elemzések segítségével további jellemzőket ismertettem a belső kontrollrendszerek múködésével kapcsolatosan a hazai vállalkozásokra vonatkozóan. 


\subsection{Kritikák és kitekintések}

A disszertációmban közölt tézisek és megállapítások, mint új ismeretek, az akadémiai szegmensben tevékenykedő oktatók, kutatók és hallgatók mellett a gyakorló vállalati szakemberek, vezetők számára is új információként szolgálnak. Remélem, hogy az eredmények publikációkon keresztül a vállalati gyakorló munkatársak számára is elérhetőek lesznek a későbbiekben. Bízom benne, hogy a feltárt összefüggések, a mintaként szolgáló érettségi modellem és a kutatási eredmények a vállalatok vezetői, irányítói, gazdasági szakemberei számára is hasznosak lesznek, újdonságértékű ismeretanyagként szolgálnak majd számukra is.

A jövőre vonatkozóan ugyanakkor szükségesnek látok gyakorlati javaslatokat is megfogalmazni - magam és/vagy kutató kollégáim részére. Ezek a javaslatok a saját kutatási eredményeimmel kapcsolatosak, azok továbbvitelét, későbbi cizellálását, mélyebb feldolgozását szorgalmazzák. E javaslatok a továbblépést illetően a következők:

1. Alaposabban kell oktatni és fel kell hívni a hazai gyakorló szakmabeliek figyelmét arra, hogy az ellenőrzés és a kontroll egymásnak nem szinonimája - nyelvileg sem és tartalmilag sem. A kérdőívre kapott válaszok és a mélyinterjúk, továbbá a fókuszcsoportos megbeszélések mind rávilágítottak arra, hogy hazánkban e két fogalom kapcsán (még mindig) keveredés van. Mind a szakirodalomban, sajtóban és honlapokon, mind a képzéseken, szakkonferenciákon törekedni kell ezek szétválasztására és a különbségek egyértelműsítésére.

2. Jelen disszertációm fókuszában az üzleti szervezetek, vagyis a gazdasági társaságok és a szövetkezetek voltak. Ugyanakkor a kutatást azonos körülmények között érdemes lenne elvégezni az államháztartási szervezetek és a civil szervezetek körében is. Vélelmezem, hogy az Áht. előírásai miatt a költségvetési szerveknél erősebb intézményesülést, míg a civil szervezeteknél nem intézményesült (minimálisan múködő) kontrollrendszert tudnánk beazonosítani.

3. Az adatgyújtés során mindössze egy pénzügyi intézmény töltötte ki a kérdőívet, és az általa adott válaszok igen eltérő értékeket mutattak a többi iparágra jellemző válaszoktól. A kutatás során nem volt lehetőségem ezen iparágból további kitöltóket elérni. Ezért szükségesnek látom a felmérést megismételni, kiterjeszteni ebben az iparágban, hogy megbizonyosodjunk róla: csak egy pénzintézet látja másképp a belső kontrollrendszerét, vagy minden pénzintézet elüt a hazai összes iparági, sokasági jellemzőtől. Mindezt a BASEL III. követelmények és a vonatkozó MNB elvárások miatt is érdemes mélyebben elemezni.

4. A válaszadók alacsony száma miatt a kutatás nem lett reprezentatív, a nagyvállalatok és a részvénytársaságok túlreprezentáltak voltak a mintában. Ezért nem vonhatók le általános következtetések a hazai szervezetek 
mérete, gazdálkodási formája, tevékenységi köre, földrajzi megoszlása szerint. Emiatt szükségszerű lenne a kutatást folytatni, a válaszadók számát növelni és egy reprezentatív mintán a hipotéziseket újra tesztelni. Mindezeket akár úgy is, hogy a válaszadók névtelenül, anonim módon töltik ki a kérdőívet. További lehetőségként adódik a földrajzi országhatár kitágítása is, hiszen jelenleg csak a hazai vállalkozásokat vizsgáltam a kutatásom során, de a kérdőív akár a világ összes országában kitölt(et)hető lenne.

5. Az előre tematizált kutatási kérdőív nem tette lehetővé a pénzügyiszámviteli munkatársak, a kontrollerek és az ERP specialisták tevékenységének részletes elemzését a belső kontrollrendszerek múködésével összefüggésben. E ponton egy feltáró jellegű további kutatásra lenne szükség, mivel a $\mathrm{H} 2$ és a $\mathrm{H} 3$ hipotézisnél is látható volt, hogy a számszaki, pénzügyi adatokkal való munka markáns kontrolltevékenységi körként jelent meg, ezért ennek mélyebb tartalmát, mibenlétét alaposabban érdemes elemezni.

6. A H3 hipotézis kapcsán láthatóvá vált, hogy az automatikus kontrollok kevésbé elterjedtek, és alulértékeltnek tűnnek hazánkban a manuális kontrollokhoz képest; és azt is láttuk, hogy a vezetői kontrollok teszik ki az összes kontrolltevékenységnek majdnem a felét. Ezért szükségszerű lenne jobban rávilágítani a fókuszt az automatikus, számítógép által vezérelt, folyamatba ágyazott kontrollokra. Ezek ugyanis sok esetben olcsóbbak, valós időben alkalmazhatóak, ember által nem befolyásolhatók és könnyen nyomon követhető, visszaellenőrizhető kontrolltevékenységek.

A saját kutatásomat leíró fejezetben már felhívtam a figyelmet a kapott eredmények korlátaira, de szükségesnek érzem itt újból rámutatni ezekre a megszorításokra, melyek a következők:

a) A válaszadási hajlandóság igen alacsony, mindössze 132 kiértékelhető vállalat került be a mintába, így a válaszadási hajlandóság 0,395\% lett, míg a minimálisan elvárt mintaelemszám 4800 hazai vállalakozás lett volna ahhoz, hogy reprezentativitásról beszélhessünk. A válaszadók esetében nem zárhatjuk ki a szelekciós torzítást sem, mert a kvótás mintavételt nem alkalmaztam, ugyanakkor a szakmai szervezetek (BEMSZ, MCE, MMT) tagjai köréből több kitöltés érkezett. Ezért a következtetések nem tekinthetők reprezentatívnak. Habár a kapott válaszok érvényesnek tekinthetők a kitöltő 132 vállalat esetében, és elemzésre is alkalmasak voltak, de mégsem általánosíthatók a teljes hazai sokaságra vonatkozóan.

b) A válaszadók névvel ellátva adták meg válaszaikat számomra, és ennek tudatában is voltak. Ezért feltételezhető, hogy a kérdőívet inkább az érettebb, bátrabb, jobban intézményesült belső kontrollrendszerrel 
rendelkező társaságok töltötték ki. Ebből következik az a feltételezés, hogy a valóságos helyzet a kb. 34 ezres populációban rosszabb, mint a 132 vállalat esetében, mert a rejtőzködők, nem válaszolók esetében a belső kontrollrendszer kevésbé érett, kevésbé fejlett, mint a választ teljes körüen megadók körében.

c) A gazdasági társasági formánál alkalmazott lehatárolásnál a társas gazdálkodókra szúkítettem vizsgálatom fókuszát, és szándékosan figyelmen kívül hagytam az egyéni vállalkozókat, az őstermelőket, a különféle társulásokat, akik (amelyek) bejegyzett darabszáma - hazánkban összességében több mint kétszerese a társas vállalkozásokénak. Ezért ha a teljes magyar gazdaságról szeretnénk átfogó képet kapni, e szereplőkre is ki kellene terjeszteni az elemzést. Ekkor ugyanis objektív úton tudjuk megállapítani, hogy a mikrovállalkozásoknál és az egyéni gazdálkodóknál van-e egyáltalán kontrollrendszer, amit elemezni lehet. Ugyanakkor módszertanilag is tovább kell vizsgálni, hogy van-e érdemi különbség pl. az egyszemélyes gazdasági társaság és az egyéni cég között, ha utóbbiban a valóságban csak egy-egy magánszemély végez tevékenységet.

d) A kérdőíves adatfelvétel és annak kiértékelése során néhány magától értetődő, munkaköri és munkaszervezéssel összefüggő feltételezéssel éltem, és ezeket nem vitattam. Így például alapul vettem, hogy ahol létezik kontrolltevékenység, ott az múködik is, vagy például ha van adott munkakör, akkor ő el is végzi a megjelölt kontrollmechanizmusokat. A valóságban azonban elképzelhető, hogy ez az ok-okozati viszony nem állja meg a helyét, mert ha létezik valami, még nem biztos, hogy múködik is, ill. megkérdőjelezhető működésének a mértéke, haszna, eredménye. Ugyanígy lehetséges az is, hogy a munkakört betöltő munkavállaló - a főáramlattal és a sokasági jellemzőkkel ellentétben - az adott cégnél nem végez kontrolltevékenységet, hanem más feladatköre van, vagy munkaköre esetleg tévesen került megállapításra. Ezeket a mély összefüggéseket csak valós megfigyelésekkel, több mélyinterjúval, egyéb kvalitatív kutatási eszközökkel lehet nagy biztonsággal feltárni, amire jelen disszertáció keretében nem volt lehetőségem, ill. szándékom.

e) Saját modellemet felülvizsgáltam a kutatási eredményeim alapján, s a normalitásnak köszönhetően statisztikai jellemzőkkel tudtam leírni az egyes érettségi szinteket, valamint neveket is tudtam adni e szinteknek. Azonban az egyes szintek minőségi jellemzőit egyenként statisztikai módszerekkel nem vizsgáltam. Ezért a kiinduló ábrán szereplő egyes minőségi jellemzőket továbbra is adottnak vélem, de ezekre vonatkozóan nem végeztem próbákat. Ez ugyanis már erősen meghaladja a H4 hipotézis vizsgálatát, sőt $\mathrm{e}$ disszertáció terjedelmét is. 


\section{FÜGGELÉK - A KONTROLLRENDSZEREK SZEREPLŐI, MŰKÖDTETŐI A VÁLLALATOKBAN}

A belső kontrollrendszerek múködését a kontrollkörnyezet erősen meghatározza, befolyással van rá, s ezt a COSO-keretrendszer ismertetésénél magam is részletesen bemutattam disszertációm III. részében. A kontrollkörnyezet egyik meghatározó eleme a vállalat szervezeti struktúrája, a vállalati struktúrában pedig olyan befolyásoló szereplőket is azonosíthattunk, akik munkavállalóként vagy szervezeti egység vezetőjeként kiemelt múködtetői, alakítói a vállalaton belüli kontrollrendszernek, azaz múködtetik a belső kontrolltevékenységek egyes típusait, illetve részt vesznek az információs és kommunikációs, illetve a monitoringtevékenységben is, azonban a coso-rendszertől többé-kevésbé elkülönülő, önálló szabályrendszerrel, normákkal, célokkal rendelkeznek a szervezeten belül.

E szereplők intenzív kölcsönhatásban vannak a belső kontrollrendszerrel, tevékenységük többé-kevésbé befolyásolja a belső kontrolltevékenységeket, vagy azokkal részben átfedésben is van, mivel azonos célokat szolgálnak (pl. küldetés és stratégia elérése), közös információs rendszert használnak (pl. tranzakciós vállalati alapadatok, könyvelési analitikák), vagy hasonló elemzési és ellenőrzési módszerekkel végzik tevékenységüket (pl. mutatószámok képzése a teljesítmények mérése során).

Az alábbiakban tehát azokat a kontrollkörnyezeti elemeket, illetve szereplőket mutatom be röviden, amelyek, illetve akik ${ }^{103}$ kulcsszereplői lehetnek egy-egy vállalati kontrolltevékenységnek, és saját küldetésük, feladatkörük alapján maguk is kontrolltevékenységekkel foglalkoznak a vállalaton belül.

E fejezet disszertációm függelékében kapott helyet. Célom az, hogy vázlatosan, de témám szempontjából célravezetően mutassam be e szereplőket, tevékenységüket, a rájuk vonatkozó külső normákat és szabályokat, illetve a szakirodalom szerinti legfontosabb jellemzőiket. E függelék összeállításánál alapvetően Löffler és társai múvéből indultam ki (Löffler et al., 2011., pp.533-612.), de más szerzők szakirodalmi

\footnotetext{
${ }^{103} \mathrm{Az}$ „amely” szó itt rendszerre, eljárásrendre, belső intézményre vonatkozik, az „aki” pedig konkrét személyre, munkavállalóra, státuszra, tisztségre. A rendszerek müködhetnek emberek nélkül is, ezek tipikusan az automatizált rendszerek, illetve az intézményesített, szabályozott eljárásrendek. A vállalaton belüli kontroll nagymértékben személyfüggő, és az automatizált rendszerek mögött is második vonalbeli személyek állnak. Ezért a rendszerek és a szabályok elemei mögött elöbb-utóbb mindig találunk személyt is, aki cselekszik, mérlegel, figyelmeztet, dönt, beavatkozik. A vállalaton belüli kontroll automatizálhatóságának határairól, korlátairól lásd bővebben (Anthony \& Govindarajan, 2009., pp.4-5.).
} 
megállapításait is idézem jelen függelékben. Fontosnak tartom rögzíteni, hogy e függelékben bemutatottak nem disszertációm folytatásaként, hanem kiegészítő, szemléltető céllal kerültek ide. E függelékben a következő kontrollmechanizmusokat, kontrollintézményeket, illetve kontrollszereplőket mutatom be részletesen:

- Függetlenített belső ellenőrzés (a belső ellenőr) (F11)

- Számviteli rendszer normái (F12)

- Könyvvizsgálati ellenőrzés (a könyvvizsgáló) (F13)

- Kontrollt gyakorló bizottságok (felügyelőbizottság, audit bizottság stb.) (F14)

- Kontrolling (a kontroller) (F15)

- Minőségirányítási rendszer (belső auditorok, minőségellenőrök) (F16)

- Egyéb kontrolláló szerepkörök (compliance manager, fraud manager, etikai felelős stb.) (F17)

\section{F11. A függetlenített belső ellenőrzés}

A vállalati belső kontrollrendszer kontrolltevékenységeinek egyik eleme a függetlenített belső ellenőrzés. A kettőt nem szabad összemosni, illetve összetéveszteni (Löffler et al., 2011., p.539.). A belső ellenőrzés normáit a Belső Ellenőrök Nemzetközi Szervezete (IIA) dolgozta ki, s egyben az IIA a belső ellenőrök legfőbb globális szakmai szervezete is. Az IIA jogelődje 1941-ben alakult meg New Yorkban abból a célból, hogy szakmai támogatást nyújtson a belső ellenőrök (internal auditor) munkájához, képviselje érdekeiket, összehangolja működésüket, segítse tudásuk és tapasztalataik megosztását. Hazánkban a Belső Ellenőrök Magyarországi Szervezete (BEMSZ) ${ }^{104}$ tömöríti az említett szereplőket és végzi az IIA célkitúzéseinek megvalósítását.

Az IIA 1978 óta adja ki és vizsgálja felül a belső ellenőrzési normákat (International Standards for the Professional Practice of Internal Auditing (Standards)) ${ }^{105}$, illetve a belső ellenőrök etikai kódexét (Code of Ethics) és a belső ellenőrzés fogalmi meghatározását (Definition of Internal Auditing). Ezen alapdokumentumokra épülve jött létre, illetve fejlődött ki a szervezetek belső ellenőrzési rendszere.

\footnotetext{
104 A magyar BEMSZ-ről bővebben itt: http://iia.hu/ (2015. 01. 16.)

105 Eredeti változata elérhető itt: https://na.theiia.org/standards-guidance/mandatoryguidance/Pages/Standards.aspx (2015. 01. 16.)
} 
Az IIA a belső ellenőrzés definícióját ${ }^{106}$ a következők szerint határozta meg: „A belső ellenörzés olyan független, objektív bizonyosságot adó eszköz és tanácsadói tevékenység, amely értéket ad a szervezet múködéséhez és javitja annak minöségét.

Módszeres és szabályozott eljárással értékeli és javítja a kockázatkezelési, a kontroll- és az irányitási folyamatok hatékonyságát, ezáltal segíti a szervezeti célok megvalósítását."

Hasonlóképpen fogalmaz az INTOSAI irányelve is, amely szerint (INTOSAI Professional Standards Committee, 2004., p.64.):

„Internal audit - Belső ellenörzés

Funkcionális eszköz, amely segítségével egy szervezet vezetése belső forrásokból szerez bizonyosságot arról, hogy azok a folyamatok, amelyekért felelösséggel tartozik, úgy müködnek, hogy minimálisra csökkentik a csalás, hiba, a nem hatékony és gazdaságtalan gyakorlat előfordulását, lehetőségét. A külső ellenőrzés számos jellemzőjével rendelkezik, de helyénvalóan annak a vezetési szintnek az utasításait hajthatja végre, amely felé jelentéstételi kötelezettsége van."

Az IIA-standard 2130. pontja konkrétan megadja a belső ellenőrzésben használt kontroll szabatos, normaszerű meghatározását, és 2130.A1 alpontjában azt, hogy az mire terjed ki (IIA, 2012.):

"2130-Kontroll

A belső ellenörzési tevékenységnek a kontrollok hatékonyságának és eredményességének értékelésével, valamint folyamatos fejlesztésük támogatásával segítenie kell a szervezetet a hatékony kontrollok fenntartásában.

2130.A1 - A belső ellenörzésnek értékelnie kell a szervezet irányítási, müködési és információs rendszerekre vonatkozó, kockázatokat kezelö kontrolljainak megfelelöségét és hatékonyságát, különös tekintettel:

- a szervezet stratégiai célkitüzéseinek teljesitésére,

- a pénzügyi és müködési adatok megbizhatóságára és zártságára,

- a müködés és az informatikai alkalmazások hatékonyságára és eredményességére,

- a vagyonvédelemre,

\footnotetext{
${ }^{106}$ A magyar fordítás a BEMSZ honlapján elérhető: http://www.iia.hu/hu/component/dms/view_document/1-abels-ellenrzes-definicioja.html (2015. 01. 16.), az eredeti angol változat elérhetősége itt: https://na.theiia.org/standards-guidance/mandatory-guidance/Pages/Definition-of-Internal-Auditing.aspx (2015. 01. 16.)
} 
- a törvények, a szabályzatok, irányelvek, eljárások és a szerződések betartására."

Látható tehát, hogy a függetlenített belső ellenőrzési tevékenység a vállalati kontrollfolyamatok szerves része, a harmadik védelmi vonal, a coso-rendszer szerinti belső kontrollrendszer egyik eleme, annak hatékony, sikeres, eredményes megvalósítására törekszik. Éppen ezért az IIA-standard a saját fogalommagyarázatai közé emelte a kontrollfolyamatok és a megfelelő kontroll definícióját is, melyek a következők:

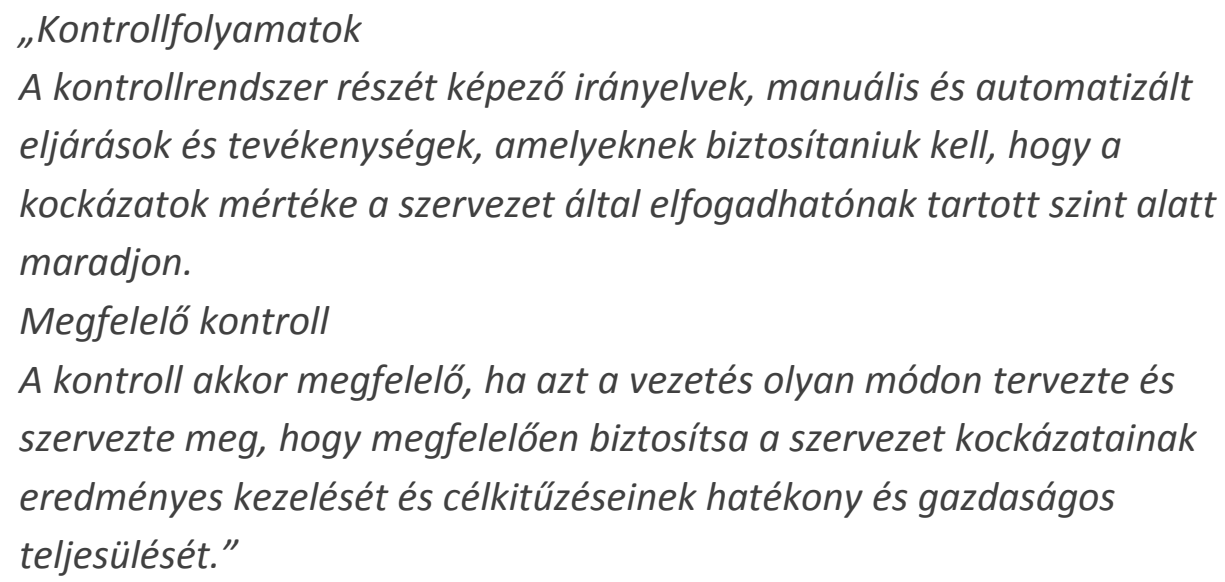

A függetlenített belső ellenőrzési tevékenység tehát egy, a vezetők számára értéket adó, a szervezeti célokat mindvégig szem előtt tartó és azok elérését segítő, folyamatos, minden egységtől független kontrollálótevékenység a vállalaton belül. A belső ellenőrzés standardja meghatározza a belső ellenőrzési feladatok tervezésének, végrehajtásának és minőségjavításának alapvető követelményeit, ezek alapvető, végrehajtási és megvalósítási normák lehetnek (IIA, 2012.), (Löffler et al., 2011., pp.539-543.), (Nagy \& Németh, 2009., pp.122-130.), (Kovács, 2007., pp.32-46.).

E standardok magukban foglalják, kimondják a következő legfontosabb elveket:

- A belső ellenőrzési feladatokat anyagi és szervezeti kötődéstől mentesen, függetlenül és tárgyilagosan kell elvégezni, ami azt is jelenti, hogy a belső ellenőrzés függelmileg is az első számú vezető alá tartozik, és munkáját, illetve megállapításait semmilyen módon nem lehet befolyásolni.

- A belső ellenőrzés a munkáját kellő gondossággal, szakértelemmel és hozzáértéssel köteles ellátni, ha ez nem biztosítható, akkor külső szakértelem bevonása szükséges.

- A belső ellenőrzési eljárásrendet írásban dokumentáltan kell szabályozni a vállalaton belül, és e célra belső ellenőrzési kézikönyvet kell készíteni. Ugyancsak írásban kell kidolgozni azt az ütemtervet, amely szerint a belső ellenőrzés a munkáját, ellenőrzési feladatait végzi. 
- Az ellenőrzéseknek hasznosulniuk kell, azaz a vállalat egészére vonatkozóan kell visszajelző, visszacsatoló funkciót ellátnia. A vállalat vezetése folyamatosan, legalább évente áttekinti a belső ellenőrzésre vonatkozóan adott belső és külső értékeléseket.

- A belső ellenőrzés munkáját a belső ellenőrzési vezető irányítja, szervezi, aki felel a tervezési, végrehajtási, koordinációs és kommunikációs feladatok ellátásáért, valamint az ő feladata a belső ellenőrzési tevékenységre vonatkozó szabályozási feladatok elvégzése is, továbbá az ellenőrzési erőforrásokkal való gazdálkodás.

A belső ellenőrzési standard meghatározza a belső ellenőrzésre hatást gyakoroló környezeti tényezőket is, melyeket összefoglalóan kontrollkörnyezetnek jelöl, és a következő fogalmi magyarázatot adja rá (IIA, 2012., p.19.):

„Kontrollkörnyezet

A vezető testületnek és a vezetésnek a szervezeten belüli kontroll

fontosságának elismerésére vonatkozó viselkedése és intézkedéseinek

összessége. A kontrollkörnyezet biztosítja a belső kontrollrendszer

elsődleges céljainak eléréséhez szükséges szabályozást és szerkezeti

keretet. A kontrollkörnyezet a következö elemekböl áll:

- Tisztesség és etikai értékek;

- A vezetés filozófiája és munkastílusa;

- Szervezeti felépítés;

- Hatáskör- és feladatmegosztás;

- Az emberierőforrás-kezelés irányelvei és gyakorlata;

- Az alkalmazottak szakértelme."

1991-ben az IIA részletes riportot jelentetett meg a Systems Auditability and Control (SAC) címmel (idézi (Sawyer et al., 2003., pp.69-71.)), melyben a vállalati kontrollrendszer sajátosságait, jellemzőit tárgyalja. E múben az IIA megnevezi a kontrollrendszerekért felelős személyeket felelősségi körükkel együtt, valamint a kontrollrendszer komponenseit a következők szerint határozza meg:

- kontrollkörnyezet (Control environment), mely a korábban leírtakhoz hasonlóan a szervezeti felépítést, a munkamegosztási elveket, a vállalaton belüli felelősségvállalás rendjét, a külső jogi és szervezeti iránymutatásokat stb. mint adottságokat veszi alapul.

- automatikus és kézi (ellenőrzési) eszközök (Manual and automated systems), ide tartoznak a különféle adatgyújtő, -tároló, -feldolgozó, -összesítő rendszerek, szoftverek és alkalmazások is.

- kontrolleljárások (Control procedures), melyek magukban foglalják a vállalaton belüli kontrolltevékenység leírását, valamint a kontrollrendszer 
elemeire és szereplőire vonatkozóan tartalmazzák a megelőző, feltáró és korrekciós kontrollok részletes leírását. Ilyen eljárások egyes elemei például: a munkavállalók mint személyek, a szervezet maga a belső eljárásrendekkel és felelősségi körökkel, az írott és követendő eljárások, illetve szabályzatok, a tervek, a vállalati könyvelés és a belső jelentések is (Sawyer et al., 2003., pp.82-86.)

A vállalaton belüli pénzügyi, megbízhatósági és teljesítményalapú ellenőrzések kialakulásában és elterjedésében jelentős szerepe volt Adrian Cadburynek, aki múvében összefoglalta a vállalatok pénzügyi ellenőrzésével, a hatékony és gazdaságos pénzügyi múködéssel és a törvényeknek és más jogszabályoknak való megfeleléssel összefüggő belső, a vállalat határain belül végrehajtandó ellenőrzési kritériumokat (Cadbury, 1992., pp.34-46.). Ennek alapján a vállalati belső ellenőrzésnek ${ }^{107}$ a következő területekre kell kiterjednie (Buxbaum, 2006., p.12.):

- vállalati politikák, tervek és azok végrehajtásának vizsgálata,

- a számviteli rendszernek és kapcsolódó rendszereinek múködése,

- pénzügyi és üzemeltetési rendszerek működése,

- a vállalati tevékenységek és működés gazdaságossága és hatékonysága,

- speciális, egyedi, cél- és utóvizsgálatok lefolytatása meghatározott témákban.

A független belső ellenőrzés kulcsszereplője a belső ellenőrzési vezető, aki a standardok alapján múködteti az alárendelt szervezeti egységet, és szervezi, irányítja a belső ellenőrzési feladatokat. A belső ellenőrzési vezető legfontosabb feladatai a következők (IIA, 2012., pp.3-17.), (NAV KEKI, 2011., pp.29-31.):

- A belső ellenőrzés munkájának értéket kell teremtenie a vállalkozás vezetése, tulajdonosai, érintettjei számára, ezért a belső ellenőrzés vezetőjének kockázatalapú (többéves stratégiai és abból levezetett éves, időszakos) terveket kell készítenie, hogy meghatározhassa a belső ellenőrzési tevékenységnek a szervezet céljaival összhangban álló prioritásait (2010. standard).

- Az elkészített és elfogadott tervek alapján a belső ellenőrzési vezető ellenőrzési erőforrások (budget és személyi állomány) felett rendelkezik, szabályozza, irányítja és dokumentálja a belső ellenőrzés tevékenységét,

\footnotetext{
107 A Cadbury-jelentés a vállalati szféra mellett a költségvetési szervezeteken belüli pénzügyi, illetve belső ellenőrzésre is hatást gyakorolt. Lásd részletesen erről Kovács Árpád két cikkét (Kovács, 2000., pp.205-212.), illetve (Kovács, 2002., pp.123-137.)
} 
és megállapításairól, eredményeiről tájékoztatja a vezetést (2060. standard).

- A belső ellenőrök (internal auditors) az egyes ellenőrzési témákat, feladataikat konkrét megbízás alapján végzik, mely megbízás rögzíti a vizsgálat célját és hatókörét (2200. standard). A megbízás kiterjed az ellenőrzési munkaprogram összeállítására, a szükséges vizsgálati erőforrások meghatározására, a téma megismerésére, az információk és adatok gyűjtésére és feltárására, azok értékelésére és a megállapítások kommunikálására is az érintettek irányába (2201-2450. standardok.).

- A belső ellenőrzés vezetője nyomon követi az egyes ellenőrzések megállapításaira tett vezetői intézkedéseket, azaz figyelemmel kíséri a realizálás folyamatát és eredményeit is, szükség szerint ezt utóvizsgálat alá vonhatja (2500. standard).

- A belső ellenőrzési vezető saját részlegének tevékenységére vonatkozóan minőségbiztosítási és -fejlesztési programot múködtet, ahol belső keretek között felülvizsgálják és értékelik a belső ellenőrzés szervezetét, múködésük hatékonyságát és eredményeiket, valamint az ellenőrzésben részt vevő munkatársak felkészültségét, és ezekről tájékoztatja a felső vezetést, illetve az egyéb érintetteket (pl. felügyelőbizottság) (1300-1321. standardok). 
A függetlenített belső ellenőrzési tevékenység összegző folyamatábrája az alábbiakban szemlélteti a belső ellenőrök rendszerszerű tevékenységét (19. ábra):

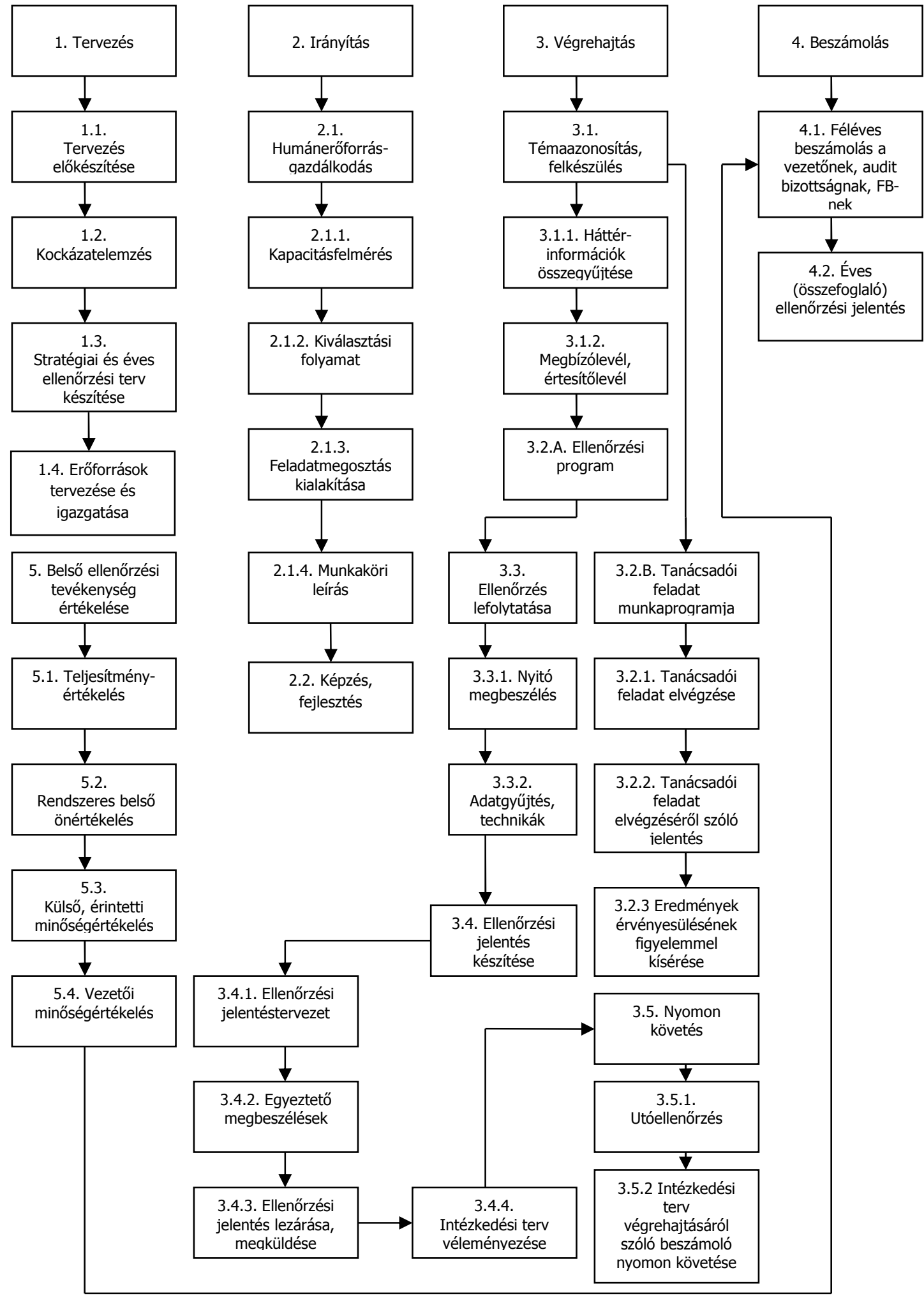

19. ábra: Függetlenitett belső ellenörzés tevékenységének átfogó folyamatábrája 5 fö folyamattal Forrás: Saját módositás, eredeti változat: Encsi Többcélú Kistérség Belső ellenörzési kézikönyv 1. sz. melléklete http://www.encsikisterseg.hu/dokumentumtar doksik/ETKT bek mellekletek.doc. (2015.01. 18.) 
A belső ellenőrzési szervezet múködésére, kiterjedésére ható tényezőket a kontrollkörnyezettel összefüggésben Badacsonyi és társai (Badacsonyi et al., 1979., pp.250-253.) és Buxbaum Miklós a következők szerint határozza meg (Buxbaum, 2006., p.22.):

- Vállalat nagysága, telepítési helyzete és mérete - mivel a nagy, több üzletágat, sok ezer fős céget átfogó belső ellenőrzési szervezet nagyságának nyilvánvalóan nagyobbnak kell lennie, mint egy pár tíz fős, egy telephelyes szervezet belső ellenőrzésének.

- A szervezet alaptevékenysége, iparági és szolgáltatási területe - ennek oka, hogy az értékteremtő folyamatok maguk is meghatározzák, hogy milyen mértékben van jelen tömegtermelés, mennyiben jellemzik specialitások a szervezetet, van-e mód standardizálásra, és ezáltal csökkenthetők-e a kockázatok, ezzel együtt az ellenőrzési kapacitás is.

- Nemzeti vagy regionális tevékenység, földrajzi kiterjedtség, piaccal való kapcsolat - amelyet az magyaráz, hogy egy monopolhelyzetben múködő, piacvezető szervezetnél nyilván kisebb kockázata van a tévedésnek és a kockázatok alulbecsülésének a szervezetre nézve, mint egy versenypiacon tevékenykedő, ebből következően sérülékenyebb, illetve versenytársai által támadható szervezetnek.

- Komplexitás, a vállalat vezetési és szervezési struktúrája - azaz a szervezet hierarchiaszintjei, a belső munka- és hatáskörmegosztás bonyolultsága, a standardizáltság mértéke mind befolyásolja azt, hogy a szervezet mekkora belső ellenőrzési apparátussal működik.

- A vállalat biztonsági igényei egyedileg befolyásolják a belső ellenőrzési szervezetet, hiszen egy bankbiztonsági vagy egy konkurencia által támadott vállalkozásban egyedi és markáns ellenőrzésekre és kontrollokra van szükség, szemben mondjuk egy újságárusító vagy egy kis boltot üzemeltető vállalkozással.

- A törvényi/felügyeleti és anyavállalati igények pedig a külső kontrollkörnyezet elemei, melyek deklaratívan írják elő a belső ellenőrzési szervezet múködésére, tevékenységére vonatkozó kötelező, követendő szabályokat. Ilyen törvényi előírás befolyásolja például a bankok, biztosítótársaságok, tőzsdén jegyzett cégek belső ellenőrzési szervezetét, de befolyással bírnak például egy engedélyezett gazdálkodóra ${ }^{108}$ vagy a költségvetési szervre vonatkozó jogszabályi előírások is.

\footnotetext{
108 Authorised Economic Operator (AEO), Magyarországon az engedélyezett gazdálkodó státusz elnevezés honosodott meg, lásd bővebben: http://www.nav.gov.hu/nav/vam/vaminformaciok/aeo/ (2015. 03. 12.)
} 
A belső ellenőrzési szervezet tipikus felépítését és az azon belüli szerep-, illetve munkaköröket Sawyer és társai ismertetik részletesen, melyek szerintük a következők (Sawyer et al., 2003., pp.846-851.):

- Belső ellenőrzésért felelős főigazgató (Chief audit executive), aki a függetlenített belső ellenőrzés első számú képviselője, s aki az igazgatótanács és a menedzsment felé képviseli a belső ellenőrzési szervezetet. Az ellenőrzési funkció kiemelkedő szereplője, az ellenőrzési szervezet „arca”, egy leader, sokszor az első számú vezető közvetlen bizalmasa ellenőrzési, audit téren.

- Belső ellenőrzés operatív vezetője (Manager), vagyis az az igazgató vagy vezetőhelyettes, aki az operatív, napi munka fő irányítója, a szakmai munkát és a belső egység adminisztrációját irányítja, koordinálja, menedzserként szervezi azt. Ellátja az egységen belüli személyzeti ügyeket, biztosítja az ellenőrzéshez szükséges fizikai infrastruktúrát (hordozható személyi számítógépek, szakkönyvek, telefon stb.), felel a belső minőségbiztosításért és a folyamatos képzési, fejlesztési feladatokért.

- Vezető belső ellenőrzési specialista (Senior Supervisor), aki az ellenőrzési programok kidolgozásáért, megvalósításáért felelős szakmai középvezető, s egyben sok esetben valamely szakmai terület specialistája is, aki módszertani, szakmai kérdésekben az ellenőrök és ellenőrzési vezetők támogatója.

- Ellenőrzési vezető vagy Vizsgálat vezető (Supervisor), aki egy-egy téma vizsgálatának lefolytatásával megbízott vezető, s aki közvetlenül irányítja és ellenőrzi a vizsgálatban részt vevő ellenőrök munkáját, de egyben maga is részt vesz az ellenőrzési munkában. Felelős egy-egy ellenőrzési megbízás alapján az ellenőrzési programterv összeállításáért, az ellenőrök munkájának összehangolásáért és a vizsgálati jelentés végső változatának elkészítéséért.

- Ellenőr (Staff), az a beosztott, aki az ellenőrzéseket végzi az ellenőrzési vezető közvetlen irányítása és az ellenőrzési program alapján.

A belső ellenőrzés szervezetében nem feltétlenül 5 hierarchiaszint van, elképzelhető, hogy egy szereplő több, fent ismertetett hierarchiaszintet egyszerre tölt be. A költségvetési szervek belső ellenőrzési szervezete például csak 3 szintet különböztet meg (belső ellenőrzési vezető, vizsgálatvezető, belső ellenőrzési munkatárs), de az elsőként említett vezető szerepkörében megjelenik az első három fenti funkció, feladat (NAV KEKI, 2011., p.78.) Ugyanakkor Sawyer ismerteti azt a munkamegosztási elvet is, amikor az ellenőrök a szervezet funkcionális területei szerint tagozódnak, specializálódnak, s ezt „silószerü" funkcióknak nevezte el. Ebben az esetben az ellenőrzési szervezet laposabb, vertikálisan kevésbé tagolt, és a 
szakmai támogató személyek és az ellenőrzést végzők egymással intenzívebb, szakmailag elkülönülő csoportokba, teamekbe tömörülnek.

\section{F12. Belső kontroll a számviteli jogszabályi keretekben}

A vállalati kontrollkörnyezet meghatározó tényezői a hatályos jogszabályi előírások és az erre épülő belső jogforrások, így ide tartozik a vállalatokra vonatkozó számviteli szabályozás is. Az intézményesülésről szóló fejezetben pedig a szabályozás, a normaalkotás fontosságát mutattam be. Így a belső kontrollrendszerek vizsgálata során fontos a vonatkozó jogszabályokat, jogi előírásokat is megvizsgálni.

A belső kontrollrendszer egyik fontos hatótere, illetve a kontrollkörnyezet egyik alapeleme a vállalkozások pénzügyi-számviteli rendszere, amelyet a vállalkozás múködtet annak érdekében, hogy éves (számviteli) beszámolóját elkészítse, és azt a legfőbb szerv elfogadja, illetve a vonatkozó belső szabályozások alapján a felügyelőbizottság azt megtárgyalja, illetve a választott könyvvizsgáló auditálja. A számviteli rendszert a vállalatok gazdasági, pénzügyi igazgatója (Chief Financial Officer) működteti, munkatársai a könyvelés, bérszámfejtés, pénzügy, treasury stb. szakterületekről kerülnek ki.

A beszámoló megbízható és valós képet kell, hogy adjon a vállalkozás vagyoni és pénzügyi helyzetéről, továbbá a múködés, a tevékenység eredményéről, nem utolsó sorban azért, mert a beszámoló nyilvános, bárki számára hozzáférhető, és ily módon az üzleti élet szereplői - nem kizárólagosan - ezen nyilvános dokumentumokból szerezhetnek információkat a vállalkozásokról.

Az üzleti évről készített éves (pénzügyi) beszámoló tartalmát és összeállításának szabályait, agazdasági események elszámolását, az alkalmazott elveket és eljárási módokat számviteli jogszabályok rögzítik. E jogszabályok az egyes országok alapvető törvényeire és más ágazati jogszabályokra építenek, és hivatkoz(hat)nak nemzetközi szervezetek különféle joganyagaira, jogforrásaira is.

Magyarországon a számvitelről szóló 2000. évi C. törvény szabályozza az alapvető számviteli kérdéseket, de alkalmazni kell az Európai Bizottság 1126/2008/EK rendeletét $^{109}$ is az 1606/2002/EK európai parlamenti és tanácsi rendelettel összhangban egyes nemzetközi számviteli standardok elfogadásáról.

\footnotetext{
109 Lásd: 1126/2008/EK rendelet, megjelent az Európai Unió hivatalos lapjában 2008. 11. 29-én, elektronikusan is hozzáférhető itt: http://eur-lex.europa.eu/legal-content/HU/TXT/PDF/?uri=CELEX:32008R1126\&from=HU (2015. 01. 18.)
} 
Továbbiakban az e jogforrásokban megtalálható, a belső kontrollrendszerekre vonatkozó alapvető előírásokat ismertetem, majd kitekintés céljából más országok jogrendszerében, illetve más jogforrásokban rögzített szabályokat is bemutatok disszertációmban. Az európai uniós és az amerikai szabályozás koncepcionális eltéréseit lásd részletesen Löffler és társai múvében (Löffler et al., 2011., pp.569579.).

\section{Kontroll a hazai számviteli szabályozásban}

A hatályos számviteli törvényünkben (2000. évi C. tv.) a kontroll szó nem szerepel, az ellenőrzés szó összesen 46 alkalommal|110 fordul elő, és az alábbi csoportosítás alapján 4 különféle értelmezésben használja azt a hazai törvény:

1. Ellenőrzési és irányítási jogok megszerzése, fenntartása valamilyen vállalkozás (úgymint leányvállalat, közös vezetésű vállalkozás, esetleg egyéb kapcsolt vállalkozás) felett. Ebben az aspektusban tehát az ellenőrzés szó az irányított vállalat feletti hatalomgyakorlás része, a konszernek és holdingvállalatok, vállalatcsoportok jellemző kifejezése, amely azt fejezi ki, hogy a tulajdonosok az érdekeltségeikbe tartozó önálló jogi személyeket ${ }^{111}$ irányítják, ellenőrzésük alatt tartják, tevékenységüket kezükben tartva arra meghatározó, jelentős befolyást gyakorolnak. Ezen ellenőrzési fogalom inkább az angolból magyarra fordított kontrollhoz áll közelebb.

„(2) E törvény alkalmazásában...

1. anyavállalat: az a vállalkozó, amely ... függetlenül a tulajdoni

hányadtól, a szavazati aránytól, a megválasztási és visszahívási jogtól döntő irányítást, ellenőrzést gyakorol" (3. § (2) 1. pont).

2. Előző évi és lezárt üzleti beszámoló ellenőrzése, és ezzel összefüggésben valamilyen jelentős összegú hiba, vagy nem jelentős összegű, de hiba feltárása, amely miatt az éves beszámoló módosítása és újbóli közzététele szükséges. Ebben az aspektusban az ellenőrzés nem más, mint lényegében önellenőrzés, egy utólagos felülvizsgálata, revíziója és tudatos módosítása a korábbi egy vagy több beszámolónak. Azaz nem a kontroll szinonimájáról van szó.

„1. ellenörzés: a jóváhagyásra jogosult testület által elfogadott beszámolóval lezárt üzleti év(ek) adatainak - a gazdálkodó, illetve az

\footnotetext{
${ }^{110} \mathrm{Az}$...ellenőr... szótöredék 63 alkalommal fordul elő a törvény szövegében, mely szótöredékből egyébként az ellenőriz, illetve önellenőriz ige, az ellenőrzés főnév, az ellenőrzött melléknév stb. képezhető. (2016. október 12én hatályos törvényszöveget figyelembe véve.)

111 Amelyek egyébként tetszőleges üzletágakba, divíziókba, divíziócsoportokba tömörülhetnek össze, közös stratégiát követhetnek, egységes felelősségi és elszámolási egységet képezhetnek a vállalatcsoporton belül.
} 
adóhatóság általi - utólagos ellenörzése az önellenörzés, illetve az adóhatósági ellenőrzés keretében" (3. § (3) 1. pontja).

3. Könyvvizsgálati ellenőrzés lefolytatása, azaz klasszikusan az éves beszámoló könyvvizsgálóval történő auditáltatása, valamint eseti jelleggel a független könyvvizsgáló igénybevétele vagyonmérleg-tervezet, közbenső mérleg, értékhelyesbítés, átalakulás stb. esetén.

„A könyvvizsgálat célja annak megállapítása, hogy a vállalkozó által az

üzleti évről készített éves beszámoló, egyszerüsített éves beszámoló, továbbá az összevont (konszolidált) éves beszámoló e törvény elöírásai szerint készült, és ennek megfelelöen megbízható és valós képet ad a vállalkozó (a konszolidálásba bevont vállalkozások együttes) vagyoni és pénzügyi helyzetéről, a müködés eredményéről. A könyvvizsgálat során ellenőrizni kell az éves beszámoló, az összevont (konszolidált) éves beszámoló és a kapcsolódó üzleti jelentés adatainak összhangját, kapcsolatát is" (155. § (1) bek.).

4. Hatósági ellenőrzés lefolytatásának részletszabályai a könyvviteli szolgáltatást nyújtókra vonatkozóan, a számukra szervezett továbbképzések hatósági ellenőrzésére vonatkozóan, valamint az ezzel kapcsolatos nyilvántartások ellenőrzésének rendjét illetően.

„A nyilvántartásba vételt végző szervezet az engedélyhez kötött

könyvviteli szolgáltatás gyakorlásának időtartama alatt lefolytatott hatósági ellenörzés keretében ellenörzi azt, hogy...(151/A. § (2) )".

A fenti 4 ellenőrzési fogalom egyike sem azonos a belső kontrollrendszerrel. Láthatjuk, hogy a törvény a vállalkozás számára saját belső kontrollmechanizmusok múködtetését nem írja elő, noha ebbe a körbe tartozik minden olyan egyéb, a számvitelről szóló törvényből is következő ellenőrzési aktus, esemény, amely a fenti négy kategóriába nem sorolható be, ugyanakkor a vállalkozó végzi el annak érdekében, hogy beszámolója és az abból kinyerhető kimutatások a tárgyévről (és a korábbi lezárt üzleti évekről) is valósak, hibátlanok, hiányosságoktól és csalástól mentesek, azaz megbízhatóak és átvitt értelemben tehát célirányra törekvő, uralma alatt tartott legyen. Ebbe a körbe sorolom azokat a tevékenységeket, mint például a pénzkezelési szabályzatban leírtak ellenőrzését a házipénztárban (14. § (8) bekezdés alapján), egyeztetések elvégzését (46. § (3) bekezdéshez kapcsolódóan), a leltározás felülvizsgálatát (69. $\S$ (1) bekezdéshez illeszkedően), de ide tartozik az intézményesített vezetői, a folyamatba épített és a független belső ellenőrzési rendszer működtetése a pénzügyi és számviteli területtel összefüggésben, mint például a bejövő számlák likvidálásának rendje, a bizonylatok alaki és tartalmi ellenőrzésének folyamatleírása, visszaélések figyelése és kiszűrése, kontrollpontok 
meghatározása a könyvelési folyamatban, adóbevallások ellenőrzése a benyújtást megelőzően, jóváhagyási kontrollok beiktatása a kifizetési folyamatokba stb.

A számviteli törvény 165 . $§$-a az alábbiak szerint rendelkezik a bizonylati ${ }^{112}$ elvről és a bizonylati fegyelemről:

„165. § (1) Minden gazdasági múveletröl, eseményröl, amely az eszközök, illetve az eszközök forrásainak állományát vagy összetételét megváltoztatja, bizonylatot kell kiállitani (készíteni). A gazdasági müveletek (események) folyamatát tükröző összes bizonylat adatait a könyvviteli nyilvántartásokban rögzíteni kell.

(2) A számviteli (könyvviteli) nyilvántartásokba csak szabályszerüen kiállított bizonylat alapján szabad adatokat bejegyezni. Szabályszerü az a bizonylat, amely az adott gazdasági müveletre (eseményre) vonatkozóan a könyvvitelben rögzítendő és a más jogszabályban elöírt adatokat a valóságnak megfelelöen, hiánytalanul tartalmazza, megfelel a bizonylat általános alaki és tartalmi követelményeinek, és amelyet hiba esetén - előírásszerüen javítottak."

A törvény ezen része megköveteli, hogy a vállalkozás csak ténylegesen megtörtént eseményről, valós adatokkal állítson ki és fogadjon be bizonylatot. Azt azonban a törvény nem szabályozza, hogy ezt a vállalkozónak, illetve a vállalkozásnak miképpen kell tennie, megvalósítania. Így arról sem rendelkezik a törvény, hogy ez a beszámolóra nézve milyen kockázatokat rejt, és a múködéssel összefüggésben a vállalkozónak ezeket hogyan kell előrejeleznie, feltárnia, kezelnie és erről az érdekeltekettájékoztatnia.

Egyetlen kivétel van azonban, ez pedig a tőzsdére bejegyzett, ott forgalmazott részvényeket vagy kötvényeket kibocsátó társaságok esete, amelyeknek vállalatirányítási nyilatkozatot kell közzétenniük. A törvény 95/B. (2) bek. e) pontja alapján e cégeknek nyilatkozatot kell tenniük belső ellenőrzési és kockázatkezelési rendszerükre vonatkozóan is.

„95/B. \& (1) Az a vállalkozó, amelynek átruházható értékpapírjait az Európai Gazdasági Térség valamely államának szabályozott piacán kereskedésre befogadták, üzleti jelentésében vállalatirányítási nyilatkozatot tesz közzé.

(2) A vállalatirányítási nyilatkozatnak legalább az alábbiakat kell tartalmaznia:

112 A bizonylat definícióját a számviteli törvény $166 . \S$ (1) bekezdése határozza meg. 
e) a vállalkozó belső ellenőrzési és kockázatkezelési rendszere(i) föbb

jellemzőinek bemutatása a beszámolókészítés összefüggésében".

A konszolidált (összevont) beszámolót készítő vállalkozásoknak a 134. § (3) bekezdése alapján a fentiekkel azonosan kell eljárniuk. Azonban egyiküknek sem kell saját belső kontrollrendszerének múködését bemutatnia nyilatkozatában - a törvény betújéből levezetve.

A számviteli törvény 8 . $\S(5)$ bekezdése az éves beszámoló összeállítása tartalmi követelményeinek való megfelelésért a következő személyeket, szervezeti egységeket teszi felelőssé:

„8. § (5) A gazdálkodó legfőbb irányító (vezető) szervén, ügyvezető szervén és felügyelötestületén belül a tagok együttes kötelezettsége - a külön jogszabályban meghatározott hatáskörükben eljárva - annak biztositása, hogy az éves beszámoló, az egyszerüsített éves beszámoló és az összevont (konszolidált) éves beszámoló [ideértve a 10. § (2) és (3) bekezdése alapján a nemzetközi számviteli standardok szerint elkészített összevont (konszolidált) éves beszámolót is], valamint a kapcsolódó üzleti jelentés összeállitása és nyilvánosságra hozatala e törvény elöírásainak megfelelöen történjen."

Ennél tovább a hazai szabályozás nem lép, nem írja kötelezően elő belső kontrollrendszer és -mechanizmusok múködtetését a megbízható és valós kép biztosítása, a számviteli alapelvek érvényesítése, a beszámolóban rögzített adatok ellenőrzése stb. érdekében.

A magyar számviteli törvényből tehát a belső kontrollrendszer müködtetésének kötelezettsége, illetve az ezért való felelősség hiányzik. Indirekt módon, a vezető tisztségviselők, illetve a vállalkozás képviseletére jogosult személyek törvényben előírt, általános felelősségére építve lehet csak azt tetten érni.

A vállalkozó felelős a könyveinek valós, csalásoktól, torzításoktól mentes, átlátható, ellenőrizhető módon történő vezetéséért, de ez szó szerint nincs a számviteli törvényünkben leírva. Természetesen a számviteli elvek, a bizonylati fegyelem és a kettős könyvvitelre vonatkozó előírások együttesen körbekerítik, legalábbis megkísérlik garantálni a vállalkozó esetében ezt, de mégis felmerül a kérdés, hogy a törvény szövegéből ezen szigorú és konkrét elvárás miért hiányzik?! Ugyanakkor a fent idézett 8 . $\S(5)$ bekezdés mégis felelőssé teszi a legfőbb szerv, a felügyelőbizottság és az ügyvezető szerv tagjait is az éves beszámoló törvényességének garantálásáért.

Kockázata a jóhiszemú vállalkozónak van, aki járhat el helytelenül a könyvelés során, amit utóbb vagy észrevesz, vagy nem. Jóhiszemű igazgatót rosszhiszemű beosztottja kijátszhatja, háta mögött csalhat, sikkaszthat stb., és erre az első számú vezető nem 
biztos, hogy rájön. A hatóság vagy ellenőrzi a vállalkozást, vagy nem; és ha ellenőrzi is, akkor sem feltétlenül bukkan rá a téves vagy valótlan gazdasági esemény elszámolására (hiszen érdek fúződik annak elrejtéséhez). Így a vállalkozás beszámolója mégis hibás, valótlan adatokat tartalmazó és emiatt félrevezető lesz, amit önellenőrzéssel javíthat, vagy hatóságilag lesz kötelezve erre évekkel később. Ennek pedig csak akkor van szankciója ${ }^{113}$, ha azt a hatóság kezdeményezi a vállalkozás ellen. Éppen ezért érdekelt az első számú vezető abban, hogy saját belső kontrollrendszert működtessen, amely szándékoltan megvédi őt a belső csalásoktól, visszaélésektől, tévedésektől és azok kockázataitól, káros következményeitől.

A hatályos számviteli törvény bizonyos könyvviteli eseteket, eszközcsoportokhoz tartozó tételeket kiemel, míg más eseményeket nem nevez meg tételesen ellenőrizhetőség végett. Például a készpénzállományt kritikusnak tekinti a törvény, de az ugyanolyan funkciójú készpénz-helyettesítők, például csekkek, utalványok forgalmának és állományának ellenőrzéséről már nem tesz említést, csakúgy mint a vevők és a szállítók jogi státuszának ellenőrzésére ${ }^{114}$ vonatkozóan sem. Kiemeli a közpénzek, közösségi támogatások ellenőrizhetőségét a 161/A. § (2) bekezdésében, de nem emeli ki a tulajdonostól, banktól, hitelezőtől kapott támogatások ${ }^{115}$ ellenőrizhetőségét, ezzel azt a látszatot keltve, hogy az nem annyira jelentős.

A hazai számviteli törvény jelentős hangsúlyt helyez a bizonylatra, annak alaki és formai követelményeit szigorúan (a mai elektronikus, számítógéppel támogatott könyvelés tükrében szinte „ókori elvekhez” ragaszkodóan) szabályozza, megkövetel utalványozót, de lehet a bizonylatnak még ellenőre, könyvelője és maga a könyvelés elrendelője is. Ez önmagában 4 külön munkakör, szerencsés esetben 4 külön személy is egy könyvelési folyamatban, de a vállalkozás első számú vezetője, képviselője, az ügyvezető, a cégvezető, a főkönyvelő, a könyveléssel megbízott személy, az ügyfélkapun keresztül megjelölt képviselő mégsem szerepel az említettek között, mint a belső kontrollrendszert egyébként működtetni köteles személyek, akikre a „segregation of duties” (jóváhagyási szintek elkülönítése) elv egyébként vonatkozna.

Összességében tehát megállapíthatjuk, hogy a magyar számviteli törvény az ellenőrzés szót négyféle értelemben is használja, melyből egyik sem vonatkozik a belső kontrollrendszerre ${ }^{116}$. Tartalmát tekintve a klasszikus számviteli ellenőrzés

\footnotetext{
${ }^{113}$ Ami a számviteli törvény 170 . -a szerint lehet polgári jogi jogviszonyból eredő kártéritési kötelezettség, büntető törvénykönyv hatálya alá eső bűntett szankciója vagy adóhatósági mulasztási bírság.

114 Értsd: létező jogi személy-e, adószáma nincs-e felfüggesztve, áll-e felszámolás, végelszámolás alatt stb.

115 Értsd: adományait, befizetéseit, átadásait, térítés nélküli juttatásait.

${ }^{116}$ A számviteli törvényből hiányzó ellenőrzési tevékenységről, illetve az ellenőrzési (keret)törvénytervezet vitaindítóját lásd bővebben Németh Pál cikkében (Németh, 1995., pp.414-417.).
} 
lezárt üzleti évre vonatkozik, melyet a vállalkozó önellenőrzéssel, a hatóság pedig külső ellenőrzéssel hajt végre. A vállalkozó felelősségét a törvény csak általánosságban említi (8.§ (5) bekezdés), a könyvelés pontosságáért való felelősséget a törvény szó szerinti formában nem mondja ki, ugyancsak nem beszél tárgyévi ellenőrzésről, valamint folyamatba épített, automatikus, illetve vezetői kontrolltevékenységekről.

\section{Ellenőrzés és kontroll a nemzetközi számviteli standardokban}

Az Európai Bizottság 1126/2008/EK rendelete a nemzetközi számviteli standardok kötelező alkalmazását írja elő, ezért a hatályos magyar számviteli törvény mellett érdemes megvizsgálni a vállalkozás által múködtetett belső kontrollrendszer és kontrollmechanizmusok kérdését a különféle nemzetközi standardokban (IAS/IFRS) is. A 1126/2008/EK rendelet erre vonatkozóan ugyanis nem tartalmaz előírást.

A nemzetközi számviteli standardok ${ }^{117}$ közül az IAS 8 számú, „Számviteli politika, a számviteli becslések változásai és hibák" című standard foglalkozik részletesen a számviteli hiba fogalmával és javításának módjával. Ennek 5 . bekezdése definiálja a lényegességet, valamint a hibát, 41 . bekezdése pedig részletesen említi, levezeti a hiba jelenségét, bekövetkezésének következményeit (Európai Közösségek Bizottsága, 2008., pp.39-40.).

„5.

...A korábbi időszaki hibák, kihagyások vagy téves bemutatások a gazdálkodó egység egy vagy több korábbi időszakra vonatkozó pénzügyi kimutatásaiban, amelyek olyan megbízható információk fel nem használásából, vagy helytelen felhasználásából származtak:

a) amelyek már rendelkezésre álltak, amikor az adott időszakra vonatkozó pénzügyi kimutatásokat közzétételre jóváhagyták; valamint

b) amelyekröl ésszerüen elvárható volt, hogy azokat beszerezzék, és az érintett pénzügyi kimutatások elkészítése és bemutatása során figyelembe vegyék.

\footnotetext{
117 Nemzetközi szövegkörnyezetben az International Accounting Standards (IAS) terjedt el, s mivel a standardokra az eredeti kibocsátás nyelvén szokás hivatkozni, a továbbiakban én is az IAS angol mozaikszót használom. Jelenleg azonban IAS standardot már nem bocsátanak ki, helyette az International Financial Reporting Standards (IFRS) standardokat használják, melyekre a 1126/2008/EK rendelet is hivatkozik. Lásd bővebben itt: http://www.ifrs.org/Pages/default.aspx (2015. 01. 18.)
} 
Ilyen hibák lehetnek a matematikai hibák, a számviteli politika alkalmazásában elkövetett hibák, tények figyelmen kívül hagyása vagy helytelen értelmezése, valamint a csalás hatásai."

\begin{abstract}
„41. Hiba merülhet fel a pénzügyi kimutatások egyes elemeinek megjelenitése, értékelése, bemutatása vagy közzététele kapcsán. A pénzügyi kimutatások nem felelnek meg az IFRS-eknek, ha azok lényeges hibákat vagy nem lényeges, de a gazdálkodó egység pénzügyi helyzetének, pénzügyi teljesítményének vagy cash flow-inak egy meghatározott bemutatása miatt szándékosan okozott hibákat tartalmaznak. A tárgyidőszakban feltárt, a tárgyidőszakra vonatkozó esetleges hibákat a pénzügyi kimutatások közzétételre való jóváhagyását megelözően javitják ki. Ugyanakkor vannak olyan esetek, amikor a lényeges hibákat csak valamely későbbi időszakban tárják fel, és ezeket a korábbi időszaki hibákat a későbbi időszakra készitett pénzügyi kimutatásokban bemutatott összehasonlító adatokban javítják ki (lásd a 42-47. bekezdést)."
\end{abstract}

A nemzetközi számviteli standard szóhasználatában az ellenőrzés - a magyar számviteli törvény egyik szóhasználatával azonosan - egyértelműen az irányított vállalat feletti uralmat ${ }^{118}$, hatalmat, rendelkezési jogot jelenti. Az IAS 8. standard a számviteli politika kialakításáról és a hiba kezeléséről rendelkezik, de ezen túlmenően az IAS/IFRS nemzetközi számviteli standardok nem írnak elő semmilyen követelményt a belső kontrollra, visszacsatolásra vonatkozóan a vállalkozások számára. Az angolszász területen elterjedt (US) GAAP szerinti standardok pedig a kontroll kapcsán a SOX ${ }^{119}$ szerinti szabályozásra hivatkoznak vissza.

\footnotetext{
118 IAS 24. 9. c) pontja alapján az ellenőrzés képesség egy (ellenőrzött) gazdálkodó egység pénzügyi és működési politikájának irányítására a tevékenységéből származó haszon megszerzése érdekében. Ilyen tipikusan a leányvállalat, közös vállalat stb.

${ }^{119}$ A Sarbanes-Oxley (SOX)-törvény 2002-ben lépett életbe az USA-ban, és a tőzsdén jegyzett vállalatok pénzügyi riportjaival kapcsolatos megbízhatóságot és felelősséget volt hivatott erősíteni a befektetői körökben. Annak 404-es cikkelyét a belső kontrollrendszerrel összefüggésben szokták említeni, mely előírja, hogy a vállalat első számú vezetőjének és a pénzügyi vezetőnek milyen belső ellenőrzési szisztémát, mechanizmust kell kiépítenie és működtetnie ahhoz, hogy a számviteli adatok és az azokból készülő beszámoló megbízható és csalásoktól, tévedésektől mentes legyen. Lásd részletesen: (Lander, 2004., pp.10-22.), illetve (Moeller, 2007., pp.179-209.)
} 


\section{F13. Kontroll a vállalati könyvvizsgálati szabályozásban}

A tulajdonosi kör és a vállalati menedzsment szétválása, valamint az ebből fakadó bizalmatlanság, bizonytalanság és a számviteli beszámoló valódiságának, alátámasztottságának közérdeke hívta életre a könyvvizsgálat intézményét ${ }^{120}$. Hazánkban a könyvvizsgálókat a Magyar Könyvvizsgálói Kamara tömöríti köztestületként, meghatározásuk szerint a könyvvizsgálat definíciója a következő (Lukács, 2005., p.137.):
„A könyvvizsgálat egy olyan speciális, komplex ellenörzési folyamat, amikor egy független szakértö (vagy szervezet) a tulajdonosok megbízásából elvégzi egy vállalkozás számviteli rendszerének felülvizsgálatát, ellenörzi a vagyoni, pénzügyi, jövedelmi helyzetéröl közzétett adatok valódiságát, és ezek alapján objektív ítéletet alkot, véleményt nyilvánít a vállalkozás egészéröl."

A könyvvizsgáló tehát ellenőriz, ellenőrzésének fókusza a számviteli rendszer és a beszámoló, ilyen módon a feladatellátása a kontrolltevékenységek egyikének tekinthető. A könyvvizsgálat célja a vállalkozás által összeállított beszámoló auditálása ${ }^{121}$, a könyvvizsgáló ennek érdekében ellenőrzi a vállalkozás pénzügyiszámviteli kimutatásait, évközi és év végi beszámolóját, meggyőződik azok valósághűségéről, hibamentességéről. Munkáját a számvitelről szóló 2000. évi C. törvény és a Magyar Könyvvizsgálói Kamaráról, a könyvvizsgálói tevékenységről, valamint a könyvvizsgálói közfelügyeletről szóló 2007. évi LXXV. törvény előírásai alapján végzi. A jelenleg hatályos jogszabályok alapján fő szabályként ${ }^{122}$ azonban magyar vállalkozásoknál csak akkor kötelező könyvvizsgálót választani, ha a társaság árbevétele két egymást követő év átlagában a 300 millió forintot és foglalkoztatottainak száma az 50 főt eléri. Ezért a könyvvizsgálati feladatok alól

\footnotetext{
120 Történelmi fejlődését a világban és hazánkban egyaránt közli, bemutatja (Lukács, 2005., pp.92-95.), valamint lásd a könyvvizsgálat történetét Magyarországon 1723-ig visszamenölegesen részletesen (Borbás, 2007.). ${ }^{121}$ A hivatalos hazai jogszabályi hivatkozás a számvitelről szóló 2000. évi C. törvény 155. § (1) bekezdése. E szerint a könyvvizsgálat célja annak megállapítása, hogy a vállalkozó által az üzleti évről készített éves beszámoló, egyszerűsített éves beszámoló, továbbá az összevont (konszolidált) éves beszámoló e törvény előírásai szerint készült, és ennek megfelelően megbízható és valós képet ad a vállalkozó (a konszolidálásba bevont vállalkozások együttes) vagyoni és pénzügyi helyzetéröl, a müködés eredményéről. A könyvvizsgálat során ellenőrizni kell az éves beszámoló, az összevont (konszolidált) éves beszámoló és a kapcsolódó üzleti jelentés adatainak összhangját, kapcsolatát is.

122 Számvitelröl szóló 2000. évi C. törvény 155. § (3)-(5/a) bekezdései alapján, a törvényszöveg 2016. március 10-én hatályos.
} 
számos vállalkozás mentesül hazánkban, akiknél tehát nincs választott könyvvizsgáló ${ }^{123}$.

A könyvvizsgálót a társaság legfőbb szerve (közgyűlés, taggyúlés, tagok gyúlése stb.) választja meg (nevezi ki), s ilyen módon neki tartozik beszámolási kötelezettséggel. Ellenőrzési tevékenysége tehát a társaságirányítás területéhez ${ }^{124}$ tartozik, a tulajdonosok érdekében jár el, külső és független partnere a vállalkozás munkaszervezetének, éppen ezért összeférhetetlen ${ }^{125}$, hogy a könyvvizsgáló egyben munkavállaló is legyen a társaságnál, vagy hogy más belső vezetői, irányítói szerepet, feladatot lásson el a vállalkozásban. A hatályos magyar számviteli törvény és a könyvvizsgálói tevékenységre vonatkozó törvény sem ír elő tartalmi kérdéseket, amelyek alapján a választott könyvvizsgáló az ellenőrzési, auditálási feladatait végzi.

Ha csak e szabályok szerint tekintenénk a könyvvizsgálati feladatokra, akkor az ő tevékenysége nem tartozna bele a belső kontrollrendszerbe, hiszen a választott könyvvizsgáló nem tagja a munkaszervezetnek, és nem múködteti a belső kontrollrendszert, legfeljebb hatással van rá, s ilyen módon a kontrollkörnyezet részének, egyik elemének tekinthető.

Ezért önmagában a könyvvizsgálati munka értekezésemben nem kaphatna önálló függeléki alfejezetet, azonban a könyvvizsgálati munkát meghatározó nemzetközi könyvvizsgálati standardok (lásd a korábban bemutatott 315-ös számviteli standardot) előírják a könyvvizsgáló számára, hogy a belső kontrollrendszert milyen elemek mentén kell feltárnia, megismernie, illetve munkáját hogyan kell végeznie, dokumentálnia, mit kell pontosan elemeznie, feltárnia, kivel kell interjút készítenie, milyen kockázatokat kell vizsgálnia, mit kell megbecsülnie stb. a könyvvizsgálati audit során. Ehhez kapcsolódóan a könyvvizsgálónak kötelessége a belső kontrollrendszereket ellenőriznie, és megbizonyosodnia arról, hogy azok múködnek, és hogy a könyvvizsgáló valóban támaszkodhat rájuk saját megállapításai során

\footnotetext{
${ }^{123}$ A Nemzetgazdasági Minisztérium Számviteli és felügyeleti főosztályának kérdésemre adott válaszából kiderül, hogy 2014. évben 33.175 darab könyvvizsgálati jelentés került kiadásra a Magyar Könyvvizsgálói Kamara nyilvántartása alapján. Tekintve, hogy Magyarországon ebben az időszakban a KSH nyilvántartásai alapján kb. 575 ezer müködő gazdasági társaság volt, így 2014-ben a hazai vállalkozások legfeljebb 5,76\%-a volt könyvvizsgálattal érintett. Ez a \% a valóságban ennél azonban feltehetően kevesebb, hiszen ugyanazon cég egyedi, konszolidált éves, átalakulási, ill. különféle pályázati és támogatási beszámolójáról is készül könyvvizsgálati jelentés, de ezek ugyanazon gazdasági társasághoz tartoznak. Pontosabb \%-os adat sajnos nem áll rendelkezésre.

${ }^{124}$ A vállalat társaságirányítási és munkaszervezeti elkülönítését lásd részletesen (Dobák \& Antal, 2013., pp.117121.) magyarázatul.

${ }^{125}$ A tulajdonosi kör és a kontroll szétválasztásáról szóló elméleti alapvetést lásd részletesebben (Barney \& Ouchi, 1986., pp.276-298.).
} 
(Bordáné, 2011., pp.79-99.). A könyvvizsgálónak értékelnie kell, hogy a vezetés létrehozta-e és fenntartja-e a becsületesség és etikus viselkedés kultúráját, valamint a kontrollkörnyezet erős és gyenge pontjait, a kontrollok hiányosságait, a menedzsment által létrehozott üzleti kockázatkezelési módszertanokat és a belső ellenőrzési rendszer múködését. Ha ezek kapcsán a könyvvizsgáló bizonytalanságot, elégtelenséget állapít meg, azt az ISA 265-ös könyvvizsgálati standard alapján kell a vezetés tudomására hoznia. Ezen kívül a könyvvizsgáló az ISA 330-as és az ISA 700as könyvvizsgálati standard szerint ítéli meg a belső kontrollrendszert.

Mivel pedig a nemzetközi könyvvizsgálati standardok az előírásokon túlmutatóan értelmező és tartalmi jellegű magyarázó részeket is magukban foglalnak, azok jó lehetőséget teremtenek arra, hogy a belső kontrollrendszert könyvvizsgálói szemmel is vázlatosan ismertethessem értekezésemben. A könyvvizsgálóknak a belső kontrollrendszer felülvizsgálatára, megismerésére vonatkozó feladatairól lásd bővebben (Roóz, 1999.), (Eilifsen et al., 2010., pp.185-254.), (Meigs et al., 1985., pp.172-251.), (O'Reilly et al., 1990., pp.187-212.). A könyvvizsgáló felelősségéről és a munkájával szemben támasztott minőségi kritériumokról, függetlenségi és bizalmi követelményekről lásd bővebben (Lukács, 2014, pp.133-145.).

\section{F14. Kontrollt gyakorló bizottságok a gazdasági társaságokról szóló törvény alapján}

A vállalaton belül kialakított szervezeti struktúra a kontrollkörnyezet egyik meghatározó eleme. A szervezeti struktúrán belül pedig felmerül a dilemma, hogy a felügyelőbizottság, az ellenőrzési bizottság és az egyéb, közgyűlés vagy legfőbb szerv által választott testületek hol kapjanak szerepet a vállalaton belüli kontrollfolyamatokban, ha ők egyébként nem is részei a vállalat munkaszervezetének.

Az ellenőrzési szakirodalom a tulajdonoshoz kapcsolódó ellenőrzési területet a felelős társaságirányítás (corporate governance) témakörén belül jelölte ki. Magyar megközelítésben leginkább a vállalatirányítás, vállalatkormányzás szavakkal fordítjuk, használjuk (Roóz, 2001.), (Angyal, 2009., pp.18-23.).

Egy szabatos megfogalmazásban, az ACCA meghatározása szerint a corporate governance jelentése a következő (BPP, 2011., p.34.):

"Corporate Governance is the system by which companies are directed and controled." 126

\footnotetext{
${ }^{126}$ Saját, nem hivatalos fordításban: A legmagasabb szintű vállalatirányitási rendszer, mely vezeti és kontrollálja a vállalatot.
} 
A vállalatkormányzásnak része a tulajdonosi tesületek(szervek, bizottságok), a vállalat operatív felső vezetése, valamint az igazgató tanács (annak tagjai) is. A tulajdonosoktól nem elkülöníthető a kontroll, s maguknak a tulajdonosoknak is érdekük, hogy vállalatukat kontroll alatt (uralmuk alatt) tartsák. Az is egyértelmú, hogy a tulajdonosi megbízottak (könyvvizsgáló, Igazgatótanács, Felügyelőbizottság, Auditbizottság külső tagjai) nem részei a munkaszervezetnek, ezért őket is a kontrollkörnyezet részeként, azonban fontos szereplőkként azonosíthatjuk témámban, mivel kontrolltevékenységeket végeznek a szervezetben.

Hazánkban a gazdasági társaságokról szóló, alapvető jogszabály korábban önálló törvényként létezett ${ }^{127}$, ma már e szabályok a Polgári Törvénykönyv (2013. évi V. törvény) részeivé váltak. E törvény 3 . része szabályozza többek között a különféle jogi formákat, a létesítő okirat, a legfőbb szerv összehívásának, a vállalat alaptőkéjének stb. szabályait. A vállalaton belüli ellenőrzésekkel kapcsolatosan a PTK részletes iránymutatást, kötelezően követendő szabályokat nem fogalmaz meg. Ugyanakkor intézményesít olyan testületet ${ }^{128}$, amely a vállalaton belüli kontrolltevékenységet felügyeli, és azt döntéseivel befolyásolja, a kontroll múködtetését pedig maga alá vonhatja. Ez a felügyelőbizottság ( $F B$, supervisory board), és bizonyos esetekben az audit bizottság is létrejöhet ilyen testületként. Fontos kijelenteni, hogy ezek a testületek nem a vállalaton belüli szervezeti egységek és nem részei a vállalat végrehajtó munkaszervezetének sem, mivel a legfőbb szervnek (közgyúlés, taggyúlés, tagok gyúlése stb.) alárendelten működnek. Ezért őket a vállalatok társaságirányítási szintjébe soroljuk be, és a tulajdonosi kontrollgyakorlás részének tekintjük őket (Sawyer et al., 2003., pp.1319-1342.), (BPP, 2011., pp.33-44.), (Löffler et al., 2011., pp.445-458.), (Kovács, 2007., pp.194199.), (Kresalek \& Merétey-Vida, 2008., pp.34-41.), (Nyikos, 1999., pp.139-146.), (Sebes, 2012., pp.37-38.), (Kamarás, 1993., pp.164-173.), (Bordáné, 2011., pp.2635.), (Roóz, 2005.).

A PTK 3. rész 3. fejezete rendelkezik a felügyelőbizottság múködéséről, megválasztásáról, tagjai visszahívásáról stb. is. A 3:120. § (2) alapján a felügyelőbizottság jogkörébe tartozik a vállalkozás éves beszámolójának - ahol van,

\footnotetext{
127 Gazdasági társaságokról szóló 2006. évi IV. törvény.

${ }^{128}$ A testület és a szervezeti egység közötti különbségtétel lényeges a téma szempontjából. A testület konzultatív jellegű fórum a vállalat vezetésében, míg a szervezeti egység operatív végrehajtói feladatokat lát el az ez alatt lévő hierarchiai szinteken. A testületeknek általában elnökük van, és döntéseiket tanácsüléseken hozzák meg. $A$ testület azonban csak esetileg ülésezik (évente néhány alkalommal), nincs állandó munkaszervezete. Ezzel szemben a szervezeti egységben munkavállalók dolgoznak általában fóállásban, az egységet vezető irányítja, az operatív döntéseket ő hozza meg, és a napi munkavégzés itt zajlik folyamatosan. Tehát az FB és az audit bizottság is testületként, a független belső ellenőrzési csoport pedig szervezeti egységként müködik a vállalkozásokban. Az FB angolszász és német jogrendbeli további megítélését lásd részletesen Kovács Árpád müvében (Kovács, 2007., p.196.).
} 
ott a felelős társaságirányítási jelentésnek ${ }^{129}$ is - írásbeli véleményezése annak elfogadása előtt, valamint a (3) bekezdés alapján az FB-nek van joga kezdeményezni a legfőbb szerv összehívását, amennyiben az ügyvezetés tevékenységének jogszabályba ütközését vagy létesítő okiratba ütközését vélelmezi, ellentétesnek ítéli meg a társaság legfőbb szerve határozataival, vagy az egyébként sérti a gazdasági társaság érdekeit. A felügyelőbizottság tehát a közgyúlés felé intézkedik ${ }^{130}$, de döntésének, határozatának megalapozásához adatokat, információkat gyűjt be a szervezettől, a vezetéstől. Ilyen formában védi a tulajdonosok vagyonát, őrzi a szervezet szabályszerű múködésének eszményét, erősíti az elszámoltathatóságot, összességében tehát kontrolláló szerepet ${ }^{131}$ is betölt a szervezet felett.

Fentiekből kifolyólag a felügyelőbizottság a kontrollkörnyezet részének tekintendő a coso-modell szerinti aspektusban, tevékenységével a tulajdonosi ellenőrzést szolgálja. Bár a jogszabály nem, a vállalati és nemzetközi gyakorlat kialakított néhány olyan elvet az FB-k múködése kapcsán, amelyek a vállalati belső kontrollrendszerrel is összefüggésben vannak. Ezek:

- A független belső ellenőrzési szervezet éves vizsgálati programtervét az FB hagyja jóvá, sőt bizonyos esetekben a belső ellenőr (internal auditor) nem is az első számú vezetőnek (CEO), hanem a felügyelőbizottságnak alárendelten múködik. Ugyancsak kialakult szokás, hogy az FB a belső ellenőr jelentéseit, valamint a realizációs folyamat eredményeiről szóló összefoglalókat is megtárgyalja, véleményezi, jóváhagyja.

- A vállalati belső kontrollrendszer múködésének eredményeiről, a cOSO ötödik komponensében tárgyalt monitoringtevékenység eredményeiről a felügyelőbizottságot rendszeresen tájékoztatni kell.

- Mivel a felügyelőbizottság testületként múködik, és jellemzően szinte kizárólagosan a vezetéstől, a menedzsmenttől kap információkat, azaz éppen azoktól, akiket ellenőriznie kell, ezért információs aszimmetria áll fenn, és az FB félrevezethetővé válik. Ennek kiküszöbölésére a felügyelőbizottság tagjai közé részben munkavállalókat, dolgozói küldötteket választanak meg, részben pedig az FB tagjai megkísérelnek legális módon, de a vezetéstől függetlenül információkat, adatokat gyűjteni a szervezetből, a szervezetről. Ennek eszköztára széles: a független szakértő/könyvvizsgáló megbízásától kezdődően a

\footnotetext{
${ }^{129}$ A társaságirányítási jelentések koncepcionális hátteréről és szabályozásáról lásd bővebben Bordáné Rabóczki Mária cikkét (Bordáné, 2010., pp.2-14.).

130 A felügyelőbizottság tagjainak ellenőrzési aktivitását, illetve ennek kritikáját lásd részletesen Osváth Sarolta cikkében (Osváth, 2000., pp.18-27.).

${ }^{131}$ A felügyelőbizottság tagjainak ellentmondásos szerepéről lásd részletesen Lukács János cikkét (Lukács, 2006., pp.137-141.).
} 
megfigyelésen és a beépülésen át az ERP rendszerhez való hozzáférésig bármilyen megoldás szóba jöhet.

- Az aktív és küldetését beteljesíteni kívánó FB maga vesz napirendjére olyan témaköröket, melyek az ügyvezetés kompetenciájától függnek, $\mathrm{s}$ ilyen módon a tulajdonosi kontrollgyakorlás aktív és közvetlen formájává válik. Ilyen témák lehetnek: piaci és értékesítési trendek, múszaki színvonal, stratégiai beruházások, vállalatközi kooperációk, termékfejlesztés és $\mathrm{K}+\mathrm{F}+\mathrm{l}$, hatékonysági mutatók (önköltség, kihasználtság, élőmunka- és anyaghányad stb.).

- Speciális tevékenységú társaságokban (pl. bank, biztosítótársaság, vagyonvédelmi szolgáltatás) az FB kiterjeszti vizsgálati tevékenységét az üzleti folyamatok szempontjából kritikus vállalati területekre is, úgymint pl. hitelkihelyezések jóváhagyása nagyobb összegben vagy nagyobb ügyfeleknek vagy belső munkatársaknak, összeférhetetlenségek vizsgálata, védelmi és biztonsági kérdések (security management), tőkemegfelelési és fizetőképességi mutatók monitoringja stb.

Témánk szempontjából - a felügyelőbizottság mellett - a másik fontos, társaságirányítási szinten múködő, tulajdonosi ellenőrző testület az audit bizottság (audit committee), amely a felügyelőbizottságtól függetlenül múködik. Hazánkban a PTK 3:291. §-a szabályozza az audit bizottságok tevékenységét. Lényegét tekintve a nyilvánosan múködő részvénytársaságoknál kell létrehozni kötelezően e testületet ${ }^{132}$. Az Európai Unióban az ide vonatkozó 2006/43/EK irányelv X. fejezete a magyar PTK-nál bővebben szabályozza - a közérdeklődésre számot tartó gazdálkodó szervezetek esetében - az audit bizottság szerepét és múködését, de annak tényleges tartalommal való megtöltése mindig a társaságokon múlik.

Az audit bizottság testületként jár el, a felügyelőbizottsági kontrollon túlmenően gyakorolja ellenőrző, kontrolláló tevékenységét a szervezetben (Moeller, 2007., pp.223-238.), (Sawyer et al., 2003., pp.1323-1342.), (BPP, 2011., pp.39-41.), (Kovács, 2007., pp.194-199.), (Kresalek \& Merétey-Vida, 2008., pp.39-41.), (Buxbaum, 2006., pp.14-17.). Ennek legfőbb eszközei, módjai a következők:

- Tagjainak egy része ( $\min .3$, max. 5 fő) független külső magánszemély, akik nem tagjai a tulajdonosi körnek sem, hanem a szakma, illetve a pénzügyi szféra elismert képviselői, személyükben feddhetetlenek, és ilyen módon az audit bizottság speciális ellenőrzési, illetve kontrolláló „tudással, ismerettel” gazdagodik „házon belül”. E független tagok eseti, egyedi

\footnotetext{
132 Magyarországon a Budapesti Értéktőzsde (BÉT) ide vonatkozó ajánlása fogalmaz meg a PTK-n túlmutató elvárásokat. Az ajánlás elérhető itt: http://bet.hu/data/cms61378/FTA_121201.doc (2015. 01.21.).
} 
ügyekben maguk is eljárhatnak, vizsgálódhatnak a szervezeten belül ${ }^{133}$, és jelentést tehetnek az audit bizottság, illetve a legfőbb szerv felé.

- A független belső ellenőrzési szervezet munkájának folyamatos figyelemmel kísérése, a belső ellenőri beszámolók és jelentések megtárgyalása, az ellenőrzési terület vezetőjének beszámoltatása ${ }^{134}$ a belső ellenőrzési rendszer múködéséről és bizonyos esetekben bérezésének, javadalmazásának meghatározása is.

- A belső auditor, a választott könyvvizsgáló, az eseti ügyekben felkért szakértő és könyvvizsgáló és más ellenőrzéssel, illetve kontrolltevékenységgel foglalkozó munkatársak tevékenységének koordinálása, munkáik összehangolása, „híd” teremtése ${ }^{135}$ e felek között a jobb kommunikáció, az összehangoltság, az egymásra épülés elősegítése érdekében.

- A kockázatkezelési és a belső kontrollrendszer működésének folyamatos monitoringja, vizsgálata, értékelése (akár külön kockázatkezelési albizottság keretében is) objektív alapokon, mutatószámokkal alátámasztva, valamint szubjektív, a nagyobb audittapasztalattal rendelkező tagok benyomására épített módon.

- A jogi normák megtartatása mellett etikai és morális kívánalmakat kommunikál, írott magatartási kódexet ad ki és ezek érvényesülését figyelemmel kíséri, valamint a csalás elleni hitvallást hirdeti a szervezeten belül.

- A felelős társaságirányítási jelentést állítja össze a szervezeten belüli kontrollok hatékonyságáról, és ezt - az elfogadását követően kommunikálja a nyilvánosság felé is, erősítve ezáltal a befektetőket, kisrészvényeseket és a fő tulajdonosokat is abban a meggyőződésükben, hogy a társaság irányítási szintjén a kontrolltevékenységek rendben zajlanak.

Bár a hazai jogszabályok nem említik, de a nemzetközi gyakorlatban bevált módon további bizottságok is létrejöhetnek a belső kontrollok vizsgálata, erősítése végett. llyenek például az önálló kompenzálási és javadalmazási bizottság, a kockázatkezelési bizottság, a szabályozási bizottság stb. (Moeller, 2007., pp.222223.).

\footnotetext{
133 Szokás emiatt őket non-executive directorként is említeni, mivel nem tagjai a munkaszervezetnek, mégis részt vesznek annak munkájában külső félként, de mégsem alvállalkozói vagy tanácsadói a végrehajtó apparátusnak. ${ }^{134}$ A belső ellenőrzési normák közül a 2060-as IIA-standard egyébiránt ezt a belső ellenőrzés vezetőjének egyébként is kötelezővé teszi. Az IIA 2002-ben publikálta a 2060-2. számú gyakorlati útmutatót (Practice Advisory) az audit bizottsággal való kapcsolattartás témájában (Sawyer et al., 2003., p.1334.)

${ }^{135}$ Az eredeti angol használatban az „interface” terjedt el, disszertációmban ettől némileg eltérve én inkább a platform, illetve a "híd” elnevezést használom. Az interface szerepet kibontva lásd részletesen (Sawyer et al., 2003., p.1337.)
} 


\section{F15. Menedzsmentkontroll mint vezetési eszköz, illetve a vállalati kontrollingfunkció}

A vállalatok szervezeti ábráján gyakran előtúnik a kontroller (controller ${ }^{136}$ ), illetve a kontrolling szervezeti egység, amely a vállalat vezetői számára riportokat, beszámolókat készít, illetve koordinálja a tervezést, kulcsteljesítmény-mutatókat kísér figyelemmel, múködteti a vezetői költségallokációs rendszert, egyedi elemzéseket készít stb. Ilyen módon ez a személy vagy szervezeti egység is kontrolláló szerepet tölt be a vállalat belső múködésében, azaz a kontrollkörnyezet része és kontrollfolyamatokat müködtet, a belső kontrollrendszer egyik eleme. A controlling, a belső ellenőrzés és a belső kontroll közötti különbségeket részletesen lásd Ruud és társa cikkének 3. számú táblázatában (Ruud \& Jenal, 2005., p.459.).

Azt, hogy mi a kontrolling feladatköre, mi tartozik bele, $\mathrm{s}$ kik a tevékenység címzettjei, haszonélvezői, nehéz egyértelműen megállapítani a sokféle kontrollingfelfogás és -nézet miatt. A különféle kontrolling-szakirodalmi megközelítéseket, a kontrollingfunkcióból eredő feladatokat, a kontrolling szervezeti kritériumainak történelmi fejlődését és nézőpontjainak különbségeit lásd részletesebben Horváth Péter (Horváth, 2011., pp.16-67.), valamint Szukits Ágnes (Szukits, 2015., pp.11-25.) múvében leírva, illetve a Nemzetközi Kontrolling Szövetség ${ }^{137}$ alapvetését a controllingterület kulcselemeit illetően (IGC, 2012., pp.13.).

\footnotetext{
136 Önmagában a pozíció írásmódja is vita tárgya a szakirodalomban, lásd bővebben (Laáb, 2011., pp.42-48.), (Véry, 2008.), noha az MTA jövevényszóként a c-vel való irásmódot javasolja (MTA Nyelvtudományi Intézet, n.d.). A magyar átírás kontroller lenne, „k" betüvel kezdve, amely az angol nyelvben használt controller szó átvétele. Az angol controlling szó azonban a német nyelvterületen is elterjedt (a német nyelvterületen ugyanakkor az angolszász országokban nem ismerik, nem használják, és a controllingfunkciót a német szakirodalom is következetesen c betüvel kezdve használja, miközben a k-val való írásmód lenne helyes Időközben a magyar vállalatok, s kiemelkedőek ezek között a multinacionális cégek, illetve a külföldi anyavállalattal müködő társaságok, is átvették a nemzetközi írásmódot, ezért az eredeti controlling szót használják szervezetükben, organigramjaikon. Mivel disszertációm magyar nyelven készült, és mindvégig törekszem a lehetséges magyar fordítást használni, így továbbiakban én a kontrolling írásmódot használom azzal a megkötéssel, hogy az egyes alfejezetekben kifejtem az egyes irányzatok fő jellemzöit, tartalmi különbségeit. Az irásmód jelentőségéröl és a szavak tartalmáról lásd bővebben (Bodnár, 2009., pp.XXI-XXVII.). 137 International Group of Controlling (IGC), szervezetükröl bővebben itt: http://www.igc-controlling.org/index.php (2015. 01. 27.)
} 


\section{Menedzsmentkontroll mint vezetői tevékenység}

A menedzsmentkontroll angolszász megközelítésben létrejött, meghonosodott kifejezés. A kontrolltevékenység fő tartalma a vezetés által folyamatosan végzett, visszacsatoló tevékenység. Anthony és Govindarajan múvében a menedzsmentkontroll kifejezést módszeresen így definiálják (Anthony \& Govindarajan, 2009., p.7.):

„A menedzsmentkontroll az a folyamat, amelynek során a vezetők annak érdekében befolyásolják a szervezet tagjainak magatartását, hogy megvalósítsák a szervezet stratégiáját."

Anthony és társa a menedzsmentkontroll-tevékenységet tehát folyamatként definiálja, és a vezetés részének, vezetői feladatnak tekinti. Művükben a menedzsmentkontroll-folyamatot a vállalati múködés részeként, rendszerbe szervezetten értelmezik (Anthony \& Govindarajan, 2009., p.4.):

„A menedzsmentkontroll-folyamat az a folyamat, amelynek révén a vezetök a szervezet minden szintjén biztositják, hogy az általuk felügyelt emberek megvalósítsák a szándékolt (szervezeti) stratégiát."

A menedzsmentkontroll-folyamat célja a célkongruencia ${ }^{138}$ megteremtése, és számos tevékenységet foglal magába, ezek közül a szerzők szerint a legfontosabbak a következők:

- tervezés, annak meghatározása, hogy a szervezetnek mit kellene tennie;

- koordináció, a tevékenységek összehangolása;

- kommunikáció, azaz az információcsere megvalósítása;

- értékelés, az információk kiértékelése;

- döntés arról, hogy van-e szükség beavatkozásra, intézkedésre;

- befolyásolás, az emberek viselkedésének megváltoztatása.

A célkongruenciából eredően a szervezeteken belüli kontrolltevékenység a vállalat több szintjén jelenik meg, ezek a következők (Anthony \& Govindarajan, 2009., pp.11-12.) és ezt elemzi (Bodnár et al., 1996., pp.25-27.):

- stratégiai szint, a stratégiaalkotás támogatása és az elfogadott stratégia lebontásának feladatai kerülnek ide;

- menedzsmentszint, amely a klasszikus vezetői folyamat, azaz a menedzsmentkontroll a már eldöntött stratégiák megvalósításában vállal szerepet;

- feladatkontroll szintje, amely az operatív végrehajtás szintjén biztosítja egy-egy meghatározott feladat eredményes és hatékony elvégzését.

\footnotetext{
138 Magyar megfelelője a célegyezőség, jelentése, hogy amennyire csak lehet, a szervezeti célokat és az egyén saját céljait összhangba kell hozni. Lásd bővebben (Anthony \& Govindarajan, 2009., pp.7-8.)
} 
A szerzők szerint a menedzsmentkontroll-rendszerek kialakítását és múködését a következő főbb elemek határozzák meg (Anthony \& Govindarajan, 2009., pp.1518.):

- a menedzsmentkontrollra ható környezeti jellemzők, ide tartoznak a kontrollfolyamatokra ható külső és belső adottságok, úgymint a szervezet stratégiája, a szervezeti struktúra, a kialakított üzletágak felelősségi és elszámolási típusokba sorolása.

- kontrollfolyamatok elemei, úgymint a stratégiai tervezés, az éves (operatív) kerettervezés, a végrehajtási tevékenység nyomon követése és a teljesítményértékelés, illetve a vezetői javadalmazás.

- a menedzsmentkontroll-rendszerek egyes szervezeti változatai, amelyek a hagyományos kontrolltevékenységek szervezeti megvalósítását foglalják magukban, ide értve a szolgáltatóközpontokat és a cégcsoportokon belüli, illetve a projektekre jellemző kontrollokat.

A menedzsmentkontroll-tevékenységet Merchant és Van der Stede müvükben elsősorban eredménykontrollként (results control) értelmezik, de felfogásukban a vezetők által végzett kontrollt Anthony és társa definíciójához hasonlóan határozzák meg (Merchant \& Van der Stede, 2012., p.6.):

„Management control, then, inculdes all the devices or systems

managers use to ensure that the behaviors and decisions of their

employees are consistent with the organisation's objectives and

strategies. The system themselves are commonly referred to as the management control system (MCSs)."

Merchant és Van der Stede a menedzsmentkontroll-rendszerek működését az elérendő eredmények kritériumai felöl közelítik meg, azaz felfogásukban a végeredmény a döntő, és ez alapján ítélhető meg a vállalat teljesítménye, illetve áttételesen a menedzsment teljesítménye, erőfeszítése is. Álláspontjuk szerint a vállalatvezetői belső kontrollrendszerek alaplogikája az eredmény-célkitűzés rendszeréből következik és a következő lépésekre tagolódik:

1. A teljesítményhez szükséges, kulcsfontosságú célkitűzések meghatározása, ide értve a vállalati üzleti modellt is, amely utóbbi szerint a társaság a saját múködését megszervezi.

2. A teljesítmények mérése, azaz annak megállapítása, hogy a kulcsteljesítmények elérésében hol tart a vállalat, illetve ennek a mérésnek milyen objektív és szubjektív részei vannak egy szervezeten belül.

3. Célértékek meghatározása a kulcsteljesítmények elérését illetően, azaz a vezetés által teljesítendő kulcsteljesítmény-mutatók minimálértékeinek meghatározása. 
4. A menedzsment jutalmazása a siker elismerése céljából abban az esetben, ha a célkitǔzések teljesültek, és a vállalat realizálta az elvárt eredményeket a kulcsteljesítmények során.

Merchant és társa múvükben az eredmények kontrollját a következő, minimálisan szükséges elemekre bontják fel:

- azonosítani kell a kontrollt annak megtestesítője/forrása szerint, így ők megkülönböztetik az üzleti folyamatokbóladódó kontrollt (pl. számítástechnikai rendszerek), a személyek által megkövetelt kontrollt (pl. auditor) és a vállalati kultúrából fakadó kontrollokat (pl. belső etikai normák), melyek együttesen hatnak a munkavállalók magatartására.

- a kontrollrendszert a következő egységekből, fő elemekből építik fel: felelősségi és elszámolási egységek kialakítása, tervezési feladatok, dolgozói javadalmazási program múködtetése, melyek így egyszerre teljesítik az eredmény-célkitűzések elérhetőségét és mérhetőségét.

- objektív teljesítménymérő és -értékelő rendszer szükségessége a szervezeten belül, melyek a vállalat rövid és hosszú távú fejlődéséről adnak képet, ide értve az értékteremtést, a piaci helyzetet, a beruházások megtérülését és a könyvelési adatokon nyugvó számszaki eredményeket, valamint kitérnek a nem vagy nehezen mérhető teljesítményfaktorokra is.

- értelmezni kell a kontrolltevékenységek környezetét, mint például a vállalatra vonatkozó jogszabályokat, a társaságirányítási struktúrát, az etikai előírásokat, a multinacionális hálózatokba való beágyazódást stb. Idetartozik a vállalat szervezeti felépítése is, beleértve a pénzügyi funkciót és az azon belüli munkaköröket, mint például a kontroller, a treasurer vagy a vezetésnek alárendelt belső auditor.

Látható, hogy Merchant és Van der Stede múvükben kiterjesztően értékelik a kontrollfolyamatokat, foglalkoznak a társaságirányítási szinttel és a napi operatív feladatok kontrolljával is. Anthony és Govindarajan ezzel szemben a kontrollfolyamatok múködésének elemeire helyezi a hangsúlyt, és mélyebben érinti a kommunikáció és a beszámolási rendszerek fontosságát. A menedzsmentkontrollrendszerek különböző megközelítéseinek hasonlóságait és kritikáit a Kontrollerek Nemzetközi Szövetsége (IGC) külön is vizsgálta, az így keletkezett összehasonlító kritikát lásd bővebben Berry és társai múvében (Berry et al., 2005., pp.17-28.).

Simons definíciójában átveszi Merchant és Van der Stede meghatározását, de a menedzsmentkontroll-rendszernek a középpontjába a vezetők információval való ellátását helyezi annak érdekében, hogy a vezetők irányítsák a vállalat tevékenységét (Simons, 1995., p.5.). Simons a vállalati kontrollrendszereket négy kategóriába sorolja be, s az információkat szerinte e kontrollok szerint kell gyújteni, 
értelmezni, s mindezt a vállalati célok elérése érdekében tenni. E szerint léteznek (Simons, 1995., pp.177-181.), (Simons, 2000., pp.301-316.):

- az üzleti lehetőséget, az alapvető üzleti modellt és a piacot vizsgáló, úgynevezett hiedelmekre irányuló kontrollok;

- a kockázatokat feltáró és attól a szervezetet megvédő, úgynevezett preventív kontrollok;

- a vállalati teljesítményt vizsgáló és a kritikus mutatókat magukban foglaló diagnosztikai kontrollok;

- a stratégia megvalósítását nehezítő, az üzleti modellt alapvetően akadályozó körülményeket és kitekintéseket, kitörési pontokat vizsgáló interaktív kontrollok.

A menedzsmentkontroll fenti, angolszász megközelítését további szerzők is átvették, illetve alapul vették, s a későbbiekben már a kontinentális országokban is hivatkoznak rájuk. Például Nilsson és társai definíciója a következő (Nilsson et al., 2011., p.14.):

"Management control consists of formalised information-based routines, structures and processes which management uses to formulate and implement strategies by influencing behaviour within the organisation."

Felfogásukban a kontroller a menedzsmentkontroll-tevékenységet ellátó vezetőket, a stratégiaalkotói és -megvalósítói szintet, valamint a vállalat működését, a stratégia megvalósítását hangolja össze.

Számos szerző - főleg korábbi, a 2000-es éveket megelőző múveikben - a menedzsmentkontroll-feladatkört a vezetői számvitel ${ }^{139}$ (management accounting) részének tekinti, és azon belül magyarázza fő tartalmi elemeit, mint például a belső riportok készítését a vezetés részére, a tervezést, illetve a költségallokációs feladatok ellátását és az árazási feladatokat (Garrison, 1985., pp.IX-XVII.), (Lucey, 1996., pp.130-254.), (Atkinson et al., 1997., pp.500-603.), (Needles et al., 1999., pp.199-328.). Múveikben a kontroller hangsúlyosan úgy jelenik meg, mint a számviteli információs rendszer egyik felhasználója, aki egyben döntés-előkészítő, illetve riportáló feladatokat is ellát ezen számviteli adatokra építve.

\footnotetext{
139 E felfogásban a számvitel alapvetően két részre osztható: ahol a vezetői számvitel a belső, azaz a menedzsment részére szóló információkat gyüjti, állítja elő, illetve elemzi, míg a pénzügyi számvitel (financial accounting) a külső feleknek szóló, klasszikus éves beszámoló összeállítására és annak könyveléssel való alátámasztására szolgál.
} 


\section{Controlling mint funkció}

A controlling kifejezés (c-vel vagy magyarosítva k-val írva), illetve a controllingkoncepció elsősorban a kontinentális országokban, főleg német nyelvterületen nyert teret, és a vezetést támogató kontrollt egyfajta funkcióként, eszközként értelmezi (Horváth \& Partners, 2009., p.15.):

„A controlling olyan funkciókat átfogó irányítási eszköz, amelynek a

feladata a tervezés, az ellenörzés és az információellátás

összehangolása. E feladat megvalósításáért a controller a felelös."

E klasszikus felfogásban a menedzsment a döntéshozó feladatkört látja el a vállalat életében, felelős az eredményekért és a stratégia megvalósításáért, míg a kontroller az ehhez szükséges információkat, javaslatokat szállítja a menedzsment számára, azaz koordináló szerepkört tölt be a vállalatban. A kontrolleri munkakör tehát eszköz a vezetés számára, rajta keresztül érvényesül a menedzsmentnek az információgyűjtő és -értékelő feladata, a kontroller látja el a tervezéssel és beszámolással kapcsolatos koordinációs és moderálási feladatokat.

A kontrollingtevékenység e felfogásban, Horváth Péter szerint klasszikusan a következőkre terjed ki:

- A kontrollingrendszer kiépítése és múködtetése általánosságban, az ehhez szükséges kontrollingszervezet kialakítása és a kontrolleri munka beágyazása a vállalati folyamatokba.

- Stratégiai, többéves (üzleti) és éves operatív (keretgazdálkodási) tervek kialakítása a vállalatban, e folyamat koordinálása, illetve ezen tervek továbbbontása szervezeti egységekre, projektekre.

- Átfogó információs és beszámolási rendszer kiépítése és múködtetése, amely a vezetőknek szóló információkat, riportokat, jelentéseket biztosítja a teljesítményekről, mutatószámok aktuális helyzetéről. Ez magában foglalja a számítógépes támogatást és a vezetői információs alkalmazások kiépítését, műkötetését is.

- A vezetői számvitelre épülő egyedi, a konkrét cégre szabott belső költséggazdálkodási, költségelszámolási és fedezetszámítási rendszer kidolgozása és működtetése - a termékek, illetve szolgáltatások hatékonyságának, fedezetének, nyereségtartalmának meghatározása végett.

Reichmann könyvében a kontrollingtevékenységek célját úgy jelöli, mint amelyek segítik a tervezési feladatokat és a tervek, illetve célkitűzések elérését, az eredmények realizálását a szervezetekben. Felfogásában idetartozik minden tevékenység, amely a stratégiai célok nyomon követésével és mérésével kapcsolatos, beleértve a pénzügyi teljesítmény mutatószámainak, az eredményességnek és a likviditásnak a nyomonkövetését (Reichmann, 1995., p.3.). 
Steven M. Bragg, noha nem német nyelvterületről származik, mégis funkcióként tekint a kontrollingra, és múvében a kontroller gyakorlati, napi feladatait veszi számba, úgymint a tervezés és a tervek irányába való haladás koordinálása, a mérés és értékelés és a beavatkozási lehetőségek elemzése (Bragg, 2011., pp.2-5.).

Francsovics Anna a controlling fejlődésének sajátosságai címú doktori értekezésében a német controllingiskola koncepcióját részletesen elemzi, bemutatja (Francsovics, 2005., pp.48-62.).

A hazai kontrolling-szakirodalom jórészt a kontinentális megközelítést alkalmazza műveiben, és elfogadja Horváth Péter meghatározását. Ennek megfelelően a tervezés, információgyưjtés és beszámolási rendszer kiépítését ismerteti múvében részletesen Hanyecz Lajos (Hanyecz, 2006., pp.20-44.). Ezt a megközelítését fogadja el a Magyar Controlling Egyesület alapítói által készített Ágazati és Funkcionális Controlling címú mú (Véry, 2004., pp.13-14.) is, mely szerint a controlling irányítási rendszerként múködik a vállalatban a menedzserek és a kontrollerek együttes munkája által.

Körmendi Lajos és Tóth Antal múvükben a controllingot elsődlegesen úgy említik, mint ami a tervezést, a terv megvalósulásának ellenőrzését, az eltérések döntéselőkészítő elemzését és az ezen tevékenységekkel összefüggő információkezelést vállalja fel (Körmendi \& Tóth, 2003., p.11.). Hasonló modellt mutat be könyvében Boda György és Szlávik Péter, akik a kontrollingot a tervek koordinálójaként, számviteli információkból kinyert tényadatok értelmezőjeként és beavatkozásra ösztönző irányítóként határozzák meg (Boda \& Szlávik, 1999., pp.15-16.). Sinkovics Alfréd könyvében például az erőforrások hatékony kihasználásának megállapítása áll a középpontban a kontroller feladatát illetően (Sinkovics, 2007., pp.20-21.). További hazai szerzők különféle, de a fentiekhez idomuló, hasonló kontrollingfelfogásait foglalja össze többek között Dr. Kondorosi Ferencné (Hágen \& Kondorosi, 2011., pp.10-22.) és Szukits Ágnes (Szukits, 2015., pp.41., 110.) is.

Látható azonban, hogy controllingtevékenység kontinentális felfogása és az angolszász megközelítés között vannak átfedések (pl. tervezési horizontok, jelentéstétel, információs adatok bázisának biztosítása, vezetők támogatása). A kontinentális kontrollingfelfogás mára igen nagymértékű közeledést mutat a menedzsmentkontroll-rendszerek angolszász megközelítésű koncepciójához. Ezt erősíti a kontrollerek küldetését ${ }^{\mathbf{1 4 0}}$ tartalmazó, 2013-ban elfogadott új IGC-

\footnotetext{
140 A magyar fordítás elérhető az International Group of Controlling (IGC) honlapján is itt: http://www.igccontrolling.org/img/pdf/controller_u.pdf (2015. 01. 27.).
} 
kinyilatkoztatás is, amely a célkitǔzésekből levezeti a kontroller legfontosabb öt feladatát is, s ebben az ellenőrzés szó már nem jelenik meg, mivel az ellenőrzést maga a vezetés végzi el, ellenben a kontrolleri feladatok a menedzsmentkontrollirányzathoz hasonló felfogást követnek (IGC, 2013., p.1.):

„A controllereknek az a küldetése, hogy a menedzsment partnereként jelentős mértékben hozzájáruljanak a szervezeti teljesítmény javításához.

A controllerek 5 fö feladata:

- A controllingfolyamat menedzselése

A controllerek kialakitják és támogatják a célkitüzés, tervezés és irányitás folyamatát annak érdekében, hogy a döntéshozók célorientáltan tudjanak tevékenykedni.

- Jövőbe tekintő koordináció

A controllerek gondoskodnak arról, hogy a szervezet tudatosan foglalkozzon a jövővel, s ezzel lehetövé teszik az esélyek kihasználását és a kockázatok kezelését.

- Célok összekapcsolása a szervezet minden szintjén A controllerek egységes egésszé integrálják az összes szervezeti szereplö céljait és terveit.

- Controllingrendszerek fejlesztése és az adatok jó minőségének a biztosítása

A controllerek fejlesztik és gondozzák a controllingrendszereket, biztositják az adatok jó minőségét és gondoskodnak a döntésekhez szükséges információkról.

- Gazdasági racionalitás feltételeinek biztositása A controllerek a szervezet közgazdasági lelkiismereteként elkötelezetten tevékenykednek az egész szervezet érdekében."

\section{F16. Kontrollálás a vállalati szintű múködési és irányítási szabványokban}

A vállalati kontrolltevékenységek között említjük a folyamatokba épített, illetve az automatizált kontrolltevékenységeket. E kontrollok jellemzően egységes szabványokban, illetve ezeket tovább bontó, belső vállalati utasításokban, normákban, eljárásrendekben testesülnek meg. A vállalatokon belüli kontroll, visszacsatolás, a vezetők irányába történő visszajelzés egyik nagy területét jelentik a 
szabványok ${ }^{141}$ által szabályozott vállalati irányítási rendszerek, mint például a minőségirányítási rendszer, környezetközpontú irányítási rendszer stb. Ezek szabályozási tárgyukból kifolyólag lehetnek átfogó irányítási szabványok (pl. minőségirányítási, környezetirányítási, munkaegészségügyi) és konkrét tárgykört, területet szabályozók (pl. kockázatkezelés, információvédelem, élelmiszer-biztonság stb.). Ezek közül is kiemelkedő és átfogó az ISO 9001:2008-as vállalati minőségirányítási szabvány, melyet a Nemzetközi Szabványügyi Szervezet ${ }^{142}$ kezel. E szabványoknak azért van jelentőségük, mert világszerte kb. egymillió ISO 9001 szerint tanúsított cég létezik, amelyek egyazon alapszabványra alapozva múködnek (Löffler et al., 2011., p.567.).

Az ezredfordulóra a különféle minőségügyi elvek konkrét standardokká, szabványokká értek meg, melyek hivatalosan elfogadottá és publikálttá váltak. Alkalmazásuk mindig önkéntes, de hatóság vagy jogszabály a szabvány/standard alkalmazását kötelezően is előírhatja. Míg korábban a minőségbiztosítás csak a termelésben volt elfogadott, és ott is inkább csak minőség-ellenőrzésből állt, később pedig minőségszabályozásnak tekintették, addig mára a PDCA ${ }^{143}$-logikákra épülő, tudatos vállalatirányítási rendszerek jelentős hangsúlyt helyeznek az átfogó kontrollokra a vállalaton belül. Jól mutatja ezt nevük is, mely a hatályos sztenderdek alapján minőségirányítási-rendszer, amely megnevezés azt jelképezi, hogy a rendszer egyben a vállalat múködésének keretet szabó irányítási filozófia is, s nem szúkül le pusztán a statisztikai mintavételre az üzemben. Fókusza az egész vállalatra, annak minden működési területére (beszerzés, értékesítés, képzés, menedzsment stb.), tervszerűségére, munkatársaira, beszállítóira is kiterjed. Az ISO szabvány lefedi a teljes értékalkotó és támogató folyamatrendszert a szervezeteken belül, ebből kifolyólag jelentős hatással bír az alkalmazott kontrollokra, kontrolltevékenységekre.

Valamennyi minőségügyi megközelítés, illetve szemlélet gyakorlatilag a PDCAciklusra építi logikáját, melynek a harmadik eleme ( $C=$ check) ugyancsak az ellenőrzési, visszacsatolási tevékenység. A „check” meghatározása a következő (Magyar Szabványügyi Testület, 2009., p.6.):

\footnotetext{
141 Hazánkban a szabványnak konkrét, törvényben rögzített definíciója van. Ez a 1995. évi XXVIII. törvény alapján a következő: „4. § (1) A szabvány elismert szervezet által alkotott vagy jóváhagyott, közmegegyezéssel elfogadott olyan műszaki (technikai) dokumentum, amely tevékenységre vagy azok eredményére vonatkozik, és olyan általános és ismételten alkalmazható szabályokat, útmutatókat vagy jellemzőket tartalmaz, amelyek alkalmazásával a rendező hatás az adott feltételek között a legkedvezőbb."

${ }^{142}$ A szervezet nevéből ered az ISO rövidítés, mivel angol eredeti neve International Organization for Standardization. A szervezetről bővebben itt lehet olvasni: http://www.iso.org/iso/home.html (2015. 01. 21.)

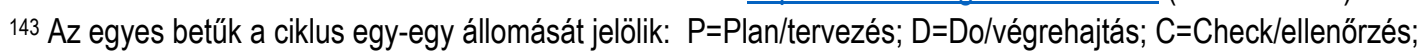
A=Act/visszacsatolás, beavatkozás.
} 
"check: (ellenörzés) a folyamatok és a termékek figyelemmel kísérése és mérése a politikákhoz, célokhoz, valamint a termékekre vonatkozó követelményekhez viszonyítva, és az eredmények jelentése."

\section{Ellenőrzés és visszacsatolás az ISO 9001 szabvány szerint}

Az ISO 9000-es szabványcsalád alapfogalmakból és szótárból (9000), a minőségirányítási rendszer alapszabványainak, követelményeinek előírásából (9001), és a tartós siker irányítási eszközeiből (9004) áll. Erre épülnek rá a további szabványok, mint például az auditszabályok (19011). Ezek összefüggéseit a folyamatszemléletű minőségirányítási modellel az alábbi összetett, 20. ábra szemlélteti.

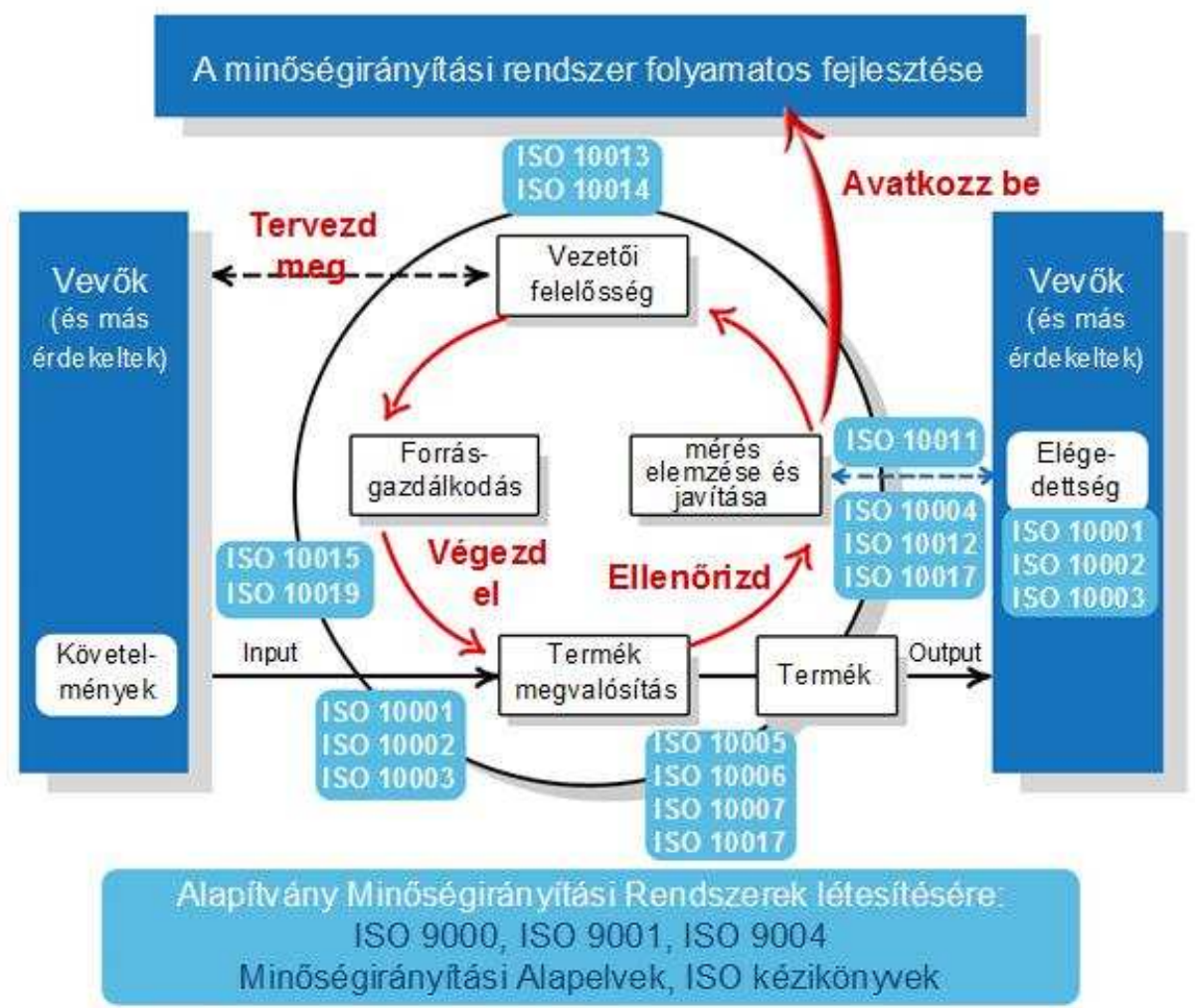

20. ábra: ISO folyamatszemléletü minőségirányítási modell és más szabványok kapcsolata Forrás: Berényi László (szerk) (2011): Minőségügy alapjai, elektronikus tananyag, Az irányítási rendszer modellje http://www.szervez.uni-miskolc.hu/blaci/minmen/az irnytsi rendszer modellje.html (2015. 01. 21.)

A jelenleg hatályos ISO 9001:2015 szabvány ${ }^{144}$ saját követelményrendszert állít a szervezetek elé, mely alapelvekből és konkrét szabványelemekből áll össze, úgymint

\footnotetext{
144 Itt a szabvány aktuális, 2016. 10. 12-én érvényes hivatkozása látható (magyar megfelelője: MSZ EN ISO 9001:2015), bár a társaságok többsége még a régebbi, ISO 9001:2009 szabvány verziója szerint müködik. A 2009-es szabvány is természetesen más, korábbi szabványokra épül, azok utódának tekinthető, mint például az
} 
dokumentációs kötelezettségek, erőforrásokkal való gazdálkodás, vezetőség felelősségi köre, tudatos döntéshozatal követelménye stb. Az ISO 9001 tanúsítványt megszerző vállalat tehát eleget tesz a szabványban leírt kritériumoknak, amennyiben a követelményeket jelentős hiba nélkül teljesíti.

Az ISO 9000:2005 szabvány mélyrehatóan foglalkozik az egyes ellenőrző-megerősítő fogalmakkal. E szabvány az ISO 9001-es szabványcsalád fogalomtára (MSZT, 2005.). Ezek szerint az egyes használt fogalmak jelentése a következő (zárójelben utána a szabvány hivatkozási pontja):

- „ellenörzés: a megfelelöség kiértékelése megfigyeléssel és itéletalkotással, továbbá értelemszerüen méréssel, vizsgálattal vagy idomszeres ellenörzéssel." (3.8.2)

- vizsgálat: egy vagy több jellemző (3.5.1.) valamely eljárás (3.4.5.) szerinti meghatározása." (3.8.3)

- „igazolás (verifikálás): annak megerősitése objektív bizonyíték (3.8.1.) szolgáltatásával, hogy az elöírt követelmények (3.1.2) teljesültek." (3.8.4.)

- „átvizsgálás: tevékenység, amely a vizsgálat tárgyára vonatkozóan az alkalmasság, a célnak való megfelelés és az eredményesség meghatározására irányul, a kitüzött célok elérése érdekében." (3.8.7.)

- „audit: auditbizonyítékok (3.9.4) nyeréséree és ezek objektív kiértékelésére irányuló módszeres, független és dokumentált folyamat (3.4.1) annak meghatározására, hogy az auditkritériumok (3.9.3.) milyen mértékben teljesülnek." (3.9.1)

A fentiekből kitűnik, hogy a minőségirányítási megközelítésben a követelmények teljesülését az igazolás és nem az ellenőrzés igazolja vissza. Más kontextusban használja a szabvány az ellenőrzés szót is, mint azt korábbiakban a pénzügyi ellenőrzésnél bemutattam. És végül az átvizsgálás szó definíciójában is más jelentést olvashatunk, mint azt a számviteli ellenőrzés szóhasználatában megszoktuk.

Ugyanakkor - a definíciók tartalmára és a szabvány logikájára építve - itt is megtaláljuk azokat az alapvető vállalatirányítási elemeket, melyek meghatározzák egy minőségközpontú irányítási rendszer követelményeit, egyben nagyban hasonulnak a COSO-keretrendszerben lefektetett célokhoz. Ezek a következők: 
- szükséges a követelmények (célok, elvárások, etalonok stb.) meghatározása, lefektetése helyben,

- folyamatos és módszeres adatgyűjtés, információfeltárás és -elemzés, kiértékelés zajlik,

- megkerülhetetlen a vezetőség felelőssége a kiértékelésben, és irányító szerepe van a folyamatokban és a visszacsatolás során,

- szükség szerint be kell avatkozni és helyesbítő vagy megelőző intézkedéseket kell tenni annak érdekében, hogy az eredeti követelményeket a szervezet teljesíthesse.

A hatályos szabványok alapján a minőségirányítás a szervezet irányításának része. $\mathrm{A}$ szervezet pedig akkor tud sikeres lenni, ha az irányítási rendszert (beleértve a minőségirányítást is) folyamatosan fejlesztik az összes érdekelt fél szükségleteinek figyelembevételével (MSZT, 2005., p.8.). Ezért a szabvány előírja és meghatározza a menedzsment, a felső vezetés konkrét szerepét a minőségirányítási rendszerekben azáltal, hogy dokumentálniuk kell a szervezet folyamatait, időközönként át kell vizsgálniuk az irányítási rendszer múködését ( $C=C h e c k$, ellenőrzés, kontroll), biztosítaniuk kell az erőforrásokat a rendszer múködtetéséhez, így a belső auditokhoz is. A visszacsatolás adatait, az audittól kapott információkat pedig fel kell dolgozniuk, szükség szerint be kell avatkozniuk, amely a PDCA-ciklus utolsó eleme ( $A=A c t$, beavatkozás, módosítás intézkedése).

A szabvány meghatározza a követelmény definícióját, amely „kinyilvánított igény vagy elvárás, amely általában magától értetődő vagy kötelező" (ISO 9000:2005. 3.1.2 pontja). Ezek azok a követelmények, amelyeket a szervezetnek folyamatai kapcsán - ide értve a termelést/szolgáltatást, a gyártást, az értékesítést stb. is -meg kell határoznia és teljesítenie kell. Ezek betartására pedig auditokat kell végeznie. Az ISO alapfogalmak szerint a minőségbiztosítási audit többlépcsős, és céljai a következők az ISO 9000:2005. 3.1.2 pontja szerint:

„Az auditokat arra használják, hogy meghatározzák a minőségirányítási rendszer követelményeinek való megfelelés mértékét."

Ebből kifolyólag az audit visszajelzés a vezetés, a menedzsment számára az általa elérendő, kitűzött célok teljesítéséről. A szabvány az auditok szintjét a következőképpen határozza meg (ISO 9000:2005. 2.8.2 pontja):

- első szint a belső önértékelés, amikor a szervezet maga ellenőrzi a követelmények teljesülését. Ez történhet folyamatba épített ellenőrzéssel és belső auditor által megtámogatott auditálással;

- második szint a vevők által elvégzett audit a beszállítónál, szolgáltatónál, melynek célja megbizonyosodni arról, hogy a partner garantálni tudja a minőséget a vevő számára; 
- harmadik szint a független, külső és általában akkreditált felek által végzett audit, melynek célja annak kimondása és tanúsítása, hogy az irányítási rendszer a szabványban rögzített követelmények szerint múködik.

Ugyanakkor Gutassy Attila a múvében az auditok felbontására más rendszerezést is használ (Gutassy, 2003., pp.20-21.): 1. Az audit tárgya szerinte lehet múködési rendszer, elóállított termék (és szolgáltatás), a szervezet maga, illetve ember (munkavállaló); míg 2. az ellenőrzést (auditot) végzők szerint megkülönböztetünk belső és külső auditot, mely utóbbi lehet vevői audit vagy tanúsító audit.

A vállalati belső auditok folyamatát és az auditdokumentációkat a 21 . ábra szemlélteti:

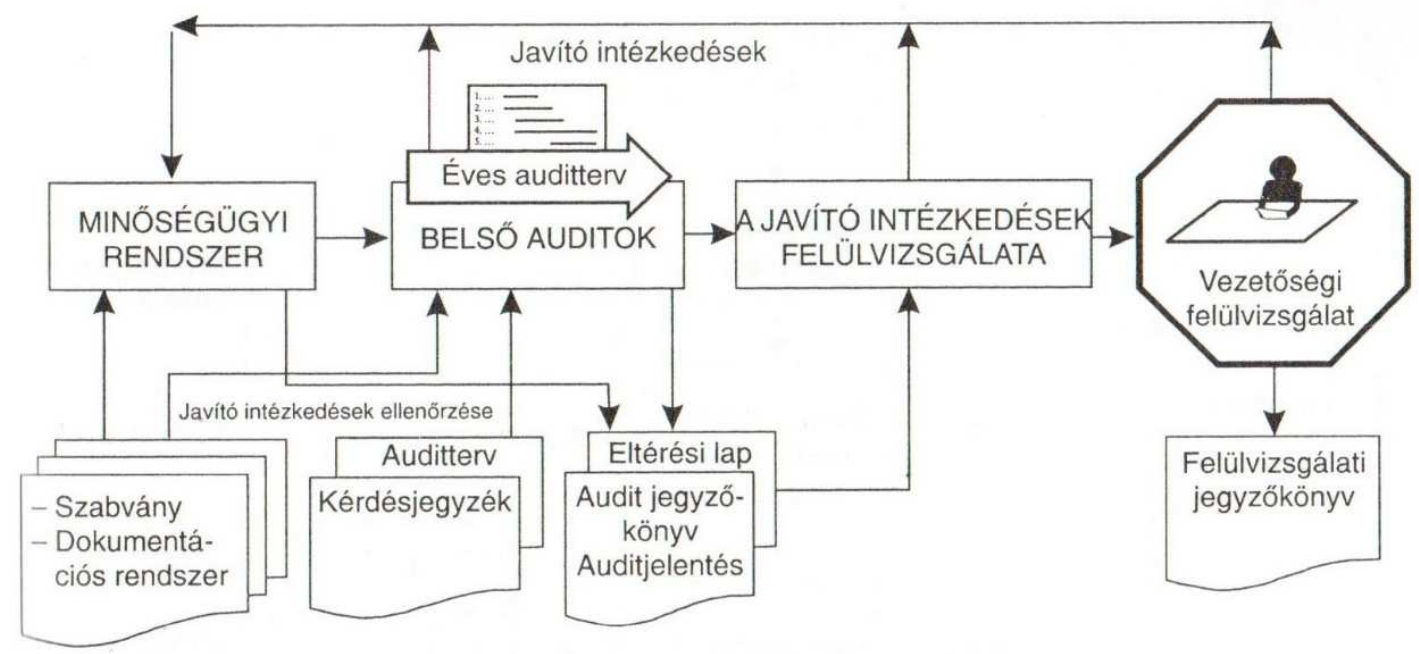

21. ábra: Minőségirányítási belső auditok folyamata és dokumentumai

Forrás: (Koczor, 2006., p.301.), 10. ábra

Az auditok tartalmát és a követelményeket az ISO 9001:2008 szabvány egyes pontjai határozzák meg. Ezek közül a pénzügyi-számviteli terület számára lényeges szempontokat (önkényesen) kiemeltem. Ezek a következők (zárójelben a végén a szabvány egyes pontjaira történő hivatkozások):

- Folyamatszemlélet: azaz a vállalkozásnak meg kell határoznia az értékesített termék előállításának vagy szolgáltatás nyújtásának egymás utáni lépéseit és azok kölcsönhatásait, s mindezeket dokumentálnia kell kézikönyvben, eljárásokban, munkautasításokban, kísérő dokumentumokban (pl. folyamatábrák) (4.1). Ebből következően az auditnak feladata annak megállapítása, hogy vannak-e a vállalati múködést irányító folyamatleírások, és azok megfelelően dokumentáltake, valamint hogy azok a ténylegesen zajló folyamatokat tartalmazzák-e.

- Vezetés felelőssége és elkötelezettsége: a vállalat vezetésének feladata a vállalati minőségirányítási rendszer működtetése, s egyben törekednie kell 
ennek megújítására (5.1). Ennek értelmében az audit során a vezetés tudatosságát és szándékát kell vizsgálni a minőségirányítási rendszer múködtetésére vonatkozóan.

- Vevőközpontúság, tudatosság és célkijelölés: vagyis a szervezetnek ismernie kell a vevő(k) igényeit, és ki kell tűznie ehhez igazodó, reális célokat, amelyeket el akar érni. Továbbá azonosítania kell azokat a követelményeket, amelyeket a külső felek támasztanak a szervezettel szemben, és amelyek a célokra hatást gyakorolnak (5.2-5.4). Az auditnak az a feladata, hogy megbizonyosodjon arról, hogy a vevői igényfelmérések és a célkitűzések megtörténtek, azok léteznek, valamint a szervezet a környezeti befolyásoló impulzusokat regisztrálja, követi, elemzi saját múködésére hatóan.

- Gondoskodás az erőforrásokról: vagyis a minőségirányítási rendszer múködtetéséhez és fejlesztéséhez szükséges anyagi, személyi, információs stb. erőforrásokat rendelkezésre kell bocsátani a vállalat munkatársai számára (6.1). Az audit során arról kell tehát megbizonyosodni, hogy milyen bizonylatok, dokumentumok igazolják azt, hogy ez megtörtént, és ez mennyire arányos, mennyire folyamatos.

- Visszacsatolás szükségessége: azaz a múködés során méréseket kell végezni, melyek a termékekre, a folyamatokra, az inputokra és az outputokra is kiterjednek. Ezeket értékelni és minősíteni kell, hasonlítani kell a tényeredményeket a tervekhez, követelményekhez, és szükség szerint be kell avatkozni (8.2-8.4). Az audittevékenység során arról kell tehát megbizonyosodni, hogy megtörténtek a mérések, van objektív és megbízható, tényszerű leírás a jelen helyzetről, és azt összevetették a célkitüzésekkel.

- Beavatkozás szükségessége: amennyiben bárki (munkatársak, vezetők, auditorok, vevők, beszállítók, hatóságok stb.) a követelményektől való eltérést azonosít, a szervezet köteles azt - a kivizsgálást követően orvosolni és a további hibás múködést kiküszöbölni, azaz a nemmegfelelőséget megszüntetni. (8.5.2-8.5.3). Az auditor feladata arról meggyőződni, hogy a nemmegfelelőségeket feltárták a múködés során, és ezekre a vállalat vezetése reagált, tényeken alapuló döntést hozott, beavatkozott, helyesbítő és megelőző intézkedéseket tett.

A követelmények teljesítését audit keretében kell megállapítani, melynek szabályrendszerét az ISO 19011:2002 szabvány írja le részletesen (MSZT, 2002.). A szabvány az auditok lebonyolításával kapcsolatosan a következőket írja elő a szervezet számára: 
- Az audit független, tárgyilagos tevékenység, melyet elfogulatlanul kell végezni, és a megállapításokat bizonyítékokra alapozva kell meghozni. Az auditoroknak etikusan, kellő szakmai gondossággal, a valósághoz húen kell állításaikat megfogalmazniuk és alátámasztaniuk (3.1-3.5 illetve 4. pont).

- Az auditokat előre tervezetten kell végezni. Szükséges éves auditprogramot összeállítani, egy-egy vizsgálatra vonatkozóan pedig audittervet kell készíteni a vizsgálat megkezdése előtt (3.11-3.12 és 5 . pont).

- Az audit lefolytatásának részletszabályait be kell tartani, mind az auditot végző, mind az auditált kötve van a szabályokhoz, előírásokhoz (6. pont).

- Az auditorok humán tudását, ismereteit folyamatosan bővíteni kell, garantálni kell, hogy munkájuk során a szükséges képzéseket és ismeretanyagokat megkapják (7. pont).

Az ISO rendszerekben használatos auditeszközök és -módszerek nem különböznek lényegesen a más modellekben ismertetett, alkalmazott vizsgálati eszközöktől ${ }^{145}$. Gutassy múvében ezeket részletesen ismerteti, úgymint nyitó értekezlet a szükséges kommunikáció megalapozásával, helyszíni ellenőrzések végzése, megfigyelés, dokumentumelemzés, interjúkészítés, mintavétel stb. (Gutassy, 2003., pp.47-57.).

Gutassy Attila és Koczor Zoltán múveikben bemutatnak több olyan szempontot is, melyek a minőségirányítás szoros kapcsolatát jelenítik meg más vállalati területekkel, így például a belső kontrollrendszerrel:

- A minőségbiztosítási rendszerek főleg folyamatba épített és azonnali ellenőrzési módszereket alkalmaznak, írnak elő a társaságok belső múködését illetően. Ilyenek például az idegenáru-átvétel, a gyártásközi ellenőrzés vagy a végellenőrzés, az itt születő igazoló bizonylatok pedig később a pénzügyi-számviteli támogató folyamatokban is megjelenhetnek. Ezzel szemben az utólagos ellenőrzések - mint például az auditok, vezetőségi átvizsgálás, beszállítók értékelése stb. - inkább reagálási, intézkedési lehetőséget, korrekciós beavatkozást tesznek lehetővé a menedzsment számára (Gutassy, 2010., pp.83-92.).

- A minőségköltségek alakulása alapvetően a minőségbiztosítási terület sajátossága, de a költségeket szem előtt tartó vezetőnek az szemléletét nagyban befolyásolják az így kapott számszaki adatok. Azt ugyanis célszerü tudni, hogy mi okozza a nem tervezett költségeket, hol vannak a fel nem

\footnotetext{
${ }^{145} \mathrm{~A}$ belső ellenőrzés, kontroll, revízió, audit stb. során alkalmazott vizsgálati eszközök és módszerek összefoglaló jegyzékét az 2. számú függelék mutatja be felsorolásszerüen.
} 
tárt veszteségek, illetve hol van az egyensúly az alul-, illetve túlszabályozásban, melyiknek mekkora a haszna és a ráfordítása a vállalatban (Koczor, 2006., pp.310-321.).

- A szabvány a vezetés számára tényeken alapuló döntéshozatalt ír elő, azonban a tények nem maguktól születnek, hanem azokra bizonyítékokat kell szolgáltatni. Ezek pedig éppen a mérésből fakadó eredményadatok, naturális és pénzügyi mutatószámok és a teljesítménymérő rendszer mutatószámai lehetnek (Koczor, 2006., pp.61-66.).

- A külső felek által megfogalmazott követelmények kapcsán a jogszabályok adta kereteket is figyelembe kell venni, a társaságnak ezeket a szabályokat azonosítania kell, és a nekik való megfelelést a vállalat múködése során biztosítani kell, s erről az auditok során ugyancsak meg kell bizonyosodni (Gutassy, 2003., p.189.), (Gutassy, 2010., p.47.).

- A kockázatkezelés a minőségirányításnak is része, nem tér el a korábban általam ismertetett COSO-ERM modelltől, illetve egyéb kockázatkezelési modellektől. A minőségirányítási rendszer is megköveteli a kockázatok feltárását, elemzését és arra előírt vezetői reakciókat. Ennek eszközei a minőségfejlesztés területén inkább műszaki jellegűek (pl. FMEA, $6 \sigma$ módszer, hibafa-elemzés, SPC), míg a vezetés és az erőforrás-kezelés területén inkább szervezési és gazdasági orientációjúak (pl. benchmarking, poka-yoke módszer, kaizen) (Koczor, 2006., pp.144-166.).

\section{Kontroll az ISO 31000 kockázatkezelési szabványban}

Az ISO 31000:2009 szabvány ${ }^{146}$ a kockázatmenedzsment szabványa, elvek gyűjteménye és hozzá kapcsolódó útmutató, mely szektorsemlegesen ${ }^{147}$ írja le a kockázatkezelés módját, elvárásait a szervezeten belül. Az ISO 31000 szabvány nem a COSO-modellt lefedő vagy azt legalizáló szabvány, de igen nagy átfedésben van az ott bemutatott, alkalmazott elvekkel, módszerekkel. Az ISO 31000 módszertani jellegű szabvány, ezért nem lehet közvetlenül tanúsításra felhasználni, de jó alapul szolgálhat a vállalaton belüli kockázatmenedzsment-módszerek kialakításához, fejlesztéséhez. Mivel pedig a kockázatok menedzselése ${ }^{148}$, kezelése erősen összefügg a szervezet környezetének monitoringjával és belső adottságainak ellenőrzésével, így a szabvány a belső kontrollt is befolyásolja (s a COSO-modell szerint a kontrollkörnyezet része is egyben) (Goutama, 2013., pp.14-17.).

\footnotetext{
146 Magyarországon MSZ EN ISO 31000:2015. szabványszámmal érhető el a magyar hivatalos fordítás.

147 Értsd: egyszerre alkalmazható az üzleti, a költségvetési és a nonprofit szférában, mivel felépítése és tartalma olyan általános elveket rögzít, amelyet valamennyi szervezet alkalmazni tud.

148 A vállalatot esetlegesen fenyegető kockázatok felsorolását lásd a 3. számú függelékben.
} 
A szabvány célja egységesíteni a vállalati kockázatok kezelésének eszköztárát. A szabvány kitér a kockázatok felismerésének, felmérésének, elemzésének és kiértékelésének rendjére, valamint a beavatkozás, a kezelés módjait is meghatározza alapszinten (Ivanyos, 2012.).

Az ISO 31000 szabvány logikai felépítését és szervezeten belüli működését a 22 . ábra szemlélteti ${ }^{149}$ :

\section{ALAPELVEK}

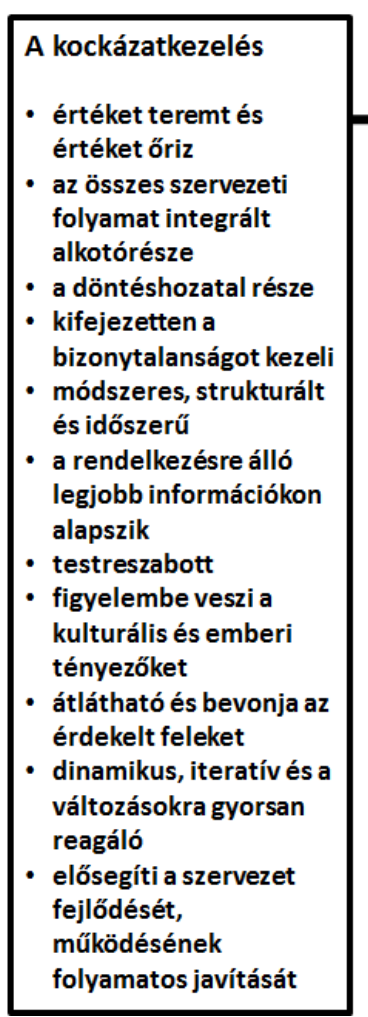

KERETRENDSZER

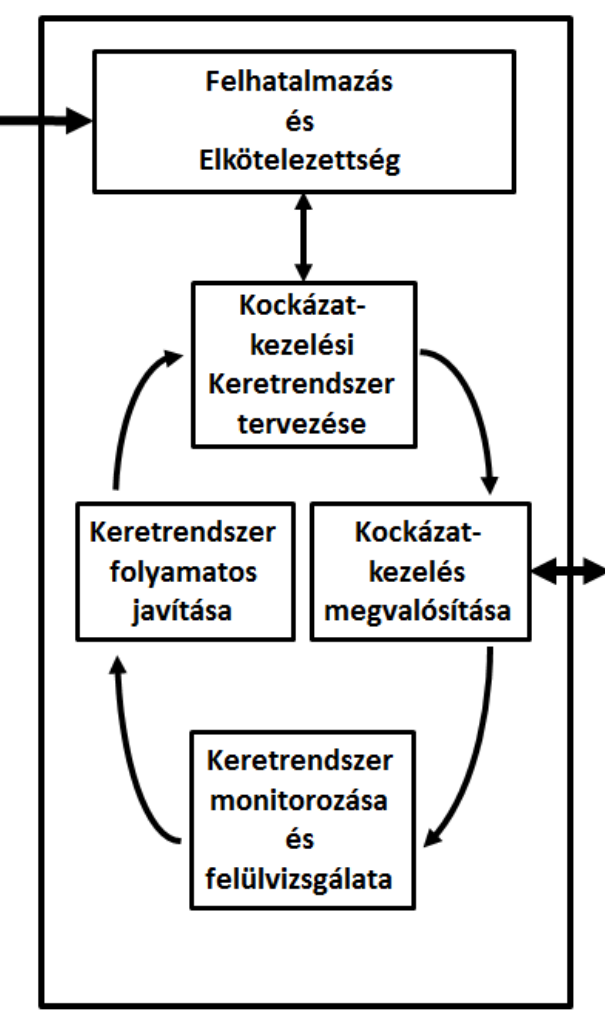

\section{FOLYAMATOK}

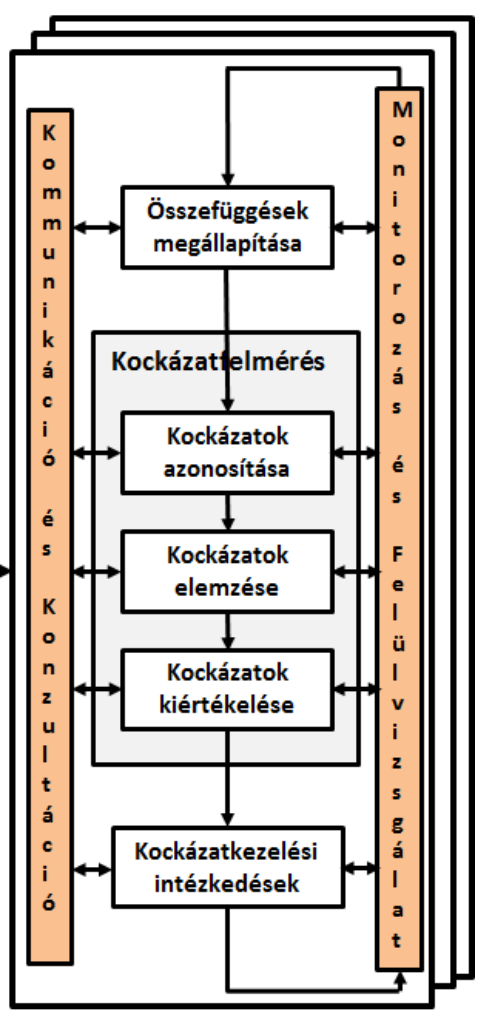

22. ábra: ISO 31000 kockázatkezelési elvek, keretrendszer és folyamatleírás

Forrás: (Ivanyos, 2012., p.1.)

\section{Kontrollok további szabványokban, normaalapú rendszerekben}

Az ISO 9001 és az ISO 31000 szabvány mellett létezik több olyan egyéb modell is, melyek a vállalati kontrollmechanizmusokra visszahatnak, azt szabályozni, standardizálni törekednek, ugyanakkor a kontroll nem hangsúlyos bennük. Ilyen például a TQM-filozófia szerint múködő irányítási elv, amely a vevői elégedettséget helyezi a középpontba, de mindezt a vállalkozás erőforrásainak leghatékonyabb kihasználása révén kívánja elérni (Gutassy, 2010., p.270.). A TQM 5 alapelve közül az

\footnotetext{
${ }^{149}$ Az eredeti ábra az ISO 31000-es szabványban Nr. 1. számmal jelölve található meg, címe: Relationships between the risk management principles, framework and process.
} 
egyik a vezetés tudatossága, hiszen ő felelős a kinyilvánított célokért, és azok elérésére kell ösztönöznie a vállalat dolgozóit is. Ennél mélyebben azonban a TQM nem érinti a belső kontroll intézményét a vállalaton belül (Koczor, 2006., pp.342346.).

A TQM-mel szemben az EFQM ${ }^{150}$-modellben a kontroll szerepe sokkal szembetűnőbb. Az EFQM egy kiválósági modell, amely az eredményességre (a vállalkozás sikerességére) helyezi a hangsúlyt úgy, hogy figyelembe veszi valamennyi érintett fél (beszállítók, munkavállalók, menedzsment, vevők stb.) közremúködését és a teljesítményhez való hozzájárulásukat. Ez pedig csak a teljesítmény mérésével, azaz mutatószámok és folyamatstandardok, vagyis belső szabályozások révén érhető el. E pontokon az EFQM és az ISO 9004:2002 szabvány összekapcsolódnak (Erdei et al., 2010., pp.14-15.).

E modellekre, illetve a PDCA-ciklusra építkezve további modellek terjedtek el, mint például a magyar Nemzeti Minőség Díj, a közigazgatásban alkalmazott Közös Értékelési Keretrendszer (Common Assessment Framework) vagy a japán 5 S elvek. Ezek mindegyike hordozza magában a szervezetekre vonatkozó tanulás, visszacsatolás, önértékelés, mérés, teljesítménycél-kitűzés stb. követelményeit.

\section{F17. A vállalati kontrollrendszer további egyéni szereplői, múködtetői}

A szervezeteken belül találunk olyan egyedi, egyéni munkakörökben dolgozókat is, akik specifikus funkciójuk, sajátos felhatalmazásuk alapján vagy egyéb úton végeznek kontrolltevékenységeket. Ezek a következők, s az alábbiakban ilyen munkaköröket mutatok majd be vázlatosan:

- Fraud manager

- Compliance manager

- Etikai koordinátor

- További egyéb (IT-auditor stb.) szereplők

A vállalatokon belüli csalásfelderítési feladatok az úgynevezett „fraud manager” munkakörhöz köthetőek, elfogadott és egységes magyar fordítása a pozíciónak azonban még nincsen. Szokás őket csalásfelderítőknek, visszaélés-detektálóknak, illetve -kivizsgálóknak is nevezni, gyakran pedig összemossák feladatkörüket a

\footnotetext{
${ }^{150}$ Az EFQM-modell az European Foundation for Quality Management (EFQM) szervezet terméke, a modellről és a szervezetről bővebben itt: http://www.efam.org/ (2015. 01. 22.)
} 
bankbiztonsági vagy a pénzmosás elleni felelősökkel ${ }^{151}$. A fraud manager-i munkakör bármilyen ágazatban alkalmazható, meghonosítható, ahol a csalás, illetve visszaélés detektálása, felderítése és leleplezése elvárt. A csalásmegelőzésről és annak szervezeti megvalósításáról lásd bővebben (BEMSZ-ETK, 2015.), a kis- és középvállalkozások számára ajánlott csalásmegelőzési programról pedig itt (Dawson, 2015., pp.3-53.).

A fraud manager a vállalaton belüli visszaélések felderítését végzi, a szándékosan elkövetett csalásokat ${ }^{152}$ kutatja és leplezi le a vállalaton belül, és jellemzően az ő feladata a "közérdekű bejelentések” kivizsgálása is a szervezetekben ${ }^{153}$. Ebből következően munkája a belső operatív végrehajtásra, a vállalat munkaszervezetére összpontosul, azon belül is a vezetőkkel szembeni vizsgálódása kiemelt jelentőségű, mivel a kontrollokat általában a vezetők múködtetik, így ők tudják azokat a legjobban kijátszani, felülírni, kiiktatni vagy a kontrollfolyamatokat eltéríteni, s így teret engedni a szándékos károkozásnak.

A visszaélés definícióját a belső ellenőrökre vonatkozó IIA-norma a következők szerint határozza meg (IIA, 2012., p.20.):

„Visszaélés

Minden jogellenes cselekedet, amelyet megtévesztés, eltitkolás vagy a bizalom megsértése jellemez. Ezek a cselekedetek nem függenek erőszakkal való fenyegetéstöl vagy fizikai kényszertől. Visszaélést egyének és szervezetek követhetnek el pénz, tulajdon vagy szolgáltatás szerzése céljából, fizetés vagy szolgáltatásvesztés elkerülésére, vagy személyes, illetve üzleti elöny elérésére."

A 240. számú nemzetközi könyvvizsgálati standard 11. (a) pontja a vállalaton belüli csalás felderítését írja elő a könyvvizsgálónak, és ennek kapcsán megadja a pénzügyi csalás egy hivatalosnak tekinthető definícióját is (Könyvvizsgálók Nemzetközi Szövetsége (IFAC), 2009., p.6.):

„Csalás - a vezetésen, az irányítással megbízott személyeken, a munkavállalókon vagy harmadik feleken belüli egy vagy több személy

\footnotetext{
151 Money anti-loundry manager, aki kifejezetten a pénzmosás elleni küzdelem szereplője, s bár ő is igyekszik visszaéléseket leleplezni, specifikusan csak a pénzmosással kapcsolatosan teszi ezt. A pénzmosás büntettének meghatározását lásd a magyar BTK 399-402. §-ában, az ez elleni küzdelemről pedig bővebben itt:

http://nav.gov.hu/nav/penzmosas (2015. 01. 27.)

152 A csalás büncselekmény, melyet a hatályos magyar BTK 373. §-a is definiál büntetőjogi értelemben, illetve szabályozza a gazdasági csalás (374. §) és az információs rendszer felhasználásával elkövetett csalás (375. §) büntetőjogi tényállását is.

${ }^{153}$ E tevékenységet a nemzetközi szakirodalom whistleblowing eljárásnak nevezi, és a magyar megközelítésben használt közérdekű bejelentő, illetve panasz benyújtása helyett sokkal nagyobb szerepe van a vállalat dolgozóitól érkező, anonim vagy névvel együtt beküldött észrevételek kivizsgálásában, elbírálásában. Lásd bővebben a SOX 806. szekcióját (Lander, 2004., pp.97-99.)
} 
által szándékosan elkövetett cselekedet, amely együtt jár a méltánytalan

vagy illegális előny szerzése céljából alkalmazott megtévesztéssel."

Amennyiben a fraud manager szándékos csalást fedez fel ${ }^{154}$, visszaélést sejt, jogosult bizonyítékokat gyújteni ennek alátámasztására, s küldetése akkor teljesül be, ha a vállalaton belüli csalást ${ }^{155}$ le tudta leplezni és ezáltal ki tudta iktatni azt a belső működésből.

A compliance ${ }^{156}$ manager (vagy compliance officer) olyan munkavállaló, aki a vállalat múködését folyamatosan a rá vonatkozó jogszabályokhoz, előírásokhoz próbálja igazítani. Magyar szövegkörnyezetben általában „megfelelési vezető” a használatos kifejezés. Az ügyvéddel és a társasági jogtanácsossal szemben a compliance manager a különféle jogszabályokban (pl. SOX, BilMoG) előírt kötelezettségből fakadóan figyelemmel kíséri a szervezetekre vonatkozó konkrét irányelveket, szabályzatokat és rendelkezéseket, és azt vizsgálja, hogy a szervezet ezeknek az előírt normáknak megfelel-e, eleget tesz-e.

Tipikus vállalati szabálytalanságok terepei a következők: gazdasági előírások/jogszabályok kijátszása, adó és társadalombiztosítás, munkaügyi és foglalkoztatási követelmények, versenyjogi és a tisztességes piaci magatartással összefüggő előírások, szellemi termékekre és immateriális vagyonra vonatkozó előírások, munkavédelmi és egészségügyi szabályok (Löffler et al., 2011., pp.607612.).

A compliance, vagyis a megfelelés hiánya egyfajta kockázat a szervezet számára, hírnévromlás, szankció, pénzbüntetés, piaci részesedés csökkenése stb. lehet a következménye. Ezért amennyiben a compliance manager eltérést, azaz valamilyen előírás megsértését tapasztalja, intézkedés céljából fordul a felső vezetéshez, szükség szerint a legfőbb szervhez, az audit bizottsághoz vagy a felügyelőbizottsághoz.

A vállalaton belüli etikai normák, az írott etikai kódexek (viselkedési ajánlásokat tartalmazó etikai standardok) a kontrollkörnyezet egyik jelentős elemének számítanak, és áthatják az egész munkaszervezetet. E normák betartásáért és

\footnotetext{
${ }^{154}$ A számvitel területén elkövetett véletlen hiba, a szándékos csalás és a kreatív könyvelés elhatárolását lásd részletesen Lukács János ez irányú cikkében (Lukács, 2007., pp.133-142.).

${ }^{155}$ A csalásnál bővebb kifejezés a gazdasági bűnözés fogalma, mely a megvesztegetést, a korrupciót is magában foglalja. Egy hazánkban elvégzett, gazdasági bűnözés tárgyú felmérés eredményeit lásd itt: http://www.pwc.com/hu/hu/kiadvanyok/globalis_gazdasagi_bunozes_felmeres/index.jhtml (2015.03. 13.). ${ }^{156}$ A compliance angol szó, önmagában egyetértést, engedelmességet jelent, üzleti használatban inkább a megfelelés szót alkalmazzuk, mert ez fejezi ki legjobban a jogi előírásoknak való engedelmességet, azaz a nekik való megfelelést. A szó jelentésével kapcsolatos bővebb kifejtést lásd: http://k-monitor.hu/bejelento/compliancemegfeleloseg (2015. 01. 27.), a vállalati compliance értékelését pedig Benedek Petra cikkében (Benedek, 2014.)
} 
fejlesztéséért felelős az etikai koordinátor ${ }^{157}$, akit olykor integritásmenedzserként ${ }^{158}$ is jelölnek a különféle publikációkban, álláshirdetésekben.

Az etikai koordinátor őrködik a szervezet morális múködése felett, kommunikálja és oktatja az etikai elvárásokat a dolgozóknak, hiteles és transzparens tevékenységvégzést követel meg; a következetesség és a felelősségvállalás nemcsak a munkavállalókra/dolgozókra, hanem a menedzsment tagjaira is kötelező. Ha az etikai koordinátor morálisan kifogásolható, de egyébként nem jogsértő tevékenységet, cselekedetet fedez fel a szervezetben, feladata annak kialakulását megvizsgálni és intézkedéseket javasolni az elhárítás, illetve a folytatólagos megelőzés érdekében. Ha az etikai vétség egyben jogsértés is, vagy kötelező belső szabályzat megsértését is jelenti, a munkavállaló felelősségre vonása is kezdeményezhető.

A fentieken túlmenően a vállalatokban kialakulnak kontrollmechanizmusok, illetve iparági standardként magától értetődően alkalmaznak egyéb kontrolleszközöket, illetve kontrolltevékenységeket, melyek speciális szereplők irányítása, menedzsmentje alatt állnak. Ilyen például a pénzintézeti területen a bankbiztonsági előírások ${ }^{159}$ alkalmazása, amelyet jellemzően bank security manager irányít, az informatikai adatvagyonnal múködő társaságok az információik védelme és az adatszivárgások megelőzése érdekében külön adatbiztonsági160 egységet működtetnek, a technológiaintenzív vállalatokban az üzleti hírszerzés és az ipari kémkedés megakadályozására pedig vállalati belső elhárítást alkalmaznak ${ }^{161}$, míg a különböző portálfejlesztő cégek a saját rendszerük réseinek feltérképezésére etikus heckereket ${ }^{162}$ foglalkoztatnak. Biztosítótársaságokban gyakori a forensic accountant munkakör, amely kifejezetten a belső könyvelésen belüli csalások felderítésére, leleplezésére szolgál. E munkavállalók valamennyien specifikus kontrolltevékenységet látnak el a szervezet céljainak elérése érdekében, a múködés zavartalanságának biztosítása, a vagyon védelme érdekében.

\footnotetext{
157 Szervezettől függően etikai biztos, etikai megbízott, etikai igazgató elnevezéssel is illetik e munkakört. ${ }^{158}$ Az integritásfelelős a költségvetési szféra sajátos munkavállalója, hazánkban a tevékenységét az 50/2013. (II. 25.) Korm. rendelet szabályozza, és szerepe a korrupciómegelőzéssel, illetve -feltárással függ össze. Lásd bővebben: http://integritas.asz.hu/asz (2015. 01. 27.)

159 Lásd hazánkban a PSZÁF által kiadott biztonságvédelmi ajánlást részletesen itt:

http://felugyelet.mnb.hu/bal_menu/szabalyozo_eszkozok/pszafhu_bt_ajanlirelvutmut/ajanlas_pszaf/pszafhu_ajanl irelvutmut_20050815_83.html?query=bankbiztons\%C3\%A1g (2015. 01. 27.)

160 Lásd bővebben az adatbiztonság célszerűségét és szükségességét a következő online cikkben:

http://www.piacesprofit.hu/infokom/biztonsagban-de-nem-bezarva-ez-a-cel/ (2015. 01. 27.) illetve a COBIT 5.

adatvédelmi szabvány bemutatását itt: https://cobitonline.isaca.org/ (2015. 01. 27.)

161 A fogalmak bővebb jelentését és az ipari kémkedés kockázatát lásd itt:

http://www.titoktan.hu/_raktar/biztonsag/Uzleti_hirszerzes_kemkedes_2_0.pdf. (2015. 01. 27.)

162 Képzésük Magyarországon is elindult, lásd bővebben:

https://www.aut.bme.hu/Pages/Research/EthicalHacking (2015. 01. 27.)
} 


\section{FÜGGELÉK - KONTROLLMÓDSZEREK ÉS -ESZKÖZÖK A GYAKORLATBAN}

Disszertációmban több pontban hivatkozom az elterjedt, a gyakorlatban bevált, használt ellenőrzési módszerekre, technikákra, eszközökre. E függelékben felsorolásszerűen összegyűjtöttemés $A B C$ sorrendben közlöm ezeket ${ }^{163}$ :

- analitikák, kimutatások, nyilvántartások tételes egyeztetése, összevetése, összehasonlítása, összepipálása, elemek vagy tételek párosítása, összepontozása;

- $\quad$ automatikus, emberi felügyelet nélküli, vezérlőegység vagy számítógép által biztosított ellenőrzés valamely méret, számadat, anyagminőség megítélése kapcsán;

- automatizált önellenőrző eljárások, öndiagnosztikai programok futtatása informatikai rendszerekben;

- bejövő, idegenáru-átvételi ellenőrzés;

- belső dokumentumok (szabályzatok, hatásköri mátrixok, belső utasítások, körlevelek, jelentések, folyamatleírások, fotók, feljegyzések, okmányok, bizonylatok stb.) átvizsgálása;

- belső szakértői megbeszélés, workshop, értekezlet, egyeztetés tartása információk, összefüggések feltárása, problémamegismerés érdekében;

- benchmarking, más szereplőknél kialakított, jó gyakorlatokhoz való hasonlítás;

- értékelési és minősítési rendszer működtetése (pl. vevők, beszállítók, munkatársak részéről);

- esemény helyszíni megfigyelése, figyelemmel kísérés, szemrevételezés, követés;

- fizikai átvizsgálás, átvilágítás, eszköz tkutatás, motozása személynek;

- informatikai eljárások, speciális elemző és döntéstámogató szoftverek felhasználása az inputadatokon végzett múveletekkel;

- írásbeli beszámoló készíttetése, jelentéstételre kötelezés, riport bekérése, nyilatkoztatás írásban;

- jóváhagyási kontroll delegálása alsóbb szintű vezető számára, többszintű aláírási jogosultság biztosítása a szervezet képviselete kapcsán, felhatalmazás kötelezettségvállalásra;

\footnotetext{
${ }^{163}$ A felsorolás saját gyűjtés, melynek összeállítása során nagyban támaszkodtam a következő művekre: (COSO, 2013a.), (COSO, 2013b.), (BPP, 2011.), (Sawyer et al., 2003.), (Meigs et al., 1985.), (Eilifsen et al., 2010.), (Gutassy, 2003.), (Gutassy, 2010.), (MSZT, 2002.), (Kovács, 2007.), (Vörös, 2008.), (Sebes, 2012.), (Badacsonyi et al., 1979.), (Lukács, 2005.), (Roóz \& Sztanó, 2000.).
} 
- kérdőíves/adatlapos megkeresés, lekérdezés, véleménykutatás, -felmérés szervezeten belül vagy azon kívül (pl. beszállítók, vevők, felettes szerv, adományozó szemszögéből);

- kísérletezés, reprodukálás, valamely folyamatban az output (végtermék) újraelőállítása;

- komplex bejárás, szemle tartása, körbejárás lefolytatása;

- külső harmadik személy, szakértő, tanácsadó felkérése valamely témában célellenőrzés, célvizsgálat lefolytatása céljából;

- mintavétel, mérés, újramérési tevékenység végzése etalonhoz/standardhoz való hasonlítással, statisztikai elemzéssel, szembeállítással;

- monitoring- és figyelmeztető rendszer múködtetése (pl. költségekre, folyamatokra, érzékelővel ellátott eszközökre vonatkozóan);

- mutatószámok képzése és ezek értékelése idősorosan, célértékekhez viszonyítva, ütköztetve vagy más formában;

- összetett számítások, üzleti elemzések, modellek készítése, pontozási rendszerek, szimulációk futtatása adott témában, különböző forgatókönyvek szerint (költség-haszon elemzés, belső megtérülés, átfutási idő hálóterv szerint stb.);

- strukturált vagy kötetlen interjúk készítése érintett személyekkel, meghallgatás tartása, tanú idézése;

- termelésközi, folyamatközi, gyártásközi ellenőrzés;

- tesztelés valóságos adatokkal (vizsgáztatás), próbavásárlás valóságos személyek segítségével;

- tételes megszámolás, fizikai leltározás, rovancsolás, jegyzékbe vétele valaminek;

- többes jóváhagyó, ellenőrző, kötelezettségvállaló, utalványozó személyek kijelölése - jogköreik, limitjeik, felelősségeik meghatározásával együtt;

- (túl)terheléses, behatolásos, hozzáférési és egyéb számítástechnikai tesztek végzése az informatikai rendszer és az eltárolt adatok, adatbázisok megbízhatóságára, védettségére, sérthetetlenségére, teljességére vonatkozóan.

- végellenőrzés, minőség-ellenőrzés, meo feladatköri ellenőrzés; 


\section{FÜGGELÉK - NEGATÍV JELENSÉGEK, JELENTŐS KOCKÁZATOK ÉS VESZÉLYEK, MELYEK A VÁLLALATOK MÜKÖDÉSÉT BEFOLYÁSOLJÁK}

Disszertációm III. részében a COSO-ERM-rendszert részletesen is bemutattam, annak kapcsán pedig többször hivatkozom a vállalatot érő negatív jelenségekre, kockázatokra, veszélyekre, melyeket a vállalkozásoknak valamilyen módon kezelniük kell. A kockázatok kezelésére egyéb más szabványok, módszerek is rendelkezésre állnak, melyeket a COSO-ERM-rendszer kritikájaként, illetve az 1 . számú függelékben ismertettem. Az alábbiakban felsorolásszerūen, példálózó jelleggel ismertetem azokat a kockázatokat, melyek a vállalatok múködését negatívan befolyásolják. Ezek a következők ${ }^{164}$ :

- tevékenységből, alapfeladatból eredő kockázatok

- alvállalkozó hibás teljesítése

- minőségi kifogások a beszállítóval szemben

- rossz, gyenge prototípus alapul vétele saját termeléshez

- átfutási idők hosszabbodása, késői vevőkiszolgálás

- múködési, gyártási költségek folyamatos emelkedése, árrés- és fedezetvesztés

- anyagok, késztermékek logisztikájával, szállításával, tárolásával kapcsolatos nehézségek, akadályok

- rossz készletgazdálkodás, anyaghiány a gyártósoron és/vagy elfekvő, inkurrens készletek felhalmozása

- külső és belső szabályozásból fakadó kockázatok

- jogszabályi környezet kedvezőtlen változása

- szabványok, termékelőírások szigorodása

- adózási és járulékfizetési szabályok módosulása

- vámügyi szabályozás, szabadkereskedelmi megállapodások változása, embargó elrendelése

- elavult, hiányos, minimálisra szorítkozó belső szabályzatok, vagy éppen túlzottan bonyolult, gyakran változó vagy egymással ellentétes belső szabályok, utasítások, rendelkezések

- jogértelmezési vitákból eredő (gyakori) perek, bírósági eljárások

- állandó hatósági bírságok fizetése

\footnotetext{
${ }^{164}$ A saját magam által választott logikai tagolás és az ott szereplő felsorolások saját gyüjtés eredményei, melynek összeállítása során nagyban támaszkodtam a következő müvekre: (Moeller, 2007., p.25.), (NAV KEKI, 2011.), (Vigvári, 2002., p.56.), (Lukács, 2009., pp.71-77.), (Bragg, 2011., pp.50-55.), (Waring \& Glendon, 1998., pp.17., 37-47.), (COSO, 2004., pp.41-47.), (Farkas \& Szabó, 2010., pp.35-56.), (Pfaff \& Ruud, 2013., pp.66-87.), (Löffler et al., 2011., pp.209-531.), (Bungartz, 2010., pp.149-301.).
} 
- emberekből, munkavállalókból eredő kockázatok

- gyenge személyes képességek, illetve készségek, betanulás hiányából fakadó hibák, károkozás

- döntési és felelősségvállalási képesség hiánya

- baleset bekövetkezése, emberi sérülés

- túz, robbanás okozása hanyagságból

- magas fluktuáció

- dolgozói összejátszás külső beszállítókkal, vállalaton belüli korrupció

- kulturális különbségekből adódó kommunikációs, illetve együttmúködési problémák

- sztrájk, munkalassító eljárások

- túl erős érdekképviseletek

- vezetési és menedzsmentkockázatok

- elégtelen vezetői kontrollrendszer múködtetése

- több vezető összejátszása, szándékos csalása a vállalat kárára

- felkészületlen vezetők ismerethiányából, tudáshiányából fakadóan hozott rossz döntések

- vállalatra nézve előnytelen szerződés megkötése, színlelt szerződés kötése

- utasító, parancsuralmi légkör kialakítása, melynek során a munkavállalókat csalásra, téves könyvelésre, adatok, illetve bizonylatok meghamisítására stb. utasítják

- pazarlás, fecsérlés, felesleges kiadások és indokolatlan beszerzések vagy kötelezettségvállalások megtétele

- elmaradó beavatkozási döntések, a visszacsatolás igényének hiánya, a tanulás és fejlődés lehetőségének kizárása a napi munkavégzés során

- rosszul megválasztott terjeszkedési, növekedési politika, felvásárlások okozta nehézségek

- technikai, technológiai kockázatok

- gépmeghibásodás miatti termeléskiesés

- gyenge minőség-ellenőrzési folyamat, hibás termékek gyártása vagy hibás szolgáltatás nyújtása

- rossz gépbeállításból eredő magas selejtarány, illetve vevői reklamációk

- dologi, anyagi jellegú kockázatok

- lopás az üzemben, raktárban, bérgyártónál, szállítóeszközön

- gépek, eszközök, terven felüli amortizálása, készletek értékvesztése hanyag kezelés, rongálás miatt

- pénzeszközök eltulajdonítása házipénztárból, széfből, páncélszekrényből, csalás bankkártyával, bankszámla-manipuláció 
- pénzhelyettesítő eszközök hamisítása, fedezetlen csekkek, értéktelen értékpapírok tulajdonlása

- vállalat szellemi tulajdonának, intellektuális tőkéjének, szabadalmainak kijátszása, kiszivárgása

- ingatlanok, épületek kialakításával, felszerelésével kapcsolatos veszélyek, úgymint beázás, fagykár, robbanás, elektromos zárlat, emelőgépek, nyomástartó edények meghibásodása

- bérbe adott területek, eszközök, vagyontárgyak károsodása, lelakása, eltulajdonítása, leszerelése a bérlő, használó által

- piaci kockázatok

- fogyasztói szokások, igények átalakulása, megváltozása

- új konkurens szereplő vagy új helyettesítő termék megjelenése

- lefelé irányuló árverseny kialakulása

- szakadás az iparági láncolatban, az értékláncban vagy az együttmúködési klaszter felbomlása

- tisztességes piaci verseny szabályaiba ütköző magatartás

- finanszírozási, likviditási kockázatok

- finanszírozó bank kihátrálása a szervezet, annak projektje mögül

- devizaárfolyamok kedvezőtlen alakulása

- finanszírozási hitel, illetve kölcsön kamatlábának emelkedése

- tulajdonostárs kiválása vagy halála

- nem fizető vevő, magas kinnlevőségek

- környezetvédelmi kockázatok

- szigorodó környezetvédelmi követelmények

- ellenséges helyi civil szervezetek, állatvédők stb. fellépése

- súlyos károsanyag-kibocsátás, túlzott emissziós következmények

- információs kockázatok

- adatszivárgás dolgozók segítségével

- rossz könyvelési adatok rögzítése, hibás számviteli beszámoló

- gyenge belső jelentések, riportok

- kozmetikázott, meghamisított számviteli beszámoló, üzleti jelentés, banki beszámoló, pályázati beszámoló

- adat-, illetve információvesztés váratlan informatikai leállás miatt

- helytelen beállításból, konfigurációkból fakadó rossz adatkonverziók, téves számítások az informatikai rendszerben

- hozzáférési jogok túlzott korlátozása, vagy éppen túlzottan megengedő politika alkalmazása

- egyéb kockázatok

- időjárás okozta vis major helyzet, természeti csapás

- terrorizmus fenyegetése, háborús helyzet kialakulása

- közüzemi szolgáltatások, energetikai kiszolgálás leállása

- járvány okozta fenyegetés a gyártott termékekre vonatkozóan

- vezetőket érő baleset, támadás, fizikai szabadságuk korlátozása 
- sajtó vagy más érdekcsoportok támadása a vállalat múködése, tevékenysége ellen a reputáció rontása céljából

- valótlan hírek, a vállalkozást lejárató rágalmak terjedése

- külső politikai nyomásgyakorlás a szervezet tevékenységére, vezetésére

- támadás vallási, származási vagy egyéb családi, rokoni kapcsolódásból kifolyólag

- munkaerő-piaci egyensúlytalanságból adódó munkaerő-elszívás, tehetséges munkavállalók megkörnyékezése 


\section{FÜGGELÉK - A VÁLLALATI BELSŐ KONTROLLRENDSZER KÖVETELMÉNYEINEK TÖRTÉNELMI FEJLŐDÉSE}

Míg a (pénzügyi) ellenőrzés és a kontroll mint kifejezések akár még az ókorig is visszavezethető ${ }^{165}$, addig a vállalati belső kontrollrendszer szakkifejezés - a menedzsmenttanokkal együtt - a modern gazdaságban jelent meg először a vezetői feladatok, funkciók meghatározására. Eltérő nézetek vannak arról, hogy a vállalati irányításban, szervezésben mi tekinthető az első olyan münek vagy modellnek, amely ősi meghatározója a mai, modernkori vállalati belső kontrollrendszernek. A standardok több lépcsőben, több esemény egymásra hatása révén alakultak ki, ezért a mai állapot megértéséhez szükségszerű egy rövid történeti áttekintést adnom a belső kontrollrendszerek fejlődési tendenciájáról a világban. Ezért ebben a függelékben a belső kontrollrendszerek kialakulásának történelmi fejlődését mutatom be vázlatosan.

\section{F41 Fejlődés a kapitalista országokban}

1934-ben az Egyesült Államokban az AICPA ${ }^{166}$ elődje előkészítette a SEC 167 megalakulását is magában foglaló Securities Exchange Act nevű törvényt, mely alapján a következő években a SEC megalkotta a saját ellenőrzési normáit Statments on Auditing Standards (SAS) néven, amelynek 1. pontjában deklaráltan szerepelt a belső kontroll kifejezés, mint vállalaton belüli rendszer. Meghatározása pedig a következő volt (Moeller, 2007., p.146.):

"Internal control comprises the plan of enterprise and all of the coordinate methods and measures adopted with a business to safeguard its assets, check the accuracy and reliability of its accounting data, promote operational efficiency, and encourage adherence to prescribed managerial policies. ${ }^{168 \prime \prime}$

\footnotetext{
165 Lásd (Kovács, 2007., p.13.) és (Sawyer et al., 2003., pp.3-5.) i.e. 3500-ig visszanyúló történelmi visszatekintését a témában.

166 American Institute of Certificated Public Accountants (AICPA), magyar megfelelője a regisztrált mérlegképes könyvelők egyesülete/kamarája lenne. A szervezetről bővebben olvashat itt: http://www.aicpa.org/ (2015. 01. 16.) 167 Securities and Exchange Commission (SEC), magyar megfelelője leginkább az egykor működő Tőzsdefelügyelet lenne. Tevékenységéről lásd bővebben: http://www.sec.gov (2015. 01. 16.)

168 Nem hiteles, saját fordításban a következőképpen hangozhat magyarul e korai meghatározás: A belső kontroll magában foglalja a vállalat által kidolgozott belső kontroll terveit és módszereit, amelyek az üzlet fenntartása érdekében intézkedésekre ösztönöznek az eszközök védelme céljából, támogatják az elszámoltathatóságot és a
} 
A standard az évtizedek során sokat változott, megkülönböztetetté vált benne az úgynevezett adminisztratív eszközökkel múködő kontrollok (értsd: döntéshozatali eljárások, szabályzatok és célkitǔzések kontrollja), valamint a könyvviteli alapokon nyugvó kontrollok (értsd: valamennyi bizonylat, könyvelési tranzakció rögzítésének, jóváhagyásának, engedélyezésének ellenőrzése).

1977-ben a Watergate-ügy következtében elfogadják a Foreign Corrupt Practices Act (FCPA) törvényt, amely elsőként nevezi meg a menedzsmentet mint felelős vállalaton belüli csoportot azért, hogy adekvát belső kontrollrendszert múködtessenek a vállalaton belül a könyvelés, az adatok és a beszámoló megbízhatóságának folyamatos fenntartása érdekében (Sawyer et al., 2003., p.87.). 1985-ben az AICPA kiadja a SAS No. 55. auditstandardot, mely kimondja, hogy a vállalati belső kontrollrendszer nem független a vállalaton belüli többi tevékenységtől, hanem 1. a kontrollkörnyezet, 2. a számviteli rendszer és 3. a belső kontrollelőírások hármasa alapján kell megítélni és múködtetni azt (Moeller, 2007., pp.154-155.).

Végül 1992-ben publikálják a COSO Internal Controls Framework modellt ${ }^{169}$, mely a korábbi SAS standardokból táplálkozva felépíti a szervezeti belső kontroll teljes keretrendszerét, majd 2004-ben a modellt Enterprise Risk Management (ERM) szemléletben kiegészítve is közlik. Így jutunk el a belső kontrollrendszer mai, modern meghatározásához. Jelenleg a 2004-ben elfogadott és 2013-ban felülvizsgált cOSO-modell szerinti belsőkontroll-keretrendszer (internal control framework) fogalommeghatározása a legelfogadottabb (lásd alább) mind a vállalati, mind az államigazgatási/államháztartási rendszerben.

1991-ben az IIA, a Belső Ellenőrök Nemzetközi Szervezete (Institute of Internal Auditors ${ }^{170}$ ) részletes riportot jelentetett meg Systems Auditability and Control (SAC) címmel (idézi (Sawyer et al., 2003., pp.69-71.)), melyben a vállalati kontrollrendszer sajátosságait, jellemzőit tárgyalja. E múben az IIA megnevezi a kontrollrendszerekért felelős személyeket felelősségi körükkel együtt, valamint a kontrollrendszer komponenseit a következők szerint határozza meg:

- kontrollkörnyezet (Control environment), mely a korábbiakhoz hasonlóan a szervezeti felépítést, a munkamegosztási elveket, a vállalaton belüli

pontos és megbízható számviteli adatok ellenőrizhetőségét, valamint elősegítik a vállalati működés hatékonyságát, és ezekhez az írott követelményekhez való ragaszkodásra ösztönzik a vezetőket.

${ }^{169}$ A teljes COSO-modell leírását lásd külön, a III. fejezetben bemutatva.

170 A szervezetröl bővebben itt olvashat: https://na.theiia.org/about-us/Pages/About-The-Institute-of-InternalAuditors.aspx (2015. 01. 16.) 
felelősségvállalás rendjét, a külső jogi és szervezeti iránymutatásokat stb. mint adottságokat veszi alapul;

- automatikus és kézi (ellenőrzési) eszközök (Manual and automated systems), ide tartoznak a különféle adatgyújtő, -tároló, -feldolgozó, összesítő rendszerek, szoftverek és alkalmazások;

- kontrolleljárások (Control procedures), melyek magukban foglalják a vállalaton belüli információs tevékenység leírását, valamint a megelőző, feltáró és korrekciókontrollok részletes leírását tartalmazzák a kontrollrendszer elemeire és szereplőire vonatkozóan. Ilyen elemek és szereplők például: a munkavállalók mint személyek, a szervezet maga a belső eljárásrendekkel és felelősségi körökkel, az írott és követendő eljárások, illetve szabályzatok, a tervek, a vállalati könyvelés és a belső jelentések is (Sawyer et al., 2003., pp.82-86.).

2002-ben fogadták el a Sarbanes-Oxley (SOX)-törvényt az Enron, Worldcom és más USA-beli cégek beszámolóinak valótlanságai okán kialakult bizalmi válság megtörésére. A törvény egyebek mellett a vállalati belső kontrollrendszerek szigorúbb felülvizsgálatát, monitoringját tette kötelezővé. A SOX-törvény 404-es pontja írja elő a menedzsment számára, hogy kötelező dokumentálnia a belső kontrollrendszerét, s a belső kontrollfolyamatokat írásban szabályoznia kell, valamint ezeket folyamatosan felül kell vizsgálnia, és múködési tapasztalatait évente riport formájában ${ }^{171}$ közzé kell tennie (Bordáné, 2011., pp.52-53.). Valamint a választott könyvvizsgálónak a belső kontrollrendszereket tesztelnie és értékelnie kell a célból, hogy a beszámolók nagy bizonyossággal elfogadható szintű adatokat tartalmazzanak, azaz megbízhatóak legyenek, és ilyen módon a vállalatok mentesek legyenek a csalásoktól és a belső visszaélésektől (Moeller, 2007., pp.180-186.), (Bungartz, 2010., pp.21-24.).

Ugyanezen időszakban az európai kontinens több országában is szigorúbb törvényi rendelkezések léptek életbe a belső kontrollrendszer múködtetése, az átlátható és transzparens múködés biztosítása, illetve a könyvvizsgáló felelősségének erősítése céljából (Löffler et al., 2011., pp.13-18.).

Németországban 1998-ban jelent meg szövetségi törvény ${ }^{172}$ a tőzsdén jegyzett társaságok kontrolljával és transzparenciájával kapcsolatos szabályokról KonTraG néven, ám e törvény a tőzsdén kívüli vállalkozások számára is előírt különféle

\footnotetext{
171 Angolban az „Internal Control over Financial Reporting” szakkifejezéssel említik ezt a közzétett beszámolótípust.

172 Gesetz zur Kontrolle und Transparenz im Unternehmensbereich (5. März 1998.)
} 
kötelezettségeket, illetve ügyvezetői felelősséget a beszámolók megbízhatósága, valamint a vállalati könyvelés és nyilvántartások hibamentességére vonatkozóan. $E$ szabályozást 2009-ben az úgynevezett BilMoG-törvény ${ }^{173}$ egészítette ki, mely szövetségi szinten szabályozta a társaságirányítási előírásokat, és megerősítette a német vállalkozásokon belüli kontrollrendszerek múködését. $\mathrm{A}$ német szabályozásról lásd bővebben (Bungartz, 2010., pp.27-35.).

Az EU országaiban 2006-ban lépett hatályba a korábbi, úgynevezett 4., 7. és 8. számú irányelvek módosítására vonatkozó 2006/46/EK irányelv ${ }^{174}$, a SOX-törvénnyel tartalmában megegyező szabályozással.

Svájcban 2008. január 1-től szigorított keretek között kell múködtetni a vállalati belső kontrollrendszert, és meghatározott vállalati kör számára a törvény kötelezően előírja annak alkalmazását, míg más vállalkozások számára az nem előírás. Ezen kívül a Swiss Code nevű tőzsdei szabály 2002 óta fogalmaz meg követelményeket a társaságirányítási jelentésekre vonatkozóan a svájci tőzsdei cégek esetében ${ }^{175}$. A Svájcban érvényes szabályozásról részletesen lásd (Pfaff \& Ruud, 2013., pp.27-50.).

Látható tehát, hogy a kontrollrendszerrel kapcsolatos elvárások az elmúlt 100 évben folyamatosan fejlődtek, bővültek, újra-, illetve átértelmeződtek a mindenkori társadalmi és gazdasági elvárások alapján. A belső kontrollrendszer, illetve a pénzügyi ellenőrzés fókuszát és fejlődésének időbeli trendjét Buxbaum Miklós a következők szerint összegzi (Buxbaum, 2006., p.13.):

\footnotetext{
173 Gesetz zur Modernisierung des Bilanzrechts (Bilanzrechtsmodernisierungsgesetz, BilMoG)

${ }^{174}$ Az Európai Parlament és a Tanács 2006/46/EK irányelve (2006. június 14.) a meghatározott jogi formájú társaságok éves beszámolójáról szóló 78/660/EGK, az összevont (konszolidált) éves beszámolóról szóló 83/349/EGK, a bankok és más pénzügyi intézmények éves beszámolójáról és konszolidált éves beszámolójáról szóló 86/635/EGK, valamint a biztosítóintézetek éves és összevont (konszolidált) éves beszámolóiról szóló 91/674/EGK tanácsi irányelv módosításáról

175 Aktuális szabályozását lásd: Federal Act on Financial Market Infrastructures and Market Conduct in Securities and Derivatives Trading (FMIA - 958.1), különösképpen annak 8.§-át. Forrás: https://www.admin.ch/opc/en/classified-compilation/20141779/index.html (letöltés: 2016. 07. 17.) valamint ehhez kapcsolódóan a Svájci Tőzsde társaságirányítási ajánlását (Directive on Information relating to Corporate Governance), forrás: https://www.six-exchange-regulation.com/dam/downloads/regulation/admissionmanual/directives/06_16-DCG_en.pdf (letöltés: 2016. 07. 17.)
} 


\begin{tabular}{|c|c|c|}
\hline Idöszak & Ellenőrzés tárgya & A vizsgálatok fókusza \\
\hline 1950 & Eszközök & Társadalmi tulajdon védelme \\
\hline 1960 & Adatok & Adatok forrása, megbízhatósága \\
\hline 1970 & Megfelelőség & Törvényesség, belső szabályozottság \\
\hline 1980 & Hatékony múködés & Gazdaságosság és hatékonyság \\
\hline 1990 & Szervezeti célok & Célok megvalósítása \\
\hline 2000 & Értékteremtés & Vállalatirányítási rendszerek \\
\hline
\end{tabular}

F42 A szovjet-szocialista államberendezkedés kontrollfilozófiájának fejlődése

A vállalaton belüli kontroll nem kizárólag a kapitalista országok sajátossága, erről tanúskodnak azok a korai források, melyek a népi ellenőrzés létrejöttét és a szocialista állami ellenőrzés rendszerét mutatják be. Ezek fő jellemzője, hogy az ellenőrzést ideológiailag többé-kevésbé átitatja a társadalmi vagyon védelme, a néphatalom és a népi demokrácia biztosítása a vállalati, illetve az állami szektorban is. Ebben a gazdasági berendezkedésben a fő hatalom az állam kezében van, standardokat is ő támaszt, és a végrehajtást is ő ellenőrzi. Mivel pedig az állam mindenható, az ellenőrzés módszereit és rendszerét is az állami elvárásokhoz igazítják.

Magyarországon a rendszerváltásig gyakorlatilag ez a típusú ellenőrzési rendszer múködött, s nyomokban, beidegződésekben, anekdotákban még a mai napig is érezteti hatását a vállalatok múködésében. Mivel pedig a belső kontrollrendszerek intézményesülésénél ennek fontos mögöttes szerepe van, dolgozatomban egy rövid alfejezetet szentelek a szocialista ellenőrzés történelmi fejlódésének bemutatására is.

A szocialista ellenőrzés alapelveit Leninnek tulajdonítják, aki 1917-ben adta ki a munkásellenőrzésről szóló rendeletet (Lenin múvei 26. köt. 277-278. old.), idézi (Somogyi, 1968., pp.19-20.). Ennek 1. pontja rögzíti, hogy valamennyi, legalább (összesen) 5 munkást és alkalmazottat foglalkoztató, illetőleg legalább évi 10.000 rubel forgalmat lebonyolító ipari, kereskedelmi, bank-, mezőgazdasági és egyéb vállalatnál be kell vezetni a termelés, a tárolás, valamint a termékek és nyersanyagok adás-vétele fölötti munkásellenőrzést. A munkásellenőrzés a vállalat/szerv által múködtetett ellenőrzési forma volt, melyet a munkások és az alkalmazottak által választott bizottság, illetve képviselő valósított meg. Fő feladatuk a fentiek ellenőrzésén túlmenően harc a szabotázs ellen, annak ellenőrzése, hogy helyesen dolgoznak-e és a minél nagyobb termelékenység biztosítása (Somogyi, 1968., p.108.). 
A munkásellenőrzés volt tehát az alapja a későbbi népi ellenőrzés, illetve az állami ellenőrzés rendszerének. A szocialista országok ezen elvek alapján rögzítették és határozták meg saját ellenőrzési szabályaikat. Ezek országonkénti jellemzőit később megosztották egymással, ennek tapasztalatait foglalja össze (Török, 1977.) múvében.

A szovjet-szocialista államokban - így hazánkban is - a második világháborút követően alakult ki az állami ellenőrzés „modern szocialista” fajtája, amely a korábbi, laikusok által végzett népi, illetve munkásellenőrzés mellett már kialakította a többszintű, központi irányítású, erősen centralizált állami ellenőrzési rendszert, melyben a minisztériumok, központi bizottságok, szakmai intézetek is feladatot, illetve felelősséget kaptak, s ezt területi, illetve helyi szinten a vállalati, szövetkezeti és tanácsi szervek is végezték. Mindeközben fennmaradt a népi ellenőrzés rendszere is (Badacsonyi et al., 1979., pp.26-29.). Az állami ellenőrzés rendszere a népi ellenőrzés mellett már külső, szakmai és belső, vezetői, illetve független revizori elemeket működtetett. A hazai állami ellenőrzés részletes jellemzőit ismerteti Kovács Árpád (Kovács, 2007., pp.67-68.) és Nyikos László (Nyikos, 2001., pp.34-49.).

Bár a szocialista állami ellenőrzés nem volt mentes a politikai áthallásoktól, az 1980as években követett módszertan már nagyban hasonlított a kapitalista országok belső ellenőrzési rendszeréhez. Ismerte a vállalaton belüli és a külső szervek ellenőrzése közötti különbségeket, meghatározta a belső kontrollrendszer elemeit, a vezetői ellenőrzés mellett a folyamatba épített ellenőrzés fogalmát is használta, különbséget tett ellenőrzés, audit és revízió között, meghatározta az ellenőrök és az ellenőrzöttek jogait, és előírásokkal szabályozta az ellenőrzés folyamatát is, s már ismerte a közérdekű bejelentés intézményét, továbbá kérdőíves, számítástechnikai és statisztikai vizsgálati módszereket is (Badacsonyi et al., 1979., pp.102-276.).

Magyarországon a rendszerváltás előtti népi demokratikus, államszocialista berendezkedésű ellenőrzési rendszer múködött, ez a rendszerváltással megszűnt, azonban nyomokban még ma is fellelhető a belső kontrollrendszerekben ${ }^{176}$. Ennek oka az lehet, hogy a 80-as években az állami ellenőrzési rendszer is adaptálni kezdte a nyugati, kapitalista ellenőrzési szisztéma módszereit és megközelítéseit.

\footnotetext{
176 Míg korábban a dolgozó munkásnép végezte az ellenőrzést a szervezetekben, ma a dolgozói képviselők teljes értékű tagként - ott ülnek a 200 főnél nagyobb létszámmal működő vállalkozások felügyelőbizottságában. A hatóságok a külső ellenőrzéseik során előszeretettel hivatkoznak arra a társadalmi elvárásra (amely olykor jogszabályokban is megtestesül), hogy az állampolgárokat helyettük és jogi eszközökkel kell megvédeni a rossz minőségű áruktól és szolgáltatásoktól (fogyasztóvédelem, élelmiszer-biztonság), vagy éppen az őket megtévesztő feltételekkel manipuláló és magas kamatokat ígérő pénzügyi vállalkozásoktól (pénzügyi felügyelet).
} 


\section{FÜGGELÉK - ADATGYŰJTŐ RENDSZER}

\section{F51 Alkalmazott adatgyűjtő kérdőív}

Kutatásom során az alábbi, magyar, angol, német nyelven elérhető adatgyújtő kérdőívet használtam, melyet a válaszadók az online felületen tudtak megtekinteni, kitölteni ${ }^{177}$.

\section{Tisztelt Kolléga! Tisztelt Kitöltő!}

Az alábbiakban részletezett, COSO tárgyú tudományos kutatásban kérem közremüködésüket, támogatásukat!

Milicz Ákos vagyok, a Budapesti Corvinus Egyetem Gazdáskodástani Doktori Iskolájának doktorjelöltje és kutatási témámban, azaz a belső kontrollrendszerek intézményesülése kapcsán végzek tudományos kutatást, mely egyben PhD disszertációm alapjául is szolgál. Jelen kérdőív kitöltésével az adatfelvételben kérem segítségüket, mely körülbelül 20 percet vesz igénybe Önöktöl!

Kérem, járuljanak hozzá Önök is válaszaikkal tudományos munkásságomhoz! Segítségüket, támogatásukat ezúton és előre is megköszönöm!

Tisztelettel és köszönettel:

Milicz Ákos, doktorjelölt

$177 \mathrm{Az}$ itt közölt kérdőívben az online felületen beállított védelmek, és adatbeviteli ellenőrző eljárások értelemszerüen nem láthatók, továbbá az itteni nyomtatott formátumhoz képest a kitöltők monitorán a kérdőív más formátumban jelent meg. 


\section{Dear Colleauge! Dear Responder!}

I would like to request your assistance in the scientific study in the COSO subject matter as detailed below, by asking that you complete the questionnaire below!

My name is Ákos Milicz, and I am a PhD candidate at the Faculty of Economics of the Corvinus University of Budapest. I am conducting a scientific study in my study subject: The Institutionalization of the Internal Control Systems of Enterprises - which is also the basis of my $\mathrm{PhD}$ thesis. Completing the questionnaire will take approximately twenty minutes.

Thank you for completing the questionnaire and assisting and contributing to my scientific study!

Sincerely,

Ákos Milicz, PhD Candidate

Sehr geehrte Kollegin, sehr geehrter Kollege! Sehr geerte(r) Ausfüller(in)!

Ich lade Sie herzlich ein an einer wissenschaftlichen Forschung über COSO teilzunehmen! Eine detailliertere Beschreibung des Forschungsvorhabens finden Sie weiter unten. Sie können dieses Vorhaben durch Ausfüllen eines Fragebogens unterstützen.

Zuerst möchte ich mich kurz vorstellen: Ákos Milicz, Doktorand am Graduiertenkolleg für BWL an der Corvinus Universität Budapest. Mein Forschungsthema widmet sich der Institutionalisierung der internen Kontrollsysteme der Gesellschaften. Aus dieser wissenschaftlichen Forschung soll später auch meine Dissertation entstehen. Die Beantwortung der Fragen dauert etwa 20 Minuten.

Ich bitte Sie nochmals darum, durch Ihre Antworten meine wissenschaftliche Arbeit zu unterstützen. Ich danke Ihnen bereits im Voraus für Ihre Hilfe und Unterstützung!

Mit freundlichen Grüßen

Ákos Milicz, Doktorand 
0. Szervezeti alapadatok / Date of Organisation / Organisationsdaten

Kérem, adja meg az Ön szervezetére vonatkozó alábbi adatokat! / Please give me the following date of your Organisation! / Bitte geben Sie mir Ihre Organisationsdaten!

Szervezet neve (ha meg akarja adni) / Name of the Organisation (optional answer)

/ Name der Organisation (freiwillige Antwort)

\section{Székhely országa / Country of headquarters / Land des Standorts}

\begin{tabular}{|c|c|}
\hline Szervezeti forma / Organisationform / Rechtsform & $\begin{array}{l}\text { Kérem, jelöljön egyet! / Please choose the one! / Bitte wählen sie nur } \\
\text { ein! }\end{array}$ \\
\hline \multicolumn{2}{|l|}{ Közigazgatás (költségvetési) szerv / budgetary institution/ Haushaltsbehörde } \\
\hline \multicolumn{2}{|l|}{ Üzleti szervezet (vállalkozás) / Enterprise / Unternehmen } \\
\hline \multicolumn{2}{|l|}{ Egyéni vállalkozó / Self Employed Company / Einzelunternehmer } \\
\hline \multicolumn{2}{|l|}{ Non-profit szervezet / Non-profit organisation / Non-profit Organisation } \\
\hline Egyéb / Other / Sonstige & \\
\hline
\end{tabular}

\begin{tabular}{|c|c|}
\hline Főtevékenység / Main activity / Haupttätigkeit & $\begin{array}{l}\text { Kérem, jelöljön egyet! / Please choose the one! / Bitte wählen sie nur } \\
\text { ein! }\end{array}$ \\
\hline Termelés / Production / Produktion & \\
\hline
\end{tabular}




\begin{tabular}{|l|l|}
\hline Szolgáltatás / Service / Diensleistung & \\
\hline Kereskedelem / Trading / Handel & \\
\hline Egyéb / Other / Sonstige & \begin{tabular}{l} 
Kérem, jelöljön egyet! / Please choose the one! / Bitte wählen sie nur \\
\hline \multicolumn{2}{|l|}{ eöbbségi tulajdonosi kör jellege/ Main owner(s) / Hauptbesitzer }
\end{tabular} \\
\hline Állami (köz)tulajdonlás / State (public)owner / Staat & \\
\hline Magánszemély(ek) / Private person(s) / Privatperson(en) & \\
\hline Vállalkozás(ok) / Company(s) / Gesellschaft(en) & \\
\hline Egyéb tulajdonos(ok) / Other owner / Sonstige Besitzer & \\
\hline
\end{tabular}




\begin{tabular}{|c|c|c|c|c|}
\hline Egyéb adatok & Other date & Sonstige Daten & $\begin{array}{l}\text { Válasz / } \\
\text { Answer / } \\
\text { Antwort }\end{array}$ & $\begin{array}{c}\text { Pénznem / } \\
\text { Currency / } \\
\text { Währung }\end{array}$ \\
\hline Cégalapítás éve & Year of establishment & Gründungsjahr & & 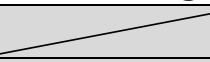 \\
\hline Főtevékenység (szövegesen) & Primary activity (in words) & Haupttätigkeit (mit Worten) & & \\
\hline Jegyzett tőke & Registered capital & Gezeichnetes Kapital & & \\
\hline Létszám (fő) 2015 végén & $\begin{array}{l}\text { Headcount (persons) end of Year } \\
2015 .\end{array}$ & Anzahl der Mitarbeiter am Ende 2015 & & \\
\hline Árbevétel 2015-ben & Revenue in 2015. & Umsatzerlöse in 2015 & & \\
\hline Mérlegfőösszeg 2015 végén & $\begin{array}{l}\text { Balance sheet total end of Year } \\
2015 .\end{array}$ & Bilanzsumme am Ende 2015 & & \\
\hline
\end{tabular}


Az Önök vállalkozása esetében a belső kontrollrendszert az alábbi tényezők egymáshoz képest milyen mértékben befolyásolják? Kérem, állítsa sorrendbe az alábbi tényezőket 1-10 közötti fordított skálán, ahol a legkisebb (1) számérték a legnagyobb befolyást, ráhatást jelenti, míg a 10-es számérték jelzi a legkisebb ráhatást, befolyást. Ha egy tényező Önöknél nem bír befolyással, jelöljék 0-val az adott választ! Ha egy helyezést már hozzárendelt egy válaszhoz, azt a számértéket nem tudja újra kiválasztani, azt az alkalmazás szürkével jelöli.

\section{In comparison to each other, to what extent do the following factors influence your Company?}

Please order the following factors on a scale between 1 and 10, where the lowest number (1) represents the greatest influence and impact, while 10 represents the smallest impact and least influence. If the factor has no influence at your Company, mark the given answer with 0 ! If you chose just an answer, you can not choose it again and it is remaked by grey color.

\section{Welchen relativen Einfluss haben folgende Faktoren auf das interne Kontrollsystem Ihres Unternehmens?}

Bitte stellen Sie eine Reihenfolge auf: (1) steht für den größten und (10) für den geringsten Einfluss. Sollte ein Faktor keinen Einfluss haben, so geben Sie bitte eine 0 an. Jede Stufe kann nur einmal ausgewählt werden, danach wird sie mit grauer Farbe gezeichnet.

\begin{tabular}{|l|l|l|}
\hline \multicolumn{1}{|c|}{ Befolyásoló tényezők } & \multicolumn{1}{|c|}{ Influence factors } & \multicolumn{1}{|c|}{ Einflussfaktoren } \\
\hline $\begin{array}{l}\text { Tulajdonosi kör jellege, tulajdonos(ok) } \\
\text { elvárásai, elö́rásai }\end{array}$ & $\begin{array}{l}\text { Owners instruction, expectations of } \\
\text { owners and shareholders }\end{array}$ & $\begin{array}{l}\text { Eigentümerstruktur, } \\
\text { Vorschriften seitens der Eigentümer }\end{array}$ \\
\hline Foglalkoztatottak száma, dolgozói létszám & Headcount, number of employees & Anzahl der Mitarbeiter \\
\hline $\begin{array}{l}\text { Vállalkozásra vonatkozó jogi elöírások, } \\
\text { jogszabályok, külső szabályozó tényezők }\end{array}$ & $\begin{array}{l}\text { Legislative requirements, laws, external } \\
\text { regulative factors }\end{array}$ & $\begin{array}{l}\text { Gesetzliche } \\
\text { Bestimmungen }\end{array}$ \\
\hline Telephelyek, fióktelepek (darab)száma & $\begin{array}{l}\text { Number of business premises and branch } \\
\text { offices }\end{array}$ & Anzahl der Niederlassungen und Standorte \\
\hline $\begin{array}{l}\text { Fötevékenység jellege, technológiája, } \\
\text { elvégzésének sajátosságai }\end{array}$ & $\begin{array}{l}\text { Kind of primary activity, main } \\
\text { technology, speciality of company }\end{array}$ & $\begin{array}{l}\text { Art, Technologie und Ausführungsmerkmale } \\
\text { der Haupttätigkeit }\end{array}$ \\
\hline
\end{tabular}

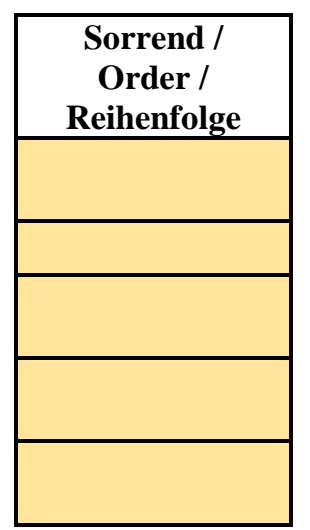




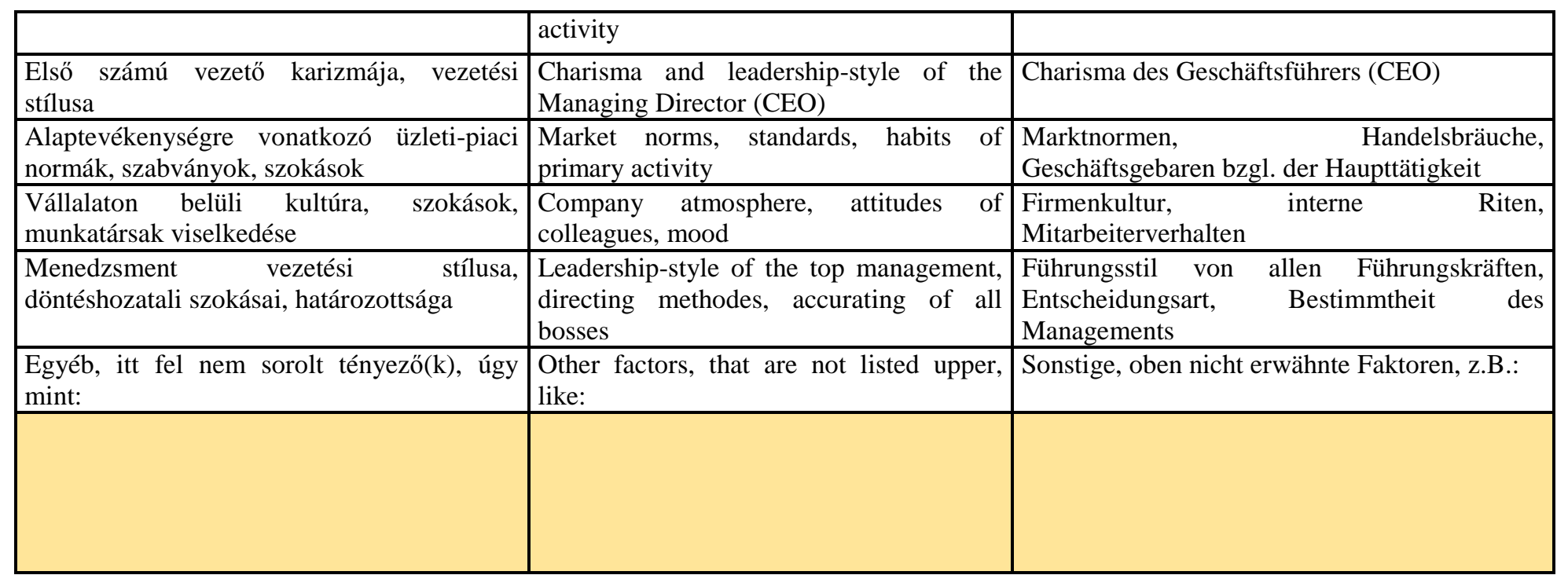

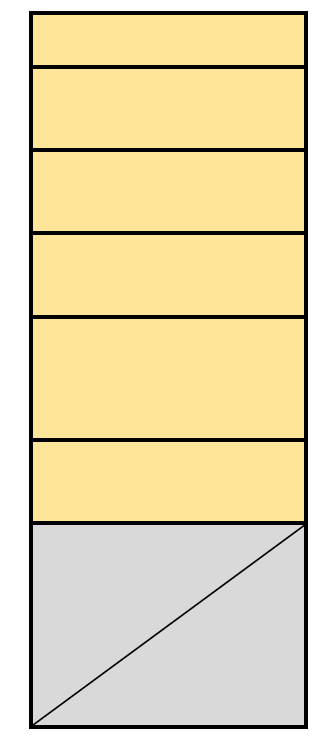




\section{Munkakörök / Jobpositions / Funktionsbereiche}

Kérem jelölje soronként, hogy az alább felsorolt munkakörökre, funkciókra mi a jellemző az Önök vállalatánál!

Minden oldalon egy-egy munkakört kell jellemeznie. Válaszait az egyes sorokban rögzítse lefelé haladva!

Please indicate by each row what is most characteristic of the listed jobs and functions at your Company!

You must assess one job-position on each page. Please write your answers in each row successively!

Bitte charakterisieren Sie die unten aufgelisteten Stellen und Funktionsbereiche, wie diese in Ihrem Unternehmen agieren! Sie finden eine/n Position/Funktionsbereich auf jeder Seite. Wir bitten um eine zeilenweise Ausfüllung.

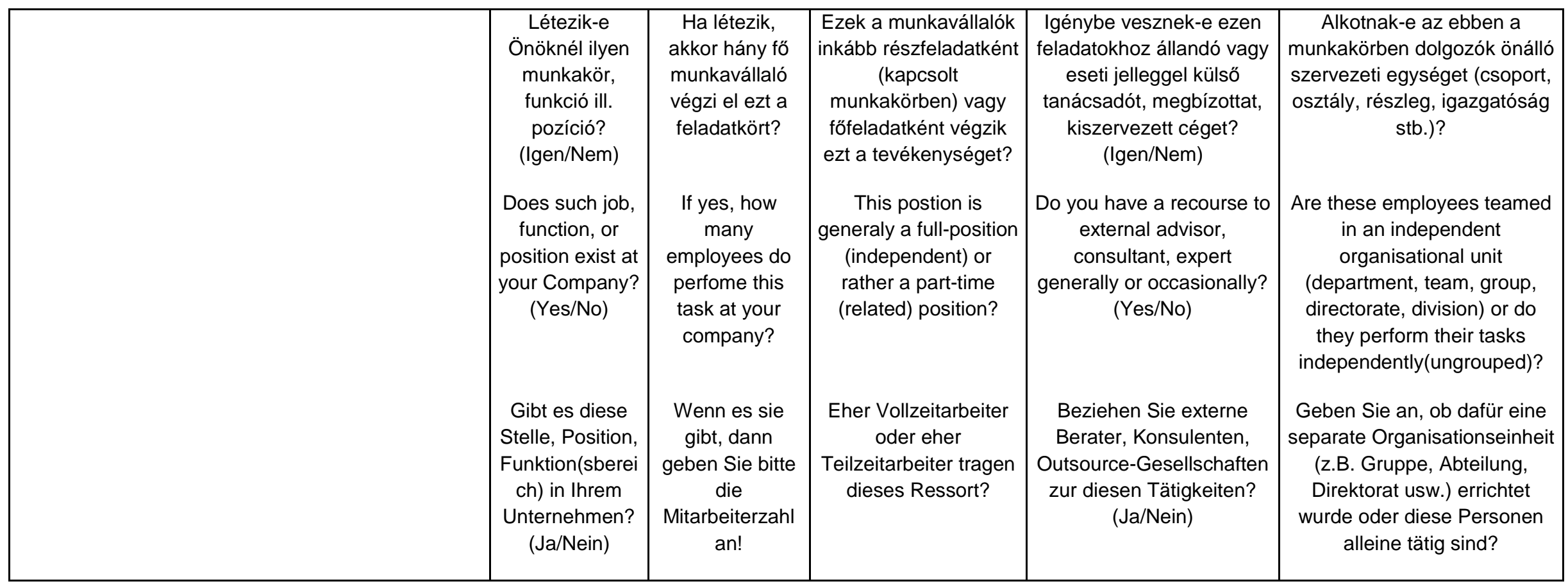




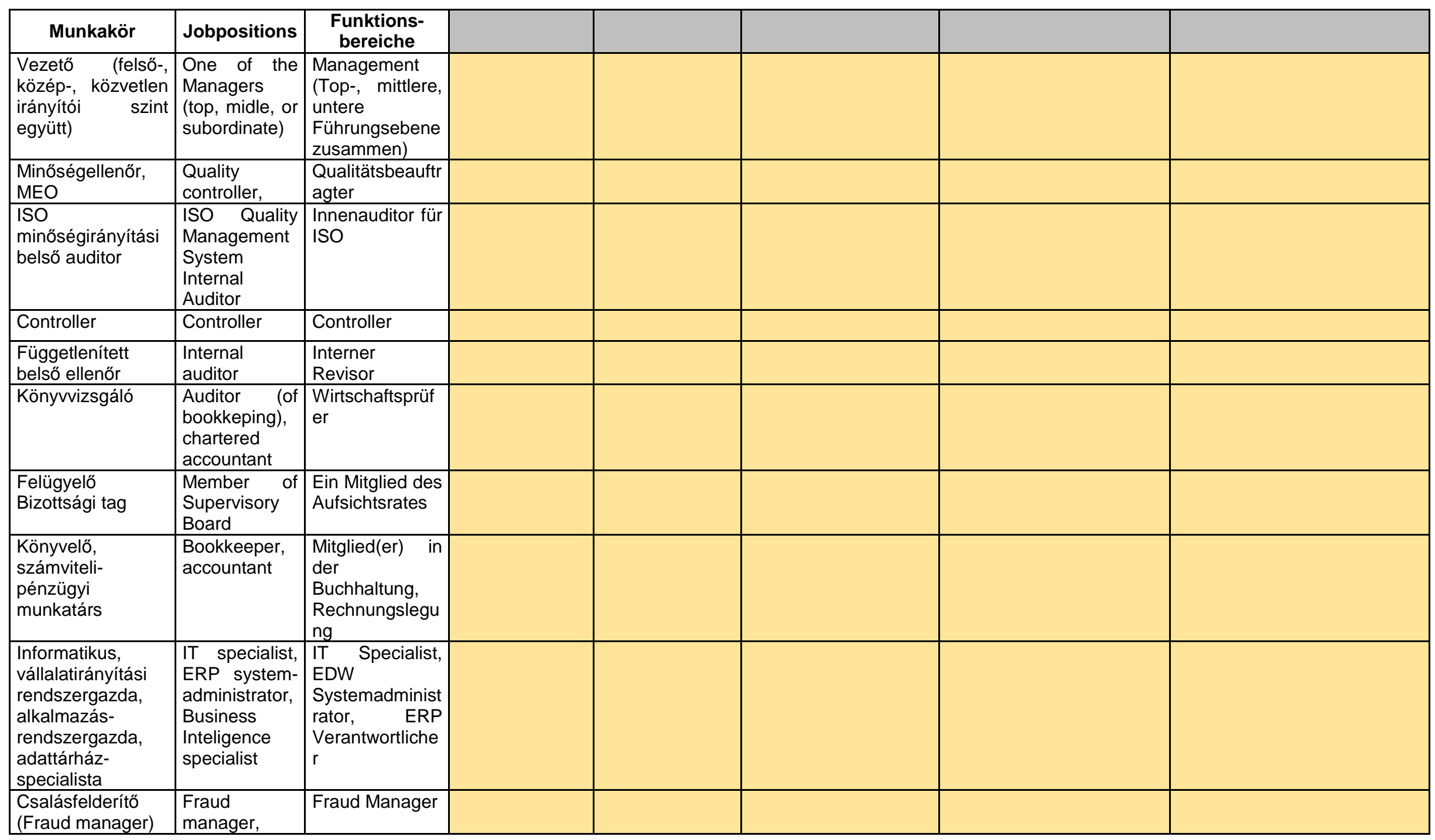




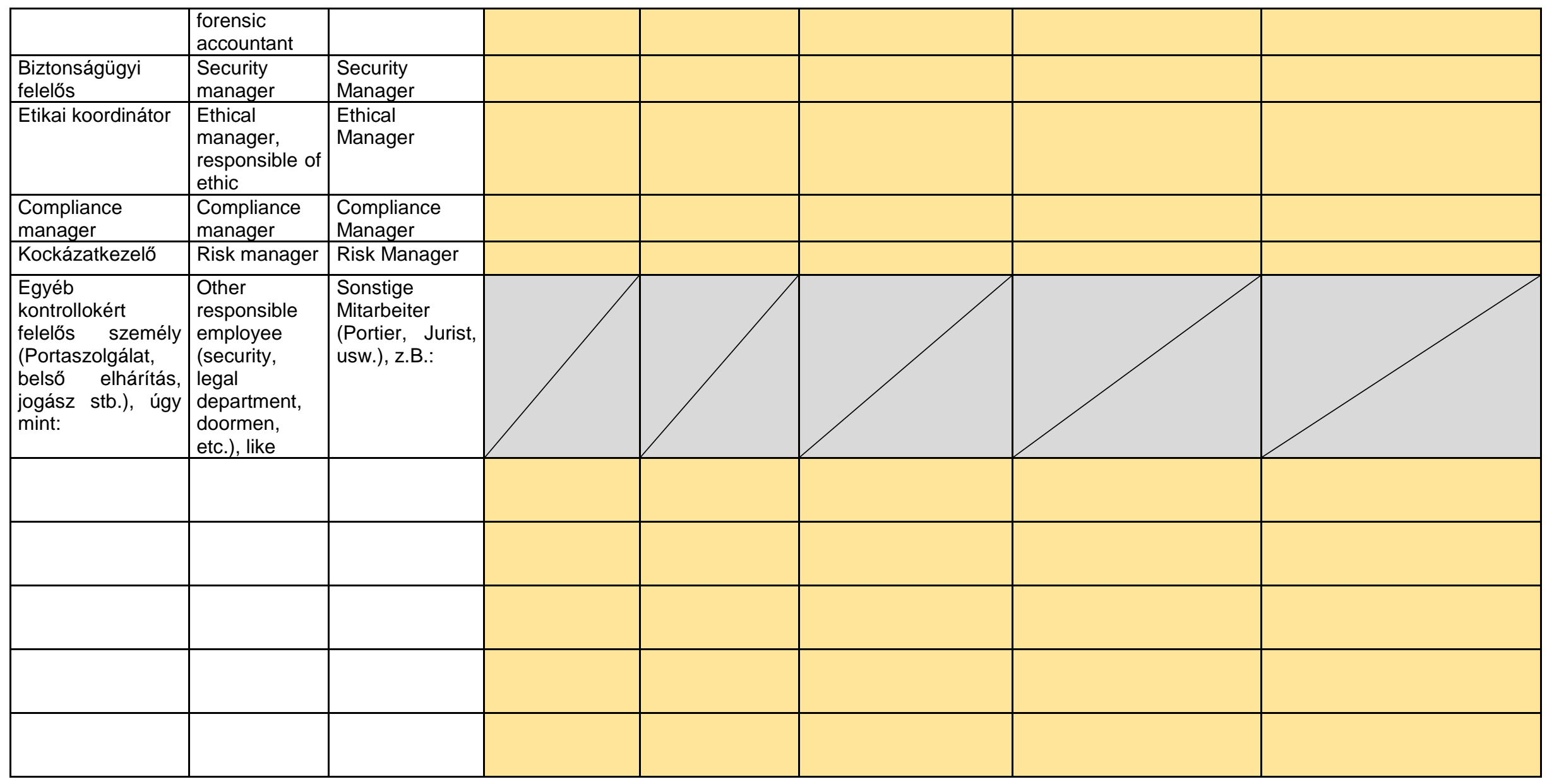


A II. pontban adott válaszai alapján, kérem, jelölje meg, hogy az alábbi kontrolltevékenységek léteznek-e Önöknél, s ha igen, azt tipikusan mely munkakört betöltő vagy mely pozícióban lévő munkavállaló végzi!

Az alábbi táblázat oszlopaiban kontrolltevékenységeket lát felsorolva egymás mellett. Adja meg azt az egyetlen munkakört/pozíciót minden sorban, aki leginkább azt a feladatot végzi, ellátja Önöknél. Csak egy konkrét munkakört adjon meg minden sorhoz!

Based on your answers provided in Item 2, please indicate whether the following control activities exist at your Company, and if yes, a person filling which job-position is it typically performed by?

You will see various control activities listed in the columns of the following table. Please select only one job/position in each rows that this activity is mostly performed by at your Company. You can choose only one job in each row.

Ausgehend aus den im Teil II gegebenen Antworten geben Sie an, ob die unten aufgeführten Kontrolltätigkeiten in Ihrem Unternehmen existieren oder nicht; und wenn ja, dann von welcher Stelle oder Funktion ausgeführt werden!

Die Tabelle listet die möglichen Kontrolltätigkeiten auf. Geben Sie spaltenweise immer nur eine Stelle oder Funktion an, die im Wesentlichen für die jeweilige Tätigkeit in Ihrer Gesellschaft zuständig ist. Bitte nur eine Stelle angeben!

\begin{tabular}{|c|c|c|c|c|}
\hline Kontrolltevékenységek & Control activities & Kontrolltätigkeiten & \begin{tabular}{|c|} 
Létezik-e a \\
tevékenység $(\mathrm{I} / \mathrm{N}) /$ \\
Activity exist $(\mathrm{Y} / \mathrm{N}) /$ \\
Tätigkeit existiert \\
$(\mathrm{J} / \mathbf{N})$
\end{tabular} & $\begin{array}{c}\text { Mely munkakör végzi } \\
\text { azt? / } \\
\text { Which job-position } \\
\text { perform it? / } \\
\text { Von welcher Stelle } \\
\text { ausgeführt? } \\
\end{array}$ \\
\hline $\begin{array}{l}\begin{array}{l}\text { Emberi felügyelet } \begin{array}{r}\text { nélküli, } \\
\text { végzett, } \\
\text { automatikusan }\end{array} \\
\text { vezérlöegység vagy } \\
\text { számítógép } \\
\text { által biztosított ellenőrzés }\end{array} \\
\end{array}$ & $\begin{array}{l}\text { Control performed without } \\
\text { human supervision, by control } \\
\text { unit or IT operation }\end{array}$ & $\begin{array}{l}\text { Automatische Kontrolle durch Regler oder } \\
\text { Computer, ohne menschliche Überwachung }\end{array}$ & & \\
\hline $\begin{array}{l}\text { Automatizált önellenőrző eljárás, } \\
\text { öndiagnosztikai programok }\end{array}$ & $\begin{array}{|lr|}\begin{array}{l}\text { Automated } \\
\text { procedure, }\end{array} & \text { self-controlling } \\
\text { applications } & \text { self-diagnostic } \\
\end{array}$ & $\begin{array}{lr}\begin{array}{l}\text { Automatisierter, } \\
\text { Kontrollvorgang, }\end{array} & \text { selbstkorrigierender } \\
\text { Programme } & \text { Selbstdiagnostik- } \\
\end{array}$ & & \\
\hline $\begin{array}{l}\text { Bejövő, } \\
\text { ellenőrzés }\end{array}$ & $\begin{array}{l}\text { Incoming and foreign-product } \\
\text { control }\end{array}$ & Wareneingangskontrolle & & \\
\hline
\end{tabular}




\begin{tabular}{|c|c|c|c|c|}
\hline $\begin{array}{l}\text { Termelésközi, folyamatközi, } \\
\text { gyártásközi ellenőrzés }\end{array}$ & $\begin{array}{|lr|}\begin{array}{l}\text { Mid-production, mid-process, } \\
\text { mid-manufacturing }\end{array} \\
\text { control }\end{array}$ & $\begin{array}{l}\text { Kontrolle während der Leistungserstellung } \\
\text { (z.B. laufende Kontrolle der Fertigung) }\end{array}$ & & \\
\hline $\begin{array}{l}\text { Végellenörzés, átadás előtti } \\
\text { minőség-ellenőrzés }\end{array}$ & $\begin{array}{l}\text { Final quality control, last } \\
\text { validation/check, control } \\
\text { belonging in the quality control } \\
\text { tasks }\end{array}$ & Endprüfung, Qualitätskontrolle & & \\
\hline $\begin{array}{l}\text { Belső szabályzatok, utasítások } \\
\text { betartásának ellenőrzése }\end{array}$ & \begin{tabular}{|l|} 
Control of compliance with and \\
observance of rules, \\
regulations, and instructions
\end{tabular} & \begin{tabular}{|l} 
Kontrolle der Einhaltung interner \\
Vorschriften und Direktiven
\end{tabular} & & \\
\hline $\begin{array}{l}\text { Komplex vezetői bejárás, szemle } \\
\text { tartása, körbejárás lefolytatása }\end{array}$ & $\begin{array}{|lrr|}\begin{array}{l}\text { Performing } \\
\text { management }\end{array} & \begin{array}{r}\text { complex } \\
\text { survey, }\end{array} \\
\text { inspection, } & \text { audit } & \text { or } \\
\text { reconnaissance } & & \\
\end{array}$ & $\begin{array}{l}\text { Übersicht verschaffen vor Ort und Stelle } \\
\text { (z.B. Besichtigung, Visitation) }\end{array}$ & & \\
\hline $\begin{array}{lr}\begin{array}{l}\text { Esemény helyszíni } \\
\text { történő }\end{array} & \text { megy távolról } \\
\text { figyelemmel } & \text { kísérés, } \\
\text { szemrevételezés, követés }\end{array}$ & $\begin{array}{l}\text { The on-site or remote } \\
\text { observation, monitoring, } \\
\text { inspection, or following of an } \\
\text { event }\end{array}$ & $\begin{array}{l}\text { Eingehende Kontrolle von Ereignissen vor } \\
\text { Ort oder aus der Ferne (z.B. Beobachtungen, } \\
\text { Messungen, fokussierte Begleitung über } \\
\text { Stunden/Tage hinweg) }\end{array}$ & & \\
\hline $\begin{array}{l}\text { Interjúk készítése } \begin{array}{r}\text { ellenőrzött } \\
\text { személyekkel, } \\
\text { tartása }\end{array} \\
\text { meghallgatás } \\
\end{array}$ & $\begin{array}{l}\text { Performing interviews with } \\
\text { audited persons }\end{array}$ & \begin{tabular}{|l} 
Interview(s) mit den \\
Personen, Anhörung(en)
\end{tabular} & & \\
\hline $\begin{array}{l}\text { Belső szakértői megbeszélés, } \\
\text { workshop, értekezlet, egyeztetés } \\
\text { tartása információk, } \\
\text { összefüggések feltárása, probléma } \\
\text { megismerése céljából }\end{array}$ & $\begin{array}{|lr|}\text { Performing } & \text { internal } \\
\text { professional discussion, } & \text { workshop, meeting, negotiation } \\
\text { for the purpose of discovering } \\
\text { information, exploring relations } \\
\text { and connections, and analyzing } \\
\text { problems }\end{array}$ & \begin{tabular}{|lrr} 
Interne Expertenberatung, & Workshop, \\
Besprechung, Abklärung & von \\
Informationen/Zusammenhängen/Problemen
\end{tabular} & & \\
\hline $\begin{array}{l}\text { Kísérletezés, reprodukálás, } \\
\text { valamely folyamatban az output } \\
\text { (végtermék) újra előállítása } \\
\text { érdekében }\end{array}$ & $\begin{array}{l}\text { Experiment and duplication for } \\
\text { the purpose of reproducing the } \\
\text { output in a certain process }\end{array}$ & \begin{tabular}{|l} 
Experimente, Reproduktion, erneute \\
Herstellung des Outputs (Endproduktes)
\end{tabular} & & \\
\hline $\begin{array}{l}\text { Próbavásárlás valóságos (külső) } \\
\text { személyek segítségével }\end{array}$ & $\begin{array}{l}\text { Test processes with the help of } \\
\text { real (outsider) persons (like }\end{array}$ & Testkäufe durch lebende Personen & & \\
\hline
\end{tabular}




\begin{tabular}{|c|c|c|c|c|}
\hline & mystery shopping) & & & \\
\hline $\begin{array}{l}\text { Adatbányászat, } r \text { statisztikai } \\
\text { elemzések végzése, speciális } \\
\text { elemzö és döntéstámogató } \\
\text { eljárások alkalmazása }\end{array}$ & \begin{tabular}{|l|} 
Data mining, performing \\
statistical analyses, application \\
of special analytical and \\
decision-making procedures
\end{tabular} & $\begin{array}{l}\text { Data Mining, statistische Auswertungen, } \\
\text { Anwendung spezieller Analyse- und } \\
\text { Entscheidungsunterstützungs-Tools }\end{array}$ & & \\
\hline $\begin{array}{l}\text { Mutatószámok képzése és ezek } \\
\text { értékelése } \\
\text { célértékekhez } \\
\begin{array}{l}\text { standarddal, tervorosan, } \\
\text { vagyony mátva, } \\
\text { vagy más formában }\end{array}\end{array}$ & $\begin{array}{l}\text { Generating indicators and their } \\
\text { evaluation in a timeline, against } \\
\text { target figures and standards, or } \\
\text { in any other format }\end{array}$ & $\begin{array}{l}\text { Bildung und Auswertung von Kennzahlen, } \\
\text { Zeitreihen- und Abweichungsanalysen }\end{array}$ & & \\
\hline $\begin{array}{lrr}\text { Összetett } & \text { számítások, } \\
\text { elemzések, modeleti } \\
\text { pontozási rendszerek, komplex } \\
\text { szimulációk fúk kuttatása adotts } \\
\text { témában, különböző } \\
\text { forgatókönyvek szerint } \\
\end{array}$ & $\begin{array}{|lr|}\text { Performing } & \text { complex } \\
\text { calculations, business analyses, } \\
\text { modeling; running r point } \\
\text { systems, simulations in a given } \\
\text { topic, based on different scripts }\end{array}$ & $\begin{array}{l}\text { Komplexe Berechnungen, wirtschaftliche } \\
\text { Analysen, Modellierung, mehrdimensionale } \\
\text { Bewertungen, Simulationen }- \text { nach } \\
\text { verschiedenen Szenarien }\end{array}$ & & \\
\hline $\begin{array}{l}\text { Benchmarking, más piaci } \\
\text { szereplöknél, } \\
\text { meglévő gyervezeteknél } \\
\text { hasonlítás }\end{array}$ & \begin{tabular}{|l} 
Benchmarking, comparison \\
with practice by other role- \\
players
\end{tabular} & $\begin{array}{l}\text { Benchmarking, Vergleich mit externen } \\
\text { Praktiken }\end{array}$ & & \\
\hline $\begin{array}{l}\text { Önértékelési és minősítési } \\
\text { rendszer működtetése (pl. vevők, } \\
\text { beszállítók, munkatársak által) }\end{array}$ & $\begin{array}{|lr|}\text { Operating a self-evaluation and } \\
\text { qualification system (e. g. by } \\
\text { customers, } & \text { suppliers, } \\
\text { employees) } & \\
\end{array}$ & $\begin{array}{l}\text { Betrieb eines Selbstevaluierungssystems } \\
\text { (z.B. für Kunden, Lieferanten, Mitarbeiter) }\end{array}$ & & \\
\hline $\begin{array}{lcr}\text { Monitoring } & \text { és } & \text { azonnali } \\
\text { figyelmeztető } & \text { rendszerek (pl. } \\
\text { költségekre, } & \text { folyamatokra, } \\
\text { érzékelővel ellátott } & \text { eszközökre) } \\
\text { müködtetése } & & \end{array}$ & $\begin{array}{l}\text { Operating monitoring and } \\
\text { instant notification systems (e. } \\
\text { g. regarding costs, processes, } \\
\text { devices with sensors) }\end{array}$ & 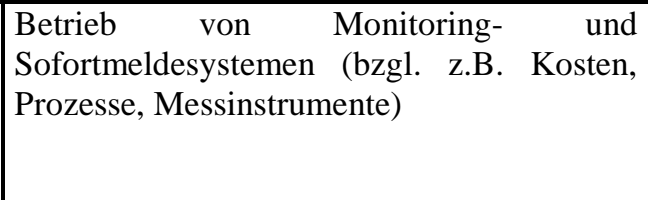 & & \\
\hline $\begin{array}{llr}\text { Külső } & \text { harmadik } & \text { személy, } \\
\text { szakértő, } & \text { tanácsadó } & \text { felkérése } \\
\text { valamely témában, célellenőrzés, } \\
\text { célvizsgálat lefolytatása céljából }\end{array}$ & $\begin{array}{l}\text { Engaging an external third } \\
\text { person, professional, expert, } \\
\text { adviser in particular topic, for } \\
\text { the purpose of performing } \\
\text { target control, target inspection }\end{array}$ & $\begin{array}{l}\text { Beauftragung von externen Experten, } \\
\text { Beratern usw. mit der Durchführung } \\
\text { gezielter Untersuchungen }\end{array}$ & & \\
\hline
\end{tabular}




\begin{tabular}{|c|c|c|c|c|}
\hline $\begin{array}{l}\text { Írásbeli beszámoló készíttetése, } \\
\text { jelentéstételre kötelezés, riport } \\
\text { bekérése, nyilatkoztatás }\end{array}$ & $\begin{array}{l}\text { Preparing a written report, } \\
\text { mandating the submission of a } \\
\text { report, requesting a report, } \\
\text { requesting a statement }\end{array}$ & $\begin{array}{l}\text { Einforderung von schriftlichen Berichten, } \\
\text { Reports, Aussagen, Erklärungen usw. }\end{array}$ & & \\
\hline $\begin{array}{l}\text { Tételes megszámolás, mérlegelés, } \\
\text { fizikai leltározás, rovancsolás, } \\
\text { jegyzékbe vétel }\end{array}$ & $\begin{array}{l}\text { Itemized counting, physical } \\
\text { inventory, } \quad \text { stock-taking, } \\
\text { keeping a registry }\end{array}$ & $\begin{array}{l}\text { Abzählen, Inventuraufnahme, Kassensturz, } \\
\text { Eintragung in ein Register }\end{array}$ & & \\
\hline $\begin{array}{lr}\text { Tárgyak és } & \text { személyek fizikai } \\
\text { átvizsgálása, } & \text { átvilágítása, } \\
\text { átkutatása, } & \text { motozása, } \\
\text { röntgenezése, szkennelése }\end{array}$ & $\begin{array}{l}\text { Physical screening, searches, } \\
\text { X-ray examination, searches of } \\
\text { persons }\end{array}$ & $\begin{array}{l}\text { Physikalische Durchsuchung, } \\
\text { Durchleuchtung, Leibesvisitation }\end{array}$ & & \\
\hline $\begin{array}{lr}\text { Analitikák, } & \text { kimutatások, } \\
\text { nyilvántartások } & \text { tételes } \\
\text { egyeztetése, } & \text { összevetése, } \\
\text { összehasonlítása, összepipálása, } \\
\text { párosítása, összepontozása } \\
\end{array}$ & $\begin{array}{l}\text { Analytics, statements, itemized } \\
\text { reconciliation, comparison, } \\
\text { checking, pairing, matching to } \\
\text { records }\end{array}$ & $\begin{array}{llr}\text { Zeilenweiser } & \text { Abgleich von } & \text { analytischen } \\
\text { Daten, } & \text { Buchungen, } & \text { Reporten, } \\
\text { Registereintragungen usw. } & \end{array}$ & & \\
\hline $\begin{array}{l}\text { Többszintü jóváhagyási kontroll } \\
\text { elöírása, második és további } \\
\text { engedélyezési szintek bevezetése, } \\
\text { értékhatárhoz kötött aláírási } \\
\text { jogkörök meghatározása }\end{array}$ & $\begin{array}{l}\text { Prescribing a multi-level } \\
\text { control, introduction of a } \\
\text { second and further licensing } \\
\text { levels, defining signing powers } \\
\text { connected to value limits } \\
\end{array}$ & $\begin{array}{l}\text { Mehrstufige } \quad \text { Genehmigungsverfahren, } \\
\text { Einführung zweiter und weiterer } \\
\text { Genehmigungsebenen, Festlegung von } \\
\text { summenabhängigen Bewilligungen }\end{array}$ & & \\
\hline $\begin{array}{l}\text { Személyükben eltérö jóváhagyó, } \\
\text { ellenőrző, kötelezettségvállaló, } \\
\text { utalványozó személyek kijelölése, } \\
\text { korlátozásokr beiktatása, } \\
\text { jogköreik, limitjeik, felelősségeik } \\
\text { meghatározásával }\end{array}$ & $\begin{array}{l}\text { Segregation of duties, } \\
\text { appointing different approving, } \\
\text { controlling, cost transfer, } \\
\text { consignment persons, their } \\
\text { powers, limits, and } \\
\text { responsibilities }\end{array}$ & $\begin{array}{llr}\text { Festlegung von unterschiedlichen } \\
\text { Genehmigungs-, Kontroll-, } & \text { Budgetierungs- } \\
\text { und Anweisungskompetenzen } & \text { mit } \\
\text { diskretionären Rechten, Limits und } & \text { untwortungen }\end{array}$ & & \\
\hline $\begin{array}{l}\text { (Túl)terheléses, behatolásos, } \\
\text { hozzáférési és egyéb tesztek } \\
\text { végzése az informatikai rendszer } \\
\text { és az eltárolt adatok, adatbázisok } \\
\text { megbízhatóságára, teljességére } \\
\text { vonatkozóan }\end{array}$ & $\begin{array}{l}\text { Performing (over)load, entry, } \\
\text { access, and other tests with } \\
\text { respect to the reliability and } \\
\text { comprehensiveness of IT } \\
\text { system, stored data, and } \\
\text { databases }\end{array}$ & $\begin{array}{l}\text { Durchführung von Informatik-Stresstests } \\
\text { bzgl. Überbelastung, Hackerattacken, } \\
\text { Zugriffssicherheit usw. und damit } \\
\text { Überprüfung der Zuverlässigkeit und } \\
\text { Vollständigkeit } \quad \text { von System(en), } \\
\text { gespeicherten Daten und Datenbanken }\end{array}$ & & \\
\hline
\end{tabular}


IV. Kontrollrendszer intézményesülése / Institutionalism of internal control system / Institutionalisierung von internen Kontrollsystemen

Az alábbiakban összetett állításokat talál a kontrollrendszerükre vonatkozóan. Kérem, adja meg állításonként, hogy az összességében mennyire jellemző az Önök belső kontrollrendszerére, annak fejlettségére!

Az alábbi 7 fokozatú skála segítségével próbálja soronként eldönteni, hogy milyen mértékben jellemző az Önök vállalatára a megadott állítás teljes egésze! Válaszát 7 fokozatú skálán tudja megadni, ahol a legnagyobb érték a 7-es, amely a maximális egyetértést jelenti az állítással, míg a legrosszabb érték az 1-es, amely a teljes elutasítását jelenti az állításnak. Ha nem tudja eldönteni, vagy nem kíván válaszolni, válassza a $0-\mathrm{t}$ !

You will find complex statements with respect to your control system below. Please specify how characteristic the following are to your internal control system and its maturity-level, in the overall consideration of the statement!

Using the following scale of 1-7, try to decide by each row the extent to which the overall statement is true for your Company! You can specify your answer on a scale of 1-7, where 7 is the highest value, which represents maximum agreement with the statement, while 1 is the lowest value, which represents complete disagreement with the statement. If you cannot decide or wish not to specify the answer, please choose the 0 !

Unten finden Sie komplexe Aussagen über Ihr Kontrollsystem. Bitte beurteilen Sie, wie zutreffend die jeweilige Aussage bzgl. Ihres internen Kontrollsystems und dessen Reifegrades ist.

Zur Beurteilung benutzen Sie bitte eine Skala von 1 bis 7! Der maximale Wert 7 steht dabei für eine völlige Übereinstimmung und der minimale Wert 1 repräsentiert eine vollständige Ablehnung bei Ihnen. Sie können auch den Wert 0 angeben, falls Sie die Beurteilung nicht vornehmen können oder wollen.

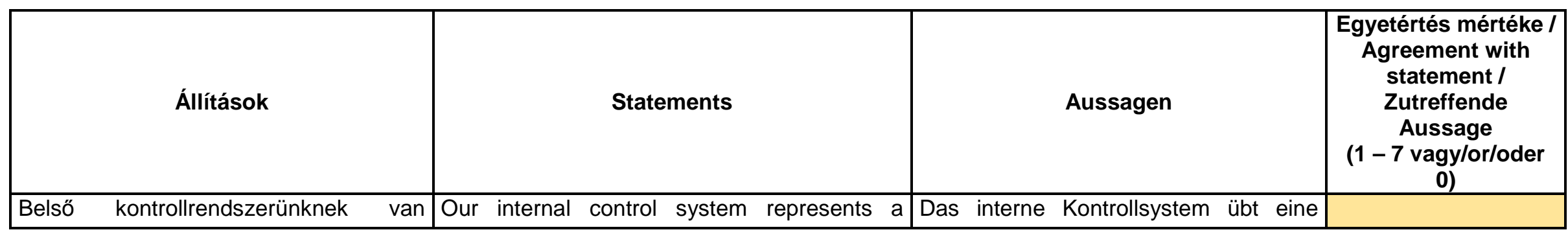


visszatartó ereje, komoly fegyelmező erőt képvisel a szervezetben. Bármely elemének megsértése jelentős szankciókkal, büntetéssel jár az érintettekkel szemben.

Müködik átfogó kockázatmenedzsmentrendszer társaságunknál,

kockázatokat eszerint mérlegeljük és cselekszünk kezelésük érdekében.

A szervezet céljai, stratégiája, továbbá a teljesítménymérési és -értékelés rendszere egy egységes, összehangolt rendszert alkot vállalatunknál.

Vannak írásban rögzített, különféle kulcsmutatószámaink, és törekszünk döntéseinket aszerint meghozni, hogy ezeket a célszámokat teljesítsük.

Maximális a vezetői elköteleződés a belső kontrollrendszer irányában, annak fontossága megkérdőjelezhetetlen, számukra magától értetődő szükségessége. Jelentőségét érzik szervezetben, és ezt deklarálják kommunikálják is a vállalat minden szintjén és minden területén a dolgozók számára.

Belső kontrollrendszerünk müködése kihatással van a beszállítókkal való kapcsolatunkra

alvállalkozóink befolyásolja megítélését és a külső szolgáltatást végző partnereink müködését is.

Amennyire lehetséges, teljes körüen alkalmazzuk a 4 szem elvét és a kontrollmixet serious control and disciplining effect in our Organisation. The violation of any part of which entails significant consequences and disciplinary measures for the relevant persons.

An overall risk management system operates at our Company, whereby by evaluate the risks and take measures for their management.

The goals, strategies, and performance measurement and evaluation systems of our Organisation constitute a unified, coordinated system at our Company.

We have key figure indicators recorded in writing, and we strive to make our decisions with a view to reach these target numbers.

The management have maximally committed themselves to the internal control system and to the unquestionability of its importance; they view its necessity as self-evident. They deem its presence in the Organisation significant, and they have declared and communicate it to the employees on all levels and each area of the Company.

The operation of our internal control system influences our relationship with our suppliers, and affects the evaluation of the performance of our subcontractors and the operation of our partners rendering external services.

As much as possible, we apply the four-eyes principle and control mix comprehensively with respect to all of our activities and all of hemmende Wirkung aus und hat eine usgeprägte Disziplinarkraft. Sollte nur ein Element nicht eingehalten werden, drohen bereits schwere Sanktionen Strafen.

Es wird ein umfassendes
Risikomanagementsystem betrieben das Risiken abwägt und zu ihrer Bekämpfung anleitet.

Ziele, Strategie, Leistungsmessungsund Leistungsbeurteilungssystem bilden ein einheitliches abgestimmtes Gefüge bei uns.

Es existieren im Unternehmen explizite Schlüsselindikatoren und wir bemühen uns, die Entscheidungsfindung auf die Erreichung ihrer Zielwerte auszurichten. Das Management steht entschlossen hinter dem internen Kontrollsystem, dessen Wichtigkeit nicht angezweifelt werden kann und dessen Notwendigkeit für selbstverständlich erachtet wird. Diese Wichtigkeit ist spürbar im Unternehmen, sie wird auf allen Ebenen und an alle Bereiche auch deklariert und kommuniziert.

as interne Kontrollsystem beeinflusst unsere Beziehungen zu den Lieferanten, die Beurteilung ihrer Leistungen, sowie

Geschäftsgebaren Subunternehmer.

Wir wenden das Vier-Augen-Prinzip und den Kontrollmix - soweit möglich bei allen Tätigkeiten und innerhalb von 


\begin{tabular}{|c|c|c|}
\hline $\begin{array}{l}\text { tevékenységünknél, ill. minden vállalati } \\
\text { területünkön. }\end{array}$ & our business and corporate areas. & allen Unternehmensbereichen an. \\
\hline $\begin{array}{l}\text { A kontrolltevékenységek teljes } \\
\text { mértékben beépültek szervezetünk } \\
\text { müködésébe, áthatják } r \quad a \\
\text { tevékenységeinket, az ellenőrzés a } \\
\text { mindennapok részévé vált. }\end{array}$ & $\begin{array}{l}\text { The control activities have completely been } \\
\text { integrated in our Organisation, permeate our } \\
\text { activities, and have become integral part of } \\
\text { our daily operation. }\end{array}$ & $\begin{array}{l}\text { Die Kontrolltätigkeiten sind vollständig } \\
\text { in unsere Operation integriert, sie } \\
\text { durchdringen unsere Tätigkeiten, das } \\
\text { Kontrollieren ist ein Teil des Alltages } \\
\text { geworden. }\end{array}$ \\
\hline $\begin{array}{l}\text { A dolgozók elfogadják a kontrollok, az } \\
\text { ellenőrzési mechanizmusok } \\
\text { létjogosultságát vállalatunkban. Nem } \\
\text { kérdőjelezik meg azok szükségességét, } \\
\text { tudomásul veszik azokat, és együtt } \\
\text { élnek velük a mindennapi munkájuk } \\
\text { során. }\end{array}$ & $\begin{array}{l}\text { The employees have accepted the legitimacy } \\
\text { of the control mechanisms in our Company. } \\
\text { They do not question their necessity, have } \\
\text { adopted them, and integrated them into their } \\
\text { daily work. }\end{array}$ & $\begin{array}{l}\text { Die Mitarbeiter halten die Kontrollen, } \\
\text { die Kontrollmechanismen für } \\
\text { angebracht. Ihre Notwendigkeit wird } \\
\text { nicht hinterfragt, man akzeptiert sie und } \\
\text { lebt damit bei der Arbeit. }\end{array}$ \\
\hline $\begin{array}{l}\text { Belső kontrollrendszerünket tudatosan } \\
\text { és folyamatosan javítjuk, fejlesztjük. }\end{array}$ & $\begin{array}{llcc}\text { We are continuously improving and } \\
\text { developing our internal control system. }\end{array}$ & $\begin{array}{l}\text { Das interne Kontrollsystem wird } \\
\text { bewusst und kontinuierlich verbessert } \\
\text { und weiterentwickelt. }\end{array}$ \\
\hline 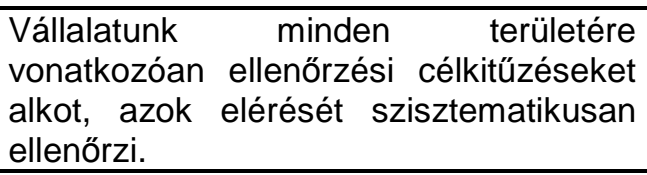 & $\begin{array}{l}\text { Our Company specifies control measure } \\
\text { targets with respect to all of its areas, and } \\
\text { systematically monitors their achievement. }\end{array}$ & $\begin{array}{l}\text { Es werden Kontrollziele für alle } \\
\text { Unternehmensbereiche definiert und } \\
\text { ihre Erreichung wird systematisch } \\
\text { überprüft. }\end{array}$ \\
\hline $\begin{array}{l}\text { A vezetés a meglévő külső szabályokon, } \\
\text { követelményeken túlmenően még } \\
\text { szigorúbb belső elvárásokat támaszt a } \\
\text { szervezet tagjaival szemben a belső } \\
\text { kontrollok működtetése során. }\end{array}$ & $\begin{array}{l}\text { In the course of the operation of the controls, } \\
\text { the management has set even stricter internal } \\
\text { expectations toward the members of the } \\
\text { Organisation than the existing external } \\
\text { regulations. }\end{array}$ & $\begin{array}{l}\text { Für die Ausführung der internen } \\
\text { Kontrollen gelten schärfere, vom } \\
\text { Management } \\
\text { Anforderungen, als sie in externen } \\
\text { Vorschriften oder } \\
\text { vorgegeben sind. }\end{array}$ \\
\hline $\begin{array}{l}\text { A kontrollok müködésére és } \\
\text { eredményességére, hatékonyságára } \\
\text { erős nyomás nehezedik a különféle } \\
\text { szereplők (tulajdonosok, hatóságok, } \\
\text { menedzsment stb.) által. }\end{array}$ & $\begin{array}{l}\text { Strong pressure and incentive are placed on } \\
\text { the operation and effectiveness of the controls } \\
\text { by the various role-players (owners, } \\
\text { authorities, management, etc.). }\end{array}$ & $\begin{array}{l}\text { Verschiedene } \\
\text { (Eigentümer, Behörden, Führungskräfte } \\
\text { usw.) üben einen verstärkten Druck } \\
\text { bzgl. der Durchführung von Kontrollen, } \\
\text { sowie deren Effizienz und Effektivität } \\
\text { aus. }\end{array}$ \\
\hline A felelősségre vonás mindig tényeken & Enforcement is always administered based on & Die Einforderung der Verantwortlichkeit \\
\hline
\end{tabular}


alapszik, a számonkérés kiindulópontja mindig a célkitǔzésektől, standardoktól, tervektől, szabályoktól, külső és belsó előírásoktól való eltérés.

A belső kontrollrendszer müködését a vezetésen kívül a tulajdonos(ok), hitelező(k), a könyvvizsgáló, ill. más külső üzleti partnerek is rendszeresen vizsgálják, ill. eredményeit figyelemmek kísérik, beszámolóikat hasznosítják.

Társaságunknál létezik írásban kiadott, részletes előírásokat

kockázatkezelési

kockázatmenezdment-politika.

Munkatársaink szabályozott belsó folyamatleírásaink és munkautasításaink alapján végzik napi feladataikat.

$A$ vállalkozás minden szintjén tisztában vannak a dolgozók az oda illö, azon tevékenységre vonatkozó alapvető jogi előírásokkal, jogszabályokkal, szabványokkal, egyéb írásban lefektetet külső normákkal.

Szabályozva vannak a belső beszámolási, jelentéstételi módok és utak. Egyértelmü a dolgozók számára hogy munkájukat illetően kinek, mikor, milyen formában, mire kiterjedően stb. kötelesek beszámolni, jelentést adni.

A belső írásos szabályrendszert egy erős, íratlan, belső kulturális cselekvés facts, and the plumb line set for accountability and consequences is always the measure of deviation from targets, standards, plans, regulations, and external and internal regulations.

In addition to the management, the internal control system is also regularly monitored by the owner(s), creditor(s), and other external business partners, who also keep track of its results and utilize its reports.

Our Company has a risk management regulation risk management policy issued in writing, containing the detailed requirements.

Our employees perform their tasks based on our regulated internal process descriptions and work instructions.

Our employees on all levels of the Company are clear about the basic legislation, legal requirements, regulations, standards, and ther written norms.

The internal reporting methods and routes are regulated. It is clear for the employees to whom, when, how, and to what extent, etc. they required to submit reports with respect to their work.

The internal written rules are completed by a set of strong internal action expectations, and

basiert ausnahmslos auf Fakten, wobe die Abweichung(en) von Zielen, Standards, Planwerten, Regel(unge)n sowie externen und internen Vorschriften als Ausgangspunkt gelten.

Das interne Kontrollsystem wird nicht nur vom Management, sondern auch von Eigentümer(n), Gläubiger(n) und anderen Geschäftspartnern überprüft diese verfolgen die Ergebnisse de Kontrollen und verwenden die erstellten Berichte.

Es existiert im unseren Unternehmen eine schriftliche RisikomanagementRegelung oder RisikomanagementPolitik, die detaillierte Vorschriften enthält.

Unsere Mitarbeiter verrichten ihre
tägliche Arbeit nach internen Prozessbeschreibungen und konkreten Anweisungen.

Arbeitnehmer auf allen

wichtigsten, für sie und ihre Arbeit

relevanten Rechtsvorschriften,

Standards und weiteren externen schriftlichen Normen.

Die Arten und Kanäle der internen

Berichterstattung sind geregelt. Die

Mitarbeiter wurden eindeutig

eingewiesen, wann, an wen, wie und worüber sie bzgl. ihrer Arbeit Bericht zu erstatten haben.

Das interne schriftliche Regelwerk wird von ungeschriebenen internen 


\begin{tabular}{|c|c|c|}
\hline $\begin{array}{l}\text { elvárás egészíti ki; magas szintű morális } \\
\text { értékrend jellemzi társaságunkat. A } \\
\text { munkavállalóknak komoly etikai } \\
\text { mércének kell megfelelniük. }\end{array}$ & $\begin{array}{l}\text { a high moral value system is associated with } \\
\text { our Company. Our employees are vetted } \\
\text { against a serious ethical standard. }\end{array}$ & $\begin{array}{l}\text { kulturellen Erwartungen bzgl. der } \\
\text { Handlungen ergänzt. Unser } \\
\text { Wertesystem zeugt von hoher } \\
\text { Unternehmensmoral. Gegenüber den } \\
\text { Mitarbeitern wird die ethische Messlatte } \\
\text { hoch angesetzt. }\end{array}$ \\
\hline $\begin{array}{l}\text { Belső kontrollrendszerünk teljes körüen } \\
\text { dokumentált, a kontrollfolyamatoknak, } \\
\text { auditoknak írásos belső szabályozása } \\
\text { (politikája, folyamatábrája, ütemterve, } \\
\text { szabályzata stb.) teljes mértékben } \\
\text { írásban rögzített. }\end{array}$ & $\begin{array}{l}\text { Our internal control system is fully } \\
\text { documented, the internal regulations (policies, } \\
\text { flow charts, schedules, rules) of the control } \\
\text { processes and audits are completely recorded } \\
\text { in writing. }\end{array}$ & $\begin{array}{l}\text { Das interne Kontrollsystem ist lückenlos } \\
\text { dokumentiert; die Kontrollabläufe und } \\
\text { Audits werden durch umfassende } \\
\text { schriftliche interne Vorschriften (Politik, } \\
\text { Ablaufdiagramm, Zeitplan usw.) } \\
\text { geregelt. }\end{array}$ \\
\hline $\begin{array}{l}\text { Nagyon kifinomult és összehangolt, } \\
\text { mélyreható kontrolltevékenységek } \\
\text { zajlanak társaságunknál, amelyek } \\
\text { képesek szinte bármilyen hibát, } \\
\text { szabályszegést, incidenst, visszaélést } \\
\text { kezelni, feltárni. }\end{array}$ & $\begin{array}{l}\text { Refined, harmonized, and penetrating control } \\
\text { activities are conducted at our Company, } \\
\text { which are capable of revealing any error, } \\
\text { violation, incident, or abuse. }\end{array}$ & $\begin{array}{l}\text { Unsere Kontrolltätigkeiten sind sehr } \\
\text { ausgereift und tief grabend, dadurch } \\
\text { sind wir in der Lage, nahezu alle Arten } \\
\text { von Fehlern, Regelverstößen, } \\
\text { Zwischenfällen, Missbräuchen zu } \\
\text { entdecken. }\end{array}$ \\
\hline 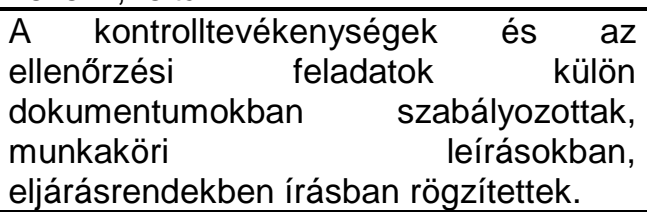 & $\begin{array}{l}\text { The control activities and audits activities are } \\
\text { regulated and recorded in writing in separate } \\
\text { documents, job descriptions, and procedures. }\end{array}$ & $\begin{array}{l}\text { Die Kontrollabläufe } \\
\text { Kontrollaufgaben sind in gesonderten } \\
\text { Dokumenten geregelt, sie wurden auch } \\
\text { in Stellenbeschreibungen und } \\
\text { Ablaufvorschriften integriert. }\end{array}$ \\
\hline $\begin{array}{l}\text { A kulcsfontosságú kontrollpontok } \\
\text { felismerésre és azonosításra kerültek } \\
\text { vállalatunk tevékenységi rendszerén } \\
\text { belül. }\end{array}$ & $\begin{array}{l}\text { The key control points have been recognized } \\
\text { and identified within the activity system of our } \\
\text { Company. }\end{array}$ & $\begin{array}{l}\text { Die Schlüsselstellen der Kontrolle } \\
\text { innerhalb unserer Tätigkeiten sind } \\
\text { identifiziert. }\end{array}$ \\
\hline $\begin{array}{l}\text { Vezetőink különféle, jól megválasztott } \\
\text { ellenőrzési módszereket alkalmaznak } \\
\text { kontrolltevékenységünk során, melyek } \\
\text { egymástól függetlenül, illetve egymással } \\
\text { párhuzamosan működnek. }\end{array}$ & $\begin{array}{l}\text { Our managers are applying well-selected } \\
\text { checking methods during our control activities, } \\
\text { which are conducted parallel with but } \\
\text { independently of each other. }\end{array}$ & $\begin{array}{l}\text { Die Führungskräfte kontrollieren durch } \\
\text { verschiedene, zutreffend ausgewählte } \\
\text { Methoden, die unabhängig voneinander } \\
\text { bzw. parallel angewendet werden. }\end{array}$ \\
\hline Vállalatunknál a kontrolltevékenységek & The control activities are adequately detailed & àtigkeiten sind hinreichend \\
\hline
\end{tabular}




\begin{tabular}{|c|c|c|}
\hline $\begin{array}{l}\text { kellően részletezettek, minden } \\
\text { folyamatunkra érdemi } \\
\text { garantálják, hiterjednek, hogy az az adott } \\
\text { tevékenységet csak jól, az előírásoknak } \\
\text { megfelelően tudják elvégezni. }\end{array}$ & $\begin{array}{l}\text { in our Company, they cover each relevant } \\
\text { process, and guarantee that the given activity } \\
\text { can only be performed well, according to the } \\
\text { regulations. }\end{array}$ & $\begin{array}{l}\text { detailliert und umfassen alle } \\
\text { wesentlichen Abläufe, wodurch } \\
\text { sichergestellt ist, dass die Prozesse nur } \\
\text { in guter Qualität d.h. den Vorschriften } \\
\text { entsprechend ablaufen können. }\end{array}$ \\
\hline $\begin{array}{l}\text { A vezetés rendszeresen méri és } \\
\text { számszerüsíti a belső kontrollrendszer } \\
\text { müködtetésével kapcsolatosan felmerült } \\
\text { költségeket és a kontrollrendszer } \\
\text { hasznait, hozadékait. }\end{array}$ & $\begin{array}{l}\text { The management regularly measure and } \\
\text { quantify the costs incurred in relation to the } \\
\text { operation of the internal control system, as } \\
\text { well as its profits and revenues. }\end{array}$ & $\begin{array}{l}\text { Die Kosten und Nutzen des internen } \\
\text { Kontrollsystems werden r vom } \\
\text { Management regelmäßig gemessen } \\
\text { und beurteilt. }\end{array}$ \\
\hline $\begin{array}{l}\text { Mindent munkavállalót igyekszünk } \\
\text { képezni a vállalkozás belső } \\
\text { kontrollrendszerének müdéséről, } \\
\text { valamint az etikus müködés, } \\
\text { szabálykövetés témakörében. }\end{array}$ & $\begin{array}{l}\text { Each employee is trained about the operation } \\
\text { of the internal control system, and in the topic } \\
\text { of ethical operation and compliance with the } \\
\text { regulations. }\end{array}$ & $\begin{array}{l}\text { Sämtliche Mitarbeiter werden über das } \\
\text { interne Kontrollsystem, über ethisches } \\
\text { Handeln und vorschriftsmäßige } \\
\text { Arbeitsverrichtung geschult. }\end{array}$ \\
\hline $\begin{array}{l}\text { A belső kontrollrendszer újszerű és } \\
\text { értékes eredményeit, „unikumszerü” } \\
\text { mintáit bemutatjukr más } \\
\text { vállalkozásoknak, példaként állítjuk az } \\
\text { érdeklődők, ill. a szakmai nyilvánosság } \\
\text { elé. }\end{array}$ & $\begin{array}{l}\text { The new and valuable results and unique } \\
\text { patterns of the internal control system are } \\
\text { made known to other enterprises and } \\
\text { demonstrated as examples to the relevant } \\
\text { and inquiring persons and the professional } \\
\text { community. }\end{array}$ & $\begin{array}{l}\text { Die neuartigen und wertvollen } \\
\text { Ergebnisse, „unikale“ Muster aus dem } \\
\text { internen Kontrollsystem werden } \\
\text { anderen Unternehmen gezeigt, sowie } \\
\text { beispielhaft dem fachlichen Publikum } \\
\text { und anderen Interessenten präsentiert. }\end{array}$ \\
\hline 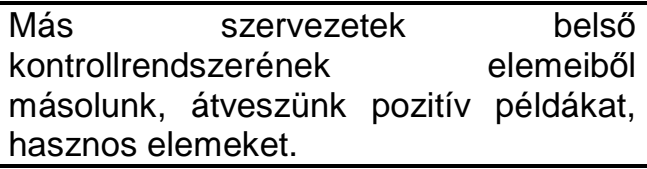 & $\begin{array}{l}\text { We copy and adopt positive examples and } \\
\text { useful elements from the internal control } \\
\text { system of other Organisations. }\end{array}$ & $\begin{array}{l}\text { Wir übernehmen positive Beispiele und } \\
\text { nützliche Elemente aus den internen } \\
\text { Kontrollsystemen anderer Firmen. }\end{array}$ \\
\hline $\begin{array}{l}\text { Társaságunknál egyértelmű gazdája, } \\
\text { formálója, alakítója, főfelelőse van a } \\
\text { belső kontrollrendszer müködtetésének. }\end{array}$ & $\begin{array}{l}\text { The operator of the internal control system } \\
\text { has an unequivocal owner, formulator, } \\
\text { modifier, and main responsible person. }\end{array}$ & $\begin{array}{llr}\text { Der Betreiber, } & \text { Ausgestalter, } \\
\text { Hauptverantwortliche des } & \text { internen } \\
\text { Kontrollsystems in } & \text { unserem } \\
\text { Unternehmen wurde } & \text { eindeutig } \\
\text { festgelegt. } & & \\
\end{array}$ \\
\hline 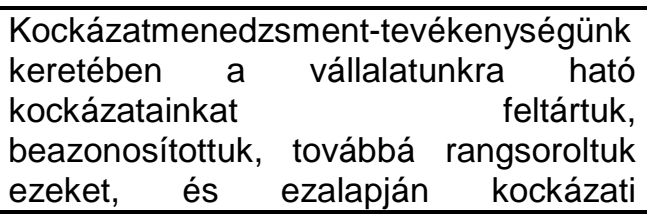 & $\begin{array}{l}\text { As part of our risk management activities, we } \\
\text { have revealed, identified, and prioritized the } \\
\text { risks impacting our Company, and, based on } \\
\text { the results, we have issues a risk } \\
\text { documentation (map, network, etc.) of the }\end{array}$ & $\begin{array}{l}\text { Im Rahmen des Risikomanagements } \\
\text { wurden die für unseren Betrieb } \\
\text { relevanten Risiken aufgedeckt, } \\
\text { priorisiert und in die Dokumentation } \\
\text { (Risikoübersicht, }\end{array}$ \\
\hline
\end{tabular}


dokumentációt (térképet, hálót stb.) készítettünk a társaságunk müködésére ható, kártékony tényezőkről.

Minden szereplőnek világos a
feladatköre és felelössége a belsô kontrollrendszer müködtetését illetően.

\section{Alkalmazunk külső szakértőket} specialistákat, tanácsadókat egy-egy kontrolltevékenység ellátása céljából.

A kontrolltevékenységeket végző személyek - munkaköri feladataikat figyelembe véve - önálló ellenőrzés vagy dominánsan kontrollt végző munkaköröket töltenek be vállalatunknál.

Belső kontrollrendszerünket erős munkamegosztás jellemzi, számos hatalommal felruházott ellenőrzési és kontrollszerepkör (munkakör, szervezet egység, ill. testület) létesült és müködik folyamatosan társaságunknál.

Társaságunknál erős az együttmüködés az ellenőrző és kontrolláló szerepkörök között, jellemző a közös vizsgálat programok tervezése, végrehajtása rendszeres a kommunikáció az ezen feladatot ellátók között.

A kontroltevékenységek egy részét külső személyek, szereplők végzik el a társaság saját munkavállalói, tisztségviselői helyett. main harmful effects affecting our Company.

Each role-player is clear about their job and area of responsibility with respect to the operation of the internal control system.

We employ external professionals, experts, specialists, and advisors to perform certain control activities.

With consideration of their jobs and activities, the persons performing the control activities at our Company occupy positions responsible for independent audit and which are predominantly control-related.

Our internal control system is characterized by strong division of labor; numerous checking and control roles (jobs, organisational units or bodies) with proper authorization have been created and are continuously operating at our Company.

There is a strong cooperation between the checking and control jobs at our Company; ypically, common inspection programs are planned and performed, and regular communication is in place between the persons performing these tasks.

Part of the control activities are performed by external persons instead of the Company's own employees and officers. aufgenommen. Dadurch sind uns diese schädlichen Faktoren bekannt.

Alle Beteiligten wissen Bescheid über

ihre Aufgabenbereiche

Verantwortlichkeiten bzgl. des inter Kontrollsystems.

Externe Experten, Spezialisten und/oder Berater werden mit der Ausführung einzelner Kontrolltätigkeiten beauftragt.

Die Kontrolltätigkeiten werden von Mitarbeitern ausgeführt, die aufgrund ihrer Stellenbeschreibungen einer selbständigen Kontrolleinheit oder dem Arbeitsgebiet „Kontrolle“ zuzuordnen sind.

Das interne Kontrollsystem is arbeitsteilig: viele Mitwirkenden (Stellen, Einheiten, Gremien) arbeiten dauerhaft auf diesem Gebiet und haben zudem eigenständige (Kontroll)Befugnisse, die sie für ihre Kontrolltätigkeiten nutzen können.

Die an der unternehmensinternen Kontrolle Mitwirkenden arbeiten eng zusammen: gemeinsame Kontrollpläne werden erstellt und abgearbeitet, die Kommunikation unter ihnen findet regelmäßig statt

Statt von eigenen Mitarbeitern werden die Kontrollätigkeiten zum Teil durch Außenstehende vollzogen. 


\begin{tabular}{|c|c|c|}
\hline $\begin{array}{l}\text { Az ellenőrzési feladatok és a } \\
\text { kontrolltevékenységek ellátásához } \\
\text { szükséges személyi állomány mindig } \\
\text { rendelkezésre áll, akik elegendő } \\
\text { munkaidő-kapacitással, } \\
\text { felkészültséggel, szakértelemmel, } \\
\text { képzettséggel tudják ellátni feladataikat. }\end{array}$ & $\begin{array}{l}\text { The human resources necessary for } \\
\text { performing the checking tasks and control } \\
\text { activities is continuously available, who are } \\
\text { able to perform their tasks with ample } \\
\text { worktime capacity, qualifications, } \\
\text { preparedness, knowledge, and skill. }\end{array}$ & $\begin{array}{l}\text { Das für die Kontrollabläufe und - } \\
\text { Tätigkeiten benötigte Personal steht } \\
\text { stets zur Verfügung - und zwar mit } \\
\text { ausreichenden Arbeitszeitkapazitäten, } \\
\text { Kenntnissen, Fachwissen und } \\
\text { Ausbildung. }\end{array}$ \\
\hline $\begin{array}{llr}\text { Az ellenőrzést } & \text { végző és } & \text { kontrollt } \\
\text { gyakorló munkatársainkat rendszeresen } \\
\text { képezzük, tudásukat és képességeiket } \\
\text { folyamatosan } & \text { fejlesztjük } r \text { annak } \\
\text { érdekében, } & \text { hogy } & \text { ellenőrző } \\
\text { tevékenységüket } & \text { minél jobban tudják } \\
\text { ellátni. } & & \end{array}$ & $\begin{array}{l}\text { We are continuously training our employees } \\
\text { performing checking and control activities, } \\
\text { and are continuously developing and } \\
\text { improving their knowledge, skills, and abilities, } \\
\text { in order to enable them to perform their } \\
\text { control activities to the best of their abilities. }\end{array}$ & 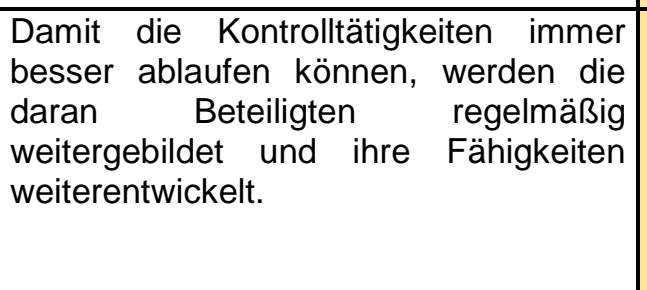 \\
\hline $\begin{array}{l}\text { Belső szabályozásunk értelmében az } \\
\text { egyes pozíciókhoz tartozó felelösségi } \\
\text { körök (megrendelö, r szakmai } \\
\text { teljesítésigazoló, aláírási jogkört } \\
\text { gyakorló, rualványozó, } \\
\text { kötelezettségvállaló, jóváhagyó stb.) } \\
\text { egyértelműen szabályozottak, teljesek, } \\
\text { hézagmentesek, átfedés nélküliek és } \\
\text { biztosítják az összeférhetetlenséget. }\end{array}$ & $\begin{array}{l}\text { The areas of responsibility (person placing } \\
\text { orders, issuing the completion certificate, } \\
\text { practicing the signing powers, authorizing } \\
\text { transfers, undertaking obligations, approving } \\
\text { decisions, etc.) within the meaning of our } \\
\text { internal rules are unambiguously regulated, } \\
\text { complete, without gaps, deficiencies, and } \\
\text { overlaps, and ensure conflict of interest. }\end{array}$ & 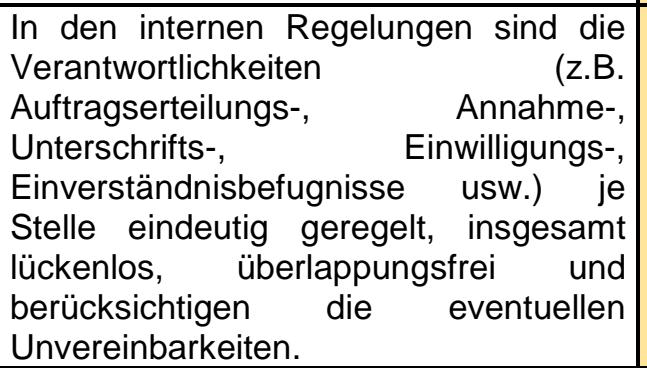 \\
\hline $\begin{array}{lrr}\text { Rendszeresen konzultálunk } & \text { külső } \\
\text { szakmai közösségekkel, csatlakozunk } \\
\text { tudományos csoportokhoz, ill. szakértői } \\
\text { szervezetekhez } \\
\text { kontrollrendszerünk } \\
\text { érdekében. }\end{array}$ & $\begin{array}{l}\text { We regularly consult external professional } \\
\text { communities, join scientific groups or expert } \\
\text { organisations in order to improve and develop } \\
\text { our internal control system. }\end{array}$ & $\begin{array}{l}\text { Um das interne } \quad \text { Kontrollsystem } \\
\text { weiterzuentwickeln, führen } \quad \text { wir } \\
\text { regelmäßige Gespräche r mit } \\
\text { Fachkreisen, sind Mitglieder in } \\
\text { wissenschaftlichen Organisationen und } \\
\text { Expertengremien. }\end{array}$ \\
\hline $\begin{array}{l}\text { A vezetés a kontrolltevékenységeket } \\
\text { ellátó erőforrások mind hatékonyabb } \\
\text { felhasználására törekszik. }\end{array}$ & $\begin{array}{l}\text { The management strive to achieve more } \\
\text { efficient utilization of the resources facilitating } \\
\text { the control activities. }\end{array}$ & $\begin{array}{|lrrr|}\text { Das } & \text { Management } & \text { strebt } & \text { die } \\
\text { effiziente(re) } & \text { Verwendung } & \text { der } \\
\text { Ressourcen in den Kontrollabläufen } & \text { an. }\end{array}$ \\
\hline $\begin{array}{lrr}\text { A } & \text { kontrollmechanizmusok } & \text { belső } \\
\text { egyeztetések, szakmai fejlesztési ötletek } \\
\text { révén, diskurzus útján fejlődnek }\end{array}$ & $\begin{array}{l}\text { The control mechanisms at our Company are } \\
\text { improved and developed by means of internal } \\
\text { negotiations, professional ideas, discussions, }\end{array}$ & $\begin{array}{lrrr}\text { Die internen } & \text { Kontrollmechanismen } \\
\text { werden durch interne Absprachen, } \\
\text { fachlichen } & \text { Ideenwettbewerb und }\end{array}$ \\
\hline
\end{tabular}




\begin{tabular}{|c|c|c|}
\hline Társaságunknál. & and brainstorming. & Diskurs weiterentwickelt. \\
\hline $\begin{array}{l}\text { A belső kontrollrendszer a legfontosabb } \\
\text { érintetteket, föntéshozókat, } \\
\text { intézkedésért felelősöket, egyéb } \\
\text { haszonélvezőket } \\
\text { folyamatosan/rendszeresen } \\
\text { jelzésekkel, információkkal, adatokkal, } \\
\text { tájékoztatásokkal a a szervezet } \\
\text { müködéséről. }\end{array}$ & $\begin{array}{l}\text { The internal control system continuously } \\
\text { provides the most important relevant persons, } \\
\text { decision makers, those responsible for } \\
\text { initiating action and taking measures, and } \\
\text { other beneficiaries with signals, feedback, } \\
\text { information, evaluation and data about the } \\
\text { operation of the organisation. }\end{array}$ & 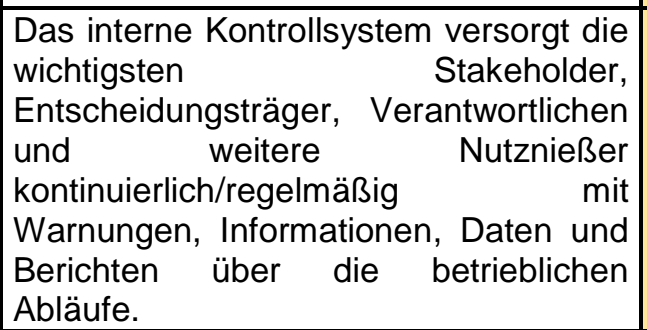 \\
\hline $\begin{array}{lrr}\text { Az } & \text { ellenőrzések ráltalános } \\
\text { megállapításait, a kontrolltevékenységek } \\
\text { legfontosabb } \quad \text { eredményeit r és } \\
\text { megállapításait kommunikáljuk a } \quad \text { a } \\
\text { munkavállalók és vezetés számára is. }\end{array}$ & $\begin{array}{l}\text { We communicate the general findings of the } \\
\text { checking activities, and the most important } \\
\text { results and findings of the control activities } \\
\text { both to the employees as well as the } \\
\text { management. }\end{array}$ & \begin{tabular}{|ll} 
Die allgemeinen & Aussagen, sowie die \\
wichtigsten & Ergebnisse r und \\
Folgerungen aus den Kontrollaktivitäten \\
werden an die Mitarbeiter und \\
Führungskräfte kommuniziert.
\end{tabular} \\
\hline 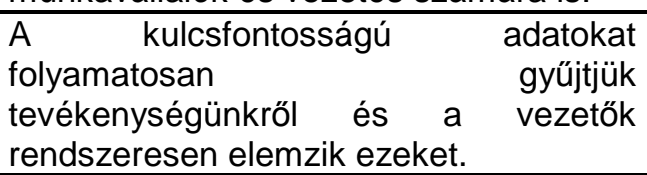 & $\begin{array}{l}\text { We are continuously collecting key data about } \\
\text { our activity, which are regularly analyzed by } \\
\text { the management. }\end{array}$ & $\begin{array}{l}\text { Die Schlüsseldaten r der } \\
\text { Geschäftstätigkeiten werden laufend } \\
\text { gesammelt und vom Management } \\
\text { regelmäßig ausgewertet. }\end{array}$ \\
\hline 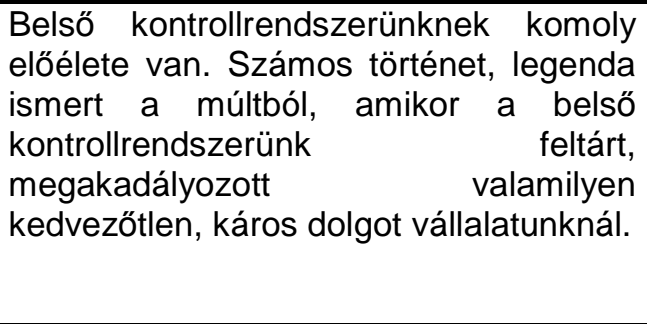 & $\begin{array}{l}\text { Our internal control system is seriously aware } \\
\text { of its history. Numerous stories are known } \\
\text { from the past when our internal control system } \\
\text { revealed, exposed, or prevented some } \\
\text { unfavorable, harmful or detrimental aspect at } \\
\text { our Company. }\end{array}$ & $\begin{array}{l}\text { Das interne Kontrollsystem kann auf } \\
\text { eine gewichtige Vorgeschichte } \\
\text { zurückblicken. Aus der Vergangenheit } \\
\text { sind viele Geschehnisse und Legenden } \\
\text { bekannt, wenn unvorteilhafte oder } \\
\text { sogar schädliche Entwicklungen vom } \\
\text { Kontrollsystem aufgedeckt und so } \\
\text { verhindert wurden. }\end{array}$ \\
\hline $\begin{array}{l}\text { A vezetés képes felismerni valamennyi } \\
\text { olyan, cégünkre ható üzleti kockázatot, } \\
\text { amely károsan befolyásolja jövőbeni } \\
\text { müködésünket, } \\
\text { kilátásainkat. }\end{array}$ & $\begin{array}{l}\text { The management is able to recognize all of } \\
\text { the business risks affecting our Company that } \\
\text { detrimentally or negatively influence our future } \\
\text { operation, results, or prospects. }\end{array}$ & $\begin{array}{l}\text { Das Management ist in der Lage, alle } \\
\text { Geschäftsrisiken zu erkennen, die die } \\
\text { zukünftigen Abläufe, Ergebnisse, } \\
\text { Aussichten beeinträchtigen können. }\end{array}$ \\
\hline
\end{tabular}


V. Egyéb észrevételek / Other comments / Sonstige Bemerkungen

Kérem, írja ide bármilyen egyéb szöveges észrevételét a kérdőív témájával, tartalmával kapcsolatosan!

Please give me any other comments in text on topic or content of this survey!

Bitte geben Sie Ihre Bemerkungen zum Thema dieses Fragebogens an!

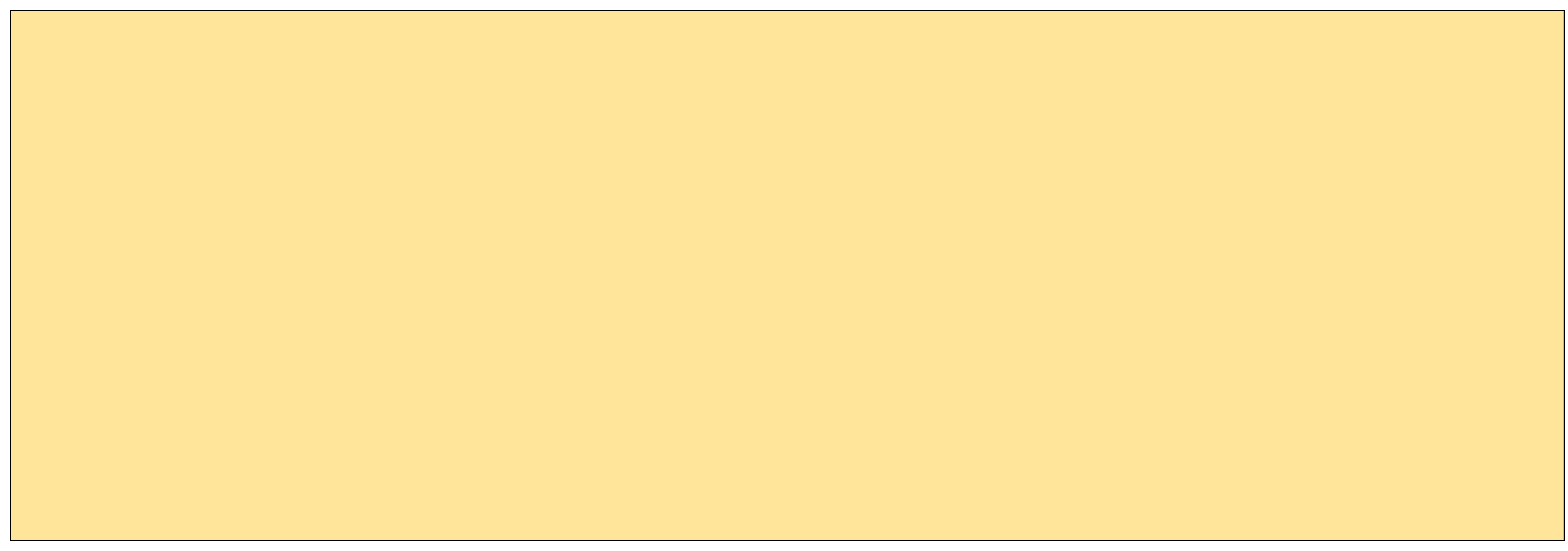




\section{F52 Adatgyűjtő alkalmazás adatbázisstruktúrája}

A kérdőíves adatgyűjtést ellátó alkalmazás MSSQL adatbázisának táblastruktúrája és a mezők közötti kapcsolat az alábbi ábrákon látható.
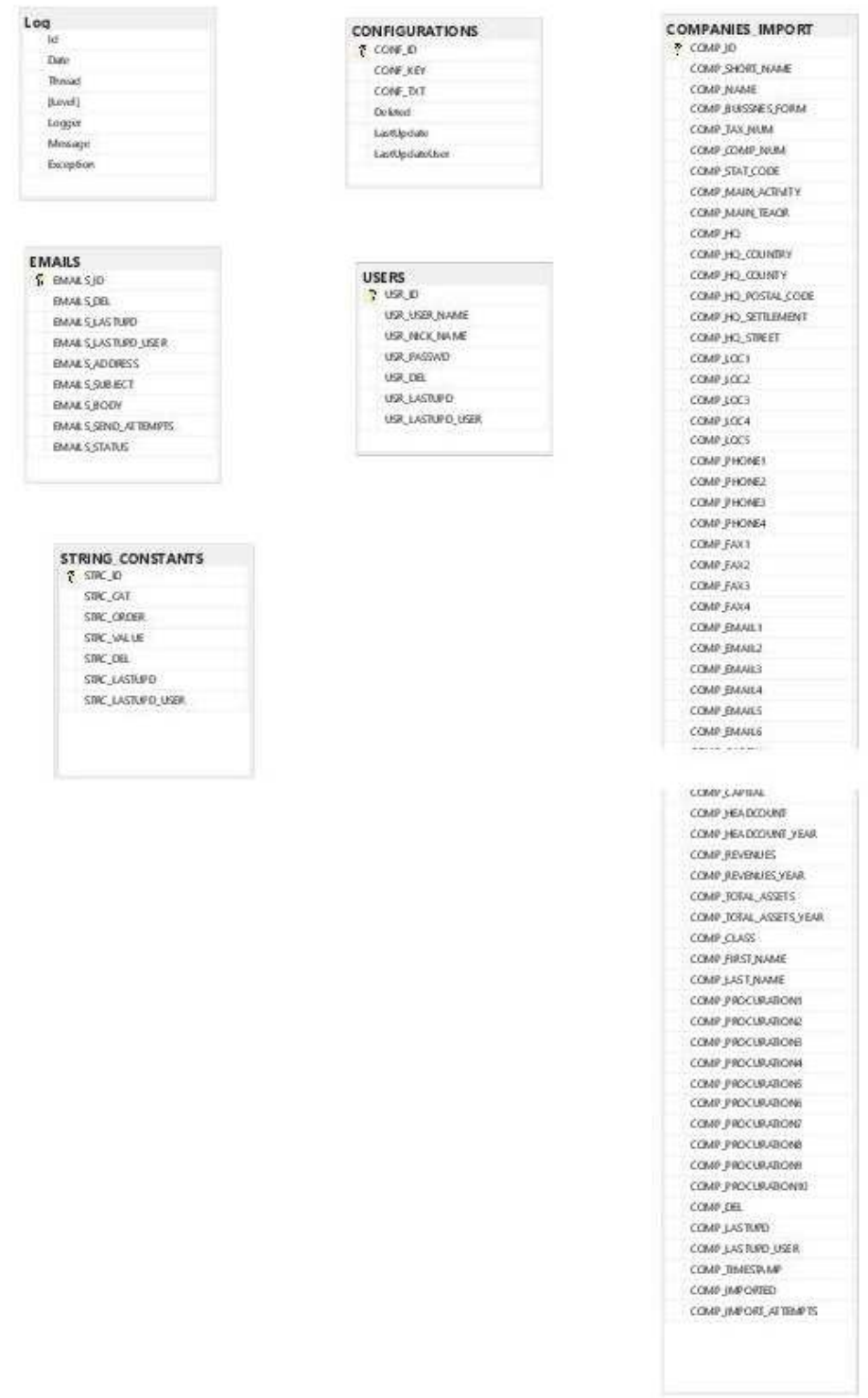

23. ábra: Alkalmazás MSSQL adatbázis - alaptáblák Forrás: saját szerkesztés 


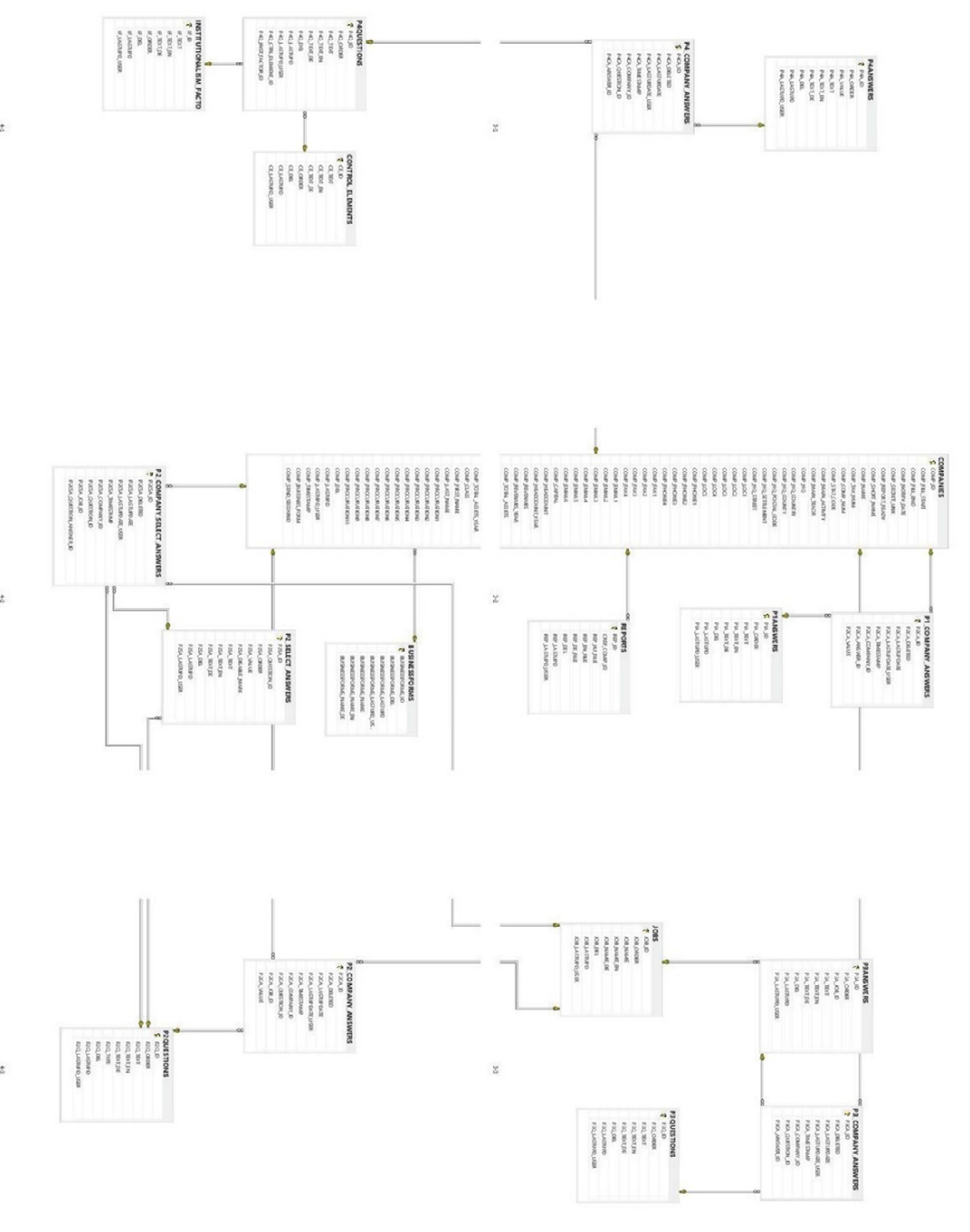

24. ábra: Alkalmazás MSSQL adatbázis - adatgyűjtő táblák Forrás: saját szerkesztés 


\section{FÜGGELÉK - MATEMATIKAI-STASZTIKAI FÜGGELÉK}

F61 A minta illeszkedése a populációhoz, $\chi^{2}$ próbák eredményei

\section{Regisztrált gazdasági szervezetek gazdálkodási forma szerinti megoszlása}

\begin{tabular}{|l|r|r|r|r|}
\hline (Mindösszesen TEÁOR08; Mindösszesen Terület) \\
\hline Gazdálkodási formák & Populáció $(\mathrm{db})$ & $\begin{array}{c}\text { \%-0s } \\
\text { megoszlás }\end{array}$ & Minta (db) & $\begin{array}{c}\text { \%-os } \\
\text { megoszlás }\end{array}$ \\
\hline Korlátolt felelösségü társaság & 28653 & $85,70 \%$ & 103 & $78,03 \%$ \\
\hline Részvénytársaság & 2211 & $6,61 \%$ & 23 & $17,42 \%$ \\
\hline Közkereseti társaság & 78 & $0,23 \%$ & 0 & $0,00 \%$ \\
\hline Betéti társaság & 1790 & $5,35 \%$ & 4 & $3,03 \%$ \\
\hline Szövetkezet & 702 & $2,10 \%$ & 2 & $1,52 \%$ \\
\hline Összesen & $\mathbf{3 3 4 3 4}$ & $\mathbf{1 0 0 , 0 0 \%}$ & $\mathbf{1 3 2}$ & $\mathbf{1 0 0 , 0 0 \%}$ \\
\hline
\end{tabular}

\begin{tabular}{|r|r|r|r|}
\hline $\begin{array}{c}\text { elméleti } \\
\text { minta }\end{array}$ & \multicolumn{1}{|c|}{$k-v$} & $\begin{array}{c}k \\
\text { négyzet }\end{array}$ & \multicolumn{1}{c|}{ osztás } \\
\hline 113,1242 & -10 & 103 & 0,995149 \\
\hline 8,729198 & 14 & 204 & 8,8546 \\
\hline 0,30795 & 0 & 0 & 0 \\
\hline 7,067057 & -3 & 9 & 2,35171 \\
\hline 2,77155 & -1 & 1 & 0,297645 \\
\hline 132 & & & $\mathbf{1 2 , 4 9 9 1}$ \\
\hline
\end{tabular}

Források: populáció: KSH adatbázis, minta: saját, a táblázat saját szerkesztés 


\section{Regisztrált gazdasági szervezetek létszámkategória szerinti megoszlása}

(Mindösszesen TEÁOR08; Mindösszesen

Terület)

\begin{tabular}{|l|r|r|r|r|}
\hline \multicolumn{1}{|c|}{ Létszámkategória } & Populáció $(\mathrm{db})$ & $\begin{array}{c}\text { \%-os } \\
\text { megoszlás }\end{array}$ & $\begin{array}{c}\text { Minta } \\
(\mathrm{db})\end{array}$ & \multicolumn{1}{c|}{$\begin{array}{c}\text { \%-os } \\
\text { megoszlás }\end{array}$} \\
\hline $\mathbf{1 0 - 1 9}$ fő & 18511 & $55,37 \%$ & 42 & $31,82 \%$ \\
\hline $\mathbf{2 0 - 4 9}$ fő & 9722 & $29,08 \%$ & 48 & $36,36 \%$ \\
\hline $\mathbf{5 0 - 2 4 9}$ fő & 4334 & $12,96 \%$ & 25 & $18,94 \%$ \\
\hline 250 fö felett & 867 & $2,59 \%$ & 17 & $12,88 \%$ \\
\hline Összesen & $\mathbf{3 3 4 3 4}$ & $\mathbf{1 0 0 , 0 0 \%}$ & $\mathbf{1 3 2}$ & $\mathbf{1 0 0 , 0 0 \%}$ \\
\hline
\end{tabular}

\begin{tabular}{|r|r|r|c|}
\hline $\begin{array}{c}\text { Elméleti } \\
\text { minta }\end{array}$ & $\mathrm{k}-\mathrm{v}$ & $\begin{array}{c}\mathrm{k} \\
\text { négyzet }\end{array}$ & \multicolumn{1}{c|}{ osztás } \\
\hline 73,08285 & -31 & 966 & 23,00342 \\
\hline 38,3832 & 10 & 92 & 1,926725 \\
\hline 17,11096 & 8 & 62 & 2,489475 \\
\hline 3,422983 & 14 & 184 & 10,84326 \\
\hline 132 & & & $\mathbf{3 8 , 2 6 2 8 8}$ \\
\hline
\end{tabular}

18. táblázat: Populáció és minta létszámkategória szerinti hasonlítása

Források: populáció: KSH adatbázis, minta: saját, a táblázat saját szerkesztés

\section{Regisztrált gazdasági szervezetek TEÁOR 08 szerinti megoszlása}

\begin{tabular}{|c|c|c|c|c|}
\hline TEÁOR08 & Populáció (db) & $\begin{array}{c}\% \text {-os } \\
\text { megoszlás }\end{array}$ & Minta (db) & $\begin{array}{c}\% \text {-os } \\
\text { megoszlás }\end{array}$ \\
\hline $\begin{array}{l}\text { A= MEZŐGAZDASÁG, } \\
\text { ERDŐGAZDÁLKODÁS, } \\
\text { HALÁSZAT }\end{array}$ & 1660 & $4,97 \%$ & 13 & $9,85 \%$ \\
\hline B= BÁNYÁSZAT, KÖFEJTÉS & 86 & $0,26 \%$ & 1 & $0,76 \%$ \\
\hline C= FELDOLGOZÓIPAR & 7577 & $22,66 \%$ & 30 & $22,73 \%$ \\
\hline
\end{tabular}

\begin{tabular}{|c|r|r|c|}
\hline $\begin{array}{c}\text { Elméleti } \\
\text { minta }\end{array}$ & $\mathrm{k}-\mathrm{v}$ & $\begin{array}{c}\mathrm{k} \\
\text { négyzet }\end{array}$ & \multicolumn{1}{c|}{ osztás } \\
\hline & & & \\
\hline 6,553808 & 6 & 42 & 3,19641521 \\
\hline 0,339535 & 1 & 0 & 0,436214537 \\
\hline 29,91458 & 0 & 0 & 0,000243231 \\
\hline
\end{tabular}




\begin{tabular}{|c|c|c|c|c|c|c|c|c|}
\hline $\begin{array}{l}\text { D= VILLAMOSENERGIA-, } \\
\text { GÁZ-, GŐZELLÁTÁS, } \\
\text { LÉGKONDICIONÁLÁS }\end{array}$ & 127 & $0,38 \%$ & 0 & $0,00 \%$ & 0,501406 & -1 & 0 & 0 \\
\hline E= VÍZELLÁTÁS & 329 & $0,98 \%$ & 4 & $3,03 \%$ & 1,298917 & 3 & 7 & 1,823961979 \\
\hline F= ÉPÍTŐIPAR & 3681 & $11,01 \%$ & 11 & $8,33 \%$ & 14,53287 & -4 & 12 & 1,134652327 \\
\hline $\begin{array}{l}\text { G= KERESKEDELEM, } \\
\text { GÉPJÁRMŰJAVÍTÁS }\end{array}$ & 7760 & $23,21 \%$ & 28 & $21,21 \%$ & 30,63708 & -3 & 7 & 0,248363214 \\
\hline $\begin{array}{l}\text { H= SZÁLLÍTÁS, } \\
\text { RAKTÁROZÁS }\end{array}$ & 1932 & $5,78 \%$ & 10 & $7,58 \%$ & 7,627684 & 2 & 6 & 0,562788134 \\
\hline $\begin{array}{l}\text { I= SZÁLLÁSHELY- } \\
\text { SZOLGÁLTATÁS, } \\
\text { VENDÉGLÁTÁS }\end{array}$ & 2199 & $6,58 \%$ & 4 & $3,03 \%$ & 8,681821 & -5 & 22 & 5,479861737 \\
\hline $\begin{array}{l}\text { J= INFORMÁCIÓ, } \\
\text { KOMMUNIKÁCIÓ }\end{array}$ & 1184 & $3,54 \%$ & 7 & $5,30 \%$ & 4,674523 & 2 & 5 & 0,772549079 \\
\hline $\begin{array}{l}\text { K= PÉNZÜGYI, BIZTOSÍTÁSI } \\
\text { tEVÉKENYSÉG }\end{array}$ & 422 & $1,26 \%$ & 1 & $0,76 \%$ & 1,666088 & -1 & 0 & 0,443673774 \\
\hline $\mathrm{L}=$ INGATLANÜGYLETEK & 824 & $2,46 \%$ & 2 & $1,52 \%$ & 3,253215 & -1 & 2 & 0,785274281 \\
\hline $\begin{array}{l}\text { M= SZAKMAI, } \\
\text { TUDOMÁNYOS, MŰSZAKI } \\
\text { TEVÉKENYSÉG }\end{array}$ & 1991 & $5,96 \%$ & 8 & $6,06 \%$ & 7,860621 & 0 & 0 & 0,002428316 \\
\hline $\begin{array}{l}\text { N= ADMINISZTRATÍV ÉS } \\
\text { SZOLGÁLTATÁST } \\
\text { TÁMOGATÓ TEVÉKENYSÉG }\end{array}$ & 2428 & $7,26 \%$ & 6 & $4,55 \%$ & 9,58593 & -4 & 13 & 2,14314958 \\
\hline
\end{tabular}




\begin{tabular}{|c|c|c|c|c|}
\hline $\begin{array}{l}\text { O= KÖZIGAZGATÁS, } \\
\text { VÉDELEM }\end{array}$ & 5 & $0,01 \%$ & 0 & $0,00 \%$ \\
\hline $\mathrm{P}=$ OKTATÁS & 155 & $0,46 \%$ & 0 & $0,00 \%$ \\
\hline $\begin{array}{l}\text { Q= HUMÁN-EGÉSZSÉGÜGYI, } \\
\text { SZOCIÁLIS ELLÁTÁS }\end{array}$ & 401 & $1,20 \%$ & 0 & $0,00 \%$ \\
\hline $\begin{array}{l}\text { R= MÜVÉSZET, } \\
\text { SZÓRAKOZTATÁS, SZABAD } \\
\text { IDŐ }\end{array}$ & 281 & $0,84 \%$ & 0 & $0,00 \%$ \\
\hline S= EGYÉB SZOLGÁLTATÁS & 392 & $1,17 \%$ & 7 & $5,30 \%$ \\
\hline $\begin{array}{l}\text { T= HÁZTARTÁS MUNKAADÓI } \\
\text { TEVÉKENYSÉGE }\end{array}$ & 0 & $0,00 \%$ & 0 & $0,00 \%$ \\
\hline $\begin{array}{l}\text { U= TERÜLETEN KÍVÜLI } \\
\text { SZERVEZET }\end{array}$ & 0 & $0,00 \%$ & 0 & $0,00 \%$ \\
\hline Összesen & 33434 & $100,00 \%$ & 132 & $100,00 \%$ \\
\hline
\end{tabular}

\begin{tabular}{|c|c|c|c|}
\hline 0,01974 & 0 & 0 & 0 \\
\hline 0,611952 & -1 & 0 & 0 \\
\hline 1,583179 & -2 & 3 & 0 \\
\hline 1,10941 & -1 & 1 & 0 \\
\hline 1,547646 & 5 & 30 & 4,246880422 \\
\hline 0 & 0 & 0 & 0 \\
\hline 0 & 0 & 0 & 0 \\
\hline 132 & & & 21,27645582 \\
\hline
\end{tabular}

19. táblázat: Populáció és minta tevékenység szerinti hasonlítása

Források: populáció: KSH adatbázis, minta: saját, a táblázat saját szerkesztés 


\section{Regisztrált gazdasági szervezetek területi (megye) megoszlása}

(Mindösszesen TEÁOR08)

\begin{tabular}{|c|c|c|c|c|c|c|c|c|}
\hline Terület (megye) & $\begin{array}{c}\text { Populáció } \\
\text { (db) }\end{array}$ & $\begin{array}{c}\% \text {-os } \\
\text { megoszlás }\end{array}$ & $\begin{array}{c}\text { Minta } \\
(\mathrm{db})\end{array}$ & $\begin{array}{c}\text { \%-os } \\
\text { megoszlás }\end{array}$ & $\begin{array}{l}\text { Elméleti } \\
\text { minta }\end{array}$ & $k-v \mid k$ & k négyzet & osztás \\
\hline Budapest & 11752 & $35,15 \%$ & 31 & $23,85 \%$ & 46,3978 & $\mid-15$ & 237 & 7,648136 \\
\hline Baranya megye & 974 & $2,91 \%$ & 8 & $6,15 \%$ & 3,845427 & 4 & 17 & 2,15756 \\
\hline Bács-Kiskun megye & 1668 & $4,99 \%$ & 11 & $8,46 \%$ & 6,585392 & 4 & 19 & 1,771706 \\
\hline Békés megye & 805 & $2,41 \%$ & 4 & $3,08 \%$ & 3,178202 & 1 & & 0,168838 \\
\hline Borsod-Abaúj-Zemplén megye & 1251 & $3,74 \%$ & 4 & $3,08 \%$ & 4,939044 & -1 & & 0,220451 \\
\hline Csongrád megye & 1124 & $3,36 \%$ & 9 & $6,92 \%$ & 4,437638 & 5 & & 2,312794 \\
\hline Fejér megye & 1115 & $3,33 \%$ & 3 & $2,31 \%$ & 4,402106 & -1 & 2 & 0,6553 \\
\hline Györ-Moson-Sopron megye & 1513 & $4,53 \%$ & 6 & $4,62 \%$ & 5,97344 & 0 & & 0,000118 \\
\hline Hajdú-Bihar megye & 1395 & $4,17 \%$ & 7 & $5,38 \%$ & 5,507567 & 1 & & 0,318194 \\
\hline Heves megye & 715 & $2,14 \%$ & 3 & $2,31 \%$ & 2,822875 & 0 & & 0,010458 \\
\hline Jász-Nagykun-Szolnok megye & 882 & $2,64 \%$ & 2 & $1,54 \%$ & 3,482204 & -1 & 2 & 1,098464 \\
\hline Komárom-Esztergom megye & 975 & $2,92 \%$ & 0 & $0,00 \%$ & 3,849375 & -4 & 15 & 0 \\
\hline Nógrád megye & 262 & $0,78 \%$ & 0 & $0,00 \%$ & 1,034396 & -1 & 1 & 0 \\
\hline Pest megye & 4201 & $12,57 \%$ & 17 & $13,08 \%$ & 16,58587 & 0 & & 0,010088 \\
\hline Somogy megye & 693 & $2,07 \%$ & 4 & $3,08 \%$ & 2,736017 & 1 & & 0,399413 \\
\hline
\end{tabular}




\begin{tabular}{|c|c|c|c|c|c|c|c|c|}
\hline Szabolcs-Szatmár-Bereg megye & 1106 & $3,31 \%$ & 7 & $5,38 \%$ & 4,366573 & 3 & & $0,990705 \mid$ \\
\hline Tolna megye & 575 & $1,72 \%$ & 3 & $2,31 \%$ & 2,270144 & 1 & & 0,177563 \\
\hline Vas megye & 746 & $2,23 \%$ & 1 & $0,77 \%$ & 2,945265 & -2 & & 3,784057 \\
\hline Veszprém megye & 912 & $2,73 \%$ & 5 & $3,85 \%$ & 3,600646 & 1 & & 0,391638 \\
\hline Zala megye & 770 & $2,30 \%$ & 5 & $3,85 \%$ & 3,040019 & 2 & & 0,768305 \\
\hline Az ország területre nem bontható adatai & 0 & $0,00 \%$ & 0 & $0,00 \%$ & 0 & 0 & 0 & 0 \\
\hline Országhatáron kívül & 0 & $0,00 \%$ & 0 & $0,00 \%$ & 0 & 0 & 0 & 0 \\
\hline Összesen & 33434 & $100,00 \%$ & 130 & $100,00 \%$ & 132 & & & 22,88379 \\
\hline
\end{tabular}

20. táblázat: Populáció és minta megye szerinti hasonlitása

Források: populáció: KSH adatbázis, minta: saját, a táblázat saját szerkesztés 


\section{F62 Hipotézistesztek eredményei}

\section{F 6.2.1 - H1 hipotézis}

A H1 hipotézisnél alkalamzott Sperman-féle rangkorrelációs együttható egyenlete:

$$
\mathbb{P}=1-\frac{6 \sum\left(R_{x}-R_{y}\right)^{2}}{N\left(N^{2}-1\right)}
$$

25. ábra: Sperman-féle rangkorrelációs együttható egyenlete Forrás: (Hunyadi \& Vita, 2006., p.165.)

Case Processing Summary

\begin{tabular}{|c|c|c|c|c|c|c|}
\hline & \multicolumn{6}{|c|}{ Cases } \\
\hline & \multicolumn{2}{|c|}{ Included } & \multicolumn{2}{|c|}{ Excluded } & \multicolumn{2}{|c|}{ Total } \\
\hline & $\mathrm{N}$ & Percent & $\mathrm{N}$ & Percent & $\mathrm{N}$ & Percent \\
\hline Tulajdonosi kör jellege, tulajdonos(ok) elvárásai, elöírásai & 125 & $94,7 \%$ & 7 & $5,3 \%$ & 132 & $100,0 \%$ \\
\hline Foglalkoztatottak száma, dolgozói létszám & 121 & $91,7 \%$ & 11 & $8,3 \%$ & 132 & $100,0 \%$ \\
\hline Vállalkozásra vonatkozó jogi előírások, jogszabályok, külső szabályozó tényezők & 130 & $98,5 \%$ & 2 & $1,5 \%$ & 132 & $100,0 \%$ \\
\hline Telephelyek, fióktelepek (darab)száma & 101 & $76,5 \%$ & 31 & $23,5 \%$ & 132 & $100,0 \%$ \\
\hline Főtevékenység jellege, technológiája, elvégzésének sajátosságai & 125 & $94,7 \%$ & 7 & $5,3 \%$ & 132 & $100,0 \%$ \\
\hline Első számú vezető karizmája, vezetési stílusa & 128 & $97,0 \%$ & 4 & $3,0 \%$ & 132 & $100,0 \%$ \\
\hline Alaptevékenységre vonatkozó üzleti-piaci normák, szabványok, szokások & 126 & $95,5 \%$ & 6 & $4,5 \%$ & 132 & $100,0 \%$ \\
\hline Vállalaton belüli kultúra, szokások, munkatársak viselkedése & 124 & $93,9 \%$ & 8 & $6,1 \%$ & 132 & $100,0 \%$ \\
\hline
\end{tabular}




\begin{tabular}{|c|c|c|c|c|c|c|}
\hline Menedzsment vezetési stílusa, döntései, határozottsága & 125 & $94,7 \%$ & 7 & $5,3 \%$ & 132 & $100,0 \%$ \\
\hline Egyéb, itt fel nem sorolt tényező(k) & 83 & $62,9 \%$ & 49 & $37,1 \%$ & 132 & $100,0 \%$ \\
\hline
\end{tabular}

21. táblázat: Befolyásoló tényezők gyakorisága a válaszadók körében

Forrás: SPSS output, saját formázással

\begin{tabular}{|c|c|c|c|c|c|c|c|c|c|c|}
\hline \multicolumn{11}{|c|}{ Report } \\
\hline & $\begin{array}{l}\text { Tulajdonosi } \\
\text { kör jellege, } \\
\text { tulajdonos(o } \\
\text { k) elvárásai, } \\
\text { előírásai } \\
\end{array}$ & $\begin{array}{c}\text { Foglalkoztatot } \\
\text { tak száma, } \\
\text { dolgozói } \\
\text { létszám } \\
\end{array}$ & $\begin{array}{c}\text { Vállalkozásra } \\
\text { vonatkozó jogi } \\
\text { előírások, } \\
\text { jogszabályok, } \\
\text { külső } \\
\text { szabályozó } \\
\text { tényezők }\end{array}$ & $\begin{array}{c}\text { Telephelyek, } \\
\text { fióktelepek } \\
\text { (darab)száma }\end{array}$ & $\begin{array}{c}\text { Főtevékenység } \\
\text { jellege, } \\
\text { technológiája, } \\
\text { elvégzésének } \\
\text { sajátosságai }\end{array}$ & $\begin{array}{c}\text { Első számú } \\
\text { vezető } \\
\text { karizmája, } \\
\text { vezetési } \\
\text { stílusa }\end{array}$ & $\begin{array}{c}\text { Alaptevékeny } \\
\text { ségre } \\
\text { vonatkozó } \\
\text { üzleti-piaci } \\
\text { normák, } \\
\text { szabványok, } \\
\text { szokások } \\
\end{array}$ & $\begin{array}{c}\text { Vállalaton } \\
\text { belüli kultúra, } \\
\text { szokások, } \\
\text { munkatársak } \\
\text { viselkedése }\end{array}$ & $\begin{array}{c}\text { Menedzsment } \\
\text { vezetési } \\
\text { stílusa, } \\
\text { döntései, } \\
\text { határozottsága } \\
\end{array}$ & $\begin{array}{l}\text { Egyéb, itt } \\
\text { fel nem } \\
\text { sorolt } \\
\text { tényező(k) }\end{array}$ \\
\hline Mean & 4,16 & 6,17 & 4,19 & 7,07 & 4,54 & 4,66 & 4,75 & 5,76 & 5,30 & 7,77 \\
\hline $\mathrm{N}$ & 125 & 121 & 130 & 101 & 125 & 128 & 126 & 124 & 125 & 83 \\
\hline Std. Deviation & 3,166 & 2,396 & 2,757 & 2,794 & 2,263 & 2,524 & 2,016 & 2,022 & 2,665 & 3,144 \\
\hline Variance & 10,023 & 5,739 & 7,598 & 7,805 & 5,121 & 6,369 & 4,063 & 4,087 & 7,100 & 9,886 \\
\hline Minimum & 1 & 1 & 1 & 1 & 1 & 1 & 1 & 1 & 1 & 1 \\
\hline Maximum & 10 & 10 & 10 & 10 & 10 & 10 & 10 & 10 & 10 & 10 \\
\hline
\end{tabular}

22. táblázat: Befolyásoló tényezök rangsorrendje, szórásjellemzói

Forrás: SPSS output, saját formázással 


\begin{tabular}{|c|c|c|c|c|c|c|c|c|c|c|c|c|}
\hline & & & $\begin{array}{c}\text { Tulajdonosi } \\
\text { kör jellege, } \\
\text { tulajdonos( } \\
\text { ok) }\end{array}$ & $\begin{array}{c}\text { Foglalkoz } \\
\text { tatottak } \\
\text { száma, } \\
\text { dolgozói }\end{array}$ & $\begin{array}{c}\text { Vállalkozásra } \\
\text { vonatkozó } \\
\text { jogi előírások, } \\
\text { jogszabályok, }\end{array}$ & $\begin{array}{c}\text { Telephelyek, } \\
\text { fióktelepek } \\
\text { (darab)száma }\end{array}$ & $\begin{array}{c}\text { Főtevékenys } \\
\text { ég jellege, } \\
\text { technológiája, } \\
\text { elvégzésének }\end{array}$ & $\begin{array}{c}\text { Első számú } \\
\text { vezető } \\
\text { karizmája, } \\
\text { vezetési }\end{array}$ & $\begin{array}{c}\text { Alaptevéke } \\
\text { nységre } \\
\text { vonatkozó } \\
\text { üzleti-piaci } \\
\end{array}$ & $\begin{array}{c}\text { Vállalaton } \\
\text { belüli kultúra, } \\
\text { szokások, } \\
\text { munkatársak }\end{array}$ & $\begin{array}{c}\text { Menedzsmen } \\
\text { t vezetési } \\
\text { stílusa, } \\
\text { döntései, }\end{array}$ & $\begin{array}{l}\text { Egyéb, } \\
\text { itt fel } \\
\text { nem } \\
\text { sorolt }\end{array}$ \\
\hline \multirow[t]{18}{*}{ Spearman's rho } & Tulajdonosi kör & Correlation & 1,000 &,$- 211^{*}$ & 151 &,$- 259^{* *}$ &, 094 &, 120 &,- 126 &,$- 222 *$ &, 025 &,$- 526^{*}$ \\
\hline & jellege, & Sig. (2-tailed) & & 023 &, 096 &, 010 & ,310 &, 190 &, 171 &, 016 &, 786 &, 000 \\
\hline & tulajdonos(ok) & $\mathrm{N}$ & 125 & 116 & 123 & 98 & 119 & 121 & 120 & 117 & 119 & 79 \\
\hline & Foglalkoztatottak & Correlation &,$- 211^{*}$ & 1,000 &,$- 256^{* *}$ & ,291* &,$- 193^{*}$ &,- 179 &,$- 211^{*}$ &,- 114 &,$- 326^{* *}$ & ,338** \\
\hline & száma, dolgozói & Sig. (2-tailed) & 023 & &, 005 &, 003 &, 036 &, 050 &, 021 & ,225 &, 000 & ,002 \\
\hline & létszám & $\mathrm{N}$ & 116 & 121 & 120 & 99 & 118 & 120 & 119 & 116 & 116 & 81 \\
\hline & Vállalkozásra & Correlation &, 151 &,$- 256^{* *}$ & 1,000 &,$- 197^{*}$ &, $231^{* *}$ &,$- 207^{*}$ & $207^{*}$ &,$- 359^{* *}$ &,- 153 &,- 168 \\
\hline & vonatkozó jogi & Sig. (2-tailed) & 096 &, 005 & &, 048 &, 010 &, 020 &, 021 & 000 & 091 & 130 \\
\hline & elöírások, & $\mathrm{N}$ & 123 & 120 & 130 & 101 & 124 & 126 & 124 & 122 & 123 & 83 \\
\hline & Telephelyek, & Correlation &,$- 259^{* *}$ & ,291** &,$- 197^{\star}$ & 1,000 &,$- 211^{*}$ &,$- 248^{*}$ &,$- 260^{* *}$ &, 010 &,$- 444^{* *}$ &, $327^{* *}$ \\
\hline & fióktelepek & Sig. (2-tailed) &, 010 & 003 &, 048 & &, 036 &, 013 &, 009 & ,921 &, 000 & ,004 \\
\hline & (darab)száma & $\mathrm{N}$ & 98 & 99 & 101 & 101 & 99 & 100 & 100 & 97 & 98 & 74 \\
\hline & Főtevékenység & Correlation & ,094 &,$- 193^{*}$ &, $231^{* *}$ &,$- 211^{*}$ & 1,000 &,$- 184^{*}$ & ,128 &,$- 221^{*}$ &,- 030 &,$- 383^{* *}$ \\
\hline & jellege, & Sig. (2-tailed) &, 310 & 036 & ,010 &, 036 & &, 042 & ,163 & 016 &, 746 & ,000 \\
\hline & technológiája, & $\mathrm{N}$ & 119 & 118 & 124 & 99 & 125 & 122 & 121 & 119 & 120 & 81 \\
\hline & Első számú & Correlation &, 120 &,- 179 &,$- 207^{\star}$ &,$- 248^{*}$ &,$- 184^{*}$ & 1,000 &,$- 184^{*}$ &,- 017 &, $339^{* *}$ &,$- 243^{*}$ \\
\hline & vezető karizmája, & Sig. (2-tailed) &, 190 & 050 &, 020 & ,013 &, 042 & &, 041 & ,856 &, 000 & 028 \\
\hline & vezetési stílusa & $\mathrm{N}$ & 121 & 120 & 126 & 100 & 122 & 128 & 124 & 122 & 123 & 82 \\
\hline
\end{tabular}




\begin{tabular}{|c|c|c|c|c|c|c|c|c|c|c|c|}
\hline $\begin{array}{l}\text { Alaptevékenységr } \\
\text { e vonatkozó } \\
\text { üzleti-piaci }\end{array}$ & $\begin{array}{l}\text { Correlation } \\
\text { Sig. (2-tailed) } \\
\mathrm{N}\end{array}$ & $\begin{array}{r}-, 126 \\
, 171 \\
120 \\
\end{array}$ & $\begin{array}{r}-, 211^{\circ} \\
, 021 \\
119 \\
\end{array}$ & $\begin{array}{r}, 207^{\circ} \\
, 021 \\
124 \\
\end{array}$ & $\begin{array}{r}-, 260 " \\
, 009 \\
100 \\
\end{array}$ & $\begin{array}{r}, 128 \\
, 163 \\
121 \\
\end{array}$ & $\begin{array}{r}-, 184^{*} \\
, 041 \\
124 \\
\end{array}$ & $\begin{array}{r}1,000 \\
126 \\
\end{array}$ & $\begin{array}{r}, 016 \\
, 863 \\
122 \\
\end{array}$ & $\begin{array}{r}-, 047 \\
, 609 \\
122 \\
\end{array}$ & $\begin{array}{r}-, 110 \\
, 326 \\
82 \\
\end{array}$ \\
\hline $\begin{array}{l}\text { Vállalaton belüli } \\
\text { kultúra, szokások, } \\
\text { munkatársak }\end{array}$ & $\begin{array}{l}\text { Correlation } \\
\text { Sig. (2-tailed) } \\
\mathrm{N}\end{array}$ & $\begin{array}{r}-, 222^{*} \\
, 016 \\
117 \\
\end{array}$ & $\begin{array}{r}-, 114 \\
, 225 \\
116 \\
\end{array}$ & \begin{tabular}{r|}
,$- 359^{*}$ \\
, 000 \\
122 \\
\end{tabular} & $\begin{array}{r}, 010 \\
, 921 \\
97 \\
\end{array}$ & $\begin{array}{r}-, 221^{*} \\
, 016 \\
119 \\
\end{array}$ & $\begin{array}{r}-, 017 \\
, 856 \\
122 \\
\end{array}$ & $\begin{array}{r}, 016 \\
, 863 \\
122 \\
\end{array}$ & $\begin{array}{r}1,000 \\
. \\
124 \\
\end{array}$ & $\begin{array}{r}, 198^{*} \\
, 030 \\
121 \\
\end{array}$ & $\begin{array}{r}, 236 * \\
, 033 \\
82 \\
\end{array}$ \\
\hline $\begin{array}{l}\text { Menedzsment } \\
\text { vezetési stílusa, } \\
\text { döntései, }\end{array}$ & $\begin{array}{l}\text { Correlation } \\
\text { Sig. (2-tailed) } \\
\mathrm{N}\end{array}$ & $\begin{array}{r}.025 \\
, 786 \\
119 \\
\end{array}$ & $\begin{array}{r}-, 326 " \\
, 000 \\
116 \\
\end{array}$ & $\begin{array}{r}-, 153 \\
, 091 \\
123 \\
\end{array}$ & $\begin{array}{r}-, 444^{-1} \\
, 000 \\
98 \\
\end{array}$ & $\begin{array}{r}-, 030 \\
, 746 \\
120 \\
\end{array}$ & $\begin{array}{r}, 339^{\prime \prime} \\
, 000 \\
123 \\
\end{array}$ & $\begin{array}{r}-, 047 \\
, 609 \\
122 \\
\end{array}$ & $\begin{array}{r}, 198^{*} \\
, 030 \\
121 \\
\end{array}$ & $\begin{array}{r}1,000 \\
. \\
125 \\
\end{array}$ & $\begin{array}{r}-, 291 * \\
, 008 \\
82 \\
\end{array}$ \\
\hline $\begin{array}{l}\text { Egyéb, itt fel nem } \\
\text { sorolt tényezö(k) }\end{array}$ & $\begin{array}{l}\text { Correlation } \\
\text { Sig. (2-tailed) } \\
\mathrm{N}\end{array}$ & $\begin{array}{r}-, 526 \\
, 000 \\
79\end{array}$ & $\begin{array}{r}, 338 \\
, 002 \\
81\end{array}$ & $\begin{array}{r}-, 168 \\
, 130 \\
83\end{array}$ & $\begin{array}{r}, 327^{*} \\
, 004 \\
74\end{array}$ & $\begin{array}{r}-, 383^{*} \\
, 000 \\
81\end{array}$ & $\begin{array}{r}-, 243^{*} \\
, 028 \\
82\end{array}$ & $\begin{array}{r}-, 110 \\
, 326 \\
82\end{array}$ & $\begin{array}{r}, 236^{*} \\
, 033 \\
82\end{array}$ & $\begin{array}{r}-, 291^{*} \\
, 008 \\
82\end{array}$ & 1,000 \\
\hline
\end{tabular}

*. Correlation is significant at the 0.05 level (2-tailed).

**. Correlation is significant at the 0.01 level (2-tailed). 


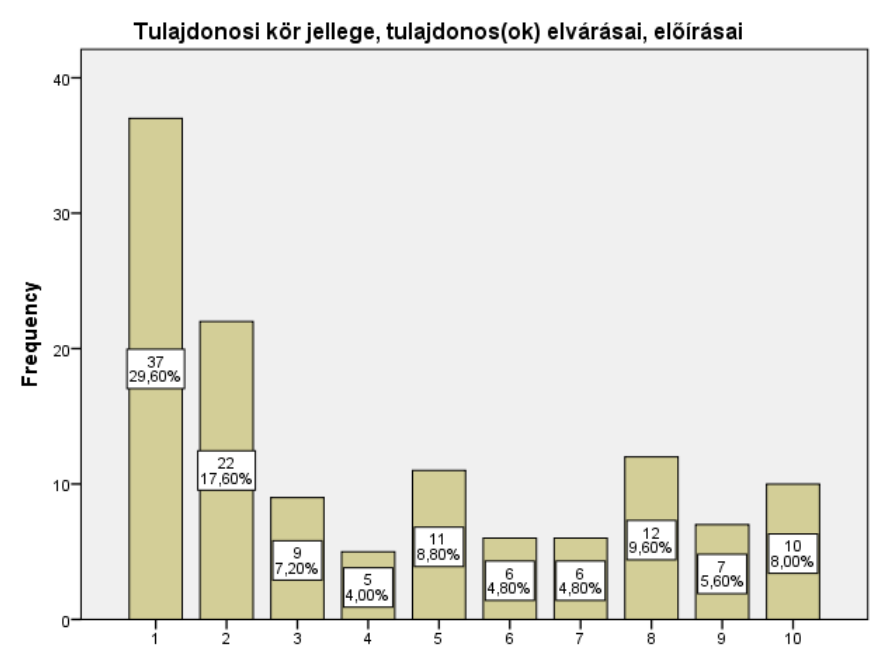

Tulajdonosi kör jellege, tulajdonos(ok) elvárásai, elôirásai

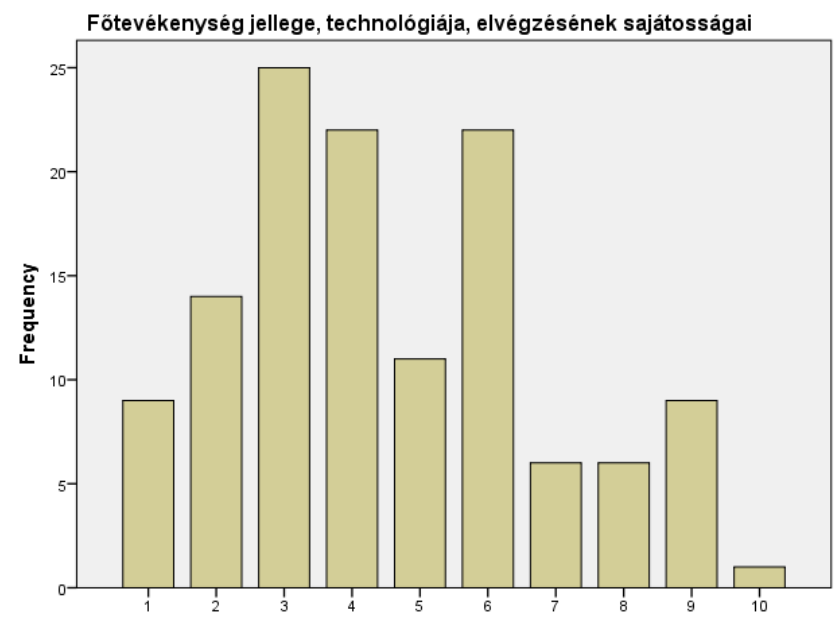

Fötevékenység jellege, technológiája, elvégzésének sajajtosságai

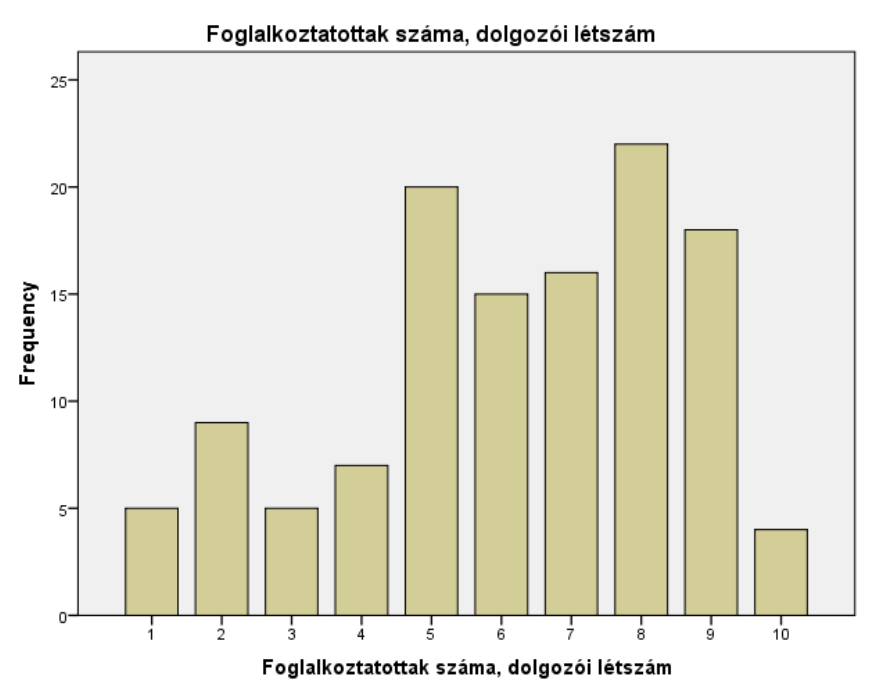

Vállalkozásra vonatkozó jogi elöírások, jogszabályok, külső szabályozó

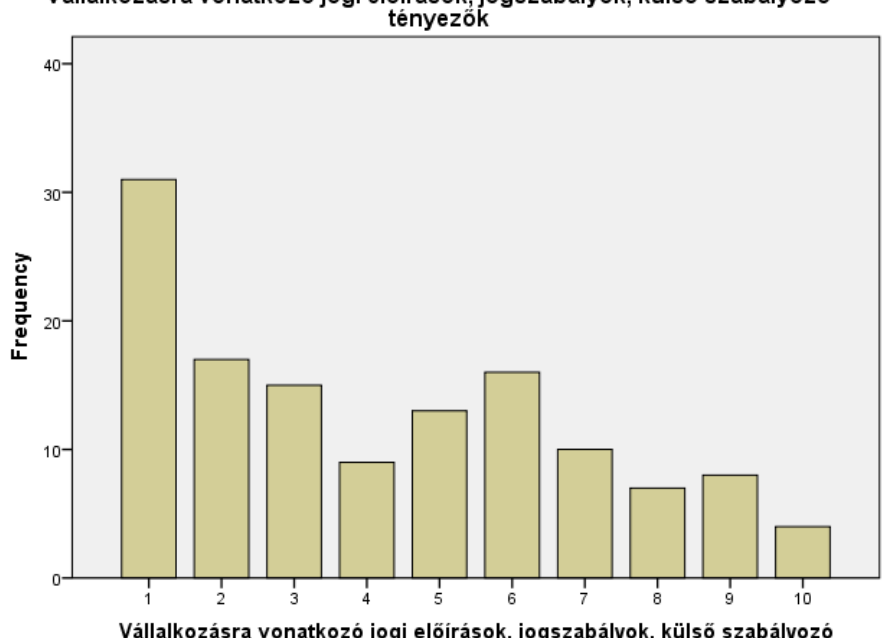

lốrások, jogszabályok, külsö szabályozó 


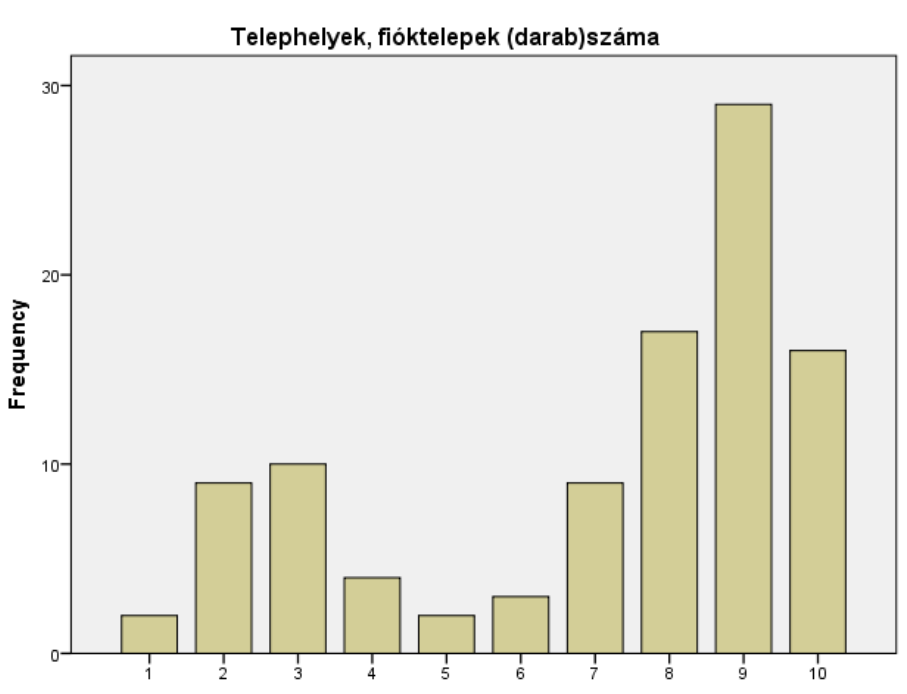

Telephelyek, fióktelepek (darab)száma

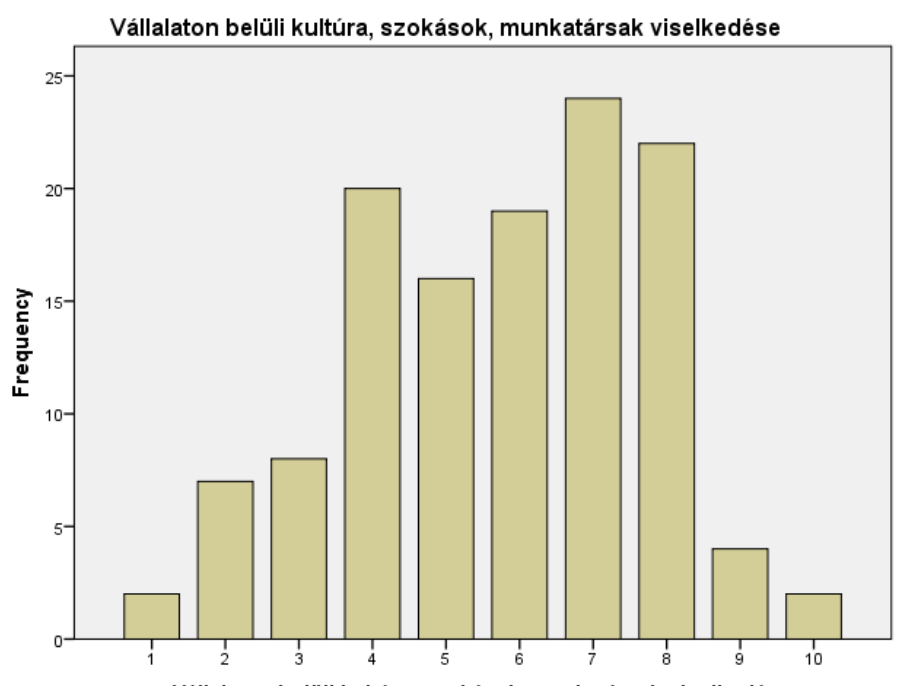

Vállalaton belüli kultúra, szokások, munkatársak viselkedése
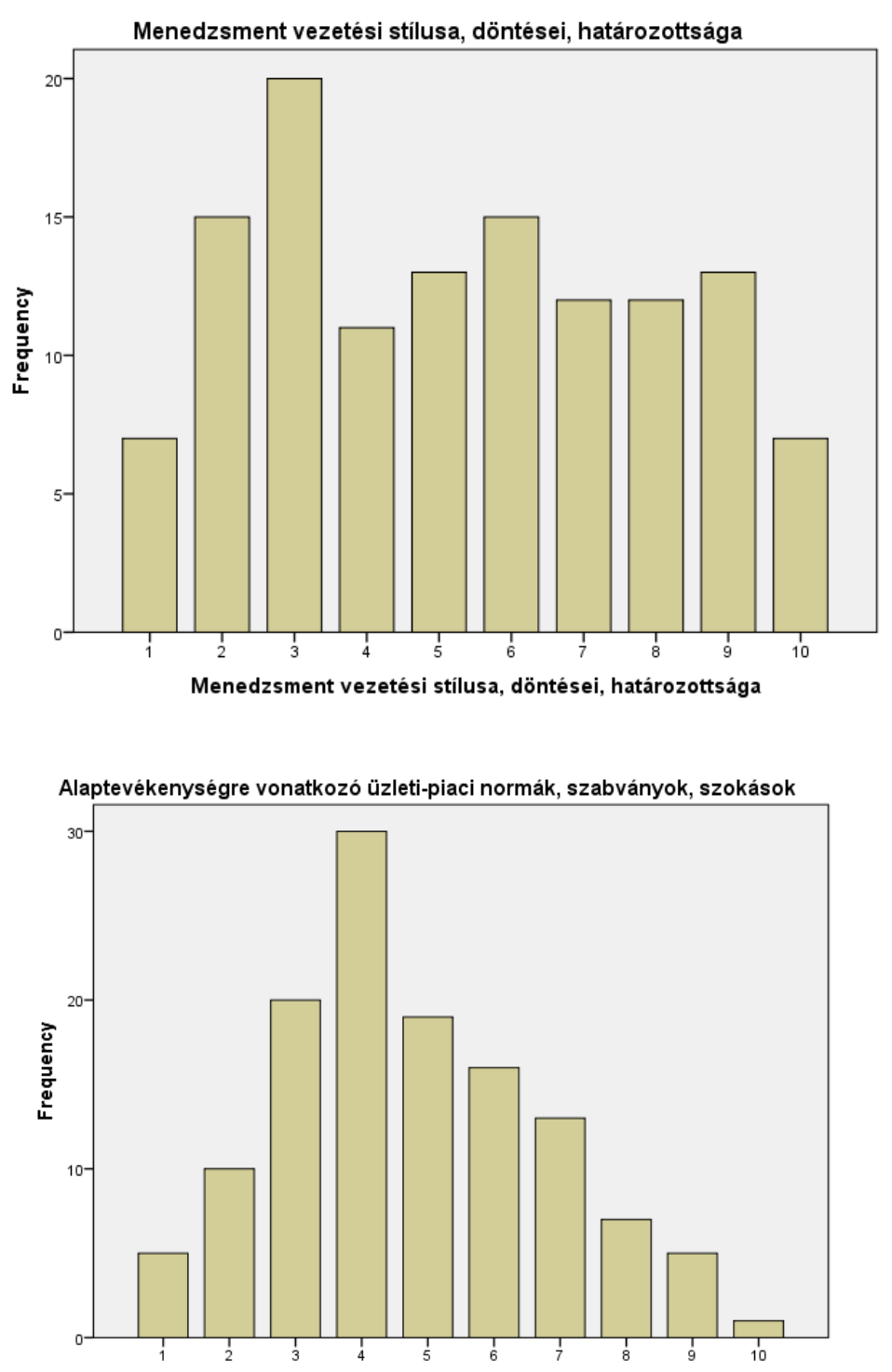

Alaptevékenységre vonatkozó üzleti-piaci normák, szabványok, szokások 


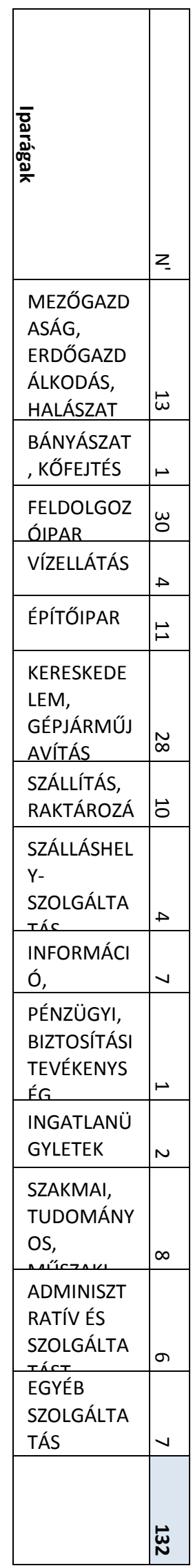

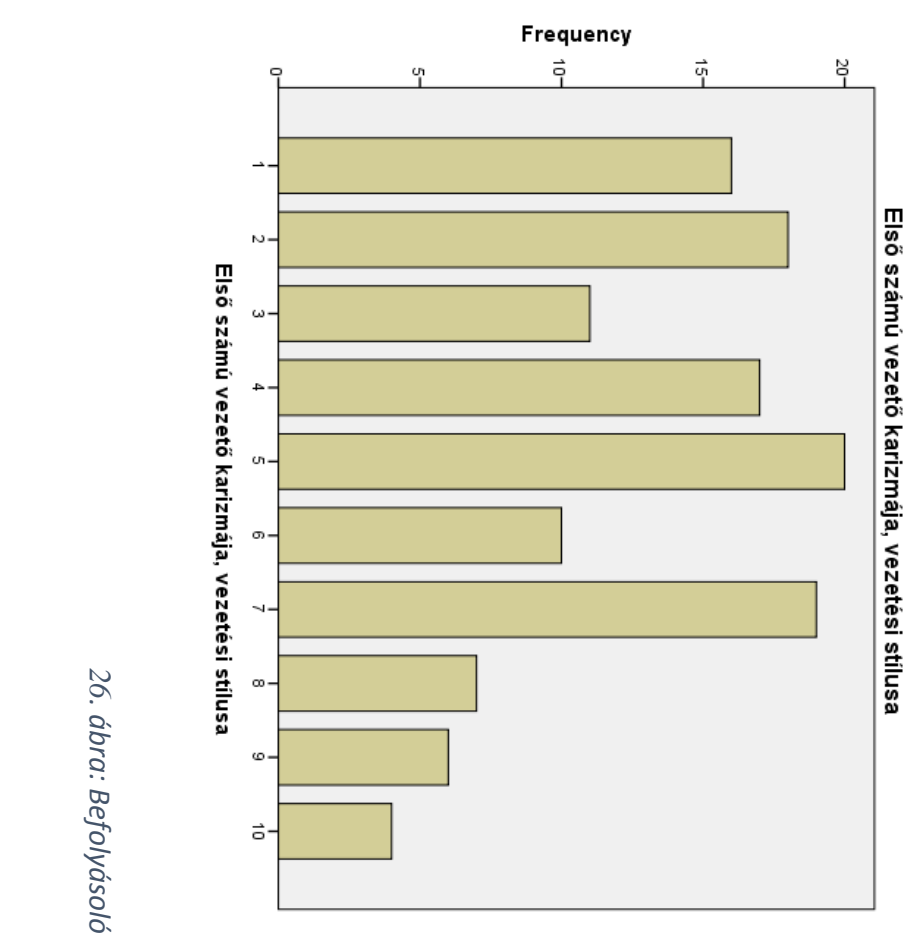

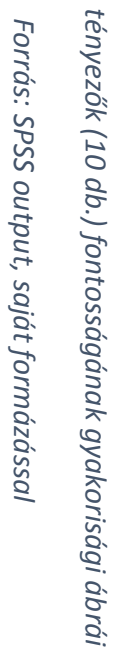

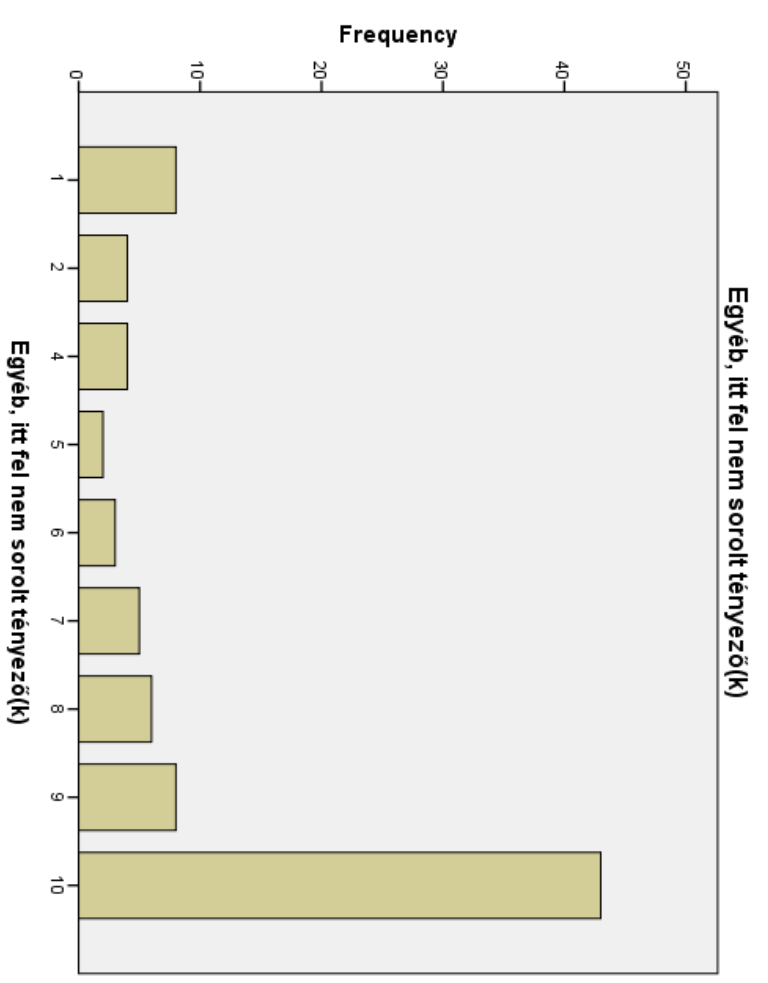




\begin{tabular}{|c|c|c|c|c|c|c|c|c|c|c|c|c|c|c|c|}
\hline Bef. tényezők / Iparágak & A & B & C & E & $\mathbf{F}$ & G & H & I & J & K & L & M & $\mathbf{N}$ & $s$ & Végösszeg \\
\hline Tulajdonosi kör jellege, & 5,38 & 3,00 & 3,86 & 4,75 & 3,00 & 4,38 & 3,30 & 5,00 & 4,43 & 10,00 & 2,00 & 3,83 & 3,33 & 5,60 & 4,16 \\
\hline Vállalkozásra vonatkozó jogi & 4,00 & 6,00 & 3,40 & 4,75 & 4,55 & 4,48 & 4,80 & 3,25 & 5,00 & 7,00 & 4,00 & 3,00 & 3,67 & 5,86 & 4,19 \\
\hline Főtevékenység jellege, & 4,46 & 2,00 & 4,14 & 5,00 & 4,82 & 5,00 & 4,11 & 3,00 & 4,33 & 8,00 & 4,00 & 4,88 & 4,83 & 4,83 & 4,54 \\
\hline Első számú vezető & 4,77 & 1,00 & 5,14 & 5,75 & 5,60 & 4,30 & 4,60 & 6,00 & 5,29 & 2,00 & 5,00 & 3,88 & 3,33 & 3,17 & 4,66 \\
\hline Alaptevékenységre & 4,67 & 7,00 & 3,93 & 5,25 & 5,91 & 4,67 & 4,70 & 5,50 & 4,00 & 9,00 & 4,50 & 5,00 & 6,00 & 4,33 & 4,75 \\
\hline Menedzsment vezetési & 5,85 & 4,00 & 5,26 & 4,75 & 5,82 & 4,93 & 6,56 & 6,67 & 6,14 & 6,00 & 2,50 & 4,75 & 4,17 & 4,83 & 5,30 \\
\hline Vállalaton belüli kultúra, & 6,92 & 5,00 & 5,71 & 5,75 & 6,09 & 5,27 & 5,89 & 6,00 & 4,57 & 5,00 & 8,00 & 5,50 & 6,40 & 5,50 & 5,76 \\
\hline Foglalkoztatottak száma, & 6,17 & 8,00 & 6,43 & 5,00 & 6,18 & 6,36 & 5,00 & 7,50 & 4,50 & 3,00 & 6,00 & 6,71 & 5,67 & 7,80 & 6,17 \\
\hline Telephelyek, fióktelepek & 6,73 & 9,00 & 7,86 & 6,25 & 6,33 & 7,00 & 6,00 & 2,33 & 6,75 & 4,00 & 10,00 & 9,50 & 8,50 & 6,50 & 7,07 \\
\hline Egyéb, itt fel nem sorolt & 7,00 & 10,00 & 8,33 & 7,00 & 7,60 & 7,38 & 10,00 & 6,50 & 5,50 & 1,00 & 9,00 & 7,83 & 9,20 & 7,75 & 7,77 \\
\hline
\end{tabular}

\begin{tabular}{|c|r|}
\hline $\mathrm{N}$ & Nr. \\
\hline 125 & 1 \\
\hline 121 & 2 \\
\hline 130 & 3 \\
\hline 101 & 4 \\
\hline 125 & 5 \\
\hline 128 & 6 \\
\hline 126 & 7 \\
\hline 124 & 8 \\
\hline 125 & 9 \\
\hline 83 & 10 \\
\hline
\end{tabular}

Tényezők rangsorrendje

\begin{tabular}{|c|c|c|c|c|c|c|c|c|c|c|c|c|c|c|c|}
\hline Tulajdonosi kör jellege, & 5 & 3 & 2 & 1 & 1 & 2 & 1 & 4 & 3 & 10 & 1 & 2 & 1 & 6 & 1 \\
\hline Vállalkozásra vonatkozó jogi & 1 & 6 & 1 & 1 & 2 & 3 & 5 & 3 & 6 & 7 & 3 & 1 & 3 & 7 & 2 \\
\hline Foótevékenység jellege, & 2 & 2 & 4 & 4 & 3 & 6 & 2 & 2 & 2 & 8 & 3 & 5 & 5 & 3 & 3 \\
\hline Első számú vezetô & 4 & 1 & 5 & 7 & 4 & 1 & 3 & 6 & 7 & 2 & 6 & 3 & 1 & 1 & 4 \\
\hline Alaptevékenységre & 3 & 7 & 3 & 6 & 6 & 4 & 4 & 5 & 1 & 9 & 5 & 6 & 7 & 2 & 5 \\
\hline Menedzsment vezetési & 6 & 4 & 6 & 1 & 5 & 5 & 9 & 9 & 9 & 6 & 2 & 4 & 4 & 3 & 6 \\
\hline Vállalaton belüli kultúra, & 9 & 5 & 7 & 7 & 7 & 7 & 7 & 6 & 5 & 5 & 8 & 7 & 8 & 5 & 7 \\
\hline Foglalkoztatottak száma, & 7 & 8 & 8 & 4 & 8 & 8 & 6 & 10 & 4 & 3 & 7 & 8 & 6 & 10 & 8 \\
\hline Telephelyek, fióktelepek & 8 & 9 & 9 & 9 & 9 & 9 & 8 & 1 & 10 & 4 & 10 & 10 & 9 & 8 & 9 \\
\hline Egyéb, itt fel nem sorolt & 10 & 10 & 10 & 10 & 10 & 10 & 10 & 8 & 8 & 1 & 9 & 9 & 10 & 9 & 10 \\
\hline
\end{tabular}

Sperman-féle rangkorreláció

Valószinúség \begin{tabular}{l|l|l|l|l|l|l}
0,83 & 0,75 & 0,95 & 0,68 & 0,99 & \\
$99 \%$ & $98 \%$ & $99 \%$ & $95 \%$ & $99 \%$ &
\end{tabular}

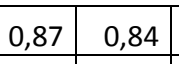

\begin{tabular}{l|l|l|}
0,41 & 0,52 \\
\hline
\end{tabular}

\begin{tabular}{r|r|r|r|r|r|}
$-0,73$ & 0,85 & 0,92 & 0,84 & 0,47 & 1,00 \\
\hline $98 \%$ & $99 \%$ & $99 \%$ & $99 \%$ & nincs & $100 \%$ \\
\hline
\end{tabular}
24. táblázat: Befolyásoló tényezők rangkorrelációja iparáganként Forrás: SPSS output, saját formázással 


\begin{tabular}{|l|r|r|}
\hline \multicolumn{1}{|c|}{ Befolyásoló tényezök } & Hipotézis & \multicolumn{1}{c|}{ Minta } \\
\hline Tulajdonosi kör jellege, tulajdonos(ok) elvárásai, előírásai & 1 & 1 \\
\hline Vállalkozásra vonatkozó jogi előírások, jogszabályok, külső szabályozó tényezők & 3 & 2 \\
\hline Főtevékenység jellege, technológiája, elvégzésének sajátosságai & 5 & 3 \\
\hline Első számú vezető karizmája, vezetési stílusa & 6 & 4 \\
\hline Alaptevékenységre vonatkozó üzleti-piaci normák, szabványok, szokások & 7 & 5 \\
\hline Menedzsment vezetési stílusa, döntései, határozottsága & 9 & 6 \\
\hline Vállalaton belüli kultúra, szokások, munkatársak viselkedése & 8 & 7 \\
\hline Foglalkoztatottak száma, dolgozói létszám & 2 & 8 \\
\hline Telephelyek, fióktelepek (darab)száma & 4 & 9 \\
\hline Egyéb, itt fel nem sorolt tényező(k) & 10 & 10 \\
\hline
\end{tabular}

25. táblázat: Befolyásoló tényezők rangsorrendje a hipotézisben és a mintában - összehasonlitás

Forrás: SPSS output, saját formázással

Correlations

\begin{tabular}{|c|c|c|c|c|}
\hline & & & Hipotezis & Minta \\
\hline \multirow[t]{6}{*}{ Spearman's rho } & Hipotezes & Correlation Coefficient & 1,000 & ,286 \\
\hline & & Sig. (2-tailed) & . & ,424 \\
\hline & & $\mathrm{N}$ & 10 & 10 \\
\hline & \multirow[t]{3}{*}{ Minta } & Correlation Coefficient & ,286 & 1,000 \\
\hline & & Sig. (2-tailed) & ,424 & \\
\hline & & $\mathrm{N}$ & 10 & 10 \\
\hline
\end{tabular}

26. táblázat: H1 hipotézis és a minta szerinti rangsorrend elemzése

Forrás: SPSS output, saját formázással 


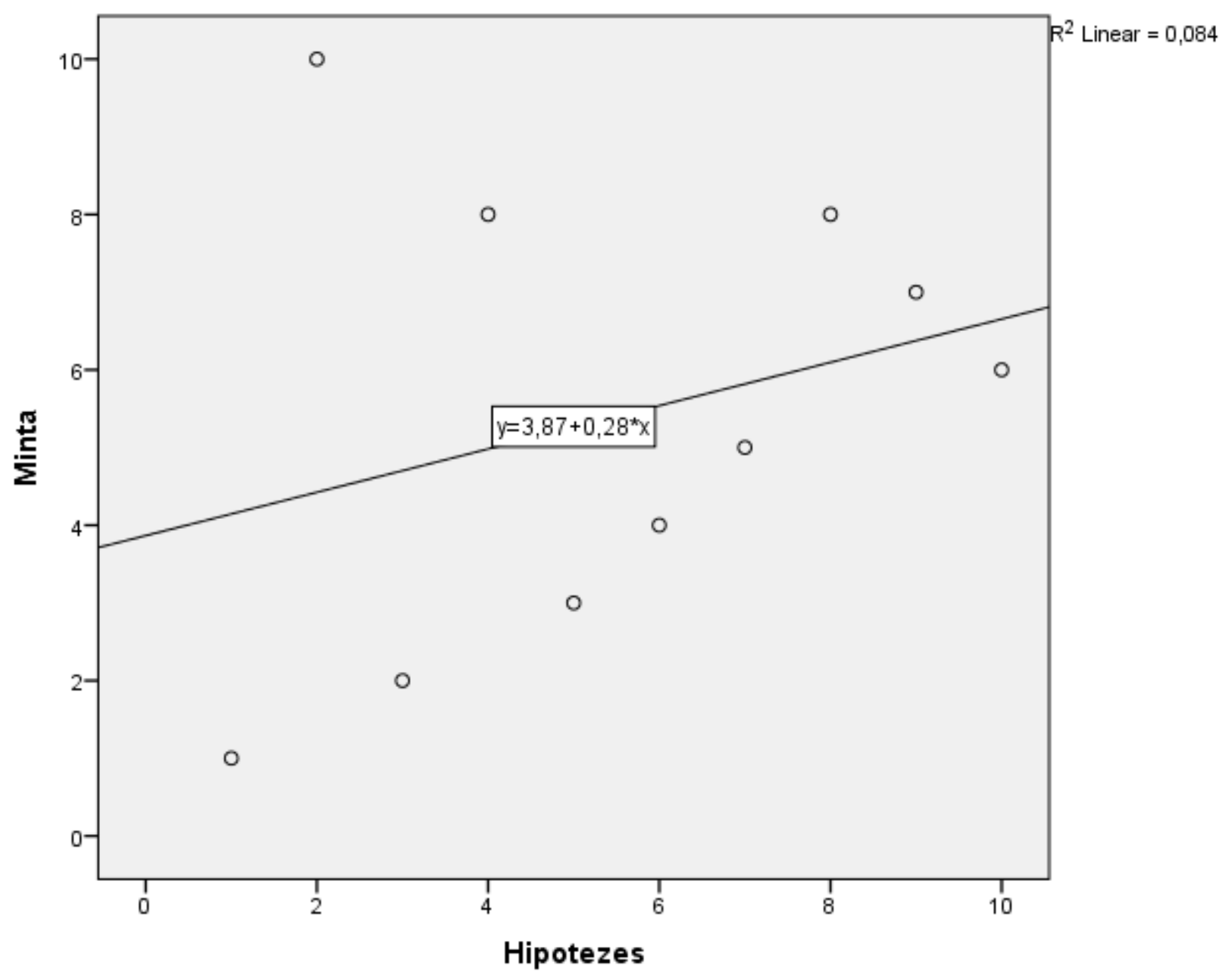

27. ábra: A H1 hipotézisben és a minta szerinti rangsorrendek korrelációs scatterplot diagrammja Forrás: SPSS output, saját formázással 


\section{F 6.2.2- H2 hipotézis}

A H2 hipotézisben és a mintában megvalósuló tényleges rangsor összehasonlítása egymással.

\begin{tabular}{|l|r|r|}
\hline \multicolumn{1}{|c|}{ Szereplök } & Hipotézis & \multicolumn{1}{c|}{ Minta } \\
\hline Vezető (felső-, közép-, közvetlen irányítói szint együtt) & 1 & 1 \\
\hline Könyvelő, számviteli-pénzügyi munkatárs & 8 & 2 \\
\hline $\begin{array}{l}\text { Informatikus, vállalatirányítási rendszergazda, alkalmazás-rendszergazda, adattárház } \\
\text { specialista }\end{array}$ & 9 \\
\hline ISO minőségirányítási belső auditor & 2 & 4 \\
\hline Controller & 3 & 5 \\
\hline Egyéb kontrollokért felelős személy (Portaszolgálat, belső elhárítás, jogász, stb.) & 5 & 6 \\
\hline Könyvvizsgáló & 7 & 7 \\
\hline Minőségellenőr, MEO & 6 & 8 \\
\hline Felügyelő Bizottsági tag & 4 & 9 \\
\hline
\end{tabular}

27. táblázat: Kulcsszereplők szerinti rangsor a hipotézisben és a mintában - összehasonlitás

Forrás: SPSS output, saját formázással 


\section{Correlations}

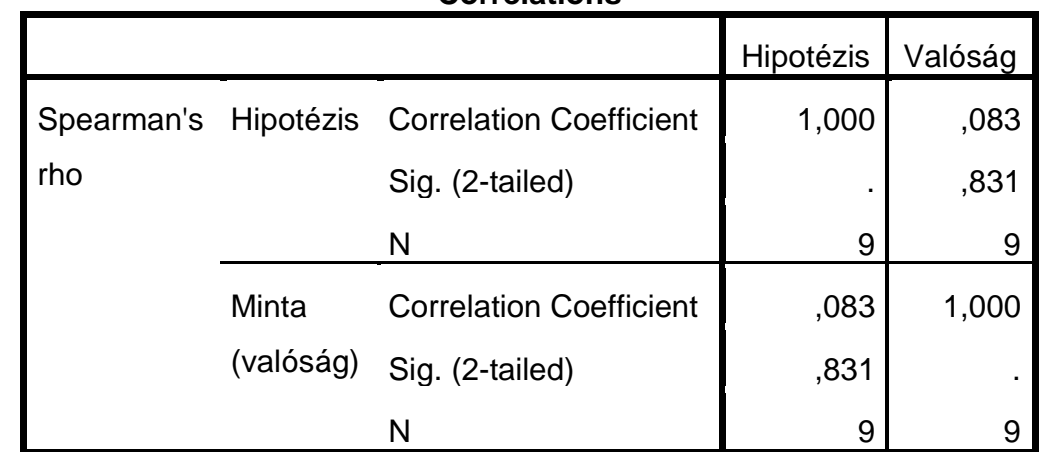

28. táblázat: H2 hipotézis és a minta szerinti rangsorrend elemzése

Forrás: SPSS output, saját formázással

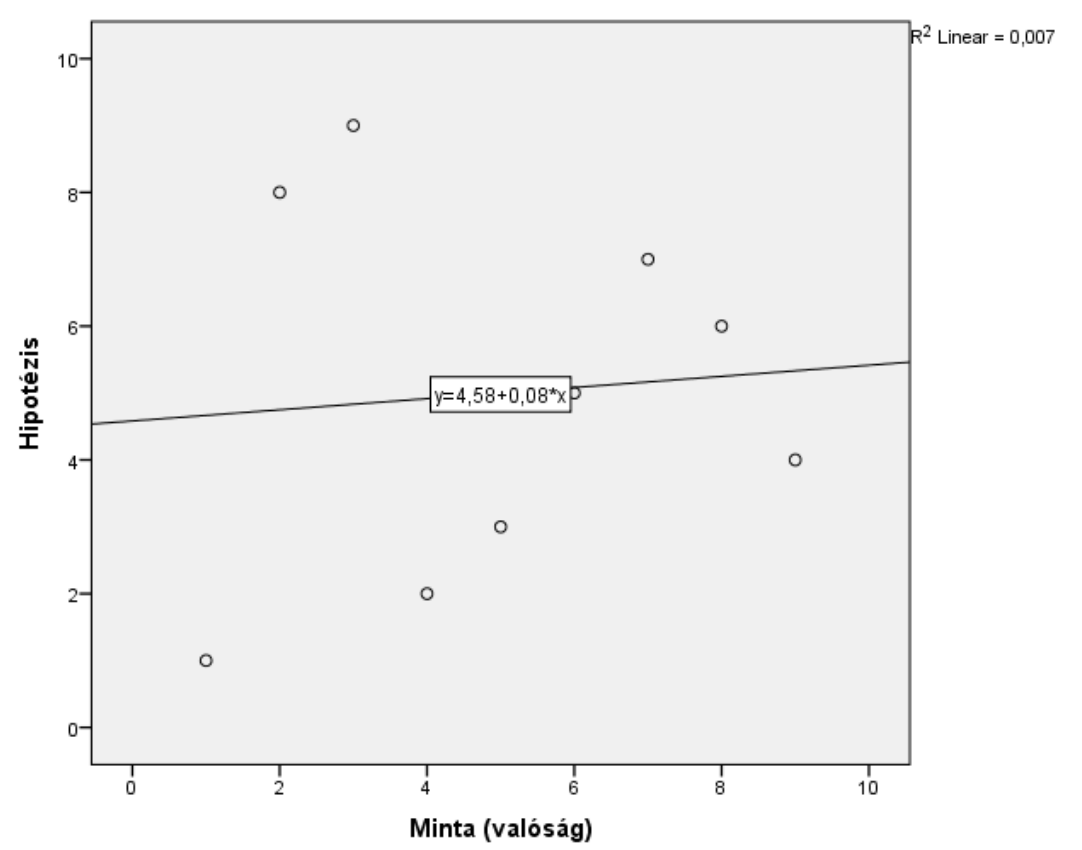

28. ábra: A H2 hipotézisben és a minta szerinti rangsorrendek korrelációs scatterplot diagrammja

Forrás: SPSS output, saját formázással 


\section{F 6.2.3 - H3 hipotézis}

Tevékenységek és felelöseik kereszttábla-elemzése

A H3 hipotézisben vizsgált egyes kontrolltevékenységek és az ellátásukért felelős szereplők:

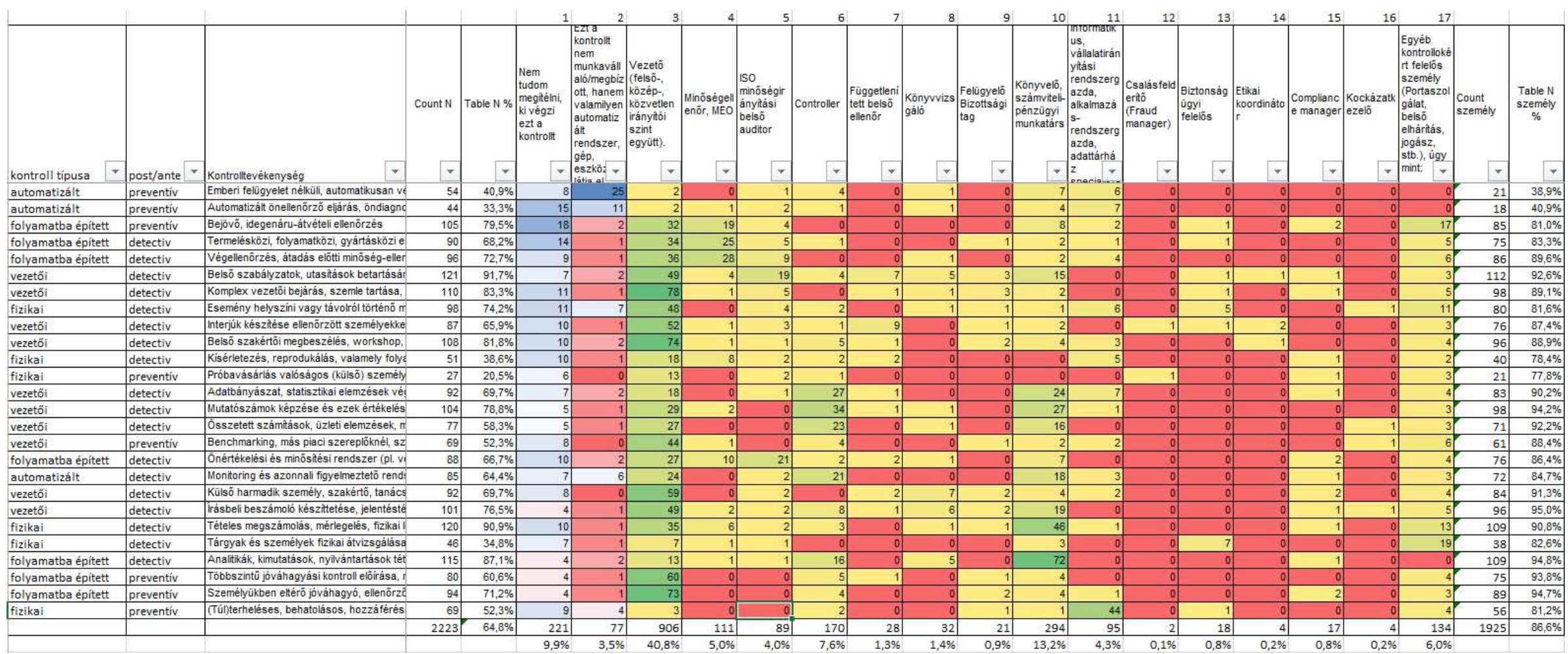

29. táblázat: A kontrolltevékenységekeket ellátó munkakörök - kereszttábla

Forrás: SPSS output, saját formázással 
Kontrolltevékenységek klaszterelemzése

Case Processing Summarya

\begin{tabular}{|c|c|c|c|c|c|c|c|}
\hline \multicolumn{8}{|c|}{ Cases } \\
\hline \multirow{2}{*}{\multicolumn{2}{|c|}{ Valid }} & \multicolumn{4}{|c|}{ Rejected } & & \\
\hline & & Missing & Ialue & Negativ & Value & \multicolumn{2}{|c|}{ Total } \\
\hline $\mathrm{N}$ & Percent & $\mathrm{N}$ & Percent & $\mathrm{N}$ & Percent & $\mathrm{N}$ & Percent \\
\hline 132 & $100,0 \%$ & 0 & $0,0 \%$ & 0 & $0,0 \%$ & 132 & $100,0 \%$ \\
\hline
\end{tabular}

a. Chi-square between Sets of Frequencies used

30. táblázat: Klaszterelemzésbe bevont válaszolók száma

Forrás: SPSS output, saját formázással

\begin{tabular}{|c|c|c|c|c|c|c|}
\hline \multirow[b]{3}{*}{ Stage } & \multicolumn{5}{|c|}{ Agglomeration Schedule } & \multirow[b]{3}{*}{ Next Stage } \\
\hline & \multicolumn{2}{|c|}{ Cluster Combined } & \multirow[b]{2}{*}{ Coefficients } & \multicolumn{2}{|c|}{ Stage Cluster First Appears } & \\
\hline & Cluster 1 & Cluster 2 & & Cluster 1 & Cluster 2 & \\
\hline 1 & 22 & 23 & 5,419 & 0 & 0 & 13 \\
\hline 2 & 2 & 3 & 11,449 & 0 & 0 & 12 \\
\hline 3 & 5 & 8 & 17,949 & 0 & 0 & 4 \\
\hline 4 & 5 & 7 & 24,765 & 3 & 0 & 16 \\
\hline 5 & 11 & 12 & 31,917 & 0 & 0 & 14 \\
\hline 6 & 15 & 16 & 39,362 & 0 & 0 & 13 \\
\hline 7 & 9 & 10 & 46,941 & 0 & 0 & 17 \\
\hline 8 & 4 & 17 & 54,543 & 0 & 0 & 9 \\
\hline
\end{tabular}




\begin{tabular}{|c|c|c|c|c|c|c|}
\hline 9 & 4 & 18 & 62,398 & 8 & 0 & 15 \\
\hline 10 & 13 & 14 & 70,296 & 0 & 0 & 14 \\
\hline 11 & 19 & 21 & 78,635 & 0 & 0 & 15 \\
\hline 12 & 1 & 2 & 87,174 & 0 & 2 & 22 \\
\hline 13 & 15 & 22 & 95,834 & 6 & 1 & 18 \\
\hline 14 & 11 & 13 & 104,532 & 5 & 10 & 20 \\
\hline 15 & 4 & 19 & 113,368 & 9 & 11 & 19 \\
\hline 16 & 5 & 6 & 122,422 & 4 & 0 & 19 \\
\hline 17 & 9 & 20 & 132,755 & 7 & 0 & 22 \\
\hline 18 & 15 & 24 & 143,369 & 13 & 0 & 21 \\
\hline 19 & 4 & 5 & 154,305 & 15 & 16 & 20 \\
\hline 20 & 4 & 11 & 166,248 & 19 & 14 & 21 \\
\hline 21 & 4 & 15 & 179,227 & 20 & 18 & 23 \\
\hline 22 & 1 & 9 & 192,539 & 12 & 17 & 23 \\
\hline 23 & 1 & 4 & 208,646 & 22 & 21 & 0 \\
\hline
\end{tabular}

Forrás: SPSS output, saját formázással 


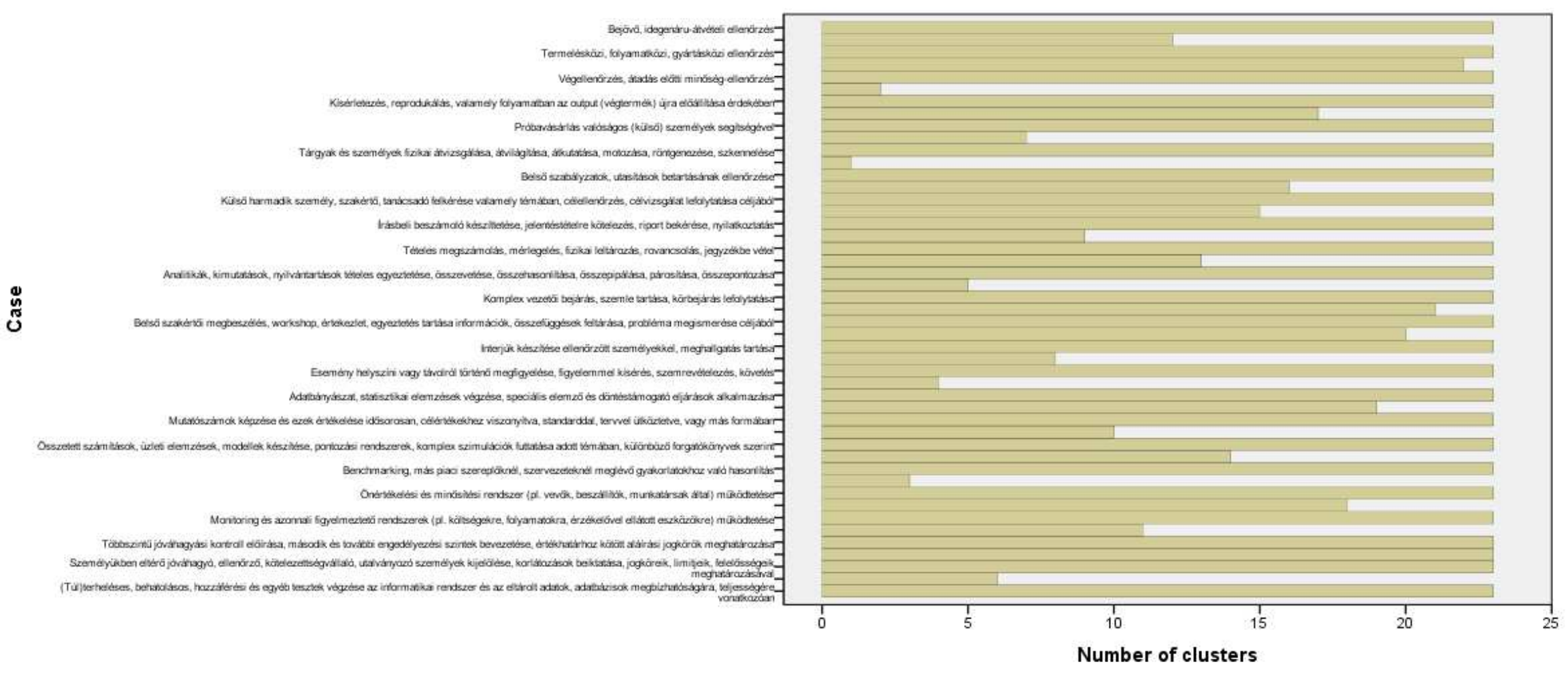

29. ábra: Kontrolltevékenységek klasztereire vonatkozó "jégcsapdiagram" Forrás: SPSS output, saját formázással 
Dendrogram using Ward Linkage

Rescaled Distance Cluster Combine

Tobbbszintữjóváhagyásikontrollelôirásamásodikéstovább Személyükbeneltérōjojováhagyóellenỗrōkötelezettségvál

Önértékelésiésminőssitésirendszerpl.vevôkkbeszáliltókm

Monitoringésazonnalifigyelmestetốrendszerekpl.kötségekrefol

Túterhelésesbehatolásoshozzátérésiésegyébtestekvégzé

Adatbányászatstatisstikaielemzésekvégzésespeciáliselemzô

Mutatószzámokképzéseésezekértékeléseidő̉sorosancélérté

összetettszámításoküzletielemzésekmodellekkészitésepont

Benchmarkingmáspiaciszereplốkné|szervezeteknélmeglévỗgyako

Belsỗszabályzatokutasításokbetartásánakellenỗrése

Külsỗharmadikszemélyszakértớtanácsadófelkérésevalamelyt

Irásbelibeszámolókészittetés sjelentéstételrekötelezés

Tételesmegszámolásmérlegelésfizikailettározásrovancsolás

Analitikákkimutatásoknyilvántartásoktételesegyettetéseöss

Komplexvezetốibejárás szemletartásakörrejáráslefolytatása

Belsỗszakértỗimegbeszélésworkshopértekezletegyeztetéstart

Interjúkkészitéseellenỗzöttszemélyekkelmeghallgatástart

Eseményhelyszinivagytávolrótöorténốmegfigyelésefigyelemm

Termelésközifolyamatközigyártásköziellenỗzés

Végellenổrésátadáselốttiminõségellenỗrés

Bejövỗidegenáruátvételeiellenỗzés

Kiséretezésreprodukálásvalamelyfolyamatbanazoutputvégtem

Próbavásárásvalóságoskülsõoszemélyeksegitségével

Tárgyakésszemélyekfizikaiátvizsgálásaátvilágitásaátku

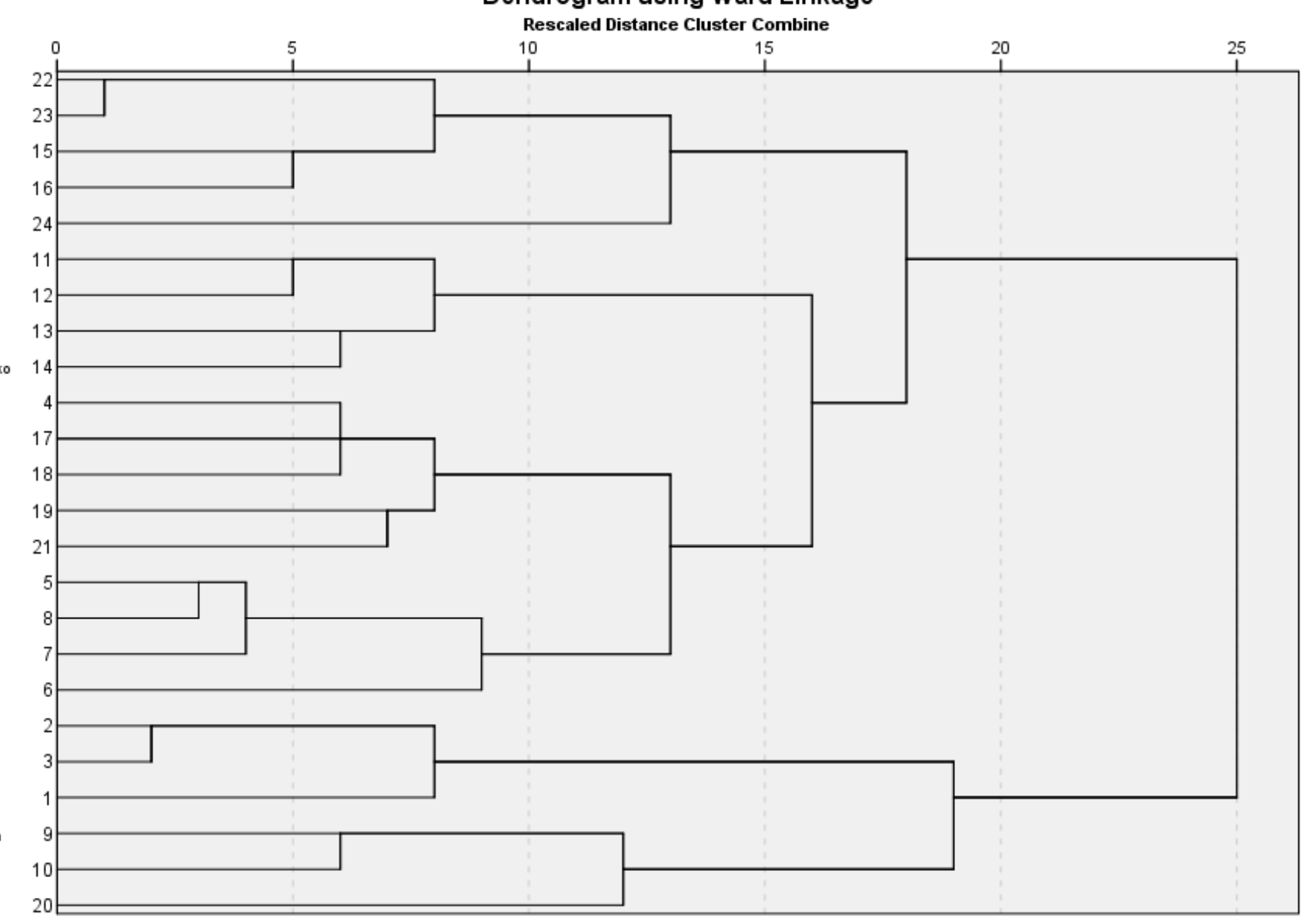

30. ábra: Kontrolltevékenységek klasztereit ábrázoló dendogram

Forrás: SPSS output, saját formázással 


\section{Kontrolltevékenységek faktorelemzése}

Az alábbi faktormodellt főkomponens-elemzés módszerrel (Principal componenet) állítottam elő, rotálást és súlyokat nem alkalmaztam, a változókat nem standardizáltam és nem zártam ki egyetlen változót sem.

A kapott eredmények szerint a 26 darab kontrolltevékenységet lehetséges 4 darab összetett faktorra redukálni, melyek értelmezése, tartalommal való feltöltése azonban mindig a kutató feladata és felelőssége. A konkrét esetben a faktoroknak én a következő értelmezést adom, egyúttal közlöm a faktorok varianciaelemzéséből származó magyarázó erőit \%-osan kifejezve:

- Az első faktor 50,37\%-ban magyarázza, képviseli az összes bele tartozó kontrolltevékenységet. Itt kaptak helyet a pénzügyi számadatokkal (statisztikai elemzések, kimutatások, analitikák, mutatószámok, teljesítménymérés, stb.) kapcsolatos kontrollok, a folyamatba épített ellenőrzések (elő-, köztes- és végellenőrzés, próbavásárlások, stb.) és a szabályozó célú preventív kontrollok (jóváhagyási szintek meghatározása, belső előírások megtartásának ellenőrzése, stb.). Látható, hogy ez a komponens önmagában is összetett, egyetlen kifejezésbe tömörítve azt mondhatjuk, hogy ezek a nem vezetők által gyakorolt, hanem inkább a szakmai szereplők által végzett kontrolltevékenységek.

- A második faktorkomponens a teljes kontrolltevékenység-halmazból 26,78\%-ot képvisel, itt kaptak helyet jórészt a vezetői kontrollok (szemle, konzulensek-tanácsadók bevonása, problémafeltáró értekezletek, stb.), valamint az adatok és a tárgyak/eszközök fizikai kontolljai (terheléses vizsgálatok, átkutatások). Ebbe a faktorcsoportba öt darab tevékenység került bele, ezeket leginkább direkt kontrolloknak, azaz közvetlenül vezető által, vagy más személy (pl. biztonsági őr, IT rendszergazda, stb.) gyakorolt kontrolltevékenységeknek tekinthetjük.

- A harmadik faktor 11,91\%-os súllyal testesíti meg az automatizált, önellenőrző eljárásokon nyugvó kontrolltevékenységeket. Mindösszesen 3 darab ilyen komponens van ebben a faktortényezőben.

- A negyedik faktor mindössze a fennmaradó 10,94\%-ot magyarázza meg, mely egyetlen kontrolltevékenységet takar: az események megfigyelését, szemrevételezését.

\begin{tabular}{|c|c|c|c|c|}
\hline \multicolumn{5}{|c|}{ Component Matrix } \\
\hline & \multicolumn{4}{|c|}{ Component } \\
\hline & 1 & 2 & 3 & 4 \\
\hline Termelésközi, folyamatközi, gyártásközi ellenörzés & ,976 & ,180 &, 101 &,- 075 \\
\hline
\end{tabular}




\begin{tabular}{|c|c|c|c|c|}
\hline Adatbányászat, statisztikai elemzések végzése, speciális elemző és döntéstámogató eljárások alkalmazása & ,948 &, 065 &,- 206 & ,234 \\
\hline Tételes megszámolás, mérlegelés, fizikai leltározás, rovancsolás, jegyzékbe vétel & 911 &, 108 &,- 188 &,- 350 \\
\hline Végellenőrzés, átadás előtti minőség-ellenőrzés & ,906 & ,216 & ,327 & , 162 \\
\hline $\begin{array}{l}\text { Analitikák, kimutatások, nyilvántartások tételes egyeztetése, összevetése, összehasonlítása, összepipálása, párosítása, } \\
\text { összepontozása }\end{array}$ & ,906 & ,216 & ,327 & , 162 \\
\hline Próbavásárlás valóságos (külső) személyek segítségével & ,873 &,- 201 & ,321 &,- 309 \\
\hline $\begin{array}{l}\text { Összetett számítások, üzleti elemzések, modellek készítése, pontozási rendszerek, komplex szimulációk futtatása adott } \\
\text { témában, különböző forgatókönyvek szerint }\end{array}$ & ,806 &, 534 &,- 125 & ,223 \\
\hline $\begin{array}{l}\text { Monitoring és azonnali figyelmeztető rendszerek (pl. költségekre, folyamatokra, érzékelövel ellátott eszközökre) } \\
\text { működtetése }\end{array}$ & ,806 &, 534 &,- 125 & ,223 \\
\hline $\begin{array}{l}\text { Mutatószámok képzése és ezek értékelése idősorosan, célértékekhez viszonyítva, standarddal, tervvel ütköztetve, vagy } \\
\text { más formában }\end{array}$ & ,802 & ,450 &,- 387 &,- 068 \\
\hline Benchmarking, más piaci szereplőknél, szervezeteknél meglévő gyakorlatokhoz való hasonlítás & ,762 & ,487 &,- 425 &,- 038 \\
\hline Írásbeli beszámoló készíttetése, jelentéstételre kötelezés, riport bekérése, nyilatkoztatás & ,713 &,- 684 &,- 101 & 120 \\
\hline $\begin{array}{l}\text { Személyükben eltérő jóváhagyó, ellenőrző, kötelezettségvállaló, utalványozó személyek kijelölése, korlátozások } \\
\text { beiktatása, jogköreik, limitjeik, felelősségeik meghatározásával }\end{array}$ & ,713 &,- 684 &,- 101 & 120 \\
\hline $\begin{array}{l}\text { Többszintű jóváhagyási kontroll elöírása, második és további engedélyezési szintek bevezetése, értékhatárhoz kötött } \\
\text { aláírási jogkörök meghatározása }\end{array}$ & ,713 &,- 684 &,- 101 & 120 \\
\hline Interjúk készítése ellenőrzött személyekkel, meghallgatás tartása & ,711 &,- 643 & ,275 & 071 \\
\hline Kísérletezés, reprodukálás, valamely folyamatban az output (végtermék) újra elöállítása érdekében & ,708 & ,248 & ,357 &,- 556 \\
\hline Belső szabályzatok, utasítások betartásának ellenőrzése & ,671 &,- 379 & ,487 &,- 411 \\
\hline Bejövő, idegenáru-átvételi ellenőrzés & ,623 &, 615 &,- 466 & , 128 \\
\hline Tárgyak és személyek fizikai átvizsgálása, átvilágítása, átkutatása, motozása, röntgenezése, szkennelése & ,324 & ,836 &, 360 & ,259 \\
\hline $\begin{array}{l}\text { (Túl)terheléses, behatolásos, hozzáférési és egyéb tesztek végzése az informatikai rendszer és az eltárolt adatok, } \\
\text { adatbázisok megbízhatóságára, teljességére vonatkozóan }\end{array}$ & ,371 & ,791 & ,481 &,- 064 \\
\hline
\end{tabular}




\begin{tabular}{|c|c|c|c|c|}
\hline $\begin{array}{l}\text { Külső harmadik személy, szakértő, tanácsadó felkérése valamely témában, célellenörzés, célvizsgálat lefolytatása } \\
\text { céljából }\end{array}$ & ,646 &,- 742 &,- 143 &, 107 \\
\hline Komplex vezetöi bejárás, szemle tartása, körbejárás lefolytatása & ,646 &,- 742 &,- 143 &, 107 \\
\hline $\begin{array}{l}\text { Belső szakértői megbeszélés, workshop, értekezlet, egyeztetés tartása információk, összefüggések feltárása, probléma } \\
\text { megismerése céljából }\end{array}$ & ,655 &,- 735 &,- 137 & , 109 \\
\hline Önértékelési és minősítési rendszer (pl. vevők, beszállitók, munkatársak által) müködtetése & ,495 & ,477 &,- 596 &, 415 \\
\hline Automatizált önellenőrző eljárás, öndiagnosztikai programok &,- 096 & ,205 &, 630 &, 742 \\
\hline Emberi felügyelet nélküli, automatikusan végzett, vezérlöegység vagy számítógép által biztosított ellenőrzés & ,202 &,- 208 & ,612 &, 736 \\
\hline Esemény helyszíni vagy távolról történő megfigyelése, figyelemmel kísérés, szemrevételezés, követés &, 565 & 305 &, 306 &,- 703 \\
\hline
\end{tabular}

Forrás: SPSS output, saját formázással

Tekintettel arra, hogy a faktormodell eredményeképpen 4 faktor (főkomponens) adódott, a kontrolltevékenységeket ebben a szemszögben kellene vizuálisan is ábrázolni. A plot ábráján ugyanakkor 4 darab eltérő dimenziót nem lehet megjeleníteni, ezért ezt látványosan ábrán szemléltetni nem tudom. Ezért a plot ábrát értekezésemben itt nem közlöm.

Az elemzés eredményeképpen kapott 4 komponens arra is utal, hogy a vizsgált cégeknél elkülönülnek a vezetői kontrollok (2. komponens), az automatizált kontrollok (3. komponens), illetve az összes egyéb csoportba sorolható kontrolltevékenység (1. és 4. komponens), úgy mint folyamatba épített kontrollok, szabályozást visszaellenőrző kontrollok, számadatokkal operáló kontrollok, fizikai kontrollok. Ez gazdagabb altípusokra enged következtetni, mint amit én a H3 hipotézisben használtam folyamatba épített kontroll és fizikai kontroll kategóriákként. Másrészt a faktorelemzés azt is visszaigazolta, hogy a vizsgált hazai vállalatok alkalmazzák a kontrollmixet, azaz mind detektív és preventív, mind manuális és automatizált kontrolltevékenységeket végeznek egyszerre, egymás mellett. 
Total Variance Explained

\begin{tabular}{|c|c|c|c|c|c|c|c|c|c|}
\hline \multirow[b]{2}{*}{ Component } & \multicolumn{3}{|c|}{ Initial Eigenvalues } & \multicolumn{3}{|c|}{ Extraction Sums of Squared Loadings } & \multicolumn{3}{|c|}{ Rotation Sums of Squared Loadings } \\
\hline & Total & $\%$ of Variance & Cumulative \% & Total & $\%$ of Variance & Cumulative \% & Total & $\%$ of Variance & Cumulative \% \\
\hline 1 & 13,096 & 50,369 & 50,369 & 13,096 & 50,369 & 50,369 & 8,811 & 33,888 & 33,888 \\
\hline 2 & 6,963 & 26,779 & 77,149 & 6,963 & 26,779 & 77,149 & 8,407 & 32,333 & 66,221 \\
\hline 3 & 3,096 & 11,909 & 89,057 & 3,096 & 11,909 & 89,057 & 5,682 & 21,854 & 88,075 \\
\hline 4 & 2,845 & 10,943 & 100,000 & 2,845 & 10,943 & 100,000 & 3,100 & 11,925 & 100,000 \\
\hline 5 & $2,699 \mathrm{E}-15$ & $1,038 \mathrm{E}-14$ & 100,000 & & & & & & \\
\hline 6 & $1,743 \mathrm{E}-15$ & $6,703 \mathrm{E}-15$ & 100,000 & & & & & & \\
\hline 7 & $1,412 \mathrm{E}-15$ & $5,429 \mathrm{E}-15$ & 100,000 & & & & & & \\
\hline 8 & $7,599 \mathrm{E}-16$ & $2,923 \mathrm{E}-15$ & 100,000 & & & & & & \\
\hline 9 & $6,830 \mathrm{E}-16$ & $2,627 \mathrm{E}-15$ & 100,000 & & & & & & \\
\hline 10 & $4,793 \mathrm{E}-16$ & $1,843 \mathrm{E}-15$ & 100,000 & & & & & & \\
\hline 11 & $3,543 \mathrm{E}-16$ & $1,363 \mathrm{E}-15$ & 100,000 & & & & & & \\
\hline 12 & $3,026 \mathrm{E}-16$ & $1,164 \mathrm{E}-15$ & 100,000 & & & & & & \\
\hline 13 & $2,547 \mathrm{E}-16$ & $9,794 \mathrm{E}-16$ & 100,000 & & & & & & \\
\hline 14 & $2,066 \mathrm{E}-16$ & $7,947 \mathrm{E}-16$ & 100,000 & & & & & & \\
\hline 15 & $1,531 \mathrm{E}-16$ & $5,887 \mathrm{E}-16$ & 100,000 & & & & & & \\
\hline 16 & $4,578 \mathrm{E}-17$ & $1,761 \mathrm{E}-16$ & 100,000 & & & & & & \\
\hline 17 & $9,198 \mathrm{E}-19$ & $3,538 \mathrm{E}-18$ & 100,000 & & & & & & \\
\hline 18 & $-5,985 E-17$ & $-2,302 \mathrm{E}-16$ & 100,000 & & & & & & \\
\hline 19 & $-1,173 \mathrm{E}-16$ & $-4,511 \mathrm{E}-16$ & 100,000 & & & & & & \\
\hline 20 & $-2,291 \mathrm{E}-16$ & $-8,812 \mathrm{E}-16$ & 100,000 & & & & & & \\
\hline 21 & $-2,866 \mathrm{E}-16$ & $-1,102 \mathrm{E}-15$ & 100,000 & & & & & & \\
\hline
\end{tabular}




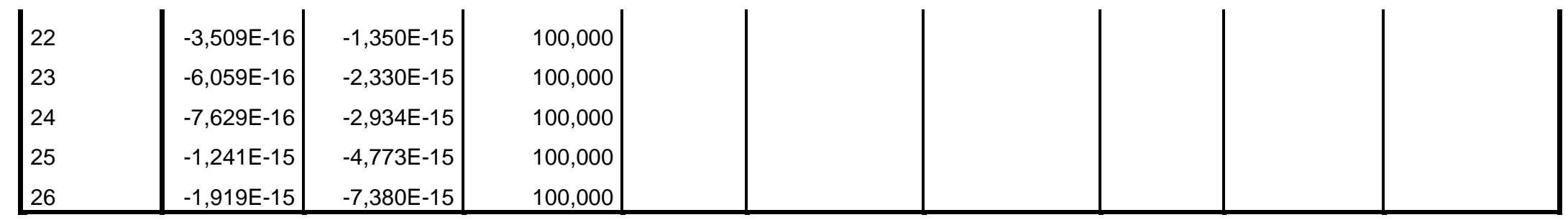

Extraction Method: Principal Component Analysis.

33. táblázat: Kontrolltevékenységek varianciatáblázata

Forrás: SPSS output, saját formázással

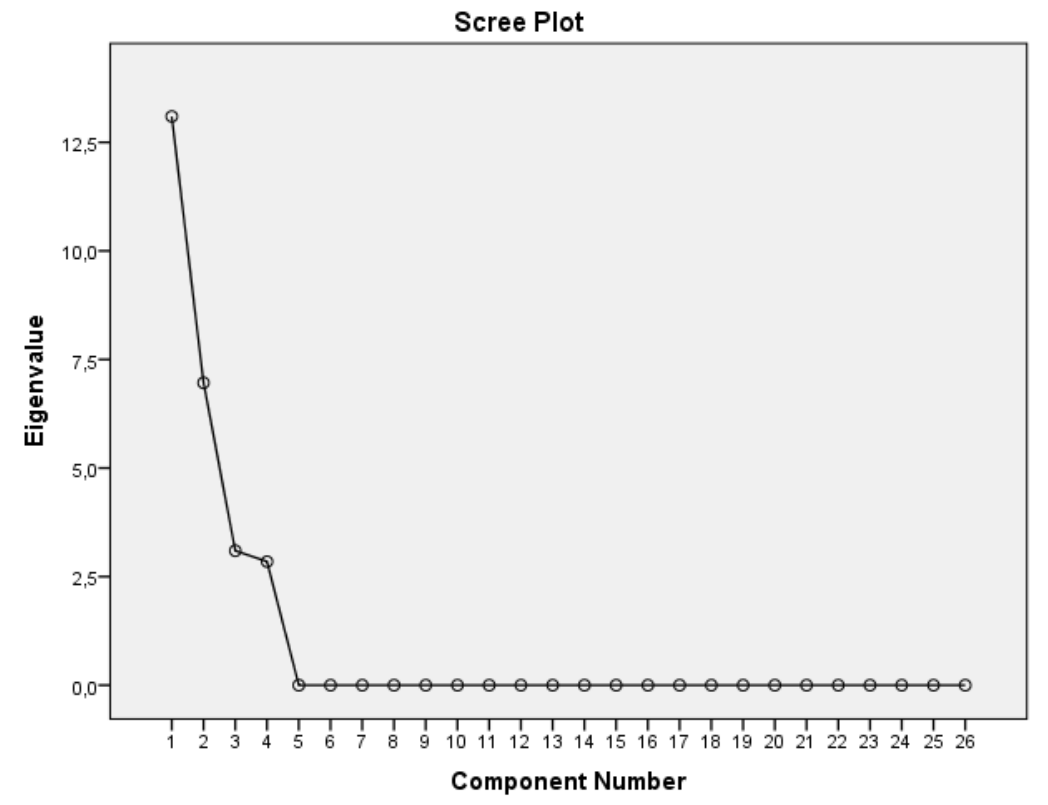

31. ábra: Kontrolltevékenységekböl képzett faktorkomponensek sceeplotja

Forrás: SPSS output, saját formázással 
Kontrolltevékenységek müködésére vonatkozó binomiális próba

Azt a kérdést, hogy egy kontrolltevékenység egyébként múködik-e a válaszadók 75\%-a körében vagy sem, statisztikai módszerekkel is meg lehet válaszolni. Ehhez azonban a kapott válaszokat saját algoritmussal igen/nem (múködik/nem múködik) típusú kétállású válaszokra kellett átkonvertálnom és a kapott eredményeket binomiális tesztnek vetett alá mind a 26 kontrolltevékenység esetében. Múködőnek tekintettem szigorúan azt a kontrolltevékenységet, ahol a válaszadó konkrét munkakört jelölt meg annak ellátójaként, míg nem múködőnek tekintettem akkor, ha nem válaszolt, vagy nem tudta megmondani, hogy ki végzi el a konkrét kontrolltevékenységet vállalkozásánál. A teszt kapott eredményeit a 32. táblázatban közlöm. Az eredményekből kitűnik, hogy szignifikánsan csak 3 kontrolltevékenység esetében esetben tudjuk azt álítani, hogy az adott kontrolltevékenység nem múködik és csak 2 esetében tudjuk azt biztosra álítani, hogy múködik. A többi 21 kontrolltevékenység esetében a válaszadók 75\%-ára vonatkozóan nem lehet egyértelmú választ adni, tehát ez a módszer igazán jó eredményre nem vezetett.

A kontrolltevékenységek múködésére vonatkozó szignifikancia-szint elemzést egyoldalú binomiális teszttel végeztem el. Ennek eredményét az alábbi 34. táblázat tartalmazza. Az elfogadási küszöbérték 75\%-os volt minden kontrolltevékenységre vonatkozóan (lásd Test Prop. oszlop). A teszt p értékeit (szignifikancia értékeit) a táblázat legutolsó oszlopa (Exact Sig. (1-tailed) tartalmazza.

Binomial Test

\begin{tabular}{|c|c|c|c|c|c|c|}
\hline & & Category & $\mathrm{N}$ & Observed Prop. & Test Prop. & Exact Sig. (1- \\
\hline $\begin{array}{l}\text { Emberi felügyelet nélküli, automatikusan végzett, vezérlőegység } \\
\text { vagy számítógép által biztosított ellenőrzés }\end{array}$ & $\begin{array}{l}\text { Group } 1 \\
\text { Group } 2 \\
\text { Total }\end{array}$ & $\begin{array}{l}\text { NEM Működik } \\
\text { Müködik }\end{array}$ & $\begin{array}{r}111 \\
21 \\
132 \\
\end{array}$ & $\begin{array}{r}, 84 \\
, 16 \\
1,00 \\
\end{array}$ & ,75 & ,008 \\
\hline Automatizált önellenőrző eljárás, öndiagnosztikai programok & $\begin{array}{l}\text { Group } 1 \\
\text { Group } 2 \\
\text { Total }\end{array}$ & $\begin{array}{l}\text { NEM Működik } \\
\text { Müködik }\end{array}$ & $\begin{array}{r}114 \\
18 \\
132\end{array}$ & $\begin{array}{r}, 86 \\
, 14 \\
1,00\end{array}$ & ,75 & ,001 \\
\hline
\end{tabular}




\begin{tabular}{|c|c|c|c|c|c|c|}
\hline Bejövő, idegenáru-átvételi ellenőrzés & $\begin{array}{l}\text { Group } 1 \\
\text { Group } 2 \\
\text { Total }\end{array}$ & $\begin{array}{l}\text { NEM Müködik } \\
\text { Müködik }\end{array}$ & $\begin{array}{r}47 \\
85 \\
132 \\
\end{array}$ & $\begin{array}{r}, 36 \\
, 64 \\
1,00\end{array}$ &, 75 &, $000^{\mathrm{a}}$ \\
\hline Termelésközi, folyamatközi, gyártásközi ellenörzés & $\begin{array}{l}\text { Group } 1 \\
\text { Group } 2 \\
\text { Total } \\
\end{array}$ & $\begin{array}{l}\text { Müködik } \\
\text { NEM Müködik }\end{array}$ & $\begin{array}{r}75 \\
57 \\
132 \\
\end{array}$ & $\begin{array}{r}, 57 \\
, 43 \\
1,00 \\
\end{array}$ &, 75 &, $000^{\mathrm{a}}$ \\
\hline Végellenőrzés, átadás előtti minőség-ellenőrzés & $\begin{array}{l}\text { Group } 1 \\
\text { Group } 2 \\
\text { Total } \\
\end{array}$ & $\begin{array}{l}\text { Müködik } \\
\text { NEM Müködik }\end{array}$ & $\begin{array}{r}86 \\
46 \\
132 \\
\end{array}$ & $\begin{array}{r}, 65 \\
, 35 \\
1,00 \\
\end{array}$ &, 75 &, $007^{\mathrm{a}}$ \\
\hline Belső szabályzatok, utasítások betartásának ellenőrzése & $\begin{array}{l}\text { Group } 1 \\
\text { Group } 2 \\
\text { Total } \\
\end{array}$ & $\begin{array}{l}\text { Működik } \\
\text { NEM Müködik }\end{array}$ & $\begin{array}{r}112 \\
20 \\
132 \\
\end{array}$ & $\begin{array}{r}, 85 \\
, 15 \\
1,00 \\
\end{array}$ &, 75 &, 004 \\
\hline Komplex vezetöi bejárás, szemle tartása, körbejárás lefolytatása & $\begin{array}{l}\text { Group } 1 \\
\text { Group } 2 \\
\text { Total } \\
\end{array}$ & $\begin{array}{l}\text { Müködik } \\
\text { NEM Müködik }\end{array}$ & $\begin{array}{r}98 \\
34 \\
132 \\
\end{array}$ & $\begin{array}{r}, 74 \\
, 26 \\
1,00 \\
\end{array}$ &, 75 &, $453^{\mathrm{a}}$ \\
\hline $\begin{array}{l}\text { Esemény helyszíni vagy távolról történő megfigyelése, figyelemmel } \\
\text { kísérés, szemrevételezés, követés }\end{array}$ & $\begin{array}{l}\text { Group } 1 \\
\text { Group } 2 \\
\text { Total } \\
\end{array}$ & $\begin{array}{l}\text { NEM Müködik } \\
\text { Müködik }\end{array}$ & $\begin{array}{r}52 \\
80 \\
132 \\
\end{array}$ & $\begin{array}{r}, 39 \\
, 61 \\
1,00 \\
\end{array}$ &, 75 &, $000^{\mathrm{a}}$ \\
\hline Interjúk készítése ellenőrzött személyekkel, meghallgatás tartása & $\begin{array}{l}\text { Group } 1 \\
\text { Group } 2\end{array}$ & $\begin{array}{l}\text { NEM Müködik } \\
\text { Müködik }\end{array}$ & $\begin{array}{l}56 \\
76\end{array}$ & $\begin{array}{l}, 42 \\
, 58\end{array}$ &, 75 &, $000^{\mathrm{a}}$ \\
\hline
\end{tabular}




\begin{tabular}{|c|c|c|c|c|c|c|}
\hline & Total & & 132 & 1,00 & & \\
\hline $\begin{array}{l}\text { Belső szakértői megbeszélés, workshop, értekezlet, egyeztetés } \\
\text { tartása információk, összefüggések feltárása, probléma } \\
\text { megismerése céljából }\end{array}$ & $\begin{array}{l}\text { Group } 1 \\
\text { Group } 2 \\
\text { Total }\end{array}$ & $\begin{array}{l}\text { Müködik } \\
\text { NEM Müködik }\end{array}$ & $\begin{array}{r}96 \\
36 \\
132\end{array}$ & \begin{tabular}{r|}
, 73 \\
, 27 \\
1,00
\end{tabular} &, 75 &, $303^{\mathrm{a}}$ \\
\hline $\begin{array}{l}\text { Kísérletezés, reprodukálás, valamely folyamatban az output } \\
\text { (végtermék) újra előállitása érdekében }\end{array}$ & $\begin{array}{l}\text { Group } 1 \\
\text { Group } 2 \\
\text { Total }\end{array}$ & $\begin{array}{l}\text { NEM Müködik } \\
\text { Müködik }\end{array}$ & $\begin{array}{r}92 \\
40 \\
132 \\
\end{array}$ & \begin{tabular}{r|}
, 70 \\
, 30 \\
1,00 \\
\end{tabular} &, 75 &, $097^{\mathrm{a}}$ \\
\hline Próbavásárlás valóságos (külső) személyek segítségével & $\begin{array}{l}\text { Group } 1 \\
\text { Group } 2 \\
\text { Total }\end{array}$ & $\begin{array}{l}\text { NEM Müködik } \\
\text { Müködik }\end{array}$ & $\begin{array}{r}111 \\
21 \\
132 \\
\end{array}$ & \begin{tabular}{r|}
, 84 \\
, 16 \\
1,00 \\
\end{tabular} &, 75 &, 008 \\
\hline $\begin{array}{l}\text { Adatbányászat, statisztikai elemzések végzése, speciális elemző és } \\
\text { döntéstámogató eljárások alkalmazása }\end{array}$ & $\begin{array}{l}\text { Group } 1 \\
\text { Group } 2 \\
\text { Total }\end{array}$ & $\begin{array}{l}\text { Müködik } \\
\text { NEM Müködik }\end{array}$ & $\begin{array}{r}83 \\
49 \\
132 \\
\end{array}$ & \begin{tabular}{r|}
, 63 \\
, 37 \\
1,00 \\
\end{tabular} &, 75 &, $001^{\mathrm{a}}$ \\
\hline $\begin{array}{l}\text { Mutatószámok képzése és ezek értékelése idősorosan, } \\
\text { célértékekhez viszonyítva, standarddal, tervvel ütköztetve, vagy más } \\
\text { formában }\end{array}$ & $\begin{array}{l}\text { Group } 1 \\
\text { Group } 2 \\
\text { Total }\end{array}$ & $\begin{array}{l}\text { NEM Müködik } \\
\text { Müködik }\end{array}$ & $\begin{array}{r}34 \\
98 \\
132 \\
\end{array}$ & \begin{tabular}{r|}
, 26 \\
, 74 \\
1,00 \\
\end{tabular} &, 75 &, $000^{\mathrm{a}}$ \\
\hline $\begin{array}{l}\text { Összetett számítások, üzleti elemzések, modellek készítése, } \\
\text { pontozási rendszerek, komplex szimulációk futtatása adott témában, } \\
\text { különböző forgatókönyvek szerint }\end{array}$ & $\begin{array}{l}\text { Group } 1 \\
\text { Group } 2 \\
\text { Total }\end{array}$ & $\begin{array}{l}\text { NEM Müködik } \\
\text { Müködik }\end{array}$ & $\begin{array}{r}61 \\
71 \\
132 \\
\end{array}$ & \begin{tabular}{r|}
, 46 \\
, 54 \\
1,00 \\
\end{tabular} &, 75 &, $000^{\mathrm{a}}$ \\
\hline Benchmarking, más piaci szereplöknél, szervezeteknél meglévő & Group 1 & NEM Müködik & 71 &, 54 &, 75 &, $000^{\mathrm{a}}$ \\
\hline
\end{tabular}




\begin{tabular}{|c|c|c|c|c|c|c|}
\hline gyakorlatokhoz való hasonlítás & $\begin{array}{l}\text { Group } 2 \\
\text { Total }\end{array}$ & Müködik & $\begin{array}{r}61 \\
132 \\
\end{array}$ & $\begin{array}{r}, 46 \\
1,00 \\
\end{array}$ & & \\
\hline $\begin{array}{l}\text { Önértékelési és minősitési rendszer (pl. vevők, beszállítók, } \\
\text { munkatársak által) müködtetése }\end{array}$ & $\begin{array}{l}\text { Group } 1 \\
\text { Group } 2 \\
\text { Total }\end{array}$ & $\begin{array}{l}\text { NEM Müködik } \\
\text { Müködik }\end{array}$ & $\begin{array}{r}56 \\
76 \\
132\end{array}$ & $\begin{array}{r}, 42 \\
, 58 \\
1,00\end{array}$ &, 75 &, $000^{\mathrm{a}}$ \\
\hline $\begin{array}{l}\text { Monitoring és azonnali figyelmeztető rendszerek (pl. költségekre, } \\
\text { folyamatokra, érzékelővel ellátott eszközökre) müködtetése }\end{array}$ & $\begin{array}{l}\text { Group } 1 \\
\text { Group } 2 \\
\text { Total }\end{array}$ & $\begin{array}{l}\text { NEM Müködik } \\
\text { Müködik }\end{array}$ & $\begin{array}{r}60 \\
72 \\
132 \\
\end{array}$ & $\begin{array}{r}, 45 \\
, 55 \\
1,00 \\
\end{array}$ &, 75 &, $000^{\mathrm{a}}$ \\
\hline $\begin{array}{l}\text { Külső harmadik személy, szakértő, tanácsadó felkérése valamely } \\
\text { témában, célellenőrzés, célvizsgálat lefolytatása céljából }\end{array}$ & $\begin{array}{l}\text { Group } 1 \\
\text { Group } 2 \\
\text { Total } \\
\end{array}$ & $\begin{array}{l}\text { NEM Müködik } \\
\text { Müködik }\end{array}$ & $\begin{array}{r}48 \\
84 \\
132 \\
\end{array}$ & $\begin{array}{r}, 36 \\
, 64 \\
1,00 \\
\end{array}$ &, 75 &, $000^{a}$ \\
\hline $\begin{array}{l}\text { Írásbeli beszámoló készíttetése, jelentéstételre kötelezés, riport } \\
\text { bekérése, nyilatkoztatás }\end{array}$ & $\begin{array}{l}\text { Group } 1 \\
\text { Group } 2 \\
\text { Total } \\
\end{array}$ & $\begin{array}{l}\text { NEM Müködik } \\
\text { Müködik }\end{array}$ & $\begin{array}{r}36 \\
96 \\
132 \\
\end{array}$ & $\begin{array}{r}, 27 \\
, 73 \\
1,00 \\
\end{array}$ &, 75 &, $000^{\mathrm{a}}$ \\
\hline $\begin{array}{l}\text { Tételes megszámolás, mérlegelés, fizikai leltározás, rovancsolás, } \\
\text { jegyzékbe vétel }\end{array}$ & $\begin{array}{l}\text { Group } 1 \\
\text { Group } 2 \\
\text { Total } \\
\end{array}$ & $\begin{array}{l}\text { NEM Müködik } \\
\text { Múködik }\end{array}$ & $\begin{array}{r}23 \\
109 \\
132 \\
\end{array}$ & $\begin{array}{r}, 17 \\
, 83 \\
1,00 \\
\end{array}$ &, 75 &, $000^{\mathrm{a}}$ \\
\hline $\begin{array}{l}\text { Tárgyak és személyek fizikai átvizsgálása, átvilágítása, átkutatása, } \\
\text { motozása, röntgenezése, szkennelése }\end{array}$ & $\begin{array}{l}\text { Group } 1 \\
\text { Group } 2 \\
\text { Total } \\
\end{array}$ & $\begin{array}{l}\text { NEM Müködik } \\
\text { Müködik }\end{array}$ & $\begin{array}{r}94 \\
38 \\
132 \\
\end{array}$ & $\begin{array}{r}, 71 \\
, 29 \\
1,00 \\
\end{array}$ &, 75 &, $182^{\mathrm{a}}$ \\
\hline
\end{tabular}




\begin{tabular}{|c|c|c|c|c|c|c|}
\hline $\begin{array}{l}\text { Analitikák, kimutatások, nyilvántartások tételes egyeztetése, } \\
\text { összevetése, összehasonlítása, összepipálása, párosítása, } \\
\text { összepontozása }\end{array}$ & $\begin{array}{l}\text { Group } 1 \\
\text { Group } 2 \\
\text { Total }\end{array}$ & $\begin{array}{l}\text { Múködik } \\
\text { NEM Müködik }\end{array}$ & $\begin{array}{r}109 \\
23 \\
132 \\
\end{array}$ & $\begin{array}{r}, 83 \\
, 17 \\
1,00 \\
\end{array}$ &, 75 & ,025 \\
\hline $\begin{array}{l}\text { Többszintű jóváhagyási kontroll elöirása, második és további } \\
\text { engedélyezési szintek bevezetése, értékhatárhoz kötött aláirási } \\
\text { jogkörök meghatározása }\end{array}$ & $\begin{array}{l}\text { Group } 1 \\
\text { Group } 2 \\
\text { Total }\end{array}$ & $\begin{array}{l}\text { NEM Müködik } \\
\text { Müködik }\end{array}$ & $\begin{array}{r}57 \\
75 \\
132\end{array}$ & $\begin{array}{r}, 43 \\
, 57 \\
1,00\end{array}$ &, 75 &, $000^{\mathrm{a}}$ \\
\hline $\begin{array}{l}\text { Személyükben eltérő jóváhagyó, ellenőrző, kötelezettségvállaló, } \\
\text { utalványozó személyek kijelölése, korlátozások beiktatása, jogköreik, } \\
\text { limitjeik, felelősségeik meghatározásával }\end{array}$ & $\begin{array}{l}\text { Group } 1 \\
\text { Group } 2 \\
\text { Total } \\
\end{array}$ & $\begin{array}{l}\text { NEM Müködik } \\
\text { Müködik }\end{array}$ & $\begin{array}{r}43 \\
89 \\
132 \\
\end{array}$ & $\begin{array}{r}, 33 \\
, 67 \\
1,00 \\
\end{array}$ &, 75 &, $000^{a}$ \\
\hline $\begin{array}{l}\text { (Túl)terheléses, behatolásos, hozzáférési és egyéb tesztek végzése } \\
\text { az informatikai rendszer és az eltárolt adatok, adatbázisok } \\
\text { megbízhatóságára, teljességére vonatkozóan }\end{array}$ & $\begin{array}{l}\text { Group } 1 \\
\text { Group } 2 \\
\text { Total }\end{array}$ & $\begin{array}{l}\text { NEM Müködik } \\
\text { Müködik }\end{array}$ & $\begin{array}{r}76 \\
56 \\
132 \\
\end{array}$ & $\begin{array}{r}, 58 \\
, 42 \\
1,00\end{array}$ & ,75 &, $000^{\mathrm{a}}$ \\
\hline
\end{tabular}

a. Alternative hypothesis states that the proportion of cases in the first group $<, 75$.

34. táblázat: Kontrolltevékenységek müködésére vonatkozó binomiális teszt eredményei

Forrás: SPSS output, saját formázással 


\section{F 6.2.4 - H4 hipotézis}

Egyetértés változóra vonatkozó vizsgálatok

A H4 hipotézis kapcsán vizsgált állításokkal való egyetértés átlagának és szórásának elemzését az alábbiakban közlöm:

Descriptives

\begin{tabular}{|c|c|c|c|c|}
\hline & & & Statistic & Std. Error \\
\hline \multirow{13}{*}{$\begin{array}{l}\text { Az egyetértések átlaga } \\
\text { mutató }\end{array}$} & \multicolumn{2}{|l|}{ Mean } & 4,1005 & , 11807 \\
\hline & $95 \%$ Confidence Interval for & Lower Bound & 3,8667 & \\
\hline & Mean & Upper Bound & 4,3342 & \\
\hline & \multicolumn{2}{|l|}{$5 \%$ Trimmed Mean } & 4,1191 & \\
\hline & \multicolumn{2}{|l|}{ Median } & 4,2766 & \\
\hline & \multicolumn{2}{|l|}{ Variance } & 1,701 & \\
\hline & \multicolumn{2}{|l|}{ Std. Deviation } & 1,30413 & \\
\hline & \multicolumn{2}{|l|}{ Minimum } & 1,25 & \\
\hline & \multicolumn{2}{|l|}{ Maximum } & 6,83 & \\
\hline & \multicolumn{2}{|l|}{ Range } & 5,58 & \\
\hline & \multicolumn{2}{|l|}{ Interquartile Range } & 2,01 & \\
\hline & \multicolumn{2}{|l|}{ Skewness } &,- 195 &, 219 \\
\hline & \multicolumn{2}{|l|}{ Kurtosis } &,- 632 & ,435 \\
\hline \multirow{3}{*}{$\begin{array}{l}\text { Az egyetértés szórása } \\
\text { mutató }\end{array}$} & \multicolumn{2}{|l|}{ Mean } & 1,3138 &, 03980 \\
\hline & \multirow{2}{*}{$\begin{array}{l}95 \% \text { Confidence Interval for } \\
\text { Mean }\end{array}$} & Lower Bound & 1,2351 & \\
\hline & & Upper Bound & 1,3926 & \\
\hline
\end{tabular}




\begin{tabular}{|l|r|r|}
\hline 5\% Trimmed Mean & 1,3058 & \\
\hline Median & 1,2964 & \\
\hline Variance &, 193 & \\
\hline Std. Deviation &, 43956 & \\
\hline Minimum &, 00 & \\
\hline Maximum & 2,56 & \\
\hline Range & 2,56 & \\
\hline Interquartile Range &, 59 & \\
\hline Skewness &, 234 &, 219 \\
\hline Kurtosis &, 422 &, 435 \\
\hline
\end{tabular}

35. táblázat: Egyetértési változó átlag és szórásmutatójának leiró adatai

Forrás: SPSS output, saját formázással

Tests of Normality

\begin{tabular}{|l|r|r|r|r|r|r|}
\hline & \multicolumn{4}{|c|}{ Kolmogorov-Smirnova } & \multicolumn{3}{|c|}{ Shapiro-Wilk } \\
\cline { 2 - 7 } & Statistic & \multicolumn{1}{|c|}{$\mathrm{df}$} & \multicolumn{1}{c|}{ Sig. } & \multicolumn{1}{c|}{ Statistic } & \multicolumn{1}{c|}{ df } & \multicolumn{1}{c|}{ Sig. } \\
\hline Az egyetértések átlaga mutató &, 063 & 122 &, $200^{*}$ &, 984 & 122 &, 159 \\
Az egyetértés szórása mutató &, 054 & 122 &, $200^{*}$ &, 991 & 122 &, 597 \\
\hline
\end{tabular}

*. This is a lower bound of the true significance.

a. Lilliefors Significance Correction

36. táblázat: A változók normalitástesztjének eredményei

Forrás: SPSS output, saját formázással 


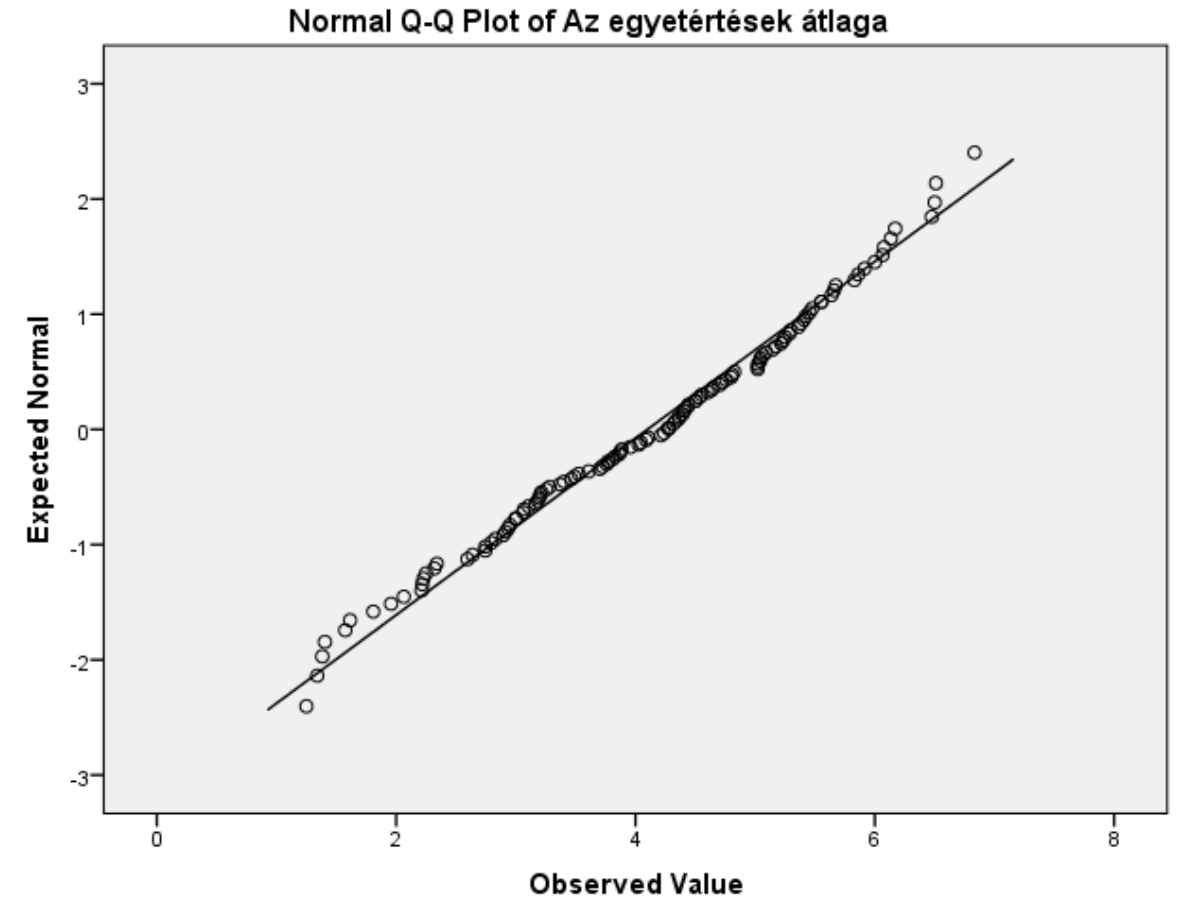

32. ábra: Az egyetértések átlagára vonatkozó változó normalitástesztjének Q-Q ábrája Forrás: SPSS output, saját formázással

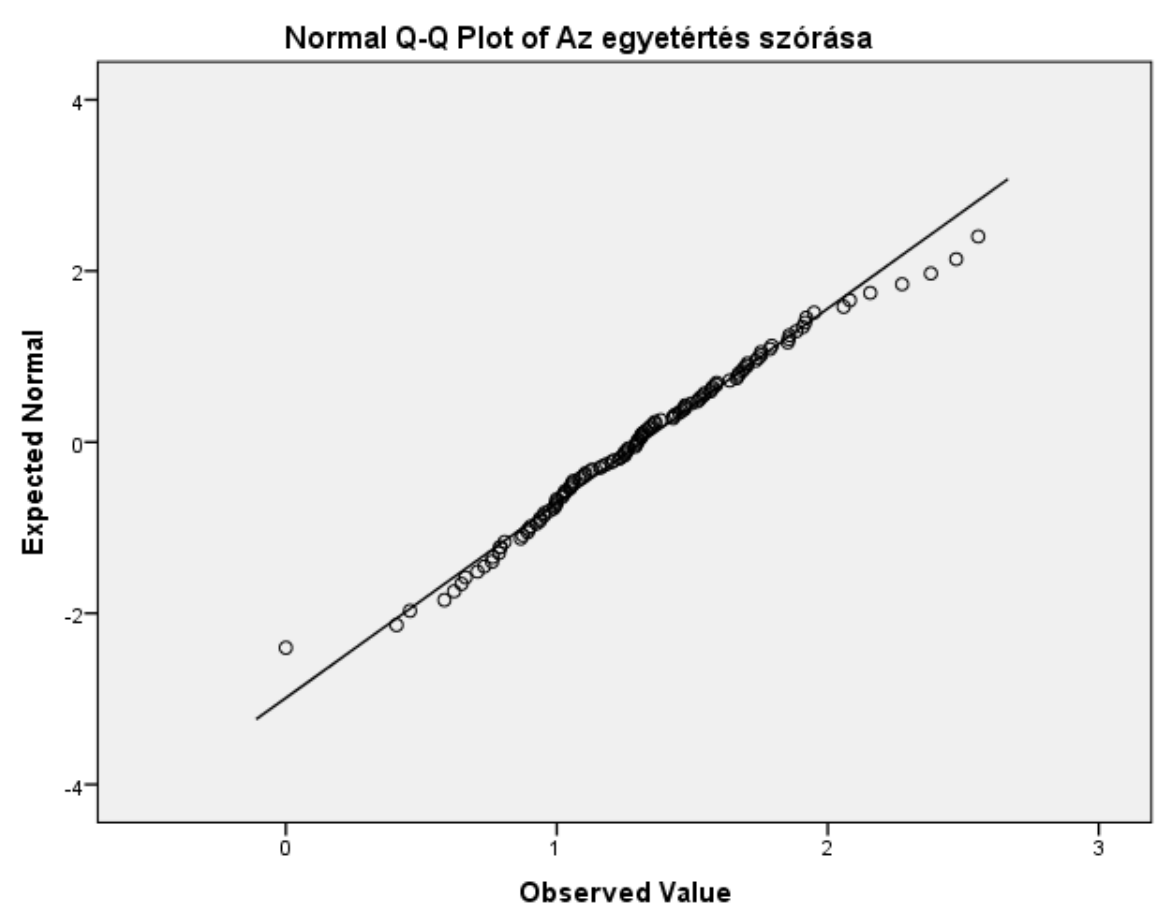

33. ábra: Az egyetértések szórására vonatkozó változó normalitástesztjének Q-Q ábrája Forrás: SPSS output, saját formázással 


\begin{tabular}{|c|c|c|c|}
\hline \multicolumn{4}{|c|}{ Statistics } \\
\hline & & $\begin{array}{c}\text { Az egyetértések } \\
\text { átlaga mutató }\end{array}$ & $\begin{array}{c}\text { Az egyetértés } \\
\text { szórása mutató }\end{array}$ \\
\hline \multirow[t]{2}{*}{$\mathrm{N}$} & Valid & 122 & 122 \\
\hline & Missing & 10 & 10 \\
\hline \multicolumn{2}{|l|}{ Mean } & 4,1005 & 1,3138 \\
\hline \multicolumn{2}{|l|}{ Median } & 4,2766 & 1,2964 \\
\hline \multicolumn{2}{|l|}{ Mode } & $3,00^{\mathrm{a}}$ & ,79 \\
\hline \multicolumn{2}{|c|}{ Std. Deviation } & 1,30413 & ,43956 \\
\hline \multicolumn{2}{|l|}{ Variance } & 1,701 & , 193 \\
\hline \multicolumn{2}{|l|}{ Skewness } &,- 195 & ,234 \\
\hline \multicolumn{2}{|c|}{ Std. Error of Skewness } & ,219 & ,219 \\
\hline \multicolumn{2}{|l|}{ Kurtosis } &,- 632 & ,422 \\
\hline \multicolumn{2}{|c|}{ Std. Error of Kurtosis } & ,435 & ,435 \\
\hline \multicolumn{2}{|l|}{ Sum } & 500,26 & 160,29 \\
\hline \multirow[t]{6}{*}{ Percentiles } & 10 & 2,2341 &, 7879 \\
\hline & 20 & 2,9446 & ,9533 \\
\hline & 25 & 3,0965 & ,9993 \\
\hline & 40 & 3,8128 & 1,1871 \\
\hline & 50 & 4,2766 & 1,2964 \\
\hline & 60 & 4,5000 & 1,3790 \\
\hline
\end{tabular}




\begin{tabular}{|l|l|l|}
75 & 5,1064 & 1,5880 \\
\hline 80 & 5,2896 & 1,6863 \\
\hline 90 & 5,7830 & 1,8764 \\
\hline
\end{tabular}

a. Multiple modes exist. The smallest value is shown

37. táblázat: Az egyetértések átlagának és szórásának percentilisei Forrás: SPSS output, saját formázással

\section{Statistics}

Az egyetértések átlaga mutató
\begin{tabular}{|llr|}
\hline $\mathrm{N}$ & Valid & 122 \\
\cline { 3 - 4 } & Missing & 10 \\
\hline Mean & 4,1005 \\
\hline Median & & 4,2766 \\
\hline Mode & $3,00^{\mathrm{a}}$ \\
\hline Percentiles & 2,28 & 1,3747 \\
\cline { 3 - 3 } & 15,87 & 2,7704 \\
\hline & 50 & 4,2766 \\
\hline & 84,13 & 5,4404 \\
\hline & 97,72 & 6,5021 \\
\hline
\end{tabular}

a. Multiple modes exist. The smallest

value is shown

38. táblázat: Az egyetértés átlaga változó $3 \sigma$ szabály szerinti küszöbértékei

Forrás: SPSS output, saját formázással 


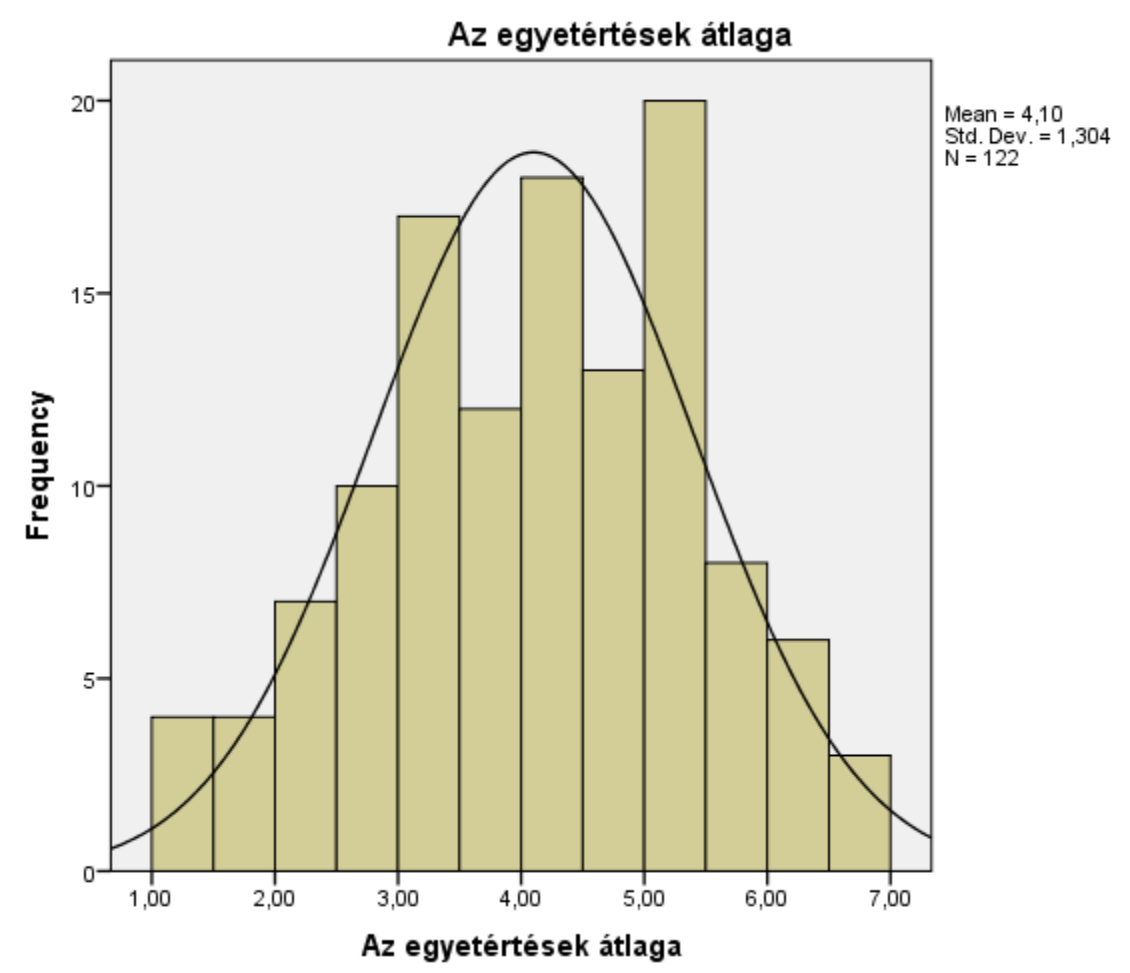

34. ábra: Az egyetértések átlaga változó hisztogramja Forrás: SPSS output, saját formázással

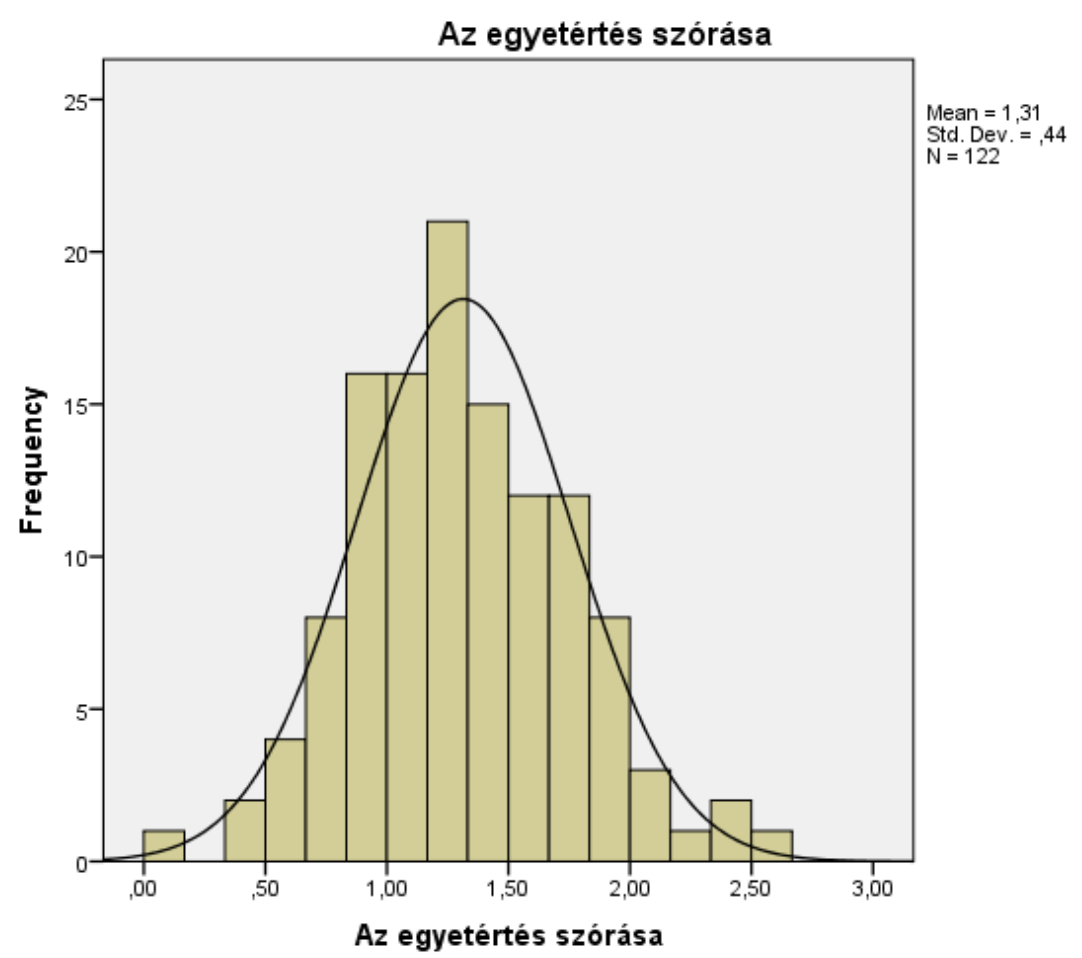

35. ábra: Az egyetértések szórása változó hisztogramja Forrás: SPSS output, saját formázással 


\title{
F 6.3 - Másodlagos kutatási eszközökkel elért eredmények
}

\author{
F 6.3.1 Vállalati esettanulmányok
}

\section{Magyar Suzuki Zrt.}

\section{MÉLYINTERJÚ ÖSSZEFOGLALÓ}

\section{a Magyar Suzuki Zrt. belső kontrollrendszerének intézményesülése kapcsán}

0. Kérem röviden ismertesse meg a céget velem, adjon egy összefoglaló képet a vállalatról (főtevékenység, létszám, forgalom, tulajdonosi kör, szervezeti felépítés, leányvállalatok, tanúsítványok, számviteli rendszer fontosabb adatai, stb.)!

A Magyar Suzuki Zrt. 1991. 04. 21-én alakult meg Esztergomi székhellyel, az egykori szovjet laktanya területén. Fő tevékenységi köre a személygépjármű gyártás, melyet 1992. október 01-e óta folyamatosan végez. Kezdetben csak a magyar piacra termelt, azonban a társaság múködési köre idő közben kiszélesedett, ma már saját gyártású gépjármúveit exportálja más EU és harmadik országokba, ill. import tevékenysége révén hazánkban személygépkocsik értékesítésével, gépjárműalkatrész-kereskedelemmel (pótalkatrész ellátás), közúti motorok és motorcsónak-motorok belföldi disztribúciójával is foglalkozik. Az általa importált termékeket, ill. a saját gyártású termékeit a hazai Suzuki márkakereskedéseknek értékesíti. A cég 2015-ben összesen mintegy 185.533 darab gépkocsit gyártott, egyúttal kb. 7500 gépjármúvet adott el Magyarországon, ezzel a hazai piacon 9,72\%-os részesedést ért el az új gépjármúvek üzembe helyezését tekintve.

A vállalat fő tulajdonosa 97,5\%-ban a Suzuki Motors Corporation (továbbiakban $\mathrm{SMC}$ ), amely a tokiói tőzsdén jegyzett részvénytársaság. A Magyar Suzuki Zrt-nél Igazgatóság és Felügyelő Bizottság múködik. Az Igazgatóság jelenleg 7 tagból áll. $A$ Felügyelő Bizottságnak jelenleg 3 tagja van. Audit Bizottsága azonban nincsen. A cég operatív vezetését a Vezérigazgató (Managing Director), Naoyuki Takeuchi látja el.

A vállalat statisztikai állományi létszáma 2015. december 31-én 2818 fő volt. 2015ben árbevétele 1.975.526.562 euró volt, amely 28,3 \% növekedést jelent az előző évhez viszonyítva. A társaság a magyar számviteli törvények szerint, euróban vezeti a könyveit, és negyedévente az anyavállalat felé IFRS szerinti konszolidált jelentést küld meg. A cég QAD nevű vállalatirányítási rendszert használ, melyet 1998 évben vezetett be 
A cég AEO tanúsítvánnyal bír, ISO 9001 és ISO 14001 szerint tanúsított cég. Egyéb tanúsítványa nincs. 2009 februárja óta rendelkezik a vállalat AEO tanúsítvánnyal. Részletek Suzuki Motor Corporation: 2015 évi pénzügyi jelentéséből a vállalati célkitűzésekre vonatkozóan (Annual Report 2015):

A Suzuki Csoport fő vállalati politikája a következő: „Gondolkodj okosabban, dolgozz keményebben, és egyesítsd a Suzuki Csoportot; győzzük le a kihívásainkat és navigáljunk egy fényesebb jövő felé".

A Csoport erőfeszítéseket tesz, hogy minden területen „Okosabb, Kevesebb, Könnyebb, Rövidebb, és Tisztább" legyen, és eredményes, logikusan kapcsolódó, egészséges múködés jellemezze.

Vezetőink és alkalmazottaink szigorúan betartanak minden jogszabályt, társadalmi normát, belső szabályt, stb., tisztességesen és őszintén cselekednek.

1. Hogyan írná le a vállalatuk belső kontrollrendszerének aktuális állapotát? Mi jellemzi azt? Milyen elemeit tartja fontosnak? Milyen jelzőkkel/határozószókkal tudja jellemezni azt? Mit emel ki lényegesnek vele kapcsolatosan?

Kulcsszavak:

- komplex: a jogszabályokon túlmenően sok eleme van, a tulajdonos előírásai, a JSOX rendszer, a lean filozófia, az informatikai rendszerekre vonatkozó szabályozások, stb. mind egyszerre keverednek benne.

- erősen szabályozott: folyamatleírások kockázatelemzéssel, belső eljárások és utasítások szabják meg a legtöbb üzleti tevékenységet a vállalatban.

- Toyota módszereket alkalmaz a háttérben: bevezette és használja a lean menedzsment módszertant, múködteti a kaizen, gemba és $5 S$ rendszereket, a dolgozókat folyamatosan újítási javaslatokra sarkallja.

- tulajdonos által erősen meghatározott: az SMC alapvetően meghatározza a működtetendő belső kontrollrendszert, amely kockázatelemzésen - pl. JSOX compliance audit- alapokon nyugszik, a tulajdonos ennek múködését auditálja is.

- folyamatszemléletû: a teljes kontrollrendszer folyamatokban gondolkodik, input-output viszonyokat vizsgál a vállalatban. Az üzleti főfolyamatok részfolyamatokra, alfolyamatokra bomlanak tovább, és ezekhez csatlakoztatva jelennek meg a kontrollok

2. Hogyan alakult ki a belső kontrollrendszer Önöknél? Mik voltak az első lépések, csírák, tetten érhető nyomok a szervezetben? Időben előre haladva milyen érettségi, fejlettségi szintjei voltak a belső 


\section{kontrollrendszernek Önöknél? Milyen stációi, fokozatai azonosíthatók a szervezet múltbeli életében? Mi mozgatta a fejlődést? Mi volt a fejlődés motorja, kiváltó oka?}

Az alapító SMC 1991-ben Esztergomba hozta a saját technológiáját és az ahhoz tartozó mindenféle ellenőrzési módszertanát. A gyártás során ennek használatát szigorúan megkövetelte. Nem hozta azonban magával a logisztikai rendszerét és a pénzügy-számviteli rendszerét, ezért annak kiépítése és fejlesztése mindvégig magyar hatáskörben történt, az általános tulajdonosi előírások és magyar törvények, jogszabályok betartása mellett.

Az alapítást követően a vállalat ISO 9001 és ISO 14001 szabvány szerinti tanúsítást szerzett, amelyben az alapvető minőségirányítási és környezetirányítással kapcsolatos folyamatait szabályozta.

Az SMC 2007-ben előírta, hogy a cégnél önálló és függetlenített belső ellenőrzési szervezetet kell kiépíteni és múködtetni, így 2008. január 01-től a társaságban megkezdi múködését az Internal Audit szervezet (továbbiakban Internal Audit szervezet, amely a Magyar Suzuki Zrt. belső ellenőrzési szervezetét jelenti) közvetlenül a vezérigazgató alá rendelten. Ekkor vezették be a vállalatnál a jelenleg is múködő, J-SOX compliance audit alapokon nyugvó belső kontrollrendszert. Ennek részeként elkészítették az üzleti folyamatok kockázati térképét és az ehhez kapcsolódó folyamatleírásokat a kontrollpontokkal, kontrolltevékenységekkel együtt. Egyúttal kijelölték az üzleti folyamatok konkrét gazdáit is.

A válság hatására 2009-ben a gyártási volumen komoly visszaesést szenvedett el, ezért kiemelt hangsúlyt kapott a további költségcsökkentés, ill. a szervezettebb, tudatosabb előállítási, gyártási folyamatok kialakítása. A válság hatására a tulajdonos előírta, elvárja a fegyelmezettebb és gazdaságosabb múködést. A válság gyakorlatilag még ma is érződik a cégen, mert a 2015-ben értékesített gépjármúvek darabszáma nem éri el a 2008 évben gyártott mennyiséget. A 2015-ben gyártott autók száma a 2009 évben gyártott mennyiséghez hasonló, ezért ez az elvárás jelenleg is fennáll.

Mára egy komplex, átfogó, szinte mindenre kiterjedő belső kontrollrendszer alakult $\mathrm{ki}$, amely valamennyi termelési és üzleti folyamatot felöleli. Az Internal Audit szervezet a gyártási folyamatokra vonatkozó folyamatosan karbantartott belső kontrollrendszert nem auditálja. A vállalat Minőség Biztosítási kézikönyve szerint az üzemeknek SOS-okat (Suzuki Operating Standards) és múveleti utasításokat (Working Process Sheet) kell készíteniük, és be kell tartaniuk, hogy nagyon jó minőségű terméket állítsanak elő. A Minőségbiztosítási Osztályon működő ISO belső auditorok ezek meglétét és betartását ellenőrzik. 


\section{Az Önök cégének belső kontrollrendszerét mely tényezők befolyásolják}

leginkább? Mely faktorok vannak rá legnagyobb hatással? Mi gyakorolja rá a legnagyobb alakító erőt, mi fejti ki rá a legnagyobb hatást? (Néhány lehetséges faktor: vállalati méret, tulajdonosi előírás, külső jogszabályi kötelezettség, stb.)

A belső kontrollrendszerre alapvetően hatással van az, hogy a magyar törvényeknek, jogszabályoknak és a tulajdonos SMC elvárásainak kell megfelelni. Az SMC előírja a belső kontrollrendszer legfontosabb összetevőit és ezt a hazai Zrt. kiegészíti a magyar törvényeknek, jogszabályoknak való megfeleléssel. Jelenleg a belső kontrollrendszer JSOX alapokon nyugszik, amelyben a COBIT, a COSO valamint a fraud management és a compliance terület elemei integrálva találhatók meg.

Részletek Suzuki Motor Corporation: 2015 évi pénzügyi jelentéséből (Annual Report 2015):

Vállalatirányítás: A vállalatirányításra vonatkozó alapfogalmak

A tisztességes és hatékony múködéssel a Vállalat mindenkor úgy kívánja, hogy megbízható legyen minden érdekelt fél számára, beleértve a részvényeseket, ügyfeleket, partnercégeket, helyi közösségeket, és alkalmazottakat, és hogy folyamatosan növekvő cég legyen, miközben a nemzetközi közösség számára is további hozzájárulást nyújt. Annak érdekében, hogy megvalósítsuk ezt a szándékot, a Vállalat úgy tekint a vállalatirányítás fejlesztésére, mint az egyik legfontosabb kérdés a megfelelő vállalati menedzsment területén, és intenzíven hoz különféle intézkedéseket ennek céljából.

Továbbá annak érdekében, hogy a társadalom és az érdekelt felek bízzanak bennünk, azonnal, tisztességes és pontos módon tájékoztatást nyújtunk a törvényeknek és szabályozásoknak megfelelően, és saját érdekünkből kifolyólag nyilvánosságra hozzunk minden olyan információt, amiből arra a következtetésre juthatunk, hogy az előnyös a vállalat megismerése szempontjából. A vállalat átláthatóságát tovább fogjuk növelni.

Az Magyar Suzuki Zrt-nél nem múködik Audit Bizottság (Board of Company Auditors), hanem csak az anyavállalatnál.. Az SMC Audit Osztálya jelent a Board of Company Auditors-nak és a Corporate Strategy Committee-nek. Továbbá tehát konszern szinten valamennyi gyártó és disztribúciós cég, ill. érdekeltség belső kontrollrendszerét felügyeli, auditálja Japánból.

A Magyar Suzuki Zrt-nél a közgyúlés a társaság legfőbb szerve, amely a részvényesek összességéből áll. A közgyúlés elnöke a vezérigazgató. A közgyűlés kizárólagos hatáskörébe tartozik a PTK-ban leírt, tipikusan a legfóbb szervre vonatkozó ügyekben dönteni. 
Az igazgatóság a társaság ügyvezető szerve, amelynek jelenleg 7 tagja van. Képviseli a társaságot harmadik személyekkel szemben, valamint bíróságok és más hatóságok előtt. Az igazgatóság alakítja ki és irányítja a társaság munkaszervezetét és gondoskodik a társaság üzleti könyveinek szabályszerű vezetéséről. Az igazgatóság rendszeresen tarja üléseit, amelyeken stratégiai jelentőségú napirendi pontokat és esetleges kockázatokat beszélnek meg, illetve döntéseket hoznak a törvényeknek, jogszabályoknak megfelelően. Feladatai közé tartozik, hogy a társaság számviteli törvény szerinti beszámolóját és az adózott eredmény felhasználására vonatkozó javaslatát a közgyúlés elé terjessze. A társaság a vezérigazgatóját az igazgatóság saját tagjai közül válassza meg egy évre, és aki nem a Ptk. 3:283§ szerinti vezérigazgató, mivel az Igazgatóság jogait nem ő gyakorolja, hanem az Igazgatóság. A vezérigazgató elsősorban a társaság operatív irányításáért és napi működésért felel. A fent meghatározott hatáskörben a vezérigazgató jogosult minden olyan rutin döntést meghozni, amely nem tartozik a közgyűlés vagy az igazgatóság kizárólagos hatáskörébe. A társaság munkavállalóival kapcsolatos munkáltatói jogokat a vezérigazgató gyakorolja. A belső ellenőrzési rendszer működtetéséért, annak függetlenségéért és hatékony múködéséért is egyúttal a Vezérigazgató felel, aki e feladatának és felelősségének teljesítése érdekében maga alá rendelten múködteti a Zrt. Internal Audit szervezetét.

A vállalatirányítási alapelvekből kifolyólag a vállalat erőfeszítéseket tesz, hogy mindenkit tájékoztasson a szabálykövetési követelményekről (compliance), az etikai kódexben foglaltakról, és folyamatosan erősíti a belső ellenőrzési rendszert. Az etikai kódexet a dolgozóknak évente oktatják, mert az etikus viselkedés fontos a vállalatnál.

A Magyar Suzuki Zrt. belső kontrollrendszer erősen szabályozott és központosított konszern szinten coso elveket felhasználva a coso Belső Kontroll - Integrált Keretrendszer lehetővé teszi, hogy a Vállalat hatékonyan és eredményesen dolgozzon ki olyan belső kontrollrendszert, amelyek elemei igazodnak a változó üzleti és működési környezethez, a kockázatokat elfogadható szintre csökkentik, támogatják az ésszerű döntéshozatalt és a szervezet irányítását. A Menedzsment és az Igazgatóság folyamatosan döntéseket hoznak, hogy áthatóan fejlesszék és alkalmazzák a kontrollokat az egész szervezeten belül.

A J-SOX compliance audit fő területei a következők:

a) Éves pénzügyi beszámoló (magyar számviteli törvény alapján, az IFRS-t jelenleg még nem vezették be a vállalatnál.

b) Általános kontrollok múködése a vállalatban (JSOX alapon).

i. Értékesítési főfolyamat és kritikus utak (vevői kapcsolattartás, rendelésfelvétel, árképzés, kiszállítás a vevőnek, számlázás) 
ii. Anyagáramlási főfolyamat és kritikus utak (beszerzés, készletezés, belső anyagmozgatás, gyártás - valamint az ehhez kapcsolódó kísérő folyamatok, mint például leltározás, selejtezés, stb.)

iii. pénzügyi folyamatok és kritikus utak (a fófolyamatokhoz kapcsolódóan a kimenő és bejövő bizonylatok kezelése, követeléskezelés, elhatárolások, céltartalékok, tárgyi eszközök kezelése, stb.)

c) Általános informatikai kontrollok múködése (COBIT alapokon).

d) Informatikai alkalmazások(szoftverek) részletes kontrolljai.

Az SMC meghatározza a főfolyamatokon belül a kritikus utat, amely az érték előállítás lánc mentén halad végig a szervezetben. Természetesen Magyar Suzuki Zrt a helyi sajátosságoknak megfelelően kiegészíti azt. Ezért a belső kontrollrendszer egyúttal épít, építkezik a belső folyamatszabályozásra, azaz a belső üzleti folyamatokra. Ebben a kontroll rendszerben 17 föfolyamat van, amelyeket 45 alfolyamatra bontottak le, és 130 kontrollpontot tesztelnek a JSOX operatív tesztelési terve szerint. A hazai Zrt. Internal Audit szervezete 10 folyamatgazdával dolgozik együtt. A folyamatgazdák elvégzik a kockázatelemzést, és az Internal Audit tanácsadói szerepét igénybe szokták venni. Amennyiben a tesztelés során kiderül, hogy a kontroll tevékenységet a folyamatgazda nem megfelelően állapította meg, vagy a kontroll nem múködik, akkor a folyamatgazda akciótervet készít a hiba kijavítására. Majd az Internal Audit teszteli, hogy az akciótervet hatékonyan bevezették-e. A tesztelést angol nyelven dokumentálják az anyavállalat által rendelkezésre bocsátott rendszerben.

A belső kontrollrendszer múködéséhez az SMC Audit Osztálya évente írásos ellenőrzési listákat (check lists) állít össze angol és japán nyelven, és küld meg valamennyi leányvállalatának konszern szinten. Ebben megadja a témakörökkel kapcsolatos kockázatokat és kontrollokat. Ezeket át kell nézni, ki kell egészíteni a helyi sajátságoknak megfelelően, és a „walk through test” keretében mintavételezéssel kell meggyőződnie az Internal Audit szervezetnek, hogy a kontrollok effektíven múködnek-e. Amennyiben egy kontroll nem múködik, akkor a felelős osztálynak vagy üzemnek akciótervet kell készítenie. Az Internal Audit szervezet kezdeményezheti akcióterv elkészítését és nyomon kell követnie, hogy az adott terület az akciótervet bevezette-e, és a kontroll ennek megfelelően múködike. A tesztelés dokumentálása angol nyelven történik

A Magyar Suzuki Zrt. Internal Audit szervezete éves auditterv keretében azt vizsgálja, hogy a fent jellemzett „check list”-ekben és a J-SOX Operation Test-eknél előírt kontrollokat elvégezték-e. Továbbá azt is vizsgálja, hogy a kontroll leírása (dokumentációja), tartalma(design) megfelelő-e. Ha az Internal Audit a dokumentumokból, adatokból megállapítja, hogy a kontroll nem müködött (nem 
múködtették, vagy elégtelen az eredménye) vagy a kontroll leírása, tartalma nem jó, akkor arról értesíti a szakterületet, akinek akciótervet kell kidolgoznia a hiba, hiányosság orvoslására vonatkozóan. Az anyavállalat az éves felülvizsgálata során ezen belső ellenőrzési jelentéseket ill. háttérdokumentumokat (akciótervek, kontrollok gyakorlásának bizonyítékai) kéri be felülellenőrzés céljából.

A tulajdonosnak ezt a szándékát, előírását nem lehet kikerülni, nem lehet negligálni. A magyar vezetők megértették és elfogadják, hogy az anyavállalat jelentős hangsúlyt helyez a szabályszerű, dokumentált múködésre. Ha nem lenne kötelező ennek múködtetése, állításuk szerint a vezetők akkor is fenntartanák a rendszert, mivel annak több hasznát is látják, tapasztalták már. Úgy mint:

- segíti a vállalat kormányzását, nem engedi a káosz és anarchia kialakulását;

- rávilágít múködési nehézségekre, felszínre hozza a problémákat és rákényszeríti a vezetést ezek kezelésére, megoldására;

- további költségek megtakarítását teszi lehetővé;

- optimalizálási, hatékonyságjavítási eredményeket hoz, átfedéseket és párhuzamosságokat szüntet meg;

A J-SOX compliance audit elveken nyugvó folyamatleírásokat írásban dokumentálják a JSOX Audit szoftverben, a változásokról automatikus publikálással értesítik a dolgozókat. Amikor az üzleti folyamatban változtatnak valamit, az üzleti folyamat gazdája köteles a változtatást a folyamatleírásokban is átvezetni és erről az Internal Audit szervezetet értesíteni. Ha a folyamatok az elmúlt egy évben megváltoztak a korábbi évekhez képes, a módosított dokumentáció alapján az Internal Audit szervezet teszteli a megváltozott folyamatban a kontrollok meglétét és múködését. A megváltozott folyamatokról és az audit tesztek eredményeiről az SMC Audit Osztályát is tájékoztatni kell.

Tulajdonos által működtetett SMC Audit Osztály évente szúrópróbaszerűen, dokumentumok bekérésével ellenőrzi a Magyar Suzuki belső kontrollrendszerének működését, 2015-ben pedig átfogóan a helyszínen győződött meg annak múködéséről. Az SMC könyvvizsgálója, Seimei Audit Corporation mely 5 évente ellátogat Esztergomba és saját módszertanával pénzügyi auditot végez, mely révén teszteli a belső kontrollrendszer múködését.

4. Kik működtetik a belső kontrollrendszert, a vállalaton belüli kontrollfolyamatokat Önöknél? Hol helyezkednek ők el a vállalti struktúrában? Sorrendbe lehet-e állítani őket súlyuk, befolyásoló erejük alapján? Egyedül vagy csoportban dolgoznak? Kihez tartoznak függelmileg, kinek jelentenek? (Néhány lehetséges válasz: vezető (menedzserek, igazgatók) szerepet betöltő személyek; minőségirányítási rendszer 


\section{auditorai ill. minőségellenőrök; vállalati controllerek; függetlenített belső ellenőrök; Kockázatkezelési specialisták; stb.)}

A belső kontrollrendszer globális fő felelőse a vállalatnál az első számú vezető, azaz a Vezérigazgató.

A Magyar Suzuki Zrt-nél is múködik a „The 3-lines of Defence” model. Az első védelmi vonalat az üzleti folyamatok tulajdonosai töltik be, kockázatelemzést végeznek és a szükséges preventív vagy detektív kontrollokat beépítik, hogy a kockázatokat csökkentsék és a kitűzött üzleti célokat elérjék. A saját tevékenységieket monitorozzák.

A második védelmi vonalat az ún. „oversight” funkciók mint pl. a pénzügy, HR, minőségbiztosítás stb. látják el, amelyek pl. eljárásokat készítenek és bizonyosságot adnak, hogy a kontrollok múködnek .

- A Társaság jogi csoportja vizsgálja, hogy a kötendő szerződések, belső szabályzatok és utasítások a törvényeknek, a jogszabályoknak megfelelnek-e. Munkavállalókkal kapcsolatos esetleges vizsgálatokat ők végzik, és amennyiben szükséges a Zrt. Internal Audit szervezetét is bevonják A társaság célzottan whistleblowing csatornát tart fenn, és 2016. áprilisa óta a magyar vállalatnál dolgozók is bejelenthetik észrevételeiket.

- A Társaságnál az ISO 9001 és ISO 14001 szabványok érdekében minőségirányítási és környezetirányítási auditokat végeznek. Belső auditorokat folyamatosan képeznek feladataik ellátására. Az Internal Audit tanácsadói funkciójánál fogva együtt dolgozik az ISO belső audittal az eljárások készítése vagy módosítása során.

- A Társaság Pénzügyi lgazgatója alatt múködik Controlling részleg is 4 fővel. A controlling felel a cégszintű üzleti tervezési és beszámolási folyamatokért, a riportok elkészítéséért, a vállalati szintű mutatószámok (célértékek) méréséért. .

- A Társaság informatikai szervezete felelős az IT rendszer szakszerű múködtetéséért, amelybe a hardware és az alkalmazások mind beleértendők. Munkájukat a COBIT előírásai szerint végzik ill. szervezik. Az ő felelősségük az adatvédelem, a jogosultságkezelés múködtetése, stb. a különféle alkalmazások esetében.

- A társaságnál nevesítetten kockázatkezelési terület nincs, ilyen munkakör nem létezik. Mint már korábban említettük az üzleti folyamatok tulajdonosai végzik a kockázatkezelést a saját területükön. A társaságnál úgy nevezett belső elhárítás, --- védelmi szervezet nem működik. Azonban nyomokban e tevékenység megtalálható. A vállaltnál külön részleg foglalkozik a vagyonvédelemmel. A vállalatnál kamerás megfigyelés van, hogy a vállalat vagyonát védjék. Munkahelyi sérülések, balesetek kivizsgálására is 
felhasználhatják a felvételeket a tények megállapítása érdekében a törvényes kereteknek megfelelően.

A harmadik védelmi vonalat az Internal Audit szervezet tölti be. Monitorozza és kommunikálja a belső kontrollrendszer hiányosságait időben azoknak, akik az adott üzleti folyamatokért felelősek, valamint a vezérigazgatónak.

Az Internal Audit szervezet 2 fóállású alkalmazottal múködik. A csoport feladata komplex, az SMC Audit Osztályának szakmai felügyelete alatt a konszernszintű kiadott szabályozások szerint a belső kontrollrendszer szisztematikus vizsgálatát végzik. Jelentéseiket a vizsgált szakterület kapja meg, másolatban tájékoztatásul a Vezérigazgató és a Pénzügyi Igazgató. Az Internal Audit negyedévente beszámol a munkájáról a Vezérigazgatónak és az SMC-nek kérésre. Az Internal Audit compliance tevékenységet is ellát. Az ellenőrzések során vizsgálja törvényeknek, jogszabályoknak és belső eljárásoknak való megfelelést.

A társaság könyvvizsgálója ellenőrzi a pénzügyi folyamatok során alkalmazott belső kontrollrendszer elemeit és maga is teszteli azokat. Nagyrészt azonban épít az Internal Audit megállapításaira. A könyvvizsgáló és az Internal Audit aktívan együttműködik, egymás megállapításait kölcsönösen elfogadják.

Az Internal Audit szervezetnek megvan a lehetősége arra, hogy hiányzó kompetencia bevonása érdekében külső szakértőt, tanácsadót kérjenek fel eseti jelleggel. Erre az elmúlt 3 évben többször sor került célirányos vizsgálat lefolytatása céljából.

5. Az Önök belső kontrollrendszerének mindennapi múködésével kapcsolatosan az alábbi szervezetelméleti kérdéseket, dilemmákat hogy látja:

a. legitimitás: Legitim-e Önöknél a belső kontrollrendszer? Ha igen, mitől legitim, elfogadott, megkérdőjelezhetetlen az Önök belső kontrollrendszerének léte és múködése?

A belső kontrollrendszer legitimitását egyrészről a Vezérigazgató adja, aki múködteti a rendszert, erőforrásokat biztosít hozzá, és akinek a támogatása ill. elvárása nélkül a múködtetés nehezebb lenne. Másrészt a legitimitás a tulajdonostól (SMC) érkezik, akit az SMC Audit Osztálya testesít meg.

b. aktorok: Vannak-e kulcsszereplők az Önök vállalatának belső kontrollrendszere kapcsán, és miért/mitől ők azok? Miben nyilvánul meg az ő kulcsszerepük? 
A kulcsszereplők fentebb már szerepelnek feladataikkal, szerepükkel együtt: Vezérigazgató, üzleti területeken belül a belső folyamatgazdák, Internal Audit szervezet, informatikai terület és jogi csoport.

c. hatalom: Fontos-e a hatalom, az uralom alatt tartás a coso kapcsán Önöknél? Miben, ill. mennyire függ össze a belső kontrollrendszer múködése Önöknél a hatalom gyakorlásával, az irányítással?

A hatalom, ill. a hatalomgyakorlás a Suzuki vállalati kultúrájából következően így nem érzékelhető, nem tetten érhető. Az üzleti folyamatok tulajdonosainak felelőssége a saját folyamatuk uralása, szakszerű irányítása, de ez a vállalat működéséből ered, nem pusztán hatalom gyakorlásából.

A vállalat törekszik az automatizált kontrollok müködtetésére, azaz a manuális (ember által múködtetett) kontrollok helyett folyamatba épített, gépek/szoftverek által végzett azonnali kontrollok elvégzését részesíti előnyben. Ebből kifolyólag a hatalom ill. az irányítás nem kötődik emberi szereplőkhöz, munkakörökhöz, mert azt maga a folyamat végzi el. A mások oldalon lévő dolgozó/munkavállaló pedig természetesnek veszi, hogy a folyamat maga szabályozza, irányítja az ő munkáját (nem pedig egy ember utasítja őt).

Az Internal Audit az üzleti folyamatok tulajdonosait és az általuk kijelölt dolgozókat oktatja a Magyar Suzuki Zrt. belső kontrollrendszeréről.

d. formalizáltság: A belső kontrollrendszerüket inkább az írásos (formalizált, szabályozott) vagy inkább íratlan normák (szokások, viselkedési sémák) jellemzik? Hogyan tudná leírni „belső szabályokkal" az Önök COSO rendszerének mindennapi müködését?

Fentebb kifejtett okokból és az ott elmondott példák alapján állíthatjuk, hogy a belső kontrollrendszer erősen formalizált, szabályzatokban, folyamatleírásokban testesül meg. A szokásjog („Úgy szoktuk...”, „Ezer éve...”) minimális, ha ilyet az Internal Audit szervezet feltár, kéri annak írásba foglalását és a folyamatleírásokban való rögzítését. A vállalatban általános elvárás, hogy minden standardokban legyen rögzítve, előírva. Ugyanakkor a szervezetben erős a lean kultúra is, amely mint mögöttes szabályozóerő van jelen a szervezetben.

e. elvonatkoztatottság: Milyen szimbólumokban, legendákban, hiedelmekben, jelekben, vállalati szokásokban érhető tetten a belső kontrollrendszer múködése Önöknél?

Nincsenek ilyen elemek, a belső kontrollrendszer nem képez hiedelmeket, legendákat. Nincsenek tetten érhető szimbólumok. Az Internal Audit szervezet sem 
olyan szervezet, akitől félni kell, mert munkáját az SMC előírásainak való megfelelés érdekében végzi, de partnernek tekinti az üzleti területen a belső folyamatok gazdáit.

f. izomorfizmus: Adni és kapni - mennyiben igaz ez az Önök belső kontrollrendszerére? Milyen mértékben másoltak máshol müködő jó gyakorlatokat? Honnan, milyen külső forrásokból merítettek ötleteket a fejlesztéshez ill. kiknek adták tovább a saját tapasztalatukat?

A belső kontrollrendszer fejlesztése, fejlődése az SMC-n és Magyar Suzuki Zrt-n múlik. Az SMC által előírt, bevezettetett újdonságok meghatározóak a Magyar Suzuki Zrt-nél is. Ezen kívül a könyvvizsgáló tanácsai tekinthetők fejlesztési javaslatoknak is, ill. sok operatív kontrollelem származik a kaizen körök működéséből, amikor a dolgozók adnak újítási javaslatot egy-egy folyamatban.

A belső kontrollrendszerbe beépített, kívülről érkező egyéb impulzus kevés. Megemlítendő a BEMSZ, melynek rendezvényein az Internal Audit szervezet munkatársai is részt vesznek és onnan tudást hoznak haza, valamint forrásnak számít még a szakirodalom, az internet ill. a munkatársak korábbi munkahelyen szerzett munkatapasztalatok is.

A tudástranszfer az anyavállalat irányába is múködik. Ha az SMC értékes, jó helyi gyakorlatot fedez fel a Magyar Suzuki Zrt. múködésében, azt adaptálja és alkalmazását konszern szinten előírja minden leányvállalatára vonatkozóan.

6. Bármi egyéb olyan dologról szeretne-e említést tenni, amiről eddig nem esett szó, de az Önök belső kontrollrendszere kapcsán feltétlenül fontosnak látja elmondani?

Nincs ilyen dolog.

7. Technikai információk a mélyinterjú létrejötte, lebonyolítása kapcsán

Rögzítve: Esztergomban a Magyar Suzuki Zrt. székhelyén 2016. március 8-án délután 2 óra időtartamban

A mélyinterjút készítette: Milicz Ákos doktorjelölt, Budapesti Corvinus Egyetem

Verziószám: 5.0

A mélyinterjúban partner volt: Kovács Anikó Internal Audit szervezeti Vezető és Majdán Alexandra Belső ellenőr munkatárs. 
A Magyar Suzuki Zrt. részéről átnézte és jóváhagyta: módosításokat és egyeztetéseket követően Kovács Anikó Internal Audit Vezető 2016. év 08. hó 01. napján.

Magyar Telekom Nyrt.

MÉLYINTERJÚ-Összefoglaló

a Magyar Telekom Nyrt. belső kontrollrendszerének intézményesülése kapcsán

0. Kérem röviden ismertesse meg a céget velem, adjon egy összefoglaló képet a vállalatról (főtevékenység, létszám, forgalom, tulajdonosi kör, szervezeti felépítés, leányvállalatok, tanúsítványok, számviteli rendszer fontosabb adatai, stb.)!

A Magyar Telekom Nyrt. Magyarország piacvezető mobil és vezetékes távközlési szolgáltató vállalata, emellett komplex informatikai szolgáltatásokat nyújt partnerei számára, és kommunikációs eszközök kereskedelmével foglalkozik.

A vállalat többségi tulajdonosa közvetetten a Deutsche Telekom AG, aki az aktuális részvénykönyvi adatok alapján a társaság részvényeinek 59,21 \%-ával rendelkezik. $A$ Társaság kisebbségi részvényplakettje a Budapesti Értéktőzsde (BÉT) „A" szekciójában forog.

A Társaság 2015. évi értékesítésből származó árbevétele 502 milliárd forint körül alakult, a közvetlen foglalkoztatotti létszám a NYrt-ben kb. 6.900 fő. Mérlegfőösszege 2015. december 31-én 1016 Mrd. forint volt. A Társaság tartósan nyereséges, a 2015-ös üzleti évben a részvények névértéke után 15\%-os osztalékot fizetett ki. A Társaságnak megközelítőleg 2360 db. telephelye, fióktelepe van. A vállalatnak $14 \mathrm{db}$. leányvállalata van, ezek között olyan ismert cégeket találunk mint a T-System Magyarország Zrt., GTS Hungary Kft., vagy az E2 Hungary Zrt.

A Vállalat 5 féle szabványt múködtet, ezeket tanúsító auditokkal folyamatosan fenntart, fejleszt. A Társaság jelenleg SAP vállalatirányítási rendszert használ. A cégen belül számos tevékenység a cégcsoport más vállalatához, ill. leányvállalathoz van kiszervezve, ezért a Magyar Telekom Nyrt.-re vonatkozó adatok csak korlátozásokkal tükrözik a cégcsoport teljes tevékenységi körét, méretét, múködési sajátosságait.

1. Hogyan írná le a vállalatuk belső kontrollrendszerének aktuális állapotát? Mi jellemzi azt? Milyen elemeit tartja fontosnak? Milyen 


\section{jelzőkkel/határozószókkal tudja jellemezni azt? Mit emel ki lényegesnek vele kapcsolatosan?}

A Magyar Telekom belső kontrollrendszerének legfontosabb, alapvető jellemzői a következők:

- Átfogó: azaz valamennyi funkciót átfed, amely a vállalat működése során felmerül.

- Kockázatalapú (risk based): minden évben fókuszál azokra a kiemelt, kockázatosnak ítélt új területekre (pl. felvásárlás, új üzletág, új termék, új IT rendszer), amelyek újdonságot jelentenek az adott gazdasági évben, és emiatt kockázatot is hordoznak magukban, mert nem rutinszerü üzletmenet jellemzi őket. Emiatt a kontrollrendszer évről-évre változik, magában hordozza szükségszerüen a változások átvezetését.

- Többségi tulajdonos által predesztinált: a Deutsche Telekom kiadja azokat az alapelveket (principle), amelyeket a belső kontrollrendszer múködtetése során kötelező figyelembe venni, alkalmazni.

- Tranzakció szintű kontrollokra koncentrál: igyekszik az elemi tranzakciók mélységéig bevezetni a kontrollokat és vizsgálni azok múködését, megvalósulását, eredményességét.

- 3 védelmi vonal elvét követi: a kontrollrendszer a modell elvei alapján épül fel, első vonalban az üzleti folyamatok kontrollfelelősei vannak, második vonalban a támogató kontrollt végzők, harmadik vonalban a függetlenített belső ellenőrzés.

- Erősen pénzügyi beszámoló orientált: alapvetően az éves (magyar számviteli törvény szerinti) beszámoló elkészítésének megbízhatóságára helyeződik a hangsúly benne ( $\mathrm{kb}$. 70\% súllyal), a maradék 30\%-ban a jogi megfeleléssel (compliance) és múködési kockázati kérdésekkel foglalkozik. Nem része ennek a rendszernek a technológiai folyamatok, a mindennapi, operatív vezetői ellenőrzések rendje és a kontrollkörnyezet részletes elemzése, melyeket a kontrollrendszer külső adottságként kezel. A szabályozói és piaci kockázatok gyűjtése és elemzése a vállalati kockázatkezelő manager feladata.

- Éves ciklusok szerint múködő: a belső kontrollrendszer elemei egy évig stabilak, minden kontrollfolyamat, ill. kontrolltevékenység egy naptári évre vonatkozóan van múködésben, utána - ha a kockázatelemzések, DT előírások, jogszabályok miatt már érdektelen - kikerülhet a Telekom kontrollrendszeréből. Fél év elteltével -a második dokumentációs fázisbanvan lehetőség a megváltozott szervezeteket/IT rendszereket módosítani, kontrollt törölni. Új kockázat hozzáadására már nem kerül sor év közben.

- Angol nyelvű rendszer: mind az alkalmazott belső szoftver, mind a DT dokumentációja, mind a létrehozott dokumentumok angol nyelvúek, a kontrollfelelősök angolul készítik el dokumentumaikat. 
2. Hogyan alakult ki a belső kontrollrendszer Önöknél? Mik voltak az első lépések, csírák, tetten érhető nyomok a szervezetben? Időben előre haladva milyen érettségi, fejlettségi szintjei voltak a belső kontrollrendszernek Önöknél? Milyen stációi, fokozatai azonosíthatók a szervezet múltbeli életében? Mi mozgatta a fejlődést? Mi volt a fejlődés motorja, kiváltó oka?

1991-ban a Magyar Távközlési Vállalatot részvénytársasággá alakítják át és 1993ban privatizálják. A részvénytársasági formában működő Rt-ben létrejön az IIA standardokon alapuló független belső ellenőrzési csoport. A new yorki tőzsdére történő bevezetés előtt nem volt strukturált kontrollrendszer és külön szervezet a MT-nál. A kontrollokat a területek vezetői határozták meg és múködtették a belső szabályozások alapján. A belső kontrollrendszert 1996-ban a Belső Ellenőrzési Csoport építette ki, miután az Igazgatótanács erre felhatalmazást adott. 2002-ben létrejön az elkülönített belső kontrollrendszer és az ezt gondozó szervezeti egység is. Innentől kezdve a Belső Ellenőrzés (IA) és a Belső Kontrollrendszer (COSO) párhuzamosan, de egymástól független tevékenységrendszerként létezett.

Mivel a Magyar Telekom részvényit a Budapesti Értéktőzsdén és a New York-i Értéktőzsdére is bevezették 1997-ben, valamint a többségi tulajdonos DT részvényit is jegyzeték a New Yorki tőzsdén, szükségszerű és egyben kötelező volt eleget tenni a Sarbanes-Oxley törvény(SOX) törvény előírásainak is 2005-től. E kettős ok miatt a Magyar Telekomban ebben az időszakban erősen SOX orientált, a SOX törvénynek megfelelő belső kontrollrendszer múködött, azt kiszolgáló SOX IT TOOL rendszerrel megtámogatva.

Miután 2011-ben a Magyar Telekom és a Deutsce Telekom részvényeit is kivezették a New York-i tőzsdéről, a belső kontrollrendszer fókusza is megváltozott. A Magyar Telekom vezetősége elkötelezett maradt egy megbízható belső kontrollrendszer múködtetéséért, mellyel biztosítható a pénzügyi beszámolók hitelessége, a működési és megfelelőségi kockázatok lefedése. Ennek érdekében vezették be Deutsche Telekom által -a COSO értékelési módszertan alapján- kidolgozott új belső kontrollrendszert (Internal Control System, továbbiakban: ICS), mely megfelel az európai szabályozásnak (EU 8-as direktíva), és a Budapesti Értéktőzsde (BÉT) ajánlásainak. 2012. óta az ICS IT TOOL rendszer támogatja a kontrollok dokumentálását. Habár a SOX szerinti alapelvek, elvárások megmaradtak, az ICS-en belül inkább a kockázatok (risks) váltak fontossá, melyek meghatározásában a menedzsmentnek is van alakító szerepe, lehetősége.

3. Az Önök cégének belső kontrollrendszerét mely tényezők befolyásolják leginkább? Mely faktorok vannak rá legnagyobb hatással? Mi gyakorolja rá 
a legnagyobb alakító erőt, mi fejti ki rá a legnagyobb hatást? (Néhány lehetséges faktor: vállalati méret, tulajdonosi előírás, külső jogszabályi kötelezettség, stb.)

Meghatározó jelentősége van a többségi tulajdonosnak (Deutsche Telekom), aki cégcsoport szinten rendelkezik a múködtetendő belső kontrollrendszer alapelveiről (principles). Ez kötelező érvényű előírás minden Telekom cégnél. Ehhez a DT biztosítja a monitoringhoz szükséges informatikai platformot (ICS IT TOOL), valamint a kapott adatok és információk alapján meghatározza a belső kontrollrendszer tárgyévi kritikus pontjait (scoping) is.

A belső kontrollrendszer alakításában jelentős befolyása a helyi menedzsmentnek (1 fő Vezérigazgató és 7 fő vezérigazgató-helyettes), valamint az alájuk rendelt szervezeti egységek vezetőnek (pl. belső ellenőrzés vezetője, belső kontrollrendszer menedzsere, stb.), akik a vezérigazgató-helyetteseken keresztül befolyásolják, alakítják a belső kontrollrendszert (design).

A belső kontrollrendszert alakítja még a társaság választott könyvvizsgálója (jelenleg a PWC), aki a könyvvizsgálati munkája során feltárt hiányosságok, kockázatok kapcsán fogalmaz meg a belső kontrollrendszer erősítésére vonatkozó ajánlásokat a menedzsmentnek címezve.

Befolyással van még a rendszerre a Budapesti Értéktőzsde felelős társaságirányítási ajánlása, a kontrollkörnyezet részét képező jogszabályok és standardok, melyeket a társaság külső adottságként kezel, de figyelembe vesz a belső kontrollrendszer kialakításánál, formálásánál.

Önálló befolyással bírnak még a jelentős könyvelési tételek, amelyek az úgynevezett „szabad szemmel is látható tételek”, mint például a társasági adó, „telekom adó”, adományozás és szponzoráció tételei, IFRS-re való átállás miatti rendszermódosítások, új számlázási rendszer bevezetése stb. Ezek - mivel jelentős kockázatot hordoznak magukban - önmagukban is kontrolltevékenység alanyaivá válnak a belső kontrollrendszeren belül.

4. Kik müködtetik a belső kontrollrendszert, a vállalaton belüli kontrollfolyamatokat Önöknél? Hol helyezkednek ők el a vállalti struktúrában? Sorrendbe lehet-e állítani őket súlyuk, befolyásoló erejük alapján? Egyedül vagy csoportban dolgoznak? Kihez tartoznak függelmileg, kinek jelentenek? (Néhány lehetséges válasz: vezető (menedzserek, igazgatók) szerepet betöltő személyek; minőségirányítási rendszer auditorai ill. minőségellenőrök; vállalati controllerek; függetlenített belső ellenőrök; Kockázatkezelési specialisták; stb.) 
A belső kontrollrendszer múködtetéséért alapvetően a menedzsment felelős. A belső kontrollrendszer éves hatókörét (scope card) a belső kontrollrendszert gondozó senior főmunkatárs (a Magyar Telekom struktúrájában managernek nevezik, valójában ő belső szakértője a COSO rendszernek), a belső ellenőrzés, a könyvvizsgáló adatszolgáltatása alapján a DT állítja össze. A tervezet összeállítása során a menedzsment javaslattal élhet, hogy mely kontrolltevékenységek, kontrollelemek hogyan alakuljanak a következő naptári évben. Az éves kockázati listát az audit bizottság, az ügyvezető bizottság és az igazgatótanács hagyja jóvá.

A belső kontrollrendszer múködtetéséért összesen 165 fő kontrollfelelős felel a vállalaton belül vezetői kijelölés alapján. Ők írásos kinevezést, megbízást erre a feladatra írásban nem kapnak. Ők olyan munkatársak (nem feltétlenül vezetői státuszban lévő alkalmazottak), akik tevékenységük révén kötelesek egy-egy kontrollt működtetni az üzleti folyamatokban. A kontrollrendszer összesen 16 funkciót, annak mintegy 52 főfolyamatát fedi le a vállalatnak, azaz szinte teljeskörűen kiterjed minden tevékenységre. A kontrollfelelősök összesen 224 féle tranzakció során végeznek valamiféle kontrolltevékenységet, ami lehet például engedélyezés, jóváhagyás, összehasonlítás, paraméterbeállítás, utólagos ellenőrzés. Az ő kötelességük jelezni, ha az üzleti folyamatban változás állt be, módosult valamilyen elvárás, új eljárásrend, új szoftver, megváltozott jogszabály, stb. esete áll fenn. Nekik ilyenkor a változásokhoz kell igazítaniuk a kontrolltevékenységeket is, mely a következő éves ciklusban mint megváltozott kontrollfolyamat lesz jelen az ICS-ben is.

A vállalaton belül a Jogi és Társasági Ügyek Vezérigazgatóságán belül egy elkülönített szervezeti egység (továbbiakban ICS csoport) gondozza a belső kontrollrendszert, amelyet szakértő manager vezet. A csoport feladata az „éves ciklusokra” épülő rendszer gondozása, a munkatársak segítése a kontrolltevékenységek gyakorlásában, valamint a monitoring tevékenység ellátása a coso rendszer múködését illetően. A csoport 2-3 (ideális esetben 3 állandó fő) munkavállalóból áll.

Céljuk annak biztosítása, hogy a Magyar Telekom múködése megfeleljen az irányelveknek, specifikációknak, törvényi előírásoknak, szabályozásoknak, illetve ezek biztosításához folyamatokat dolgoz ki, annak érdekében, hogy védje a shareholder-eket és a nagyközönséget a szervezeten belüli folyamati/eljárási hibáktól és a tisztességtelen gyakorlattól.

Feladatuk a múködés hatékonyságának növelése, a pénzügyi beszámoló megbízhatóságának biztosítása és a törvényeknek és szabályoknak való megfelelőség érdekében meghatározzák és kialakítják módszertanokat a belső kontrollrendszer javítására vonatkozóan. 
Az üzleti területek vezetőivel együttmüködve azonosítják, elemzik a problémákat, akció terveket egyeztetnek, tájékoztatást nyújtanak a haladásról a határidőkhöz képest.

Az ICS csapat irányítása az ICS vezető feladata, aki Riportok készít az Audit Committee, Management Committee, Board of Directors, Deutsche Telekom és a Budapesti Értéktőzsde részére. A belső kontrollrendszerrel kapcsolatos dokumentációs és önértékelési feladatok koordinálása, módszertani felülvizsgálata a fő feladata a DT által megszabott határidők betartásával. Ezen kívül a Magyar Telekomon belüli folyamatváltozások nyomon követése, leképezése az ICS-ben, a felhasználók támogatása az ICS rendszer használatában, külső és belső auditorral való együttmúködés, a DT által szervezett tréningeken való részvétel, a munkahelyi vezető által meghatározott, a belső kontrollrendszer múködtetésével kapcsolatos egyéb feladatok elvégzése.

Fentieken kívül aktív kontrolltevékenységet végeznek a szervezetben a minőségirányítási rendszer belső auditorai, a kockázatelemző szakértő, controllerek, a compliance csoport tagjai, akik mind a második védelmi vonalban végzik szakmai tevékenységüket. Ezen kívül 12 fős belső ellenőrzési csoport látja el a harmadik védelmi vonalba tartozó kontrollfeladatokat.

A Telekom csoporton belül a belső kontrollrendszer úgynevezett éves ciklusokra épül rá, azaz minden naptári évnek önálló scope-ja, dokumentálási fázisa, kontrolltesztelése és visszacsatolása van. Egy ilyen ciklus általában a következő logikai elemekből áll össze:

- kora tavaszi időszak: scoping időszaka a Magyar Telekomnál, amikor a menedzsment elvégzi a kockázatos területek feltárását, ill. ebben a szakaszban adja ki a DT a tárgyévre vonatkozó részletes elvárás-rendszerét is.

- tavaszi időszak: kontrollokat tartalmazó belső dokumentumokat elkészítik az üzleti területek kontrollfelelősei és azt betöltik a ICS IT TOOL-ba. E folyamatot a ICS szakértője felügyeli.

- nyári időszak: tesztelés, melynek során a kontrollfelelősök az alapelvekre vonatkozóan önértékelő (önbevalló) teszteket végeznek el és dokumentálnak le, míg a belső ellenőrzés, a könyvvizsgáló ill. az ICS csoport független belső teszteket végez a tranzakciók szintjén. A tesztek eredményei a kiértékelések (test result). A tesztelés időszakában a kontrollfelelősök felmérik és számszerúsítik, hogy az általuk múködtetett kontrollok hiányosságai az éves beszámolóra várhatóan milyen hatással vannak. Eltérés, hiányosság esetén a póttevékenységet, ill. intézkedést rendelnek el a kontrollfelelősök, melynek eredményeit az ICS csoport utóellenőrzi. 
- kora őszi időszak: a riportok elkészítésének időszaka. Az előzetes jelentést a vezérigazgató és a pénzügyi vezérigazgató-helyettes írja alá, majd beterjesztésre kerül az audit bizottság, az ügyvezető bizottság, az igazgatótanács illetve a többségi tulajdonos felé.

- őszi-téli időszak:,Dokumentáció javítása, kontrollok felvétele vagy törlése. Eekkor kerül sor az ismétlő tesztek elvégzésére is.

- tárgyévet követő tavaszi időszak: a lezárási szakasz, melynek során elkészül a Magyar Telekom összegző jelentése, egyúttal lezárják az ICS IT TOOL rendszerben a tárgyévre vonatkozó kontrollrendszert. Az összegző jelentést megkapja a menedzsment, az Audit Bizottság, a tulajdonos(DT) valamint egy kivonatát a BÉT.

5. Az Önök belső kontrollrendszerének mindennapi müködésével kapcsolatosan az alábbi szervezetelméleti kérdéseket, dilemmákat hogy látja:

a. legitimitás: Legitim-e Önöknél a belső kontrollrendszer? Ha igen, mitől legitim, elfogadott, megkérdőjelezhetetlen az Önök belső kontrollrendszerének léte és múködése?

A belső kontrollrendszernek egyrészről a tulajdonosi elvárás képezi a legitimitását, hiszen az anyavállalat kötelezően írja elő a múködetését és annak bizonyos részleteit is. Másrészről a menedzsment felismerte, hogy az ICS segítségére van a mindennapi múködésben, ezért a múködtetéséért is kiáll és fontosnak tartja, amelyet a Gazdasági Vezérigazgató-helyettes által kiadott közlemény(kommunikáció) minden dolgozóval is tudat közvetlenül.

b. aktorok: Vannak-e kulcsszereplők az Önök vállalatának belső kontrollrendszere kapcsán, és miért/mitől ők azok? Miben nyilvánul meg az ő kulcsszerepük?

A főbb aktorokat fentebb az 5. pontban részleteztük, tevékenységeiket és felelősségi köreiket bemutattuk.

c. hatalom: Fontos-e a hatalom, az uralom alatt tartás a coso kapcsán Önöknél? Miben, ill. mennyire függ össze a belső kontrollrendszer müködése Önöknél a hatalom gyakorlásával, az irányítással?

A Magyar Telekom belső szervezeti kultúrájában ez a fajta hatalmi szempont nem jelenik meg. A kontrollfelelősök a kinevezésük okán végzik a kontrollokat, ez számukra inkább kötelesség, mellyel néhány jog is együtt jár, ám ettől ők még nem válnak a szervezeten belül hatalmi központokká. 
d. formalizáltság: A belső kontrollrendszerüket inkább az írásos (formalizált, szabályozott) vagy inkább íratlan normák(szokások, viselkedési sémák) jellemzik? Hogyan tudná leírni „belső szabályokkal" az Önök coso rendszerének mindennapi müködését?

A belső kontrollrendszert teljes mértékben és kötelezően írásos formában, dokumentációs kötelezettség mellett kell működtetni. Az ICS IT TOOL maga, a kontrolltevékenységek leírása, a riportok, a tesztelések eredményei, az akciótervek, az intézkedések, a DT által kiadott alapelvek mind-mind írásos formában állnak rendelkezésre és az ICS minden információját kötelező is írásba fektetni. Mindezeket lehetőség szerint elektronikus formában teszik.

e. elvonatkoztatottság: Milyen szimbólumokban, legendákban, hiedelmekben, jelekben, vállalati szokásokban érhető tetten a belső kontrollrendszer múködése Önöknél?

Legendák és hiedelmek léteznek az ICS múködése kapcsán, de ezek nagy része nem valós csak munkatársaink egy része gondolja, hogy az ICS valaki miatt van, kötelező rossz, és a kontrollok el nem végzése büntetést von maga után. Valójában ilyen szankciórendszer nincsen, habár a kontrollfelelősök premizálási rendszerében egy elem az, ha valaki az ICS-ből eredő kötelességeit nem teljesíti határidőre és megfelelő minőségben, ami a dolgozók néha büntetésként élnek meg.

Ugyanakkor az is elvárás a kontrollfelelősök irányába, hogy az elvégzendő kontrolltevékenységeket úgy írják le, hogy az a napi gyakorlatot tükrözze és tényleg azokat a kontrollokat, ellenőrzési pontokat tartalmazza, amit az adott területen (folyamatban, rendszerben, tevékenységben) egyébként is elvégeznek a munkatársak. Tehát a kontrollrendszernek konkrétnak kell lennie, hogy azt egy tanult, de külső laikus fél is megértse, hogy hogyan kell elvégezni. Ezért a kontrollrendszer nem lehet elvont, elvonatkoztatott.

f. izomorfizmus: Adni és kapni - mennyiben igaz ez az Önök belső kontrollrendszerére? Milyen mértékben másoltak máshol müködő jó gyakorlatokat? Honnan, milyen külső forrásokból merítettek ötleteket a fejlesztéshez ill. kiknek adták tovább a saját tapasztalatukat?

A Telekom csoporton belül múködik az úgynevezett DT Best Practise rendszer, amiben a legjobb gyakorlatot mutatják be az egyes kontrollelemek kapcsán. Ezen kívül a tagvállalatok ICS managerei évente egy-két alkalommal szakmai konzultáció céljából találkoznak személyesen is egymással, amely belső találkozókat a DT központja szervez meg. Itt mód nyílik a tudástranszferre, a mások által használt módszerek megismerésére. 
A cégcsoporton kívül az ICS Csoport tagjai továbbképzéseken vesznek részt, ill. konferenciákon hallgatnak előadásokat. Másik oldalról a vállalat tagjai is tartanak előadásokat az ICS-ről az érdeklődők számára, főképp annak prevenciós részét szokták kiemelni.

6. Bármi egyéb olyan dologról szeretne-e említést tenni, amiről eddig nem esett szó, de az Önök belső kontrollrendszere kapcsán feltétlenül fontosnak látja elmondani?

Nincs ilyen.

7. Technikai információk a mélyinterjú létrejötte, lebonyolítása kapcsán

Rögzítve: Budapesten a Magyar Telekom Nyrt. székhelyén 2016. június 20-án délután 2 óra időtartamban

A mélyinterjút készítette: Milicz Ákos doktorjelölt, Budapesti Corvinus Egyetem

Verziószám: 2.1

A mélyinterjúban partner volt: Vas Tünde Internal Control System szakértő

A Magyar Telekom Nyrt. részéről átnézte és jóváhagyta: módosításokat követően Vas Tünde Internal Control System szakértő 2016. év július hó 25. napján.

Auchan Magyarország Kft.

\section{MÉLYINTERJÚ-Összefoglaló}

az Auchan Magyarország Kft. belső kontrollrendszerének intézményesülése kapcsán

0. Kérem röviden ismertesse meg a céget velem, adjon egy összefoglaló képet a vállalatról (főtevékenység, létszám, forgalom, tulajdonosi kör, szervezeti felépítés, leányvállalatok, tanúsítványok, számviteli rendszer fontosabb adatai, stb.)!

Az Auchan Magyarország Kft. 1996-ban alakult, 1998-ban nyitotta meg első áruházát Budaörsön, 2012-ben a cég felvásárolta a CORA Áruházakat, így jelenleg 
összesen 19 darab hipermarketet és 3 darab logisztikai központot múködtet Magyarországon. Fő tevékenységi köre az élelmiszer és nem élelmiszer termékek kiskereskedelme, de a társaság 18 darab benzinkutat is üzemeltet, valamint pénzügyi szolgáltatásokat nyújt vevőinek és ingatlan bérbeadással is foglalkozik.

Az AUCHAN fő stratégiája, hogy jó áron nyújtsa termékeit a vevőknek, de emellett vásárlói élményt is tudjon nyújtani. Áruházaiban 40-70 ezer darab közötti termékből (szortiment) válogathat a fogyasztó. 2015. évet nézve az AUCHAN a hetedik legnagyobb forgalmú áruházlánc Magyarországon, az FMCG szektor egyik legnagyobb szereplője. Forgalma a 2015. évben kb. $337 \mathrm{Mrd}$. forint volt, az alkalmazotti létszám közel 7000 fő., mérlegfőösszege 120 Mrd. forint körül volt.

A vállalat kizárólagos tulajdonosa a francia székhelyű Auchanhyper SA, mely egyben az Auchan cégcsoport holdingközpontjának is tekinthető. A társaságot ügyvezetőként a vezérigazgató irányítja, aki az igazgatótanács jogkörét is gyakorolja, mivel külön igazgatótanács nem múködik a KFT-nél. A vezérigazgató az operatív irányítás első számú embere a vállalatnál. Felügyelő Bizottság a tulajdonos által kijelölt tagokból, képviselőkből áll.- A vállalatnál Audit Igazgatóság működik nemzetközi és hazai szinten.

A Vállalat minden telephelyén HACCP múködik, melyet auditokkal folyamatosan fenntart, fejleszt. A Társaság jelenleg Oracle vállalatirányítási rendszert használ.

\section{Hogyan írná le a vállalatuk belső kontrollrendszerének aktuális állapotát?} Mi jellemzi azt? Milyen elemeit tartja fontosnak? Milyen jelzőkkel/határozószókkal tudja jellemezni azt? Mit emel ki lényegesnek vele kapcsolatosan?

Az Auchan Magyarország Kft. belső kontrollrendszerét az alábbi kulcsszavakkal lehet legjobban jellemezni, leírni:

- Átfogó: valamennyi tipikus vállalati tevékenységet, funkciót lefed, amely a szervezeten belül felmerül, azaz a szabályszerűség és a pénzügyi riportálás mellett az áruházi folyamatok valamennyi területére is kiterjed.

- Erősen kereskedelem orientált: a Kft. főtevékenységéből eredően annak érdekében múködtetik, hogy az áruházi kereskedelmi tevékenység megfelelő nyereséget eredményezzen

- Decentralizált: A múködtetési feladatok nagyrésze, ill. az eredményességért való felelősség az áruházakra van delegálva, mivel ott zajlik az alaptevékenység, ezért az Áruházvezetők döntései révén, helyben valósulnak meg a kontrolltevékenységek jelentős hányada.

- Tulajdonosi standardok és magyar előírások mixeként múködik: A francia Auchan központ kiadja a cégcsoportra egységes elvárás-rendszert a 
kontrollokra vonatkozóan, azt a magyar Kft. kiegészíti a hazai jogszabályokból eredő előírásokkal, helyi szabályozások miatti ellenőrzési tevékenységekkel. A kettő együtt képezi az elérendő követelményeket.

- Visszacsatolás vezérelt: A kontrollok eredményeit (audit)riportokban és egyéb dokumentációkban (pl. terv-tény kimutatások) rögzítik, ezek a megállapítások indukálják a beavatkozásokat, későbbi intézkedési terveket.

- Erősen szabályozott, dokumentált: Valamennyi eleme írásban (szabályzatban, feljegyzésben, eljárásban, munkautasításban, jelentésben, stb.) rögzített.

- Éves ciklus jellemzi: A Kft. átfogó auditterve mindig egy üzleti évre szól, ennek a ciklusnak a végén születik összegző értékelés a kontrollok tárgyévi működéséről, hatékonyságáról.

- Magyar nyelvű rendszer: minden létrehozott dokumentum magyar nyelven készül el

2. Hogyan alakult ki a belső kontrollrendszer Önöknél? Mik voltak az első lépések, csírák, tetten érhető nyomok a szervezetben? Időben elöre haladva milyen érettségi, fejlettségi szintjei voltak a belső kontrollrendszernek Önöknél? Milyen stációi, fokozatai azonosíthatók a szervezet múltbeli életében? Mi mozgatta a fejlődést? Mi volt a fejlődés motorja, kiváltó oka?

Az Auchan Magyarország Kft. 1996-ban jött létre, 1998-ban nyitotta meg első áruházát. A magyar vállalat menedzsmentje készen kapta a követendő szabályokat, menedzsment rendszereket az anyavállalattól. Ezek az alapvető előírások, modellek érdemben nem változtak azóta sem. Ennek része az áruházi menedzsmentstruktúra, ebből következően az ott végzett kontrolltevékenységek, valamint a központban ellátott kontrollfunkciók is.

A Kft. működésében azóta „kisebb” fejlesztések, változtatások léptek életbe, melyek befolyásolták a kontrollok múködésének rendszerét is. Ilyenek például a szervezeti struktúra változása, a lean térnyerése és vele együtt a belső folyamatok átalakulása, és új, innovatív megoldások születése (pl. elektronikus dokumentummenedzsment), amihez a kontrollrendszernek is igazodnia kellett. A változások másik okozója maga a piac változása volt, amelyek új és új kihívások elé állították a céget (pl. töltőállomások megnyitása, bizalomkártya bevezetése, webshop nyitása), melyekkel párhuzamosan a belső ügyviteli, irányítási és ellenőrzési folyamatok is szükségképpen megváltoztak, jellemzően bővültek az új tevékenységek miatt. Ez pedig arra késztette a menedzsmentet, hogy a megváltozott ill. új folyamatokban a kontrollokat is kialakítsák, újraszervezzék. Ugyancsak erős hatással bír a kontrollrendszerre az IT eszközök térnyerése, mivel a vállalat célja a belső 
folyamatai egy részének gépesítése IT eszközökkel, azaz emberi beavatkozástól függetlenné tétele ( $p l$. készletfigyelés, rendelések kezelése, súlyalapú ellenőrzések elvégzése, stb.). Ezen törekvések pedig azt követelik meg, hogy az alkalmazott kontrollokat is az automatizált vállalatirányítási rendszerbe illesszék bele, azaz folyamatosan felértékelődik az IT és a digitális adatkezelés szerepe a cégnél.

3. Az Önök cégének belső kontrollrendszerét mely tényezők befolyásolják leginkább? Mely faktorok vannak rá legnagyobb hatással? Mi gyakorolja rá a legnagyobb alakító erőt, mi fejti ki rá a legnagyobb hatást? (Néhány lehetséges faktor: vállalati méret, tulajdonosi előírás, külső jogszabályi kötelezettség, stb.)

Meghatározó jelentőségű a hazai jogi szabályozás, ill. ezek változásai (lásd pl. vasárnapi boltzárás, fizetendő bérpótlékok, kötelező nyereségminimum követelménye, stb.). A cégre vonatkozó külső előírások (pl. élelmiszerbiztonsági előírások, származásra és beszerzési minimumárakra vonatkozó szabályok, jövedéki szabályozás az üzemanyagok esetében, készpénz-kezelési és szállítási előírások, adatvédelmi jogszabályok, munkaügyi előírások, stb.) alapvetően meghatározzák a kereskedelmi tevékenység kereteit hazánkban, ezekhez az AUCHAN áruházainak is alkalmazkodniuk kell. A kontrollok itt ebben az aspektusban a jogszabályoknak, előírásoknak való megfelelést biztosítják, ill. a szabályok változása esetén a megváltozott előírásokhoz való mihamarabbi alkalmazkodást ellenőrzik vissza.

Második legnagyobb hatással a központból érkező, csoportszintű szabályozások bírnak, ezek írják elő az alapvetően követendő ellenőrzési és visszacsatolási feladatokat áruházi és központi szinten is. Ezek a tulajdonosi előírások minden országban egyformák, azonos alapműködést, csoportszintű minimumot írnak elő. Ezt egészítik ki az egyes országok helyi vezetései a saját országuk specialitásaival, az egyes helyi cégek egyedi szükségességeiből fakadó „bővítményekkel”.

A harmadik legnagyobb befolyással maga a piaci trendek vannak. A kereskedelmi szektor gyorsan változik, sok az újdonság, és ez gyors reagálást tesz szükségessé. A gyorsan bekövetkező, radikális változások pedig megkövetelik az újszerū, innovatív ellenőrzési eszközök, módszerek bevezetését is az áruházakban. Ezeknek az új eszközöknek pedig velejárója, hogy azok kontrollját is be kell vezetni, amely szintén újdonságszerű, mint például szortiment változás, online kassza, EKÁER.

4. Kik múködtetik a belső kontrollrendszert, a vállalaton belüli kontrollfolyamatokat Önöknél? Hol helyezkednek ők el a vállalti struktúrában? Sorrendbe lehet-e állítani őket súlyuk, befolyásoló erejük 
alapján? Egyedül vagy csoportban dolgoznak? Kihez tartoznak függelmileg, kinek jelentenek? (Néhány lehetséges válasz: vezető (menedzserek, igazgatók) szerepet betöltő személyek; minőségirányítási rendszer auditorai ill. minőségellenőrök; vállalati controllerek; függetlenített belső ellenőrök; Kockázatkezelési specialisták; stb.)

A vállalat múködésén belül a kontrolltevékenységeket két szinten (áruház és központ) és kétféle aspektusban (szabályszerűségi és pénzügyi) gyakorolják, amely követi a szervezet felépítését, múködését.

Fizikai értelemben az első szint maga az alaptevékenység színtere, azaz az áruház ill. a logisztikai központok. Második szinten pedig a budaörsi központban látnak el koordináló, ill. különféle szakmai kontrollfunkciókat, és innen irányítják az egyes auditokat is, például a felügyelő bizottság múködése az RSE audit, KPMG ellenőrzés. Szakmai értelemben pedig szétválnak a védelmi vonalak szerinti kontrolltevékenységek áruházi, központi igazgatósági és belső ellenőrzési feladatokra, ezek két pólusba koncentrálnak: egyfelől szabályszerúségi aspektusból, másfelől pénzügyi-eredményességi aspektusból vizsgálják a múködést.

Áruházi szint: $A z$ áruházakat 3 fős vezetés irányítja, az áruházigazgató, a humánerőforrás-vezető, és az áruházi kontrolling vezető. Mindhárman munkáltatói joggal rendelkeznek az áruház 300-600 fős létszámból álló alkalmazottai felett, felelnek az áruházi tervek megvalósulásáért, a vagyon (eszközök, készletek, készpénz, stb.) megóvásáért, a szabályok betartásáért. Ők tekinthetők az első védelmi vonalnak, munkájukat az áruházi -managerek és senior managerek segítik, mint az alkalmazottak feletti közvetlen irányítói szintek.

Az áruházigazgatót személyi és munkaügyi kérdésekben a humánerőforrás-vezető, míg gazdasági ügyekben az áruházi controller támogatja, utóbbi - nevével ellentétben - lényegében az áruház gazdasági vezetője, akihez minden gazdasági funkció betagozódik. E három személy irányítása alatt működnek az áruházon belüli direkt (közvetlen) kontrollok, amely az áruház teljes tevékenységét lefedik, de ezek erősen kereskedelemorientáltak (pl. készletfigyelés, élelemiszerbiztonsági monitoring, biztonságtechnikai ellenőrzések, stb.).

Központi szint: a központban hat funkcionális igazgatóság múködik a Vezérigazgató alatt, ezek a szervezeti egységek alakítják, biztosítják az országon belüli egységes múködést, szabályozzák ill. koordinálják az áruházak és a logisztikai központok működését. Valamint itt működik a központi belső ellenőrzési szervezet is.

E funkcionális területek a következők:

- Termékigazgató, aki alá tartozik a beszerzés, kínálat, kereskeldelmi terv és a minőségbiztosítási rendszer múködtetése, beleértve a szabványoknak való megfelelést és az élelmiszerlánc-biztonsági előírások alkalmazásának ellenőrzését is. 
- Humánerőforrás igazgató, aki a személyi ügyekért és a bérpolitikáért felel.

- Pénzügyi Igazgató, aki a számviteli rendszer múködtetése mellett a jogi osztályt is irányítja, aki az általános jogszabályi megfelelésért(compliance) felelős. Emellett a pénzügyi igazgató felel az éves és évközi pénzügyi beszámolók szakszerű, megbízható, valós, naprakész elkészítésének rendszerszintű kialakításáért, a számviteli adatok biztosításáért, valamint az expanzióért és a beruházás menedzsementért, ill. a vállalti kapcsolatokért.

- Teljesítmény igazgató, aki felel a controlling tevékenységekért, a belső ellenőrzésért és a biztonságtechnikai központi szintű irányításáért. Ezen igazgatóság végzi az áruházi tevékenységek ellenőrzését is, valamint az indirekt beszerzéseket is.

- Innovációs Igazgató, aki az újszerű eszközök, módszerek bevezetéséért, meghonosításáért felel (pl. digitalizálás, stb.).

- Hatékonysági Igazgató, aki alá tartoznak az általános szervezési kérdések, a és az IT részleg. Ezen igazgatóság egyrészről az informatikai rendszer auditját végzi el, másrészt a különféle szakterületek visszacsatolásai alapján elkészítik a belső szabályozások módosításait, aktualizálását, valamint felügyeli a lean menedzsentet, a supply chain és a logisztikai területeket.

A központban múködik tehát a második és a harmadik védelmi vonal. A kontrollrendszer egyik alapeleme az éves audit terv (road map), amely kb. 50 darab különféle vizsgálati témát foglal magában. Az éves auditterv pontjait kockázati elbírálás alapján határozza meg a magyar felsővezetés, azonban 2 évente a tulajdonos iránymutatást ad ki, hogy melyek az általa annak minősített témák, melyeket kötelező figyelembe venni. Az éves auditterv konkrét pontjaira előbbiek alapján a központi igazgatók, ill. az áruházvezetők tesznek javaslatot (változó, úgynevezett hangsúlyos pontok), emellett csoportszinten előírják a minden évben kötelezően vizsgálandó témaköröket (állandó pontok - mint például biztonságtechnika, benzinkút-üzemeltetés, HACCP, pénzkezelés). A végleges audit tervet a Vezérigazgató fogadja el és a Felügyelő Bizottság hagyja jóvá.

A Teljesítmény Igazgatóságon belül működő belső ellenőrzési szervezet az elfogadott audit terv alapján végzi az ellenőrzéseket, melyek témától függően az áruházakra és/vagy a központra terjednek ki. Az auditok célja összetett, egyrészről bizonyosságot akarnak nyerni a kijelölt témák kapcsán, másrészt támogató céllal végzik azt, hogy a hibák, hiányosságok kiküszöbölésre kerüljenek. Amennyiben az audit egységesítendő, nem szabályozott múködését fedez fel, központi szinten javaslatot tesz a folyamat egységesítésére, szabályozására a Hatékonysági Igazgatóság felé.

Az auditok teljeskörűek egy-egy téma kapcsán, rendszerszinten vizsgálnak minden összefüggést, beleértve a szabálykövetést, a bizonylatolást, a téma eredményre gyakorolt hatását, a felmerülő kockázatok kezelési módját, stb. Az auditok lehetnek 
előre bejelentettek és véletlenszerüek, megállapításaikat ellenőrzési pontok (check listák) segítségével 1-4 közötti kategória valamelyikébe sorolják be.

$\mathrm{Az}$ auditok eredményeiről riport készül, melyet a vizsgált szakterület, a Vezérigazgató és a Felügyelő Bizottság kap meg. Az audit által feltárt hiányosságokra az illetékes vezetőknek, áruház-igazgatóknak intézkedési tervet kell kidolgozniuk és azt a belső ellenőrzés részére meg kell küldeniük. A belső ellenőrzési szervezet 3 fővel múködik.

A kontrollrendszer másik nagy alapeleme a kontrolling szervezet által múködtetett, folyamatos visszacsatolást biztosító pénzügyi kontrolling rendszere. Ennek célja folyamatosan (havonta) képet kapni a kereskedelemi tevékenység eredményességéről, az elért nyereségről (fedezetekről), a forgalmi és költség, ill. ráfordítás adatokról. A kontrolling rendszer alapelemeit - a kereskedelmi szektor sajátosságainak megfelelően - a tulajdonos írja elő, ő határozza meg hangsúlyos részeit. A kontrolling rendszer fő szereplői a budaörsi központban múködő Teljesítmény Igazgatóságon, a Pénzügyi Igazgatóságon, valamint az áruházak és a logisztikai központok saját kontrollerei. A vállalaton belül összesen

25 fő tevékenykedik kontrolling vezetői és 30 fő kontrolling asszisztensi munkakörben.

A kontrolling tevékenységek közül a következők a hangsúlyosak a kontrollok rendszerszintű gyakorlása kapcsán: rövid-, közép-, és hosszú távú célkitűzések nyomon kísérése, azaz a különféle mutatószámok alakulásának vizsgálata; terv-tény elemzés és az eltérések feltárása valamint hatásgyakorlás a negatív eltérések kiküszöbölésében; veszteségfeltárás és -elhárítás a saját vagyonkezelési területen; különféle fedezetvizsgálatok elvégzése termékre, szortimentre, kategóriára; havi zárások elvégzése ill. irányítása helyi szinten ide értve az adatok helyességének ellenőrzését is; beruházás gazdaságossági számítások végzése és a beruházási projektek nyomon követése. Mindezek mellett a kontrollerek a saját áruházuk gazdasági vezetői is, ezért munkakörük része a különféle számlák, bizonylatok validálása, működtetést érintő megrendelések jóváhagyása, leltárak megszervezése és az eltérések kivizsgálása, stb.

A kontrollerek munkájukat az Oracle vállalatirányítási rendszerrel szimbiózisban végzik (szükség szerint paraméterezik a beállításokat is), ill. heti telefonos és havi értekezlet formájában egyeztetik az aktuális kérdéseket egymással és szükség szerint kezdeményezik a központban egy-egy jelenség kivizsgálását vagy a gyakorlat egységesítését, írásban történő szabályozását. A kontrollerek mindezek mellett egyegy termékkör ügyviteli felelősei is a vállalatnál, valamint ellenőrzik a kiadott szabályzatok betartását is.

$A z$ éves audittervtől függetlenül a cég múködését független választott könyvvizsgálóként a KPMG is elvégzi a tulajdonos megbízásából. Ezen kívül az 
informatikai rendszer biztonságos és megbízható múködését 3 évente külső IT audit keretében szakértők tesztelik.

5. Az Önök belső kontrollrendszerének mindennapi működésével kapcsolatosan az alábbi szervezetelméleti kérdéseket, dilemmákat hogy látja:

a. legitimitás: Legitim-e Önöknél a belső kontrollrendszer? Ha igen, mitől legitim, elfogadott, megkérdőjelezhetetlen az Önök belső kontrollrendszerének léte és müködése?

A belső kontrollrendszert a belépő munkavállalók „készen” kapják, azt kötelező elfogadniuk. Ez a szocializáció részeként a napi munkavégzésbe is beivódik, ezért megkérdőjelezhetetlenné válik. Másrészről a kontrollt gyakorlók és a kontrolláltak is mellérendelt, azaz partneri szerepben vannak, javaslatokat tehetnek a probléma megoldására, ezért érdekeltek az együttműködésben, ill. a kontrollrendszer eredményes és közös működtetésében, mert azt látják, hogy az értük van, számukra is megoldásokat hoz.

b. aktorok: Vannak-e kulcsszereplők az Önök vállalatának belső kontrollrendszere kapcsán, és miért/mitől ők azok? Miben nyilvánul meg az ő kulcsszerepük?

A főbb aktorokat az 5. pontban felsoroltuk tevékenységeikkel, hatásköreikkel együtt.

c. hatalom: Fontos-e a hatalom, az uralom alatt tartás a coso kapcsán Önöknél? Miben, ill. mennyire függ össze a belső kontrollrendszer müködése Önöknél a hatalom gyakorlásával, az irányítással?

Az Auchan belső légkörét a hatalomgyakorlás nem jellemzi, elhatárolódnak a vezetők ettől a felfogástól. A partneri szerepet, a kölcsönös támogatást részesíti előnyben a belső kontrollok kapcsán is.

A belső kontrollrendszeren belül az egyéni felelősség természetesen jelen van, egyegy vezető felel a saját területén a mutatószámokért, a célok teljesüléséért, a tervek megvalósulásáért. Ha elmaradás látszik, az az éves egyéni premizálásában is megmutatkozik, csakúgy mintha valamilyen szabálytalanságot tár fel a belső ellenőrzés vizsgálatai során a múködési területével kapcsolatosan. Ám ez önmagában nem jelenti a hatalom gyakorlását, mint kényszerítő eszköz. A múködés része és velejárója, hogy a Központ ellenőrzi a tevékenységeket. A vállalat egyéni fejlődési lehetőséget biztosít a vállalat minden dolgozójának, egyéni projektekkel, amivel a kihatnak a globális múködésre, ez mint motiváló eszköz nagyon hatékony. 
d. formalizáltság: A belső kontrollrendszerüket inkább az írásos (formalizált, szabályozott) vagy inkább íratlan normák(szokások, viselkedési sémák) jellemzik? Hogyan tudná leírni „belső szabályokkal" az Önök coso rendszerének mindennapi múködését?

A múködés során igyekeznek minden procedúrát, eljárást, szabályt írásban lefektetni a dolgozók és a vezetők számára is. Az áruházigazgatók és két helyettesük szóbeli utasítást (ezt is írásos folyamatszabályozás írja le általánosságban) is adhat a dolgozóknak, de az állandósított kontrolltevékenységek formalizáltak és írásban szabályozottak. A belső ellenőrzés által végzett auditok etalonja mindig az írásban lefektetett dokumentáció, ill. kiadott szabályozás. Ha valami nincs szabályozva, intézkedést hoznak annak írásba fektetéséről.

e. elvonatkoztatottság: Milyen szimbólumokban, legendákban, hiedelmekben, jelekben, vállalati szokásokban érhető tetten a belső kontrollrendszer múködése Önöknél?

Nincsenek ilyen szimbólumok, elvonatkoztatott elemek, hiedelmek. Az elvárásokat le kell írni, konkrétan rögzíteni kell a későbbi objektív számonkérés érdekében. Ezeket a szabályokat terjeszteni kell az elosztólistákon keresztül, oktatni kell bevezetés előtt, nyomon kell követni őket, ezért nem lehetnek elvontak, legendák szintjén létezőek.

f. izomorfizmus: Adni és kapni - mennyiben igaz ez az Önök belső kontrollrendszerére? Milyen mértékben másoltak máshol müködő jó gyakorlatokat? Honnan, milyen külső forrásokból merítettek ötleteket a fejlesztéshez ill. kiknek adták tovább a saját tapasztalatukat?

A vállalaton belüli tudásmegosztást úgynevezett szinergiák keretében végzik, ide tartozik a különféle kontrollok kapcsán szerzett gyakorlatok megosztása is. Ilyen szinergiának számít a havi, személyes kontrolleri találkozó is, de vannak egy-egy témában speciálisták is, akik szakértő managerként oktatják, képzik a többieket is abban a témában. A belső auditor és/vagy igazgató vesz részt az egyes szakszinergiák összejövetelin, ahol megosztásra kerülnek a jó és rossz gyakorlatok egyaránt.

A cégcsoporton kívüli tudásmegosztás nem jellemző a cégre, de esetenként előfordul, hogy az Auchan munkatársai kapcsolatot tartanak a szakterületükön múködő szakmai, civil szervezetekkel. Például az Audit Igazgató tagja az Országos Kereskedelmi Szövetségnek(OKSZ) melyen keresztül a hazai élelmiszerbiztonsági jogszabály-tervezetekhez első kézből jut hozzá, azokat ott véleményezi, ill. a kérdésben eszmecserét folytat a szakmai többi képviselőjével. 
6. Bármi egyéb olyan dologról szeretne-e említést tenni, amiről eddig nem esett szó, de az Önök belső kontrollrendszere kapcsán feltétlenül fontosnak látja elmondani?

Nincs ilyen.

7. Technikai információk a mélyinterjú létrejötte, lebonyolítása kapcsán

Rögzítve: Budaörsön az Auchan Magyarország Kft. székhelyén 2016. július 1-én délelőtt 1,5 óra időtartamban

A mélyinterjút készítette: Milicz Ákos doktorjelölt, Budapesti Corvinus Egyetem

Verziószám: 2.0

A mélyinterjúban partner volt: Balázs Ildikó Audit Igazgató és Leicht Balázs központi kontrolling vezető

$\mathrm{Az}$ Auchan Magyarország Kft. részéről átnézte és jóváhagyta: módosításokat követően Balázs Ildikó Audit Igazgató 2016. 07. 27-én. 


\section{F 6.3.2 Fókuszcsoportos megbeszélések emlékeztetői \\ BEMSZ workshop}

\section{Összegzés a 2016. januári BEMSZ Szakmai délutánról}

Téma: Belső kontrollrendszerek intézményesülése

Helyszín és időpont: Budapest Unicredit Bank székház, 2016. 01. 26.

A BEMSZ 2016. január 26-án tartotta a BEMSZ évindító szakmai délutánját az Unicredit Székházában, ahol mintegy 30 résztvevő tekintette át a belső kontrollrendszerről szóló felvezető előadást, majd hozzászóltak az ott elhangzott állításokhoz, vitaindító kérdésekhez. A szakmai délután meghívott vendége Milicz Ákos volt, aki a Budapest Corvinus Egyetem doktorjelöltje, és kutatási témája a hazai vállalatok belső kontrollrendszerinek múködésének, illetve intézményesülésének mélyreható vizsgálata.

Az előadás keretében a résztvevők megismerkedhettek az ellenőrzés és a kontroll viszonyával, vezetői aspektusával, majd részletes betekintést nyerhettek a belső kontrollrendszer COSO I. és COSO II. féle modelljébe, annak elöírásaiba. A felvezető prezentáció végén az előadó a jelenlévőkhöz fordult és egyrészt kérte véleményüket az elhangzottakkal kapcsolatosan, másrészt kutatási kérdésekkel szólította meg a résztvevőket.

A résztvevő́k mind államháztartási, mind vállalati szférából, különféle iparágakból képviseltették magukat és saját tapasztalataikat fogalmazták meg a belső kontrollrendszer múködésével, intézményesülésével kapcsolatosan. Az előadást követő szakmai vita legfontosabb pontjai, megállapításai összegzésképpen az alábbiak:

1. A kontroll definíciója kismértékben kiegészítésre szorul. Uralom mellett (helyett) érdemes használni a hatalom szót ill. a definícióban az irányítási funkciót megjeleníteni. A vezetónek ugyanis hatalma van, ami abból eredezik, hogy felelős a vállalat múködtetéséert, eredményeiért, fejlődéséért, stb. Ez a felelősség pedig párosul hatalommal, azaz összefügg az intézkedési joggal, ami mögött az irányítási jog húzódik meg. A vezető tehát azért gyakorol kontrollt, mert irányítani (vezetni) akarja a szervezetet a kijelölt irányba.

2. A belső kontroll eredeti angol és szokásos magyar fordításában van egy jelentősnek tekinthető eltérés. Az angol definícióban: „other personel” -t 
olvashatunk, míg a magyar definícióban rendszeresen alkalmazott szerepel. Pedig az other personel-ben benne van (benne lehet) az outsourced szolgáltatását nyújtó beszállító, a külső tanácsadó, a tulajdonos céghez kinevezett megbízottja is, aki a kontrollrendszer mindennapi múködésére ugyancsak hatással van, de mégsem alkalmazottja a cégnek. Az angol elnevezés tehát jobb, megengedőbb, befogadóbb.

3. Belső ellenőrzés elhelyezése a COSO kockában vita tárgya. A belső ellenőrök számára nem egyértelmú a helyük a coSO modellben: van ahol a tevékenység a monitoringhoz kerül, máshol pedig a kontrolltevékenységek részének tekintik őt. Pedig szerencsésebb lenne COSO-n kívül állóként kezelni őt, mivel kívülről értékeli a teljes COSO múködését. Tehát fogalmilag kizárt, hogy annak része legyen. Különösen kritikus ez rossz fordításból eredő magyar szabályozások esetében, amikor egy jogszabályi előírás egyenesen azt mondja ki, hogy a belső ellenőr működteti a belső kontrollrendszert (lásd például HPT 154. § (3) bek.) a belső ellenőrzési rendszer helyett.

4. A compliance szerepe és súlya sokkal nagyobb a valóságban, mint ahogyan azt a védelmi vonalakról alkotott 6 . ábra mutatja. Az ábra nem méretarányos, a résztvevők érzékelése az, hogy a compliance áthatja a teljes védelmi rendszer minden zegét-zugát, nagyobb létszámmal és nagyobb büdzsével rendelkezik, mint a többi szakosított szereplő a második védelmi vonalban. Ezt azonban az ábra nem tükrözi vissza.

5. A kontrollt befolyásoló tényezők közül a szabályozó környezet kissé kilóg a több szempont közül: Az állami előírás előbbre való, mint a tulajdonosi szándék ill. a vállalat mérete. A kontrollrendszerre vonatkozó állami, hatósági előírást kötelező végrehajtani. III. az is előfordulhat, hogy a tulajdonos saját elhatározásából szigorúbb előírásokat ír elő, mint amit a jogszabály vagy hatóság előír a vállalat belső kontrollrendszerére vonatkozóan.

6. A kontrollt müködtető személyek (szereplők) listájában a választott könyvvizsgálónak nincs helye. A GT által előírt, tulajdonosi testület által választott könyvvizsgáló vizsgálja és elemzi a kontrollok múködését, és ezek eredményességéről ad visszajelzését. De nem befolyásolja a belső kontrollrendszer múködését, és nem veszi $\mathrm{ki}$ a részét a kontrolltevékenységekből. 
MCE IGC workshop

\section{Összegzés a 2016. februári MCE IGC munkacsoport ülésének keretében lefolytatott workshopról}

Téma: Hogyan intézményesülnek a vállalatok belső kontrollrendszerei?

Helyszín és időpont: Balatonkenese Hotel Telekom, 2016. 02. 25-26.

A COSO alapokon nyugvó belső kontrollrendszerről (Internal Control System) és a vállalatokon belül működő három védelmi vonalról (The Three Lines Defense Model) tartott bevezető előadást Milicz Ákos pénteken este a résztvevők számára. $A z$ előadás felvezető részében Ákos ismertette a megközelítésében használt fogalmak jelentését (ellenőrzés, kontroll, vezetői visszacsatolási formák, stb.) majd bemutatta a coso keretrendszer nemzetközi szabványát, illetve a szervezeteken belül működő 3 védelmi vonalból álló modellt, végül kitért a belső controllrendszerek intézményesülési aspektusára is.

Előadásának második részében összehasonlította a belső kontrollrendszer legfontosabb elemeit és az ICV-IGC által közzétett Controlling alapvetés tartalmát és azt a kérdést vizsgálta közelebbröl, hogy a két területnek hol vannak közös pontjai ill. átfedései egymással. A szombati workshopok innen folytatódtak, ahol két csoport egymást követően, de egymástól függetlenül arról diskurált, hogy a controllereknek hol a helye és mi lehet a szerepe a védelmi vonalak rendszerében.

Mindkét csoport arra a megállapításra jutott, hogy a controllereknek helyük van a belső kontrollrendszerekben, küldetésüket és funkciójukat nagyrészt a második védelmi vonalban töltik be, bár munkaidejük egy kis részében 1 . vonalbeli konkrét operatív ellenőrzési ill. 3. vonalbeli globális és átfogó vizsgálatokat is végeznek. Ezáltal esetenként átlépnek e két védelmi vonalba is. Mindkét csoport leszögezte, hogy a controller szerepei, a controlling tevékenységek ill. a controller szervezeti elhelyezkedése külön-külön is vizsgálat alá vonható, mert ebben nincs tiszta, egyértelmú és egyetlen univerzális válasz arra, hogy Mi a controlling? .

A csoportok azt is leszögezték, hogy a controlleri tevékenységek nagyobbik hányada az operatív múködéssel, azaz az értékteremtő folyamattal kapcsolatos, de a jó controller megállapításával a vezetést is támogatja, szolgálja egyúttal, hiszen a szervezet hatékony és eredményes múködéséről mutat képet a menedzsment számára és a beszámolók elkészítésért (de nem azok tartalmáért) felel. Kevésbé hangsúlyos múködésében a szabálykövetés ellenőrzése, azaz a compliance kérdéskör.

A workshopokon elhangzott fontosabb konkrét megállapítások, részletes állítások: 
1. A controller a célokért felel és nem a hogyanokért. A controller a második védelmi vonalban is csak feltár, kérdez, elemez, rávilágít összefüggésekre. Segítő, támogató funkciója ebben kimerül, a felelősséget nem vonhatja el az operációtól és nem mondhatja meg a szakterület helyett, hogy hogyan kell valamit csinálni, vagy éppen elkerülni valamit. Hívó erejű kérdésekkel, fajsúlyos állításokkal vezeti rá a menedzsment és a szakterület figyelmét a problémákra, kockázatokra, károkra. (Szemben például a minőségirányítási területtel, amely bár szintén a 2 . védelmi vonalban múködik, mégis munkautasításokban, belső előírások formájában, mérési standardok segítségével konkrétan megmondja az operációban dolgozók számára, hogy mi elfogadható, és hogyan kell valamit szakszerüen elvégezni a minőség elérése végett.).

2. A controller a 2. védelmi vonalban felsorolt szervezetek közül kiemelten együttmúködik az IT területtel (ha az ERP rendszer nem a controlling irányítása alatt áll), a kockázatkezeléssel, és a minőségirányítással, valamint kevésbé erős a kapcsolata a compliance területtel. Utóbbi akkor tud értékes kapcsolat lenni a controller számára, ha az erős belső folyamatleírásokkal az üzletmenet részletes szabályozásáról gondoskodik, és ilyen módon a controller tud tőle kérdezni, ill. irányadó dokumentációt szerezni a „hogyan kellene elvégezni...?" típusú kérdéseihez.

3. A controller vállalaton belüli hasznossága, és így a védelmi vonalakban betöltött eredményes múködése attól függ, hogy a vezető mit vár el a controllertől, mennyire tekinti partnernek, mennyire nyitott a megállapításaira. Azon vállalatoknál, ahol a controller csak adatszolgáltató szerepben van („riportgyártó droid”, „szellemi rabszolga”), ott nehéz a védelmi vonalban betöltött hasznosságát megállapítani. A controlling funkció ezesetben a kontrollkörnyezet része - hiszen létezik és működik ám érdemi hasznossága a belső kontrollrendszer szempontjából kicsi és kontrolltevékenység nem kapcsolódik hozzá.

4. A résztvevők érzékelik azt a tendenciát, hogy a controller hagyományos feladatai mellett többször fordul elő olyan egyéb feladat, amely a normál controlleri szerepbe kevésbé illik bele, de a vállalat vezetése, vagy a közvetlen felsővezető megköveteli, hogy ebben a controlling is vegyen részt feltáró, elemző, kiértékelő munkájával. Ezen feladatok jelentős részben a védelmi vonalak modelljében jól beazonosíthatóan az 1 . vonalhoz tartozó belső kontrolltevékenységek. 


\section{FÜGGELÉK - TÁRGYMUTATÓ}

Disszertációmban gyakrabban előforduló, kulcsszavak jegyzéke az oldalszámok feltüntetésével a következő:

aktorok, 23, 76, 78, 92, 93, 99, 111

audit bizottság, 65, 66, 70, 93, 111, 165, 185, 187

belső ellenőrzés, 34, 36, 37, 40, 48, 51, 52, 70, 80, 93, 96, 107, 116, 126, 165, 166, $167,168,169,170,171,173,188,189,203$

belső kontrollrendszer, 18, 19, 20, 21, 22, 26, 27, 35, 36, 41, 42, 45, 46, 49, 50, 51, $52,54,57,59,60,61,63,64,66,67,68,73,75,84,91,96,97,99,100,101$, $102,104,106,107,108,109,110,112,113,115,118,119,121,165,168,174$, $178,180,184,186,188,189,216,217,218,219,221$

compliance, 19, 35, 42, 46, 52, 55, 59, 64, 70, 94, 98, 102, 109, 111, 116, 124, 126, 165,208

coso, 20, 21, 22, 26, 27, 42, 45, 53, 54, 55, 56, 57, 58, 59, 60, 61, 64, 66, 67, 68, 69, $71,72,73,83,87,95,101,102,103,107,108,109,110,111,114,115,116$, $164,167,186,199,204,212,217$

COSO-ERM, 56, 68, 69, 83, 87, 107, 212

felelős társaságirányítás, 72, 184

felügyelőbizottság, 48, 65, 93, 111, 114, 131, 165, 170, 174, 178, 184, 185, 186, 187

Governance SPICE, 71, 72, 105

ICS, 51

institucionalista szervezetelmélet, 76

intézményesülés, $20,23,75,76,77,78,79,80,81,82,83,84,86,87,88,89,90,91$, $92,93,94,95,96,98,99,100,101,102,107,110,111,112,113,116$

intézményi szociológia, 18, 20, 75, 91, 93, 98, 99, 101

védelmi vonalak, 69, 70, 108, 115 


\section{FÜGGELÉK - RÖVIDÍTÉSEK JEGYZÉKE}

Disszertációmban gyakran használt fontosabb rövidítések jegyzéke a következő:

BEMSZ: Belső Ellenőrök Magyarországi Közhasznú Szervezete

CAE: Chief Audit Executive

CEO: Chief Executive Officer

CFO: Chief Financial Officer

COBIT: Control Objectives for Information and related Technology

COO: Chief Organisation/Operational Officer

COSO: Committee of Sponsoring Organizations of the Treadway Commission

COSO-ERM: Committee of Sponsoring Organizations of the Treadway Commission Enterprise Risk Management

CSV: Comma-Separated Values

FB: Felügyelő Bizottság

GFO: Gazdálkodási Formakód (Gazdasági Szervezetek Regiszteréhez használt osztályozásban)

IAS: International Accounting Standards

IFAC: International Federation of Accountants

IFRS: International Financial Reporting Standards

IGC: International Group of Controlling

IIA: Institute of Internal Auditors

INTOSAI: International Organisation of Supreme Audit Institutions

ISA: International Standards on Auditing

ISACA: Information Systems Audit and Control Association

ISO: International Organization for Standardization

KKV: Kis és középvállalkozás

KSH: Központi Statisztikai Hivatal

MCE: Magyar Controlling Egyesület

MSZT: Magyar Szabványügyi Testület 
PDCA: Plan, Do, Check, Act szavak kezdőbetúiből képzett mozaikszó SOX: Sarbanes-Oxley törvény

SZMSZ: Szervezeti és Múködési Szabályzat

TEÁOR: Tevékenységek Egységes Ágazati Osztályozási Rendszere

TQM: Total Quality Management

USA: United States of America 


\section{HIVATKOZÁSOK}

Ackoff, R.L. (1970.) A concept of corporate planing. New York: John Whiley \& Sons.

Ackoff, R.L. (1971.) Towards a System of Systems Concepts. Management Sience, 17.(11.), pp.661-671.

Amudo, A. \& Inanga, E.L. (2009.) Evaluation of Internal Control Systems: A Case Study from Uganda. International Research Journal of Finance and Economics, 27.(1.), pp.124-144. Available at: http://wenku.baidu.com/view/25987b785acfa1c7aa00ccd8.html [Accessed 16. February 2015.].

Anderson, D.J. \& Eubanks, G. (2015.) Leveraging COSO Across the Three Lines of Defense. 1st ed. Altamonte Springs, Florida, USA: Committee of Sponsoring Organizations of the Treadway Commission. Available at: https://global.theiia.org/standards-guidance/Public\%20Documents/2015Leveraging-COSO-3LOD.pdf [accessed 11. March 2016.].

Andorka, R. (2003.) Bevezetés a szociológiába. Budapest: Osiris.

Angyal, Á. (2009.) Vállalatok társadalmi felelössége, felelős társaságirányítás. Budapest: Kossuth Kiadó.

Anthony, R.N. \& Govindarajan, V. (2009.) Menedzsmentkontroll-rendszerek. Budapest: Panem Kiadó.

Arwinge, O. (2013.) Internal Control - A Study of Concept and Themes. Uppsala: Physica-Verlag.

Atkinson, A.A., Banker, R.D., Kaplan, R.S. \& Young, S.M. (1997.) Management Accounting. második ed. New Jersey: Prentice-Hall International.

Babbie, E. (2001.) A társadalomtudományi kutatás gyakorlata. nyolcadik ed. Budapest: Balassi.

Badacsonyi, G., Kamarás, J. \& Kovács, L. (1979.) A vállalatok és költségvetési szervezetek ellenörzése. Budapest: Közgazdasági és Jogi Könyvkiadó.

Barley, S.R. \& Tolbert, P.S. (1997.) Institutionalization and Structuration: Studying the Links between Action and Institution. Organization Studies, 18.(1.), pp.93-117. Available at: http://digitalcommons.ilr.cornell.edu/articles/130. 
Barney, J.B. \& Ouchi, W.G., eds. (1986.) Organizational economics. London: JosseyBass Publishers.

Bayer, J. (1999.) A politikatudomány alapjai. Budapest: Napvilág kiadó.

BEMSZ-ETK. (2015.) Belső ellenőrzés és csalásmegelőzés. Translated by T. György. Budapest: BEMSZ-ETK Zrt.

Benedek, P. (2014.) A vállalati compliance értékelése. Vezetéstudomány, XLV. évf.(7-8. szám), pp.29-39.

Benedek, M., Szenténé, T.K. \& Béres, D. (2014.) Belső kontrolok a települési önkormányzatoknál. Pénzügyi Szemle, 59.(3.), pp.316-329.

Berger, P.L. \& Luckmann, T. (1998.) A valóság társadalmi felépitése. Budapest: Jószöveg Múhely Kiadó.

Berry, A.J., Broadbent, J. \& David, O. (2005.) Managemet Control - Theories, Issues and performance. második ed. Hampshire: Palgrave Macmillan.

Bertalanffy, L.V. (1969.) Az általános rendszerelmélet problémái. In J. Kindler \& I. Kiss, eds. Rendszerelmélet. Budapest: Közgazdasági és Jogi Könyvkiadó. pp.25-38.

Bierstaker, J.L., Hunton, J.E. \& Thibodeau, J.C. (2009.) Do Client-Prepared Internal Control Documentation and Business Process Flowcharts Help or Hinder an Auditor's Ability to Identify Missing Controls? Auditing: A Journal of Practice \& Theory, 28.(1.), pp.79-94.

Biró, A.Z. et al. (1991.) Intézményesülés és intézményi struktúrák. Janus, 8.(1.), pp.67.

Blumné, B.E. (2011.) A dokumentációs kontrollok fejlesztése a belső ellenőrzési kontrollrendszerekben. In BGF-Magyar Tudomány Ünnepe emlékkötet. Budapest: BGF. pp.383-393.

Boda, G. \& Szlávik, P. (1999.) Vezetői kontrolling. Budapest: Közgazdasági és Jogi Könyvkiadó.

Bodnár, V. (2009.) Miért éppen menedzsmentkontroll? In Menedzsmentkontrollrendszerek. Budapest: Panem Kiadó. pp.XXI-XXVII.

Bodnár, V., Császár, C. \& Dobák, M. (1996.) A kontroll mint vezetői funkció. Vezetéstudomány, XXVII.(3.), pp.22-35. 
Bodnár, V., Dobák, M. \& Lázár, L. (1997.) A "Szervezettervezés és menedzsmentkontroll" alprojekt zárótanulmánya. 23rd ed. Budapest: BKE Vállalatgazdaságtan Tanszék.

Bodnár, P. \& Paróczai, P. (1995.) Gazdasági Informatika. Budapest: Pénzügyi és Számviteli Főiskola.

Bodonyi, M., Márkus, G. \& Malatinszkyné Lovas, I. (2001.) Közpénzek ellenörzése II. Budapest: Perfekt Kiadó.

Borbás, M. (2007.) A könyvvizsgálat története magyarországon. Budapest: Magyar Könyvvizsgálóio Kamara.

Bordáné, R.M. (2010.) A társaságirányítási jelentés és a könyvvizsgáló szerepvállalása - Új elem az európai pénzügyi beszámolási kultúrában. Vezetéstudomány, XLI. évf.(2010. 11. szám), pp.2-14.

Bordáné, R.M. (2011.) Társaságirányítás - Számvitel. Budapest: BCE.

Bordáné, R.M. (2012.) A versenyképesség és a társaságok belső ellenőrzése. Vezetéstudomány, 43.(11.), pp.19-33.

Boulding, K.E. (1956.) General Systems Theory-The Skeleton of Science. Management Sience, 2.(3.), pp.197-208.

BPP. (2011.) ACCA Paper F8 - Audit and Assurance (International). ötödik ed. London: BPP Learning Media.

Bragg, S.M. (2011.) the Controller's function. New Jersey: Wiley.

Braun, T. \& Schubert, A. (2008.) INTERDISZCIPLINARITÁS. ELFOGADJUK-E MAGYARORSZÁGON? Magyar Tudomány, 169.(1.), pp.78-85.

Brignall, S. \& Modell, S. (2000.) An institutional perspective on performance measurement and management in the 'new public sector. Management Accounting Research, 11.(3.), pp.281-306.

Brown Jr., D.E. et al. (2004.) Internal Control Requirements Under Sarbanes-Oxley Challenge Outsourcing Marketplace. Venulex Legal Summaries, Q2, pp.1-8.

Bungartz, O. (2010.) Handbuch Interne Kontrollsysteme (IKS). Berlin: Erich Schmidt Verlag GmbH\&Co.

Burns, J. \& Scapens, R.W. (2000.) Conceptualizing management accounting change: an institutional framework. Management Accounting Research, 11.(1.), pp.325. 
Business Process Modelling for Governance SPICE \& Internal Financial Control (BPM-GOSPEL) konzorcium. (2012.) Felelôs Vállalkozások Irányítási Modellje - A Vállalkozások Irányítási Képességének Fejlesztéséhez. [elektronikus dokumentum] Budapest: Trusted Bussiness Partner - Budapesti Gazdasági Főiskola.

Available

at:

http://www.trusted.hu/attachments/article/46/Felel\%C5\%91s\%20V\%C3\%A 1llalkoz\%C3\%A1sok\%20lr\%C3\%A1ny\%C3\%ADt\%C3\%A1si\%20Modellje.pdf [accessed 15. January 2015.].

Buxbaum, M. (2006.) Vállalati internal audit a gyakorlatban. Budapest: ETK Szolgáltató Zrt.

Cadbury, A. (1992.) The financial aspects of corporate governance. London: Gee and Co. Ltd.

Chambers, A. \& Odar, M. (2015.) A new vision for internal audit. Managerial Auditing Journal, 30.(1.), pp.34-55.

Chang, S.-I., Yen, D.C., Chang, I.-C. \& Jan, D. (2014.) Internal control framework for a compliant ERP system. Information \& Management, 51.(2.), pp.187-205.

Chikán, A. (2008.) Vállalatgazdaságtan. negyedik ed. Budapest: Aula.

Chikán, A., Czakó, E. \& Zoltayné, P.Z. (2010.) Vállalati versenyképesség válsághelyzetben - Gyorsjelentés a 2009. évi kérdíves felmérés eredményeiről. Budapest: BCE Vállalatgazdaságtan Intézet Versenyképesség Kutatóközpont. Available at: http://www.unicorvinus.hu/fileadmin/user upload/hu/kutatokozpontok/versenykepesseg/ GYORSJELENTES 2010.pdf [accessed 10. March 2015.].

Colbert, J.L. \& Bowen, P.L. (1997.) A Comparison of Internal Controls: COBIT ${ }^{\circledR}, S A C$, COSO and SAS 55/78. [elektronikus dokumentum] Pittsford. Available at: http://ddata.over-blog.com/xxxyy/0/32/13/25/a-comparison-of-internalcontrols-cobit--sac--coso-and-sas-5578.pdf. [accessed 16. January 2015.].

COSO. (2004.) Enterprise Risk Management - Integrated Framework (Executive Summary). [elektronikus kiadvány] New York: Committee of Sponsoring Organizations of the Treadway Commission. Available at: http://www.coso.org/documents/COSO ERM ExecutiveSummary.pdf [accessed 14. January 2015.].

COSO. (2004.) Enterprise Risk Management Framework Reference Copy. [elektronikus publikáció] New Work: The Committee of Sponsoring Organizations of the Treadway Commission. Available at: 
http://www.coso.org/documents/Framework\%20Reference\%20Secured.pdf [accessed 03. February 2015.].

COSO. (2006.) Internal Control over Financial Reporting - Guidance for Smaller Public Companies - Volume I. - II. 1st ed. Committee of Sponsoring Organizations of the Treadway Commission.

COSO. (2013a.) Internal Control - Integrated Framework (2013) - Framework and Appendices. New York: AICPA. Available at: https://publication.cpa2biz.com/Coso/coso.aspx\# [accessed 03. February 2015.]. elektronikus példány.

COSO. (2013b.) Internal Control Over External Financial Reporting: A Compendium of Approaches and Examples. [elektronikus anyag] New York: AICPA. Available at: https://publication.cpa2biz.com/Coso/coso.aspx\# [accessed 03. February 2015.].

COSO. (2015) LEVERAGING COSO ACROSS THE THREE LINES OF DEFENSE. 1st ed. Altamonte Springs, Florida, USA: COSO. Available at: http://www.coso.org/documents/COSO-2015-3LOD-PDF.pdf [accessed 01. October 2016.].

Covaleski, M.A., Dirsmith, M.W. \& Weiss, J.M. (2013.) The social construction, challenge and transformation of a budgetary regime: The endogenization of welfare regulation by institutional entrepreneurs. Accounting, Organizations \& Society, pp.333-364.

Dambrin, , Lambert, C. \& Sponem, S. (2007.) Control and change-Analysing the process of institutionalisation. Management Accounting Research, 18.(2.), p.172-208. Available at: http://www.sciencedirect.com/science/article/pii/S1044500507000108\# [Accessed 03. February 2015.].

Dambrin, C., Lambert, C. \& Sponem, S. (2007.) Control and change-Analysing the process of institutionalisation. Management Accounting Research, 18.(2.), pp.172-208.

Dana, R.H. \& Zhongxia (Shelly), Y. (2009.) Why Do Some Accelerated Filers with SOX Section 404 Material Weaknesses Provide Early Warning under Section 302? Auditing: A Journal of Practice \& Theory, 28.(2.), pp.247-271.

D'Aquila, J.M. \& Houmes, R. (2014.) COSO's Updated Internal Control and Enterprise Risk Management Frameworks. CPA Journal, pp.54-59. 
Davila, A., Foster, G. \& Li, M. (2009.) Reasons for management control systems adoption: Insights from product development systems choice by early-stage entrepreneurial companies. Accounting, Organizations \& Society, 34(3/4.), pp.322-347.

Dawson, S. (2015.) Internal Control/Anti-Fraud program design for the smal business - A guide for companies NOT subject to the Sarbanes-Oxley Act. New Jersey: Wiley.

Deloitte \& Touche, 2012. Head of Internal Audit Survey 2014 Capturing insight. pp.1-20. Available at: http://www2.deloitte.com/content/dam/Deloitte/ie/Documents/Audit/201 4 internal audit survey deloitte ireland.pdf. [Accessed 2014.].

Deloitte. (2013.) Felmérés a belső ellenőrzés és a compliance helyzetéről 2013. Budapest: Deloitte Magyarország Vállalati kockázatkezelési tanácsadási osztálya. Available at: http://etkrt.hu/images/dokumentumok/deloitte eloadas.pdf [accessed 09. March 2015.].

Deumes, R. \& Knechel, W.R. (2008.) Economic Incentives for Voluntary Reporting on Internal Risk Management and Control Systems. Auditing: A Journal of Practice \& Theory, 27(1), pp.35-66.

Dillman, D.A. (1994) The design and administration of mail surveys. Annu. Rev. Sociology, 1991.(17.), pp.225-249.

DiMaggio, P.J. \& Powell, W.W. (1991.) The New Institutionalism in Organisational Analysis. Chicago: The University of Chicago Press.

DiMaggio, P.J. \& Powell, W.W. (2011.) Új intézményi megközelítés a szervezetekben. Replika, 74.(1.), pp.63-95. Magyar fordítás, eredeti cím: The New instituticionalism in Organisational Analysis, University of Chicago Press, p1-27.

Dobák, M. (1996.) Szervezeti formák és vezetés. In KJK-Kerszöv Kiadó. Budapest, 1996.

Dobák, M. \& Antal, Z. (2013.) Vezetés és szervezés. In Akadémiai Kiadó. Budapest, 2013.

Dormán, I.Z., Görgényi, G. \& Horváth Margit. (2013.) A belső kontrollrendszer működésének értékelése a központi költségvetési szerveknél. Pénzügyi Szemle, 58.(2.), pp.200-219. 
Eilifsen, A., Messier, W., Glover, S.M. \& Prawitt, D.F. (2010.) Auditing and Assurance Services. London: McGraw-Hill.

Erdei, J., Nagy, J.B., Topár, J. \& Tóth, Z.E. (2010.) Minőségmenedzsment -. Budapest, 2010. Budapesti Műszaki és Gazdaságtudományi Egyetem.

Ernst \& Young, 2012. The Future of Internal Audit Is Now. June. Available at: http://www.ey.com/Publication/vwLUAssets/Future IA/\$FFILE/12041354105 Future\%20IA\%20whitepaper FINAL.pdf. [Accessed 09. February 2015.].

Európai Közösségek Bizottsága. (2008.) Bizottság 1126/2008/EK rendelete. In Európai Közösségek Bizottsága. Brüsszel, 2008. Európai Unió.

EY. (2014) Updated 2013 COSO Framework - fraud risk assessments [PDF file]. EY (1.0) Available at: http://www.ey.com/Publication/vwLUAssets/ey-cosoframework-fraud-risk-assessment/\$̧FILE/ey-coso-framework-fraud-riskassessment.pdf [Accessed 05 March 2015].

Falus, I. \& Ollé, J. (2008.) Az empirikus kutatások gyakorlata. Budapest: Nemzeti Tankönyvkiadó.

Farkas, Z. (2001.) A társadalmi viszonyok - Az intézményes szociológia elmélete. Miskolc: Bíbor Kiadó.

Farkas, Z. (2005.) A KULTÚRA, A SZABÁLYOK ÉS AZ INTÉZMÉNYEK. [elektronikus jegyzet] Miskolc: Miskolci Egyetem. Available at: http://mek.oszk.hu/03000/03092/03092.htm\#19 [accessed 04. February 2015.].

Farkas, S. \& Szabó, J. (2010.) A vállalati kockázatkezelés kézikönyve. harmadik ed. Budapest-Pécs: Dialóg Campus.

Fayol, H. (1984.) Ipari és általános vezetés. Budapest: Közgazdasági és Jogi Könyvkiadó.

Feischmidt, M. (2013.) Az empirikus kutatások kvalitatív módszereinek episztemológiai alapvetései. In Kvalitatív módszerek az empirikus társadalom és kultúrakutatásban. Budapest: ELTE MMI.

Fekete, I., Galambos, P., Ákos, E. \& Jenza, P. (2006.) Integrált kockázatelemzés és kezelés alkalmazási lehetőségei a közszférában. Budapest: ETK Zrt.

Francsovics, A. (2005.) A controlling fejlődésének sajátosságai (doktori disszertáció). Budapest: Budapesti Corvinus Egyetem. 
Fulcher, J. \& Scott, J. (1999.) Sociology. Oxford: Oxford University Press.

Garrison, R.H. (1985.) Managerial Accounting. negyedik ed. Texas: Business Publications.

Gatzert, N. \& Kolb, A. (2014.) Risk Measurement and Management of Operational Risk in Insurance Companies from an Enterprise Perspective. Journal of Risk and Insurance, 81.(3.), pp.683-708.

Ghauri, P. \& Gronhaug, k. (2011.) Kutatásmódszertan az üzleti tudományokban. Budapest: Akadémia Kiadó.

Giddens, A. (1995.) Szociológia. Budapest: Osiris.

Goodin, R.E. \& Klingemann, H.-D. (2003.) A politikatudomány új kézikönyve. Budapest: Osiris.

Goretzki, L., Strauss, E. \& Weber, J. (2013.) An institutional perspective on the changes in management accountants' professional role. Management Accounting Research, 24.(1.), pp.41-63.

Goutama, B. (2013.) Implementing Enterprise Risk Management with ISO 31000:2009. In TUV Rheinland. ?, 2013.

Graham, L. (2015.) Internal Control Audit and Compliance - Documentation and Testing Under the New COSO Framework. New Jersey: Wiley.

Groenewegen, J. (2004.) Who Should Control the Firm? Insights from New and Original Institutional Economics. Journal of Economic Issues, 38.(2.), pp.353361.

Gulick, L. \& Urwick, L., eds. (1937.) Papers on the science of administration. New York: Institute of Public Administration.

Gutassy, A. (2003.) Menedzsmentrendszerek auditálása. In TÜV Rheinland Intercert. Budapest, 2003.

Gutassy, A. (2010.) Ellenőrzés és minőségbiztosítás. In Müszaki Könyvkiadó. Budapest, 2010.

Gyüre, L. (2012.) Belső kontrollok kialakítása és működtetése az önkormányzati vagyongazdálkodás kockázatainak csökkentésére. Pénzügyi Szemle, 57.(2.), pp.183-193.

Hágen, I.Z. \& Kondorosi, F. (2011.) Kontrolling kezdőknek és haladóknak. Debrecen: Controll 2003. Kft. 
Hajdu, O. (2003.) Többváltozós statisztikai számítások. 2003.: KSH.

Hanyecz, L. (2006.) A controlling rendszere. Budapest: Saldo.

Hayne, C. \& Free, C. (2014.) Hybridized professional groups and institutional work: COSO and the rise of enterprise risk management. Accounting, Organizations \& Society, 39.(5.), pp.309-330.

Hermanson, D.R., Smith, J.L. \& Stephens, N.M. (2012.) How Effective are Organizations' Internal Controls? Insights into Specific Internal Control Elements. Current Issues in Auditing, 6.(1.), pp.A31-50.

Hermanson, D.R. \& Zhongxia, Y. (2009.) Why Do Some Accelerated Filers with SOX Section 404 Material Weaknesses Provide Early Warning under Section 302? Auditing: A Journal of Practice \& Theory, 28.(2.), pp.247-271.

Héthy, L. \& Makó, C. (1972.) A vállalati kontroll mechanizmus és a szervezetlenség. Budapest: MTA Szociológiai Intézete.

Hirth, R.B. \& Chambers, R.F., 2015. HAPPY ANNIVERSARY, COSO! Internal Auditor, 2015. 08. Augustus. pp.77-79.

Horngren, C.T. et al. (2008.) Introduction to Management Accounting. New Jersey: Pearson.

Horváth \& Partners. (2009.) Controlling - Út egy hatékony controlling-rendszerhez. Budapest: Complex Kiadó.

Horváth, I. (1973.) Ipari rendszerelmélet. Budapest: Közgazdasági és Jogi Könyvkiadó.

Horváth, P. (2011.) Controlling. tizenkettedik ed. München: Wahlen.

Huang, S.-M., Hsieh, P.-G., Tsao, H.-H. \& Hsu, P.-Y. (2008.) A structural study of internal control for ERP system environments: a perspective from the Sarbanes-Oxley Act. International Journal of Management \& Enterprise Development, 5.(1.), pp.102-121.

Hunyadi, L. \& Vita, L. (2006.) Statisztika közgazdászoknak. harmadik ed. Budapest: $\mathrm{KSH}$.

Hwang, M.S. (2009) Process Quality Levels of ISO/IEC 15504, CMMI and K-model. International Journal of Software Engineering and Its Applications, 3.(1.), pp.33-42. 
ICAEW. (1999.) Internal Control - Guidance for Directors on the Combined Code. London: The Institute of Chartered Accountants in England \& Wales (ICAEW).

IFAC. (2009.) 315. témaszámú nemzetközi könyvvizsgálati standard - A lényeges hibás állítás kockázatának azonositása és felmérése a gazdálkodó egység és környezetének megismerésén keresztül. New York: Könyvvizsgálók Nemzetközi Szövetsége.

IGC, 2012. Alapvetés - A controlling kulcselemei az ICV és az IGC értelmezésében. Alapvetés - A controlling kulcselemei az ICV és az IGC értelmezésében, [elektronikus közzététel] november. pp.1-8. Available at: http://www.igccontrolling.org/img/pdf/ICV IGC Valuepaper HUN.pdf [Accessed 27. January 2015.].

IGC, 2013. Controllerek küldetése. Controllerek küldetése, [elektronikus kiadás] January. p.1. Available at: http://mce.hu/index.php?option=com content\&view=category\&layout=blo g\&id=163\&Itemid=200205 [Accessed 27. January 2015.].

IIA. (2012.) INTERNATIONAL STANDARDS FOR THE PROFESSIONAL PRACTICE OF INTERNAL AUDITING. Florida: The Institute of Internal Auditors. Available at: https://na.theiia.org/standards-

guidance/Public\%20Documents/IPPF\%202013\%20English.pdf [accessed 14. January 2015.]. control szónál.

IIA. (2013.) IIA POSITION PAPER: THE THREE LINES OF DEFENSE IN EFFECTIVE RISK MANAGEMENT AND CONTROL. 1st ed. Altamonte Springs, Florida, USA: The Institute of Internal Auditors. Available at: https://global.theiia.org/standardsguidance/Public\%20Documents/PP\%20The\%20Three\%20Lines\%20of\%20Def ense\%20in\%20Effective\%20Risk\%20Management\%20and\%20Control.pdf [accessed 11. March 2016.].

IIA. (2013a) A BELSŐ ELLENŐRZÉS SZAKMAI GYAKORLATÁNAK NEMZETKÖZI NORMÁI (NORMÁK). 2013th ed. Translated by B.E.K.S. (BEMSZ). [elektronikus dokumentum] Florida: The Institute of Internal Auditors. Available at: http://iia.hu/hu/component/dms/view document/15-iia-normak-2013magyar-egysegesitett.html [accessed 16. January 2015.].

IIA. (2013b) IIA POSITION PAPER: THE THREE LINES OF DEFENSE IN EFFECTIVE RISK MANAGEMENT AND CONTROL. 1st ed. Altamonte Springs, Florida, USA: The Institute of Internal Auditors. Available at: 
https://global.theiia.org/standards-

guidance/Public\%20Documents/PP\%20The\%20Three\%20Lines\%20of\%20Def ense\%20in\%20Effective\%20Risk\%20Management\%20and\%20Control.pdf

[accessed 11. March 2016.].

INTOSAI Professional Standards Committee. (2004.) Irányelvek a belsö kontroll standardokhoz a közszférában. Translated by Á. Endre. [elektronikus kiadás] Bécs: INTOSAI Fôtitkárság - RECHNUNGSHOF. Available at: http://www.asz.hu/modszertan/iranyelvek-a-belso-kontroll-standardokhoza-kozszferaban-intosai-gov-9100/issai-9100.pdf.

IT Governance Institute. (2007.) COBIT 4.1 - Magyar Változat. 41st ed. Translated by I.E. Egyesülete. USA: IT Governance Institute. Available at: https://www.isaca.hu/index.php/item/download/7 822f1a15a39e685d3596 00cf1adac96f [accessed 11. March 2016.].

Ivanyos, J. (2011.) A vállalati kockázatkezelés. [Elektronikus tananyag] Budapest: Budapesti Gazdasági Főiskola. Available at: http://www.tankonyvtar.hu/hu/tartalom/tamop412A/0007 e3 kockazatme nedzsment scorm/borito ZE5Sxsb0vurNioDr.html [accessed 14. January 2014.].

Ivanyos, J. (2012.) Kockázatkezelés a vállalatirányítás nézőpontjából. In Trusted Business Partners Kft. Budapest, 2012.

Ivanyos, J. \& Roóz, J. (2010.) Új megközelítés a közszféra belső kontrollrendszereinek értékelésére. Pénzügyi Szemle, 55.(2.), pp.364-379.

Janvrin, D.J. et al. (2012.) The Updated coso Internal Control--Integrated Framework: Recommendations and Opportunities for Future Research. Journal of Information Systems, 26.(2.), pp.189-213.

Junxun, L. \& Xiaoyan, W. (2008.) Design and Evaluation to Internal Control of Shaanxi Textile Enterprises. International Business Research, 1.(4.), pp.157161.

Available

at:

http://www.ccsenet.org/journal/index.php/ibr/article/view/821/811

[Accessed 16. February 2015.].

Kamarás, J. (1993.) A gazdasági ellenőrzés módszertani alapjai. Budapest: Perfekt Kiadó.

Kehl, D. \& Rappai, G. (2006.) Mintaelemszám tervezése Likert-skálát alkalmazó lekérdezésekben. Statisztikai Szemle, 84.(9.), pp.848-875. 
Kerr, D.S. \& Murthy, U.S. (2013.) The importance of the CobiT framework IT processes for effective internal control over financial reporting in organizations: An international survey. Information \& Management., 50.(7.), pp.590-597.

Kieser, A. (2003.) Szervezetelméletek. Budapest: BKAE Vezetés és Szervezés Tanszék.

Kimmel, P.D., Weygandt, J.J. \& Kieso, D.E. (2005.) Principles of Accounting - Tools for Business Decision Making. Hoboken: John Wiley\&Sons Inc.

Kindler, J. \& Kiss, I. (1969.) Rendszerelmélet. Budapest: Közgazdasági és Jogi Könyvkiadó.

Kinney, W.R..J. (2000.) Research Opportunities in Internal Control Quality and Quality Assurance. Auditing: A Journal of Practice \& Theory, 19., pp.83-90.

Koczor, Z., ed. (2006.) Minőségirányítási rendszerek fejlesztése. Budapest: TüV Rheinland Intercert.

Kontz, H. \& O'Donnell, C. (1972.) Principles of Management: An analysis of managerial functions. New York: McGraw-Hill.

Kotter, J.P. (1991.) Mit csinálnak a vezetők valójában? Harvard business manager magyar kiadás, 1.(2.), pp.8-16.

Kovács, Á. (2000.) A belső ellenőrzés szabványai - az USA kormányzati intézményeiben bevezetett gyakorlat. Pénzügyi szemle, 2000. évf.(3. szám), pp.205-212.

Kovács, Á. (2002.) Új kihívások a pénzügyi ellenőrzés fejlesztésében. Pénzügyi Szemle, 2002. évf.(2. szám), pp.123-137.

Kovács, Á. (2007.) Az ellenőrzés rendszere és módszerei. Budapest: Perfekt Kiadó.

Könyvvizsgálók Nemzetközi Szövetsége (IFAC). (2009.) 240. témaszámú nemzetközi könyvvizsgálati standard - A könyvvizsgáló csalással összefüggő felelössége a pénzügyi kimutatások könyvvizsgálatánál. New York: Könyvvizsgálók Nemzetközi Szövetsége (IFAC).

Körmendi, L. \& Tóth, A. (2003.) A controlling tudományos megközelítése és alkalmazása. Budapest: Perfekt.

KPMG. (2013.) The Road to Transition: COSO's Internal Control 2013 - Integrated Framework [PDF file]. KPMG (1.0) Available at: http://www.kpmg.com/TH/en/topics/ACl/events/ACForum/Documents/vol 
October 2016].

KPMG. (2014.) Sustainability of Internal Controls. In KPMG., 2014.

Kresalek, P. \& Merétey-Vida, Z. (2008.) Ellenörzési alapismeretek. Budapest: Perfekt Kiadó.

Kurniawanti, I.A. (2010.) CRITIQUES TOWARDS COSO'S ENTERPRISE RISK MANAGEMENT (ERM) FRAMEWORK IN ITS BASIC ASSUMPTIONS. Majalah Ekonomi, XX.(3.), pp.312-328.

Laáb, Á. (2011.) Döntéstámogató vezetői számvitel - elméleti és módszertani irányok. Budapest: Complex.

Lander, G.P. (2004.) What is Sarbanes-Oxley? New York: McGraw-Hill.

Lawrence B., S., Mortimer A., D. \& James, H.S. (2003) Sawyer's Internal Auditing: The Practice of Modern Internal Auditing. 5th ed. Altimore, Florida, USA: IIA.

Lawrence, T.B. \& Suddaby, R. (2006.) Institutions and Institutional Work. In 5.R. Clegg, C. Hardy, T.B. Lawrence \& W.R. Nord, eds. Handbook of organization studies. London: SAGE. pp.215-254.

Löffler, H., Ahammer, M., Kerschbaumer, H. \& Nayer, M. (2011.) Handbuch zum Internen Kontrollsystem - Anforderungen anhand des Jahresabschlusses und organisatorischen Aufbaus eines Unternehmens. második ed. Wien: Linde Verlag.

Lucey, T. (1996.) Management Accounting. London: DP Publications.

Lukács, J. (2005.) A könyvvizsgálat szükségessége, fogalma, célja, alapelvei, tervezése és szervezése. In T. Bíró, ed. Könyvvizsgálat és ellenörzés. Budapest: Magyar Könyvvizsgálói Kamara. pp.135-146.

Lukács, J. (2006.) Gondolatok a felügyelő bizottság ellentmondásos szerepéről. Társadalom és Gazdaság, 2006. évf.(1. szám), pp.137-141.

Lukács, J. (2007.) Kreatív számvitel, véletlen hiba, szándékos csalás. Társadalom és gazdaság, 2007. évf.(1. szám), pp.133-142.

Lukács, J. (2009.) Ellenörzés és könyvvizsgálat alapjai. Budapest: BCE Pénzügyi Számvitel Tanszék. Egyetemi jegyzet.

Lukács, J. (2014) Ellenőrzési Esettanulmányok. Budapest: Magyar Könyvvizsgálói Kamara. 
Magyar Szabványügyi Testület. (2009.) Minőségirányítási rendszerek. Követelmények (ISO 9001:2008). In Magyar Szabványügyi Testület. Budapest, 2009.

Magyar Tudományos Akadémia Nyelvtudományi Intézetének munkatársai. (2003.) Magyar Értelmező Kéziszótár. Budapest: Akadémia Kiadó.

Majoros, P. (2004.) A kutatásmódszertan alapjai. Budapest: Perfekt.

Margaret E., B.-H. \& Leon A.M., S. (2000.) Integrity and Internal Control in Information Systems: Strategic Views on the Need for Control. Massatchusetts: Kluwer Academic Publishers.

Marta, J.K.M. et al. (2013.) Perceptions about ethics institutionalization and quality of work life: Thai versus American marketing managers. Journal of Business Research, 66.(3.), pp.381-389.

McKiney, W. \& Mone, M.A. (2003.) Neo-Institutional Theory. In H. Tsoukas \& C. Knudsen, eds. Organisation Theory. Oxford: Osford University Press. pp.361365.

Meigs, W.B., Whittington, O.R. \& Meigs, R.F. (1985.) Principles of auditing. 8th ed. Illinois: Irwin.

Merchant, K.A. \& Van der Stede, W.A. (2012.) Management control systems. harmadik ed. Harlow: Pearson.

Merétey-Vida, Z. (2007.) Belső kontrollrendszerek. Számadó, 16.(11.), pp.3-7.

Meyer, J.W. \& Rowan, B. (1977.) Institutionalized Organisations: Formal Structure as myth and Ceremony. American Journal of Sociology, 83.(2.), pp.340-363.

Milicz, Á. (2011.) Ellenőrzési aspektusok a vállalatok versenyképességének szemszögéből - TM15 mühelytanulmány. Budapest: BCE Vállalatgazdaságtan Intézet, Versenyképesség Kutatóközpont. Available at: http://www.unicorvinus.hu/fileadmin/user upload/hu/kutatokozpontok/versenykepesseg/ TAMOP MUHELYTANULMANYOK 1 -110/TM15 Miliczakos Ellenorzes.pdf.

Moeller, R.R. (2007.) COSO Enterprise Risk Management - Understanding the new integrated ERM framework. New Jersey: John Wiley \& Sons, Inc.

Morris, J.J. (2011.) The Impact of Enterprise Resource Planning (ERP) Systems on the Effectiveness of Internal Controls over Financial Reporting. Journal of Information Systems, 25.(1.), pp.129-157. 
MSZT. (2002.) Útmutató a minőségirányítási és/vagy környezetközpontú irányítási rendszerek auditjához. In Magyar Szabványügyi Testület. Budapest, 2002.

MSZT. (2005.) Minőségirányítási rendszerek. Alapok és szótár (ISO 9000:2005). In Magyar Szabványügyi Testület. Budapest, 2005.

MSZT. (2015.) MSZ ISO 31000 - Kockázatfelmérés és -kezelés. Alap-és irányelvek. 1st ed. Budapest: Magyar Szabványügyi Testület.

MTA Nyelvtudományi Intézet, n.d. Controller írásmód. Helyesírási tanácsadó portál. Available

at: http://helyesiras.mta.hu/helyesiras/default/hqa?page=6\&qcat1=ldegen+sza vak+\%C3\%A9s+nevek\# [Accessed 17. February 2015.].

Nagy, O. \& Németh, E. (2009.) Államháztartási szakellenőrzés. Budapest: Perfekt Kiadó.

Naidu, N.V.R. \& Rao, T.K. (2008.) Management and Entrepreneurship. New Delhi: I. K. International Pvt. Ltd.

NAV KEKI. (2011.) ABPE I. - Általános ellenőrzési modul tananyag. [elektronikus tananyag] Budapest: Nemzeti Adó- és Vámhivatal.

Needles, B.E., Powers, M., Mills, S.K. \& Anderson, H.R. (1999.) Managerial Accounting. ötödik ed. New York: Houghton Mifflin Company.

Németh, P. (1995.) Az ellenőrzési törvénytervezetről. Számvitel és könyvvizsgálat, pp.414-417.

Nilsson, F., Olve, N.-G. \& Parment, A. (2011.) Controlling for competitiveness. Malmő: Liber - Copenhagen Business School Press.

Nulty, D.D. (2008.) The adequacy of response rates to online and paper surveys: what can be done? Assessment \& Evaluation in Higher Education, 33.(3.), pp.301-314.

Nyikos, L. (1999.) Az ellenőrzés rendszere Magyarországon. Budapest: SALDO Kiadó.

Nyikos, L. (2001.) Közpénzek ellenörzése I. Budapest: Perfekt Kiadó.

O'Reilly, V.M., Hirsch, M., Defliese, P.L. \& Jaenicke, H. (1990.) Montgomery's Auditing. New York: John Wiley \& Sons.

Orovai, L. (2006.) Kutatói feladat adatgyűjtésének internetes támogatása. Acta Agraria Kaposváriensis, 10.(3.), pp.75-87. 
Osváth, S. (2000.) Meddig lesznek a törvényesség fügefalevelei a felügyelőbizottságok? Ellenőrzési Figyelö, 2000.(4. szám), pp.18-27.

Ouchi, W.G. (1979.) A CONCEPTUAL FRAMEWORK FOR THE DESIGN OF ORGANIZATIONAL CONTROL MECHANISMS. Management Science, 25.(9.), pp.833-848.

Owusu-Ansah, S. \& Ganguli, G. (2010.) Voluntary Reporting on Internal Control Systems and Governance Characteristics: An Analysis of Large U.S. Companies. Journal of Managerial Issues, 22.(3), pp.383-408.

Pallai, K. \& Kis, N. (2014.) A teljesség felé. Integritásképzés- és kutatás a Nemzeti Közszolgálati Egyetemen. Pénzügyi Szemle, 59.(2.), pp.167-180.

PCAOB. (2012.) OBSERVATIONS FROM 2010 INSPECTIONS OF DOMESTIC ANNUALLY INSPECTED FIRMS REGARDING DEFICIENCIES IN AUDITS OF INTERNAL CONTROL OVER FINANCIAL REPORTING. Washington: PCAOB. Available at: http://pcaobus.org/inspections/documents/12102012 release 2012 06.pdf [accessed 15. February 2015.].

Pfaff, D. \& Ruud, F. (2013.) Schweitzer Leitfaden zum Internen Kontrollsystem (IKS). hatodik ed. Zürich: Orell Füsli Verlag.

Pintér, R. \& Kátay, B. (2010.) A hibrid adatfelvétel módszertani kihívásai. Statisztikai Szemle, 88.(7-8.), pp.723-737.

PwC, 2014. 2014 State of the Internal Audit Profession Study. March. pp.1-28.

Available at:

http://www.pwc.com/en M1/m1/publications/documents/pwc-state-ofthe-internal-audit-profession-2014.pdf [Accessed 09. March 2015.].

PwC. (2014.) Gazdasági bünözés - Az üzleti életet fenyegető globális veszély. Budapest: PwC. Available at: http://www.pwc.com/hu/hu/kiadvanyok/globalis gazdasagi bunozes felm eres/assets/Globalis gazdasagi bunozes 2014 magyar riport.pdf [accessed 18. February 2015.].

PwC. (2016) PWC COSO ERM microsite [Online]. (1.0) Available from: https://www.pwc.com/coso-erm [Accessed 01 October 2016].

Quinn, L.R. (2006) COSO AT A CROSSROAD. Strategic Finance, 88.(1.), pp.42-49.

Radácsi, L. (2000.) Szervezeti etika és etikai intézményesités Ph.D. értekezés. Budapest: BKÁE. 
Rathe, A.W. (1960.) Management controls in business. In Malcolm, D.G. \& Rowe, A.J. Management control systems. New York: John Wiley \& Sons. pp.28-62.

Reichmann, T. (1995.) Controlling mit kennzahlen und managementberichten. negyedik ed. München: Verlag Franz Valen.

Roóz, J. (1999.) A könyvvizsgálat és az ellenőrzés viszonya, új irányzatok az ellenőrképzésben az Európai Unióban és Magyarországon. EU Working Papers, 2.(2.), pp.3-19. Available at: http://epa.oszk.hu/00000/00026/00004/pdf/euwp EPA00026 19990200 3-019.pdf.

Roóz, J. (2001.) Vállalatirányítás-ellenőrzési rendszer (Corporate Governance) fejlődési tendenciái Európában. CEO Magazin, 2.(1.), pp.13-16.

Roóz, J. (2005.) Külső ellenőrzés szerepe az új corporate governance struktúrában. In Tanulmányok Czabán János tiszteletére. Miskolc: Miskolci Egyetem Gazdálkodástudományi Kara. pp.409-422.

Roóz, J. \& Sztanó, I. (2000.) Ellenörzési Euro Konform Módszerek. Budapest: Saldo.

Ruud, T.F. \& Jenal, L. (2005.) Licht im Internal-Control-Dschungel. INTERNE REVISION, pp.455-60.

Sacomano, N.M., Serra Truzzi, O.M. \& Kirschbaum, C. (2013.) Isomorphism and Institutional Control in a Modular Plant of the Automotive Industry. Revista Brasileira de Gestão de Negócios, 15.(49.), pp.524-544.

Sajtos, L. \& Mitev, A. (2007.) SPSS Kutatási és Adatelemzési Kézikönyv. Budapest: Alinea.

Salamon, P. (2013.) Az ellenörzések rendszere és összefüggései - OKJ okleveles pénzügyi revizor képzés tananyaga. OKJ képzési anyag. Budapest: BGF Pénzügyi és Számviteli Kar Továbbképzési Intézet.

Saly, F. (2006.) Belső ellenőrzés az önkormányzatoknál és intézményeiknél. Budapest: ETK Szolgáltató Zrt.

Sawyer, L., Dittenhofer, M. \& Scheiner, J. (2003.) Sawyer's Internal auditing. 5th ed. Florida: The Institute of Internal Auditors.

Schwartz, M. (2014.) Good Management of Risk, Internal Control, and Everything, Else: Getting Back to the Basics. Management Accounting Quarterly, 15.(4.), pp.1-11.

Sebes, J. (2012.) Az ellenőrzés módszertana. Budapest: Kolor Optika. 
Selznick, P. (1996.) Institucionalism "Old" and "New". Administrative Science Quarterly, 41.(2.), pp.270-277.

Shapiro, B. \& Matson, D. (2008.) Strategies of resistance to internal control regulation. Accounting, Organizations \& Society, 33.(2/3.), pp.199-228.

Sharma, U., Lawrence, S. \& Lowe, A. (2010.) Institutional contradiction and management control innovation: A field study of total quality management practices in a privatized telecommunication company. Management Accounting Research, 21.(4.), pp.251-264.

Sieweke, J. (2014.) Imitation and Processes of Institutionalization--Insights from Bourdieu's Theory of Practice. Schmalenbach Business Review, 66.(1.), pp.24-42.

Simons, R. (1995.) Levers of Control. Boston: Harvard Business School Press.

Simons, R. (2000.) Performance measurement \& control systems for implementing strategy. New Jersey: Prentice Hall.

Sinkovics, A. (2007.) Költség- és pénzügyi kontrolling. Budapest: Complex.

Somogyi, Z., ed. (1968.) Vezetés, szervezés, ellenörzés - Lenin szemelvények. Budapest: Szövetkezeti Gazdaságszervezési és Számítástechnikai Iroda.

Szukits, Á. (2015.) Management control system design and the organisational role of controllers. Budapest: Budapesti Corvinus Egyetem. Research Proposal.

Tabuena, J., 2015. Setting COSO Goals for Avoiding Risk, Adding Value. Compliance Week, 2015. 04. April. pp.32-33.

Taylor, F.W. (1983.) Üzemvezetés - A tudományos vezetés alapjai. Budapest: Közgazdasági és Jogi Könyvkiadó.

TI, 2010. Versenykultúra felmérés 2010 - Eredmények és Tanúságok. nov. pp.1-17. Available at: http://transparency.hu/uploads/docs/versenykultura felmeres 2010.pptx [Accessed 10. March 2015.].

Tolbert, P.S. \& Zucker, L.G. (1996.) The Institutionalization of Institutional Theory. In S. Clegg, C. Hardy \& W. Nord, eds. Handbook of organisationa Studies. Longon: SAGE. pp.175-190.

Torlak, O., Tiltay, M.A., Ozkara, B.Y. \& Dogan, V. (2014.) The perception of institutionalisation of ethics and quality of work-life: The perspective of Turkish managers. Social Business, 4.(2.), pp.169-180. 
Török, L. (1977.) Az állami ellenörzés rendszere az európai szocialista országokban. Budapest: MTA Állam és jogtudományi intézetének kiadványa.

Transparency International Magyarország. (2011.) NEMZETI INTEGRITÁS TANULMÁNY. Budapest: Transparency International Magyarország. Available at: http://transparency.hu/NIS kozszfera [accessed 20. February 2015.].

Turner, L.D. \& Owhoso, V. (2009.) Use ERP Internal Control Exception Reports to Monitor and Improve Controls. Management Accounting Quarterly., 10.(3.), pp.41-50.

Tysiac, K., 2015. COSO: Internal control a challenge with outsourced providers. Jurnal of Accountancy, [elektronikus cikk] 2015. 02. 06. February. pp.1-3. Available at: http://journalofaccountancy.com/news/2015/feb/how-toapply-COSO-to-outsourced-providers-201511682.html [Accessed 14. February 2015.].

Veblen, T. (1969.) Institutional Approach. In Types of economic theory. New York: Augustus M. Kelley Publishers. p.611.

Vértesy, L. (2012.) Közigazgatás, ellenörzés, gazdálkodás. Budapest: Nemzeti Közszolgálati Egyetem. Available at: http://vtki.uninke.hu/uploads/media items/vertesy-laszlo-kozigazgatas-ellenorzesgazdalkodas.original.pdf [accessed 12. January 2015.].

Véry, Z., ed. (2004.) Ágazati és funkcionális controlling. Budapest: Saldo.

Véry, Z., 2008. Controlling vagy Kontrolling? Menedzsment Fórum, 2008. július 7. július. p.1. Available at: http://blog.mfor.hu/controlling/1480.html [Accessed 17. February 2015.].

Vigvári, A. (2002.) Az ellenőrzési funkció felértékelődése és a modern gazdálkodás kihívásai. Vezetéstudomány, XXXIII. évf.(10. szám), pp.45-57.

Vigvári, A. (2005.) Pénzügyi ellenőrzés - egy funkció több szerepben. In A. Vigvári, ed. Pénzügyi ellenőrzés - egy funkció több szerepben. Budapest: Budapesti Műszaki és Gazdaságtudományi Egyetem. Gazdaság- és Társadalomtudományi Kar. Pénzügy és Számvitel Tanszék. pp.1-180.

Vijayakumar, A.N. \& Nagaraja, N. (2012) Internal Control Systems : Effectiveness of Internal Audit in Risk Management at Public Sector Enterprises. BVIMR Management Edge, 5.(1.), pp.1-8.

Világgazdaság Online, 2013. A magyar vállalatok csak papíron küzdenek a visszaélések ellen. Világgazdaság Online, 17. April. Available at: 
http://www.vg.hu/vallalatok/a-magyar-vallalatok-csak-papiron-kuzdenek-avisszaelesek-ellen-401824 [Accessed 16. February 2015.].

Vitell, S. \& Singhapakdi, A. (2008.) The Role of Ethics Institutionalization in Influencing Organizational Commitment, Job Satisfaction, and Esprit de Corps. Journal of Business Ethics, 81.(2.), pp.343-353.

Vörös, L. (2008.) Az ellenörzés rendszere és általános módszertana. Budapest: Saldo Kiadó.

Waring, A.E. \& Glendon, A.I. (1998.) Managing Risk. London: Thomson Learning.

Weber, M. (1987.) Gazdaság és társadalom. Budaperst: Közgazdasági és Jogi Könyvkiadó.

Wilkins, A.M. \& Haun, A.L. (2014.) Reframing the Discussion on Internal Control. CPA Journal, 84.(10.), pp.48-51.

Williamson, D. (2007.) The COSO ERM framework a critique from systems theory of management control. International Journal of Risk Assesment and management, 7.(8.), pp.1089-119.

Wilson, T., Wells, S., Little, H. \& Ross, M. (2014.) A History of Internal Control: From Then to Now. Academy of Business Journal, 1., pp.73-89.

Yi, Y., Liu, Y., He, H. \& Li, Y. (2012.) Environment, governance, controls, and radical innovation during institutional transitions. Asia Pacific Journal of Management, 29.(3.), pp.689-708.

Zhang, J. \& Pany, K. (2008.) Current Research Questions on Internal Control over Financial Reporting Under Sarbanes-Oxley. CPA Journal, 78.(2.), pp.42-45. 


\section{SZERZŐ TÉMÁBAN SZÜLETETT PUBLIKÁCIÓI}

\section{MILICZ ÁKOS}

Publikációs jegyzék - 2016. 08. 20.

MTMT azonosító: 10033879

\section{Magyar nyelvü publikációk}

\section{Könyv, könyvfejezet}

Milicz Ákos(2014): Ellenőrzési szerepek és gyakorlatok a szervezetek belső életében. Digitális szöveggyűjtemény Menedzsmentkontroll (controlling) tárgyhoz, In: Vezetés és Kontroll Tanszéki kollektíva szöveggyűjteménye, Budapest: Budapesti Corvinus Egyetem, Vezetéstudományi Intézet, Elérhetőség: http://www.tankonyvtar.hu/hu/tartalom/tamop412A/20110048 MK controlling alapjai szoveg/adatok.html p.1-13. 13

Milicz Ákos(2011): Ellenőrzési aspektusok a vállalatok versenyképességének szemszögéböl.

Múhelytanulmány, kutatási jelentés BCE Vállalatgazdaságtan Intézet, Budapesti Corvinus Egyetem, Budapest, p. 23 ISSN 1787-6915 (Online)

Milicz Ákos(2011): Civil projektmenedzsment: Sikeres projektek nonprofit szervezetekben. Könyv, IKF Alapítvány, Budapest, P.147

ISBN 1978-963-08-1429-4

Gerő Márton, Madár Csaba, Milicz Ákos(2006): Helyi Önkormányzat és az Ifjúság - A települési ifjúsági tanácsok müködése.

Könyv, DIPA Tanácsadók és Fejlesztók Szakmai Egyesülete, Cegléd

Madár Csaba (szerk.), p1-68.

ISBN 9632299604

\section{$\underline{\text { Referált folyóirat cikk }}$}

Milicz Ákos, Jenővári Márton(2015): Kontroller-feladatkörök - A hazai álláshirdetésekben In: VEZETÉSTUDOMÁNY: Budapesti Corvinus Egyetem Corvinus School of Management, Budapest, 2015 (12): pp. 22-33.

Milicz Ákos(2016): Kvantitatív módszerekkel támogatott üzemgazdasági ellenőrzések, különös tekintettel a Benford-törvény alkalmazhatóságára In: STATISZTIKAI SZEMLE 94:(6) pp. 611-634., KSH, Budapest 


\section{Egyéb folyóirat, cikk}

Milicz Ákos(2010): Stratégiai menedzsment és Balanced Scorecard rendszer az Edinburgh-i Egyetemen In: FELSŐOKTATÁSI MŰHELY: AZ EDUCATIO TÁRSADALMI SZOLGÁLTATÓ KHT, ORSZÁGOS FELSŐOKTATÁSI INFORMÁCIÓS KÖZPONT KIADVÁNYA, Budapest, 2010 (II.): 25-41. 16,

Milicz Ákos(2011): Önkormányzati belső ellenőrzés időszerű kérdései. In: JEGYZŐ ÉS KÖZIGAZGATÁS, XIII (4), p29.

Milicz Ákos(2009): Titokzatos nonprofitok.

Piac és Profit 2009. 12. szám, p.2.

Dr. Bodnár Viktóra, Borbély András, Endersz Frigyes, Milicz Ákos, Radó István, Török Sándor, Zabrák Izabella(2003): Tervezés Felmérés 2003.: Felmérés a controlling rendszer helyzetéről a hazai közép- és nagyvállalatok körében, különös tekintettel a tervezés kérdéskörére.

Zabrák Izabella (szerk.)

Kutatási jelentés, összefoglaló, IFUA Horváth\&Partners Kft., Budapest, p. 1-18.

Milicz Ákos(2004): A non-profit szervezetek (ngo) belső kultúrájának és kontroll mechanizmusainak vizsgálata a szervezeti teljesítmény szemszögéből.

Kutatási jelentés, DIPA Egyesület, Cegléd, p. 1-16.

Drótos György-Milicz Ákos-Móricz Péter(2004): Versenyképesség kutatási eredmények Gyorsjelentés részlet Chikán Attila, Czakó Erzsébet, Zoltayné Paprika Zita (szerk.) In: Fókuszban a verseny - Gyorsjelentés a 2004. évi kérdőíves felmérés eredményeiről, BKÁE, Budapest

\section{Konferencia kiadvány}

Milicz Ákos(2013): A controller képzés kihívásai: Beszámoló a Magyar Controlling Egyesület tagjai körében végzett kérdőíves kutatásról.

In: Dénes Tamásné (szerk.)

Beszámoló A kommunikáció szerepe a controller gyakorlatában című MCE konferenciáról, MCE, Budapest: 1-3. 3

Milicz Ákos-Drótos György(2013): Végzős controller hallgatók szaktudása és a hazai munkaerőpiaci elvárások.

Kérdőíves felmérés eredményeinek közzététele az MCE 2013. 10. 17-i konferenciáján , Drótos György: Hogyan változik a controller szerepe (és hogyan reflektáljon erre a felsőoktatás)? címú előadásának részeként, Kecskemét, p. 1-2.

Milicz Ákos(2011): CIVIL PROJEKTMENEDZSMENT: A hazai civil szervezetek által megvalósított projektek elemzése a pályáztatók szemszögéből nézve.

In: Taylor után 100 évvel - Vezetéstudományi és emberi erőforrás kihívások a 21. század elején, Szeged, SZTE, Egyesület Közép-Európa kutatására, 1-15. 15 
Milicz Ákos(2011): Tapasztalatok a hazai civil szervezetek projektmenedzsment képességéről.

In: Fiatal Regionalisták VII. Konferenciája, Győr, SZIE, 1-14. 14

Milicz Ákos(2012): Vállalati kontroll-tevékenység a versenyképesség szolgálatában. Vitairat, Budapesti Corvinus Egyetem, Versenyképesség Kutató Központ, Vezetés és Kontroll Tanszék, Budapest, p.53

\section{$\underline{\text { Tankönyv, tananyagok }}$}

Milicz Ákos(2014): AVEX Kft. KERÉKPÁR ÜZLETÁG - FOLYAMATKÖLTSÉG-SZÁMÍTÁS AVEX Kft. 5/e. esettanulmány.

Budapest: Budapesti Corvinus Egyetem, Vezetéstudományi Intézet, Budapest, p.1-7.

Milicz Ákos(2014): Beszámolók készítése és értelmezése

AVEX Kft. 7/b. esettanulmány.

Budapest: Budapesti Corvinus Egyetem, Vezetéstudományi Intézet, Budapest, p.1-5.

Milicz Ákos(2014): Controlling feladatok az AVEX Kft-nél

AVEX Kft. 7/c. eset.

Budapest: Budapesti Corvinus Egyetem, Vezetéstudományi Intézet, Budapest, p.1-5.

Milicz Ákos(2014): Kiszervezési döntések előkészítése és értékelése

AVEX Kft. 2/b. esettanulmány.

Budapest: Budapesti Corvinus Egyetem, Vezetéstudományi Intézet, Budapest, p.1-7.

Milicz Ákos(2014): Projektmenedzsment tapasztalatok egy ERP rendszer bevezetése kapcsán a Tojás Kft-nél.

Tojás Kft. Esettanulmány

Budapest: Budapesti Corvinus Egyetem, Vezetéstudományi Intézet, Budapest, p.1-3.

\section{Egyéb publikációk}

Milicz Ákos(2016): Gondolta-e, hogy ennyiféle belső ellenőrt alkalmaznak a cégek?

Ismeretterjesző cikk, Megjelent: 2016. április 11., pp. 1-2. Magyarország

Link: http://www.portfolio.hu/premium/gondolta-

e hogy ennyifele belso ellenort alkalmaznak a cegek.229694.html

Milicz Ákos(2011): A tanulókkal kapcsolatos iskolai konfliktusok pedagógiai és jogi megítélése.

MsC Szakdolgozat közgazdász-tanár szakon,

BCE Társadalomtudományi kar, Budapest 
Milicz Ákos(2005): Egységes és integrált civil adatbázis megvalósíthatósági tanulmánya. DIPA Egyesület, Cegléd, p. 1-80.

Milicz Ákos(2003): Diákönkormányzatok controlling és teljesítményértékelés rendszerének elmélete és gyakorlata.

TDK dolgozat, BKÁE Gazdálkodástudományi kar, Budapest, p.1-134.

Milicz Ákos(2002): Diákönkormányzatok gazdálkodása - Kutatási Jelentés

PMDH Egyesület, Budapest

Idegen nyelvü publikációk

\section{Referált folyóirat cikk}

Ákos Milicz(2016): Market Role of the State and Possibilities to Control this Role at Public Enterprises

In: PÉNZÜGYI SZEMLE/PUBLIC FINANCE QUARTERLY 2016:(2), Budapest pp. 205-228.

\section{Konferencia kiadvány}

Ákos Milicz(2012): Current challenges and possibilities to control state's role in Hungary. In: Crisis Aftermath: Economic Policy Changes in the EU and its Member States Conference Proceedings, Szeged, Magyarország, (2012.03.08-09.)

Szeged: SZTE Gazdaságtudományi Kar, 13, pp.257-269. 